Presidente da República Jair Messias Bolsonaro

Ministro da Economia

Paulo Roberto Nunes Guedes

Secretário Especial de Fazenda

Waldery Rodrigues Junior

INSTITUTO BRASILEIRO

DE GEOGRAFIA E

ESTATÍSTICA - IBGE

Presidente

Susana Cordeiro Guerra

Diretor-Executivo

Fernando José de Araújo Abrantes

ÓRGÃOS ESPECÍFICOS SINGULARES

Diretoria de Pesquisas

Eduardo Luiz G. Rios Neto

Diretoria de Geociências

João Bosco de Azevedo

Diretoria de Informática

David Wu Tai

Centro de Documentação e Disseminação de Informações

Marise Maria Ferreira

Escola Nacional de Ciências Estatísticas

Maysa Sacramento de Magalhães

UNIDADE RESPONSÁVEL

Centro de Documentação e Disseminação de Informações

Gerência de Recuperação de Informações

Isabela Mateus de Araujo Torres 
ISSN 1808-1983

(C) IBGE. 2019

As opiniões emitidas nesta publicação são de exclusiva e inteira responsabilidade do(s) autor(es), não exprimindo, necessariamente, o ponto de vista do IBGE.

Capa / Cover - Leonardo Martins, Gerência de Editoração - CDDI

Fundação Iberê//berê Foundation

Retrato de Sr. Laurindo/Portrait of Mr. Laurindo, [1942]

Iberê Camargo, Restinga Seca-RS

Projeto gráfico editorial / Printing Project - Luiz Carlos Chagas Teixeira e Leonardo Martins, Gerência de Editoração - CDDI

Impressão / Printing - Centro de Documentação e Disseminação de Informações - CDDI

Brasil em números = Brazil in figures / IBGE. Centro de Documentação

e Disseminação de Informações. - Vol. 1 (1992- ). - Rio de Janeiro:

IBGE, 1992-

Anual.

Publicações anteriores: "O Brasil em números" = ISSN 0524-2010, v.1 e v.2 $(1960,1966)$ e "Brasil: séries estatísticas retrospectivas" = ISSN 00680842, v.1 e v.2 (1970, 1977).

Título e texto também em inglês: Brazil in figures = ISSN 0103-9970.

ISSN 1808-1983

1. Brasil - Estatística. I. IBGE. Centro de Documentação e Disseminação de Informações.

Gerência de Biblioteca e Acervos Especiais RJ-IBGE/92-15 (rev. 2011)
CDU 31(81)(05)

PERIÓDICO 


\section{Agradecimentos \\ Acknowledgments}

O IBGE agradece aos colaboradores abaixo relacionados, que com seus textos analíticos e comentários enriqueceram o conteúdo desta obra.

IBGE would like to thank the following collaborators for their analyses and comments that enriched this publication.

Alessander Mario Kerber

André Frossard Pereira de Lucena

André Moreira Cunha

Aniela Fagundes Carrara

Ari da Silva Fonseca Filho

Basílio Sartor

Daniel Neves Schmitz

Daniela Dias Kuhn

Ednaldo Aparecido Ribeiro

Gabriela Soares

Geisa Daise Gumiero Cleps

Igor Tadeu Stemler

Julian Borba

Luís Eduardo Afonso
Manoel Carlos de Castro Pires

Márcio de Almeida D'Agosto

Marcos Aurelio Saquet

Maria Luiza Adams Sanvitto

Marilis Lemos de Almeida

Marisa Ribeiro Teixeira Duarte

Mary Ann Menezes Freire

Paulo Dabdab Waquil

Rafael Garaffa

Ricardo Dathein

Ricardo de Sampaio Dagnino

Roberto Muniz Barretto de Carvalho

Roberto Verdum

Wagner Nóbrega 


\section{Iberê Foundation}

\section{The Foundation}

The Iberê Foundation was created in 1995 with the mission of preserving, studying and promoting the works of Iberê Camargo, besides bringing the public closer to one of the greatest names of the Brazilian art in the 20th century and fostering reflection on culture and education by means of transdisciplinary programs and the promotion of artistic production.

Every year the Foundation organizes exhibits, seminars, meetings with artists and curators, courses, workshops, among other activities on the works of the artist and approaching themes related to modern and contemporary art, bringing together, besides visual arts, other artistic manifestations - cinema, music, architecture, theater and literature - and a variety of fields of knowledge.

The current building of the Foundation, inaugurated in May 2008, is a project of the Portuguese architect Álvaro Siza Vieira and has a total area of $8,250 \mathrm{~m}^{2}$, built on land donated by the Rio Grande do Sul State Government, on the banks of the Guaíba River. It is considered one of the most important works ever conceived by Siza, who has projects built in Portugal, Spain, France, Italy, China, Japan, Russia and South Korea. Álvaro Siza Vieira was awarded the Golden Lion at the 8th Architecture Biennale in Venice, in 2002 (an unmatched prize for South America, at the time) and the Mies Crown Hall Americas Prize, in 2014, for this work, as the building established itself as an architectural landmark not only for the city of Porto Alegre, but for the country as well. 


\section{Fundação lberê}

\section{A Fundação}

A Fundação lberê foi criada em 1995 com a missão de preservar, investigar e divulgar a obra de lberê Camargo, além de aproximar o público deste que é um dos grandes nomes da arte brasileira do Século XX, estimulando a reflexão sobre cultura e educação por meio de programas transdisciplinares e do fomento à própria produção artística.

A cada ano, são organizadas exposições, seminários, encontros com artistas e curadores, cursos, oficinas, entre outras atividades, que versam sobre sua obra e temas ligados à arte moderna e contemporânea, articulando, além das artes visuais, outras manifestações artísticas - como o cinema, a música, a arquitetura, o teatro e a literatura - e os mais diversos campos do conhecimento.

A atual sede da Fundação, inaugurada em maio de 2008, foi projetada pelo arquiteto português Álvaro Siza Vieira e conta com uma área total de $8250 \mathrm{~m}^{2}$, construída em terreno doado em 1996 pelo Governo do Estado do Rio Grande do Sul, às margens do Guaíba. Este é considerado um dos mais importantes trabalhos já realizados por Siza, que já fez projetos em Portugal, Espanha, França, Itália, China, Japão, Rússia e Coréia do Sul. Por ele, recebeu o troféu Leão de Ouro da 8 a Bienal de Arquitetura de Veneza, em 2002 (prêmio, até então, inédito para a América do Sul), e o Mies Crown Hall Americas Prize, em 2014, configurando-se como um referencial arquitetônico não apenas para a cidade de Porto Alegre, mas também para o País. 
The building has exhibition rooms, an atrium, a storage room, a center for documentation and research, an engraving studio, a studio for educational programs, an auditorium, a store, a coffee shop, a parking lot and an environmental park projected by the Gaia Foundation. In addition to promoting the works of Iberê Camargo and of other prominent Brazilian artists, the cultural center has organized exhibitions in partnership with other institutions, such as the Cisneros Foundation and the New York Museum of Modern Art (MoMA).

Currently, the lberê Foundation collection is formed by 3,246 drawings and gouaches, 1,570 engravings and 216 paintings, all of which are carefully kept in the storage room specially designed for their preservation.

\section{The Artist}

An artist of incomparable prowess and sensitivity, lberê Camargo was the author of an extensive work that includes paintings, gouaches and engravings. He was born in November 1914, in Restinga Seca, a city in the hinterlands of the state of Rio Grande do Sul.

In 1927, he began his painting studies at the School of Arts and Crafts of Santa Maria (RS). In 1936, he moved to Porto Alegre. There he met Maria Coussirat Camargo, a student at the Arts Institute (IA), whom he married three years later. In 1942, the year of his first exhibition, the artist and his wife moved to Rio de Janeiro, which would be their home for the following four decades.

An admirer and a friend of Brazilian artists such as Goeldi and Guignard, Iberê Camargo traveled to Europe in 1948 (having been awarded a trip for his painting Lapa, of 1947) in search of technical improvement. During his stay, he copied works done by masters of painting in the museums he visited and studied engraving and painting with Giorgio de Chirico, Carlo Alberto Petrucci, Leone Augusto Rosa, Antonio Achille and André Lhote.

Back to Brazil in 1950, Iberê won several prizes and participated in a number of international events such

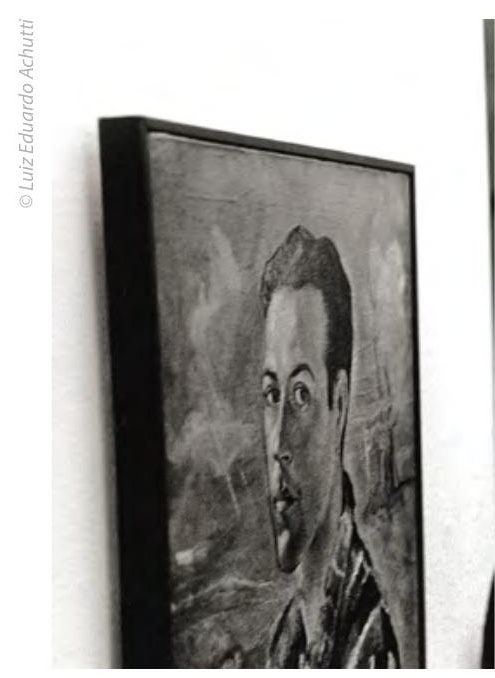


as the São Paulo Art Biennale, the Spanish-American Biennale, in Madrid, the Venice Art Biennale and the Tokyo Engraving Biennale. In the end of the 1950s, due to a herniated disk, he had no choice but work in his studio full time, and then he came up with one of the most recurring themes in his paintings: the Spools (Carretéis), childhood toys that led him into a phase of abstraction and remained in his works until the end. Throughout his life, he showed a strong leadership in the artistic and intellectual world. Among several other activities, a highlight is his participation in the organization of the Black and White Exhibit, in 1954, and, in the following year, of the Miniature Salon, both conceived as forms of protest against the high taxes charged on foreign art materials.

In the 1980s, Iberê Camargo's painting returned to figuration. Throughout his life, the artist never lined up with currents or movements. In 1982, he moved back to Porto Alegre, where he produced two of his most famous series: Cyclists (os Ciclistas) and The idiots (as Idiotas). Iberê Camargo died in August 1994, at the age of 79.

Iberê Foundation

Translated by: Aline Milani Romeiro Pereira 
São Paulo, Bienal Hispano-Americana de Arte, em Madri, Bienal de Veneza, Bienal de Gravuras, em Tóquio, entre outras. Foi no final dos anos 1950 que, devido a uma hérnia de disco que o obrigou a pintar no interior de seu ateliê, o artista desenvolveu um dos temas mais recorrentes em sua pintura: os Carretéis, brinquedos de sua infância que o levaram, mais tarde, à abstração e que estiveram presentes em sua obra até a fase final.

Ao longo de sua vida, exerceu forte liderança no meio artístico e intelectual. Entre várias outras atividades, destaca-se sua participação na organização do Salão Preto e Branco, em 1954, e, no ano seguinte, do Salão Miniatura, ambos realizados em protesto às altas taxas de importação de material artístico.

Na década de 1980, retomou a figuração. Mas, ao longo de toda a sua produção, nunca se filiou a correntes ou movimentos. Em 1982, retornou a Porto Alegre, onde produziu duas de suas séries mais conhecidas: os Ciclistas e as Idiotas. Faleceu em agosto de 1994, aos 79 anos de idade.

Fundação lberê 
Fundação Iberê

Iberê Foundation

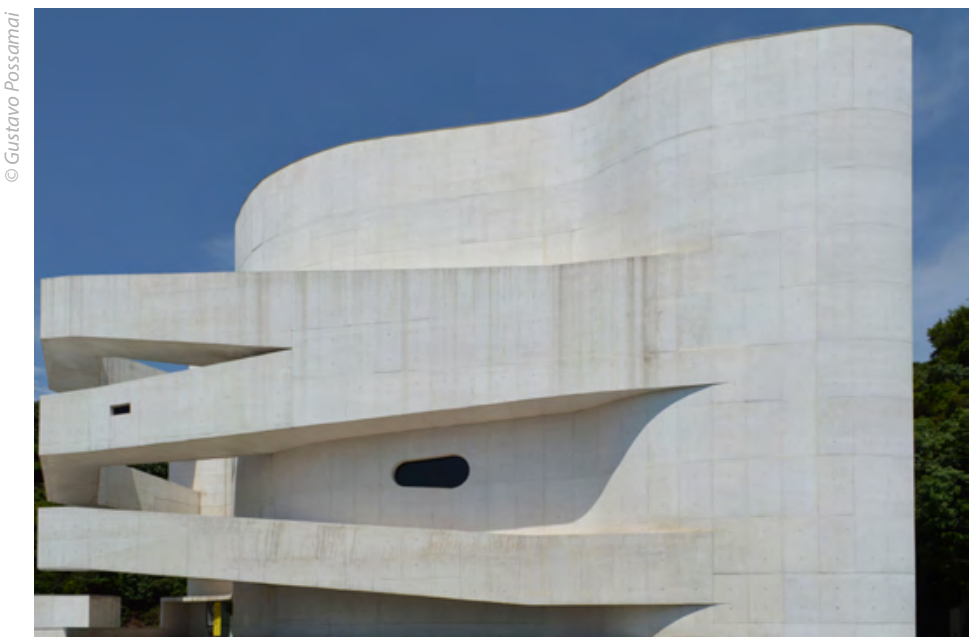




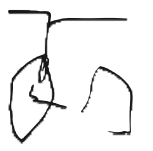

Fundação Iberê

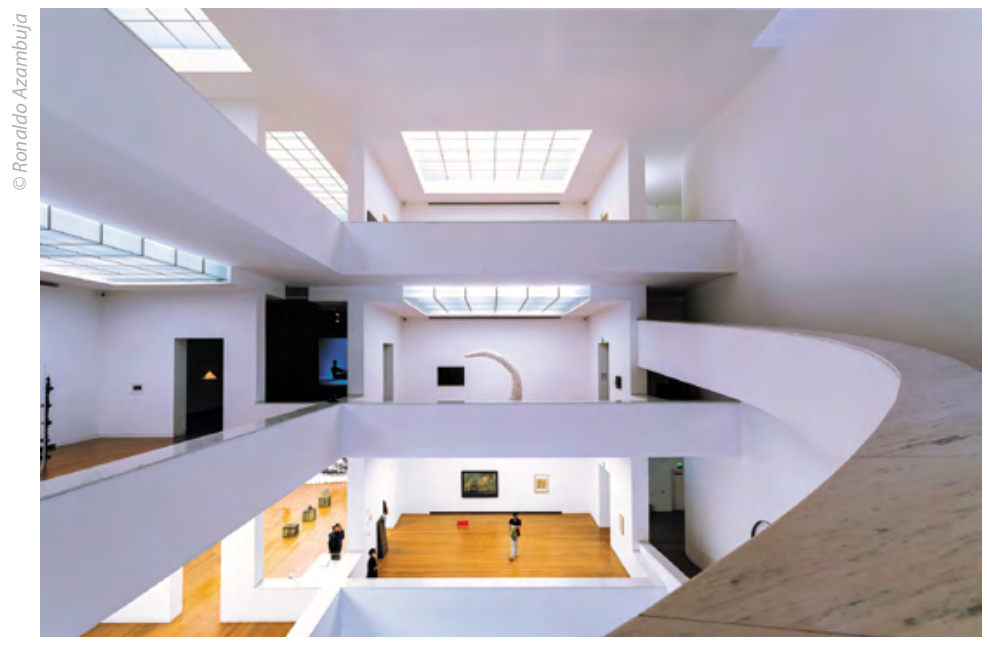


Obras e imagens cedidas pela Fundação Iberê reproduzidas neste volume Works and images granted by the lberê Foundation reproduced in this volume

Capa Cover

Retrato de Sr. Laurindo/Portrait of Mr. Laurindo, [1942]

Iberê Camargo, Restinga Seca (RS), 1914

Óleo sobre tela/Oil on canvas

$50 \times 45,7 \mathrm{~cm}$

Fotografia/Photograph: Fabio Del Re (Viva Foto)

\section{Foto do Artista - Iberê Camargo}

Iberê e seu autorretrato da década de 1940/ Iberê and his self-portrait in the 1940s, Porto Alegre, 1993.

Fotografia/Photograph: Luiz Eduardo Achutti Acervo Documental Fundação Iberê/ Iberê Foundation Collection

\section{Foto externa do Museu Outside picture of} the Museum

Fundação Iberê /lberê Foundation

Fotografia/Photograph: Gustavo Possamai

Foto interna do Museu Inside Picture of the Museum

Fundação Iberê/lberê Foundation

Fotografia/Photograph: Ronaldo Azambuja

\section{Uma breve história do Brasil A brief history} of Brazil

Autorretrato/Self-portrait, [1943]

Iberê Camargo, Restinga Seca (RS), 1914

Óleo sobre tela/Oil on canvas

$69 \times 59 \mathrm{~cm}$

Fotografia/Photograph: Fundação Iberê/lberê Foundation

\section{Território Territory}

Retrato de Maria Coussirat Camargo/Portrait of Maria Coussirat Camargo, 1943

Iberê Camargo, Restinga Seca (RS), 1914

Óleo sobre tela/Oil on canvas

$52 \times 46,5 \mathrm{~cm}$

Fotografia/Photograph: Fundação Iberê/lberê Foundation

População Population

Sem título/Untitled, 1989

Iberê Camargo, Restinga Seca (RS), 1914

Nanquim e pastel oleoso sobre papel/Indian ink and oil pastel on paper

$32,5 \times 23,5 \mathrm{~cm}$

Fotografia/Photograph: Fabio Del Re (Viva Foto)
Habitação Housing

Sem título/Untitled, 1990

Iberê Camargo, Restinga Seca (RS), 1914

Guache, tinta de esferográfica e lápis

stabilotone sobre papel/Gouache, ballpoint

ink and stabilotone pencil on paper

$18 \times 24,7 \mathrm{~cm}$

Fotografia/Photograph: Fabio Del Re (Viva Foto)

\section{Saúde Health}

Sem título/Untitled, 1993

Iberê Camargo, Restinga Seca (RS), 1914

Guache, nanquim e lápis stabilotone sobre

papel/Gouache, Indian ink and stabilotone

pencil on paper

$35 \times 50 \mathrm{~cm}$

Fotografia/Photograph: Fabio Del Re (Viva Foto)

Previdência Social Social Security

Sem título/Untitled, [1959]

Iberê Camargo, Restinga Seca (RS), 1914

Óleo sobre papel/Oil on paper

$38,5 \times 56 \mathrm{~cm}$

Fotografia/Photograph: Fabio Del Re (Viva Foto)

\section{Educação Education}

Sivuca no meu ateliê/Sivuca in my studio, 1986 Iberê Camargo, Restinga Seca (RS), 1914

Grafite e lápis stabilotone sobre papel/

Graphite and stabilotone pencil on paper

$33,2 \times 24,2 \mathrm{~cm}$

Fotografia/Photograph: Fabio Del Re (Viva Foto)

Trabalho Labor

Lambe-lambe I/Lambe-lambe I, 1988

Iberê Camargo, Restinga Seca (RS), 1914

Óleo sobre tela/Oil on canvas

$42 \times 30 \mathrm{~cm}$

Fotografia/Photograph: Fabio Del Re (Viva Foto)

Participação Política Political Participation

O delírio/Delirium, 1987

Iberê Camargo, Restinga Seca (RS), 1914

Guache, lápis stabilotone e grafite sobre papel/ Gouache, stabilotone pencil and

graphite on paper

$99 \times 68,7 \mathrm{~cm}$

Fotografia/Photograph: Fabio Del Re (Viva Foto) 


\section{Preços Prices}

Ascensão l/Ascension I, 1973

Iberê Camargo, Restinga Seca (RS), 1914

Óleo sobre tela/Oil on canvas

$57 \times 40 \mathrm{~cm}$

Fotografia/Photograph: Fabio Del Re (Viva Foto)

\section{Contas Nacionais National Accounts}

Dado cor-de-rosa/Pink dice, 1982

Iberê Camargo, Restinga Seca (RS), 1914

Óleo sobre madeira/Oil on wood

$25 \times 35 \mathrm{~cm}$

Fotografia/Photograph: Fundação Iberê/lberê Foundation

\section{Agropecuária Agriculture}

Jaguari/Jaguari, 1941

lberê Camargo, Restinga Seca (RS), 1914

Óleo sobre tela/Oil on canvas

$40 \times 30 \mathrm{~cm}$

Fotografia/Photograph: Fundação Iberê//berê

Foundation

\section{Indústria Industry}

Um carretel/Spool, 1960

Iberê Camargo, Restinga Seca (RS), 1914

Água-forte e água-tinta/Etching and water-ink $49,5 \times 28,2 \mathrm{~cm}$

Fotografia/Photograph: Fabio Del Re (Viva Foto)

\section{Energia Energy}

O homem da flor na boca: um ato de amor à vida/Man with the flower-mouth: an act of love for life, 1992

Iberê Camargo, Restinga Seca (RS), 1914

Guache e lápis stabilotone sobre papel/

Gouache and stabilotone pencil on paper

$100,2 \times 69,9 \mathrm{~cm}$

Fotografia/Photograph: Fabio Del Re (Viva Foto)

\section{Comércio Trade}

Palhaço/Clown, 1987

Iberê Camargo, Restinga Seca (RS), 1914

Óleo sobre tela/Oil on canvas

$57,2 \times 40 \mathrm{~cm}$

Fotografia/Photograph: Fabio Del Re (Viva Foto)

\section{Transportes Transportation}

Ciclistas/Cyclists, 1989

Iberê Camargo, Restinga Seca (RS), 1914

Óleo sobre tela/Oil on canvas

$180 \times 213 \mathrm{~cm}$

Fotografia/Photograph: Fundação Iberê/lberê Foundation

\section{Turismo Tourism}

Outono no Parque da Redenção II/Fall in the Park of Redemption II, 1988

Iberê Camargo, Restinga Seca (RS), 1914

Óleo sobre tela/Oil on canvas

$65 \times 92 \mathrm{~cm}$

Fotografia/Photograph: Fundação Iberê/lberê Foundation

\section{Comunicações Communication}

Mímica/Mimic, 1987

Iberê Camargo, Restinga Seca (RS), 1914

Lápis stabilotone e nanquim sobre papel/

Stabilotone pencil and Indian ink on paper

$35,2 \times 50 \mathrm{~cm}$

Fotografia/Photograph: Fabio Del Re (Viva Foto)

Finanças Públicas Public Finances

Símbolos/Symbols, 1976

Iberê Camargo, Restinga Seca (RS), 1914

Óleo sobre tela/Oil on canvas

$93 \times 132 \mathrm{~cm}$

Fotografia/Photograph: Fundação Iberê/Iberê Foundation

\section{Comércio Exterior Foreign Trade}

Solidão/Solitude, 1994

Iberê Camargo, Restinga Seca (RS), 1914

Óleo sobre tela/Oil on canvas

$200 \times 400 \mathrm{~cm}$

Fotografia/Photograph: Luiz Eduardo Achutti

Ciência e Tecnologia Science and Technology

Diálogo/Dialogue, 1987

Iberê Camargo, Restinga Seca (RS), 1914

Óleo sobre tela/Oil on canvas

$42 \times 30 \mathrm{~cm}$

Fotografia/Photograph: Fabio Del Re (Viva Foto)

Poder Judiciário Judicial Power

Autorretrato/Self-portrait, [1990]

Iberê Camargo, Restinga Seca (RS), 1914

Lápis de cor sobre papel/Colored pencil on

canvas

$25,6 \times 36,6 \mathrm{~cm}$

Fotografia/Photograph: Fabio Del Re (Viva Foto)

\section{Meio Ambiente Environment}

Dentro do mato/Inside the bush, 1941-1942

Iberê Camargo, Restinga Seca (RS), 1914

Óleo sobre tela/Oil on canvas

$40 \times 30 \mathrm{~cm}$

Fotografia/Photograph: Fabio Del Re (Viva Foto) 


\section{Contents}

Foreword 32

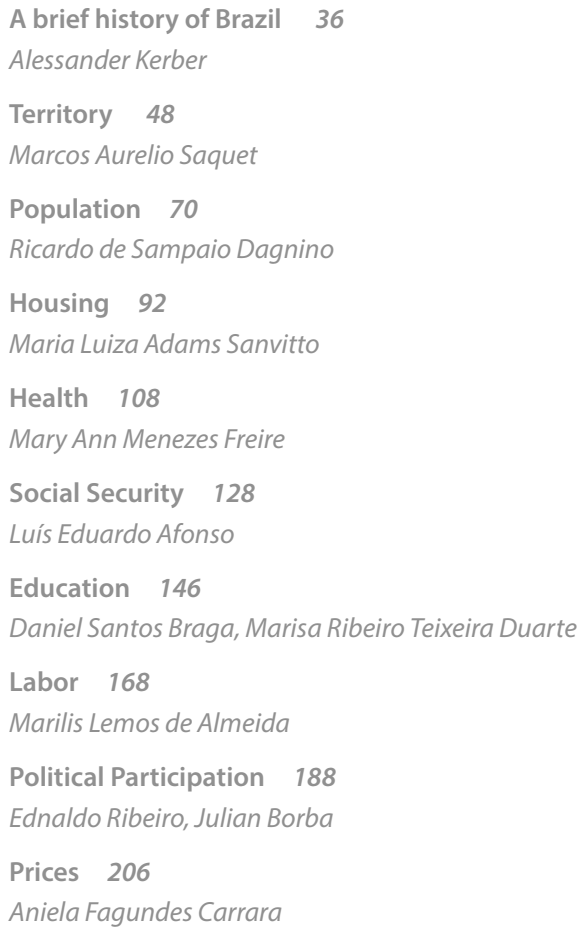




\section{Sumário}

Apresentação 33

Uma breve história do Brasil $\quad 37$

Alessander Kerber

Território 49

Marcos Aurelio Saquet

População 71

Ricardo de Sampaio Dagnino

Habitação 93

Maria Luiza Adams Sanvitto

Saúde 109

Mary Ann Menezes Freire

Previdência Social 129

Luís Eduardo Afonso

Educação 147

Daniel Santos Braga, Marisa Ribeiro Teixeira Duarte

Trabalho 169

Marilis Lemos de Almeida

Participação Política 189

Ednaldo Ribeiro, Julian Borba

Preços 207

Aniela Fagundes Carrara 
National Accounts 224

Manoel Pires

Agriculture 238

Daniela Dias Kühn, Paulo Dabdab Waquil

Industry 258

Ricardo Dathein

Energy 278

Rafael Garaffa, André F.P. Lucena

Trade 300

Geisa Daise Gumiero Cleps

Transportation 320

Márcio de Almeida D 'Agosto, Daniel Neves Schmitz Gonçalves

Tourism 340

Ari da Silva Fonseca Filho

Communications 358

Basilio Sartor

Public Finances 378

Wagner Nóbrega

Foreign Trade 402

André Moreira Cunha

Science and Technology 416

Roberto Muniz Barretto de Carvalho

Judicial Power 436

Lucas Delgado, Igor Tadeu Silva Viana Stemler,

Gabriela Moreira de Azevedo Soares

Environment 454

Roberto Verdum

References 473 
Contas Nacionais 225

Manoel Pires

Agropecuária 239

Daniela Dias Kühn, Paulo Dabdab Waquil

Indústria 259

Ricardo Dathein

Energia 279

Rafael Garaffa, André F.P. Lucena

Comércio 301

Geisa Daise Gumiero Cleps

Transportes 321

Márcio de Almeida D 'Agosto, Daniel Neves Schmitz Gonçalves

Turismo 341

Ari da Silva Fonseca Filho

Comunicações 359

Basilio Sartor

Finanças Públicas 379

Wagner Nóbrega

Comércio Exterior 403

André Moreira Cunha

Ciência e Tecnologia 417

Roberto Muniz Barretto de Carvalho

Poder Judiciário 437

Lucas Delgado, Igor Tadeu Silva Viana Stemler,

Gabriela Moreira de Azevedo Soares

Meio Ambiente 455

Roberto Verdum

Referências 473 


\section{Tabelas Tables}

\section{Território Territory}

1.1 Área total do País - 2018

Total area of Brazil - 2018

1.2 Evolução político-administrativa do País - 1940/2018

Administrative evolution of Brazil - 1940/2018

1.3 Pontos extremos do País e suas distâncias - 2018

Extreme points of Brazil and their distances - 2018

64

1.4 Pontos mais altos do País - 2016

Highest points in Brazil - 2016

1.5 Localização geográfica dos Municípios das Capitais

e distância a Brasília - 2018

Geographic location of the Municipalities of the Capital and

distance to Brasília - 2018

67

População Population

2.1 População residente, por situação do domicílio e sexo - 2010

Resident population, by urban/rural housing unit and sex-2010

84

2.2 Indicadores demográficos - 2010

Demographic indicators - 2010

2.3 Projeções de população e taxas - 2010-2020

Population projections and rates - 2010-2020

88

\section{Habitação Housing}

3.1 Domicílios particulares permanentes, pessoas residentes em domicílios particulares permanentes e média de pessoas, por domicílio particular permanente e dormitório em domicílio particular permanente, segundo as Grandes Regiões - 2017

Permanent private housing units, persons residents in permanent private housing units, and average number of persons, per permanent private housing units and per bedroom in permanent private housing units,

by Major Regions - 2017

Saúde Health

4.1 Dez principais causas de óbitos de residentes, por sexo - 2017

Ten leading causes of deaths of residents, by sex - 2017

4.2 Cobertura vacinal, por Unidades da Federação - 2018

Immunization coverage, by Federation Unit - 2018 
4.3 Internações, mortalidade hospitalar e média de permanência no Sistema Único de Saúde - SUS - 2018

Hospitalization, deaths in hospitals and average length of stay

in the Unified Health System - SUS - 2018

\section{Previdência Social Social Security}

5.1 Recebimentos e pagamentos da Previdência Social - 2006-2017 Social Security revenues and payments - 2006-2017

5.2 Distribuição dos benefícios ativos, urbano e rural - 2014-2017

Distribution of active benefits: urban and rural - 2014-2017

5.3 Benefícios concedidos pela Previdência Social - 2014-2017

Benefits granted by Social Security - 2014-2017

5.4 Quantidade de pessoas físicas contribuintes do Regime Geral

de Previdência Social - RGPS, por categoria - 2007-2017

Number of individuals contributing to the General Social

Security System - RGPS, by category - 2007-2017

\section{Educação Education}

6.1 Taxa de analfabetismo das pessoas de 10 anos ou mais de idade, por sexo, segundo os grupos de idade - Brasil - 2º trimestre de 2017 Illiteracy rate of persons 10 years old and over, by sex and age groups - Brazil - 2nd. Quarter 2017

6.2 Média de anos de estudo das pessoas de 10 anos ou mais de idade, por sexo, segundo os grupos de idade - Brasil - 2º trimestre de 2017 Average of years of schooling of persons 10 years old and over, by sex and age groups - Brazil - 2nd. Quarter 2017

6.3 Distribuição das pessoas de 25 anos ou mais de idade, por Grandes Regiões, segundo o sexo e o nível de instrução - 2º trimestre de 2017 Distribution of persons 25 years old and over, by Major Regions, sex and level of schooling - 2nd. Quarter 2017

6.4 Distribuição das pessoas que frequentavam escola ou creche, por Grandes Regiões, segundo o nível e a rede de ensino que frequentavam - $2^{\circ}$ trimestre de 2017

Distribution of persons who attended school or nursery,

by Major Regions, level of schooling and type of school attended - 2nd. Quarter 2017

6.5 Taxa de frequência a creche das crianças de 0 a 3 anos de idade, por sexo, segundo as Grandes Regiões - 20 trimestre de 2017 Attendance rate to nursery of children 0 to 3 years old, by sex and Major Regions - 2nd. Quarter 2017

6.6 Taxa de escolarização das pessoas de 4 anos ou mais de idade, por Grandes Regiões, segundo os grupos de idade e o sexo - 2o trimestre de 2017

Attendance rate of persons 4 years old and over, by Major Regions, age groups and sex - 2nd. Quarter 2017 


\section{Trabalho Labor}

7.1 Distribuição das pessoas de 14 anos ou mais de idade, ocupadas na semana de referência, por Grandes Regiões, segundo algumas características - 2017

Distributions of persons 14 years old and over, employed in the reference week, by Major Regions and some characteristics - 2017

7.2 Distribuição das pessoas de 14 anos ou mais de idade, ocupadas, na semana de referência, por Grandes Regiões, segundo os grupamentos de atividade do trabalho principal - 2017 Distribution of persons 14 years old and over, employed in the reference week, by Major Regions and groups of section of activity in the main job - 2017

\section{Participação Política Political Participation}

8.1 Média de eleitores por seção, seções e eleitores existentes - 2018 Average voters by polling section, polling sections and voters - 2018

8.2 Distribuição percentual dos resultados da apuração para governador - 2018

Percentage distribution of vote cast for governor - 2018

8.3 Candidatos eleitos por cargo, segundo os partidos políticos - 2018 Candidates elected by political party - 2018

\section{Preços Prices}

9.1 Índice Nacional de Preços ao Consumidor Amplo - IPCA - 2018

Extended National Consumer Price Index - IPCA - 2018

9.2 Variação acumulada no ano do Índice Nacional de Preços ao Consumidor - INPC e do Índice Nacional de Preços ao Consumidor Amplo - IPCA - 2005-2018

Cumulative change in the year of the Extended National Consumer Price Index - IPCA and of the National Consumer Price Index - INPC - 2005-2018

9.3 Custo médio, número-índice e variação acumulada no ano, na construção civil, segundo as Grandes Regiões e Unidades da Federação - Dezembro 2018

Average cost, index-number and cumulative change in the year in civil construction, by Major Regions and Federation Units - December 2018

9.4 Variação acumulada no ano do Índice Nacional da Construção Civil - 2009-2018

Cumulative change in the year of the National Index of Civil

Construction - 2009-2018 


\section{Contas Nacionais National Accounts}

10.1 Principais agregados macroeconômicos - 2016-2018

Main macroeconomic aggregates - 2016-2018

10.2 Participação percentual dos impostos e do valor adicionado, a preços básicos no Produto Interno Bruto - PIB, e dos setores de atividade, no valor adicionado a preços básicos - 2016-2018 Percentage participation of taxes and of value added at basic prices in the Gross Domestic Product - GDP, and of the sectors of activity, in value added at basic prices - 2016-2018

10.3 Composição do Produto Interno Bruto - PIB, sob a ótica da despesa - 2016-2018

Composition of Gross Domestic Product - GDP, considering expenditures - 2016-2018

10.4 Variação da taxa trimestral do Produto Interno Bruto - PIB, por setor de atividade - 2017-2018 Quarterly rate change of the Gross Domestic Product - GDP, by sector of activity - 2017-2018

10.5 Principais relações macroeconômicas - 2016-2018 Main macroeconomic relationships - 2016-2018

Agropecuária Agriculture

11.1 Principais produtos agrícolas, segundo valor da produção e principal Unidade da Federação produtora - 2017

Major agricultural crops, according to the value of production and main producer Federation Unit - 2017

11.2 Efetivo dos rebanhos e das aves - 2016-2017

Number of livestock and poultry on farms - 2016-2017

11.3 Quantidade e valor dos produtos de origem animal e variação anual - 2016-2017

Amount and value of products of animal origin and annual variation - 2016-2017

11.4 Produção madeireira da extração vegetal e da silvicultura - 2016-2017 Production from wood wild crop harvesting and silviculture - 2016-2017

Indústria Industry

12.1 Produção industrial, segundo as seções e atividades de indústria - 2016-2018 Industrial output, according to industry sectors and activities - 2016-2018

12.2 Produção industrial - 2014-2017 Mining and manufacturing production - 2014-2017

12.3 Produção industrial e grau de intensidade de energia elétrica - 2016-2018

Industrial output and intensity of eletricity consumption - 2016-2018 
12.4 Variáveis selecionadas das unidades locais industriais de empresas industriais com 5 ou mais pessoas ocupadas, segundo as Grandes Regiões e as Unidades da Federação - 2016 Selected variables of industrial local units with 5 or more employed persons, by Major Regions and Federation Units - 2016

\section{Energia Energy}

13.1 Dados gerais de energia - 2015-2017

General energy data - 2015-2017

13.2 Geração de energia elétrica - 2016-2017

Generation of electricity - 2015-2016

13.3 Produção de petróleo e oferta interna de energia, por países selecionados - 2017

Petroleum production and total primary energy supply,

by selected country - 2017

13.4 Potencial hidrelétrico, segundo as bacias hidrográficas - 2018

Hydroelectric potential, according to river basin - 2018

\section{Comércio Trade}

14.1 Dados gerais do comércio - 2016

General data of trade - 2016

14.2 Número de empresas, pessoal ocupado, salários e receita total, segundo as divisões do comércio - 2016

Number of companies, employed persons, salaries and total

revenue, by trade segments - 2016

14.3 Participação dos segmentos do comércio - 2016

Participation of trade segments - 2016

Transportes Transportation

15.1 Extensão das malhas viárias do País - 2018

Extension of transportation networks in Brazil - 2018

15.2 Dados gerais do transporte ferroviário - 2016-2017

General data of railway transportation - 2016-2017

15.3 Movimento de carga, por tipo de navegação - 2010-2018

Cargo transportation by modal of navigation - 2010-2018

\section{Turismo Tourism}

16.1 Chegadas de turistas no Brasil - 2015-2017

Tourist arrivals to Brazil - 2015-2017

16.2 Chegadas de turistas no Brasil, por Unidades da Federação de acesso - 2015-2017

Tourist arrivals to Brazil, by Federation Unit of arrival - 2015-2017

16.3 Agências de turismo cadastradas no CADASTUR - 2017

Travel and tourism agencies listed in CADASTUR- 2017 


\section{Comunicações Communications}

17.1 Organização dos Correios e Telégrafos - 2014-2018

Organization of Postal and Telegraph Services - 2014-2018

17.2 Tráfego postal - 2014-2018

Postal traffic - 2014-2018

17.3 Telefones em serviço - 2018

Telephones in service - 2018

17.4 Televisão e radiodifusão - 2014-2018

Television and radio broadcasting - 2014-2018

17.5 Banda larga fixa, por Grandes Regiões e Unidades

da Federação - 2015-2018

Fixed broadband access, by Major Regions and

Federation Units 2015-2018

17.6 Banda larga móvel, por Grandes Regiões e Unidades

da Federação - 2015-2018

Mobile broadband access, by Major Regions

and Federation Units - 2015-2018

375

Finanças Públicas Public Finances

18.1 Evolução da dívida líquida do setor público - 2007-2018

Public sector net debt evolution - 2007-2018

18.2 Evolução da dívida bruta do governo geral - 2012-2018

General government gross debt evolution - 2012-2018

18.3 Necessidades de financiamento do setor público - 2015-2018

Public sector net borrowing - 2015-2018

18.4 Dívida líquida do setor público - 2015-2018

Public sector net debt-2015-2018

393

18.5 Dívida líquida e superávit primário, por Grandes Regiões - 2015-2018

Net debt and primary surplus, according to Major Regions - 2015-2018

394

18.6 Despesa liquidada da União - 2013-2018

Government paid expenses - 2013-2018

395

18.7 Despesa liquidada da União, por áreas de atuação/funções - 2017-2018 Government paid expenses, according to practice areas - 2017-2018

\section{Comércio Exterior Foreign Trade}

19.1 Balanço de pagamentos - 2015-2018

Balance of payments - 2015-2018

19.2 Exportação - 2016-2018

Exports - 2016-2018

19.3 Importação - 2016-2018

Imports - 2016-2018 


\section{Ciência e Tecnologia Science and Technology}

20.1 Investimentos nacionais em pesquisa e desenvolvimento, por setores, em relação ao Produto Interno Bruto - PIB - 2015-2016

National investments in research and development, by sectors, vis-à-vis Gross Domestic Product - GDP - 2015-2016

20.2 Recursos dos governos estaduais aplicados em ciência e tecnologia - 2011-2016

State government resources invested in science and technology - 2011-2016

20.3 Indicadores selecionados dos cursos de pós-graduação - 2003-2017 Selected indicators in Master's and Doctoral programs - 2003-2017

20.4 Instituições, grupos de pesquisa, pesquisadores e doutores em ciência e tecnologia - 2006/2016

Institutions, research groups, researchers and doctors in science and technology - 2006/2016

20.5 Artigos brasileiros e do mundo publicados em periódicos científicos internacionais indexados pela Scopus e percentual do Brasil em relação ao mundo em número de artigos e de citações recebidas - 2002-2017

Brazilian and World papers published in international scientific journals indexed by Scopus and Brazilian relative contribution to World publication and citation - 2002-2017

20.6 Pedidos depositados e decisões dos processos sobre patentes - 2013-2018 Patent applications filed and patent decisions - 2013-2018

\section{Poder Judiciário Judicial Power}

21.1 Informações de estrutura, recursos humanos e litigiosidade - 2013-2017 Information on structure, human resources and litigiousness - 2013-2017

21.2 Informações de estrutura, recursos humanos e litigiosidade por ramo de justiça - 2017

Information on structure, human resources and litigiousness, by court of justice - 2017

\section{Meio Ambiente Environment}

22.1 Número de violações do padrão primário nacional de qualidade do ar de PM10, nas Regiões Metropolitanas de Salvador (Camaçari), Belo Horizonte, Vitória, Rio de Janeiro, São Paulo, Curitiba e Porto Alegre - 1996-2017 Number of violations of the national primary ambient air quality standards of PM10 in the metropolitan areas of Salvador (Camaçari), Belo Horizonte, Vitória, Rio de Janeiro, São Paulo, Curitiba and Porto Alegre - 1996-2017 
22.2 Média anual da Demanda Bioquímica de Oxigênio - DBO, em corpos de água selecionados, nas Unidades da Federação de Pernambuco, Bahia, Espírito Santo, Minas Gerais, Rio de Janeiro, São Paulo, Paraná e Rio Grande do Sul - 2007-2017 Annual average of Biochemical Oxygen Demand - BOD, in selected water bodies of Pernambuco, Bahia, Espírito Santo, Minas Gerais, Rio de Janeiro, São Paulo, Paraná and Rio Grande do Sul - 2007-2017

22.3 Número e área das Unidades de Conservação Federais, segundo o tipo de uso e as categorias de manejo - 2017 Number and areas of Federal Conservation Units, by type of use and management categories - 2017

\section{Gráficos Graphs}

\section{População Population}

2.1 Composição relativa da população residente, por sexo e grupos de idade - 1991/2010

Relative composition of the resident population, by sex and age groups - 1991/2010

2.2 Projeção da população - 2010/2020

Population projections - 2010/2020

2.3 Taxas brutas de natalidade e mortalidade - 2010-2030

Crude birth and death rates - 2010-2030

2.4 Esperança de vida ao nascer - 1930/2020 Life expectancy at birth - 1930/2020

2.5 Taxa média geométrica de crescimento anual - 1940/2010 Average geometric rate of annual increase - 1940/2010

\section{Habitação Housing}

3.1 Distribuição dos domicílios particulares permanentes, por condição de ocupação - 2017 Distribution of permanent private housing units, by tenure - 2017

3.2 Distribuição dos domicílios particulares permanentes, por existência de rede geral de abastecimento de água, segundo as Grandes Regiões - 2017

Distribution of permanent private housing units, by presence of water supply system and Major Regions - 2017 
3.3 Distribuição dos domicílios particulares permanentes, por existência de serviço de coleta de lixo, segundo as Grandes Regiões - 2017

Distribution of permanent private housing units, by existence

of garbage collection service and Major Regions - 2017

Saúde Health

4.1 Casos de Aids por ano de diagnóstico e sexo- 2008-2017

AIDS cases, by year of diagnosis and sex - 2008-2017

\section{Educação Education}

6.1 Taxa de analfabetismo das pessoas de 15 anos ou mais de idade, por situação do domicílio - Brasil - 2º trimestre de 2017

Illiteracy rate of persons 15 years and over, by urban/rural

housing units - Brazil - 2nd. Quarter - 2017

6.2 Taxa de analfabetismo das pessoas de 15 anos

ou mais de idade, por Grandes Regiões - 2º trimestre de 2017

Illiteracy rate of persons 15 years old

and over, by Major Regions - 2nd. Quarter 2017

165

6.3 Média de anos de estudo da população de 10 anos ou mais

de idade, por grupos de idade - $2^{\circ}$ trimestre de 2017

Average years of schooling of persons 10 years old and over,

by age groups - 2nd. Quarter 2017

165

\section{Trabalho Labor}

7.1 Taxa de participação na força de trabalho, na semana de referência, das pessoas de 14 anos ou mais de idade, por sexo, segundo os grupos de idade - Brasil - 2017

Labor force participation rate in the reference week of persons 14 years old and over, by sex and age groups - Brazil - 2017

7.2 Distribuição das pessoas de 14 anos ou mais de idade, ocupadas na semana de referência, por contribuição para instituto de previdência em qualquer trabalho, segundo as Grandes Regiões - 2017

Distribution of persons 14 years old and over, employed in the reference week, by contribution to social security in any job and Major Regions - 2017

7.3 Percentual de pessoas ocupadas no grupamento da indústria geral, na população de 14 anos ou mais de idade, ocupada na semana de referência, por Grandes Regiões - 2017

Percentage of employed persons in the group general industry

in the population 14 years old and over, employed

in the reference week, by Major Regions - 2017 


\section{Participação Política Political Participation}

8.1 Governadores eleitos, por partido político - 2018

Governors elected, by political party - 2018

8.2 Senadores eleitos, por partido político - 2018

8.2 - Senators elected, by political party - 2018

202

Preços Prices

9.1 Variação mensal do Índice Nacional de Preços ao Consumidor

Amplo - IPCA - 2018

Monthly change of the Extended National Consumer

Price Index IPCA - 2018

9.2 Variação mensal do Índice Nacional da Construção Civil - 2017-2018 Monthly change of the National Index of Civil Construction 2017-2018

9.3 Custos total por metro quadrado, parcela de materiais e de mão de obra - dez. 2018

Cost per square meter, total, of material and of labor force - Dec. 2018

221

9.4 Variação mensal das parcelas de materiais e de mão de obra na composição do Custo Nacional da Construção Civil - 2018 Monthly change of material and of labor force in the composition of the National Cost of Civil Construction - 2018

9.5 Variação acumulada do Custo Nacional e Custos Regionais da Construção Civil - 2018 Cumulative change of the National and Regional Costs of Civil Construction - 2018

Agropecuária Agriculture

11.1 Área plantada, quantidade produzida e valor da produção de cereais, leguminosas e oleaginosas - 2007-2017 Planted area, amount produced and value of production of cereals, legumes and oilseeds - 2007-2017

11.2 Participação das Unidades da Federação no valor da produção agrícola - 2017

Brazilian states participation in the value of agricultural production - 2017

11.3 Estoques dos principais produtos armazenados em 31.12 - 2011-2017 Stocks of main products stored on Dec 31 - 2011-2017

11.4 Peso das carcaças - 2012-2017 Weight of carcasses - 2012-2017

11.5 Participação das principais espécies na produção da piscicultura - 2017 Participation of the main species in the production of fish farming - 2017

11.6 Área total existente em 31.12 dos efetivos da silvicultura, por Grandes Regiões - 2017

Total silviculture area existing on Dec 31, by Major Regions - 2017 


\section{Indústria Industry}

12.1 Taxas anuais de crescimento da produção industrial, por grandes categorias econômicas - 2015-2018

Annual growth rates of industrial output, by major economic categories - 2015-2018

12.2 Produção de aço bruto, por países selecionados - 2017

Production of crude steel, by selected countries - 2017

12.3 Produção de aço bruto, da América Latina - 2017

Production of crude steel, in Latin America - 2017

Energia Energy

13.1 Produção de energia primária - 2005-2017

Primary energy production - 2005-2017

13.2 Evolução da oferta interna de energia - Brasil - 2005-2017

Primary Energy Supply - Brazil - 2005-2017

13.3 Evolução do consumo final de energia, por fonte - Brasil - 2005-2017

Evolution of final energy consumption, by source - Brazil - 2005-2017

13.4 Evolução do consumo final de energia, por setor - Brasil - 2005-2017

Evolution of Final energy consumption, by sector - Brazil - 2005-2017

13.5 Dependência externa de energia, por fonte - Brasil - 2005-2017

Dependence on foreign energy, by source - Brazil - 2005-2017

13.613 .6 - Evolução do consumo final de energia em relação ao valor agregado, por setor - Brasil - 2005-2017

Final energy consumption in relation to the added value, by

sector - Brazil - 2005-2017

13.7 Participação de fontes renováveis na matriz energética - 2017-2018

Share of renewable sources in the energy matrix - 2017-2018

13.8 Importação de derivados de petróleo e outros combustíveis

Brasil - 2008-2017

Imports of petroleum products and other fuels - Brazil - 2008-2017

13.9 Consumo final de energia do setor industrial e por PIB

de cada setor - Brasil - 2008-2017

Final consumption of energy in the industrial sector and

by GDP of the industrial sector - Brazil - 2008-2017

\section{Comércio Trade}

14.1 Participação dos segmentos na receita total do comércio varejista e de veículos - Brasil - 2016

14.1 - Participation of segments in total revenue of retail and

vehicle trade-Brazil - 2016

14.2 Participação dos segmentos na receita total do comércio atacadista - Brasil - 2016

Participation of activities in total revenue of whosale trade - Brazil - 2016 
14.3 Participação das empresas, por faixas de pessoal ocupado, na receita operacional líquida do comércio - 2016

Participation of companies, by ranges of employed persons, in net operating revenue of trade - 2016

14.4 Evolução da receita operacional líquida, por faixas de pessoal ocupado - 2015-2016

Evolution of net operating revenue, by ranges of employed persons - 2015-2016

14.5 Participação das empresas, por faixas de pessoal ocupado, no total de pessoal ocupado do comércio - 2016

Participation of companies in total employed persons in trade, by ranges of employed persons - 2016

\section{Transportes Transportation}

15.1 Matriz de transporte de passageiros e cargas, por modalidades - Brasil - 2018 Matrix of passenger and cargo transportation by mode - Brasil - 2018

15.2 Habitantes por autoveículo em alguns países - 2001/2015 Inhabitants per vehicle in selected countries - 2001/2015

15.3 Movimento de carga, por tipo de navegação - 2010-2018 Cargo transportation by modal of navigation - 2010-2018

15.4 Evolução da quantidade de voos - 2009-2018

Evolution of the number of flights - 2009-2018

15.5 Evolução da quantidade de passageiros transportada - 2009-2018 Evolution of the number of passengers transported - 2009-2018

15.6 Carga aérea transportada - 2009-2018 Air cargo transported - 2009-2018

\section{Turismo Tourism}

16.1 Dez cidades brasileiras mais visitadas pelos turistas estrangeiros para lazer - 2016-2017 Ten most visited cities in Brazil by foreign tourists, for leisure - 2016-2017

16.2 Despesa da balança de pagamentos da conta turismo - 2010-2017 Expenditure in the balance of payments of tourism account - 2010-2017

16.3 Receita da balança de pagamentos da conta turismo - 2010-2017 Revenue in the balance of payments of tourism account - 2010-2017

16.4 Taxa de câmbio e saldo da balança de pagamentos da conta turismo - 2008-2017 Exchange rate and balance of tourism account - 2008-2017

\section{Comunicações Communications}

17.1 Evolução dos terminais telefônicos - 2010-2018

Telephone lines in service - 2010-2018 
Finanças Públicas Public Finances

18.1 Dívida do setor público - 2008-2018

Public debt-2008-2018

18.2 Dívida líquida do setor público - 2008-2018

Public sector net debt-2008-2018

18.3 Prazo médio dos títulos federais - 2009-2018

Average term of federal securities - 2009-2018

18.4 Dívida líquida dos governos regionais - 2008-2018

Net debt of regional governments - 2008-2018

Comércio Exterior Foreign Trade

19.1 Comércio exterior - 2011-2018

Foreign trade - 2011-2018

19.2 Reservas internacionais - 2003-2018

International reserves - 2003-2018

414

Ciência e Tecnologia Science and Technology

20.1 Dispêndios do governo federal em pesquisa e desenvolvimento, por instituições - 2016

Federal government expenditures on research

and development, by institution - 2016

20.2 Artigos brasileiros publicados em periódicos científicos internacionais indexados pela Scopus e respectivo percentual em relação ao mundo - 2002-2017

Brazilian papers published in international scientific journals indexed by Scopus and respective percent contribution

in relation to the world - 2002-2017

Poder Judiciário Judicial Power

21.1 Série histórica do total de processos ingressados - 1990-2017

Time series of total issued cases - 1990-2017

21.2 Percentual de processos em tramitação, por ramo de justiça - 2017

Percentage of cases in progress, by court of justice - 2017

Meio Ambiente Environment

22.1 Desflorestamento bruto anual na Amazônia Legal - 1992-2017

Annual gross deforestation in Legal Amazon - 1992-2017

22.2 Focos de calor no Brasil, na Amazônia Legal e em Unidades de Conservação e Terras Indígenas - 2008-2017

Hot spots in Brazil, in the Legal Amazon and in Conservation Units and Indian Lands - 2008-2017

22.3 Comercialização de agrotóxicos e afins, por área plantada - Brasil - 2001-2016

Commercialization of agrochemicals and the like,

by planted area - Brazil - 2001-2016 


\section{Quadro Figure}

Participação Política Political Participation

8.1 Partidos políticos com votação - 2018

Political parties with votes -2018

\section{Mapas Maps}

\section{Território Territory}

\subsection{Mapa político do Brasil}

Political map of Brazil

1.2 Pontos extremos e pontos mais altos do País

\section{Convenções / Symbols used}

... Dado numérico não disponível; Figure not available;

.. Não se aplica dado numérico; Not applicable;

- Dado numérico igual a zero não resultante de arredondamento; Zero not resulting from rounding;

0; 0,0 Dado numérico igual a zero resultante de arredondamento de um dado numérico originalmente positivo. Originally positive numerical data rounded to zero. 


\section{Foreword}

Dear reader,

You have in your hands the 2019 edition of Brazil in Figures, a publication annually issued by the IBGE with information that enhances knowledge of important aspects of the Brazilian reality.

Each of the themes presented herein has received the contribution of renowned experts who have enriched and highlighted the data, tables and graphs with their commentaries. It is a valuable reference tool and a base for analysis and planning in a number of spheres.

This time, the publication is illustrated with works from the Iberê Foundation, located in Porto Alegre, in the state of Rio Grande do Sul. The lberê Foundation was created in 1995, aiming at maintaining, investigating and disseminating the work of Iberê Camargo, besides gathering the public of one of the greatest names figures of the Brazilian arts in the 20th century. Each chapter of the publication begins with images of artworks from the Foundation.

Brazil in Figures is compact in its format, light and easy to handle. As a bilingual publication, in Portuguese and English, the impact and scope of the information are even wider.

For more details, you can visit the IBGE page on the Internet at $<$ www.ibge.gov.br>.

Take some knowledge of Brazil with you! Read and enjoy Brazil in Figures! 


\section{Apresentação}

Prezado leitor,

Você tem em mãos o Brasil em Números, Edição 2019, publicação editada anualmente pelo IBGE contendo informações que aprofundam o conhecimento sobre importantes aspectos da realidade brasileira.

Cada assunto abordado recebeu a contribuição de destacados especialistas na área, que enriquecem e ressaltam com seus comentários os dados, tabelas e gráficos apresentados. Trata-se de um valioso instrumento de consulta e de base para análises e planejamento em diversas esferas.

Desta vez, a publicação é ilustrada com obras da Fundação Iberê, localizada em Porto Alegre, no Estado do Rio Grande do Sul. A Fundação Iberê foi criada em 1995 com a missão de preservar, investigar e divulgar a obra de lberê Camargo, além de aproximar o público deste que é um dos grandes nomes da arte brasileira do Século XX. Cada capítulo da publicação se inicia com imagens das obras de arte presentes na Fundação.

O Brasil em Números é compacto em seu formato, leve e fácil de manusear. Por ser uma publicação bilíngue, português e inglês, amplia-se ainda mais o impacto e a abrangência das informações.

Para maiores detalhes, você pode visitar a página do IBGE na Internet, no endereço $<w w w . i b g e . g o v . b r>$.

Leve conhecimento sobre o Brasil junto a você! Leia e desfrute do Brasil em Números!

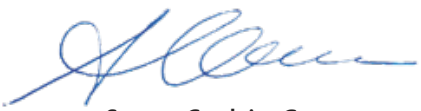

Susana Cordeiro Guerra

Presidente do IBGE / President of IBGE 



\section{Uma breve história do Brasil A brief history of Brazil}

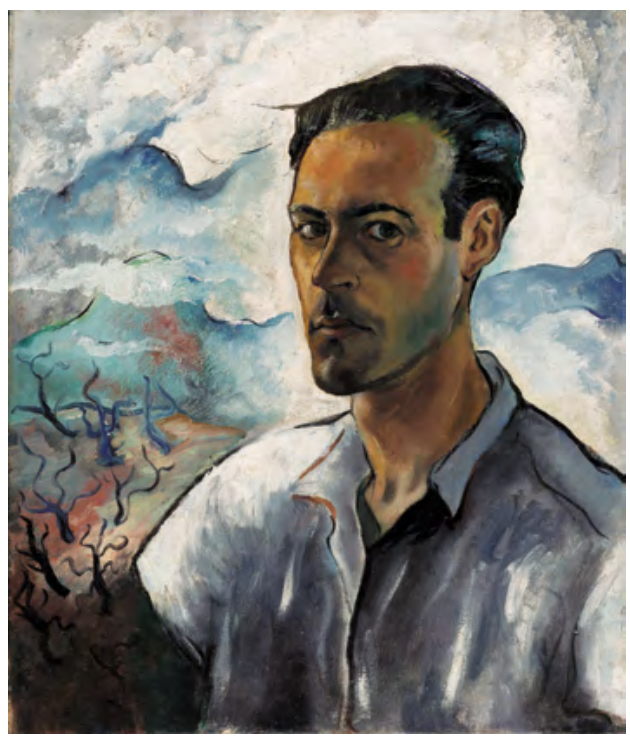

Autorretrato, [1943] Self-portrait

Iberê Camargo 


\title{
A brief history of Brazil
}

\author{
Alessander Kerber ${ }^{1}$
}

\section{Nationalism and regionalism in Carmen Miranda and Carlos Gardel}

The boom of the radio, cinema and phonographic industry, taken place in Brazil in the 1930s and in Argentina a little before that, in the 1920s, motivated the emergence of the first mass media artists that became national idles. Some of those artists acted as mediators in the construction and dissemination of the national identity versions in both countries. In this article, I will analyze the life and work of two of the most famous artists in those countries in the period, who also presented a version of those two national identities: Carmen Miranda and Carlos Gardel. The success of both artists was not bounded within the nations which they would represent, but reached the international arena, spreading an imagery concept of Brazil and Argentina to several other countries.

The artistic career of Carlos Gardel began a little before World War I. However, his greatest success comes with the recording of the song $\mathrm{Mi}$ noche triste in 1917, a tango of Samuel Castriota and Pascual Contursi. It is considered the first tango song and a milestone in the history of tango itself. From that year until his tragic death, in a plane accident in 1935, Gardel turned out to be the most successful Argentine artist and, till nowadays, he remains as the greatest tango icon.

\footnotetext{
1 Associate Professor of the History Department and of the Postgraduation Program of History of the Federal University of Rio Grande do Sul (UFRGS).
} 


\title{
Uma breve história do Brasil
}

\author{
Alessander Kerber ${ }^{1}$
}

\section{Nacionalismos e regionalismos em Carmen Miranda e Carlos Gardel}

A massificação do rádio, do cinema e da indústria fonográfica ocorrida no Brasil a partir da década de 1930 e na Argentina um pouco antes, já a partir da década de 1920, possibilitou o surgimento dos primeiros artistas de massa que se tornam ídolos nacionais. Alguns desses artistas atuaram como mediadores na construção e difusão de versões acerca das identidades nacionais nos dois países. No presente artigo, analiso a trajetória e a obra dos dois artistas de maior sucesso nesses países nesse período, os quais também apresentaram uma versão acerca dessas duas identidades nacionais: Carmen Miranda e Carlos Gardel. O sucesso destes dois artistas não se restringiu apenas às fronteiras das nações das quais se tornaram representantes, mas tornou-se internacional, difundindo um imaginário acerca do Brasil e da Argentina em vários outros países.

A trajetória artística de Carlos Gardel começou ainda antes da Primeira Guerra. Contudo, seu grande sucesso ocorre com a gravação em 1917 da canção Mi noche triste, tango de Samuel Castriota e Pascual Contursi. Essa canção é considerada o primeiro tango-canção e marco na história do tango. Desde aquele ano até sua trágica morte por acidente de avião no ano de 1935, Gardel foi o artista argentino de maior sucesso e se tornou até a atualidade o ícone máximo do tango.

1 Professor Associado do Departamento de História e do Programa de Pós-Graduação em História da Universidade Federal do Rio Grande do Sul (UFRGS). 
The artistic career of Carmen Miranda began in the end of the 1920s, but her striking success was due to the recording of the Carnival march Tahi, in 1930. Throughout the 1930s, she was the biggest LP seller and the most well-paid artist in Brazil. In 1939, she went to the United States, making a one-year career there and coming back to Brazil, in 1940. When she came back, though, she was coldly received by some of her fans and criticized as being Americanized. Feeling hurt, she went back to the United States to return only just before her death, in $1955^{2}$.

Those artists' careers coincide with a cultural turn in the most disseminated versions of national identities in both countries, by which some of the popular, ethnic and regional profiles - previously not considered - began to feature as national representations. Carmen and Gardel played a part in the process of construction and dissemination of those representations as national profiles.

The turn was not restricted to the massification of the means of communication in which the artists featured. In the political sphere, a year before Gardel's boom with Mi noche triste, in Argentina, Hipólito Yrigoyen of the União Cívica Radical (Civic radical Union - UCR) had won the elections, which represented a victory of the urban average segments, of immigrants and, to some extent, of workers against oligarchies that had dominated the Argentinian politics so far. Simultaneously, the tango, previously associated with the outskirts, prostitutes, marginal people, became the most successful musical style of Argentina, present also in the Buenos Aires' high-society spheres after the success reached in France.

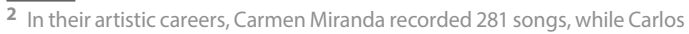
Gardel, 930. A great part of those songs deals precisely with representing Brazil and Argentina. Concerning movies, Carmen worked in A voz do Carnaval (1933), directed by Adhemar Gonzaga and Humberto Mauro (Cinédia); Alô, alô, Brazil (1935), directed by Wallace Downey, João de Barro and Alberto Ribeiro (WaldowCinédia); Estudantes (1935), directed by Wallace Downey (Waldow-Cinédia); Alô, alô, Carnaval (1936), directed by Adhemar Gonzaga (Waldow-Cinédia); Banana da terra (1938), directed by Wallace Downey (Sonofilmes); Down Argentine way (1940), directed by Irving Cummings (Fox). However, some of the oldest movies she worked in are no longer available. Gardel featured, in 1930, in ten short films in which, in each of them, he sings a song of his: Añoranzas; Cancero; Enfundála mandolina; Mano a mano; El carretero; Padrino pelado; Rosa de otoño; Tengo miedo; Viejo smoking; Yira, Yira. He also featured in Luces de Buenos Aires (1931), directed by Adelqui Millar (Paramount); Esperame (1932), directed by Luis Gasnier (Paramount); La casa es seria (1932), directed by Jaquelux (Paramount); Melodía de arrabal (1933), directed by Luis Gasnier (Paramount); Cuesta abajo (1934), directed by Luis Gasnier (Paramount); El tango en Broadway (1934), directed by Luis Gasnier (Paramount); The big broadcast of 1935 (1935), directed by Norman Taurog and Theodore Reed (Paramount); El día que me quieras (1935), directed by John Reinhardt (Paramount); Tango Bar (1935), directed by John Reinhardt (Paramount). 
A trajetória artística de Carmen Miranda começou no final dos anos 1920, mas seu estrondoso sucesso se deu a partir da gravação da marchinha de carnaval Tahi, em 1930. Durante toda a década de 1930, foi a maior vendedora de discos e artista mais bem paga do Brasil. Em 1939, ela embarcou para os Estados Unidos, fazendo um ano de carreira por lá e voltando para o Brasil, em 1940. Na sua volta, foi recebida com frieza por alguns setores de seu público e criticada como americanizada. Magoada, ela voltou para os Estados Unidos para só voltar pouco antes de sua morte, em $1955^{2}$.

A trajetória artística desses artistas coincide com um período de mudanças nas versões mais difundidas sobre as identidades nacionais nos dois países, no qual determinadas representações populares, étnicas e regionais, anteriormente excluídas, passaram a ser apresentadas como nacionais. Carmen e Gardel atuaram nesse processo de construção e difusão dessas representações como nacionais.

Essas mudanças não se referem apenas à massificação desses meios de comunicação nos quais os artistas atuaram. No âmbito político, um ano antes do sucesso de Gardel com Mi noche triste havia ocorrido, na Argentina, a vitória eleitoral de Hipólito Yrigoyen da União Cívica Radical (UCR), o que representou uma vitória de segmentos médios urbanos, de imigrantes e em alguma medida de trabalhadores contra as oligarquias que dominavam a política argentina até então. Nesse mesmo período, o tango, anteriormente associado aos subúrbios, à prostituição, aos excluídos passou a ser o estilo musical de maior sucesso na Argentina, passando inclusive a estar presente nos salões da alta sociedade portenha depois que obteve sucesso na França.

2 Em suas trajetórias artísticas, Carmen Miranda gravou 281 canções e Carlos Gardel 930. Grande parte dessas canções tratam justamente de representar o Brasil e a Argentina. No cinema, Carmen atuou nos filmes A voz do Carnaval (1933), dirigido por Adhemar Gonzaga e Humberto Mauro (Cinédia); Alô, alô, Brasil (1935), dirigido por Wallace Downey, João de Barro e Alberto Ribeiro (Waldow-Cinédia); Estudantes (1935), dirigido por Wallace Downey (Waldow-Cinédia); Alô, alô, Carnaval (1936), dirigido por Adhemar Gonzaga (Waldow-Cinédia); Banana da terra (1938), dirigido por Wallace Downey (Sonofilmes); Down Argentine way (1940), dirigido por Irving Cummings (Fox). Contudo, alguns dos filmes mais antigo que contaram com sua participação não existem mais. Gardel atuou, em 1930, em dez curtas nos quais, em cada um, canta um número de seu repertório: Añoranzas; Cancero; Enfundá la mandolina; Mano a mano; El carretero; Padrino pelado; Rosa de otoño; Tengo miedo; Viejo smoking; Yira, Yira. Também atuou em Luces de Buenos Aires (1931), dirigido por Adelqui Millar (Paramount); Esperame (1932), dirigido por Luis Gasnier (Paramount); La casa es seria (1932), dirigido por Jaquelux (Paramount); Melodía de arrabal (1933), dirigido por Luis Gasnier (Paramount); Cuesta abajo (1934), direção de Luis Gasnier (Paramount); El tango en Broadway (1934), dirigido por Luis Gasnier (Paramount); The big broadcast of 1935 (1935), dirigido por Norman Taurog e Theodore Reed (Paramount); El día que me quieras (1935), dirigido por John Reinhardt (Paramount); Tango Bar (1935), dirigido por John Reinhardt (Paramount). 
In Brazil, the year of astonishing success of Carmen with Tahi was marked by the 1930 Revolution, which also represented a political defeat to the old oligarchies of the Café com leite 3 politics and beginning of a process through which black and mixed popular segments began to have some of their cultural production, as Carnival and samba, acknowledged as national representations.

Carmen and Gardel also had the project of representing Brazil and Argentina, although they had not been born in those countries. Carmen Miranda was born in Portugal, in 1909, and her family migrated to Brazil in 1910. This piece of information was kept secret in the beginning of her career. Her behavior and speech, often resorting to popular slangs of Rio de Janeiro, made it difficult for anyone to guess she was an immigrant. When the information about her Portuguese origin leaked, a journalist of the newspaper El País asked her if she had been born in Rio. She answered that she was "a daughter of Portugal, although her heart was Brazilian."

Gardel was not born in Argentina either. There are two main versions about his origin: one, defended by the Uruguayans, that he would have been born in Taquarembó, in the countryside of that country; and another that he would have been born in France. In both versions, he would have migrated to Argentina in his childhood with his mother. Anyway, in most of his songs and movies, whenever there is a reference to a national identity, it is Argentina that is depicted. Gardel, as Carmen, also tried to hide his immigrant origin. When asked about his real nationality by a journalist, he answered: "Mi patria es el tango" and "Soy ciudadano de la calle Corrientes".

In the songs and movies of Carmen and Gardel, there are several symbols that represent Rio de Janeiro and Buenos Aires. However, despite the identification with both cities, Carmen and Gardel sought representativeness of other regional identities in the construction of their imagery. More specifically, Carmen became famous wearing baiana ${ }^{4}$ costumes, whereas Gardel, to a large extent, used the image of the gaucho, related to the Argentinian countryside. They used to wear costumes seen as typical of those regions (Gardel, in the beginning of his career and in some presentations, especially in Europe and, Carmen,

3 A period of Brazilian politics dominated by the landed gentries of São Paulo (coffee producers) and Minas Gerais (dairy farmers). The name alludes to the popular beverage café com leite, "coffee with milk", referring to the states' respectively dominant industry.

${ }^{4}$ Women from the state of Bahia, usually those who sell "acarajé", a typical dish of the state. 
No Brasil, o ano do estrondoso sucesso de Carmen com Tahi foi marcado pela Revolução de 1930, que também representou uma derrota política das antigas oligarquias da política do Café com Leite e início de um processo através do qual segmentos populares urbanos negros e mestiços passaram a ter algumas de suas manifestações culturais, como o carnaval e o samba, apresentados como representação nacional.

Carmen e Gardel também tinham o projeto de representar o Brasil e a Argentina, apesar de não terem nascido nesses países. Carmen Miranda nasceu em Portugal, em 1909, e sua família imigrou para o Brasil em 1910. Essa informação foi mantida em segredo no começo de sua carreira. Seu comportamento e sua fala, empregando constantemente gírias populares do Rio de Janeiro, faziam com que fosse difícil alguém imaginar sua origem imigrante. Quando vazou a informação de que era portuguesa, um jornalista do jornal $O$ País lhe perguntou se ela nascera no Rio. Ela respondeu que "era filha de Portugal, embora seu coração fosse brasileiro".

Gardel também não nasceu na Argentina. Há duas principais versões sobre sua origem, uma defendida pelos uruguaios de que ele teria nascido em Taquarembó, no interior daquele país, e outra que teria nascido na França. Em ambas as versões ele imigrou para a Argentina na infância com sua mãe. De qualquer forma, a maior parte de suas canções e filmes, quando ocorre referência a alguma identidade nacional, se trata da Argentina. Gardel, como Carmen, também tentou esconder sua origem imigrante. Quando perguntado sobre sua real nacionalidade por algum jornalista, respondeu: "Mi patria es el tango" e "Soy ciudadano de la calle Corrientes".

Encontram-se nas músicas e filmes de Carmen e de Gardel vários símbolos que representam o Rio de Janeiro e Buenos Aires. Contudo, apesar dessa identificação com ambas as cidades, Carmen e Gardel buscaram representações de outras identidades regionais na construção de suas imagens. Mais especificamente, Carmen ficou consagrada com a imagem de baiana, enquanto que Gardel, em grande medida, utilizou a imagem do gaucho, ligada ao interior argentino. Eles utilizaram-se de vestimentas consideradas típicas dessas regiões (Gardel em seu início de carreira e em algumas apresentações, principalmente na Europa e, Carmen, a partir de 1938). Além de estarem associadas a determinadas regiões, as imagens do gaucho e da baiana, vendendo suas comidas típicas, representam identidades populares, o que denota que esses artistas se afirmavam como populares e afirmavam símbolos de grupos populares como legitimamente nacionais. 
as of 1938). Besides being associated to certain regions, the images of the gaucho and of the baiana, selling their typical foods, representing popular identities, demonstrate that the artists reaffirmed themselves as popular and set popular groups symbols' as legitimately national.

The image of the baiana built by Carmen also fits in the ideology of miscegenation, which began being disseminated in Brazil in the 1930s. The cloth on her back, referring to the African heritage, the Bonfim $^{5}$, pointing out to the Candomblé religion, then the golden rosary, relating to Catholicism. In the end, the baiana was presented by Carmen as the representation that best expresses that synthetic nature of Brazil. And, most importantly, a harmonious synthesis, representing the popular layers of Brazil in pacific coexistence with the elites - hiding the class and ethnic-cultural conflicts, which was in line with the ideology largely emphasized by the National State.

In Argentina, whose history was marked exactly by the conflict between town and country, between Buenos Aires and the countryside, between civilization and barbarism, Gardel used basically two images: that of the gaucho and that of the sophisticated man of Buenos Aires. However, he presented a certain blend of those two images. For example, in the movie El día que me queiras, of 1935, Gardel plays a gaucho wearing not traditional hat, but the cosmopolitan one, worn in the 1930s on the streets of big cities as Paris, New York and... Buenos Aires. In that same movie, one can also see that the handkerchief tied to his neck, a typical garment of the gaucho, is to the side. Were it not for the other gauchos with a handkerchief around the neck next to him, whoever saw that image would probably get in doubt as to the item: whether it was a handkerchief or a scarf, commonly worn by the sophisticated men of cold-weather countries.

In this sense, one could say that Carmen and Gardel built versions of the Brazilian and Argentinian national identities, mixing symbolic elements of distinct popular identities, ethnicity and regions.

The building of national identity versions is linked to the existing powers, since the very choice and use of symbols as national representations does, at the same time, discriminate whomever belongs or does not belong to the nation, who is part of it and who is not, the hierarchy, what should and what should not be valued. In the Brazilian and Argentinian cases, the careers of Carmen Miranda and Carlos Gardel help explain some of those choices.

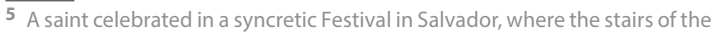
Bonfim Church are washed.
} 
A figura da baiana construída por Carmen também vai ao encontro da ideologia da miscigenação, que passou a ser promovida no Brasil nos anos 1930. O pano da costa, lembrando a herança africana, o Bonfim, que lembrava o Candomblé, logo após o rosário de ouro, que lembrava a Igreja Católica. Enfim, a baiana era apresentada por Carmen como a representação que melhor expressaria essa forma de síntese do Brasil. E, importante, uma síntese harmônica, que representava as camadas populares brasileiras em convívio pacífico com as elites, ocultando os conflitos de classe e étnico-raciais, convergindo com essa ideologia que passou a ser promovida pelo Estado Nacional.

Na Argentina, cuja história foi marcada justamente por conflitos entre a cidade e o campo, entre Buenos Aires e o interior, entre civilização e barbárie, Gardel utilizou basicamente duas imagens: a do gaucho e a do homem sofisticado de Buenos Aires. Contudo, ele apresentava certa mescla entre estas duas imagens. Por exemplo, no filme El día que me quieras, de 1935, Gardel, apresenta um gaucho utilizando um chapéu não tradicional, mas o cosmopolitamente presente, nos anos 1930, nas ruas de grandes cidades como Paris, Nova lorque e... Buenos Aires. No mesmo filme, também se percebe que o lenço amarrado em seu pescoço, peça típica da indumentária do gaucho, está amarrado para o lado. Se não houvesse outros gauchos com lenço no pescoço ao lado dele, quem visualizasse essa imagem provavelmente ficaria em dúvida se tratava-se de um lenço ou de um cachecol, comumente usado por homens sofisticados de vários países de clima frio.

Nesse sentido, poder-se-ia afirmar que Carmen e Gardel construíram versões acerca das identidades nacionais brasileira e argentina misturando elementos simbólicos de distintas identidades populares, étnicas e regionais.

A construção de versões sobre as identidades nacionais está ligada às relações de poder existentes, pois ao se escolher determinados símbolos e afirmá-los como representações nacionais se está, ao mesmo tempo, dizendo quem faz e quem não faz parte da nação, quais são os incluídos e os excluídos, qual é a hierarquia, o que deve ser valorizado e promovido e o que não. Para os casos brasileiro e argentino, as trajetórias artísticas de Carmen Miranda e de Carlos Gardel ajudam a explicar algumas dessas escolhas. 


\section{References}

BARSKY, O.; BARSKY, J. Gardel: la biografia. Buenos Aires: Taurus, 2004.944 p.

CAPELATO, M. H. R. Multidões em cena: propaganda política no varguismo e no peronismo. São Paulo; Campinas: Fapesp: Papirus, 1998. 311 p. (Textos do tempo).

GARCIA, T.C.O itverde e amarelo de Carmen Miranda: 1930-1946. São Paulo: Fapesp: Annablume, 2004. 251 p. Originally presented as the author's dissertation (Doctoral program-São Paulo University, 2001).

GARRAMUÑO, F. Modernidades primitivas: tango, samba e nação. Belo Horizonte: Ed. UFMG, 2009. 219 p. (Humanitas).

KERBER, A. Carlos Gardel e Carmen Miranda: representações da Argentina e do Brasil. Porto Alegre: Ed. UFRGS, 2014. 223 p. Originally presented as the author's dissertation (Doctoral program-Federal University of Rio Grande do Sul, 2007). 


\section{Referências}

BARSKY, O.; BARSKY, J. Gardel: la biografia. Buenos Aires: Taurus, 2004. 944 p.

CAPELATO, M. H. R. Multidões em cena: propaganda política no varguismo e no peronismo. São Paulo ; Campinas: Fapesp : Papirus, 1998. 311 p. (Textos do tempo).

GARCIA, T. C. O it verde e amarelo de Carmen Miranda: 1930-1946. São Paulo: Fapesp: Annablume, 2004. 251 p. Originalmente apresentada como tese do autor (doutoradoUniversidade São Paulo, 2001).

GARRAMUÑO, F. Modernidades primitivas: tango, samba e nação. Belo Horizonte: Ed. UFMG, 2009. 219 p. (Humanitas).

KERBER, A. Carlos Gardel e Carmen Miranda: representações da Argentina e do Brasil. Porto Alegre: Ed. UFRGS, 2014. 223 p. Originalmente apresentada como tese do autor (doutorado-Universidade Federal do Rio Grande do Sul, 2007). 



\section{Território Territory}

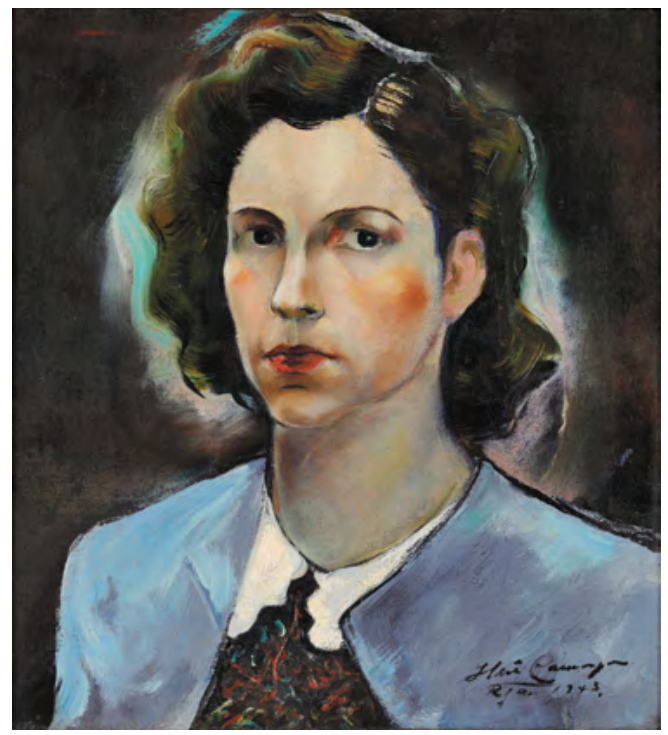

Retrato de Maria Coussirat Camargo, 1943 Portrait of Maria Coussirat Camargo

Iberê Camargo 


\section{Territory}

\section{Marcos Aurelio Saquet ${ }^{1}$}

The formation of the Brazilian territory is the result of multiple contributions, considering, therefore, different trans-multiscale and trans-temporal relations put into effect through the centuries. Historically and geographically speaking, the territory is a condition and a product of society-nature relations, in its geopolitical, economic, cultural and environmental multidimensionality (SAQUET, 2015). Thus, Brazil, as a territorial formation, comprises a myriad of elements and processes, social classes and groups, climates and reliefs, vegetation and waters, original and transformed due to class and imperialist interests which mark our people culturally, and in a violent way. We refer to the mass, sacrificed, proletarian, rough - sertanejo ${ }^{2}$, caboclo, Creole, bumpkin, gaucho -, antagonistic, disparate, stratified, oppressed, endured, of Tupi, Lusitano, mameluco (Brazilindia), African - introduced in Brazil from 1538 onward -, Italian, German, Japanese and Polish origin, among others (RIBEIRO, 2015). Historically, a people that worked hard to build a country of continental size, with $8,510,820.623 \mathrm{~km}^{2}$, unevenly distributed among the Brazilian macro-regions, especially in the North, with $45.25 \%$ of the total area of the country $(3,851,281.390 \mathrm{~km} 2)$ and in the Central-West, with $18.87 \%(1,606,239.030 \mathrm{~km} 2)$ (Table 1.1).

1 PhD in Geography (São Paulo State University "Júlio de Mesquita Filho" - UNESP) and Post-Doctoral researcher in Territory and Development from the Polytechnic University of Turin (UniTO). Associate Professor at the State University of Western Paraná (Unioeste), Postgraduate Program in Sustainable Rural Development (PPGDRS) and researcher for the Territorial Studies Group (GETERR).

2 Sertanejo is the person who lives in the country. 


\title{
Território
}

\author{
Marcos Aurelio Saquet ${ }^{1}$
}

A formação do território brasileiro é resultado de múltiplas determinações considerando-se, portanto, distintas relações transmultiescalares e transtemporais efetivadas ao longo dos séculos. O território é, histórica e geograficamente, condição e produto das relações sociedade-natureza, em sua pluridimensionalidade geopolítica, econômica, cultural e ambiental (SAQUET, 2015). Assim, o Brasil, como uma formação territorial, contém uma miríade de elementos e processos, grupos e classes sociais, climas e relevos, vegetações e águas, originários e transformados em virtude dos interesses classistas e imperialistas que marcam, cultural e violentamente, nosso povo. Referimo-nos ao povo-massa, sacrificado, proletário, rústico (sertanejo, caboclo, crioulo, caipira, gaúcho), antagônico, díspar, estratificado, oprimido, sofrido, de matriz tupi, lusitana, mameluca (brasilíndia), africana (introduzidos no Brasil a partir de 1538), italiana, alemã, japonesa, polonesa, entre outros (RIBEIRO, 2015) . Povo que trabalhou muito, historicamente, para construir um país de tamanho continental, com $8510820,623 \mathrm{~km}^{2}$, distribuídos desigualmente entre as macrorregiões brasileiras, especialmente no Norte com 45,25\% da área total do País (3 $851281,390 \mathrm{~km}^{2}$ ) e

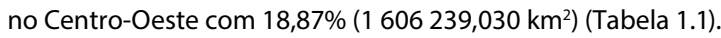

1 Doutor em Geografia (Universidade Estadual Paulista "Júlio de Mesquita Filho" - UNESP) e Pós-Doutor em Território e Desenvolvimento pelo Politécnico e Università di Torino (UniTO). Professor Associado da Universidade Estadual do Oeste do Paraná (Unioeste), Programa de Pós-Graduação em Desenvolvimento Rural Sustentável (PPGDRS) e pesquisador do Grupo de Estudos Territoriais (GETERR). 


\section{The Portuguese conquest}

Thousands of Indigenous and Africans were killed in Latin America by the Portuguese and Spanish, enslaved and treated with discrimination and violence, whereas, before the conquest, the Indigenous lived happily, scattered over the territory with their languages and other original traditions (RIBEIRO, 2015). With their rituals and chants, their dances and creeds, cosmologies and thoughts, the Indigenous lived integrated with nature, with unique tastes and knowledge, identities and important communal values, reproduced century after century in the midst of the social conflicts, differences and contradictions.

After the Portuguese invasion and conquest, Brazil faced domination and slavery, extraction and exploitation of natural resources, political strengthening of the rural aristocracy, establishment of unproductive landlords by means of sesmarias ${ }^{3}$, expansion of the Portuguese empire territory, foreign immigration - Germans, Italian, Polish, Swiss and Japanese, among others -, increasing production of goods to trade in Europe - sugar, coffee, rubber, cacao -, as well as the implementation of the salaried labor, urbanization and the genesis of modern industry drastically breaking that Indigenous territorial organization. Capitalist modernism, brutal and destructive, overwhelmingly prevails (FALS BORDA, c2001), implementing the Christianization and territorial division of labor, inciting its social and sexual division, spreading viruses and bacteria, together with the (de)materialization of the subordination of the original Brazilian people.

\section{Portuguese and Brazilian territorial expansion}

According to Prado Júnior (1986), the Portuguese settlement expanded at first (1640-1770), followed by the heyday of the Colony (1770-1808), going through slavery, its abolishment due to foreign pressure, especially from England, until the bourgeois aurora, with the liberal boost post-1930 based on the so-called urban-industrial development model. The territory had been thoroughly shaped and delimited since the Treaty of Tordesillas in 1494, and tentatively administered by means of the 15 Hereditary Captaincies. The discovery of mines of gold and silver by the Spanish in the 16th century in Mexico, Peru and Bolivia led to the expansion of mercantile and imperial capitalism, an explorer of natural resources, deepening the geopolitical conflicts in Latin America. Between 1580 and 1640, the Portuguese made a number of raids into the territory, looking for Indigenous peoples to enslave,

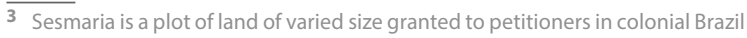
by the Portuguese monarchy in recognition of service to the crown. 


\section{A conquista portuguesa}

Milhares de indígenas e africanos foram mortos na América Latina pelos portugueses e espanhóis, escravizados e violenta e discriminadamente tratados, sabendo-se que, antes da conquista, os indígenas viviam alegres, espalhados com suas línguas e demais costumes originais (RIBEIRO, 2015). Com seus rituais e cantos, suas danças e crenças, cosmologias e pensamentos, os indígenas viviam integrados com a natureza, com saberes e sabores singulares, identidades e importantes valores comunitários, reproduzidos secularmente em meio às contradições, diferenças e conflitos sociais.

No Brasil, a partir da invasão e conquista portuguesa, acontece a dominação e a escravidão, a extração e exploração das riquezas naturais, o fortalecimento político da aristocracia rural, a instituição do latifúndio improdutivo por meio das sesmarias, o alargamento imperial do território português, a imigração estrangeira (alemães, italianos, poloneses, suíços, japoneses, entre outros), o incremento da produção de mercadorias para comercialização na Europa (açúcar, café, borracha, cacau), bem como a implantação do trabalho assalariado, a urbanização e a gênese da indústria moderna, rompendo-se drasticamente com aquela organização territorial indígena. Há predomínio avassalador do modernismo capitalista, cruel e destrutivo (FALS BORDA, c2001), implantando-se a cristianização e a divisão territorial do trabalho, acirrando-se a divisão social e sexual do mesmo, difundindo-se vírus e bactérias, juntamente com a (i)materialização da subalternização do povo brasileiro originário.

\section{A expansão territorial portuguesa e brasileira}

Inicialmente, segundo Prado Júnior (1986), ocorre a expansão da colonização portuguesa (1640-1770), seguida pelo apogeu da Colônia (1770-1808), passando pela escravidão, por sua abolição em virtude da pressão estrangeira, sobretudo inglesa, até a aurora burguesa, com a impulsão liberal do pós-1930 a partir do chamado modelo de desenvolvimento urbano-industrial. Já a partir do Tratado de Tordesilhas, em 1494, tenta-se dar forma e delimitar o território conquistado a ferro e fogo, tentando-se administrá-lo por meio das 15 Capitanias Hereditárias. Com a descoberta de minas de ouro e prata pelos espanhóis, a partir do Século XVI, no México, no Peru e na Bolívia, ocorre a expansão do capitalismo mercantil, imperial e exploratório das riquezas naturais, agravando-se os conflitos geopolíticos na América Latina. Entre 1580 e 1640, os portugueses fizeram várias incursões no território, procurando indígenas para escravizar, ouro, prata e diamantes. E, como deveriam estar restritos a uma estreita faixa litorânea, os portugueses invadiram 
for gold, silver and diamonds. Restricted to a narrow coastal stretch, the Portuguese invaded Spanish lands, expanding their territorial domains beyond the Meridian of Tordesillas by means of, for example, the foundation of Colônia do Sacramento in 1680, near Buenos Aires, and of a number of military camps in the Indigenous lands.

The disputes and guerillas led to another treaty, that of Madrid, in 1750, establishing other limits and borders: the Portuguese ceded Colônia do Sacramento and received from the Spanish the Jesuit reductions in the south of Brazil. It was like a decision, from thousands of kilometers away, to exterminate thousands of Indigenous and constructions built by Spanish Jesuit priests. Limits mean a socially established division. As such, they were constantly trespassed due to strategic projects of Portugal and Spain. Therefore, the Treaty of Saint Ildefonso was signed in 1777, which reinforced the Spanish domination in the Prata basin and confirmed the Portuguese territorial expansion. The mobility and spirit of domination of the bandeirantes ${ }^{4}$ were key to open ways that worked as paths for the Portuguese expansion (ANDRADE, 1989, 1995).

The idea of border emerges with the Modern State from the 14th and 15th centuries onward. Initially plotted as an imaginary line on the maps and vaguely practiced by the governments, borders become a reality in the 18th century, due to the need to establish the points and lines that marked the sovereignty of a State, as it was redefined in Brazil along the 19th century and beginning of the 20th century.

Brazil, Argentina, Uruguay and Paraguay were involved in a series of conflicts, both internally and externally, until 1870, when the Paraguayan War was over (1864-1870). In that war, Argentina and Brazil, supported by England, destroyed part of Paraguay, substantially eliminating its population and strengthening themselves both economically and geopolitically. According to Andrade (1989), some border issues were only defined in the of the 19th century and beginning of the 20th century, like the Guyanas Issue, Acre Issue and Palmas Issue.

The Brazilian Empire begins in 1822 with the proclamation of the country's political independence, though the conflicts remained. During the 19th century, other very important processes occurred, like the abolition of slavery (1888), abolition of slave trade (1850), expansion of coffeegrowing, increase in the salaried labor, development of some cities in

\footnotetext{
4 Bandeirantes are 16th-18th-century Portuguese explorers in Brazil motivated by profit, known for hunting down natives for slaves as well as for locating mines of precious stones and metals.
} 
terras espanholas, aumentando seus domínios territoriais além do Meridiano de Tordesilhas como, por exemplo, através da fundação, em 1680, da Colônia do Sacramento, próxima de Buenos Aires, e de muitos acampamentos militares dispersos nas terras indígenas.

As disputas e guerrilhas acabaram condicionando outro tratado, o de Madri, em 1750, estabelecendo-se outros limites e fronteiras: os portugueses cederam a Colônia do Sacramento e receberam dos espanhóis as reduções jesuíticas do sul do Brasil. Foi como se decretasse, a milhares de quilômetros, a aniquilação de milhares de indígenas e das construções edificadas sob ordenamento dos padres jesuítas espanhóis. Os limites significam divisão socialmente definida, assim, foram transgredidos constantemente em virtude dos projetos estratégicos de Portugal e Espanha. Dessa forma, assinou-se, em 1777, o Tratado de Santo Ildefonso, que reforçou a dominação espanhola na Bacia do Prata e confirmou a expansão territorial portuguesa. A própria mobilidade e o espírito de dominação dos bandeirantes foram centrais na abertura de caminhos que funcionavam como vias da expansão portuguesa (ANDRADE, 1989, 1995).

A ideia de divisa emerge com o Estado Moderno a partir dos Séculos XIV-XV. Inicialmente como uma linha imaginária traçada nos mapas e confusamente praticada pelos governos, a divisa afirma-se concretamente no Século XVIII, em virtude da necessidade de determinar os pontos e linhas que marcavam a soberania de um estado, como se redefine, no Brasil, no decorrer do Século XIX e início do XX.

Há uma série de confrontos que se estabelecem tanto interna como externamente, envolvendo o Brasil, a Argentina, o Uruguai e o Paraguai, até 1870, quando termina a Guerra do Paraguai (1864-1870). Nessa guerra, a Argentina e o Brasil, com o apoio da Inglaterra, destroem parte do Paraguai, eliminando substancialmente sua população e se fortalecendo tanto econômica como geopoliticamente. Algumas questões de fronteira, conforme Andrade (1989), somente foram definidas no final do Século XIX e início do XX, como a Questão das Guianas, a Questão do Acre e a Questão de Palmas. Com a proclamação da independência política do Brasil, em 1822, configurase o início do Brasil Império, sem anular os conflitos em curso. Durante o Século XIX, também ocorrem outros processos muito importantes, como a abolição da escravatura (1888), a abolição do tráfico negreiro (1850), a expansão da cafeicultura, o aumento do trabalho assalariado, crescem algumas cidades do litoral brasileiro e se intensifica a imigração estrangeira, principalmente, a europeia, com alemães (1824) e italianos (1870). São processos que resultam de mudanças econômicas, geopolíticas 
the Brazilian coastline and improvement of the foreign immigration, especially from Europe, like the Germans (1824) and Italians (1870). They are processes that result from economic, geopolitical and cultural changes occurred in Brazil and at international level since the end of the 18th century, which are the basis for the reorganization of the Brazilian society and territory.

With the creation of the Federative Republic of Brazil in 1889, the hegemonic class creatively reproduced itself, fostering industrialization, followed by urbanization, favelization, agricultural modernization and, at the same time, continuing the political and ideological domination based on military mechanisms, either popular or democratic. This process continues to produce extreme inequalities in the country and in the cities, decrease of the agricultural diversity, predominance of large-scale monoculture, introduction of genetically-modified organisms, use of chemical inputs and machinery, rural expropriation, water contamination and soil erosion, among others (SAQUET, 2017). And one of the recent products of the colonization and appropriation of the Brazilian territory is the political-administrative division into municipalities. In 1940, Brazil had 1,574 municipalities, changing to 5,507 in 2000 (+249.9\%), mainly concentrated in the Northeast $(1,203)$ and Southeast $(1,025)$ (Table 1.2a). From the 2000s onward, considering the continental size and the total population, the number of Brazilian municipalities remains virtually the same, changing to 5,570, in 2018 (Table 1.2b).

It is true that the occupation and evolution of the Portuguese settlement are inherent to the expansion of capitalism at the international level, directly affecting the formation of the Brazilian territory: from mining to the culture of cacao, coffee and sugarcane, to the extraction of rubber in the Amazon, to the foreign immigration in the 19th and 20th centuries, to the March to the West, to the modernization of agriculture, to urbanization, those all are key processes to establish the limits and borders of Brazil as a Nation State. A territory expanded and built under the Portuguese imperialism until the beginning of the 19th century, based on slave labor, expropriation and killing of Indigenous populations, extraction and exports of natural resources, regional oligarchies, going through the English domination until mid-20th century, culminating in the North-American hegemony, especially at political, economic financial, industrial and technological - and military levels. A diverse and plural people, virtually without any decision-making autonomy and without the necessary conditions for a decent life, in spite of the Brazilian diversity and natural and social wealth, distributed along the 
e culturais ocorridas no Brasil e em nível internacional, desde o final do Século XVIII, e que estão na base da reorganização da sociedade e do território brasileiro.

Com o evento da República Federativa do Brasil, a partir de 1889, a classe hegemônica se reproduz criativamente, promovendo a industrialização acompanhada pela urbanização, pela favelização, pela modernização agropecuária e, ao mesmo tempo, dando continuidade à dominação ideológica e política com base em mecanismos militares, porém, também, ora ditos populares, ora democráticos. Esse processo continua gerando desigualdades extremas no campo e na cidade, diminuição da diversidade agrícola, predomínio de monocultivos em grande escala, introdução de organismos geneticamente modificados, utilização de insumos químicos e da maquinaria, expropriação rural, contaminação da água, erosão do solo, entre outros (SAQUET, 2017). E um dos produtos recentes do processo de colonização e apropriação do território brasileiro é a divisão político-administrativa em municípios. Em 1940, o Brasil tinha 1574 municípios, passando para 5507 no ano de 2000 (+249,9\%), concentrados principalmente no Nordeste (1 203) e no Sudeste (1 025) (Tabela 1.2a). A partir dos anos 2000, considerando o tamanho continental e o total da população, a quantidade de municípios brasileiros se mantém praticamente a mesma, passando para 5 570, em 2018 (Tabela 1.2b).

O fato é que os processos de ocupação e avanço da colonização portuguesa são inerentes ao movimento de expansão do capitalismo no nível internacional, rebatendo diretamente na formação do território brasileiro: desde a mineração, passando pelo cultivo de cacau, café e cana-de-açúcar, extração da borracha na Amazônia, até a imigração estrangeira dos Séculos XIX e XX, a Marcha para o Oeste, a modernização da agricultura e a urbanização, todos são processos fundamentais na definição dos limites e das fronteiras do Brasil como Estado-Nação. Território expandido e construído sob o imperialismo português até o início do Século XIX, com base no trabalho escravo, na expropriação e matança dos indígenas, na extração e exportação de riquezas naturais, nas oligarquias regionais, passando pela dominação inglesa, até meados do Século XX, culminando na hegemonia norte-americana, especialmente política, econômica (financeira, industrial e tecnológica) e militar. Povo diverso e plural, praticamente sem autonomia decisória e sem as necessárias condições para uma vida digna, apesar da diversidade e riqueza brasileiras, naturais e sociais, distribuídas entre a nascente do Rio Ailã (Uiramutã, RR) e o Arroio Chuí (Santa Vitória do Palmar, RS) 
Ailã River (Uiramutã, RR) and the Chuí Stream (Santa Vitória do Palmar, RS) - 4,378.349 km, between Seixas Point (Cabo Branco, João Pessoa) and the headwaters of Moa River (Márcio Lima, AC) - 4,326.61 km (Table 1.3).

\section{To discuss and reflect}

In the process described above, many local histories - from Latin America and Brazil - have become unimportant since the European rebirth, the English Industrial Revolution, the French Revolution and the Illuminism (MIGNOLO, [2003]), with the burning, for example, of Indigenous codices, since they were considered primitive, yet to be civilized from 1552 onward, after many of them were enslaved as they were considered soulless beings (GROSFOGUEL, 2016). Today, different and complex mechanisms exert the neo-liberal hegemony, with culturally, politically and economically-dominant classes, many times refraining popular construction of people's own emancipation.

To deepen such understanding, to discuss and reflect in order to produce solutions for the Brazilian people, we believe that we should know our territorial singularities, by investing in (in)formation, popular participation, conviviality and shared management, for understanding the territories and times and specifically contribute to the return to the territory and its inhabitants (BECATTINI; MAGNAGHI, 2015). This process of return to the territory requires identification, understanding, explanation and valuation of the identities and ecosystems, of communal bonds, subjects, knowledge and self-management and, at the same time, it demands strengthening the levels of class and place consciousness as a key mediation in the daily fight and in the construction of the territorial development in a perspective which is popular, autonomous and against the imperialist hegemony (SAQUET, 2017).

\section{References}

ANDRADE, M. C. de. Geopolítica do Brasil. São Paulo: Ática, 1989. 64 p. (Princípios, n. 165).

ANDRADE, M.C. de.Aquestão do território no Brasil. São Paulo: Hucitec:IPESP, 1995. 135 p. (Geografia: teoria e realidade, 29).

BECATTINI, G.; MAGNAGHI, A. Coscienza di classe e coscienza di luogo. In: BECATTINI, G.; MAGNAGHI, A. (Org.). La coscienza deiluoghi: il territorio come soggetto corale. Roma: Donzelli, 2015. p. 115-222.

FALS BORDA, O. Kaziyadu: registro del reciente despertar territorial en Colombia. Bogotá, D. C.: Ediciones Desde Abajo, c2001. 159 p. 
- 4 378,349 km, entre Ponta do Seixas (Cabo Branco, João Pessoa) e a nascente do Rio Moa (Márcio Lima, AC) - 4 326,61 km (Tabela 1.3).

\section{Para debater e refletir}

Nesse processo sucintamente descrito, muitas histórias locais - da América Latina e do Brasil - converteram-se em subalternas a partir do renascimento europeu, da Revolução Industrial inglesa, da Revolução Francesa e do lluminismo (MIGNOLO, [2003]), queimando-se, por exemplo, os códices indígenas, pois estes foram considerados primitivos a serem civilizados, a partir de 1552, depois de muitos serem escravizados por terem sido considerados seres sem alma (GROSFOGUEL, 2016). Atualmente, efetiva-se, por meio de diferentes e complexos mecanismos, a hegemonia neoliberal, com classes dominantes cultural, política e economicamente, reprimindo-se, muitas vezes, a construção popular para sua própria emancipação.

Para aprofundar essa compreensão, debater e refletir gerando soluções para o povo brasileiro, acreditamos que é necessário conhecer as singularidades territoriais, investindo no âmbito da (in)formação, da participação popular, da convivência e da gestão partilhada, compreendendo os territórios e os tempos para contribuir concretamente no retorno ao território e às suas gentes (BECATTINI; MAGNAGHI, 2015). Este processo de retorno ao território requer a identificação, compreensão, explicação e valorização das identidades e ecossistemas, dos vínculos comunitários, dos sujeitos, dos saberes, da autogestão, ao mesmo tempo, fortalecendo-se os níveis de consciência de classe e de lugar como mediação fundamental na luta cotidiana e na construção do desenvolvimento territorial numa perspectiva popular, autônoma e contra a hegemonia imperialista (SAQUET, 2017).

\section{Referências}

ANDRADE, M. C. de. Geopolítica do Brasil. São Paulo: Ática, 1989.64 p. (Princípios, n. 165).

ANDRADE, M. C. de. A questão do território no Brasil. São Paulo: Hucitec : IPESP, 1995. 135 p. (Geografia: teoria e realidade, 29).

BECATTINI, G.; MAGNAGHI, A. Coscienza di classe e coscienza di luogo. In: BECATTINI, G.; MAGNAGHI, A. (Org.). La coscienza dei luoghi: il territorio come soggetto corale. Roma: Donzelli, 2015. p. 115-222.

FALS BORDA, O. Kaziyadu: registro del reciente despertar territorial en Colombia. Bogotá, D. C.: Ediciones Desde Abajo, c2001. 159 p. 
GROSFOGUEL, R. A estrutura do conhecimento nas universidades ocidentalizadas: racismo/sexismo epistêmico e os quatro genocídios/ epistemicídios do longo século XVI. Sociedade e Estado, Brasília, v. 31, n. 1, p. 25-49, Jan/Apr 2016. Available from: <http://www.scielo.br/scielo. php?script=sci_arttext\&pid=S0102-69922016000100025\&lng=en\&nrm= iso>. Cited: May 2019.

MIGNOLO, W. Historias locales, diseños globales: colonialidad, conocimientos subalternos y pensamiento fronterizo. Madrid: Akal, [2003]. 452 p. (Cuestiones de antagonismo, 18).

PRADO JÚNIOR, C. História econômica do Brasil. São Paulo: Brasiliense, 1986.

RIBEIRO, D. O povo brasileiro: a formação e o sentido do Brasil. 3. ed. São Paulo: Global, 2015.

SAQUET, M. A. Por uma geografia das territorialidades e das temporalidades: uma concepção multidimensional voltada para a cooperação e para o desenvolvimento territorial. 2. ed. rev. and exp. Rio de Janeiro: Consequência, 2015. 162 p.

SAQUET, M. Consciência de classe elugar, práxis e desenvolvimento territorial. Rio de Janeiro: Consequência, 2017.

Translated by: La-Fayette Côrtes Neto 
GROSFOGUEL, R. A estrutura do conhecimento nas universidades ocidentalizadas: racismo/sexismo epistêmico e os quatro genocídios/epistemicídios do longo século XVI. Sociedade e Estado, Brasília, v. 31, n. 1, p. 25-49, jan./abr. 2016. Disponível em: <http:// www.scielo.br/scielo.php?script=sci_arttext\&pid=S0102-69922016000100025\&lng= en\&nrm=iso $>$. Acesso em: maio 2019.

MIGNOLO, W. Historias locales, diseños globales: colonialidad, conocimientos subalternos y pensamiento fronterizo. Madrid: Akal, [2003]. 452 p. (Cuestiones de antagonismo, 18).

PRADO JÚNIOR, C. História econômica do Brasil. São Paulo: Brasiliense, 1986.

RIBEIRO, D. O povo brasileiro: a formação e o sentido do Brasil. 3. ed. São Paulo: Global, 2015.

SAQUET, M. A. Por uma geografia das territorialidades e das temporalidades: uma concepção multidimensional voltada para a cooperação e para o desenvolvimento territorial. 2. ed. rev. e ampl. Rio de Janeiro: Consequência, 2015. 162 p.

SAQUET, M. Consciência de classe e lugar, práxis e desenvolvimento territorial. Rio de Janeiro: Consequência, 2017. 
Tabela 1.1 - Área total do País - 2018

Table 1.1 - Total area of Brazil - 2018

(continua/to be continued)

\begin{tabular}{|c|c|c|c|}
\hline \multirow{3}{*}{$\begin{array}{c}\text { Grandes Regiões } \\
\text { e } \\
\text { Unidades da Federação/ } \\
\text { Major Regions and Federation Units }\end{array}$} & \multicolumn{3}{|c|}{$\begin{array}{c}\text { Área total/ } \\
\text { Total area }\end{array}$} \\
\hline & \multirow{2}{*}{$\begin{array}{l}\text { Absoluta } \\
\left(\mathrm{km}^{2}\right) / \\
\text { Absolute } \\
\left(\mathrm{km}^{2}\right)\end{array}$} & \multicolumn{2}{|c|}{$\begin{array}{c}\text { Relativa (\%)/ } \\
\text { Relative (\%) }\end{array}$} \\
\hline & & $\begin{array}{l}\text { Brasil/ } \\
\text { Brazil }\end{array}$ & $\begin{array}{l}\text { Regiões/ } \\
\text { Regions }\end{array}$ \\
\hline Brasil/ B razil & 8510820,623 & 100,00 & .. \\
\hline Norte/North & 3851281,390 & 45,25 & 100,00 \\
\hline Rondônia & 237765,233 & 2,79 & 6,17 \\
\hline Acre & 164123,738 & 1,93 & 4,26 \\
\hline Amazonas & 1559168,117 & 18,32 & 40,48 \\
\hline Roraima & 224273,831 & 2,64 & 5,82 \\
\hline Pará & 1245759,305 & 14,64 & 32,35 \\
\hline Amapá & 142470,762 & 1,67 & 3,70 \\
\hline Tocantins & 277720,404 & 3,26 & 7,21 \\
\hline Nordeste/Northeast & 1551991,426 & 18,24 & 100,00 \\
\hline Maranhão & 329642,170 & 3,87 & 21,24 \\
\hline Piauí & 251616,823 & 2,96 & 16,21 \\
\hline Ceará & 148894,757 & 1,75 & 9,59 \\
\hline Rio Grande do Norte & 52809,602 & 0,62 & 3,40 \\
\hline Paraíba & 56467,239 & 0,66 & 3,64 \\
\hline Pernambuco & 98068,021 & 1,15 & 6,32 \\
\hline Alagoas & 27843,295 & 0,33 & 1,79 \\
\hline Sergipe & 21926,908 & 0,26 & 1,41 \\
\hline Bahia & 564722,611 & 6,64 & 36,39 \\
\hline Sudeste/Southeast & 924565,469 & 10,86 & 100,00 \\
\hline Minas Gerais & 586521,121 & 6,89 & 63,44 \\
\hline Espírito Santo & 46074,444 & 0,54 & 4,98 \\
\hline Rio de Janeiro & 43750,423 & 0,51 & 4,73 \\
\hline São Paulo & 248219,481 & 2,92 & 26,85 \\
\hline Sul/South & 576743,308 & 6,78 & 100,00 \\
\hline Paraná & 199305,236 & 2,34 & 34,56 \\
\hline Santa Catarina & 95730,921 & 1,12 & 16,60 \\
\hline Rio Grande do Sul & 281707,151 & 3,31 & 48,84 \\
\hline
\end{tabular}


Tabela 1.1 - Área total do País - 2018

Table 1.1 - Total area of Brazil - 2018

(conclusão/concluded)

\begin{tabular}{|c|c|c|c|}
\hline \multirow{3}{*}{$\begin{array}{c}\text { Grandes Regiões } \\
\text { e } \\
\text { Unidades da Federação/ } \\
\text { Major Regions and Federation Units }\end{array}$} & \multicolumn{3}{|c|}{$\begin{array}{l}\text { Área total/ } \\
\text { Total area }\end{array}$} \\
\hline & \multirow{2}{*}{$\begin{array}{c}\text { Absoluta } \\
\left(\mathrm{km}^{2}\right) / \\
\text { Absolute } \\
\left(\mathrm{km}^{2}\right)\end{array}$} & \multicolumn{2}{|c|}{$\begin{array}{c}\text { Relativa (\%)/ } \\
\text { Relative (\%) }\end{array}$} \\
\hline & & $\begin{array}{l}\text { Brasil/ } \\
\text { Brazil }\end{array}$ & $\begin{array}{l}\text { Regiões/ } \\
\text { Regions }\end{array}$ \\
\hline Centro-Oeste/Central-West & 1606239,030 & 18,87 & 100,00 \\
\hline Mato Grosso do Sul & 357145,535 & 4,20 & 22,23 \\
\hline Mato Grosso & 903206,997 & 10,61 & 56,23 \\
\hline Goiás & 340125,715 & 4,00 & 21,18 \\
\hline Distrito Federal/Federal District & 5760,783 & 0,07 & 0,36 \\
\hline
\end{tabular}

Fonte/Source: IBGE, Diretoria de Geociências, Coordenação de Estruturas Territoriais, Malha Municipal 2018.

\section{Mapa 1.1 - Mapa político do Brasil Map 1.1 - Political map of Brazil}

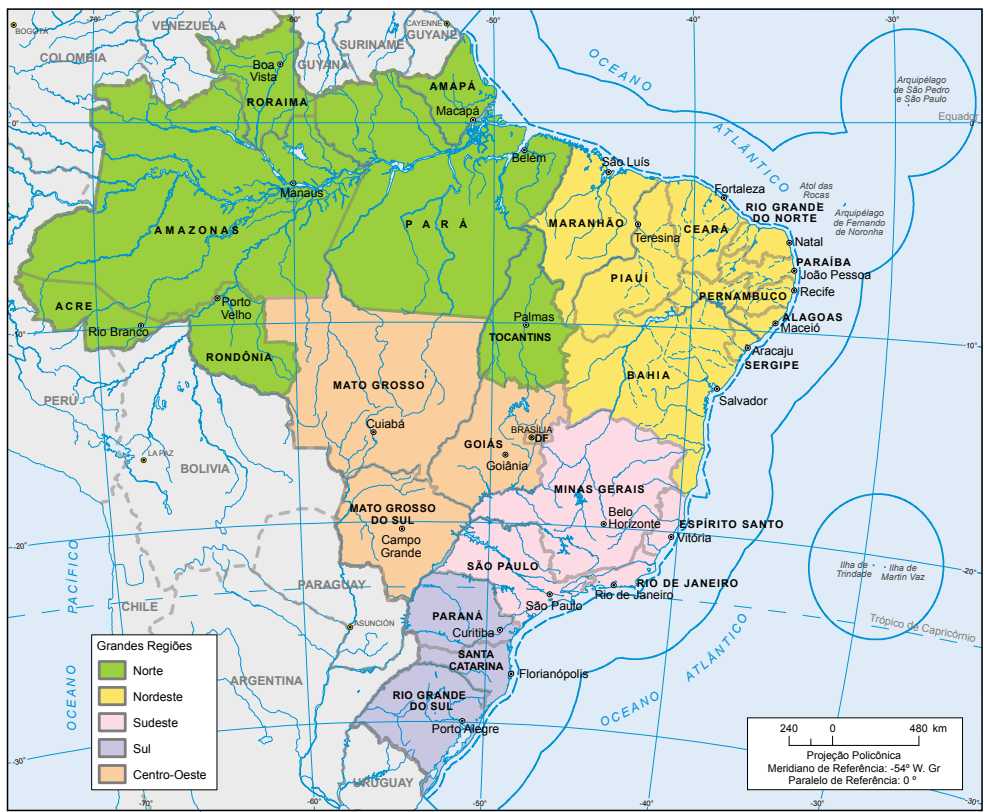

Fonte/Source: IBGE, Diretoria de Geociências. 
Tabela 1.2 - Evolução político-administrativa do País - 1940/2018

Table 1.2 - Administrative evolution of Brazil - 1940/2018

\begin{tabular}{|c|c|c|c|c|c|c|c|}
\hline \multirow{2}{*}{$\begin{array}{l}\text { Grandes Regiões e } \\
\text { Unidades da Federação/ } \\
\text { Major Regions and } \\
\text { Federation Units }\end{array}$} & \multicolumn{7}{|c|}{$\begin{array}{l}\text { Municípios criados e instalados (Até 01.09)/ } \\
\text { Municipalities created and installed (Until Sep 1st) }\end{array}$} \\
\hline & $1940(1)$ & 1950 & 1960 & 1970 & 1980 & 1990 & 2000 \\
\hline Brasil/Brazil & 1574 & 1889 & 2766 & 3952 & 3974 & 4491 & 5507 \\
\hline Norte/North & 88 & 99 & 120 & 143 & 153 & 298 & 449 \\
\hline Rondônia & - & 2 & 2 & 2 & 7 & 23 & 52 \\
\hline Acre & 7 & 7 & 7 & 7 & 12 & 12 & 22 \\
\hline Amazonas & 28 & 25 & 44 & 44 & 44 & 62 & 62 \\
\hline Roraima & - & 2 & 2 & 2 & 2 & 8 & 15 \\
\hline Pará & 53 & 59 & 60 & 83 & 83 & 105 & 143 \\
\hline Amapá & - & 4 & 5 & 5 & 5 & 9 & 16 \\
\hline Tocantins & - & - & - & - & - & 79 & 139 \\
\hline Nordeste/Northeast & 584 & 609 & 903 & 1376 & 1375 & 1509 & 1787 \\
\hline Maranhão & 65 & 72 & 91 & 130 & 130 & 136 & 217 \\
\hline Piauí & 47 & 49 & 71 & 114 & 114 & 118 & 221 \\
\hline Ceará & 79 & 79 & 142 & 142 & 141 & 178 & 184 \\
\hline Rio Grande do Norte & 42 & 48 & 83 & 150 & 150 & 152 & 166 \\
\hline Paraíba & 41 & 41 & 88 & 171 & 171 & 171 & 223 \\
\hline Pernambuco & 85 & 91 & 103 & 165 & 165 & (2) 168 & (2) 185 \\
\hline Alagoas & 33 & 37 & 69 & 94 & 94 & 97 & 101 \\
\hline Sergipe & 42 & 42 & 62 & 74 & 74 & 74 & 75 \\
\hline Bahia & 150 & 150 & 194 & 336 & 336 & 415 & 415 \\
\hline Sudeste/Southeast & 641 & 845 & 1085 & 1410 & 1410 & 1432 & 1666 \\
\hline Minas Gerais & 288 & 386 & 483 & 722 & 722 & 723 & 853 \\
\hline Espírito Santo & 32 & 33 & 37 & 53 & 53 & 67 & 77 \\
\hline Rio de Janeiro & 51 & 57 & 62 & 64 & 64 & 70 & 91 \\
\hline São Paulo & 270 & 369 & 503 & 571 & 571 & 572 & 645 \\
\hline Sul/South & 181 & 224 & 414 & 717 & 719 & 873 & 1159 \\
\hline Paraná & 49 & 80 & 162 & 288 & 290 & 323 & 399 \\
\hline Santa Catarina & 44 & 52 & 102 & 197 & 197 & 217 & 293 \\
\hline Rio Grande do Sul & 88 & 92 & 150 & 232 & 232 & 333 & 467 \\
\hline Centro-Oeste/Central-West & 80 & 112 & 244 & 306 & 317 & 379 & 446 \\
\hline Mato Grosso do Sul & - & - & - & - & 55 & 72 & 77 \\
\hline Mato Grosso & 28 & 35 & 64 & 84 & 38 & 95 & 126 \\
\hline Goiás & 52 & 77 & 179 & 221 & 223 & 211 & 242 \\
\hline Distrito Federal/Federal District & - & - & 1 & 1 & 1 & 1 & 1 \\
\hline
\end{tabular}


Tabela 1.2 - Evolução político-administrativa do País - 1940/2018

Table 1.2 - Administrative evolution of Brazil - 1940/2018

(conclusão/concluded)

\begin{tabular}{|c|c|c|c|c|c|c|c|c|}
\hline \multirow{2}{*}{$\begin{array}{l}\text { Grandes Regiões e } \\
\text { Unidades da Federação/ } \\
\text { Major Regions and } \\
\text { Federation Units }\end{array}$} & \multicolumn{8}{|c|}{$\begin{array}{l}\text { Municípios criados e instalados (Até 01.09)/ } \\
\text { Municipalities created and installed (Until Sep 1st) }\end{array}$} \\
\hline & 2009 & 2010 & 2013 & 2014 & 2015 & 2016 & 2017 & 2018 \\
\hline Brasil/Brazil & 5565 & 5565 & 5570 & 5570 & 5570 & 5570 & 5570 & 5570 \\
\hline Norte/North & 449 & 449 & 450 & 450 & 450 & 450 & 450 & 450 \\
\hline Rondônia & 52 & 52 & 52 & 52 & 52 & 52 & 52 & 52 \\
\hline Acre & 22 & 22 & 22 & 22 & 22 & 22 & 22 & 22 \\
\hline Amazonas & 62 & 62 & 62 & 62 & 62 & 62 & 62 & 62 \\
\hline Roraima & 15 & 15 & 15 & 15 & 15 & 15 & 15 & 15 \\
\hline Pará & 143 & 143 & 144 & 144 & 144 & 144 & 144 & 144 \\
\hline Amapá & 16 & 16 & 16 & 16 & 16 & 16 & 16 & 16 \\
\hline Tocantins & 139 & 139 & 139 & 139 & 139 & 139 & 139 & 139 \\
\hline Nordeste/Northeast & 1794 & 1794 & 1794 & 1794 & 1794 & 1794 & 1794 & 1794 \\
\hline Maranhão & 217 & 217 & 217 & 217 & 217 & 217 & 217 & 217 \\
\hline Piauí & 224 & 224 & 224 & 224 & 224 & 224 & 224 & 224 \\
\hline Ceará & 184 & 184 & 184 & 184 & 184 & 184 & 184 & 184 \\
\hline Rio Grande do Norte & 167 & 167 & 167 & 167 & 167 & 167 & 167 & 167 \\
\hline Paraíba & 223 & 223 & 223 & 223 & 223 & 223 & 223 & 223 \\
\hline Pernambuco & (2) 185 & (2) 185 & (2) 185 & (2) 185 & (2) 185 & (2) 185 & (2) 185 & (2) 185 \\
\hline Alagoas & 102 & 102 & 102 & 102 & 102 & 102 & 102 & 102 \\
\hline Sergipe & 75 & 75 & 75 & 75 & 75 & 75 & 75 & 75 \\
\hline Bahia & 417 & 417 & 417 & 417 & 417 & 417 & 417 & 417 \\
\hline Sudeste/Southeast & 1668 & 1668 & 1668 & 1668 & 1668 & 1668 & 1668 & 1668 \\
\hline Minas Gerais & 853 & 853 & 853 & 853 & 853 & 853 & 853 & 853 \\
\hline Espírito Santo & 78 & 78 & 78 & 78 & 78 & 78 & 78 & 78 \\
\hline Rio de Janeiro & 92 & 92 & 92 & 92 & 92 & 92 & 92 & 92 \\
\hline São Paulo & 645 & 645 & 645 & 645 & 645 & 645 & 645 & 645 \\
\hline Sul/South & 1188 & 1188 & 1191 & 1191 & 1191 & 1191 & 1191 & 1191 \\
\hline Paraná & 399 & 399 & 399 & 399 & 399 & 399 & 399 & 399 \\
\hline Santa Catarina & 293 & 293 & 295 & 295 & 295 & 295 & 295 & 295 \\
\hline Rio Grande do Sul & 496 & 496 & 497 & 497 & 497 & 497 & 497 & 497 \\
\hline Centro-Oeste/Central-West & 466 & 466 & 467 & 467 & 467 & 467 & 467 & 467 \\
\hline Mato Grosso do Sul & 78 & 78 & 79 & 79 & 79 & 79 & 79 & 79 \\
\hline Mato Grosso & 141 & 141 & 141 & 141 & 141 & 141 & 141 & 141 \\
\hline Goiás & 246 & 246 & 246 & 246 & 246 & 246 & 246 & 246 \\
\hline Distrito Federal/Federal District & 1 & 1 & 1 & 1 & 1 & 1 & 1 & 1 \\
\hline
\end{tabular}

Fonte/Source: IBGE, Diretoria de Geociências, Coordenação de Estruturas Territoriais, Banco de Estruturas Territoriais.

(1) Unidades administrativas em 01.09. (2) Inclui o Distrito Estadual de Fernando de Noronha.

(1) Administrative units on July 1st. (2) Includes the State District of Fernando de Noronha. 
Tabela 1.3 - Pontos extremos do País e suas distâncias - 2018

Table 1.3 - Extreme points of Brazil and their distances - 2018

\begin{tabular}{|c|c|c|c|c|}
\hline \multirow{2}{*}{$\begin{array}{l}\text { Extremo/ } \\
\text { Extreme } \\
\text { points }\end{array}$} & \multicolumn{2}{|c|}{$\begin{array}{l}\text { Coordenadas geográficas/ } \\
\text { Geographic coordinates }\end{array}$} & \multirow{2}{*}{$\begin{array}{l}\text { Localização/ } \\
\text { Location }\end{array}$} & \multirow{2}{*}{$\begin{array}{c}\text { Distância } \\
(\mathrm{km}) / \\
\text { Distance } \\
(\mathrm{km})\end{array}$} \\
\hline & $\begin{array}{l}\text { Latitude/ } \\
\text { Latitude }\end{array}$ & $\begin{array}{l}\text { Longitude/ } \\
\text { Longitude }\end{array}$ & & \\
\hline $\begin{array}{l}\text { Norte/ } \\
\text { North }\end{array}$ & $+05^{\circ} 16^{\prime} 18.628^{\prime \prime}$ & $-60^{\circ} 12^{\prime} 44.833^{\prime \prime}$ & $\begin{array}{l}\text { Nascente do rio Ailã } \\
\text { (Uiramutã - RR)/Source of } \\
\text { Ailã river (Uiramutã - RR) }\end{array}$ & \\
\hline $\begin{array}{l}\text { Sul/ } \\
\text { South }\end{array}$ & $-33^{\circ} 45^{\prime} 04.241^{\prime \prime}$ & $-53^{\circ} 23^{\prime} 41.472^{\prime \prime}$ & $\begin{array}{l}\text { Arroio Chuí (Santa Vitória } \\
\text { do Palmar - RS)/Chuí Brook } \\
\text { (Santa Vitória do Palmar - RS) }\end{array}$ & - 4378,349 \\
\hline $\begin{array}{l}\text { Leste/ } \\
\text { East }\end{array}$ & $-07^{\circ} 09^{\prime} 18.406^{\prime \prime}$ & $-34^{\circ} 47^{\prime} 35.111^{\prime \prime}$ & $\begin{array}{l}\text { Ponta do Seixas (Cabo Branco/ } \\
\text { João Pessoa - PB)/Point of Seixas } \\
\text { (Cape Branco/João Pessoa - PB) }\end{array}$ & \\
\hline $\begin{array}{l}\text { Oeste/ } \\
\text { West }\end{array}$ & $-07^{\circ} 32^{\prime} 09.460^{\prime \prime}$ & $-73^{\circ} 59^{\prime} 25.620^{\prime \prime}$ & $\begin{array}{l}\text { Nascente do rio Moa (Mâncio } \\
\text { Lima - AC)/Source of Moa river } \\
\text { (Mâncio Lima-AC) }\end{array}$ & 4326,61 \\
\hline
\end{tabular}

Fonte/Source: IBGE, Diretoria de Geociências, Coordenação de Estruturas Territoriais, Malha Municipal 2018. Nota: Coordenadas Geográficas no datum SIRGAS2000, com distâncias em linha reta obtidas através do modelo elipsoidal./Note: Geographic Coordinates in datum SIRGAS 2000 with distances in a straight line obtained from the ellipsoidal model. 
Mapa 1.2 - Pontos extremos e pontos mais altos do País Map 1.2 - Extreme points and highest points in Brazil

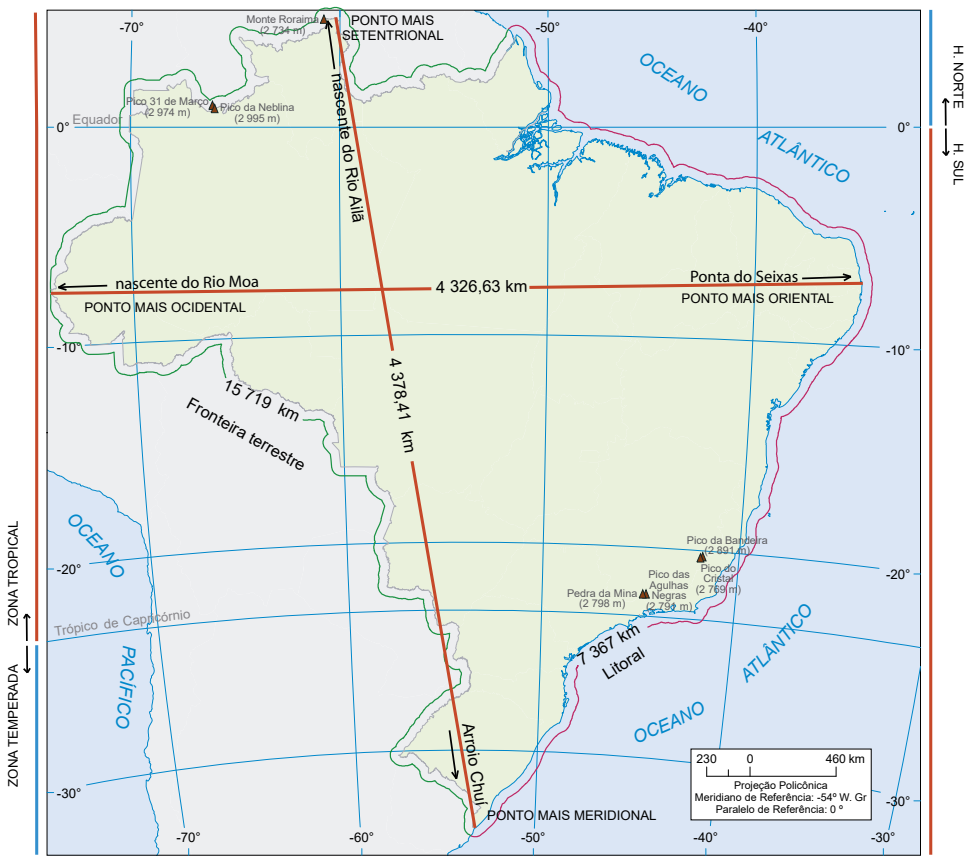

Fonte/Source: IBGE, Diretoria de Geociências. 


\section{Tabela 1.4 - Pontos mais altos do País - 2016}

Table 1.4 - Highest points in Brazil - 2016

\begin{tabular}{|c|c|c|c|}
\hline $\begin{array}{l}\text { Topônimos/ } \\
\text { Toponyms }\end{array}$ & $\begin{array}{c}\text { Unidades da Federação/ } \\
\text { Federative Units }\end{array}$ & $\begin{array}{l}\text { Localização/ } \\
\text { Location }\end{array}$ & $\begin{array}{l}\text { Altitude }(\mathrm{m}) / \\
\text { Altitude }(m)\end{array}$ \\
\hline $\begin{array}{l}\text { Pico da Neblina (1) / } \\
\text { Neblina Peak (1) }\end{array}$ & Amazonas & $\begin{array}{l}\text { Serra Imeri/ } \\
\text { Imeri Range }\end{array}$ & 2995,3 \\
\hline $\begin{array}{l}\text { Pico } 31 \text { de Março (1) / } \\
31 \text { de Março Peak (1) }\end{array}$ & Amazonas (2) & $\begin{array}{l}\text { Serra Imeri/ } \\
\text { Imeri Range }\end{array}$ & 2974,2 \\
\hline $\begin{array}{l}\text { Pico da Bandeira (1) / } \\
\text { Bandeira Peak (1) }\end{array}$ & Minas Gerais/Espírito Santo & $\begin{array}{l}\text { Serra do Caparaó/ } \\
\text { Caparaó Range }\end{array}$ & 2891,3 \\
\hline $\begin{array}{l}\text { Pedra da Mina (1) / } \\
\text { Mina Rock (1) }\end{array}$ & Minas Gerais/São Paulo & $\begin{array}{l}\text { Serra da Mantiqueira/ } \\
\text { Mantiqueira Range }\end{array}$ & 2798,1 \\
\hline $\begin{array}{l}\text { Pico das Agulhas Negras (1)/ } \\
\text { Agulhas Negras Peak (1) }\end{array}$ & Minas Gerais/Rio de Janeiro & $\begin{array}{l}\text { Serra do Itatiaia/ } \\
\text { Itatiaia Range }\end{array}$ & 2790,9 \\
\hline $\begin{array}{l}\text { Pico do Cristal (1)/ } \\
\text { Cristal Peak (1) }\end{array}$ & Minas Gerais & $\begin{array}{l}\text { Serra do Caparaó/ } \\
\text { Caparaó Range }\end{array}$ & 2769,1 \\
\hline $\begin{array}{l}\text { Monte Roraima (1) / } \\
\text { Roraima Mount (1) }\end{array}$ & Roraima (2) (3) & $\begin{array}{l}\text { Serra do Pacaraima/ } \\
\text { Pacaraima Range }\end{array}$ & 2734,1 \\
\hline $\begin{array}{l}\text { Morro do Couto (4) / } \\
\text { Couto Mount (4) }\end{array}$ & Rio de Janeiro & $\begin{array}{l}\text { Serra das Prateleiras/ } \\
\text { Prateleiras Range }\end{array}$ & 2687,0 \\
\hline $\begin{array}{l}\text { Pedra do Sino de Itatiaia/ } \\
\text { Sino de Itatiaia Rock }\end{array}$ & Minas Gerais & $\begin{array}{l}\text { Serra da Mantiqueira/ } \\
\text { Mantiqueira Range }\end{array}$ & 2670,0 \\
\hline $\begin{array}{l}\text { Pico dos Três Estados/ } \\
\text { Três Estados Peak }\end{array}$ & $\begin{array}{l}\text { São Paulo/Minas Gerais/ } \\
\text { Rio de Janeiro }\end{array}$ & $\begin{array}{l}\text { Serra da Mantiqueira/ } \\
\text { Mantiqueira Range }\end{array}$ & 2665,0 \\
\hline $\begin{array}{l}\text { Pedra do Altar (4) / } \\
\text { Altar Rock (4) }\end{array}$ & Rio de Janeiro & $\begin{array}{l}\text { Serra da Mantiqueira/ } \\
\text { Mantiqueira Range }\end{array}$ & 2663,0 \\
\hline $\begin{array}{l}\text { Morro da Cruz do Negro / } \\
\text { Cruz do Negro Mount }\end{array}$ & Espírito Santo & $\begin{array}{l}\text { Serra do Caparaó/ } \\
\text { Caparaó Range }\end{array}$ & 2658,0 \\
\hline $\begin{array}{l}\text { Pedra Roxa/ } \\
\text { Roxa Rock }\end{array}$ & Espírito Santo & $\begin{array}{l}\text { Serra do Caparaó/ } \\
\text { Caparaó Range }\end{array}$ & 2649,0 \\
\hline $\begin{array}{l}\text { Pico do Tesouro/ } \\
\text { Tesouro Peak }\end{array}$ & Espírito Santo & $\begin{array}{l}\text { Serra do Caparaó/ } \\
\text { Caparaó Range }\end{array}$ & 2620,0 \\
\hline $\begin{array}{l}\text { Pico da Maromba (4) / } \\
\text { Maromba Peak (4) }\end{array}$ & Rio de Janeiro & $\begin{array}{l}\text { Serra da Mantiqueira/ } \\
\text { Mantiqueira Range }\end{array}$ & 2613,0 \\
\hline $\begin{array}{l}\text { Morro do Massena / } \\
\text { Massena Mount }\end{array}$ & Minas Gerais/Rio de Janeiro & $\begin{array}{l}\text { Serra do Itatiaia/ } \\
\text { Itatiaia Range }\end{array}$ & 2603,0 \\
\hline $\begin{array}{l}\text { Pico da Cabeça de Touro / } \\
\text { Cabeça de Touro Peak }\end{array}$ & São Paulo & $\begin{array}{l}\text { Serra Fina } \\
\text { Fina Range }\end{array}$ & 2600,0 \\
\hline
\end{tabular}

Fonte/Source: IBGE, Diretoria de Geociências, Coordenação de Cartografia, Cadastro de Pontos mais Altos do Brasil e Coordenação de Geodésia, Projeto Pontos Culminantes.

Nota: Foram considerados os pontos com altitude superior a 2600 metros. / Note: Only the points over 2600 meters were included.

(1) Altitudes obtidas a partir da aplicação da versão 2015 do modelo de ondulação geoidal (MAPGEO 2015). (2) Fronteira com a Venezuela. (3) Fronteira com a Guiana. (4) Base Cartográfica Vetorial Contínua do Estado do Rio de Janeiro - 1:25 000./ (1) Altitudes obtained through the 2015 version of the geoid undulation model (MAPGEO2015). (2) Venezuela border. (3) Guyana border. (4) Continuous Vectorial Cartographic Base of Rio de Janeiro state - 1:25000 


\section{Tabela 1.5 - Localização geográfica dos Municípios das Capitais e distância a Brasília - 2018}

Table 1.5 - Geographic location of the Municipalities of the Capital and distance to Brasília - 2018

\begin{tabular}{|c|c|c|c|c|}
\hline \multirow{2}{*}{$\begin{array}{c}\text { Municípios das Capitais/ } \\
\text { Municipalities of } \\
\text { the capital }\end{array}$} & \multicolumn{2}{|c|}{$\begin{array}{l}\text { Localização geográfica/ } \\
\text { Geographic location }\end{array}$} & \multicolumn{2}{|c|}{$\begin{array}{l}\text { Distância a Brasilia }(\mathrm{km}) / \\
\text { Distance to Brasília }(\mathrm{Km})\end{array}$} \\
\hline & $\begin{array}{l}\text { Latitude/ } \\
\text { Latitude }\end{array}$ & $\begin{array}{l}\text { Longitude/ } \\
\text { Longitude }\end{array}$ & $\begin{array}{c}\text { Em reta (1)/ } \\
\text { Straight line (1) }\end{array}$ & $\begin{array}{l}\text { Rodoviária (2)/ } \\
\text { Road (2) }\end{array}$ \\
\hline Porto Velho (RO) & $-8^{\circ} 45^{\prime} 58^{\prime \prime}$ & $-63^{\circ} 54^{\prime} 34^{\prime \prime}$ & 1904,002 & 2589 \\
\hline Rio Branco (AC) & $-9^{\circ} 58^{\prime} 21^{\prime \prime}$ & $-67^{\circ} 48^{\prime} 36^{\prime \prime}$ & 2250,489 & 3123 \\
\hline Manaus (AM) & $-3^{\circ} 8^{\prime} 10^{\prime \prime}$ & $-60^{\circ} 1^{\prime} 32^{\prime \prime}$ & 1933,07 & 3490 \\
\hline Boa Vista (RR) & $2^{\circ} 49^{\prime} 15^{\prime \prime}$ & $-60^{\circ} 40^{\prime} 21^{\prime \prime}$ & 2501,02 & 4275 \\
\hline Belém (PA) & $-1^{\circ} 27^{\prime} 19^{\prime \prime}$ & $-48^{\circ} 30^{\prime} 19^{\prime \prime}$ & 1595,799 & 2120 \\
\hline Macapá (AP) & $0^{\circ} 2^{\prime} 12^{\prime \prime}$ & $-51^{\circ} 3^{\prime} 6^{\prime \prime}$ & 1793,730 & $\ldots$ \\
\hline Palmas (TO) & $-10^{\circ} 11^{\prime} 4^{\prime \prime}$ & $-48^{\circ} 20^{\prime} 1 "$ & 624,400 & 973 \\
\hline São Luís (MA) & $-2^{\circ} 31^{\prime} 55^{\prime \prime}$ & $-44^{\circ} 17^{\prime} 52^{\prime \prime}$ & 1527,526 & 2157 \\
\hline Teresina (PI) & $-5^{\circ} 5^{\prime} 26^{\prime \prime}$ & $-42^{\circ} 49^{\prime} 2^{\prime \prime}$ & 1314,589 & 1789 \\
\hline Fortaleza (CE) & $-3^{\circ} 43^{\prime} 27^{\prime \prime}$ & $-38^{\circ} 31^{\prime} 31^{\prime \prime}$ & 1691,499 & 2378 \\
\hline Natal (RN) & $-5^{\circ} 47^{\prime} 4^{\prime \prime}$ & $-35^{\circ} 12^{\prime} 29^{\prime \prime}$ & 1779,777 & 2422 \\
\hline João Pessoa (PB) & $-7^{\circ} 6^{\prime} 55^{\prime \prime}$ & $-34^{\circ} 53^{\prime} 24^{\prime \prime}$ & 1717,457 & 2245 \\
\hline Recife (PE) & $-8^{\circ} 3^{\prime} 46^{\prime \prime}$ & $-34^{\circ} 53^{\prime} 20^{\prime \prime}$ & 1658,798 & 2220 \\
\hline Maceió (AL) & $-9 \circ 39 ' 37 "$ & $-35^{\circ} 44^{\prime} 22^{\prime \prime}$ & 1487,959 & 1928 \\
\hline Aracaju (SE) & $-10^{\circ} 54^{\prime} 48^{\prime \prime}$ & $-37 \circ 3^{\prime} 5^{\prime \prime}$ & 1296,379 & 1652 \\
\hline Salvador (BA) & $-12^{\circ} 58^{\prime} 27^{\prime \prime}$ & $-38^{\circ} 30^{\prime} 44^{\prime \prime}$ & 1062,295 & 1446 \\
\hline Belo Horizonte (MG) & $-19^{\circ} 55^{\prime} 25^{\prime \prime}$ & $-43^{\circ} 56^{\prime} 11^{\prime \prime}$ & 625,869 & 716 \\
\hline Vitória (ES) & $-20^{\circ} 19^{\prime} 16^{\prime \prime}$ & $-40^{\circ} 20^{\prime} 21^{\prime \prime}$ & 948,925 & 1238 \\
\hline Rio de Janeiro (RJ) & $-22^{\circ} 54^{\prime} 10^{\prime \prime}$ & $-43^{\circ} 10^{\prime} 26^{\prime \prime}$ & 936,888 & 1148 \\
\hline São Paulo (SP) & $-23 \circ 33^{\prime} 5^{\prime \prime}$ & $-46^{\circ} 38^{\prime} 4 "$ & 875,646 & 1015 \\
\hline Curitiba (PR) & $-25^{\circ} 25^{\prime} 2^{\prime \prime}$ & $-49^{\circ} 16^{\prime} 7^{\prime \prime}$ & 1081,759 & 1366 \\
\hline Florianópolis (SC) & $-27 \circ 35^{\prime} 51^{\prime \prime}$ & $-48^{\circ} 32^{\prime} 59^{\prime \prime}$ & 1317,011 & 1673 \\
\hline Porto Alegre (RS) & $-30^{\circ} 1^{\prime} 48^{\prime \prime}$ & $-51^{\circ} 13^{\prime} 43^{\prime \prime}$ & 1621,605 & 2027 \\
\hline Campo Grande (MS) & $-20^{\circ} 27^{\prime} 45^{\prime \prime}$ & $-54^{\circ} 36^{\prime} 31^{\prime \prime}$ & 877,744 & 1134 \\
\hline Cuiabá (MT) & $-15^{\circ} 36^{\prime} 2^{\prime \prime}$ & $-56^{\circ} 6^{\prime} 1 "$ & 875,725 & 1133 \\
\hline Goiânia (GO) & $-16^{\circ} 40^{\prime} 49^{\prime \prime}$ & $-49^{\circ} 15^{\prime} 23^{\prime \prime}$ & 173,581 & 209 \\
\hline Brasília (DF) & $-15^{\circ} 47^{\prime} 4^{\prime \prime}$ & $-47^{\circ} 54^{\prime} 29^{\prime \prime}$ & .. & .. \\
\hline
\end{tabular}

Fonte/Source: IBGE, Diretoria de Geociências, Coordenação de Estruturas Territoriais.

(1) Coordenadas Geográficas no datum SIRGAS2000 - (Sedes Municipais 2018) e a Distância a Brasília em linha reta foram obtidas através modelo elipsoidal.(2) Dados do Departamento Nacional de Infraestrutura de Transportes - DNIT.

(1) Geographic Coordinates in datum SIRGAS 2000 - (Municipal Headquarters 2018) and distance to Brasilia in a straight line were obtained from the ellipsoidal model. (2) Data from the National Department of Transportation Infrastructure - DNIT. 



\section{População Population}

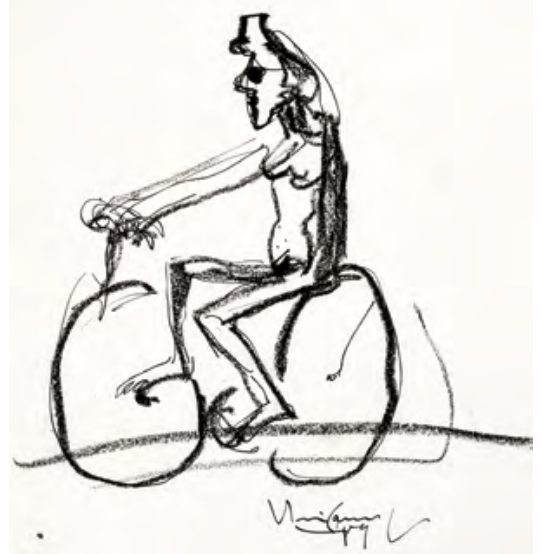

Sem título, 1989

Untitled

Iberê Camargo 


\title{
Population
}

\author{
Ricardo de Sampaio Dagnino ${ }^{1}$
}

\section{Demographic elements to understand Brazil and its transitions}

Identifying the demographic elements that comprise the population status (structure, dimension and spatial distribution), the demographic variables (birth, mortality, migration) and the demographic dynamics allows us to better understand Brazil and its transitions.

The present article - grounded on data based on the last Population Censuses of the Brazilian Institute of Geography and Statistics (IBGE) and on data used in the Population Projections of the IBGE - 2018 Review - intends to draw a current picture of the resident population in Brazil.

Over the last decades, the population structure has been undergoing significant changes resulting from what demographers tend to describe as demographic transition - a social phenomenon that affects all the Brazilian population, although it can have many faces stemming from regional and social diversities. The phenomenon is materialized in the reduction of mortality followed by a drop in birth rates (CARMO; CAMARGO, 2018).

$1 \mathrm{PhD}$ in Demography from the State University of Campinas - UNICAMP Professor of the Interdisciplinary Department, North Coast Campus, Federal University of Rio Grande do Sul (UFRGS). 


\section{População}

Ricardo de Sampaio Dagnino'

\section{Elementos demográficos para compreender o Brasil e suas transições}

Identificar os elementos demográficos que compõem o estado da população (estrutura, dimensão e distribuição espacial), as variáveis demográficas (natalidade, mortalidade, migrações) e as dinâmicas demográficas permite melhor compreender o Brasil e suas transições.

Este texto baseia-se nos dados obtidos a partir dos últimos Censos Demográficos do Instituto Brasileiro de Geografia e Estatística (IBGE) e nos dados utilizados nas Projeções da População do IBGE - Revisão 2018 para esboçar um panorama atual sobre a população residente no País.

Nas últimas décadas, a estrutura da população vem passando por alterações significativas decorrentes daquilo que os demógrafos costumam chamar de transição demográfica - um fenômeno social que apesar de afetar toda população brasileira, apresenta-se de maneira diferenciada, em função das desigualdades sociais e diversidades regionais - e que se manifesta na redução da mortalidade, seguida da diminuição na natalidade (CARMO; CAMARGO, 2018).

1 Doutor em Demografia pela Universidade Estadual de Campinas (UNICAMP). Professor do Departamento Interdisciplinar, Campus Litoral Norte, Universidade Federal do Rio Grande do Sul (UFRGS). 
The demographic dynamics seen in the age pyramids (Graph 2.1) shows the changes in the age structure and in the sex distribution taken place in the last decades: as time goes by, the pyramid changes its form, having its base narrowed down, i. e., shrinking the relative weight of the young populations and making aging quite evident. The population projection (Graph 2.2) indicates that the number of children and youngsters will decrease and the relative weight of the elderly to the population as a whole will keep growing, mostly in the case of women, who have a higher life expectancy than men. Therefore, demographic aging will advance rapidly.

Nowadays the number of adults (between 15 and 59 years old) surpasses that of youngsters (0-14 years old) and elderly (60 years old and over); such a ratio is called demographic bonus (CARMO; CAMARGO, 2018) or demographic dividend (TURRA, 2018). In an ideal world, such combination favors income generation by the adults in order to compensate for the kids and the elderly; however, in the real world, such balance depends on the insertion of the adults in the economy by means of job generation, employment and income which are not entirely dependable on demographic factors.

The population figures presented in Table 2.1 shows that in 2010 the population had reached 190 million inhabitants, of which 160 million lived in urban households (Table 2.1), i. e., an urbanization degree above $80 \%$ (Table 2.2). Thus, Brazil is placed among the countries with the highest demographic dimension and the most urbanized on the planet. Nevertheless, the rural population in 2010 is still very significant: there are nearly 30 million persons (a bigger population than that in several countries), of which 18 million are in the North and Northeast Regions - corresponding to $62 \%$ of the entire rural population (Table 2.1). Those two regions, while showing lower percentages of urban population, with DU (degree of utilization) of $70 \%$ (Table 2.2), underwent urbanization increase in the last decades. Moreover, the urban population has been growing in all regions and represents a very distinct phenomenon, known as urban transition, present since 1940, but sharpening in the last decades (CARMO; CAMARGO, 2018).

The greatest increments of urban population in the Metropolitan Areas, mainly in the megalopolis comprising the areas of São Paulo and Rio de Janeiro, are quite evident. On the other hand, the dynamics among small towns and medium cities have been calling the attention too, as well as some movements in the countryside of Brazil. 
A dinâmica demográfica observada nas pirâmides etárias (Gráfico 2.1) evidencia as mudanças na estrutura etária e na distribuição dos sexos, ocorridas nas últimas décadas: com o passar do tempo a pirâmide vai mudando de aspecto e deixa de ter uma base larga, ou seja, diminui o peso relativo das populações jovens e o envelhecimento da estrutura etária fica mais claro. A projeção da população (Gráfico 2.2) mostra que o número de crianças e jovens irá diminuir e o peso relativo dos idosos no conjunto da população continuará crescendo, sobretudo no caso das mulheres, que possuem expectativa de vida mais elevada do que os homens. Dessa forma o envelhecimento demográfico avançará rapidamente.

Atualmente, a quantidade de adultos (entre 15 e 59 anos de idade) supera os jovens ( 0 a 14 anos) e os idosos (60 anos e mais); a esta relação se dá o nome de bônus demográfico (CARMO; CAMARGO, 2018) ou dividendo demográfico (TURRA, 2018). Em termos ideias, essa conjuntura é propícia para que os adultos gerem a renda necessária para sustentar as crianças e os idosos, mas em termos concretos essa sustentação depende da inserção dos adultos na economia, através da geração de trabalho, emprego e renda, que não dependem exclusivamente de fatores demográficos.

A dimensão da população apresentada na Tabela 2.1 mostra que em 2010 a população havia chegado aos 190 milhões de habitantes, dos quais 160 milhões residiam em domicílios em situação urbana (Tabela 2.1), o que indicava um grau de urbanização (GU) superior a 80\% (Tabela 2.2). Assim, o Brasil se posiciona entre os países com maior dimensão demográfica e entre os mais urbanizados do planeta. Entretanto, a população rural em 2010 ainda é bastante expressiva: são praticamente 30 milhões de pessoas (uma população maior do que a encontrada em diversos países) dos quais 18 milhões estão nas Regiões Norte e Nordeste, o que equivale a $62 \%$ de toda a população rural brasileira (Tabela 2.1). Essas duas regiões apesar de possuírem os menores percentuais de população urbana, com GU de 70\% (Tabela 2.2), experimentaram crescimento da urbanização nas últimas décadas. Aliás, o crescimento das populações urbanas vem ocorrendo em todas as regiões e representa um fato bastante expressivo, conhecido como transição urbana e que tem sido verificada desde 1940, acentuando-se nas últimas décadas (CARMO; CAMARGO, 2018).

É evidente que os maiores incrementos de população urbana ocorrem nas regiões metropolitanas, sobretudo na megalópole formada pelas regiões de São Paulo e Rio de Janeiro, mas chama a atenção o que está ocorrendo nas cidades pequenas e médias do Brasil, bem como as dinâmicas no interior do País. 
Despite the urban growth, the rural population is still there and very much present in the large extensions of agricultural lands, forests, woods, fields and in protected areas (Conservation Units and Indigenous Lands), where a significant part of the population exists and resists. Because of that, it is very didactic to analyze what occurs in the North Region, a vast territory inserted in the Legal Amazon, bordering several countries and occupying a strategic position in the geopolitics of the South America, with socio-demographic characteristics of its own.

The North Region occupies nearly four million square kilometers, which represents $45 \%$ of the National Territory and had, in 2010 , a population of 16 million inhabitants - $8 \%$ the Brazilian population (Table 2.1) - which corresponds to the lowest demographic density of the country, just four inhabitants by square kilometer (Table 2.2). Despite what has been already said about the Amazon, there is not a proper demographic emptiness going on there, what we truly have there is a territory with a highly concentrated population in urban areas, on the one hand, and a sparse and rarefied population presence in large rural areas (DAGNINO, 2014), on the other hand.

For many decades, the Amazon has been a border area of very active agricultural, mineral, demographic and speculative expansion. An indication of such phenomena is the accelerated demographic growth. In the 2000s, the North Region recorded the highest average rate of annual growth of the country, 2.1\% per year, whereas the Brazilian population grew 1.2\% per year (Table 2.2). In some Federation Units of the North Region, as Roraima and Amapá, the growth surpassed 3\% per year, a fact that contributes to the idea of an area of border expansion.

As already mentioned, the North has the lowest rates of population living in urban areas, however the data derived from Table 2.1 show that region recorded the highest pace of growth of the urban population, increasing 29\% between 2000 and 2010, whereas in Brazil as a whole the increase was of $16 \%$. In the previous period, between 1991 and 2000, the total population growth (urban and rural) in the Amazon Biome - delimitation that does not coincide exactly with the Legal Amazon - was above that of the total Brazilian population and great part of such increase occurred in already consolidated urban areas (HOGAN; MARANDOLA JÚNIOR; OJIMA, 2010).

The coefficient of masculinity, also known as sex ratio, indicates the numeric relation between men and women and, when it surpasses 100 , it means there are more men in the population. In Brazil, the only Federation Units with the coefficient of masculinity above 100 are those belonging to the North Region and Mato Grosso, all of them inside the Legal Amazon (Table 2.2). This fact can indicate that there is a selective migration, very typical of border areas. 
Apesar do crescimento urbano, a população rural não deixa de existir e ela ainda é muito presente nas grandes extensões de áreas agrícolas, florestas, matas, campos e nas áreas protegidas (Unidades de Conservação e Terras Indígenas), onde uma parte significativa da população existe e resiste (DAGNINO, 2014). Nesse sentido, é bastante didático analisar o que ocorre na Região Norte, esse vasto território inserido na Amazônia Legal, que faz fronteira com diversos países, ocupa uma posição estratégica na geopolítica da América do Sul e possui características sociodemográficas bastante peculiares.

A Região Norte, ocupa cerca de quatro milhões de quilômetros quadrados, o que representa 45\% do Território Nacional e possuía, em 2010, uma população de 16 miIhões de habitantes - $8 \%$ da população brasileira (Tabela 2.1) - o que corresponde à mais baixa densidade demográfica do País, apenas quatro habitantes por quilômetro quadrado (Tabela 2.2). Apesar do que já foi dito sobre a Amazônia, não se trata de um vazio demográfico, mas sim de um território com população altamente concentrada em áreas urbanas, de um lado, e de uma presença de população esparsa e rarefeita nas imensas áreas rurais (DAGNINO, 2014).

Por muitas décadas a Amazônia tem sido uma área de fronteira de expansão agropecuária, mineral, demográfica e especulativa bastante ativa. Um indicador desse fenômeno é o crescimento demográfico acelerado. Na década de 2000, a Região Norte experimentou a maior taxa média de crescimento anual do País, 2,1 \% ao ano, enquanto que a população brasileira cresceu 1,2\% ao ano (Tabela 2.2). Em algumas Unidades da Federação da Região Norte como Roraima e Amapá o crescimento superou $3 \%$ ao ano, fato que contribui com a ideia de uma área de fronteira de expansão.

Como já vimos, o Norte possui as menores taxas de população residindo em áreas urbanas, porém os dados derivados da Tabela 2.1 permitem verificar que essa região experimentou o mais elevado ritmo de crescimento da população urbana, crescendo $29 \%$ entre 2000 e 2010 , ao passo que no Brasil como um todo o aumento foi de $16 \%$. No período anterior, entre 1991 e 2000, o crescimento da população total (urbana e rural) no bioma Amazônia - delimitação que não coincide exatamente com a Amazônia Legal - foi superior ao da população total brasileira e grande parte desse aumento ocorreu em áreas urbanas já consolidadas (HOGAN; MARANDOLA JÚNIOR; OJIMA, 2010).

O coeficiente de masculinidade, também conhecido como razão de sexos, indica a relação numérica entre homens e mulheres e quando for superior a 100 significa que há mais homens na população. No Brasil, as únicas Unidades da Federação com coeficiente de masculinidade superior a 100 são aquelas pertencentes à Região Norte e, também, o Mato Grosso, todas Unidades da Federação pertencentes à Amazônia Legal (Tabela 2.2). Esse fato pode indicar que há uma seletividade na migração, bastante característica de áreas de fronteira. 
This group of indicators help us understand that the territorial occupation, agglomeration and, finally, urbanization processes of the Amazon are different from what is seen all over the National Territory and points out to the regional and social inequalities that the country as a whole still faces.

A third transition joins the demographic and urban transitions and allows the understanding of the immense changes we are undergoing. It is the epidemiological transition that represents the end of the prevalence of deaths caused by infectious diseases and the beginning of the prevalence of deaths caused by heart diseases, neoplasms, external causes and chronic degenerative diseases. (CARMO; CAMARGO, 2018). However, it is crucial to observe that those transitions are profoundly interrelated and that they could be included in others such as the transition in the schooling profile, in the labor market, in the relations of gender and in family arrangements (TURRA, 2018).

Understanding the transitions makes it easier to analyze Table 2.3, which brings the main demographic variables that affect the Brazilian demographic dynamics: mortality and fertility/birth.

The Gross Mortality Rate (GMR), which started falling in the 1930s, tends to keep dropping until it reaches a minimal point - as it can be seen in Table 2.3, when it achieves 6.37 deaths per each 1,000 inhabitants in 2014. From that year on, it begins to increase: in 2020, the projection is of a GMR of 6.56 per each 1,000 inhabitants and in 2030 it will be higher than 7 (Graph 2.3). This increasing GMR is due to the bigger number of persons aged above 60 years old, those elderly are increasing more and more in the Brazilian population. But that does not mean that the elderly will live less. On the contrary, life expectancy at birth will go on rising and a person born in 2020 will live on average up to 77 years old (Graph 2.4), which corresponds to four more years than a person born in 2010 (Table 2.3).

As to mortality of children under one year of age - an indicator that reflects the living conditions of a population - for decades the country has been undergoing a significant decrease of the Infant Mortality Rate: in 2010 it was of 17.22 per 1,000 live births and in 2020 it should be 11.56 (Table 2.3). Due to the epidemiological transition and the gains obtained through the years in health, sanitation and education, mostly in the areas where there was an intense urban transition, the GMR includes less and less children.

The Total Fertility Rate (TFR), as expected, keeps the downward trend below the replacement level ( 2.1 children per woman) and tends to reach 1.76 children per woman in 2020 (Table 2.3). However, a non-expected fact 
Esses indicadores selecionados ajudam a compreender que os processos de ocupação territorial, de aglomeração e, finalmente, de urbanização da Amazônia são diferentes do que ocorre no restante do Território Nacional e é indicativo das desigualdades regionais e sociais que o País como um todo ainda experimenta.

Uma terceira transição soma-se às transições demográfica e urbana e permite compreender as intensas alterações pelas quais estamos passando. Trata-se da transição epidemiológica que representa o fim do predomínio das mortes causadas por doenças infectocontagiosas e o início da prevalência dos óbitos por doenças cardiovasculares, neoplasias, causas externas e doenças crônico-degenerativas (CARMO; CAMARGO, 2018). Mas é imperativo notar que estas transições estão profundamente interconectadas entre si e que a estas poderiam ser incluídas outras como as transições no perfil educacional, no mercado de trabalho, nas relações de gênero e nos arranjos familiares (TURRA, 2018).

A partir desse entendimento sobre as transições fica mais fácil realizar a análise da Tabela 2.3, que contém as principais variáveis demográficas que operam sobre a dinâmica demográfica brasileira: a mortalidade e a fecundidade/natalidade.

A Taxa Bruta de Mortalidade (TBM) que começou a cair na década de 1930 tende a continuar diminuindo até alcançar um ponto mínimo - que é o que se verifica na Tabela 2.3, quando ela chegará a 6,37 mortes por mil habitantes em 2014. A partir desse ano ela tende a aumentar: em 2020, projeta-se uma TBM de 6,56 por mil habitantes e em 2030 ela será maior que 7 (Gráfico 2.3). Esta TBM ascendente é causada por um maior volume de pessoas em idade acima de 60 anos, esses idosos serão cada vez mais numerosos na população brasileira. Mas isso não significa que os idosos viverão menos. Pelo contrário, a esperança de vida ao nascer continuará crescendo e uma pessoa nascida em 2020 viverá em média até os 77 anos (Gráfico 2.4), isso corresponde a quatro anos a mais do que um nascido em 2010 (Tabela 2.3).

Em relação à mortalidade de crianças menores de um ano de idade - um indicador que reflete as condições de vida da população - há décadas que o País experimenta uma significativa queda na Taxa de Mortalidade Infantil: em 2010 ela era de 17,22 por 1000 nascidos vivos e em 2020 ela deverá ser de 11,56 (Tabela 2.3). Devido à transição epidemiológica e os ganhos adquiridos ao longo dos anos em saúde, saneamento e educação, sobretudo nas áreas onde houve intensa transição urbana, a TBM contém cada vez menos crianças.

A Taxa de Fecundidade Total (TFT), como era de se esperar, segue caindo abaixo do nível de reposição (2,1 filhos por mulher) e tende a chegar a 1,76 filhos por muIher em 2020 (Tabela 2.3). Porém, um fato não esperado e não aderente às transi- 
and apart from the transitions mentioned calls the attention. It concerns the trend of births between 2015 and 2017: the TFR, which was 1.8, falls to 1.7 in 2016 and rises again in the next year, reaching 1.78, i. e., the TFR falls and then increases, but not to surpass the TFR of 2015 (Table 2.3 and Graph 2.3). Demographers still have not come to an agreement in relation to the decline causes in the number of births, but there is already strong evidence that linking that decrease to both the reduction in conception, caused by the delayed pregnancy, and the interruption of pregnancy, related to the increased number of abortions (CASTRO et al., 2018). Both phenomena seem to be associated, to a lesser or greater extent, to the Brazilian economic crisis initiated in 2015, but also to the Zika virus epidemic (ZIKV) - possibly related to microcephaly and fetal malformation, which would cause restrictions to several pregnant or pregnant-to-be women. Undoubtedly, the epidemic topic, mostly those related to mosquitoes, deserve further research, to account for, for instance, their effect on demographic variables and, in consequence, their relationship with the demographic dynamics and the population welfare.

Finally, it is worth registering that the Brazilian population, after having lived such transitions - demographic, urban and epidemiological - and undergone the intense relationship they have with the social, economic and environmental dynamics will hardly ever repeat the high growth rates seen between the 1950s and 1970s. The trend seen by the projections indicates that the population will grow lesser and lesser and, before the 2050s, a dropping movement of the absolute number of inhabitants will take place.

However, low growth comes together with the aging of the age structure and with the end of the demographic dividend, in which the elderly and the children surpass the portion of the economically active population. A smaller and older population stems from the transitions already anticipated by demographers 35 years ago and how sad it is to realize that few policy makers have understood the message or even tried to consider the effect such transitions impose on social, economic and social security policies (TURRA, 2018). What is left to us now is praying that demographers be listened to, at least, for the sake of the next 35 years. 
ções vistas anteriormente chama a atenção. Trata-se do comportamento dos nascimentos entre os anos 2015 e 2017: a TFT, que era 1,8, cai para 1,7 em 2016 e volta a subir no ano seguinte, chegando a 1,78, isto é, a TFT cai e depois aumenta, mas não chega a superar a TFT de 2015 (Tabela 2.3 e Gráfico 2.3). Os demógrafos ainda não têm total acordo sobre as causas desse declínio no número de nascimentos, porém já existem fortes evidências que permitem associar essa queda tanto com a redução na concepção, causada pela postergação da gravidez, quanto com a interrupção da gestação, relacionada ao elevado número de abortos (CASTRO et al., 2018). Ambos fenômenos parecem estar associados, em maior ou menor grau, à crise econômica brasileira iniciada em 2015, mas também à epidemia de Zika vírus (ZIKV) - que estaria causando microcefalia e malformações fetais, impondo restrições a diversas mulheres grávidas ou que estavam desejando ter filhos (CASTRO et al., 2018). Sem dúvida este tema das epidemias, sobretudo estas ligadas aos mosquitos, merecem ser melhor estudadas assim como os efeitos destas sobre as variáveis demográficas e consequentemente suas relações com a dinâmica demográfica e o estado da população.

Por fim, cabe registrar que a população brasileira, depois de vivenciar estas transições demográfica, urbana e epidemiológica e experimentar a intensa relação destas com as dinâmicas sociais, econômicas e ambientais dificilmente repetirá as elevadas taxas de crescimento verificadas entre as décadas de 1950 e 1970 (Gráfico 2.5). A tendência colocada pelas projeções indica que a população crescerá cada vez mais lentamente e, antes da década de 2050 , iniciará um processo de redução no número absoluto de habitantes.

Entretanto, o baixo crescimento vem acompanhado de um envelhecimento da estrutura etária e do fim do dividendo demográfico, no qual os idosos e as crianças superam a porção da população potencialmente economicamente ativa. Uma população menor e mais envelhecida é a consequência das transições que os demógrafos já anteciparam há 35 anos e é triste perceber que poucos formuladores de políticas entenderam o recado e/ou procuraram considerar os efeitos destas transições nas políticas sociais, econômicas e previdenciárias (TURRA, 2018). Resta torcer para que os demógrafos sejam ouvidos, pelo menos, para os próximos 35 anos. 


\section{References}

CARMO, R. L. do; CAMARGO, K. C.M. Dinâmica demográfica brasileira recente: padrões regionais de diferenciação. Rio de Janeiro: IPEA, 2018. 107 p. (Texto para Discussão, 2415). Available from: <http://www.ipea.gov.br/portal/ images/stories/PDFs/TDs/td_2415.pdf>. Cited: May 2019.

CASTRO, M. C. et al. Implications of Zika virus and congenital Zika syndrome for the number of live births in Brazil. Proceedings of the National Academy of Sciences, Washington, DC, v. 115, n. 24, p. 6177-6182, Jun. 2018. Available from: <https://www.pnas.org/content/115/24/6177>. Cited: May 2019.

DAGNINO, R. de S. Dinâmica demográfica e indicadores socioeconômicos em escala intramunicipal: Municípios de Altamira e São Félix do Xingu, Estado do Pará, entre 2000 e 2010. 2014. Tese (Doutorado) - Programa de Pós-Graduação em Demografia, Universidade Estadual de Campinas, Campinas, 2014. Available from: <https://www.researchgate.net/ publication/277003332_Dinamica_demografica_e_indicadores_ socioeconomicos_em_escala_intramunicipal_na_fronteira_Municipios_de_ Altamira_e_Sao_Felix_do_Xingu_Estado_do_Para_entre_2000_e_2010>. Cited: May 2019.

HOGAN, D. J.; MARANDOLA JÚNIOR, E.; OJIMA, R. População e ambiente: desafios à sustentabilidade.São Paulo: Blücher, 2010.105 p. (Sustentabilidade, v. 1).

TURRA, C. M. Os ajustes inevitáveis da transição demográfica no Brasil. In: ANDRADE, M. V.; ALBUQUERQUE, E. da M. (Ed). Alternativas para uma crise de múltiplas dimensões. Belo Horizonte: Centro de Desenvolvimento e Planejamento da UFMG, 2018. 440 p. (População e Economia). Available from: <https://www.cedeplar.ufmg.br/publicacoes/colecao-populacaoeconomia/1067-alternativas-para-uma-crise-de-mu-Itiplas-dimenso-es-1volume>. Cited: May 2019.

Translated by: Gisele Flores Caldas Manhães 


\section{Referências}

CARMO, R. L. do; CAMARGO, K. C. M. Dinâmica demográfica brasileira recente: padrões regionais de diferenciação. Rio de Janeiro: IPEA, 2018. 107 p. (Texto para Discussão, 2415). Disponível em: <http://www.ipea.gov.br/portal/images/stories/PDFs/TDs/ td_2415.pdf $>$. Acesso em: maio 2019.

CASTRO, M. C. et al. Implications of Zika virus and congenital Zika syndrome for the number of live births in Brazil. Proceedings of the National Academy of Sciences, Washington, DC, v. 115, n. 24, p. 6177-6182, Jun. 2018. Disponível em: <https://www. pnas.org/content/115/24/6177>. Acesso em: maio 2019.

DAGNINO, R. de S. Dinâmica demográfica e indicadores socioeconômicos em escala intramunicipal: Municípios de Altamira e São Félix do Xingu, Estado do Pará, entre 2000 e 2010. 2014. Tese (Doutorado) - Programa de Pós-Graduação em Demografia, Universidade Estadual de Campinas, Campinas, 2014. Disponível em: <https://www. researchgate.net/publication/277003332_Dinamica_demografica_e_indicadores_ socioeconomicos_em_escala_intramunicipal_na_fronteira_Municipios_de Altamira_e_Sao_Felix_do_Xingu_Estado_do_Para_entre_2000_e_2010>. Acesso em: maio 2019.

HOGAN, D. J.; MARANDOLA JÚNIOR, E.; OJIMA, R. População e ambiente: desafios à sustentabilidade. São Paulo: Blücher, 2010. 105 p. (Sustentabilidade, v. 1).

TURRA, C. M. Os ajustes inevitáveis da transição demográfica no Brasil. In: ANDRADE, M. V.; ALBUQUERQUE, E. da M. (Ed.). Alternativas para uma crise de múltiplas dimensões. Belo Horizonte: Centro de Desenvolvimento e Planejamento da UFMG, 2018. 440 p. (População e Economia). Disponível em: <https://www.cedeplar.ufmg.br/publicacoes/ colecao-populacao-economia/1067-alternativas-para-uma-crise-de-mu-Itiplasdimenso-es-1-volume>. Acesso em: maio 2019. 


\section{Gráfico 2.1 - Composição relativa da população residente, por sexo e grupos de idade - 1991/2010}

Graph 2.1 - Relative composition of the resident population, by sex and age groups - 1991/2010

80 anos e mais/80 years and over 75 a 79 anos $/ 75$ to 79 years old 70 a 74 anos $/ 70$ to 74 years old 65 a 69 anos $/ 65$ to 69 years old 60 a 64 anos $/ 60$ to 64 years old 55 a 59 anos $/ 55$ to 59 years old 50 a 54 anos $/ 50$ to 54 years old 45 a 49 anos $/ 45$ to 49 years old 40 a 44 anos $/ 40$ to 44 years old 35 a 39 anos $/ 35$ to 39 years old 30 a 34 anos $/ 30$ to 34 years old 25 a 29 anos $/ 25$ to 29 years old 20 a 24 anos/20 to 24 years old 15 a 19 anos/15 to 19 years old 10 a 14 anos/10 to 14 years old 5 a 9 anos $/ 5$ to 9 years old 0 a 4 anos $/ 0$ to 4 years old

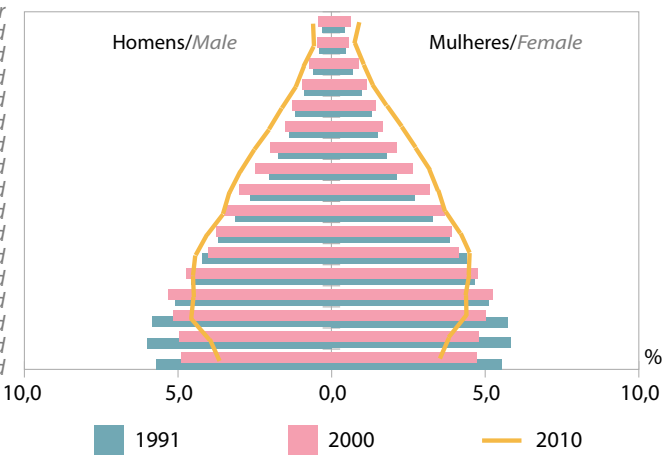

Fonte/Source: IBGE, Censo Demográfico 1991/2010.

\section{Gráfico 2.2 - Projeção da população - 2010/2020}

\section{Graph 2.2 - Population projections - 2000/2020}

80 anos e mais/80 years and over

75 a 79 anos $/ 75$ to 79 years old 70 a 74 anos/70 to 74 years old 65 a 69 anos/65 to 69 years old 60 a 64 anos/60 to 64 years old 55 a 59 anos $/ 55$ to 59 years old 50 a 54 anos $/ 50$ to 54 years old 45 a 49 anos $/ 45$ to 49 years old 40 a 44 anos/40 to 44 years old 35 a 39 anos/35 to 39 years old 30 a 34 anos/30 to 34 years old 25 a 29 anos/25 to 29 years old 20 a 24 anos/20 to 24 years old 15 a 19 anos/15 to 19 years old 10 a 14 anos/10 to 14 years old 5 a 9 anos $/ 5$ to 9 years old 0 a 4 anos $/ 0$ to 4 years old

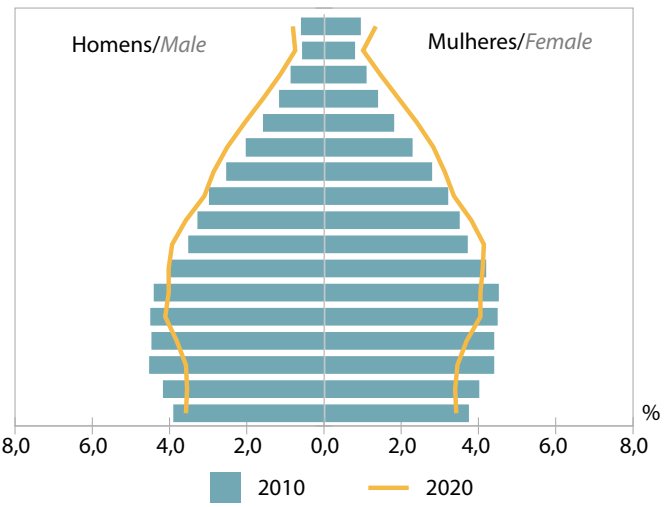

Fonte/Source: IBGE, Diretoria de Pesquisas, Coordenação de População e Indicadores Sociais, Projeção da População do Brasil por Sexo e Idade para o Período 2010-2060 - Revisão 2018. 


\section{Gráfico 2.3 - Taxas brutas de natalidade e mortalidade - 2010-2030}

Graph 2.3 - Crude birth and death rates - 2010-2030

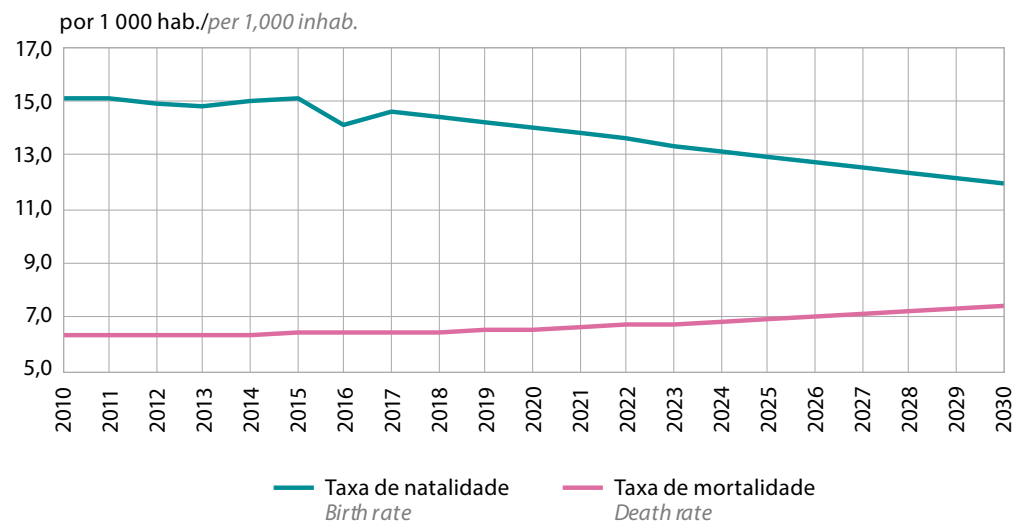

Fonte/Source: IBGE, Diretoria de Pesquisas, Coordenação de População e Indicadores Sociais. Projeção da população do Brasil e Unidades da Federação por sexo e idade para o período 2010-2060- Revisão 2018.

\section{Gráfico 2.4 - Esperança de vida ao nascer - 1930/2020}

Graph 2.4 - Life expectancy at birth - 1930/2020

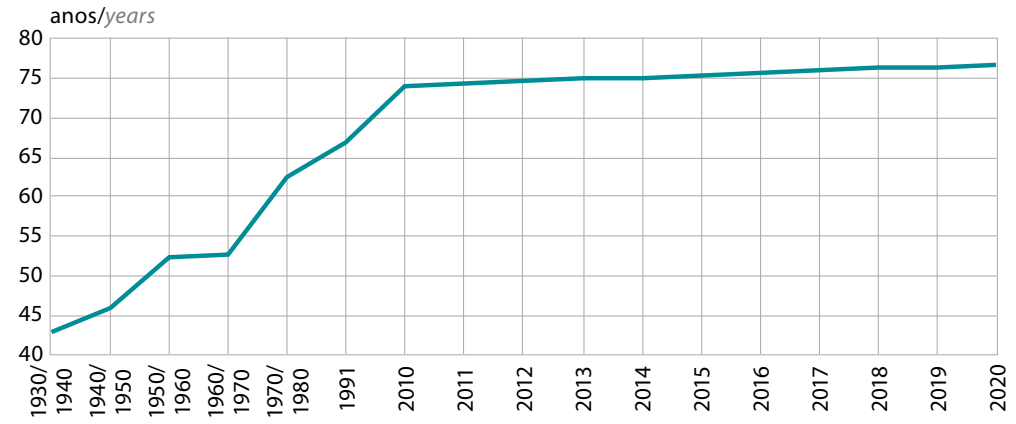

Fonte/Source: IBGE, Diretoria de Pesquisas, Coordenação de População e Indicadores Sociais, Tábuas Construídas e Projeção da População do Brasil e Unidades da Federação por sexo e idade para o período 2010-2060-Revisão 2018. 
Tabela 2.1 - População residente, por situação do domicílio e sexo - 2010

Table 2.1 - Resident population, by urban/rural housing unit and sex - 2010

(continua/to be continued)

\begin{tabular}{|c|c|c|c|c|c|}
\hline \multirow{3}{*}{$\begin{array}{l}\text { Grandes Regiões } \\
\text { e } \\
\text { Unidades da Federação/ } \\
\text { Major Regions and } \\
\text { Federation Units }\end{array}$} & \multicolumn{5}{|c|}{ População residente/ Resident population } \\
\hline & \multirow{2}{*}{$\begin{array}{l}\text { Total/ } \\
\text { Total }\end{array}$} & \multicolumn{2}{|c|}{$\begin{array}{l}\text { Situação do domicílio/ } \\
\text { Housing unit }\end{array}$} & \multicolumn{2}{|c|}{$\begin{array}{l}\text { Sexo/ } \\
\text { Sex }\end{array}$} \\
\hline & & $\begin{array}{l}\text { Urbana/ } \\
\text { Urban }\end{array}$ & $\begin{array}{l}\text { Rural/ } \\
\text { Rural }\end{array}$ & $\begin{array}{c}\text { Homens/ } \\
\text { Male }\end{array}$ & $\begin{array}{l}\text { Mulheres/ } \\
\text { Female }\end{array}$ \\
\hline $\begin{array}{l}\text { Brasil/ } \\
\text { Brazil }\end{array}$ & 190755799 & 160925804 & 29829995 & 93406990 & 97348809 \\
\hline $\begin{array}{l}\text { Norte/ } \\
\text { North }\end{array}$ & 15864454 & 11664509 & 4199945 & 8004915 & 7859539 \\
\hline Rondônia & 1562409 & 1149180 & 413229 & 795157 & 767252 \\
\hline Acre & 733559 & 532279 & 201280 & 368324 & 365235 \\
\hline Amazonas & 3483985 & 2755490 & 728495 & 1753179 & 1730806 \\
\hline Roraima & 450479 & 344859 & 105620 & 228859 & 221620 \\
\hline Pará & 7581051 & 5191559 & 2389492 & 3821837 & 3759214 \\
\hline Amapá & 669526 & 601036 & 68490 & 335135 & 334391 \\
\hline Tocantins & 1383445 & 1090106 & 293339 & 702424 & 681021 \\
\hline $\begin{array}{l}\text { Nordeste/ } \\
\text { Northeast }\end{array}$ & 53081950 & 38821258 & 14260692 & 25909046 & 27172904 \\
\hline Maranhão & 6574789 & 4147149 & 2427640 & 3261515 & 3313274 \\
\hline Piauí & 3118360 & 2050959 & 1067401 & 1528422 & 1589938 \\
\hline Ceará & 8452381 & 6346569 & 2105812 & 4120088 & 4332293 \\
\hline Rio Grande do Norte & 3168027 & 2464991 & 703036 & 1548887 & 1619140 \\
\hline Paraíba & 3766528 & 2838678 & 927850 & 1824379 & 1942149 \\
\hline Pernambuco & 8796448 & 7052210 & 1744238 & 4230681 & 4565767 \\
\hline Alagoas & 3120494 & 2297860 & 822634 & 1511767 & 1608727 \\
\hline Sergipe & 2068017 & 1520366 & 547651 & 1005041 & 1062976 \\
\hline Bahia & 14016906 & 10102476 & 3914430 & 6878266 & 7138640 \\
\hline
\end{tabular}


Tabela 2.1 - População residente, por situação do domicílio e sexo - 2010

Table 2.1 - Resident population, by urban/rural housing unit and sex - 2010

(conclusão/concluded)

\begin{tabular}{|c|c|c|c|c|c|}
\hline \multirow{3}{*}{$\begin{array}{l}\text { Grandes Regiões } \\
\text { e } \\
\text { Unidades da Federação/ } \\
\text { Major Regions and } \\
\text { Federation Units }\end{array}$} & \multicolumn{5}{|c|}{ População residente/ Resident population } \\
\hline & \multirow{2}{*}{$\begin{array}{l}\text { Total/ } \\
\text { Total }\end{array}$} & \multicolumn{2}{|c|}{$\begin{array}{c}\text { Situação do domicílio/ } \\
\text { Housing unit }\end{array}$} & \multicolumn{2}{|c|}{$\begin{array}{l}\text { Sexo/ } \\
\text { Sex }\end{array}$} \\
\hline & & $\begin{array}{l}\text { Urbana/ } \\
\text { Urban }\end{array}$ & $\begin{array}{l}\text { Rural/ } \\
\text { Rural }\end{array}$ & $\begin{array}{l}\text { Homens/ } \\
\text { Male }\end{array}$ & $\begin{array}{l}\text { Mulheres/ } \\
\text { Female }\end{array}$ \\
\hline $\begin{array}{l}\text { Sudeste/ } \\
\text { Southeast }\end{array}$ & 80364410 & 74696178 & 5668232 & 39076647 & 41287763 \\
\hline Minas Gerais & 19597330 & 16715216 & 2882114 & 9641877 & 9955453 \\
\hline Espírito Santo & 3514952 & 2931472 & 583480 & 1731218 & 1783734 \\
\hline Rio de Janeiro & 15989929 & 15464239 & 525690 & 7625679 & 8364250 \\
\hline São Paulo & 41262199 & 39585251 & 1676948 & 20077873 & 21184326 \\
\hline $\begin{array}{l}\text { Sul/ } \\
\text { South }\end{array}$ & 27386891 & 23260896 & 4125995 & 13436411 & 13950480 \\
\hline Paraná & 10444526 & 8912692 & 1531834 & 5130994 & 5313532 \\
\hline Santa Catarina & 6248436 & 5247913 & 1000523 & 3100360 & 3148076 \\
\hline Rio Grande do Sul & 10693929 & 9100291 & 1593638 & 5205057 & 5488872 \\
\hline $\begin{array}{l}\text { Centro-Oeste/ } \\
\text { Central-West }\end{array}$ & 14058094 & 12482963 & 1575131 & 6979971 & 7078123 \\
\hline Mato Grosso do Sul & 2449024 & 2097238 & 351786 & 1219928 & 1229096 \\
\hline Mato Grosso & 3035122 & 2482801 & 552321 & 1549536 & 1485586 \\
\hline Goiás & 6003788 & 5420714 & 583074 & 2981627 & 3022161 \\
\hline $\begin{array}{l}\text { Distrito Federal } \\
\text { Federal District }\end{array}$ & 2570160 & 2482210 & 87950 & 1228880 & 1341280 \\
\hline
\end{tabular}

Fonte/Source: IBGE, Censo Demográfico 2010. 
Tabela 2.2 - Indicadores demográficos - 2010

Table 2.2 - Demographic indicators - 2010

(continua/to be continued)

\begin{tabular}{|c|c|c|c|c|}
\hline $\begin{array}{l}\text { Grandes Regiões } \\
\text { e } \\
\text { Unidades da } \\
\text { Federação/ } \\
\text { Major Regions and } \\
\text { Federation Units }\end{array}$ & $\begin{array}{l}\text { Taxa de } \\
\text { urbani- } \\
\text { zação } \\
(\%) / \\
\text { Urbanization } \\
\text { rate (\%) }\end{array}$ & $\begin{array}{l}\text { Taxa média } \\
\text { geométrica de } \\
\text { crescimento } \\
\text { anual } \\
(2000 / 2010) / \\
\text { Average } \\
\text { geometric } \\
\text { rate of annual } \\
\text { Increase } \\
\text { (2000/2010) }\end{array}$ & $\begin{array}{c}\text { Densidade } \\
\text { demográfica } \\
\left(\text { hab. } / \mathrm{km}^{2}\right) / \\
\text { Demographic } \\
\text { density } \\
\text { (inhab. } / \mathrm{km}^{2} \text { ) }\end{array}$ & $\begin{array}{c}\text { Coeficiente } \\
\text { de mascu- } \\
\text { linidade/ } \\
\text { Ratio of } \\
\text { males to } \\
\text { females }\end{array}$ \\
\hline $\begin{array}{l}\text { Brasil/ } \\
\text { Brazil }\end{array}$ & 84,36 & 1,17 & 22,43 & 95,95 \\
\hline $\begin{array}{l}\text { Norte/ } \\
\text { North }\end{array}$ & 73,53 & 2,09 & 4,12 & 101,85 \\
\hline Rondônia & 73,55 & 1,25 & 6,58 & 103,64 \\
\hline Acre & 72,56 & 2,78 & 4,47 & 100,85 \\
\hline Amazonas & 79,09 & 2,16 & 2,23 & 101,29 \\
\hline Roraima & 76,55 & 3,34 & 2,01 & 103,27 \\
\hline Pará & 68,48 & 2,04 & 6,07 & 101,67 \\
\hline Amapá & 89,77 & 3,45 & 4,69 & 100,22 \\
\hline Tocantins & 78,80 & 1,80 & 4,98 & 103,14 \\
\hline $\begin{array}{l}\text { Nordeste/ } \\
\text { Northeast }\end{array}$ & 73,13 & 1,07 & 34,15 & 95,35 \\
\hline Maranhão & 63,08 & 1,52 & 19,81 & 98,44 \\
\hline Piauí & 65,77 & 0,93 & 12,40 & 96,13 \\
\hline Ceará & 75,09 & 1,30 & 56,76 & 95,10 \\
\hline Rio Grande do Norte & 77,81 & 1,33 & 59,99 & 95,66 \\
\hline Paraíba & 75,37 & 0,90 & 66,70 & 93,94 \\
\hline Pernambuco & 80,17 & 1,06 & 89,63 & 92,66 \\
\hline Alagoas & 73,64 & 1,01 & 112,33 & 93,97 \\
\hline Sergipe & 73,52 & 1,49 & 94,35 & 94,55 \\
\hline Bahia & 72,07 & 0,70 & 24,82 & 96,35 \\
\hline
\end{tabular}


Tabela 2.2 - Indicadores demográficos - 2010

Table 2.2 - Demographic indicators - 2010

(conclusão/concluded)

\begin{tabular}{|c|c|c|c|c|}
\hline $\begin{array}{c}\text { Grandes Regiões } \\
\text { e } \\
\text { Unidades } \\
\text { da Federação/ } \\
\text { Major Regions and } \\
\text { Federation Units }\end{array}$ & $\begin{array}{l}\text { Taxa de } \\
\text { urbani- } \\
\text { zação } \\
(\%) / \\
\text { Urbanization } \\
\text { rate (\%) }\end{array}$ & $\begin{array}{l}\text { Taxa média } \\
\text { geométrica de } \\
\text { crescimento } \\
\text { anual } \\
(2000 / 2010) / \\
\text { Average } \\
\text { geometric } \\
\text { rate of annual } \\
\text { Increase } \\
(2000 / 2010)\end{array}$ & $\begin{array}{c}\text { Densidade } \\
\text { demográfica } \\
\left(\text { hab. } / \mathrm{km}^{2}\right) / \\
\text { Demographic } \\
\text { density } \\
\text { (inhab. } / \mathrm{km}^{2} \text { ) }\end{array}$ & $\begin{array}{c}\text { Coeficiente } \\
\text { de mascu- } \\
\text { linidade/ } \\
\text { Ratio of } \\
\text { males to } \\
\text { females }\end{array}$ \\
\hline $\begin{array}{l}\text { Sudeste/ } \\
\text { Southeast }\end{array}$ & 92,95 & 1,05 & 86,92 & 94,64 \\
\hline Minas Gerais & 85,29 & 0,91 & 33,41 & 96,85 \\
\hline Espírito Santo & 83,40 & 1,27 & 76,25 & 97,06 \\
\hline Rio de Janeiro & 96,71 & 1,06 & 365,23 & 91,17 \\
\hline São Paulo & 95,94 & 1,09 & 166,25 & 94,78 \\
\hline $\begin{array}{l}\text { Sul/ } \\
\text { South }\end{array}$ & 84,93 & 0,87 & 48,58 & 96,32 \\
\hline Paraná & 85,33 & 0,89 & 52,40 & 96,56 \\
\hline Santa Catarina & 83,99 & 1,55 & 65,29 & 98,48 \\
\hline Rio Grande do Sul & 85,10 & 0,49 & 39,79 & 94,83 \\
\hline $\begin{array}{l}\text { Centro-Oeste/ } \\
\text { Central-West }\end{array}$ & 88,80 & 1,91 & 8,75 & 98,61 \\
\hline Mato Grosso do Sul & 85,64 & 1,66 & 6,86 & 99,25 \\
\hline Mato Grosso & 81,80 & 1,94 & 3,36 & 104,30 \\
\hline Goiás & 90,29 & 1,84 & 17,65 & 98,66 \\
\hline Distrito Federal/Federal District & 96,58 & 2,28 & 444,07 & 91,62 \\
\hline
\end{tabular}

Fonte/Source: IBGE, Censo Demográfico 2010. 
Tabela 2.3 - Projeções de população e taxas - 2010-2020
Table 2.3 - Population projections and rates - 2010-2020

\begin{tabular}{|c|c|c|c|c|c|c|}
\hline $\begin{array}{l}\text { Ano/ } \\
\text { Year }\end{array}$ & $\begin{array}{l}\text { População/ } \\
\text { Population }\end{array}$ & $\begin{array}{c}\text { Taxa } \\
\text { bruta } \\
\text { de natalidade } \\
\text { (por } 1000 \text { hab.)/ } \\
\text { Crude live } \\
\text { birth rate } \\
\text { (per 1,000 resid.) }\end{array}$ & $\begin{array}{c}\text { Taxa } \\
\text { bruta } \\
\text { de mortalidade } \\
\text { (por } 1000 \text { hab.)/ } \\
\text { Crude } \\
\text { death rate } \\
\text { (per 1,000 resid.) }\end{array}$ & $\begin{array}{c}\text { Esperança } \\
\text { de vida } \\
\text { ao nascer/ } \\
\text { Life } \\
\text { expectancy } \\
\text { at birth }\end{array}$ & $\begin{array}{c}\text { Taxa de } \\
\text { mortalidade } \\
\text { infantil } \\
\text { (por } 1000 \\
\text { nascidos } \\
\text { vivos)/ Infant } \\
\text { mortality rate } \\
\text { (per 1,000 } \\
\text { live births) }\end{array}$ & $\begin{array}{l}\text { Taxa } \\
\text { de } \\
\text { fecundi- } \\
\text { dade } \\
\text { total/ } \\
\text { Total } \\
\text { fertility } \\
\text { rate }\end{array}$ \\
\hline 2010 & 194890682 & 15,08 & 6,36 & 73,86 & 17,22 & 1,75 \\
\hline 2011 & 196603732 & 15,13 & 6,35 & 74,20 & 16,43 & 1,76 \\
\hline 2012 & 198314934 & 14,89 & 6,34 & 74,52 & 15,69 & 1,75 \\
\hline 2013 & 200004188 & 14,77 & 6,35 & 74,84 & 15,02 & 1,74 \\
\hline 2014 & 201717541 & 15,01 & 6,37 & 75,14 & 14,40 & 1,78 \\
\hline 2015 & 203475683 & 15,09 & 6,39 & 75,44 & 13,82 & 1,80 \\
\hline 2016 & 205156587 & 14,14 & 6,41 & 75,72 & 13,29 & 1,70 \\
\hline 2017 & 206804741 & 14,61 & 6,44 & 75,99 & 12,81 & 1,78 \\
\hline 2018 & 208494900 & 14,41 & 6,47 & 76,25 & 12,35 & 1,77 \\
\hline 2019 & 210147125 & 14,20 & 6,51 & 76,50 & 11,94 & 1,77 \\
\hline 2020 & 211755692 & 13,99 & 6,56 & 76,74 & 11,56 & 1,76 \\
\hline
\end{tabular}

Fonte/Source: IBGE, Diretoria de Pesquisas, Coordenação de População e Indicadores Sociais, Gerência de Estudos e Análises da Dinâmica Demográfica. Projeção da população do Brasil e Unidades da Federação por sexo e idade para o período 2010-2060 - Revisão 2018. 
Gráfico 2.5 - Taxa média geométrica de crescimento anual - 1940/2010

Graph 2.5 - Average geometric rate of annual increase - 1940/2010

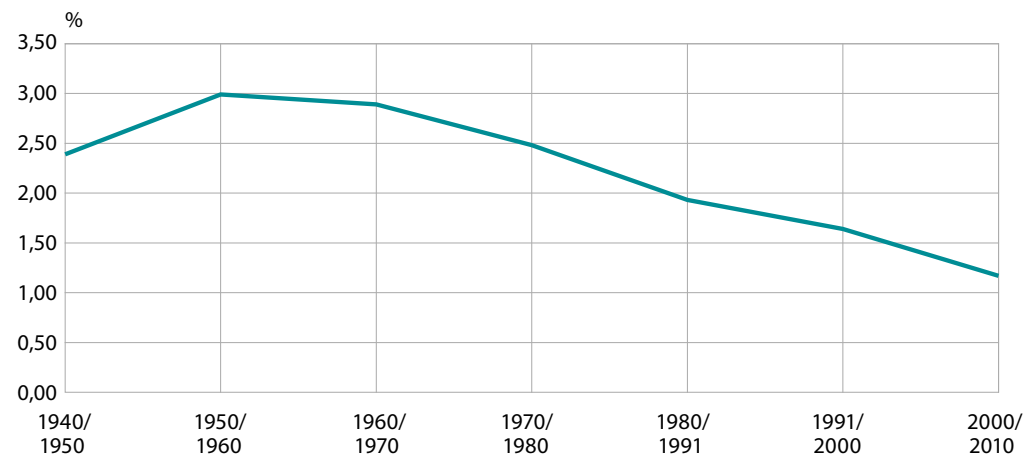

Fonte/Source: IBGE, Censo Demográfico 1940/2010. 



\section{Habitação Housing}

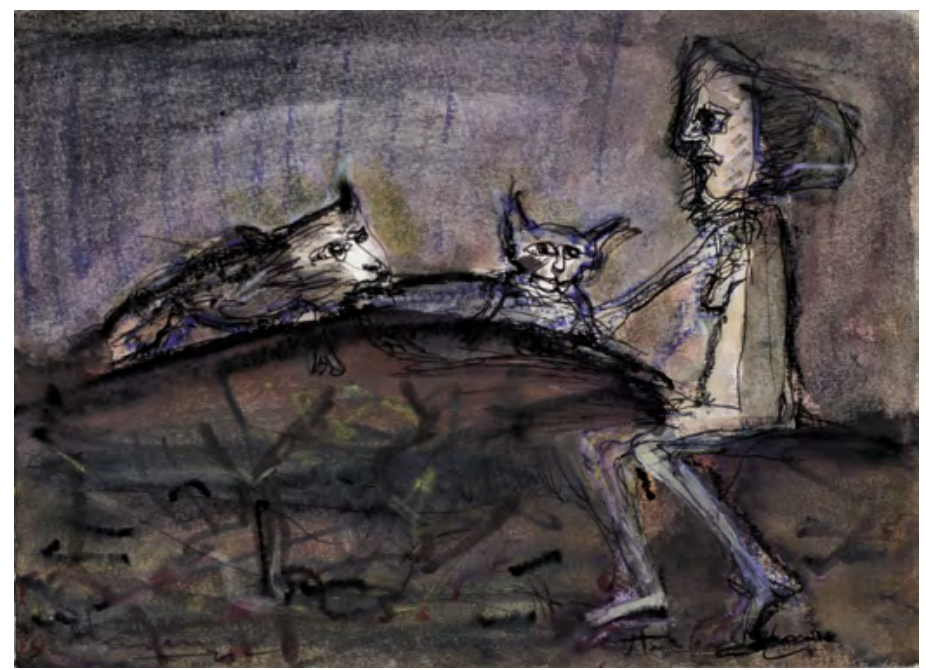

Sem título, 1990

Untitled

Iberê Camargo 


\title{
Housing
}

\author{
Maria Luiza Adams Sanvitto ${ }^{1}$
}

\section{Urbanization and housing shortage in Brazil}

The process of urbanization in Brazil had its beginnings in the 18th century, and it was consolidated in the decades of 1940 and 1950, in the 20th century, following the expansion of cities. As an outcome of the concentration of industry in cities, and of the subsequent ruralurban migration process that attracted a mass of workers, the country left behind its predominantly rural status. The accelerated urban growth had a strong impact on big centers, since those were not well-structured enough to supply the demands resulting from such population increase. Furthermore, the offer of work by that incipient industrial activity did not match the needs of the workforce migrating to the city. That was the seed of housing shortage in Brazil. The housing deficit and the rise of favelas became one of the structural problems in the Brazilian society. The population is concentrated in in big cities, lacking measures that might solve housing, infrastructure, health and education shortage, which are the main urban social problems in Brazil.

$1 \mathrm{PhD}$ in Architecture from the Research and Graduate Program (PROPAR) of the Federal University of Rio Grande do Sul (UFRGS), Professor at the Faculty of Architecture and at PROPAR, UFRGS. 


\section{Habitação}

Maria Luiza Adams Sanvitto ${ }^{1}$

\section{A urbanização e a carência habitacional no Brasil}

O processo de urbanização iniciou no Brasil no Século XVIII, consolidando-se a partir das décadas de 1940 e 1950 do Século XX, com expansão das cidades. O País deixou sua condição predominantemente rural, através de um processo migratório campo-cidade, consequência da concentração industrial nas cidades, atraindo grande massa de trabalhadores para essa atividade. $O$ crescimento urbano acelerado causou forte impacto nos grandes centros, sem estrutura que respondesse às necessidades desse incremento populacional. Além disso, a oferta de trabalho na incipiente atividade industrial não correspondeu à demanda da mão de obra migrada do campo para a cidade. Estava assim lançada a raiz do problema da carência habitacional no Brasil. $O$ déficit habitacional e a favelização se tornaram problemas estruturais da sociedade brasileira, com a concentração populacional nas grandes cidades, sem providências que pudessem atender à carência habitacional, de infraestrutura, saúde e educação, principais problemas sociais urbanos no Brasil.

1 Doutora em Arquitetura pelo Programa de Pesquisa e Pós-Graduação em Arquitetura (PROPAR), da Universidade Federal do Rio Grande do Sul (UFGRS), Professora da Faculdade de Arquitetura e do PROPAR, UFGRS. 


\section{Housing policies}

Housing policies in Brazil have gone through different stages throughout history. The development of official initiatives to provide housing for the low-income population in Brazil can be divided into three phases linked to different funding institutions. The first one, preceding the creation of the National Housing Bank (BNH), marked the start of state intervention by means of the experience with Pension and Retirement Institutes - IAPs - that worked in a fragmented way, and served their associates, only, after the second half of the 1930s; the Popular House Foundation (FCP), created in 1946, the first national initiative aimed at low-income populations; and the Popular Housing Department (DHP), which belonged to the city government of the Federal District at the time, still in the 1940s. The second phase started after the implementation of $\mathrm{BNH}$, created as one of the first deeds by the recently established military regime in 1964; the third phase, the post-BNH period, started after the extinction of the bank, in 1986. That dismantled the housing program in Brazil and the states and municipalities were left to supply their own housing demands.

During its period of operation, between 1964 and 1986, the BNH granted funding at an unprecedented rate in Brazil. BNH's housing projects used urban voids and expanded the outskirts of big and average cities. Those projects consisted of small houses in private lots, or of apartment blocks built in a collective area, most of the times without an elevator (COMAS, 1983, p. 21).

Some of the problems pointed out in the BNH housing projects were their size, since many times each project had more than 1,000 housing units, the lack of proper infrastructure, their far-off location, the repetition of one same design in projects that did not consider the specificities of each area. The housing projects funded by BNH were severely criticized, most specifically with regard to the gradual decrease of architectural quality, monotony, lack of identity, absence of spatial configuration or demarcation for the use of open spaces.

With the end of $\mathrm{BNH}$, in 1986, there was no longer a national and comprehensive model of housing policy, and that was replaced by municipal and state initiatives. Differently from what happened in the $\mathrm{BNH}$ years, smaller-scale housing programs began to support the construction of smaller buildings, in actions spread among many instances of the government, with own resources or using resources obtained from alternative funding. That resulted in scattered, successful experiences, but at a small scale. 


\section{As políticas habitacionais}

As políticas habitacionais passaram por diversos momentos ao longo da história no Brasil. O desenvolvimento das iniciativas oficiais no provimento de habitações para a população brasileira de baixa renda pode ser dividido em três fases, de acordo com os órgãos financiadores. A primeira delas, o período pré-Banco Nacional da Habitação (BNH), marcou o início da intervenção estatal através da experiência dos Institutos de Aposentadoria e Pensões - os IAPs, que atuavam de forma fragmentária, atendendo apenas aos associados a partir da segunda metade da década de 1930; a Fundação da Casa Popular (FCP), criada em 1946, primeira iniciativa de âmbito nacional voltada à população de baixa renda; e o Departamento de Habitação Popular (DHP), órgão da prefeitura do então Distrito Federal, também da década de 1940. A segunda fase se definiu com a implantação do $\mathrm{BNH}$, uma das primeiras ações do regime militar recém instalado em 1964; a terceira, o período pós-BNH, teve início com a extinção do banco em 1986, desarticulando o programa habitacional no País, restando aos estados e municípios a busca de alternativas que pudessem suprir a carência de moradias.

Durante o seu período de atuação, entre 1964 e 1986, o BNH concedeu financiamentos em escala sem precedentes no Brasil. Os conjuntos habitacionais do BNH ocuparam vazios urbanos e expandiram a periferia das grandes e médias cidades. Eram formados por pequenas casas em lotes privatizados, ou blocos de apartamentos implantados numa área coletivizada, em sua maioria sem elevador (COMAS, 1983, p. 21).

Nos conjuntos habitacionais do BNH são apontados problemas como sua dimensão, muitas vezes chegando a mais de mil unidades, ausência de infraestrutura adequada, localização periférica, repetição de um mesmo modelo de edificação em projetos que não consideraram as especificidades de diferentes regiões. Muitas críticas foram feitas aos projetos financiados pelo $\mathrm{BNH}$, mais especificamente sobre a gradativa diminuição da qualidade arquitetônica, monotonia, falta de identidade, ausência de configuração espacial ou definição de uso dos espaços abertos.

Com o encerramento das atividades do BNH, em 1986, deixou de existir um modelo de caráter nacional e abrangente, dando lugar a iniciativas municipais e estaduais. De uma forma diversa ao período $\mathrm{BNH}$, os programas habitacionais de menor escala passaram a promover conjuntos menores, ações pulverizadas em diversas instâncias governamentais, com recursos próprios ou buscados em fontes alternativas de financiamento. Resultaram em experiências esparsas, bem-sucedidas, mas em pequena escala. 
From 2003 on, after the City Statute was sanctioned (Law no. 10,257, of $10 / 07 / 2011$ ) and the Ministry of the Cities was created, housing and urban policies reached a new level. Having been created on 01/01/2003, the Ministry of the Cities had as its main objective to formulate national urban policies and to provide local governments with technical and financial support. My House, My Life (MCMV), a program linked to the Ministry of the Cities, was released by the federal government in March 2009 with the objective of subsidizing, in partnership with states and municipalities, the purchase of a house or apartment. That program has a wide spectrum of coverage since it encompasses income ranges from zero to ten minimum wages.

The MCMV program deals with fighting against the housing deficit by means of large-scale production and should be recognized exactly as such. There are problems, nevertheless. The program provides those who are responsible for purchasing the land and developing the project with the right to choose the location for construction. The issue is approached as the provision of housing units, only, with no consideration about the fact that living somewhere presupposes availability of commercial areas, education, health and leisure, besides infrastructure services that can complement human activities. It is not only about housing provision, but about the construction of a city. As stated by architect and professor Pablo Benetti, winner of prize Favela-Bairro, in 1993, "popular forms of housing are also part of the efforts towards the building of a city" (BENETTI, 2012).

A revision in social housing programs existing in Brazil, since their implementation in 1940's up to nowadays, shows us we lack options when it comes to the supply of housing demands, both in terms of the provision of homes and of the implementation of institutional policies. It is worth mentioning that the matter must be faced not only as provision of housing, but as mode of organization of cities, since urban living is not limited to a shelter that protects us, but to the fulfilment of other human needs.

\section{Housing shortage}

By means of the index of Distribution of permanent private housing units, by tenure, in Brazil, of 2018, the IBGE reports that $74.5 \%$ of those housing units are owned by their residents, whereas $15.1 \%$ are rented. That difference indicates the strength of the home-owning culture that dates back to the 1940's. Prior to Decree-law no. 4,598, of 20/08/1942, known as Lei do Inquilinato (Tenant's Law), which used to keep renting 
A partir de 2003, após a sanção do Estatuto da Cidade (Lei n. 10.257, de 10.07.2001) e a criação do Ministério das Cidades, as políticas habitacionais e urbanas ganharam novo patamar. Criado em 01.01.2003, o Ministério das Cidades teve como objetivo formular a política urbana em nível nacional e fornecer apoio técnico e financeiro a governos locais. Vinculado ao Ministério das Cidades, o Programa Minha Casa, Minha Vida (MCMV), lançado em março de 2009 pelo governo federal, tem por objetivo o subsídio para a aquisição da casa ou apartamento próprio, em parceria com estados e municípios. Trata-se de programa com espectro de atendimento bastante amplo, compreendendo faixas de renda de zero até 10 salários mínimos.

O MCMV diz respeito ao enfrentamento do déficit habitacional por meio da produção em larga escala que, como tal, deve ser reconhecido. Por outro lado, problemas existem. O programa delega a escolha da localização aos responsáveis pela aquisição da terra e elaboração de projetos. A questão é abordada unicamente como provimento de unidades habitacionais, desconsiderando que morar pressupõe provimento de comércio, educação, saúde e lazer, além da disponibilidade de serviços de infraestrutura que possam complementar as atividades humanas. Não se trata somente da provisão habitacional, mas da construção de cidade. Como afirma o arquiteto e professor Pablo Benetti, ganhador de prêmio do Programa Favela-Bairro, em 1993, "formas populares de habitação também fazem parte deste esforço de edificação da cidade" (BENETTI, 2012).

Uma revisão nos programas de habitação social existentes no Brasil, desde sua implementação na década de 1940 aos dias de hoje, nos revela que o atendimento à demanda habitacional no País carece de alternativas, tanto no que se refere ao provimento de moradias quanto às políticas institucionais. Destaca-se ainda a necessidade de encarar a questão não apenas como suprimento de unidade habitacional, mas como organização de cidades, uma vez que a vivência urbana não se restringe ao abrigo que nos acolhe, mas ao atendimento das demais necessidades humanas.

\section{Carência habitacional}

Por meio do índice de Distribuição dos domicílios particulares permanentes, por condição de ocupação, no Brasil, de 2017, o IBGE nos informa que 74,5\% desses domicílios são de propriedade de seus moradores, enquanto $15,1 \%$ são imóveis alugados, revelando uma forte cultura de propriedade do imóvel que remonta à década de 1940 no País. Anterior ao Decreto-Lei n. 4.598, de 20.08.1942, conhecido como Lei do Inquilinato, que congelava os aluguéis por um período de dois anos, o acesso 
prices unchanged for a period of two years, paying a monthly rent was the primary form of access to housing. That law discouraged the construction of housing units for renting, while contributing to the production of real estate for sale. The myth of home-owning was firstly sustained due to the work of the $\mathrm{BNH}$, a program that dedicated more than two decades to the granting of funding for home-owning, and, more recently, due to the MCMV program.

Ten years after the creation of MCMV, giving access to more than 5.5 million families to home-owning (SIMÃO; QUINTÃO, 2019), the situation of the Brazilian housing deficit, of 7,757 million housing units $^{2}$, is still a national problem.

\section{Inadequacy of infrastructure}

Problems related to housing shortage in Brazil occur repeatedly. Since the days of the BNH, there has also been an absence of proper infrastructure for the existing housing units. The provision of housing with a big number of units demands wide construction areas, and that pushes such initiatives towards the outskirts of cities, areas usually deprived of adequate infrastructure, even nowadays. The problems observed include matters such as urban transportation, rain drainage, water supply, sewage, garbage disposal, networks of electricity and telecommunications.

The IBGE surveys refer to infrastructure problems in housing areas by means of indexes. One of them, about Distribution of permanent private housing units, by existence of garbage collection services, by Major Region, shows there is direct supply of that demand in $91.7 \%$ of the housing units in the Southeast Region; in $86.1 \%$ of those in in the South Region and in $85.1 \%$ of the housing units in the CentralWest. In the other Major Regions the indexes are lower, with direct garbage collection in $69.8 \%$ of the housing units in the North Region and in $69.6 \%$ of those in the Northeast Region. Consequently, in those locations the number of housing units with indirect or non-existing garbage collection is bigger. In that respect, what stands out is the absence of that type of service in $20 \%$ of the housing units in the North Region.

$\overline{2}$ Data of 2015 based on the National Household Sample Survey (PNAD). For more details, see:VILLAS BOAS, B.; CONCEIÇÃO, A. Déficit de moradias no país já chega a 7,7 milhões. Valor Econômico, São Paulo, 3 maio 2018. Brasil. Available from: <https://www.valor.com.br/brasil/5498629/deficit-de-moradias-no-pais-jachega-77-milhoes>. Cited: May 2019. 
à moradia se dava prioritariamente por meio de pagamento mensal de aluguel. Essa lei desestimulou construção de moradias destinadas à locação, incrementando a produção de unidades imobiliárias a serem vendidas. O mito da casa própria foi estimulado ainda pela atuação do $\mathrm{BNH}$, programa com atuação durante mais de duas décadas na concessão de financiamento para aquisição da casa própria e, mais recentemente, pelo MCMV.

Passados dez anos da criação do MCMV, com acesso de mais de 5,5 milhões de famílias à casa própria (SIMÃO; QUINTÃO, 2019), a situação do déficit habitacional brasileiro, em 7,757 milhões de moradias ${ }^{2}$, continua sendo um problema nacional.

\section{Inadequação da infraestrutura}

Os problemas da carência habitacional no Brasil se repetem. Desde o período do $\mathrm{BNH}$, somam-se à questão da ausência de infraestrutura adequada às moradias existentes. O provimento de habitações com grande número de unidades demanda áreas extensas, o que conduz as iniciativas às periferias das cidades, desprovidas de infraestrutura adequada, ainda nos dias atuais. Os problemas dizem respeito a questões como transporte urbano, drenagem pluvial, abastecimento de água, esgoto sanitário, coleta de lixo, redes de energia e telecomunicação.

As pesquisas do IBGE demonstram problemas de infraestrutura nas áreas habitacionais por meio de seus índices. Um deles, que diz respeito à Distribuição dos domicílios particulares permanentes, por existência de serviço de coleta de lixo, segundo as Grandes Regiões, revela o atendimento direto desta coleta em 91,7\% domicílios na Região Sudeste, 86,1\% na Região Sul e 85,1\% na Região Centro-Oeste. Nas demais regiões esses índices são menores, com coleta de lixo direta em $69,8 \%$ dos domicílios na Região Norte e $69,6 \%$ na Região Nordeste. Consequentemente, nessas regiões o número de domicílios com coleta indireta ou a inexistência desse serviço é maior. Nesse quesito, o que mais chama a atenção é a ausência de coleta de lixo em 20,0\% dos domicílios na Região Norte.

2 Dado de 2015, que tem como base a Pesquisa Nacional por Amostra de Domicílios (PNAD). Para informações detalhadas, consultar: VILLAS BOAS, B.; CONCEIÇÃO, A. Déficit de moradias no país já chega a 7,7 milhões. Valor Econômico, São Paulo, 3 maio 2018. Brasil. Disponível em: <https://www.valor.com.br/brasil/5498629/deficit-de-moradias-no-pais-jachega-77-milhoes>. Acesso em: maio 2019. 
With reference to water supply, by means of the observed Distribution of permanent private housing units, by existence of general water supply system, by Major Regions, the higher level of urban development is confirmed in the Southeast, South and Central-West Regions, with indexes that are approximately the same as those in previous years. In this respect, the Northeast records a significantly higher index than the North Region, since $77.9 \%$ of the housing units in the former use a general system and internal pipping, versus $56.4 \%$ in the latter. Once again, more scarcity of infrastructure is observed in the North Region, where $40.8 \%$ of the housing units do not have access to water supply services.

\section{Final remarks}

The information presented above evidences a higher level of urban development in the South, Southeast and Central-West Regions of Brazil. On the other hand, those questions expose the lack of urban infrastructure in the Northeast Region, and the even more serious conditions in the North. Undoubtedly, issues related to urban development are associated to economic development in different regions and show the need of subsidized assistance actions in the most underprivileged northern states.

Above all, the awareness about human needs should be preponderant. If people leave the field in search of opportunities in the cities, the urbanity they are looking for goes beyond a roof or a home. So, housing means not only a group of houses, but the construction of urban centers that demand specific infrastructure.

\section{References}

BALBIM, R. Serviço de moradia social ou locação social: alternativas à política habitacional. Brasília: Instituto de Pesquisa Econômica Aplicada - Ipea, 2015. (Texto para discussão, 2134). Available from: <http://www.ipea.gov.br/ portal/index.php?option=com_alphacontent\&view=alphacontent\&ltem id=351>. Cited: May, 2019.

BENETTI, P. Habitação social e cidade: desafios para o ensino de projeto. Rio de Janeiro: Rio Books, 2012. 103 p.

BONDUKI, N. Origens da habitação social no Brasil: arquitetura moderna, lei do inquilinato e difusão da casa própria. São Paulo: Estação Liberdade : FAPESP, 1998. 342 p. 
No que diz respeito ao abastecimento de água, por meio da verificação da Distribuição dos domicílios particulares permanentes, por existência de rede geral de abastecimento de água, segundo as Grandes Regiões, o nível de desenvolvimento urbano mais elevado se confirma nas Regiões Sudeste, Sul e Centro-Oeste, com índices aproximadamente iguais aos anteriores. Nesse quesito, a Região Nordeste apresenta um índice significativamente mais elevado do que a Região Norte, com 77,9\% dos domicílios com rede geral e canalização interna no Nordeste do País, enquanto esse índice reduz para $56,4 \%$ no Norte. Mais uma vez a Região Norte demonstra uma carência maior de infraestrutura com $40,8 \%$ de domicílios sem serviço de abastecimento de água.

\section{Considerações finais}

As questões acima expostas demonstram um nível de desenvolvimento urbano superior nas Regiões Sul, Sudeste e Centro-Oeste do Brasil. Por outro lado, trazem à tona a carência de infraestrutura urbana na Região Nordeste, e uma situação ainda mais preocupante na Região Norte. Evidentemente, as questões de desenvolvimento urbano estão associadas ao desempenho econômico das diferentes regiões, demonstrando a necessidade de ações assistenciais mais subsidiadas nos estados ao norte do País com maior carência.

Acima de tudo a consciência das necessidades humanas devem ser preponderantes. Se as pessoas deixaram o campo em busca de oportunidades nas cidades, a urbanidade que buscam vai além de um teto ou uma casa. Sendo assim, não se trata apenas de um conjunto de habitações, mas da construção de núcleos urbanos que demandam a infraestrutura necessária.

\section{Referências}

BALBIM, R. Serviço de moradia social ou locação social: alternativas à política habitacional. Brasília: Instituto de Pesquisa Econômica Aplicada - Ipea, 2015. (Texto para discussão, 2134). Disponível em: <http://www.ipea.gov.br/portal/index.php?option=com_alphacontent\&view=alphacontent\&ltemid=351>. Acesso em: maio 2019.

BENETTI, P. Habitação social e cidade: desafios para o ensino de projeto. Rio de Janeiro: Rio Books, 2012. 103 p.

BONDUKI, N. Origens da habitação social no Brasil: arquitetura moderna, lei do inquilinato e difusão da casa própria. São Paulo: Estação Liberdade : FAPESP, 1998. 342 p. 
COMAS, C. E. D. Oespaço da arbitrariedade. Revista do Serviço Público, Brasília, v.40, n. 1, 1983. Available from: <http://revista.enap.gov.br/index.php/RSP/ issue/archive> Cited: March 1, 2017.

FERREIRA, J. S. W. Produzir casas ou construir cidades? Desafios par um novo Brasil urbano: parâmetros de qualidade para a implantação de projetos habitacionais e urbanos. São Paulo: FUPAM : LABHAB, 2012.

SIMÃO, E.; QUINTÃO, C. Com futuro indefinido, Minha Casa faz dez anos. ValorEconômico, São Paulo, 22 mar. 2019. Empresas. Available from: <https:// www.valor.com.br/empresas/6174609/com-futuro-indefinido-minha-casafaz-dez-anos>. Cited: May, 2019.

VILLAS BOAS, B.; CONCEIÇÃO, A. Déficit de moradias no país já chega a 7,7 milhões. Valor Econômico, São Paulo, 3 maio 2018. Available from: <https:// www.valor.com.br/brasil/5498629/deficit-de-moradias-no-pais-ja-chega-77milhoes>. Cited: March 1, 2019.

Translated by: Aline Milani Romeiro Pereira 
COMAS, C. E. D. O espaço da arbitrariedade. Revista do Serviço Público, Brasília, v. 40, n. 1, 1983. Disponível em: <http://revista.enap.gov.br/index.php/RSP/issue/ archive $>$. Acesso em: maio 2019.

FERREIRA, J. S. W. Produzir casas ou construir cidades? Desafios par um novo Brasil urbano: parâmetros de qualidade para a implantação de projetos habitacionais e urbanos. São Paulo: FUPAM : LABHAB, 2012.

SIMÃO, E.; QUINTÃO, C. Com futuro indefinido, Minha Casa faz dez anos. Valor Econômico, São Paulo, 22 mar. 2019. Empresas. Disponível em: <https://www.valor.com. br/empresas/6174609/com-futuro-indefinido-minha-casa-faz-dez-anos $>$. Acesso em: maio 2019.

VILLAS BOAS, B.; CONCEIÇÃO, A. Déficit de moradias no país já chega a 7,7 milhões. Valor Econômico, São Paulo, 3 maio 2018. Disponível em: <https://www.valor.com. $\mathrm{br} / \mathrm{brasil} / 5498629 /$ deficit-de-moradias-no-pais-ja-chega-77-milhoes $>$. Acesso em: maio 2019. 


\section{Gráfico 3.1 - Distribuição dos domicílios particulares permanentes, por condição de ocupação - 2017 \\ Graph 3.1 - Distribution of permanent private housing units, by tenure - 2017}

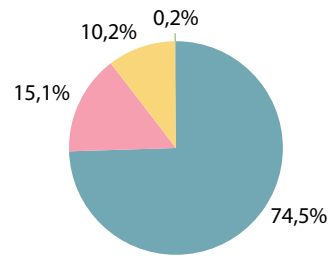

\begin{tabular}{|c|c|c|}
\hline Próprio & $\begin{array}{l}\text { Alugado } \\
\text { Renter }\end{array}$ & Cedido \\
\hline
\end{tabular}

Fonte/Source: IBGE, Diretoria de Pesquisas, Coordenação de Trabalho e Rendimento, Pesquisa Nacional por Amostra de Domicílios Contínua 2017.

Nota: Informações das entrevistas realizadas nos domicílios visitados pela primeira vez em cada um dos quatro trimestres do ano./Note: Information of the interviews carried out in the housing units visited for the first time in each one of the four quarters of the year.

\section{Gráfico 3.2 - Distribuição dos domicílios particulares permanentes, por existência de rede geral de abastecimento de água, segundo as Grandes Regiões - 2017}

Graph 3.2 - Distribution of permanent private housing units, by presence of water supply system and Major Regions - 2017

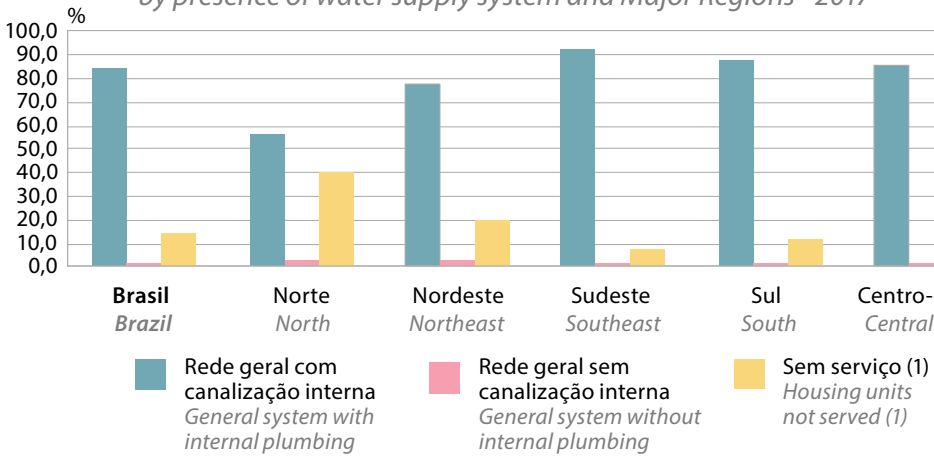

Fonte/Source: IBGE, Diretoria de Pesquisas, Coordenação de Trabalho e Rendimento, Pesquisa Nacional por Amostra de Domicílios Contínua 2017.

Nota: Informações das entrevistas realizadas nos domicílios visitados pela primeira vez em cada um dos quatro trimestres do ano./Note: Information of the interviews carried out in the housing units visited for the first time in each one of the four quarters of the year.

(1) Domicílios com abastecimento de água através de poço ou nascente ou outras formas./ (1) Housing units with water supply through wells or wellspring or other types. 


\section{Gráfico 3.3 - Distribuição dos domicílios particulares permanentes, por existência de serviço de coleta de lixo, segundo as Grandes Regiões - 2017}

Graph 3.3 - Distribution of permanent private housing units, by existence

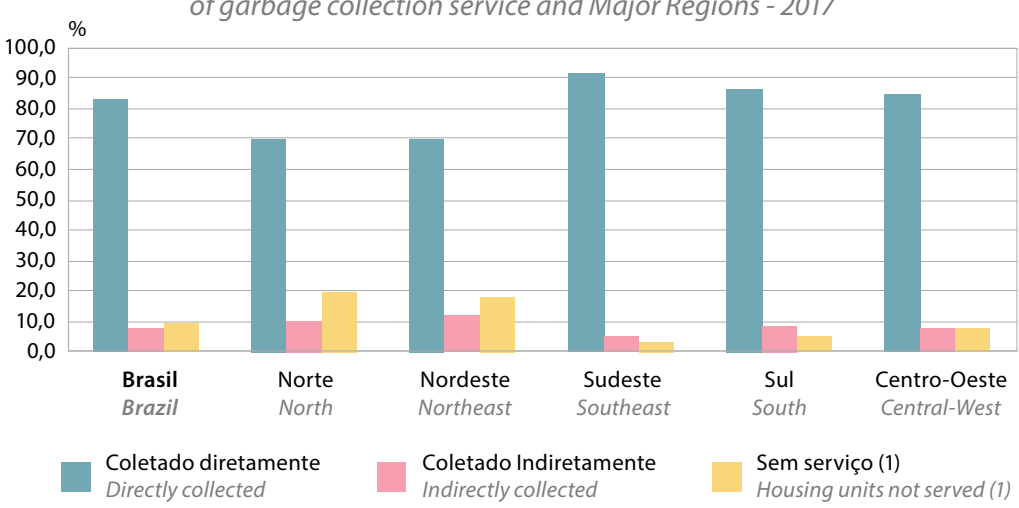

Fonte/Source: IBGE, , Diretoria de Pesquisas, Coordenação de Trabalho e Rendimento, Pesquisa Nacional por Amostra de Domicílios Contínua 2017.

Nota: Informações das entrevistas realizadas nos domicílios visitados pela primeira vez em cada um dos quatro trimestres do ano/Note: Information of the interviews carried out in the housing units visited for the first time in each one of the four quarters of the year.

(1) Domicílio cujo lixo é queimado, enterrado ou dado outro destino./(1) Housing unit whose garage is burned, buried or given another destination. 
Tabela 3.1 - Domicílios particulares permanentes, pessoas residentes em domicílios particulares permanentes e média de pessoas, por domicílio particular permanente e dormitório em domicílio particular permanente, segundo as Grandes Regiões - 2017

Table 3.1 - Permanent private housing units, persons residents in permanent private housing units, and average number of persons, per permanent private housing units and per bedroom in permanent private housing units, by Major Regions - 2017

\begin{tabular}{|c|c|c|c|c|}
\hline \multirow[b]{2}{*}{$\begin{array}{l}\text { Grandes Regiões/ } \\
\text { Major Regions }\end{array}$} & \multirow[b]{2}{*}{$\begin{array}{l}\text { Domicílios } \\
\text { particulares } \\
\text { permanentes/ } \\
\text { Permanent } \\
\text { private } \\
\text { housing units } \\
(1000)\end{array}$} & \multirow{2}{*}{$\begin{array}{l}\text { Pessoas } \\
\text { residentes } \\
\text { em domicílios } \\
\text { particulares } \\
\text { permanentes/ } \\
\text { Persons } \\
\text { residents in } \\
\text { permanent } \\
\text { private } \\
\text { housing units } \\
(1000)\end{array}$} & \multicolumn{2}{|c|}{$\begin{array}{l}\text { Média de pessoas/ } \\
\text { Average number of persons }\end{array}$} \\
\hline & & & $\begin{array}{l}\text { Por domicílio } \\
\text { particular } \\
\text { permanente/ } \\
\text { Per permanent } \\
\text { private } \\
\text { housing units }\end{array}$ & $\begin{array}{l}\text { Por dormitório } \\
\text { em domicílio } \\
\text { particular } \\
\text { permanente/ } \\
\text { Per bedroom } \\
\text { in permanent } \\
\text { private } \\
\text { housing units }\end{array}$ \\
\hline Brasil/ Brazil & 69471 & 206172 & 3,7 & 1,7 \\
\hline Norte/North & 5114 & 17625 & 4,4 & 2,0 \\
\hline Nordeste/Northeast & 18181 & 56300 & 3,9 & 1,7 \\
\hline Sudeste/Southeast & 30261 & 87014 & 3,5 & 1,7 \\
\hline Sul/South & 10537 & 29483 & 3,4 & 1,6 \\
\hline Centro-Oeste/Central-West & 5379 & 15750 & 3,6 & 1,7 \\
\hline
\end{tabular}

Fonte/Source: IBGE, Diretoria de Pesquisas, Coordenação de Trabalho e Rendimento, Pesquisa Nacional por Amostra de Domicílios Contínua 2017.

Nota: Informações das entrevistas realizadas nos domicílios visitados pela primeira vez em cada um dos quatro trimestres do ano/Note: Information of the interviews carried out in the housing units visited for the first time in each one of the four quarters of the year. 


\section{Saúde Health}

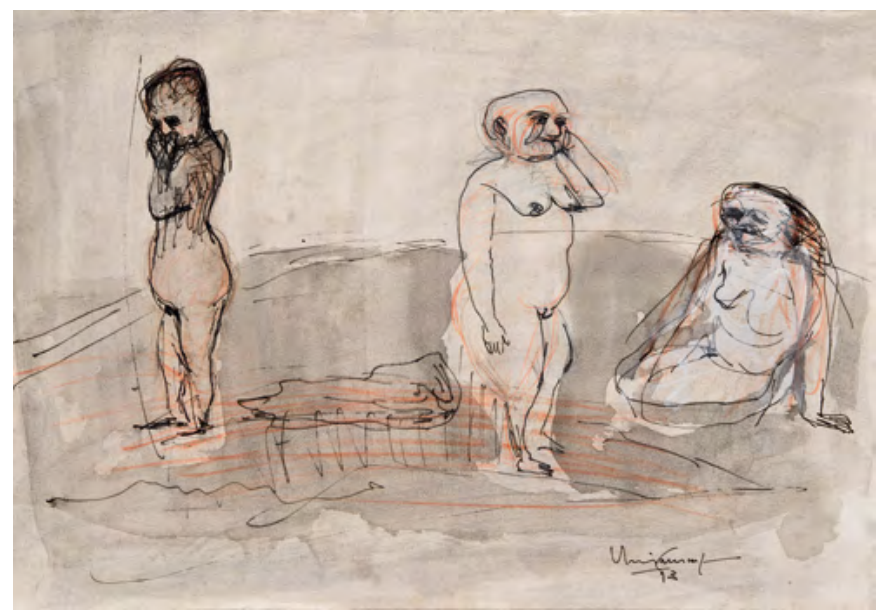

Sem título, 1993

Untitled

Iberê Camargo 


\section{Health}

\section{Mary Ann Menezes Freire ${ }^{1}$}

The right to health in Brazil was achieved as a result of a big social movement. The Sanitary Reform, which inaugurated a new era in the 1980s, occurred through a multiple, heterogeneous and articulate movement. A fight for the right to health. A fight for democracy. A collective enterprise for the sake of the common good from the perspective of differences.

Understanding the role of the State in policy-making requires having access to the multiplicity of the population demands and to the territories where they are housed. Thinking of a Unified Heath System (SUS) supposed to meet the needs of such a large country, with its diverse and heterogeneous compositions is the same as thinking of a dynamic social protection system, responsive to the social, economic, political, cultural and population transformations, among others. That requires constant mobilization and reformulation processes in order to establish its role and guarantee the fulfillment of its goals before society. Somehow, talking about the complexity of SUS is dealing with a field of social practices built on several tensions, a territory of permanent social and historical disputes. Approaching some of the different topics that cross-cut it is trying to give visibility to the forces and tensions which operate within it so that its potential, as well as its weaknesses and operational issues, can be clearly seen and its form, established.

\section{Vaccination coverage}

\footnotetext{
1 Nurse. PhD in Sciences from the Federal University of the State of Rio de Janeiro (UNIRIO). Professor of the Department of Public Health Nursing (DESP) of UNIRIO.
} 


\section{Saúde}

\section{Mary Ann Menezes Freire ${ }^{1}$}

O direito à saúde no Brasil foi conquistado a partir de um grande movimento social. A Reforma Sanitária, que deu novo tom à década de 1980, se deu por um movimento múltiplo, heterogêneo, articulador. Uma luta pelo direito à saúde. Uma luta pela democracia. Um coletivo em prol de um bem comum a partir da diferença.

Compreender o papel do Estado na execução das políticas públicas requer acessar a multiplicidade de demandas da população e dos territórios aos quais estas estão inseridas. Pensar em um Sistema Único de Saúde (SUS) que deve atender um país de dimensões continentais, diverso, heterogêneo em suas diversas composições, é pensar em um sistema de proteção social dinâmico e interativo com as transformações sociais, econômicas, políticas, culturais, demográficas, dentre outras, o que exige constantes processos de mobilização e reformulação para alicerçar o seu papel e garantir a execução dos seus objetivos junto à sociedade.

De certa forma, falar sobre a complexidade do SUS é tratar de um campo de práticas sociais, edificado sob diversas tensões, espaço esse permanente de disputas, sociais e históricas. Abordar algumas das diversas temáticas que o transpassam é tentar dar visibilidade à essas forças e tensões que o operam, no intuito de deixar claro a sua potência, suas fragilidades e seus territórios de práticas, onde se estabelece sua conformação.

1 Enfermeira. Doutora em Ciências pela Universidade Federal do Estado do Rio de Janeiro (UNIRIO). Professora do Departamento de Enfermagem em Saúde Pública (DESP), da UNIRIO. 
Despite the several advances, there are clearly internal challenges in the development of the National Immunization Program (PNI), which today undergoes a downward trend in the coverage. As it can be seen in Table 4.2, the reduction of the coverage is complex and can be attributable to several factors, such as: the current political and economic scenario; the false sense of protection against illnesses; the increasing movement of fake news on vaccination; and some health services' structural issues.

The return of measles, in 2018 , and the confirmation of one more case of the disease in February 2019, completing more than one year of sustained transmission of the infection in the country, had us lose the title granted by the Pan American Health Organization (PAHO) in 2016 of disease-free zone. The vaccine that prevents such aggravation, the triple viral, which also prevents mumps and rubella, has integrated the vaccination schedule since 1995 and is available, as well as all the others, for free in the primary health care units. However, the coverage has not reached the target of $95 \%$ (the first dose coverage stood at $81.9 \%$, in 2018), which puts the population at risk concerning that disease.

Presenting the same pattern is poliomyelitis, which had been eliminated from the country in 1989. In the years 2016, 2017 and 2018, the vaccine coverage against polio stood for the first time more than 10 percentage points below the target, which is also $95 \%: 84.4 \%$, in $2016 ; 83.4 \%$, in 2017, and $77.2 \%$ in 2018 .

The problem becomes even more serious when one can see that the other vaccines follow the same trend, as it is the case of Hepatitis B, with $80.6 \%$ of coverage in 2018 . The decreasing indicators of these and other important vaccines started in 2016 and have been decreasing ever since, getting far apart of the program's targets and of the health planning. A very worrying scenario.

The data call even more attention when it comes to the indicators by area/Brazilian states, with a highlight to the uneven distribution of the vaccination coverage. That confirms what the Ministry of Heath had already found out in 2018: more than half of the Brazilian cities do not have an adequate coverage for most of the vaccines in the schedule.

In a context of several weaknesses that are part of the current situation of the PNI and of the vaccination coverage in the country, it is necessary to make financial investments in the Primary Care Health Units (APS), in the working process of the health professionals, in the potential of the popular education on health, expanding and making it easier to have access to services and information. 


\section{Cobertura vacinal}

Apesar dos inúmeros avanços, evidencia-se aqui desafios inerentes ao desenvolvimento do Programa Nacional de Imunizações (PNI), que vive hoje um cenário de queda nas coberturas. Como pode-se observar na Tabela 4.2, a redução das coberturas é complexa e pode ser explicada por muitos fatores, tais como, o atual contexto de fragilidade política e econômica; a falsa sensação de segurança em relação às doenças; o crescente movimento que atua com a divulgação de informações falsas sobre vacinação; e algumas questões organizacionais dos serviços de saúde.

O retorno do sarampo, em 2018, e a confirmação de mais um caso da doença em fevereiro de 2019, completando, assim, mais um ano de transmissão sustentada da infecção no País, fez com que perdêssemos o título recebido, em 2016, de área livre da doença, pela Organização Pan-Americana da Saúde (OPAS). A vacina que previne esse agravo, a tríplice viral, que também combate a caxumba e a rubéola, presente no calendário desde 1995, encontra-se disponível, assim como todas as outras, de forma gratuita nas unidades de atenção primária à saúde. Apesar disso, o que se tem observado é a cobertura abaixo da meta de $95 \%$ (a cobertura da primeira dose ficou em 81,9\%, em 2018), o que coloca a população em risco para desenvolvimento da doença.

Segue a mesma tendência, a poliomielite, que foi eliminada do País, em 1989. Nos anos de 2016, 2017 e 2018, a cobertura da vacina contra a pólio ficou, pela primeira vez, mais de 10 pontos percentuais abaixo da meta, que também é de $95 \%: 84,4 \%$, em 2016; 83,4\%, em 2017, e 77,2\% em 2018.

O problema torna-se ainda maior quando se constata que outras vacinas seguem o mesmo movimento, como a da hepatite B, com $80,6 \%$ de cobertura em 2018 . Os indicadores em queda dessas e de outras importantes vacinas começou em $2016 \mathrm{e}$ tem se repetido a cada ano, em descompasso com a trajetória do programa e com o planejamento em saúde. Um cenário de intensa preocupação.

Os dados chamam ainda mais atenção quando analisamos os indicadores por região/estado brasileiro, destacando a distribuição desigual da cobertura das vacinas, confirmando o que o Ministério da Saúde já havia sinalizado em 2018: mais da metade das cidades brasileiras não têm cobertura adequada para a maioria das vacinas do calendário nacional.

Em um contexto de fragilidades diversas que envolvem a situação atual do PNI e das coberturas vacinais no País, é necessário investimentos financeiros nas unidades de Atenção Primária à Saúde (APS), no processo de trabalho dos profissionais de saúde, na potência da educação popular em saúde, ampliando e facilitando o acesso, aos serviços e à informação. 


\section{HIV/Aids}

The surveillance of the human immunodeficiency virus (HIV) and of the virus responsible for the Acquired Immunodeficiency Syndrome (Aids) and the aggravation monitoring is conducted by the Department of Surveillance, Prevention and Control of Sexually Transmitted Diseases, of HIV/ Aids and Viral Hepatitis (DIAHV) of the Ministry of Health and they focus on three aspects: diagnosis/ virus infection, evolution to Aids and deaths. The indicators concerning the diagnosed cases, approached in this publication, are important information to public policies of disease prevention and control in the country.

The investment in the Brazilian program can be seen in the numbers. The 2018 HIV/Aids Epidemiological Bulletin, released by the Ministry of Health, revealed a drop of almost $16 \%$ in the number of new cases of HIV in the last five years. Concerning the Aids cases, the country has been recording annually an average of 40 thousand new cases in the last five years. The annual number of cases of Aids has been diminishing since 2013 , when it reached 43,269 cases; in 2017, there were 37,791 recorded cases.

In relation the cases of Aids, considering sexes, also according to the 2018 HIV/Aids Epidemiological Bulletin, in Brazil, from 1980 to June 2018 , there were $606,936(65.5 \%)$ cases of Aids in men and 319,682 (34.5\%), in women. In the period from 2002 to 2008, the sex ratio, which means the relation between the number of cases of Aids in men and women, kept at 15 cases in men for each 10 cases in woman; however, from 2009 on, there was a gradual reduction in the cases of Aids among women and an increase of cases among men, making the sex ratio go to 22 cases in men for each 10 cases in women in 2016, remaining as such in 2017. Considering the last 10 years, the detection rate of Aids in men had increased between 2007 and 2011 (24.8 to 28.3 cases/100,000 inhabitants). This rate was kept stable until 2013, when it fell again. In 2017, Aids detection in men was of 26.0 cases for each 100,000 inhabitants. Among women, there was a downward trend in this rate in the last 10 years, which went from 15.8 cases $/ 100,000$ inhabitants in 2007, representing a reduction of $30 \%$.

Such indicators can be justified by the greater and easier access to rapid tests, made available for free in the APS units, providing better diagnoses, due to the reduction between the diagnosis date and the beginning of the treatment and also due to the guarantee of available treatment for everyone. Despite all political and economic 


\section{HIV/Aids}

A vigilância do vírus da imunodeficiência humana (HIV) e causador da Síndrome da Imunodeficiência Adquirida (Aids) e o monitoramento do agravo são conduzidos pelo Departamento de Vigilância, Prevenção e Controle das Infecções Sexualmente Transmissíveis, do HIV/Aids e Hepatites Virais (DIAHV) do Ministério da Saúde e centram-se em três aspectos: diagnóstico/infecção pelo vírus, evolução para Aids e óbitos. Os indicadores que se referem aos casos diagnosticados, tratados nesta publicação, consistem em importantes subsídios para as políticas públicas de prevenção e controle da doença no País.

Os investimentos no programa brasileiro se refletem em números. O Boletim Epidemiológico HIV/Aids 2018, divulgado pelo Ministério da Saúde, revelou uma queda de quase $16 \%$ no número de novos casos de HIV nos últimos cinco anos. No que diz respeito aos casos de Aids, o País tem registrado, anualmente, uma média de 40 mil novos casos nos últimos cinco anos. O número anual de casos de Aids vem diminuindo desde 2013, quando atingiu 43269 casos; em 2017, foram registrados 37791 casos.

Ao observarmos os casos de Aids considerando os sexos, ainda segundo o Boletim Epidemiológico HIV/Aids 2018, no Brasil, de 1980 até junho de 2018, foram registrados 606936 (65,5\%) casos de Aids em homens e 319682 (34,5\%), em mulheres. No período de 2002 a 2008, a razão de sexos, expressa pela relação entre o número de casos de Aids em homens e mulheres, manteve-se em 15 casos em homens para cada dez casos em mulheres; no entanto, a partir de 2009, observou-se uma redução gradual dos casos de Aids em mulheres e um aumento nos casos em homens, refletindo-se na razão de sexos, que passou a ser de 22 casos de Aids em homens para cada dez casos em mulheres em 2016, razão que se manteve em 2017. Considerando-se os últimos 10 anos, observou-se que a taxa de detecção de Aids em homens apresentou aumento entre 2007 e 2011 (24,8 para 28,3 casos/100 000 habitantes). Essa taxa se manteve estável até 2013, quando voltou a cair. Em 2017, a detecção de Aids entre homens foi de 26,0 casos a cada 100000 habitantes. Entre as mulheres, observou-se tendência de queda dessa taxa nos últimos 10 anos, que passou de 15,8 casos/100 000 habitantes em 2007, para 11,1 em 2017, representando uma redução de $30 \%$.

Tais indicadores podem ser justificados pelo maior e mais fácil acesso aos testes rápidos, disponibilizados gratuitamente nas unidades de APS, com consequente melhoria no diagnóstico, pela redução entre o tempo de diagnóstico e o início do tratamento e pela garantia do tratamento disponível para todos. Apesar de todas as 
weaknesses, the program remains as an example of good resource management and care production.

The evolution and good indicators, however, do not prevent the presence of some problems. The investments in the expansion of health education, including sexual education, in the fight against stigma, the prevention campaigns, either in schools or in health services, should not stop being prioritized.

\section{Main death causes}

Looking at the relationship between health and disease in men and women allows us to deepen the health debate, going beyond the biological determinism, putting the topics in the realm of the social organization between the sexes. The field of health has been progressively incorporated to the gender perspective, aiming at the understanding of the relationships that are established between men and women in society and the use of health services. In this sense, looking at the indicators that comprise the 10 main death causes in Brazil, by sex, can provide information to the formulation of a hypothesis to explain the differences in the mortality and morbidity profiles.

The 10 main death causes of men and women reflect important differences between their ways of life and death. Among the several uses of mortality rates are the assessment of the health conditions of a population and the assessment of the health policies and programs, as those targeted at monitoring preventable deaths (for example, womb cancer, breast cancer, etc.). That kind of analysis is fundamental to identify the population groups at risk and redirect the priorities in the prevention and treatment of the diseases that generate more deaths.

On the presented tables, referring to the years 2015 and 2017, there are some patterns: more men than women die; circulatory diseases and neoplasm are a highlight among death causes, in both sexes; external causes of death stand out due the great occurrence among men, to the point it is, on the general table, the third main death cause in the country. Respiratory diseases and nutritional endocrine and metabolic diseases complete the ranking of the five leading causes of death in the country.

Brazil has undergone a constant and complex process of change in the illness and death profile of the population, with sharp decrease of mortality due to transmissible diseases and a significant reduction of preventable causes, which has made a positive impact on the rise of 
fragilidades políticas e econômicas, o programa permanece como um exemplo de boa gestão de recursos e de produção de cuidado.

As evoluções e os bons indicadores não deixam que algumas preocupações ainda se façam presentes. Os investimentos na ampliação da educação em saúde, incluindo educação sexual, o combate ao estigma, as campanhas de prevenção, sejam em escolas ou nos serviços de saúde, não devem deixar de ser priorizados.

\section{Principais causas de óbitos}

Olhar para as relações saúde $x$ doença em homens e mulheres nos permite discussões aprofundadas, para além do determinismo biológico, situando-as no âmbito da organização social da relação entre os sexos. O campo da saúde tem progressivamente incorporado a perspectiva de gênero visando compreender as relações que se estabelecem entre homens e mulheres na sociedade e suas repercussões para o estado de saúde, adoecimento e morte, bem como o acesso e a utilização de serviços de saúde. Nesse sentido, olhar para os indicadores que retratam as 10 principais causas de óbito no Brasil, por sexo, pode subsidiar o desenvolvimento de hipóteses explicativas para as diferenças dos perfis de mortalidade e morbidade.

As 10 principais causas de óbitos de homens e mulheres refletem diferenças importantes entre os modos de viver e morrer. Entre os diversos usos das estatísticas de mortalidade encontra-se a avaliação da situação de saúde de uma população; e a avaliação de políticas e programas de saúde, como os orientados a acompanhar óbitos preveníveis (por exemplo, câncer de útero, câncer de mama etc). Esse tipo de análise é fundamental para identificar os grupos populacionais de risco e reorientar as prioridades na prevenção e no tratamento das doenças que produzem mais óbitos.

Nas tabelas apresentadas, referentes aos anos de 2015 e 2017, observa-se alguns padrões: morrem mais homens do que mulheres; as doenças do aparelho circulatório e as neoplasias figuram com destaque entre principais causas de óbitos, em ambos os sexos; os óbitos por causas externas se destacam pela grande ocorrência no sexo masculino, a ponto de se manter, no quadro geral, como a terceira principal causa de óbito no País. As doenças do aparelho respiratório e as doenças endócrinas nutricionais e metabólicas completam o ranking das cinco principais causas de óbitos no País.

O Brasil tem vivenciado um contínuo e complexo processo de mudança do perfil de adoecimento e morte da população, com queda acentuada da mortalidade por 
life expectancy. As a result, there has also been occurring an increase of chronic non-communicable diseases, as diabetes, heart diseases, cancer, among others, as well as deaths due to violent causes, which has challenged the several sectors of the country to control such phenomenon.

Although the mortality profile is similar between the years surveyed and, for some of the causes, there is also variation between the sexes, it is worth mentioning here the differences as to the importance of some specific issues that highlight the inequalities, making it even more urgent to give attention to and invest in public policies that go beyond health.

\section{Hospital indicators}

Information on hospitalizations, hospital mortality, and length of stay of the users in the care units are essential for the planning of health care and promotion. Such information is relevant to measure performances, making it possible to monitor and assess their quality.

Analyzing the areas that concentrate the main causes of hospitalizations and hospital mortality, as well as the time spent by the user in the service, demanding specific care, allows us to reflect on the effectiveness of health promotion and prevention actions, on the quality of assistance and service, in the case of preventable deaths and prolonged stay, and consequently, on the proportional expenses of SUS in relation to those demands.

Table 4.3 shows the biggest occurrence of hospitalizations in the areas of medical, surgical, obstetrical, and pediatrics, in relation to the year 2018. With regard to the hospital mortality rate, the indicators that stand out refer to the areas of prolonged care, physiology, internal medicine and surgery. On the other hand, the highest average hospital stays refer to the area of prolonged care, psychiatry, phthisiology, mental health - day hospital and Aids - due to the aggravation characteristics of such diseases.

These indicators, besides being fundamental for the management of hospital services, should be joined with more detailed indicators about the health conditions of the Brazilian population and its demands, for a better diagnosis of the situation, better distribution of investments, and better qualification of professionals and services that make up the SUS Health Care Network (RAS). 
doenças transmissíveis e redução significativa das causas evitáveis de morte, o que impactou positivamente no aumento da expectativa de vida. Com isso, também vem ocorrendo aumento das doenças crônicas não transmissíveis, como diabetes, doenças cardiovasculares, cânceres, entre outras, além das mortes por violência, que têm desafiado os diversos setores do País para o controle desse fenômeno.

Embora o perfil de mortalidade seja semelhante entre os anos apresentados e, para algumas causas, também apresentem poucas variações entre os sexos, destaca-se aqui as diferenças, o quanto a magnitude de algumas causas específicas ressaltam as desigualdades, que destacam a necessidade de maior atenção e investimento em políticas públicas, para além da área da saúde.

\section{Indicadores hospitalares}

As informações sobre as internações, mortalidade hospitalar e tempo de permanência do usuário nessas unidades são fundamentais para o planejamento da atenção e promoção da saúde. Tais informações são relevantes indicadores de desempenho, possibilitando avaliação de qualidade e monitoramento.

Analisar as áreas que concentram as principais causas de internações e mortalidade hospitalar, assim como o tempo de permanência do usuário no serviço, demandando cuidados específicos, nos possibilita refletir sobre a efetividade das ações de promoção da saúde e prevenção de agravos, sobre a qualidade da assistência e do serviço, no caso das mortes evitáveis e do tempo de permanência prolongado, e consequentemente, sobre os gastos proporcionais do SUS com relação a essas demandas.

Observa-se na Tabela 4.3, em relação ao ano de 2018, os maiores números de internações nas áreas de clínica médica, clínica cirúrgica, obstetrícia e pediatria. No que diz respeito à taxa de mortalidade hospitalar, os indicadores que mais se destacam dizem respeito às áreas de cuidados prolongados, tisiologia, clínica médica e clínica cirúrgica. Já as maiores médias de permanência referem-se à área de cuidados prolongados, psiquiatria, tisiologia, saúde mental - hospital-dia e Aids - justificadas pelas características dos agravos que se enquadram nestas.

Tais indicadores, além de serem fundamentais para a gestão dos serviços hospitalares, devem ser articulados a indicadores mais detalhados acerca das condições de saúde da população brasileira e suas demandas, para um melhor diagnóstico da situação, melhor direcionamento de investimentos, e melhor qualificação dos profissionais e serviços que compõem toda a Rede de Atenção à Saúde (RAS) do SUS. 


\section{Far from... final remarks}

Knowing health indicators of a population, understanding them in their context of occurrence, and thinking of a production of full, equal and effective care is vital to guide the decision-making processes, not only in the scope of design and implementation of policies, but also in the scope of the management of the system and services, and of the health care micropolitics.

\section{References}

BOLETIM EPIDEMIOLÓGICO HIV AIDS 2018. Brasília, DF: Secretaria de Vigilância em Saúde, v. 49, n. 53, 2018. Available from: <http://www.aids.gov. br/pt-br/pub/2018/boletim-epidemiologico-hivaids-2018>. Cited:May 2019.

MENDES, E.V. As redes de atenção à saúde. 2. ed. Brasília, DF: Organização Pan-Americana da Saúde, 2011.549 p. Available from: <http://bvsms.saude. gov.br/bvs/publicacoes/redes_de_atencao_saude.pdf>. Cited: May 2019.

MERHY, E. E. et al. (Org.). Avaliação compartilhada do cuidado em saúde: surpreendendo o instituído nas redes. Rio de Janeiro: Hexis, 2016. (Políticas e cuidados em saúde, 1). Available from: <http://historico.redeunida.org.br/ editora/biblioteca-digital/colecao-micropolitica-do-trabalho-e-o-cuidadoem-saude/politicas-e-cuidados-em-saude-livro-1-avaliacao-compartilhadado-cuidado-em-saude-surpreendendo-o-instituido-nas-redes-pdf/ at_download/file>. Cited: May 2019.

SANTOS, L.; CAMPOS, G.W.S. SUS Brasil: a região de saúde como caminho. Saúde e Sociedade. São Paulo, v. 24, n. 2, p. 438-446, 2015. Available from: $<$ http://www.scielo.br/pdf/sausoc/v24n2/0104-1290-sausoc-24-02-00438. pdf>. Cited: May 2019.

STEVANIM, L. F. E agora Zé? Baixa cobertura das principais vacinas compromete programa brasileiro de imunizações, reconhecido internacionalmente. Radis. Rio de Janeiro: Fiocruz, n. 196, jan. 2016. Available from: <https://radis.ensp.fiocruz.br/index.php/revista/todas-edicoes $>$. Cited: May 2019. 


\section{Considerações... que não se findam aqui}

Conhecer os indicadores de saúde de uma população, compreendê-los em seu território, e pensar numa produção de cuidado integral, igualitária e efetiva, é importante para orientar a tomada de decisão, não apenas no âmbito da formulação e implementação das políticas de saúde, mas também no âmbito da gestão do sistema e serviços, e da micropolítica do cuidado em saúde.

\section{Referências}

BOLETIM EPIDEMIOLÓGICO HIV AIDS 2018. Brasília, DF: Secretaria de Vigilância em Saúde, v. 49, n. 53, 2018. Disponível em: <http://www.aids.gov.br/pt-br/pub/2018/ boletim-epidemiologico-hivaids-2018>. Acesso em: maio 2019.

MENDES, E.V. As redes de atenção à saúde. 2. ed. Brasília, DF: Organização Pan-Americana da Saúde, 2011.549 p. Disponível em: <http://bvsms.saude.gov.br/bvs/publicacoes/ redes_de_atencao_saude.pdf $>$. Acesso em: maio 2019.

MERHY, E. E. et al. (Org.). Avaliação compartilhada do cuidado em saúde: surpreendendo o instituído nas redes. Rio de Janeiro: Hexis, 2016. (Políticas e cuidados em saúde, 1). Disponível em: <http://historico.redeunida.org.br/editora/biblioteca-digital/ colecao-micropolitica-do-trabalho-e-o-cuidado-em-saude/politicas-e-cuidados-emsaude-livro-1-avaliacao-compartilhada-do-cuidado-em-saude-surpreendendo-oinstituido-nas-redes-pdf/at_download/file>. Acesso em: maio 2018.

SANTOS, L.; CAMPOS, G.W.S. SUS Brasil: a região de saúde como caminho. Saúde e Sociedade. São Paulo, v. 24, n. 2, p. 438-446, 2015. Disponível em: <http://www.scielo.

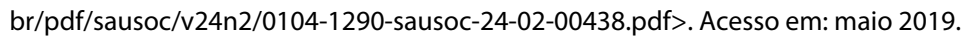

STEVANIM, L. F. E agora Zé? Baixa cobertura das principais vacinas compromete programa brasileiro de imunizações, reconhecido internacionalmente. Radis. Rio de Janeiro: Fiocruz, n. 196, jan. 2019. Disponível em: <https://radis.ensp.fiocruz.br/index. php/revista/todas-edicoes>. Acesso em: maio 2019. 
Tabela 4.1 - Dez principais causas de óbitos de residentes, por sexo - 2017

Table 4.1 - Ten leading causes of deaths of residents, by sex - 2017

(continua/to be continued)

\begin{tabular}{llll}
\hline Causas de óbitos/ & Total (1)/ & Homens/ \\
Causes of death & Motal (1) & Male & Female \\
& & \\
\hline
\end{tabular}

Total/

1309510

732594

576284

Total

Doenças do aparelho circulatório/

355928

186338

169557

Diseases of the circulatory system

Neoplasias (tumores)/

220332

115748

104571

Neoplasms (tumors)

Doenças do aparelho respiratório/

156987

79418

77546

Diseases of the respiratory system

Causas externas/

$157372 \quad 129020$

28169

External causes

Sintomas, Sinais e Achados Anormais de Exames Clínicos e de Laboratório não Classificados em outra parte/

Symptoms, signs and abnormal findings of laboratory and clinic checkups not elsewhere classified

Doenças endócrinas nutricionais e metabólicas/ 
Tabela 4.1 - Dez principais causas de óbitos de residentes, por sexo - 2017

Table 4.1 - Ten leading causes of deaths of residents, by sex - 2017

(conclusão/concluded)

$\begin{array}{llcc}\text { Causas de óbitos/ } & \text { Total (1)/ } & \text { Homens/ } & \text { Mulheres/ } \\ \text { Causes of death } & \text { Total (1) } & \text { Male } & \text { Female }\end{array}$

Doenças do aparelho digestivo/

$65498 \quad 40184 \quad 25304$

Diseases of the digestive system

Algumas doenças infecciosas e parasitárias/

55326

30951

24366

Certain infectious and parasitic diseases

Doenças do aparelho geniturinário/

40447

19264

21180

Diseases of the genitourinary system

Doenças do sistema nervoso/

38082

17182

20895

Diseases of the nervous system

Outros/

65669

34481

30971

Others

Fonte/Source: Informações de saúde (Tabnet). Mortalidade: dados preliminares. In: Brasil. Ministério da Saúde. Datasus. Brasília, DF, [2018]. Disponível em/ Avaible from:

<http://tabnet.datasus.gov.br/cgi/tabcgi.exe?sim/cnv/pobt10uf.def>.Acesso em: jan. 2019/ Cited: Jan 2019.

Nota: As causas de óbitos descritas correspondem ao Capítulo CID-10./Note: Causes of death presented according to Chapter ICD-10.

(1) Inclusive óbitos de sexo não informado./ (1) Including deaths of unknown sex. 
Tabela 4.2 - Cobertura vacinal, por Unidades da Federação - 2018

Table 4.2 - Immunization coverage, by Federation Unit - 2018

(continua/to be continued)

\begin{tabular}{|c|c|c|c|c|c|}
\hline $\begin{array}{l}\text { Unidades da Federação/ } \\
\text { Federation Units }\end{array}$ & $\begin{array}{c}\text { BCG / } \\
\text { BCG vaccine } \\
\text { (against } \\
\text { tuberculosis) }\end{array}$ & $\begin{array}{l}\text { Contra } \\
\text { hepatite B/ } \\
\text { Against } \\
\text { hepatite B }\end{array}$ & $\begin{array}{l}\text { Poliomielite/ } \\
\text { Against } \\
\text { Poliomyelitis }\end{array}$ & $\begin{array}{c}\text { Tríplice } \\
\text { viral D1/ } \\
\text { Triple viral } \\
\text { vaccine D1 }\end{array}$ & $\begin{array}{l}\text { Tetra viral/ } \\
\text { Tetra viral } \\
\text { Vaccine }\end{array}$ \\
\hline Brasil/Brazil & 86,96 & 80,63 & 77,22 & 81,92 & 28,59 \\
\hline Norte/North & 82,27 & 64,08 & 68,97 & 76,55 & 48,66 \\
\hline Rondônia & 85,48 & 85,36 & 86 & 87,28 & 48,85 \\
\hline Acre & 83,86 & 56,67 & 64,74 & 71,73 & 47,96 \\
\hline Amazonas & 95,6 & 77,69 & 76,86 & 87,7 & 56,95 \\
\hline Roraima & 95,33 & 76,6 & 70,05 & 84,14 & 64,57 \\
\hline Pará & 71,49 & 49,26 & 59,78 & 67,69 & 40,79 \\
\hline Amapá & 96,1 & 60,93 & 65,61 & 74,32 & 49,41 \\
\hline Tocantins & 82,01 & 83,26 & 82,19 & 81,05 & 59,84 \\
\hline Nordeste/Northeast & 85,42 & 79,96 & 77,51 & 83,25 & 8,6 \\
\hline Maranhão & 82,2 & 68,74 & 67,99 & 71,47 & 13,75 \\
\hline Piauí & 91,03 & 82,01 & 76,58 & 80,58 & 1,94 \\
\hline Ceará & 94,76 & 100,92 & 97,39 & 103,25 & 11,18 \\
\hline Rio Grande do Norte & 96,88 & 73,92 & 74,17 & 80,28 & 9,27 \\
\hline Paraíba & 100,58 & 87,54 & 84,74 & 87,95 & 7,75 \\
\hline Pernambuco & 102,23 & 93,83 & 89,86 & 100,99 & 10,54 \\
\hline Alagoas & 102,79 & 95,12 & 88,14 & 100,21 & 18,7 \\
\hline Sergipe & 76,11 & 91,87 & 84,78 & 91,96 & 0,63 \\
\hline Bahia & 59,32 & 56,96 & 57,25 & 59,92 & 3,33 \\
\hline Sudeste/Southeast & 89,81 & 82 & 77,2 & 81,1 & 18,43 \\
\hline Minas Gerais & 93,55 & 91,58 & 87,48 & 90,27 & 8,93 \\
\hline Espírito Santo & 90,9 & 98,57 & 86,09 & 91,25 & 6,57 \\
\hline Rio de Janeiro & 91,81 & 78,66 & 73,29 & 83,07 & 8,34 \\
\hline São Paulo & 87,4 & 77,71 & 73,49 & 75,6 & 27,18 \\
\hline
\end{tabular}


Tabela 4.2 - Cobertura vacinal, por Unidades da Federação - 2018

Table 4.2 - Immunization coverage, by Federation Unit - 2018

(conclusão/concluded)

\begin{tabular}{lccccc}
\hline \multicolumn{1}{c}{$\begin{array}{c}\text { Unidades da Federação/ } \\
\text { Federation Units }\end{array}$} & $\begin{array}{c}\text { BCG/ } \\
\begin{array}{c}\text { BCG vaccine } \\
\text { (against } \\
\text { tuberculosis) }\end{array}\end{array}$ & $\begin{array}{c}\text { Contra } \\
\text { hepatite B/ } \\
\text { Against } \\
\text { hepatite B }\end{array}$ & $\begin{array}{c}\text { Poliomielite/ } \\
\text { Against } \\
\text { Poliomyelitis }\end{array}$ & $\begin{array}{c}\text { Tríplice } \\
\text { viral D1/ } \\
\text { Triple viral } \\
\text { vaccine D1 }\end{array}$ & $\begin{array}{c}\text { Tetra viral/ } \\
\text { Tetra viral } \\
\text { Vaccine }\end{array}$ \\
\hline Sul/South & 86,72 & 89,78 & 81,73 & 84,55 & 62,96 \\
Paraná & 89,05 & 92,74 & 83,5 & 85,65 & 60,62 \\
Santa Catarina & 83,91 & 91,23 & 80,79 & 82,07 & 62,02 \\
Rio Grande do Sul & 86,05 & 85,55 & 80,42 & 85,01 & 66,16 \\
Centro-Oeste/Central-West & 85,08 & 82,67 & 79,55 & 83,96 & 61,45 \\
Mato Grosso do Sul & 100,07 & 84,12 & 83,64 & 93,49 & 68,84 \\
Mato Grosso & 80,85 & 76,89 & 76,73 & 78,74 & 51,65 \\
Goiás & 81,5 & 84,38 & 78,72 & 82,66 & 55,05 \\
Distrito Federal/Federal District & 83,53 & 84,64 & 80,86 & 83,93 & 80,46 \\
\hline
\end{tabular}

Fonte/Source: Informações de saúde (Tabnet). Epidemiológicas e morbidade. In: Brasil. Ministério da Saúde. Datasus. Brasília, DF, [2018]. Disponível em/Available from : <http://www2.aids.gov.br/cgi/ tabcgi.exe?tabnet/br.def>. Acesso em: jan. 2019/Cited : Jan. 2019.

Notas:

1. Data de atualização dos dados: 30/01/2019.

2. Os dados apresentados em 2013 se referem à soma dos seguintes dados:

- Até Junho de 2013: dados do API DOS

- A partir de Julho de 2013: APIWEB + SIPNI Web (exceção: Acre, Ceará, Distrito Federal , Goiás, Mato Grosso do Sul, Mato Grosso, Pará, Paraná, Rio de Janeiro, Sergipe, Maranhão e Tocantins por digitação duplicada).

3. Base de dados do ano de 2013 foi encerrada em 23/03/2015.

4. Doses aplicadas durante o MRC (pneumo 10 e meningo C) e Multivacinação.

5. Dados do ano de 2014 são parciais. Referem-se ao recebimento das informações do APIWEB + SIPNI até a data de 23/03/2015.

Notes:

1. Data updated on January 30, 2019

2. The data presented in 2013 refers to the sum of the following data:

- Up to June 2013: data from API DOS

- From July 2013 onwards: APIWEB + SIPNI Web (except for: Acre, Ceará, Federal District, Goiás, Mato Grosso do Sul, Mato Grosso, Pará, Paraná, Rio de Janeiro, Sergipe, Maranhão and Tocantins, due to duplicate typing).

3. 2013 database ended on March 23, 2015.

4. Doses applied during MRC (pneumo 10 and meningo $C$ ) and Multi-vaccination.

5. 2014 data are partial. They refer to information received from APIWEB + SIPNI up to March 23, 2015. 
Tabela 4.3 - Internações, mortalidade hospitalar e média de permanência no Sistema Único de Saúde - SUS - 2018

Table 4.3 - Hospitalization, deaths in hospitals and average length of stay in the Unified Health System - SUS - 2018

\begin{tabular}{|c|c|c|c|}
\hline $\begin{array}{l}\text { Especialidades/ } \\
\text { Specialty }\end{array}$ & $\begin{array}{l}\text { Internações/ } \\
\text { Hospitalization }\end{array}$ & $\begin{array}{c}\text { Taxa de } \\
\text { mortalidade } \\
\text { hospitalar/ } \\
\text { Death rate in } \\
\text { hospitals (\%) }\end{array}$ & $\begin{array}{l}\text { Média de } \\
\text { permanência/ } \\
\text { Average } \\
\text { length of stay }\end{array}$ \\
\hline Total/Total & 11685367 & 4,28 & 5,3 \\
\hline Clínica cirúrgica/Surgery & 3809312 & 2,04 & 3,9 \\
\hline Obstetrícia/Obstetrics & 2219621 & 0,03 & 2,6 \\
\hline Clínica médica/Internal medicine & 4038898 & 9,72 & 6,3 \\
\hline \multicolumn{4}{|l|}{ Cuidados prolongados (crônicos)/ } \\
\hline Long-term care (chronic) & 22808 & 31 & 89,2 \\
\hline Psiquiatria/Psychiatry & 150656 & 0,23 & 35,3 \\
\hline Tisiologia/Phthisiology & 5725 & 6,64 & 35,2 \\
\hline Pediatria/Pediatrics & 1220995 & 1,69 & 6,1 \\
\hline Reabilitação/Rehabilitation & 14844 & 0,05 & 12,1 \\
\hline Clínica cirúrgica - hospital dia/ & 151852 & 0,01 & 0,1 \\
\hline \multicolumn{4}{|l|}{ Surgery - day hospital } \\
\hline Aids - hospital dia/ AIDS - day hospital & 7666 & 0,04 & 19,7 \\
\hline \multicolumn{4}{|l|}{ Fibrose cística - hospital-dia/ } \\
\hline Cystic fibrosis - day hospital & 1 & - & 11 \\
\hline \multicolumn{4}{|l|}{ Pós-transplante - hospital dia/ } \\
\hline After transplant - day hospital & 7619 & 0,71 & 9,9 \\
\hline Geriatria - hospital dia/Geriatrics - day hospital & 630 & - & 13,9 \\
\hline \multicolumn{4}{|l|}{ Saúde mental - hospital dia/ } \\
\hline Mental health - day hospital & 12584 & - & 26,9 \\
\hline Saúde mental - clínico/Mental health - clinical & 22156 & 0,4 & 10,2 \\
\hline
\end{tabular}

Fonte/Source: Informações de saúde (Tabnet). Internações hospitalares do [Sistema Único de Saúde SUS]. In: Brasil. Ministério da Saúde. Datasus. Brasília, DF, [2018]. Disponível em/Available from: <http://tabnet.datasus.gov.br/cgi/deftohtm.exe?sih/cnv/sxuf.def>. Acesso em: jan. 2019/Cited: Jan . 2019. 


\section{Gráfico 4.1 - Casos de Aids por ano de diagnóstico e sexo- 2008-2017}

Graph 4.1 - AIDS cases, by year of diagnosis and sex - 2008-2017

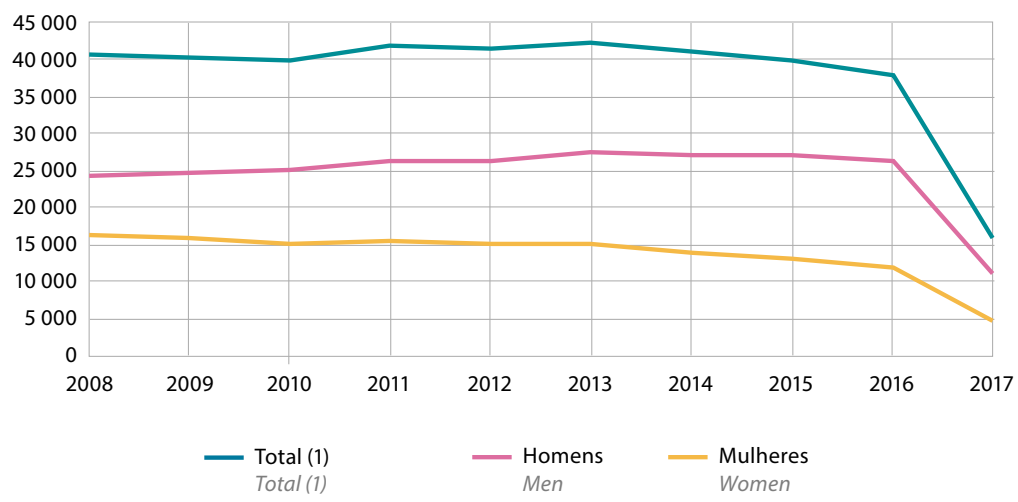

Fonte/Source: Informações de saúde. Epidemiológicas e morbidade. In: Brasil. Ministério da Saúde. Datasus. Brasília, DF, [2018]. Disponível em/Available from:

<http://www2.aids.gov.br/cgi/tabcgi.exe?tabnet/br.def>. Acesso em: jan. 2019/Cited: Jan. 2019.

(1) Inclusive de sexo não informado./ (1) Including of unknown sex. 



\section{Previdência Social Social Security}

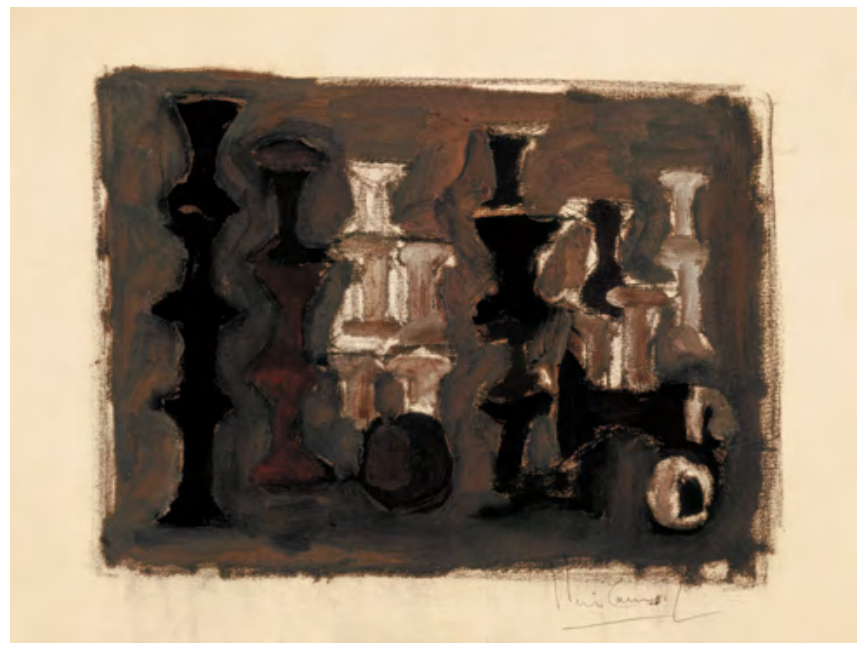

Sem título, [1959]

Untitled

Iberê Camargo 


\title{
Social Security
}

\author{
Luís Eduardo Afonso ${ }^{1}$
}

\section{Reflections on social security: an analysis of the large numbers of the General Social Security System}

Social security has been the most important item in the Brazilian economic and political agenda over the last years. Similarly, it has been the object of special attention of researchers in many countries (DIAMOND, 2018; BONENKAMP, 2017). Based on this fact, this brief article analyzes the aggregate data of the General Social Security System - RGPS of the National Institute for Social Security - INSS and attempts to analyze the behavior of the revenue and expenditure. The final part comprises a brief reflection on the balance of the social security system and the need for a social security reform.

\section{Aggregate data: revenue, expenditure and deficit}

As shown in Table 5.1, the primary result of the RGPS presents periods with different characteristics for its several components between 2006 and 2017. From 2008 to 2012, the gross collection increased more than $40.6 \%$ in real terms. Its own collection shows a similar behavior, with an increase of $36.7 \%$. The pattern shown in these time series is directly linked with the behavior of the economy. A period of high growth of the Gross Domestic Product - GDP and expansion of the

1 Lecturer from the University of São Paulo - USP, Associate professor of the Department of Accounting and Actuarial Science of the School of Economics, Business and Accounting of the University of São Paulo - FEA-USP. 


\title{
Previdência Social
}

\author{
Luís Eduardo Afonso' 1
}

\section{Reflexões sobre a previdência social: uma análise dos grandes números do Regime Geral de Previdência Social}

Nos últimos anos a previdência social tem sido o item mais importante na agenda econômica e política do Brasil. Da mesma forma, vem sendo objeto da atenção de pesquisadores em diversos países (DIAMOND, 2018; BONENKAMP, 2017). Com base nesse fato, este breve artigo analisa os dados agregados do Regime Geral de Previdência Social (RGPS) do Instituto Nacional do Seguro Social (INSS) e procura analisar o comportamento das receitas e das despesas. Na parte final é feita uma breve reflexão sobre o equilíbrio do sistema previdenciário e a necessidade de uma reforma previdenciária.

\section{Dados agregados: receita, despesa e déficit}

Conforme apresentado na Tabela 5.1, de 2006 a 2017, o resultado primário do RGPS apresenta períodos com características distintas para os seus diversos componentes. De 2008 a 2012 a arrecadação bruta cresceu mais de 40,6\% reais. A arrecadação própria exibe comportamento similar, com aumento de $36,7 \%$. O padrão verificado para estas séries está diretamente ligado ao comportamento da economia. De 2006 até 2014 , verificou-se um período de elevado crescimento do Produto Interno Bruto

1 Livre-docente pela Universidade de São Paulo (USP), Professor Associado do Departamento de Contabilidade e Atuária da Faculdade de Economia, Administração e Contabilidade da Universidade de São Paulo (FEAUSP). 
job positions of higher quality was noticed between 2006 and 2014. It is reflected in the increase of the GDP (31.3\%), of the average income of the main job (50\%), of the per capita income $(21.8 \%)$ and of the economically-active population (10.2\%). This particular combination caused the collection to rise.

This allegation is reinforced by the information in Table 5.4. The increase in the number of payers is significant up to 2011 - except for 2009 -, reducing dramatically in the 2012-2014 triennium. A sharp reversal between 2015 and 2017 impaired the collection. This triennium showed a reduction of more than 6.2 million payers, which represented a drop of more than $9.0 \%$. These data strongly contrast with the increase of 1.64 million beneficiaries $(5.0 \%)$. It was evident that the social security dependence ratio, given by the relation between the number of beneficiaries and the number of payers (SANDERSON; SCHERBOV, 2015), significantly deteriorated in a short period, changing from $46.9 \%$ to $52.7 \%$. Another point to be highlighted is the change in the composition of the group of payers. Those employed lost more than three percentage points between 2007 and 2017.

It should be noted that the downturn that affected the global economy from 2008 onward only hit Brazil in the following year. Indeed, our economy rose $5.1 \%$ in real terms in 2008. In 2009, the GDP slightly reduced about $0.1 \%$ and significantly recovered $(7.5 \%)$ in 2010 , though it was not sustained in the long term. Nevertheless, the bad economic result in 2009 did not immediately impact the collection indicators, as it was expected. In this year, the real growth of the net collection was of $7.0 \%$, significantly contrasting with the stagnation in the economic activity.

In the initial years of the time series, the growth rate of the spending with benefits is slightly lower than that of the collection. As a result, the relation between the net collection and the spending with benefits even rises in this favorable period. This basic indicator of sustainability of social security systems, which was about $74.6 \%$ in 2006 , rose almost monotonically, reaching $87.4 \%$ in 2011 . As a result, the deficit of the RGPS hit its lowest nominal result that year, about $\mathrm{R} \$ 35.5$ billion. This value represented a reduction of $21.9 \%$ in relation to the previous year. From 2006 to 2011, the net collection and spending with benefits increased $51.2 \%$ and $29.1 \%$, respectively, discounted the inflation. 
(PIB) e da expansão dos postos de trabalho de maior qualidade. Isto se reflete em aumento do PIB (31,3\%), da renda média do trabalho principal (50\%), da renda per capita $(21,8 \%)$ e da população economicamente ativa $(10,2 \%)$. Essa particular conjunção favorável é a causa dessa elevação na arrecadação.

Este argumento é reforçado pelas informações da Tabela 5.4. O crescimento no número de contribuintes é expressivo até 2011 (com a exceção temporária de 2009), reduzindo-se sobremaneira no triênio 2012-2014. De 2015 a 2017, há uma drástica reversão, com consequências danosas à arrecadação. Neste triênio há redução superior a 6,2 milhões de contribuintes, o que representa uma queda de mais de $9,0 \%$. Esses dados contrastam fortemente com aumento de 5,0\% (1,64 milhão) de beneficiários. Fica evidente que em um curto período, a razão de dependência previdenciária, dada pela relação entre número de beneficiários e o número de contribuintes (SANDERSON; SCHERBOV, 2015), teve piora expressiva, passando de $46,9 \%$ para $52,7 \%$. Outro ponto a ser destacado é a mudança na composição do grupo de contribuintes. Os empregados perdem mais de três pontos percentuais no total de 2007 a 2017.

Note-se que a recessão que afetou a economia global a partir de 2008 só atingiu o Brasil de maneira mais clara no ano seguinte. De fato, em 2008, a nossa economia cresceu 5,1\% em termos reais. Em 2009, houve uma pequena redução no PIB, da ordem de $0,1 \%$, com uma recuperação expressiva (porém não sustentada no longo prazo) de 7,5\%, em 2010. Entretanto, o mau resultado econômico de 2009, não teve impacto imediato nos indicadores de arrecadação, como a princípio seria esperado. Nesse ano, o crescimento real da arrecadação líquida foi de 7,0\%, contrastando fortemente com a estagnação na atividade econômica.

Nos anos iniciais da série, a taxa de crescimento do dispêndio com benefícios é um pouco inferior ao verificado para a arrecadação. Como resultado, neste período mais favorável, a relação entre a arrecadação líquida e o dispêndio com benefícios chega até a crescer. Esse indicador básico de sustentabilidade de sistemas previdenciários era da ordem de $74,6 \%$ em 2006 , se eleva de maneira quase monotônica, até alcançar 87,4\% em 2011. Como resultado, o déficit do RGPS alcança seu menor resultado nominal neste ano, cerca de $\mathrm{R} \$ 35,5$ bilhões. Este valor representa uma redução de 21,9\% em relação ao ano anterior. De 2006 a 2011 a arrecadação líquida e o gasto com benefícios crescem $51,2 \%$ e $29,1 \%$, respectivamente, já descontada a inflação.

Entretanto, essa melhora parece ter sido originada de fatores conjunturais (política econômica ortodoxa, elevado crescimento da China e boom das commodities), 
Nevertheless, such improvement seemed to be originated from shortterm factors - an orthodox economic policy, high growth of China and the commodity boom -, which leveraged the growth and were not repeated later. Yet, the structural factors, mainly originated from the population ageing, began to perform an important role, causing the acceleration of the increasing expenses. The real growth of the net collection was of $15.3 \%$ between 2011 and 2014, against a rise in the spending of $17.6 \%$. Such difference made the relation between the time series to fall two percentage points in relation to the peak in 2011. The collapse and inconsistencies of the economic policy adopted from 2010 onward charged a high price. The stagnation of the economy can only be compared with the crisis in 1930. The results of the RGPS were perverse, as revealed by the data of Table 5.1. We can say that the turning point occurred in the second half of the decade. The magnitude of the economic downturn reflected in the real drop of $8.3 \%$ in the net collection, against an increase of $16.8 \%$ in the spending in the 2014-2017 triennium. The increase in the expenditure coupled with the weak performance of the collection caused the deficit to grow exponentially, surpassing $\mathrm{R} \$ 182$ billion in 2017 , which means a real rise of $166 \%$ in only three years. As a result, the relation between the net collection and the benefits decreased to $67 \%$. In other words, of every three reals spent with benefits, only two were funded by the contributions. Finally, one of the most important social security indicators, the level of expenses in relation to the GDP (PALLARES-MIRALLES; ROMERO; WHITEHOUSE, 2012) changed from $6.8 \%$ to $8.5 \%$ in only three years.

\section{Why did the expenses increase?}

The growth of the amounts, i.e., of the stock of benefits was the first and more evident reason. As it can be seen in Table 5.2, the total number of active benefits increased more than $7.0 \%$ between 2014 and 2017. It was due, to a great extent, to the fast ageing of the population. From 2000 to 2020, the proportion of elderly persons shall increase from $5.6 \%$ to $9.4 \%$. This is not phenomenon exclusive to Brazil, though it has been happening here faster than in nations with similar economic and social characteristics.

It draws attention that the most relevant increase occurs in the urban retirements, which grow more than $14 \%$, reinforcing the composition effect. Retirements due to length of service represent a significant part of this benefit. As they have higher values than the average of the other 
que impulsionaram o crescimento e não viriam a se repetir posteriormente. Mas os fatores estruturais, originados principalmente do envelhecimento populacional, passaram a desempenhar papel preponderante, fazendo com que o crescimento da despesa acelerasse. De 2011 a 2014, o crescimento real da arrecadação líquida foi de $15,3 \%$, contra uma elevação do dispêndio de $17,6 \%$. Tal diferença fez, com relação entre as séries, que caísse dois pontos percentuais em relação ao ápice de 2011.

O esgotamento e as inconsistências da política econômica adotada a partir de 2010 cobraram um preço elevado. A estagnação da economia somente encontra paralelo na crise de 1930. Os resultados sobre o RGPS foram perversos, conforme evidenciado pelos dados da Tabela 5.1. Pode-se afirmar que o turning point ocorreu a partir da segunda metade da década. A magnitude do desastre econômico refletiu-se na queda real na arrecadação líquida de $8,3 \%$ frente a um incremento de $16,8 \%$ no dispêndio no triênio 2014-2017. A conjugação da elevação na despesa com o fraco resultado da arrecadação fez com que o déficit passasse a crescer de forma exponencial, ultrapassando os R\$ 182 bilhões em 2017, o que significa uma elevação real de $166 \%$ em apenas três anos. Como resultado, a relação entre a arrecadação líquida e os benefícios decresceu para $67 \%$. Ou seja, de cada três reais despendidos com benefícios, somente dois foram custeados pelas contribuições. Finalmente, um dos mais importantes indicadores previdenciários, o nível de gastos em relação ao PIB (PALLARES-MIRALLES; ROMERO; WHITEHOUSE, 2012) passou de $6,8 \%$ para $8,5 \%$ em apenas três anos.

\section{Por que as despesas aumentaram?}

O primeiro motivo, mais evidente, para a elevação do dispêndio, é o crescimento nas quantidades, ou seja, no estoque de benefícios. Conforme pode ser visto na Tabela 5.2, de 2014 a 2017, há elevação de mais de 7,0\% no total de benefícios ativos. Isto ocorre em grande parte devido ao acelerado envelhecimento da população. De 2000 a 2020 a proporção de idosos deverá crescer de 5,6\% para 9,4\%. Esse fenômeno não é exclusivo do Brasil, mas vem ocorrendo no País em velocidade mais elevada do que em nações com características econômicas e sociais similares às nossas.

Chama a atenção que a elevação mais relevante ocorra nas aposentadorias urbanas, que crescem mais de 14\%, o que reforça o efeito composição. As aposentadorias por tempo de contribuição representam parcela expressiva deste benefício. Como estas têm valores mais elevados que a média dos demais benefícios, o aumento na sua parcela leva a um incremento no dispêndio total. Cabe assinalar também que a taxa de crescimento dos benefícios urbanos $(8,6 \%)$ foi bem superior à taxa dos 
benefits, the increase in its parcel leads to a higher total expense. It should also be highlighted that the growth rate of the urban benefits (8.6\%) was quite higher than the rate of the rural ones (3.2\%). As a result, the RGPS is becoming more urban and with less welfare benefits, since the contribution of the rural workers corresponds to slightly more than $10 \%$ in relation to the expense. It is also less distributive, since the replacement rate of the length of service retirements is lower than those old-age retirements (AFONSO, 2016).

And why did the composition of the active benefits (stock) change? Because the composition of the conceded (flow) changed. Although the number of benefits has kept relatively constant over the last years (Table 5.3), some points should be highlighted. It should be noted that the reduction registered in 2015 was caused by a strike in the INSS, which dammed the flow of new benefits for a significant period of the year. From 2014 to 2017, the proportion of the retirements in the total number of new benefits changed from $22.1 \%$ to $26.7 \%$. This group showed an increase in the proportion of old-age retirements, from $12.4 \%$ to $13.8 \%$, and, mainly, of length of service retirements, from $6.1 \%$ to $9.0 \%$. On the other hand, sickness benefits reduced significantly (from nearly $45 \%$ to $38 \%$ ). As the reduction in absolute terms of this benefit was close to $15 \%$, managerial measures could refrain it, like more strict criteria for the grantings.

The second reason is linked to the values. In the end of $2018,66.5 \%$ of the RGPS benefits were equivalent to one minimum wage - MW or less. Between December 1994 and the same month in 2018, the MW had a real increase of $168.9 \%$. In other words, an increase in the MW directly impacts two thirds of the benefits paid. The continuous increase exerted a relevant impact on poverty and welfare, especially in the past. Today, such policy should be reviewed in more details, mainly in terms of its costs, given that the budget restriction of the government is increasingly tight and the social security expenses, more significant.

\section{Final remarks}

The spending of the RGPS depends on two factors. The first one, exogenous, are the demographic characteristics. The proportion of elderly persons - and beneficiaries - unequivocally tends to increase. Pay-as-you-go systems like the RGPS are affected by population ageing. The second factor, chosen by us, are the calculation rules of the values of the benefits and eligibility conditions. The revenue 
rurais $(3,2 \%)$. Como resultado, o RGPS vai ficando mais urbano e com características menos assistenciais, dado que a contribuição dos trabalhadores rurais corresponde a pouco mais de $10 \%$ em relação ao dispêndio. E também, menos distributivo, pois a taxa de reposição das aposentadorias por tempo de contribuição é inferior à das aposentadorias por idade (AFONSO, 2016).

E por que a composição dos benefícios ativos (estoque) mudou? Porque a composição dos concedidos (fluxo) se alterou. Apesar de o número de concessões ter se mantido relativamente constante nos últimos anos (Tabela 5.3), há pontos dignos de destaque. Note-se que a redução verificada em 2015 foi motivada por uma greve no INSS, que represou o fluxo de novos benefícios por um período expressivo do ano. De 2014 a 2017 a proporção das aposentadorias no total de novos benefícios passou de $22,1 \%$ para $26,7 \%$. Neste grupo, há aumento na proporção de aposentadorias por idade, de 12,4\% para 13,8\% e, principalmente, nas aposentadorias por tempo de contribuição, de 6,1\% para 9,0\%. Em contrapartida, há redução expressiva (de quase $45 \%$ para $38 \%$ ) na parcela do auxílio-doença. Como a redução em termos absolutos deste benefício foi próxima a $15 \%$, pode-se inferir que medidas gerenciais, com o maior rigor na concessão, sejam relevantes para esse fenômeno.

O segundo motivo está ligado aos valores. No final de 2018, 66,5\% benefícios do RGPS tinham valor igual ou inferior ao salário mínimo (SM). Entre dezembro de 1994 e o mesmo mês de 2018 , o SM teve um aumento real de $168,9 \%$. Ou seja, um incremento no SM impacta diretamente dois terços dos benefícios pagos. Os continuados aumentos tiveram impactos importantes sobre a pobreza e o bem-estar, principalmente no passado. Mas neste momento parece necessário repensar com mais detalhes tal política, principalmente em relação aos seus custos, dado que a restrição orçamentária do governo tem se mostrado cada vez mais apertada e os gastos previdenciários, mais expressivos.

\section{Considerações finais}

O dispêndio do RGPS é dependente de dois fatores. O primeiro, exógeno, são as características demográficas. Há inequívoca tendência de aumento da proporção de idosos (e de beneficiários). Regimes de repartição como o RGPS são afetados pelo envelhecimento populacional. O segundo fator, escolhido por nós, são as regras de cálculo dos valores dos benefícios e as condições de elegibilidade. A receita depende da forma de financiamento e da atividade econômica. As escolhas dos elementos do pension design devem ser compatíveis com as características econômicas do País. 
depends on the form of funding and economic activity. The choice of the elements of the pension design should be compatible with the economic characteristics of the country. It has not been the case in Brazil. We strongly privilege the dimension of the suitability and strongly impair the sustainability of the social security system.

As pointed by Turra (2018), the allocation of resources among generations is inconsistent, as it has been privileging the elderly persons and reducing the period in which the individuals have positive values in the generation of income along their lives. The demographic dynamics will escalate the perverse effects on the public spending and will undermine the allocation of the wealth produced. That will undermine even more the funding of the social security system when the effects of the population ageing become more evident.

Brazil has been showing a worrying inability to carry out social security reforms. Other countries are examples in which the fiscal restriction led to the dramatic reduction of the benefits, as well as to the enforcement of more restrictive eligibility conditions. The numbers that emphasize the need to change are clear, they have been for many years now. Several opportunities were lost, in more favorable demographic, economic and political conditions. This is a decision of the society, through its representatives, which directly impacts on current and, mainly, on future generations. It is neither fair nor suitable to wait any longer.

\section{References}

AFONSO, L. E. Progressividade e aspectos distributivos na previdência social: uma análise com o emprego dos microdados dos registros administrativos do RGPS. Revista Brasileira de Economia, Rio de Janeiro, v. 70, n.1, p. 3-30, Jan/ Mar 2016. Available from: <http://bibliotecadigital.fgv.br/ojs/index.php/rbe/ article/view/38338>. Cited: May 2019.

BONENKAMP, J. et al. Ageing-driven pension reforms. Journal of Population Economics, Berlin, v. 30, n. 3, p. 953-976, July 2017. Available from: <https:// link.springer.com/journal/148>. Cited: May 2019.

DIAMOND, P. A. The future of social security. Economic Inquiry, Hoboken, v. 56, n. 2, p. 661-681, Apr. 2018. Available from: <https://onlinelibrary.wiley. com/doi/epdf/10.1111/ecin.12553>. Cited: May 2019.

PALLARES-MIRALLES, M.; ROMERO, C.; WHITEHOUSE, E. International patterns of pension provision II: a worldwide overview of facts and figures. Washington, D.C.: The World Bank, 2012. 214 p. (Social protection \& Labor. 
Não tem sido o caso do Brasil. Privilegiamos em demasia a dimensão da adequação, e prejudicamos fortemente a sustentabilidade do sistema previdenciário.

Como bem aponta Turra (2018) há inconsistência na alocação de recursos entre gerações, que tem privilegiado os idosos e reduzido o período em que os indivíduos têm valores positivos na geração de renda ao longo da vida. A dinâmica demográfica exacerbará os efeitos perversos sobre o dispêndio público e comprometerá a alocação da riqueza gerada. Isto irá comprometer ainda mais o financiamento do sistema de previdência quando os efeitos do envelhecimento populacional se fizerem mais evidentes.

O Brasil tem mostrado uma preocupante incapacidade de realizar reformas previdenciárias. Não faltam exemplos de outros países, em que a restrição fiscal levou à redução drástica no pagamento dos benefícios, bem como à imposição de condições de elegibilidade mais restritivas. Os números que evidenciam a necessidade de alterações são claros, há muitos anos. Várias oportunidades foram perdidas, em condições demográficas, econômicas e políticas mais favoráveis. Esta é uma decisão da sociedade, por meio dos seus representantes, com impactos diretos sobre as atuais e, principalmente, sobre as futuras gerações. Não é justo, nem adequado, esperar mais.

\section{Referências}

AFONSO, L. E. Progressividade e aspectos distributivos na previdência social: uma análise com o emprego dos microdados dos registros administrativos do RGPS. Revista Brasileira de Economia, Rio de Janeiro, v. 70, n.1, p. 3-30, jan./mar. 2016. Disponível em: <http://bibliotecadigital.fgv.br/ojs/index.php/rbe/article/view/38338>. Acesso em: maio 2019.

BONENKAMP, J. et al. Ageing-driven pension reforms. Journal of Population Economics, Berlin, v. 30, n. 3, p. 953-976, July 2017. Disponível em: <https://link. springer.com/journal/148>. Acesso em: maio 2019.

DIAMOND, P. A. The future of social security. Economic Inquiry, Hoboken, v. 56, n. 2, p. 661-681, Apr. 2018. Disponível em: <https://onlinelibrary.wiley.com/doi/ epdf/10.1111/ecin.12553>. Acesso em: maio 2019.

PALLARES-MIRALLES, M.; ROMERO, C.; WHITEHOUSE, E. International patterns of pension provision II: a worldwide overview of facts and figures.Washington, D.C.: The Worl Bank, 2012. 214 p. (Social protection \& Labor. Discussion paper, n. 1211). Disponível em: <http://pensionreform.ru/files/wb_pensions_2012/06.2012.\%20 
Discussion paper, n. 1211). Available from: <http://pensionreform.ru/files/ wb_pensions_2012/06.2012.\%20World\%20Bank.\%20International\%20 Patterns\%20of\%20Pension\%20Provision\%20II.\%20A\%20Worldwide\%20 Overview\%20of\%20Facts\%20and\%20Figures.pdf>. Cited: May 2019.

SANDERSON, W.C.;SCHERBOV, S. Are we overly dependent on conventional dependency ratios? Population and Development Review, Hoboken, v. 41, n. 4, p. $687-708$, Dec. 2018. Available from: <https://onlinelibrary.wiley.com/ toc/17284457/2015/41/4>. Cited: May 2019.

TURRA, C. M. Os ajustes inevitáveis da transição demográfica no Brasil. In: ANDRADE, M. V.; ALBUQUERQUE, E. da M. e. (Ed.). Alternativas para uma crise de múltiplas dimensões. Belo Horizonte: Cedeplar, 2018. (População \& Economia).p. 284-307. Available from: <https://www.cedeplar.ufmg.br/ es-es/publicacoes/colecao-populacao-economia/1067-alternativas-parauma-crise-de-mu-Itiplas-dimenso-es-1-volume>.

Translated by: La-Fayette Côrtes Neto 
World\%20Bank.\%20International\%20Patterns\%20of\%20Pension\%20Provision\%20 II.\%20A\%20Worldwide\%20Overview\%20of\%20Facts\%20and\%20Figures.pdf>. Acesso em: maio 2019.

SANDERSON, W. C.; SCHERBOV, S. Are we overly dependent on conventional dependency ratios? Population and Development Review, Hoboken, v.41, n. 4, p. 687-708, Dec. 2018. Disponível em: <https://onlinelibrary.wiley.com/toc/17284457/2015/41/4>. Acesso em: maio 2019.

TURRA, C. M. Os ajustes inevitáveis da transição demográfica no Brasil. In: ANDRADE, M. V.; ALBUQUERQUE, E. da M. e. (Ed.). Alternativas para uma crise de múltiplas dimensões. Belo Horizonte: Cedeplar, 2018. (População \& Economia). p. 284-307. Disponível em: <https://www.cedeplar.ufmg.br/es-es/publicacoes/colecao-populacao-economia/1067-alternativas-para-uma-crise-de-mu-Itiplas-dimenso-es-1-volume $>$. 
Tabela 5.1 - Recebimentos e pagamentos da Previdência Social - 2006-2017 Table 5.1 - Social Security revenues and payments - 2006-2017

Recebimentos e pagamentos (1 $000000 \mathrm{R} \$) /$ Revenues and payments $(1,000,000 \mathrm{R} \$)$

$\begin{array}{ccc}\text { Ano/ } & \text { Arrecadação } & \text { Arrecadação } \\ \text { Year } & \text { bruta/ } & \text { própria/ } \\ \text { Gross } & \text { Contributions } \\ \text { revenue } & \text { (1) }\end{array}$

Arrecadação
de outras
entidades/Other
entities' revenue

(2)

$\begin{array}{ccc}\text { Arrecadação } & \begin{array}{c}\text { Pagamento de } \\ \text { benefícios } \\ \text { líquida/Net } \\ \text { revenue }\end{array} & \begin{array}{c}\text { Resultado } \\ \text { primário/ }\end{array} \\ \begin{array}{ccc}\text { do RGSS/ } & \text { Social security } \\ \text { balancent of }\end{array} & \begin{array}{c}\text { balance } \\ \text { RGPS benefits }\end{array} & \text { (4) }\end{array}$

\begin{tabular}{lllllll}
\hline 2006 & 201757 & 133015 & 9495 & 123520 & 165585 & $(-) 42065$ \\
2007 & 216489 & 153788 & 13377 & 140411 & 185293 & $(-) 44882$ \\
2008 & 243831 & 180346 & 16990 & 163356 & 199562 & $(-) 36206$ \\
2009 & 273524 & 200618 & 18609 & 182009 & 224876 & $(-) 42867$ \\
2010 & 312641 & 233513 & 21545 & 211968 & 254859 & $(-) 42891$ \\
2011 & 351545 & 271406 & 25514 & 245892 & 281438 & $(-) 35546$ \\
2012 & 396684 & 304881 & 29116 & 275765 & 316590 & $(-) 40825$ \\
2013 & 431684 & 340004 & 32857 & 307147 & 357003 & $(-) 49856$ \\
2014 & 471807 & 374017 & 36514 & 337503 & 394201 & $(-) 56698$ \\
2015 & 388477 & 351821 & 37865 & 350272 & 436090 & $(-) 85818$ \\
2016 & 396996 & 361384 & 38577 & 358137 & 507871 & $(-) 149734$ \\
2017 & 414438 & 375077 & 39463 & 374785 & 557235 & $(-) 182450$ \\
\hline
\end{tabular}

Fonte/Source: Sistema Integrado de Administração Financeira do Governo Federal (SIAFI).

(1) A conta Arrecadação própria no ano de 2016 e 2017 consideram as rubricas Arrecadação bancária, Arrecadação GPS Intra-SIAFI, Arrecadação DARF e Arrecadação compensação./The Contributions account in the year of 2016 and 2017 comprises the items Bank payments, Intra-SIAFI GPS payments, DARF payments and Clearing payments. (2) A conta Arrecadação própria no ano de 2015 considera as rubricas Arrecadação GPS, Arrecadação DARF e Arrecadação compensação./The Contributions account in the year of 2015 comprises the items GPS payments, DARF payments and Clearing payments.(2) A conta Arrecadação de outras entidades engloba Transferências a Terceiros (Repasse de Outras Entidades) e Taxa de Administração sobre Outras Entidades./The Other entities' revenue account includes Transfers to Third Parties (Transfers of Other Entities) and Administration Fees charged on Other Entities. (3) A conta Arrecadação Líquida, para os anos anteriores a 2015, corresponde a diferença entre a Arrecadação própria e a Arrecadação de outras entidades; para o ano de 2015, Arrecadação Bruta menos a soma de Arrecadação de outras entidades e Restituições. /For the years prior to 2015, the Net Revenue account corresponds to the difference between Contributions and Other entities' revenue; for 2015, it corresponds to Gross revenue less the sum of Other entities's revenue and Restitutions. (4) A conta Resultado Primário corresponde à diferença entre a Arrecação líquida e o Pagamento de benefícios do RGPS./ Social security balance corresponds to the difference between Net Revenue and Payment of RGPS benefits. 


\section{Tabela 5.2 - Distribuição dos benefícios ativos, urbano e rural - 2014-2017}

Table 5.2 - Distribution of active benefits: urban and rural - 2014-2017

\begin{tabular}{|c|c|c|c|c|}
\hline Benefícios/ Benefits & 2014 & 2015 & 2016 & 2017 \\
\hline Total/Total & 32028710 & 32658862 & 33596830 & 34294510 \\
\hline Urbano/Urban & 22774297 & 23295036 & 24120417 & 24741383 \\
\hline Previdenciários/Social security & 17706670 & 18136061 & 18823423 & 19347242 \\
\hline Aposentadorias/ Retirement pensions & 11231112 & 11617192 & 12173615 & 12812034 \\
\hline Pensões por morte/ Survivor pensions & 5018901 & 5101580 & 5214324 & 5302646 \\
\hline Auxílios/ Cash aid & 1390098 & 1368908 & 1391795 & 1161072 \\
\hline Outros/ Others & 66559 & 48381 & 43689 & 71490 \\
\hline Assistenciais/ Welfare & 4244544 & 4346952 & 4497774 & 4619945 \\
\hline $\begin{array}{l}\text { Amparos assistenciais/ Income } \\
\text { assistance }\end{array}$ & 4137995 & 4251726 & 4414323 & 4546128 \\
\hline $\begin{array}{l}\text { Rendas mensais vitalícias/Lifelong } \\
\text { monthly income }\end{array}$ & 94845 & 84091 & 72885 & 63759 \\
\hline Outros/ Others & 11704 & 11135 & 10566 & 10058 \\
\hline Acidentários/ Work-related injuries & 811849 & 801193 & 788932 & 764435 \\
\hline Aposentadorias/ Retirement pensions & 177644 & 182108 & 186964 & 191544 \\
\hline Pensões/ Survivor pensions & 114187 & 112097 & 109838 & 107505 \\
\hline Auxílios/ Cash aid & 520018 & 506988 & 492130 & 465386 \\
\hline $\begin{array}{l}\text { Encargos Previdenciários da União - EPU/ } \\
\text { Treasury Owed Pensions - EPU }\end{array}$ & 11234 & 10830 & 10288 & 9761 \\
\hline Rural/Rural & 9254413 & 9363826 & 9476413 & 9553127 \\
\hline Previdenciários/ Social security & 9137399 & 9256541 & 9378626 & 9464893 \\
\hline Aposentadorias/ Retirement pensions & 6614693 & 6714443 & 6795840 & 6894517 \\
\hline Pensões por morte/ Survivor pensions & 2305020 & 2328243 & 2350498 & 2366215 \\
\hline Auxílios/ Cash aid & 206480 & 207391 & 226281 & 195872 \\
\hline Outros/Others & 11206 & 6464 & 6007 & 8289 \\
\hline Assistenciais/ Welfare & 83550 & 75182 & 65597 & 57909 \\
\hline $\begin{array}{l}\text { Amparos assistenciais/ Income } \\
\text { assistance }\end{array}$ & - & - & - & - \\
\hline $\begin{array}{l}\text { Rendas mensais vitalícias/ Lifelong } \\
\text { monthly income }\end{array}$ & 83550 & 75182 & 65597 & 57909 \\
\hline Outros/Others & - & - & - & - \\
\hline Acidentários/ Work-related injuries & 33464 & 32103 & 32190 & 30325 \\
\hline Aposentadorias/ Retirement pensions & 12400 & 12626 & 12883 & 13116 \\
\hline Pensões/ Survivor pensions & 4058 & 3985 & 3898 & 3809 \\
\hline Auxílios/Cash aid & 17006 & 15492 & 15409 & 13400 \\
\hline
\end{tabular}

Fonte/Source: Empresa de Tecnologia e Informações Tecnológicas (Dataprev). 
Tabela 5.3 - Benefícios concedidos pela Previdência Social - 2014-2017 Table 5.3 - Benefits granted by Social Security - 2014-2017

\begin{tabular}{|c|c|c|c|c|}
\hline Benefícios/ Benefits & 2014 & 2015 & 2016 & 2017 \\
\hline Total/Total & 5211030 & 4344701 & 5132451 & 4995623 \\
\hline Previdenciários/Social security & 4554542 & 3843040 & 4532396 & 4448953 \\
\hline Aposentadorias/ Retirement pensions & 1150880 & 1058151 & 1263974 & 1391170 \\
\hline Idade/ Old age & 645687 & 575841 & 662366 & 718679 \\
\hline Invalidez/ Disability & 189651 & 161850 & 169575 & 202481 \\
\hline Tempo de contribuição/ Lenght of contribution & 315542 & 320460 & 432033 & 470010 \\
\hline Pensões por morte/ Survivor pensions & 409245 & 365262 & 410533 & 400941 \\
\hline Auxílio-doença/Sick pay & 2328151 & 1828337 & 2190808 & 1988169 \\
\hline Salário-maternidade/ Maternity pay & 631687 & 561451 & 631287 & 630741 \\
\hline Outros/ Others & 34579 & 29839 & 35794 & 37932 \\
\hline Assistenciais/ Welfare & 343990 & 279014 & 347971 & 325847 \\
\hline $\begin{array}{l}\text { Amparos assistenciais - LOAS/ Income } \\
\text { assistance }\end{array}$ & 343669 & 278683 & 347672 & 325449 \\
\hline Idoso/ Old age & 160204 & 141985 & 164720 & 156609 \\
\hline Portador de deficiência/ Impaired people & 183465 & 136698 & 182952 & 168840 \\
\hline $\begin{array}{l}\text { Pensões mensais vitalícias/ Lifelong } \\
\text { monthly pensions }\end{array}$ & 321 & 331 & 299 & 398 \\
\hline $\begin{array}{l}\text { Rendas mensais vitalícias/ Lifelong } \\
\text { monthly income }\end{array}$ & - & - & - & - \\
\hline Idoso/ Old age & - & - & - & - \\
\hline Invalidez/Impaired people & - & - & - & - \\
\hline Acidentários/ Work-related injuries & 312192 & 222450 & 251911 & 220651 \\
\hline Aposentadorias/ Retirement pensions & 10877 & 8782 & 9220 & 9319 \\
\hline Pensão por morte/ Survivor pensions & 412 & 368 & 393 & 298 \\
\hline Auxílio-doença/ Sick pay & 279868 & 196761 & 223668 & 191118 \\
\hline Auxílio-acidente/ Injury benefit & 20883 & 16399 & 18513 & 19764 \\
\hline $\begin{array}{l}\text { Auxílio-suplementar/ Supplemental } \\
\text { security income }\end{array}$ & 152 & 140 & 117 & 152 \\
\hline $\begin{array}{l}\text { Encargos Previdenciários da União - EPU/ } \\
\text { Treasury Owed Benefits - EPU }\end{array}$ & 306 & 197 & 173 & 172 \\
\hline
\end{tabular}

Fonte/Source: Empresa de Tecnologia e Informações da Previdência Social (Dataprev). 
Tabela 5.4 - Quantidade de pessoas físicas contribuintes do Regime Geral de Previdência Social - RGPS, por categoria - 2007-2017 Table 5.4 - Number of individuals contributing to the General Social Security System - RGPS, by category - 2007-2017

\begin{tabular}{|c|c|c|c|c|}
\hline $\begin{array}{l}\text { Ano/ } \\
\text { Year }\end{array}$ & $\begin{array}{l}\text { Total/ } \\
\text { Total }\end{array}$ & $\begin{array}{l}\text { Empregado/ } \\
\text { Employee }\end{array}$ & $\begin{array}{c}\text { Outro } \\
\text { contribuinte/ } \\
\text { Other } \\
\text { contributor }\end{array}$ & $\begin{array}{l}\text { Empregado } \\
\text { e outro } \\
\text { contribuinte/ } \\
\text { Employee } \\
\text { and other } \\
\text { contributor }\end{array}$ \\
\hline 2007 & 49936338 & 38788600 & 9710280 & 1437458 \\
\hline 2008 & 53964928 & 42076251 & 10235457 & 1653220 \\
\hline 2009 & 55877835 & 43439321 & 10684737 & 1753777 \\
\hline 2010 & 60197924 & 46683012 & 11548708 & 1966204 \\
\hline 2011 & 64109870 & 49508175 & 12428273 & 2173422 \\
\hline 2012 & 67246063 & 51609519 & 13333407 & 2303137 \\
\hline 2013 & 69660344 & 52948129 & 13899578 & 2812637 \\
\hline 2014 & 71339903 & 53760776 & 14714775 & 2864352 \\
\hline 2015 & 69635082 & 52070934 & 14978934 & 2585214 \\
\hline 2016 & 66652055 & 49424229 & 15027079 & 2200747 \\
\hline 2017 & 65095735 & 48275786 & 14845462 & 1974487 \\
\hline \multirow{2}{*}{\multicolumn{5}{|c|}{$\begin{array}{l}\text { Fonte/Source : Anuário estatístico da previdência social 2016. Brasília, DF: Empresa de Tecnologia e } \\
\text { Informações da Previdência Social, v. 24, 2017. Disponível em/Available from: } \\
\text { <http://www.previdencia.gov.br/dados-abertos/dados-abertos-previdencia-social/>. Acesso em: jan. } \\
\text { 2019/Cited: Jan. } 2019 . \\
\text { Notas/Notes: } 1 \text {. Os dados de 2013, } 2014 \text { e } 2015 \text { foram atualizados./The 2013, } 2014 \text { and } 2015 \text { data were } \\
\text { updated. }\end{array}$}} \\
\hline & & & & \\
\hline and 2017 & Os dados de 2016 & 017 são preliminare & $\begin{array}{l}\text { serão atualizados } n \\
\text { EPS. }\end{array}$ & EPS 2018.The 2016 \\
\hline
\end{tabular}





\section{Educação Education}

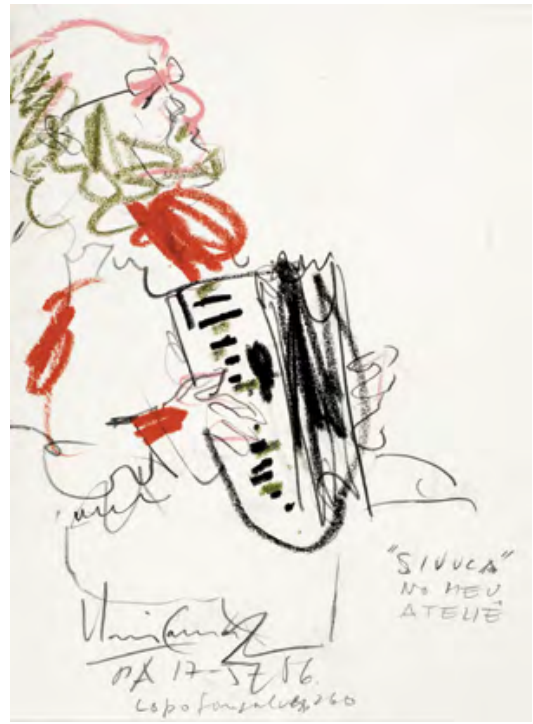

Sivuca no meu ateliê, 1986

Sivuca in my studio

Iberê Camargo 


\title{
Education
}

\author{
Daniel Santos Braga ${ }^{1}$
}

Marisa Ribeiro Teixeira Duarte²

The Federal Constitution of 1988 implemented basic school education as a subjective public right, even for persons who did not have access to it or were not able to complete their studies at the proper age. It also stipulated that our Federation Units have the duty of providing free and public education, as stated in Articles 205 and 206 (BRASIL, 1988). Public services related to the right to basic school education in the country are provided by subnational entities and in schools administered by more than five thousand municipalities and/or by the 26 Federation Units and Federal District. Those schools account for $70 \%$ of the total enrollments in basic education in the country. In 2017, there were 184.1 thousand schools in Brazil, with two thirds of them (112.9 thousand) under municipal administration, facing inequalities regarding the investment capacity of that entity. Municipal schools account for $50 \%$ of the enrollments in basic education and almost $90 \%$ of those schools were located in urban areas (CENSO..., 2017).

1 Master's in Education from the University of the State of Minas Gerais (UEMG). Assistant Professor at the Department of Sciences Applied to Education (DECAE) of the Faculty of Education of the Federal University of Minas Gerais (UFMG) and of the Newton Paiva University Center.

$2 \mathrm{PhD}$ in Education from the Federal Fluminense University (UFF). Associate Professor at the Department of School Administration and at the Graduate Program of the Faculty of Education of the Federal University of Minas Gerais (UFMG). 


\title{
Educação
}

\author{
Daniel Santos Braga ${ }^{1}$
}

Marisa Ribeiro Teixeira Duarte 2

A Constituição Federal de 1988 instituiu a educação escolar de nível básico como direito público subjetivo, inclusive àqueles que não tiveram acesso ou que não a concluíram na idade própria. Estabeleceu, também, como dever dos entes federados sua oferta pública e gratuita, conforme disposto nos Art. 205 e 206 da Constituição Federal do Brasil de 1988 (BRASIL, 1988). Os serviços públicos que efetivam o direito à educação escolar básica no País são prestados pelos entes subnacionais e em escolas administradas por mais de cinco mil municípios e/ou pelos 26 Estados da federação e Distrito Federal. Essas escolas respondem por $70 \%$ do total das matrículas na educação básica do País. Em 2017, havia 184,1 mil unidades escolares no Brasil, sendo que dois terços delas (112,9 mil) eram de dependência administrativa municipal, ente federado que apresenta capacidade de investimento fortemente desigual. Escolas municipais respondiam por $50 \%$ das matrículas na educação básica e quase 90\% dessas escolas estavam localizadas em áreas urbanas (CENSO..., 2017).

1 Mestre em Educação pela Universidade do Estado de Minas Gerais (UEMG). Professor Assistente do Departamento de Ciências Aplicadas à Educação (DECAE) da Faculdade de Educação da Universidade Federal de Minas Gerais (UFMG) e do Centro Universitário Newton Paiva.

2 Doutora em Educação pela Universidade Federal Fluminense (UFF). Professora Associada do Departamento de Administração Escolar e do Programa de Pós-Graduação da Faculdade de Educação da Universidade Federal de Minas Gerais (UFMG). 
A new National Education Plan (PNE), aiming at the reduction of inequalities in education, was approved in 2014. It will be in effect until 2024. The construction of a new agenda for the PNE included the conduction of municipal, state, regional and federal education conferences that led to the approval of a guiding document that moved through the legislative process in Congress. The annex of the law that approved the PNE sets a total of 20 targets and respective strategies on which the federation entities and civil society should focus their efforts, in order to remove barriers against the access and permanence in schools.

The Continuous National Household Sample Survey 2017 (Continuous PNAD) presents information on the meeting of PNE targets set by Law no. 13,005, of 25.06.2014, by federation entities and the Brazilian society. That article evidences how that empirical view brings relevant contributions to the agenda of public educational policies. The percentage of $6.5 \%$ of persons over 10 year of age (Table 6.1) represents more than 12.3 million persons in the country who cannot read or write. By comparing those results with previous studies on illiteracy (OSÓRIO, 2017; SANTOS; MOSER, 2016) one can observe there has been slow and continuous decrease of that phenomenon in the country. Nevertheless, a significant number of persons remain in that condition well into the 21 st century.

The PNE 2014 set as targets the eradication of illiteracy in the country, by 2024 , and the reduction of the illiteracy rate among persons over 15 to $6.5 \%$, by 2015 . The reduction expected for the population over 15 has been practically met, but with a remaining population over 40 who still cannot read or write (Table 6.1). Meeting the eradication target by 2024 demands that nationwide public policies be implemented by states and municipalities, since both entities account for $94 \%$ of the enrollments in Youth and Adult Education (EJA), in the primary school phase.

The illiterate population, whose right to education has been denied, lives mainly in the rural areas of Brazil (Graph 6.1). That group counts on small-sized education units with few resources. The regional distribution of illiteracy among persons aged 15 and over is concentrated in the poorest Major Regions in the country: North and Northeast (Graph 6.2). In the North Region, more than 145 thousand persons are illiterate and many of them live in small, far-off locations. In the Northeast Region, the resident population who cannot read or write hits 8.23 million persons. Nonetheless, an illiterate resident population can be found in the richest areas in the country (Graph 6.2). The continuation of illiteracy in this century reflects the level of 
Em 2014, com objetivo de redução de desigualdades educacionais, foi aprovado novo Plano Nacional de Educação (PNE), com vigência até 2024. A construção de uma agenda em torno do PNE envolveu a realização de conferências municipais, estaduais, regionais e nacional de educação, o que resultou na aprovação de documento orientador para a tramitação da proposição legislativa no Congresso Nacional. No anexo da lei que aprovou o PNE foram estabelecidas 20 metas e suas respectivas estratégias para as quais deveriam convergir os esforços dos entes federados e da sociedade civil, com a finalidade de eliminar as barreiras ao acesso e à permanência nas escolas.

A Pesquisa Nacional por Amostra de Domicílios Contínua 2017 (PNAD Contínua) traz informações sobre o cumprimento das metas previstas na Lei n. 13.005, de 25.06.2014, do PNE pelos entes da federação e pela sociedade brasileira. Este artigo expõe como essa empiria traz orientações relevantes às agendas de políticas públicas educacionais. O percentual de 6,5\% de pessoas acima de 10 anos (Tabela 6.1) representa mais de 12,3 milhões de pessoas que ainda não sabem ler nem escrever no País. Ao comparar esses resultados com estudos anteriores sobre analfabetismo (OSÓRIO, 2017; SANTOS; MOSER, 2016) verifica-se o lento e contínuo decréscimo desse fenômeno no País, porém permanece a presença de expressivo contingente de pessoas nessa situação, em pleno Século XXI.

O PNE 2014 estabeleceu como meta a erradicação no País do analfabetismo absoluto até 2024 e, até 2015 a redução da taxa de analfabetismo para 6,5\% da população com idade superior a 15 anos. A redução prevista para o conjunto da população acima de 15 anos foi praticamente atendida, mas com a permanência da população que não sabe ler nem escrever com idade superior a 40 anos (Tabela 6.1). O cumprimento da meta de erradicação para 2024 envolve políticas públicas de abrangência nacional a serem implementadas pelos estados e municípios, pois estes respondem por $94 \%$ das matrículas na modalidade de Educação de Jovens e Adultos (EJA), na etapa do ensino fundamental.

A população de pessoas analfabetas, cujo direito à educação foi negado, reside predominantemente nas zonas rurais brasileiras (Gráfico 6.1). São unidades escolares municipais de pequeno porte e com poucos recursos que atendem a esta população. A distribuição regional do analfabetismo de pessoas de 15 anos ou mais está concentrada nas regiões mais pobres do País, Regiões Norte e Nordeste (Gráfico 6.2). Na Região Norte, mais de 145 mil pessoas são analfabetas e muitas residem em pequenos municípios de difícil acesso. Na Região Nordeste, a população residente que não sabe ler ou escrever atinge 8,23 milhões de pessoas. Entretanto, verificam- 
educational inequality and segregation still present in the country, and the lack of commitment from the ruling elite regarding the granting of constitutional rights.

In Brazil, persons aged 10 years and over have, on average, 9.1 years of schooling (Table 6.2), although the right to education for all persons aged between 4 and 17 has been guaranteed by the State since 2009, according to clause I of Article 208 of the Federal Constitution of Brazil (BRASIL, 1988). The challenge posed to the state and to the Brazilian society to meet the target of 12 years of schooling set for the population aged between 18 and 24 by the PNE for 2024 is significant. The analysis of average years of schooling by age bracket (Graph 6.3), of the population aged 10 and over, shows that only between 25 and 29 years of age will the population complete the years of schooling corresponding to the conclusion of basic education. That takes place at least eight years after the minimum expected age.

The percentage of persons aged 25 and over that did not complete basic education is above the half of that population (53.8\% - Table 6.3). And the regional concentration of school exclusion follows a similar distribution as that of illiteracy. The North and Northeast Regions are formed by federation entities with a lower investment capacity and by cities that have the lowest human development indexes in Brazil. According to the PNE Observatory (OPNE), the average of years of schooling in the population between 18 and 29 years of age living in rural areas in 2017 was 8.3 years, and the $25 \%$ poorest ones in the Brazilian population had, on average, 8.5 years of schooling.

As the schooling levels of the population advance (Table 6.3), the South and Southeast Regions move further from the poorer Major Regions. Finishing higher education is a reality only accessible to $15.7 \%$ of the Brazilian population, and its regional distribution is similar to that of other educational levels. The percentages in the North and Northeast are below the national average, respectively, with only $11.6 \%$ and $10.3 \%$ of their populations above age 25 . It is in the progression from basic to higher education that the attendance of persons increases in the private sector in all the Major Regions (Table 6.4) .

School attendance by the Brazilian population takes place mostly in public educational systems (Table 6.4), and the opposite is true for higher education. The Southeast Region, with better income and human development levels, concentrates the highest percentages of attendance in the private segment, except for childhood education, in which the Northeast holds the highest percentage of attendance 
se pessoas analfabetas residentes nas regiões mais ricas do País (Gráfico 6.2). A permanência do analfabetismo neste século dimensiona os níveis de desigualdades e segregação educacional ainda persistentes no País e o descompromisso de suas elites dirigentes com a efetivação dos direitos constitucionais.

No Brasil, pessoas de 10 anos ou mais de idade estudaram em média 9,1 anos (Tabela 6.2), enquanto o direito à educação e dever do Estado assegura, desde 2009, a educação escolar a todos (as) na faixa etária de quatro a 17 anos, conforme estabelece o inciso I do Art. 208 da Constituição Federal do Brasil (BRASIL, 1988). O desafio posto ao Estado e à sociedade brasileira, para o cumprimento da meta de 12 anos de estudo estabelecida pelo PNE até 2024, para a população de 18 a 24 anos é expressivo. Ao desagregar por faixa etária a média de anos de estudos (Gráfico 6.3) da população com 10 anos ou mais se verifica que somente na faixa etária de 25 a 29 anos, ou seja, com pelo menos oito anos a mais da idade mínima esperada, a média da população apresenta anos de estudo correspondentes à conclusão da educação básica.

O percentual de pessoas de 25 anos ou mais que não completaram a educação básica é superior à metade dessa população (53,8\% - Tabela 6.3). E a concentração regional dessa exclusão escolar observa distribuição semelhante à do analfabetismo. As Regiões Norte e Nordeste são formadas por entes da federação com menor capacidade de investimento e por cidades com os menores índices de desenvolvimento humano do País. De acordo com o Observatório do PNE (OPNE), a média de anos de escolaridade da população entre 18 e 29 anos residente em áreas rurais, em 2017 , era de 8,3 anos e os $25 \%$ mais pobres da população brasileira tinham em média 8,5 anos de estudo.

Na medida em que se avançam os níveis de instrução da população (Tabela 6.3) as Regiões Sudeste e Sul se distanciam das regiões mais pobres. A conclusão da educação superior é acessível a apenas 15,7\% da população brasileira e sua distribuição regional é semelhante à dos demais níveis de educação. Os percentuais do Norte e do Nordeste estão abaixo da média nacional, respectivamente, com apenas 11,6\% e 10,3\% de sua população acima de 25 anos. É na progressão da educação básica para a educação superior que a frequência de pessoas cresce nas redes privadas em todas as regiões brasileiras (Tabela 6.4).

A frequência à escola da população brasileira ocorre majoritariamente em redes públicas (Tabela 6.4) e para o ensino superior a situação se inverte. A Região Sudeste, com melhores níveis de renda e de desenvolvimento humano, concentra os maiores percentuais de frequência na rede privada, com exceção da educação infantil, na 
to private schools. That phenomenon is influenced by the exclusion of poor children from the basic education step, corresponding to nursery care, and, also, by the fact that approximately $24 \%$ of the private nursery schools in the Northeast Region are partnered with the public administration.

The access to childhood education remains as a major obstacle to the fulfillment of the right to education and the meeting of PNE targets. The target of having at least half of the children aged 0 to 3 years attending nursery school is far from being met (Table 6.5). And, once more, the uneven regional distribution has an effect on the attendance of children at the expected age. The South Region, followed by the Southeast, records the highest rates in services for the early childhood, of $40 \%$ and $39.2 \%$, respectively. The North Region, in turn, records the lowest percentage: only $16.9 \%$ of the small children attend nursery school.

For the age of compulsory school attendance (4 to 17 years of age), the percentages of schooling remain below what is stated by law, especially for the ages of start ( 4 and 5 years) and conclusion of basic education (15 to 17 years - Table 6.6). The PNE target 1 established the universalization of access of children aged 4 and 5 years up to 2016, and if the national average attendance, at this age bracket, reached $91.7 \%$, it is the regional disaggregation of schooling percentages that evidences the need of political policies by territory. The schooling rate of those aged 4 and 5 years, corresponding to preschool, presents differences by Major Region, being lower in the North, as expected, but also low in the South Region of the country (Table 6.6).

The regional distribution of the schooling rate expected for the conclusion of basic education (15 to 17 years of age) points to the exclusion observed throughout the educational system. That reduced average presents a regional distribution that is similar to that of the country. Fact is, women face the worst consequences in the final steps of school education. Young women in Brazil face more exclusion when trying to complete basic education at the expected age, and, in all the Major Regions, that population has lower schooling rates when it comes to compulsory schooling levels (Table 6.6). The universalization of access to the final steps of basic education - at the expected age -, demands more investments, that is, public policies that can promote more regular participation as one grows old and also the reduction of inequalities between men and women aiming at the conclusion of school education. 
qual o Nordeste detém o maior percentual de frequência em escolas particulares. Este fenômeno é influenciado pela exclusão de crianças pobres da etapa da educação básica correspondente às creches e, ainda, por aproximadamente $24 \%$ das creches privadas na Região Nordeste serem conveniadas com o poder público.

O acesso à educação infantil permanece como um grande obstáculo para a efetivação do direito à educação e o cumprimento das metas do PNE. A meta de frequência de pelo menos metade das crianças de 0 a 3 anos nas creches está longe de ser alcançada (Tabela 6.5). E novamente a distribuição regional desigual verifica-se em relação à frequência às creches de crianças na idade esperada. A Região Sul, seguida da Sudeste apresenta as maiores taxas de atendimento à primeira infância, $40 \%$ e $39,2 \%$ respectivamente. A Região Norte, por sua vez, apresenta o menor percentual: apenas $16,9 \%$ das crianças pequenas frequentam as creches.

Para a idade de frequência escolar obrigatória (4 a 17 anos) os percentuais de escolarização permanecem aquém do previsto em lei, especialmente para as idades de ingresso (4 e 5 anos) e conclusão da educação básica (15 a 17 anos - Tabela 6.6). A meta 1 do PNE estabeleceu a universalização do acesso de crianças de 4 e 5 até 2016 e se a frequência média nacional, nesta faixa etária, atingiu 91,7\%, é a desagregação regional dos percentuais de escolarização que revelam as necessidades de políticas públicas territoriais. A taxa de escolarização dos 4 e 5 anos de idade, correspondente à pré-escola, apresenta comportamento regional diferenciado, sendo menor na Região Norte, como esperado, porém, é também menor na Região Sul do País (Tabela 6.6).

A distribuição regional da taxa de escolarização na faixa etária prevista para conclusão da educação básica (15 a 17 anos) é sugestiva da exclusão ao longo do sistema de educação escolar. Esta taxa média mais reduzida apresenta distribuição regional semelhante para o País. Porém, nesta etapa final da educação escolar são as mulheres as mais penalizadas. As jovens brasileiras sofrem exclusão mais acentuada para concluir a educação básica na idade esperada e, em todas as regiões do País, esta população para a faixa de escolaridade obrigatória, apresenta taxas de escolarização menores (Tabela 6.6). Para a universalização do acesso à etapa final da educação básica - na idade esperada - é necessário empreender maiores investimentos, ou seja, políticas públicas promotoras de trajetórias mais regulares com o progredir da idade e diminuição das desigualdades entre homens e mulheres para a conclusão da educação escolar. 


\section{Considerations}

This year, the country has witnessed the unexpected announcement of political measures to be adopted by the Ministry of Education, without any empirical evidence to support them. The writing of this article on education coincided with the disclosure of the governmental decision to cut the budget of federal higher education institutions and of federal programs aimed at basic education by $30 \%$, and to reduce the costs of the 2020 Population Census. Studies on political science, have shown, since the 1960s in the last century, that the relationships between knowledge and policies are not linear nor take precedence in the conduction of policy cycles.

Individuals and social groups do not have to share the same view on a social phenomenon, although ideological views on public policies are to be subject to evidences from public democratic debate. The results of Continuous PNAD 2017 point to a strong association between education inequalities and the socio-political organization of the country. The worst indicators are concentrated in the North and Northeast Regions, where states and municipalities record the lowest tributary resources and human development levels, against the South and Southeast, which record the best indicators. The exception is the Central-West, which presents major inequalities, such as illiteracy rates and average years of schooling as those in the poorest regions, but with access to higher education as in richer areas.

If effective measures are not taken, it seems that, until the end of the PNE term, most of its targets will not have been met and the continuation of educational inequalities in the federation territory will become permanent. Redistributive public policies are urgent and necessary if the political principle of more equal opportunities inscribed in the Federal Constitution of Brazil is to be considered true. 


\section{Considerações}

Neste último ano, o País assistiu à difusão inusitada de medidas políticas a serem adotadas pelo Ministério da Educação, sem qualquer evidência empírica que as sustentassem. A redação deste tópico sobre educação conviveu com a divulgação da decisão governamental de corte de $30 \%$ das verbas que financiam as instituições federais de educação superior, programas federais para a educação básica e, também, de redução das despesas para realização do Censo Demográfico 2020. Os estudos de ciência política, desde a década de 1960 do século passado, ensinam que as relações entre conhecimento e policies não são lineares ou pressupõem a primazia da informação na condução do ciclo das policies.

Indivíduos e grupos sociais não precisam partilhar a mesma versão de um fenômeno social, entretanto visões ideológicas sobre políticas públicas devem ser submetidas ao crivo de evidências no debate público das democracias. Os resultados da PNAD Contínua 2017 sugerem forte associação entre desigualdades educacionais e a organização político social do País. Os piores indicadores estão concentrados nas Regiões Norte e Nordeste, com estados e municípios com menores recursos tributários e níveis de desenvolvimento humano e os melhores, no Sul e no Sudeste. A exceção é a Região Centro-Oeste que apresenta maiores desigualdades, com taxas de analfabetismo e média de estudos próximas às das regiões mais pobres e acesso ao ensino superior próximo das regiões mais ricas.

Se medidas mais efetivas não forem providenciadas, tudo indica que até o encerramento da vigência do $P N E$, a maior parte de suas metas não serão concretizadas e a persistência de desigualdades educacionais no território da federação torna-se algo mais permanente. Políticas públicas de educação redistributivas são urgentes e necessárias se o princípio político de maior igualdade de oportunidade das condições de oferta inscrito na Constituição Federal do Brasil for para valer. 


\section{References}

BRASIL. Constituição (1988). Constituição da República Federativa do Brasil. Brasília, DF, 1988. Available from: <http://www.planalto.gov.br/ccivil_03/ constituicao/constituicaocompilado.htm>. Cited: May 2019.

CENSO escolar 2017: resultados e resumos. Brasília, DF: Instituto Nacional de Estudos e Pesquisas Educacionais Anísio Teixeira, [2017]. Available from: <http://inep.gov.br/resultados-e-resumos>. Cited: May 2019.

OSÓRIO, A. C. do N. Educação. Educação. Brasil em Números, Rio de Janeiro, v.25, p.151-171, 2017. Available from:<https://biblioteca.ibge.gov.br/index. php/biblioteca-catalogo?view=detalhes\&id=72>. Cited: May 2019.

PLANO NACIONAL DE EDUCAÇÃO (BRASIL). Indicadores. [Brasília, DF]: Observatório do PNE, [2019]. Available from: <http://www. observatoriodopne.org.br/home>. Cited: May 2019.

SANTOS, N. dos.; MOSER, A. Educação. Brasil em Números, Rio de Janeiro, v. 24, p. 123-139, 2016. Available from: <https://biblioteca.ibge.gov.br/index. php/biblioteca-catalogo?view=detalhes\&id=72>. Cited: May 2019.

Translated by: Aline Milani Romeiro Pereira 


\section{Referências}

BRASIL. Constituição (1988). Constituição da República Federativa do Brasil. Brasília, DF, 1988. Disponível em: <http://www.planalto.gov.br/ccivil_03/constituicao/ constituicaocompilado.htm>. Acesso em: maio 2019.

CENSO escolar 2017: resultados e resumos. Brasília, DF: Instituto Nacional de Estudos e Pesquisas Educacionais Anísio Teixeira, [2017]. Disponível em: <http://inep.gov.br/ resultados-e-resumos>. Acesso em: maio 2019.

OSÓRIO, A. C. do N. Educação. Educação. Brasil em Números, Rio de Janeiro, v. 25, p.151-171, 2017. Disponível em: <https://biblioteca.ibge.gov.br/index.php/bibliotecacatalogo?view=detalhes\&id=72>. Acesso em: maio 2019.

PLANO NACIONAL DE EDUCAÇÃO (BRASIL). Indicadores. [Brasília, DF]: Observatório do PNE, [2019]. Disponível em: <http://www.observatoriodopne.org.br/home >. Acesso em: maio 2019.

SANTOS, N. dos.; MOSER, A. Educação. Brasil em Números, Rio de Janeiro, v. 24, p. 123-139, 2016. Disponível em: <https://biblioteca.ibge.gov.br/index.php/bibliotecacatalogo?view=detalhes\&id=72>. Acesso em: maio 2019. 


\section{Tabela 6.1 - Taxa de analfabetismo das pessoas de 10 anos ou mais de idade, por sexo, segundo os grupos de idade - Brasil - 20 trimestre de 2017 \\ Table 6.1 - Illiteracy rate of persons 10 years old and over, by sex and age groups - Brazil - 2nd. Quarter 2017}

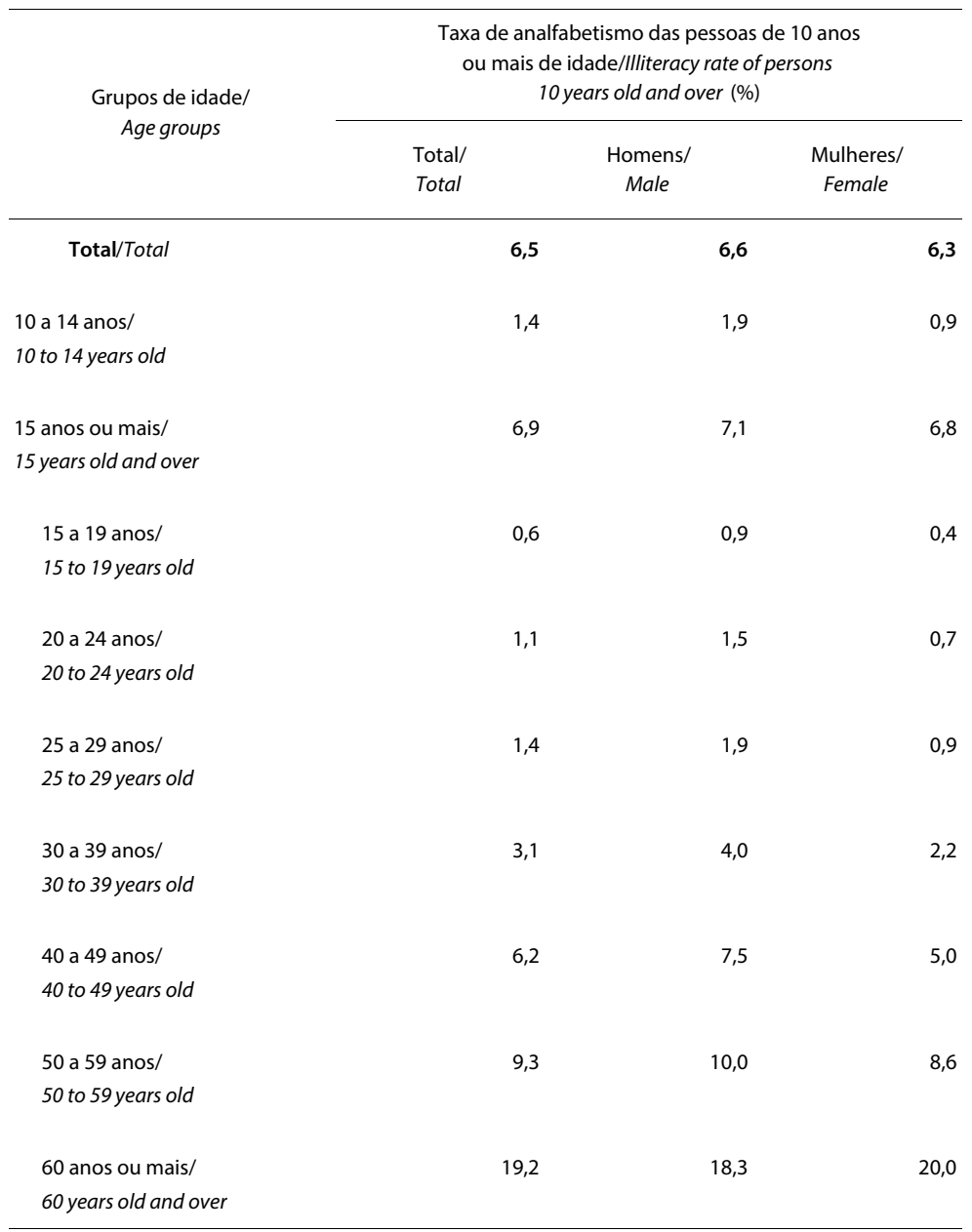

Fonte/Source: IBGE, Diretoria de Pesquisas, Coordenação de Trabalho e Rendimento, Pesquisa Nacional por Amostra de Domicílios Contínua 2017. 
Tabela 6.2 - Média de anos de estudo das pessoas de 10 anos ou mais de idade, por sexo, segundo os grupos de idade - Brasil - 2 trimestre de 2017

Table 6.2 - Average of years of schooling of persons 10 years old and over, by sex and age groups - Brazil - 2nd. Quarter 2017

\begin{tabular}{|c|c|c|c|}
\hline \multirow{2}{*}{$\begin{array}{c}\text { Grupos de idade/ } \\
\text { Age groups }\end{array}$} & \multicolumn{3}{|c|}{$\begin{array}{c}\text { Média de anos de estudo das pessoas de } 10 \text { anos } \\
\text { ou mais de idade/Average of years of schooling of persons } \\
10 \text { years old and over }\end{array}$} \\
\hline & $\begin{array}{l}\text { Total/ } \\
\text { Total }\end{array}$ & $\begin{array}{l}\text { Homens/ } \\
\text { Male }\end{array}$ & $\begin{array}{l}\text { Mulheres/ } \\
\text { Female }\end{array}$ \\
\hline Total & 9,1 & 8,9 & 9,3 \\
\hline \multicolumn{4}{|l|}{ Total } \\
\hline 10 a 14 anos/ & 5,6 & 5,5 & 5,7 \\
\hline \multicolumn{4}{|l|}{10 to 14 years old } \\
\hline 15 anos ou mais/ & 9,4 & 9,2 & 9,6 \\
\hline \multicolumn{4}{|l|}{15 years old and over } \\
\hline 15 a 17 anos/ & 9,1 & 8,8 & 9,4 \\
\hline \multicolumn{4}{|l|}{15 to 17 years old } \\
\hline 18 anos ou mais/ & 9,4 & 9,2 & 9,6 \\
\hline \multicolumn{4}{|l|}{18 years old and over } \\
\hline 18 ou 19 anos/ & 10,7 & 10,4 & 11,0 \\
\hline \multicolumn{4}{|l|}{18 or 19 years old and over } \\
\hline 20 anos ou mais/ & 9,4 & 9,2 & 9,6 \\
\hline \multicolumn{4}{|l|}{20 years old and over } \\
\hline 20 a 24 anos/ & 11,4 & 11,0 & 11,7 \\
\hline \multicolumn{4}{|l|}{20 to 24 years old } \\
\hline 25 anos ou mais/ & 9,1 & 8,9 & 9,3 \\
\hline \multicolumn{4}{|l|}{25 years old and over } \\
\hline 25 a 29 anos/ & 11,5 & 11,2 & 11,9 \\
\hline \multicolumn{4}{|l|}{25 to 29 years old } \\
\hline 30 a 39 anos/ & 10,9 & 10,5 & 11,3 \\
\hline \multicolumn{4}{|l|}{30 to 39 years old } \\
\hline 40 a 49 anos/ & 9,4 & 9,0 & 9,8 \\
\hline \multicolumn{4}{|l|}{40 to 49 years old } \\
\hline 50 a 59 anos/ & 8,5 & 8,2 & 8,7 \\
\hline \multicolumn{4}{|l|}{50 to 59 years old } \\
\hline 60 anos ou mais/ & 6,3 & 6,4 & 6,2 \\
\hline 60 years old and over & & & \\
\hline
\end{tabular}

Fonte/Source: IBGE, Diretoria de Pesquisas, Coordenação de Trabalho e Rendimento, Pesquisa Nacional por Amostra de Domicílios Contínua 2017. 
Tabela 6.3 - Distribuição das pessoas de 25 anos ou mais de idade, por Grandes Regiões, segundo o sexo e o nível de instrução - 20 trimestre de 2017 Table 6.3 - Distribution of persons 25 years old and over, by Major Regions, sex and level of schooling - 2nd. Quarter 2017

(continua/to be continued)

\begin{tabular}{|c|c|c|c|c|c|c|}
\hline \multirow{3}{*}{$\begin{array}{c}\text { Sexo e } \\
\text { nível de instrução/ } \\
\text { Sex and } \\
\text { level of schooling }\end{array}$} & \multicolumn{6}{|c|}{$\begin{array}{l}\text { Distribuição das pessoas de } 25 \text { anos ou mais de idade/ } \\
\text { Distribution of persons } 25 \text { years old and over (\%) }\end{array}$} \\
\hline & \multirow[b]{2}{*}{$\begin{array}{l}\text { Brasil/ } \\
\text { Brazil }\end{array}$} & \multicolumn{5}{|c|}{ Grandes Regiões/Major Regions } \\
\hline & & $\begin{array}{l}\text { Norte/ } \\
\text { North }\end{array}$ & $\begin{array}{l}\text { Nordeste/ } \\
\text { Northeast }\end{array}$ & $\begin{array}{l}\text { Sudeste/ } \\
\text { Southeast }\end{array}$ & $\begin{array}{l}\text { Sul/ } \\
\text { South }\end{array}$ & $\begin{array}{c}\text { Centro- } \\
\text { Oeste/ } \\
\text { Central- } \\
\text { West }\end{array}$ \\
\hline $\begin{array}{l}\text { Total/ } \\
\text { Total }\end{array}$ & 100,0 & 100,0 & 100,0 & 100,0 & 100,0 & 100,0 \\
\hline $\begin{array}{l}\text { Sem instrução/ } \\
\text { No primary education }\end{array}$ & 7,2 & 8,8 & 14,3 & 3,8 & 3,9 & 6,9 \\
\hline $\begin{array}{l}\text { Fundamental incompleto/ } \\
\text { Incompleted lower secondary education or less }\end{array}$ & 33,7 & 36,3 & 37,3 & 30,4 & 36,4 & 32,7 \\
\hline $\begin{array}{l}\text { Fundamental completo/ } \\
\text { Completed lower secondary education }\end{array}$ & 8,5 & 7,3 & 6,7 & 9,4 & 10,3 & 7,8 \\
\hline $\begin{array}{l}\text { Médio incompleto/ } \\
\text { Incompleted upper secondary education }\end{array}$ & 4,4 & 5,5 & 4,5 & 4,2 & 4,4 & 5,0 \\
\hline $\begin{array}{l}\text { Médio completo/ } \\
\text { Completed upper secondary education }\end{array}$ & 26,8 & 26,8 & 24,2 & 29,6 & 24,1 & 24,6 \\
\hline $\begin{array}{l}\text { Superior incompleto/ } \\
\text { Incompleted tertiary education }\end{array}$ & 3,7 & 3,7 & 2,7 & 3,8 & 4,4 & 4,3 \\
\hline $\begin{array}{l}\text { Superior completo/ } \\
\text { Completed tertiary education }\end{array}$ & 15,7 & 11,6 & 10,3 & 18,9 & 16,5 & 18,7 \\
\hline $\begin{array}{l}\text { Homens/ } \\
\text { Male }\end{array}$ & 100,0 & 100,0 & 100,0 & 100,0 & 100,0 & 100,0 \\
\hline $\begin{array}{l}\text { Sem instrução/ } \\
\text { No primary education }\end{array}$ & 7,2 & 9,4 & 15,5 & 3,2 & 3,3 & 7,1 \\
\hline $\begin{array}{l}\text { Fundamental incompleto/ } \\
\text { Incompleted lower secondary education or less }\end{array}$ & 35,4 & 40,2 & 39,8 & 31,2 & 37,4 & 35,7 \\
\hline $\begin{array}{l}\text { Fundamental completo/ } \\
\text { Completed lower secondary education }\end{array}$ & 8,8 & 7,3 & 6,8 & 9,6 & 10,9 & 8,3 \\
\hline $\begin{array}{l}\text { Médio incompleto/ } \\
\text { Incompleted upper secondary education }\end{array}$ & 4,8 & 5,9 & 4,6 & 4,6 & 4,9 & 5,1 \\
\hline $\begin{array}{l}\text { Médio completo/ } \\
\text { Completed upper secondary education }\end{array}$ & 26,5 & 25,1 & 22,8 & 29,9 & 24,6 & 23,9 \\
\hline $\begin{array}{l}\text { Superior incompleto/ } \\
\text { Incompleted tertiary education }\end{array}$ & 3,7 & 3,3 & 2,5 & 4,1 & 4,8 & 4,2 \\
\hline $\begin{array}{l}\text { Superior completo/ } \\
\text { Completed tertiary education }\end{array}$ & 13,7 & 9,0 & 7,9 & 17,4 & 14,2 & 15,8 \\
\hline
\end{tabular}


Tabela 6.3 - Distribuição das pessoas de 25 anos ou mais de idade, por Grandes Regiões, segundo o sexo e o nível de instrução - 20 trimestre de 2017

Table 6.3 - Distribution of persons 25 years old and over, by Major Regions, sex and level of schooling - 2nd. Quarter 2017

(conclusão/concluded)

\begin{tabular}{|c|c|c|c|c|c|c|}
\hline \multirow{3}{*}{$\begin{array}{c}\text { Sexo e } \\
\text { nível de instrução/ } \\
\text { Sex and } \\
\text { level of schooling }\end{array}$} & \multicolumn{6}{|c|}{$\begin{array}{l}\text { Distribuição das pessoas de } 25 \text { anos ou mais de idade/ } \\
\text { Distribution of persons } 25 \text { years old and over (\%) }\end{array}$} \\
\hline & \multirow[b]{2}{*}{$\begin{array}{l}\text { Brasil/ } \\
\text { Brazil }\end{array}$} & \multicolumn{5}{|c|}{ Grandes Regiões/Major Regions } \\
\hline & & $\begin{array}{l}\text { Norte/ } \\
\text { North }\end{array}$ & $\begin{array}{l}\text { Nordeste/ } \\
\text { Northeast }\end{array}$ & $\begin{array}{l}\text { Sudeste/ } \\
\text { Southeast }\end{array}$ & $\begin{array}{l}\text { Sul/ } \\
\text { South }\end{array}$ & $\begin{array}{c}\text { Centro- } \\
\text { Oeste/ } \\
\text { Central- } \\
\text { West }\end{array}$ \\
\hline $\begin{array}{l}\text { Mulheres/ } \\
\text { Female }\end{array}$ & 100,0 & 100,0 & 100,0 & 100,0 & 100,0 & 100,0 \\
\hline $\begin{array}{l}\text { Sem instrução/ } \\
\text { No primary education }\end{array}$ & 7,1 & 8,3 & 13,2 & 4,3 & 4,4 & 6,6 \\
\hline $\begin{array}{l}\text { Fundamental incompleto/ } \\
\text { Incompleted lower secondary education or less }\end{array}$ & 32,3 & 32,7 & 35,2 & 29,7 & 35,6 & 30,1 \\
\hline $\begin{array}{l}\text { Fundamental completo/ } \\
\text { Completed lower secondary education }\end{array}$ & 8,3 & 7,3 & 6,5 & 9,1 & 9,7 & 7,4 \\
\hline $\begin{array}{l}\text { Médio incompleto/ } \\
\text { Incompleted upper secondary education }\end{array}$ & 4,1 & 5,0 & 4,3 & 3,8 & 3,9 & 4,9 \\
\hline $\begin{array}{l}\text { Médio completo/ } \\
\text { Completed upper secondary education }\end{array}$ & 27,1 & 28,5 & 25,4 & 29,3 & 23,7 & 25,2 \\
\hline $\begin{array}{l}\text { Superior incompleto/ } \\
\text { Incompleted tertiary education }\end{array}$ & 3,6 & 4,1 & 2,9 & 3,6 & 4,1 & 4,4 \\
\hline $\begin{array}{l}\text { Superior completo/ } \\
\text { Completed tertiary education }\end{array}$ & 17,5 & 14,1 & 12,4 & 20,1 & 18,7 & 21,3 \\
\hline
\end{tabular}

Fonte/Source: IBGE, Diretoria de Pesquisas, Coordenação de Trabalho e Rendimento, Pesquisa Nacional por Amostra de Domicílios Contínua 2017. 
Tabela 6.4 - Distribuição das pessoas que frequentavam escola ou creche, por Grandes Regiões, segundo o nível e a rede de ensino que frequentavam - 20 trimestre de 2017

Table 6.4 - Distribution of persons who attended school or nursery, by Major Regions, level of schooling and type of school attended - 2nd. Quarter 2017

\begin{tabular}{|c|c|c|c|c|c|c|}
\hline \multirow{3}{*}{$\begin{array}{c}\text { Nível e rede de ensino que } \\
\text { frequentavam/ } \\
\text { Level of schooling and type of school } \\
\text { attended }\end{array}$} & \multicolumn{6}{|c|}{$\begin{array}{l}\text { Distribuição das pessoas que frequentavam escola ou creche/ } \\
\text { Distribution of persons who attended school or nursery (\%) }\end{array}$} \\
\hline & \multirow[b]{2}{*}{$\begin{array}{l}\text { Brasil/ } \\
\text { Brazil }\end{array}$} & \multicolumn{5}{|c|}{ Grandes Regiões/Major Regions } \\
\hline & & $\begin{array}{l}\text { Norte/ } \\
\text { North }\end{array}$ & $\begin{array}{l}\text { Nordeste/ } \\
\text { Northeast }\end{array}$ & $\begin{array}{l}\text { Sudeste/ } \\
\text { Southeast }\end{array}$ & $\begin{array}{l}\text { Sul/ } \\
\text { South }\end{array}$ & $\begin{array}{c}\text { Centro- } \\
\text { Oeste/ } \\
\text { Central- } \\
\text { West }\end{array}$ \\
\hline Creche/ Nursery & 100,0 & 100,0 & 100,0 & 100,0 & 100,0 & 100,0 \\
\hline Pública/ Public & 76,6 & 79,3 & 74,3 & 77,5 & 75,2 & 79,2 \\
\hline Particular/ Private & 23,4 & 20,7 & 25,7 & 22,5 & 24,8 & 20,8 \\
\hline Pré-escolar/Pre-primary & 100,0 & 100,0 & 100,0 & 100,0 & 100,0 & 100,0 \\
\hline Pública/ Public & 71,9 & 81,9 & 67,1 & 72,2 & 77,2 & 71,4 \\
\hline Particular/ Private & 28,1 & 18,1 & 32,9 & 27,9 & 22,8 & 28,7 \\
\hline $\begin{array}{l}\text { Fundamental (1)/ Primary and lower } \\
\text { secondary }\end{array}$ & 100,0 & 100,0 & 100,0 & 100,0 & 100,0 & 100,0 \\
\hline Pública (1)/ Public (1) & 84,1 & 91,7 & 83,2 & 81,3 & 87,3 & 84,4 \\
\hline Particular (1)/ Private (1) & 15,9 & 8,3 & 16,8 & 18,7 & 12,7 & 15,6 \\
\hline Médio/ Upper secondary & 100,0 & 100,0 & 100,0 & 100,0 & 100,0 & 100,0 \\
\hline Pública/ Public & 87,5 & 93,2 & 90,2 & 84,9 & 85,7 & 86,8 \\
\hline Particular/ Private & 12,5 & 6,8 & 9,8 & 15,2 & 14,3 & 13,2 \\
\hline Superior (2)/Tertiary education (2) & 100,0 & 100,0 & 100,0 & 100,0 & 100,0 & 100,0 \\
\hline Pública (2)/ Public (2) & 26,1 & 33,2 & 32,5 & 21,4 & 25,8 & 26,5 \\
\hline Particular (2)/ Private (2) & 73,9 & 66,8 & 67,5 & 78,6 & 74,2 & 73,6 \\
\hline
\end{tabular}

Fonte/Source: IBGE, Diretoria de Pesquisas, Coordenação de Trabalho e Rendimento, Pesquisa Nacional por Amostra de Domicílios Contínua 2017.

(1) Inclusive os estudantes de classe de alfabetização. (2) Inclusive os estudantes de curso de mestrado ou doutorado./ (1) Including the students of literacy classes. (2) Including the students of master and doctoral programs. 
Tabela 6.5 - Taxa de frequência a creche das crianças de 0 a 3 anos de idade, por sexo, segundo as Grandes Regiões - 20 trimestre de 2017

Table 6.5 - Attendance rate to nursery of children 0 to 3 years

old, by sex and Major Regions - 2nd. Quarter 2017

\begin{tabular}{|c|c|c|c|}
\hline \multirow[t]{2}{*}{$\begin{array}{l}\text { Grandes Regiões/ } \\
\text { Major Regions }\end{array}$} & \multicolumn{3}{|c|}{$\begin{array}{l}\text { Taxa de frequência a creche das crianças de } \\
0 \text { a } 3 \text { anos de idade/ } \\
\text { Attendance rate to nursery of children } \\
\text { o to } 3 \text { years old (\%) }\end{array}$} \\
\hline & $\begin{array}{l}\text { Total/ } \\
\text { Total }\end{array}$ & $\begin{array}{l}\text { Homens/ } \\
\text { Male }\end{array}$ & $\begin{array}{l}\text { Mulheres/ } \\
\text { Female }\end{array}$ \\
\hline Brasil/Brazil & 32,7 & 32,3 & 33,2 \\
\hline Norte/ North & 16,9 & 16,4 & 17,4 \\
\hline Nordeste/ Northeast & 28,7 & 28,9 & 28,4 \\
\hline Sudeste/ Southeast & 39,2 & 38,1 & 40,4 \\
\hline Sul/ South & 40,0 & 39,9 & 40,0 \\
\hline Centro-Oeste/ Central-West & 25,5 & 26,3 & 24,5 \\
\hline
\end{tabular}

Fonte/Source: IBGE, Diretoria de Pesquisas, Coordenação de Trabalho e Rendimento, Pesquisa Nacional por Amostra de Domicílios Contínua 2017.

Gráfico 6.1 - Taxa de analfabetismo das pessoas de 15 anos ou mais de idade, por situação do domicílio - Brasil - 29 trimestre de 2017 Graph 6.1 - Illiteracy rate of persons 15 years old and over, by urban/rural housing units - Brazil - 2nd. Quarter 2017

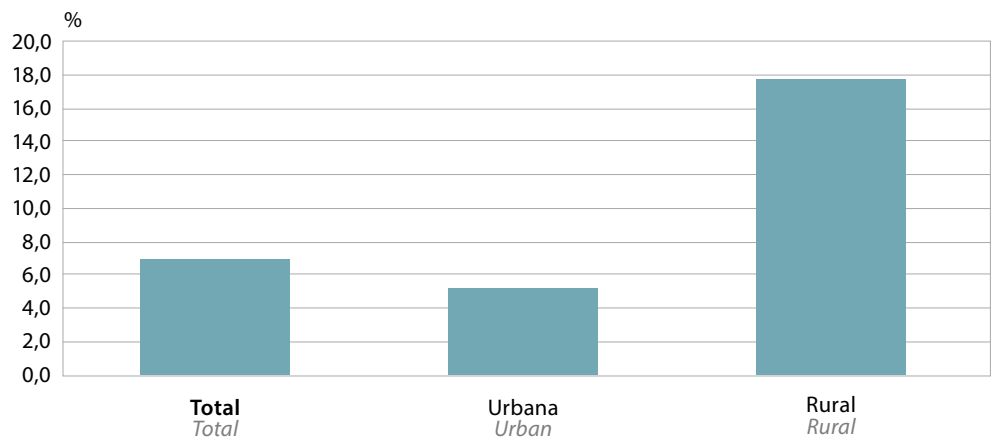

Fonte/Source: IBGE, Diretoria de Pesquisas, Coordenação de Trabalho e Rendimento, Pesquisa Nacional por Amostra de Domicílios Contínua 2017. 


\section{Tabela 6.6 - Taxa de escolarização das pessoas de 4 anos ou mais de idade, por Grandes Regiões, segundo os grupos de idade e o sexo - 20 trimestre de 2017}

Table 6.6 - Attendance rate of persons 4 years old and over, by Major Regions, age groups and sex - 2nd. Quarter 2017

\begin{tabular}{|c|c|c|c|c|c|c|}
\hline \multirow{3}{*}{$\begin{array}{l}\text { Grupos de idade e sexo/ } \\
\text { Age groups and sex }\end{array}$} & \multicolumn{6}{|c|}{$\begin{array}{c}\text { Taxa de escolarização das pessoas de } 4 \text { anos ou mais de idade/ } \\
\text { Attendance rate of persons } 4 \text { years old and over (\%) }\end{array}$} \\
\hline & \multirow[b]{2}{*}{$\begin{array}{l}\text { Brasil/ } \\
\text { Brazil }\end{array}$} & \multicolumn{5}{|c|}{ Grandes Regiões/ Major Regions } \\
\hline & & $\begin{array}{l}\text { Norte/ } \\
\text { North }\end{array}$ & $\begin{array}{l}\text { Nordeste/ } \\
\text { Northeast }\end{array}$ & $\begin{array}{l}\text { Sudeste/ } \\
\text { Southeast }\end{array}$ & $\begin{array}{l}\text { Sul/ } \\
\text { South }\end{array}$ & $\begin{array}{c}\text { Centro- } \\
\text { Oeste/ } \\
\text { Central- } \\
\text { West }\end{array}$ \\
\hline 4 ou 5 anos/ 4 to 5 years old & 91,7 & 85,0 & 94,8 & 93,0 & 88,9 & 86,9 \\
\hline Homens/Male & 91,2 & 83,9 & 94,9 & 92,5 & 88,0 & 86,3 \\
\hline Mulheres/Female & 92,1 & 86,2 & 94,7 & 93,5 & 90,0 & 87,5 \\
\hline 6 a 14 anos/ 6 to 14 years old & 99,2 & 98,9 & 99,0 & 99,3 & 99,5 & 99,3 \\
\hline Homens/Male & 99,1 & 98,9 & 99,0 & 99,2 & 99,5 & 99,2 \\
\hline Mulheres/Female & 99,3 & 99,0 & 99,1 & 99,4 & 99,5 & 99,5 \\
\hline 7 a 14 anos/ 7 a 14 years old & 99,2 & 99,1 & 99,0 & 99,3 & 99,6 & 99,4 \\
\hline Homens/Male & 99,1 & 99,0 & 99,0 & 99,2 & 99,6 & 99,2 \\
\hline Mulheres/Female & 99,3 & 99,1 & 99,1 & 99,5 & 99,5 & 99,6 \\
\hline 15 a 17 anos/ 15 to 17 years old & 87,2 & 86,6 & 86,1 & 88,7 & 85,8 & 87,0 \\
\hline Homens/Male & 87,4 & 87,6 & 86,7 & 88,3 & 86,3 & 87,4 \\
\hline Mulheres/Female & 86,9 & 85,5 & 85,3 & 89,1 & 85,3 & 86,6 \\
\hline 18 ou 19 anos/ 18 to 19 years old & 43,0 & 49,0 & 43,3 & 40,2 & 44,8 & 45,9 \\
\hline Homens/Male & 43,7 & 51,3 & 46,3 & 39,9 & 43,0 & 45,9 \\
\hline Mulheres/Female & 42,3 & 46,5 & 40,4 & 40,5 & 46,8 & 45,9 \\
\hline 20 a 24 anos/ 20 to 24 years old & 26,8 & 26,6 & 24,6 & 26,6 & 29,7 & 31,2 \\
\hline Homens/Male & 25,2 & 25,9 & 23,0 & 25,5 & 26,1 & 29,4 \\
\hline Mulheres/Female & 28,5 & 27,4 & 26,2 & 27,8 & 33,3 & 33,1 \\
\hline 25 anos ou mais/ 25 years old and over & 4,3 & 5,8 & 4,3 & 3,8 & 4,4 & 5,2 \\
\hline Homens/Male & 3,8 & 4,6 & 3,5 & 3,5 & 4,0 & 4,5 \\
\hline Mulheres/Female & 4,7 & 6,9 & 4,9 & 4,1 & 4,7 & 5,8 \\
\hline
\end{tabular}

Fonte/Source: IBGE, Diretoria de Pesquisas, Coordenação de Trabalho e Rendimento, Pesquisa Nacional por Amostra de Domicílios Contínua 2017. 


\section{Gráfico 6.2 - Taxa de analfabetismo das pessoas de 15 anos ou mais de idade, por Grandes Regiões - 20 trimestre de 2017}

Graph 6.2 - Illiteracy rate of persons 15 years old and over, by Major Regions - 2nd. Quarter 2017

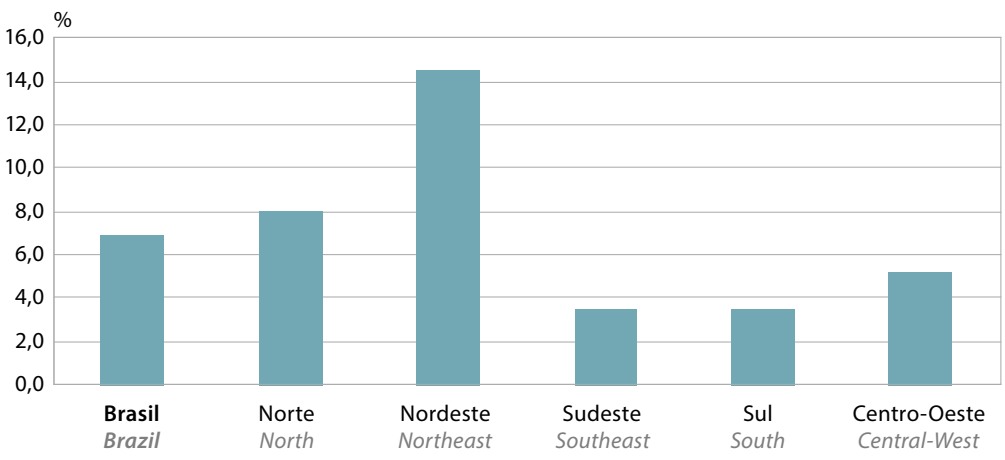

Fonte/Source: IBGE, Diretoria de Pesquisas, Coordenação de Trabalho e Rendimento, Pesquisa Nacional por Amostra de Domicílios Contínua 2017.

\section{Gráfico 6.3 - Média de anos de estudo da população de 10 anos ou mais de idade, por grupos de idade - Brasil - 20 trimestre de 2017 \\ Graph 6.3 - Average years of schooling of persons 10 years \\ old and over, by age groups - Brazil - 2nd. Quarter 2017}

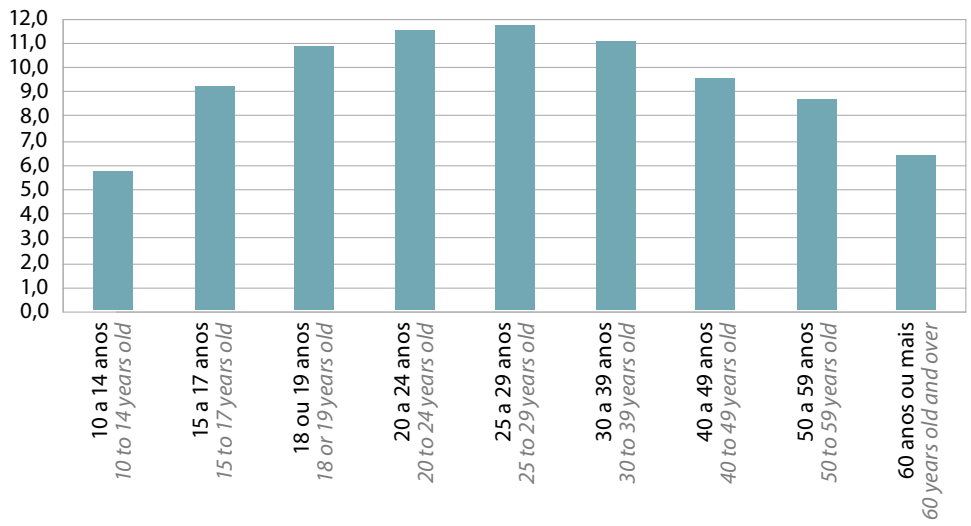

Fonte/Source: IBGE, Diretoria de Pesquisas, Coordenação de Trabalho e Rendimento, Pesquisa Nacional por Amostra de Domicílios Contínua 2017. 



\section{Trabalho Labor}

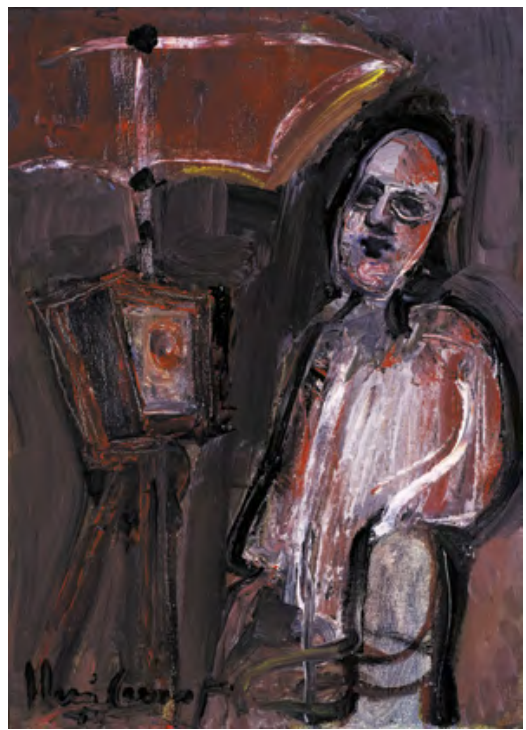

Lambe-lambe I, 1988

Lambe-lambe I

Iberê Camargo 


\title{
Labor
}

\author{
Marilis Lemos de Almeida ${ }^{1}$
}

\section{Labor in 2017: losing dynamism in the labor market and deepening social and regional inequalities}

The signs of the decreasing economic prosperity of the country have been showing since 2014 and its effects became visible in the labor market in the last quarter of 2015. Since then, the deterioration of the labor market, which had been gaining force in the two previous years, went on and got confirmed in the year 2017. The dynamism loss in the labor market has negative effects on the generation and maintenance of job positions, as well as on the quality of jobs, affecting unevenly the country's Regions and their workers. Speaking on the subject, is it never too much to emphasize that labor is a way of economic subsistence, but also a right on which citizenship is grounded, a source of social recognition and inclusion.

The analysis of labor market insertion, based on the data of the Continuous National Household Sample Survey (Continuous PNAD) from 2012 to $2017^{2}$, considers as working-age population (WAP)

$1 \mathrm{PhD}$ in Scientific and Technologic Policy from the Campinas University (UNICAMP) and Professor in the Law School of the Federal University of Pelotas (UFPel) and of the Postgraduate Program in Sociology of the Federal University of Rio Grande do Sul (UFRGS).

2 The data used in this section were obtained from Tables 1.1, 1.2, 1.3, 1.5, 1.24 and 1.26 from the 2017 Summary of Social Indicators, by the IBGE. Available from: <https://www.ibge.gov.br/estatisticas/sociais/trabalho/9221-sintese-deindicadores-sociais.html?=\&t=o-que-e $>$. Cited: May 2019. 


\title{
Trabalho
}

\author{
Marilis Lemos de Almeida ${ }^{1}$
}

\section{Trabalho em 2017: perda de dinamismo do mercado de trabalho e aprofundamento das desigualdades regionais e sociais}

Os sinais de redução da prosperidade econômica do País se estabeleceram desde 2014 e seus efeitos se fizeram presentes no mercado de trabalho no último trimestre de 2015. Desde então a deterioração do mercado de trabalho, que vinha se desenhando nos últimos dois anos, prossegue e confirma-se no ano de 2017. A perda de dinamismo do mercado de trabalho tem efeitos negativos sobre a geração e manutenção dos postos de trabalho, mas também sobre a qualidade da ocupação, afetando de forma desigual as regiões do País e seus trabalhadores e trabalhadoras. Ao falar sobre o tema não é demais lembrar que além de fonte de sustento econômico, o trabalho é um direito, base da cidadania, fonte de reconhecimento e de inclusão social.

A análise da inserção dos trabalhadores e trabalhadores no mercado de trabalho, realizada com base nos dados da Pesquisa Nacional por Amostra de Domicílios Contínua (PNAD Contínua), de 2012 a 20172, considera como pessoas em idade de trabalhar

1 Doutora em Política Científica e Tecnológica pela Universidade de Campinas (UNICAMP) e Professora da Faculdade de Direito da Universidade Federal de Pelotas (UFPel) e do Programa de Pós-Graduação em Sociologia da Universidade Federal do Rio Grande do Sul (UFRGS).

2 Os dados utilizados nesta seção foram obtidos das Tabelas 1.1, 1.2, 1.3, 1.5, 1.24 e 1.26, da Síntese de Indicadores Sociais 2018, do IBGE. Disponível em: <https://www.ibge.gov.br/ estatisticas/sociais/trabalho/9221-sintese-de-indicadores-sociais.html?=\&t=o-que-e $>$. Acesso em: maio 2019. 
those aged 14 years old or above. This group divides into those that integrate the workforce, weather as employed or unemployed $(62.2 \%)$, and those who are out of the workforce (37.8\%). Given the adversities of the present moment, the crucial point has to do with the capacity of the Brazilian labor market of employing those persons.

The participation rate kept relatively stable between the years 2012 and 2017; in the last year it was 62.2\%, but with a considerable disadvantage for women. The ranges of greatest participation, for men and women, are the intermediate ones, whereas the lowest rates are seen in both ends, youngsters and elderly. Men aged between 30 and 39,40 and 49 and 25 and 29 presented the highest participation rates, respectively, 93\%, $90.4 \%$ and $90.3 \%$. Women, with significantly inferior figures, recorded the highest participation rates in the same age brackets, but inverting the second and third positions, in favor of younger women: between 30 and 39, the participation rate is $73.9 \%$, between 25 and $29,71.6 \%$, and between 40 and 49 , it is $69.8 \%$ (Table 1.1 and Graph 7.1). A reasonable hypothesis to explain the small number of the elderly and youngsters in the workforce is the stage of life they are in; the elderly are probably retired and the youngsters, studying. However, the high presence of youngsters in the potential workforce and, specially, among the discouraged suggests that the labor market is quite impenetrable to young people.

In 2017, a significant contingent of WAP was out of the labor force (37.8\%), of whom $11.9 \%$ integrated the so-called potential workforce, that is, persons that could be back into the workforce, either as employed or as unemployed. In this group are the ones defined as discouraged, who gave up seeking a position due to circumstances that make them lose the necessary motivation to keep on searching. The self-perception that people have as to their return to the labor market, based on their previous unsuccessful experience, is an important element to explain the rise of the rate of discouragement, which has hit records. (Tables 1.1 and 1.24).

In the labor force, unemployment has been increasing rapidly since the last quarter of 2015 , when the year closed with $8.8 \%$ of unemployed persons. In the previous year, the unemployment rate had been of $6.9 \%$ and leaped to $12.5 \%$ in 2017 . It is worth highlighting that people are differently affected by the lack of employment, women being mostly affected ( $14.6 \%$ of unemployment against $10.9 \%$ among men). Next, are black and brown persons (14.7\% of unemployment against $10 \%$ among white persons) and youngsters. Among young persons 
(PIT) aquelas com 14 anos ou mais de idade. Este grupamento desdobra-se entre aqueles que integram a força de trabalho $(62,2 \%)$, seja na condição de ocupado ou de desocupado e aqueles que estão fora da força de trabalho (37,8\%). Dado o contexto adverso, a questão crucial é referente à capacidade do mercado de trabalho brasileiro de absorver essas pessoas.

A taxa de participação se manteve relativamente estável entre os anos 2012 e 2017, no último ano foi de $62,2 \%$, mas com variação por gênero bastante desfavorável para as mulheres. As faixas etárias com maior participação, para homens e mulheres, são as intermediárias, enquanto que as menores taxas se verificam em ambas as pontas, entre os mais jovens e os mais idosos. Os homens situados entre 30 e 39 anos, 40 e 49 anos e 25 e 29 anos apresentam as maiores taxas de participação, respectivamente $93 \%, 90,4 \%$ e $90,3 \%$. As mulheres, com percentuais significativamente inferiores, apresentam as maiores taxas de participação nas mesmas faixas etárias, mas com inversão entre segunda e terceira posições, em favor das mulheres mais jovens: entre 30 e 39 anos a taxa de participação é de 73,9\%, entre 25 e 29 anos, 71,6\% e entre 40 e 49 anos é $69,8 \%$ (Tabela 1.1 e Gráfico 7.1) Uma hipótese para a baixa presença de idosos e jovens na força de trabalho pode estar relacionada à fase da vida em que se encontram; os idosos por que muitos podem já estar aposentados e os muitos jovens podem estar ocupados com os estudos. Contudo, a elevada presença de jovens na força de trabalho potencial e, em particular, entre os desalentados, sugere a hipótese de um mercado de trabalho pouco permeável aos mais jovens.

Em 2017, um contigente expressivo da PIT está fora da força de trabalho (37,8\%), destes, $11,9 \%$ integram a chamada força de trabalho potencial, ou seja, pessoas que poderiam voltar a compor a força de trabalho, como ocupados ou desocupados. Neste conjunto estão os denominados desalentados, que deixaram de procurar trabalho por circunstâncias que produzem uma perda de estímulo e /ou condições de persistir na busca de uma vaga. A percepção que as pessoas têm acerca de sua chances de voltar ao mercado de trabalho, mais ou menos informadas por tentativas anteriores mal sucedidas, é um aspecto importante para o entendimento do crescimento do desalento, o qual vem batendo recordes anuais (Tabelas 1.1 e 1.24).

$\mathrm{Na}$ força de trabalho, a desocupação vem crescendo a passos largos desde o último trimestre de 2015 , quando o ano fechou com $8,8 \%$ de desocupados. No ano anterior a desocupação havia sido de 6,9\% e saltou para 12,5\% em 2017. Vale sublinhar que as pessoas são afetadas desigualmente pela falta de ocupação, sendo mais desfavorável para mulheres ( $14,6 \%$ de desocupação contra $10,9 \%$ entre os homens), pessoas pardas e pretas ( $14,7 \%$ de desocupação contra $10 \%$ registrada entre brancos) 
aged between 14 and 29, the unemployment rate is quite high, reaching $22.6 \%$ and being more critical for young women $(26.3 \%)$ and for brown or black youngsters (25\%) (Tables 1.1 and 1.2).

The employment-to-population ratio between 2012 and 2014 remained stable, nearly 57\%, but, from 2015 on, the decline starts, achieving the lowest levels of the series in 2016 (54.7\%) and in 2017 (54.4\%). In 2017, there are higher levels for men than for women, respectively, $64.6 \%$ and $45 \%$; and for brown and black persons than for white ones, respectively, $56.6 \%$ and $52.6 \%$. The employment is positively related to schooling for brown, black and white men and women, and the highest the schooling, the highest the employmentto-population ratio. A critical aspect to be considered is that, between working-age persons, in 2017, 54.9\% had not concluded primary education, that is, more than half had the lowest schooling level. In $2017,53.1 \%$ of those out of the labor force were uneducated or just had incomplete primary education (Tables 1.1 and 1.2).

Among the employed, both the ends of the age range present low participation and the youngsters aged between 15 and 19 are less present. The most present age groups are the intermediate ones, between 30 and 59, with little change among the Regions. For men aged between 30 and 49, the employment-to-population ratio is $84.8 \%$ and, for those aged between 50 and 59 , it is $73.9 \%$ the two greatest percentages recorded, much above the average employment-to-population ratio of $54.4 \%$. In contrast and exposing the great mismatches present in the labor market, the women aged 60 and over have an employment-to-population ratio of $13.8 \%$ and black and brown persons, aged 60 and over, of $21.1 \%$. Combining gender, age and color, the social inequalities that characterize Brazil become more evident (Tables 7.1 and 1.1).

Next, we will observe the behavior of the labor market in 2017, sensitive to the socio-spatial differences that reveal the regional differences that define Brazil. From the point of view of the distribution of the employed persons, $63 \%$ were in the services sector; $13 \%$ in industry, $9.5 \%$ in agriculture; $7.7 \%$ in civil construction and $6.8 \%$ in domestic services (Graph 7.3)

In all the areas, more than half of the employed are in the services sector, whose characteristics of high heterogeneity encompasses both modern activities and traditional ones, as well as those related to public education, health and services, which employ large amounts of persons. Therefore, the higher or lower presence of those activities 
e jovens. Entre os jovens de 14 a 29 anos a taxa de desocupação é muito elevada, na ordem de $22,6 \%$, sendo mais crítica a situação para mulheres jovens $(26,3 \%)$ e jovens pardos ou pretos (25\%) (Tabelas 1.1 e 1.2).

O nível de ocupação entre 2012 e 2014 permaneceu estável, em torno de 57\%, mas, a partir de 2015 inicia-se o declínio chegando aos menores níveis da série em 2016 (54,7\%) e em 2017 (54,4\%). Em 2017, observa-se níveis maiores entre homens do que entre mulheres, respectivamente $64,6 \%$ e $45 \%$; e entre brancos do que entre pretos e pardos, respectivamente, $56,6 \%$ e $52,6 \%$. A ocupação mantém correlação positiva com escolaridade para homens e mulheres brancos, pretos e pardos, e quanto maior a escolaridade, maior o nível de ocupação. $O$ aspecto crítico a ser considerado é que entre o contigente de pessoas em idade de trabalhar, em 2017, 54,9\% não completaram o ensino básico, ou seja, mais da metade possui baixíssima escolaridade. Em 2017, 53,1\% dos que estão fora da força de trabalho não possuem instrução ou apenas o fundamental incompleto (Tabelas 1.1 e 1.2).

Entre os ocupados, as duas faixas etárias extremas do espectro apresentam baixa participação, sendo os jovens entre 15 e 19 anos ainda menos presentes. Os grupos etários mais presentes são os intermediários, entre 30 e 59 anos, com pequenas variações entre as regiões. Para os homens de 30 a 49 anos o nível de ocupação é de $84,8 \%$ e para aqueles entre 50 e 59 anos é de $73,9 \%$, os dois maiores percentuais registrados, muito acima do nível de ocupação média de 54,4\%. Em contraste e expondo as imensas assimetrias presentes no mercado de trabalho, as mulheres de 60 anos ou mais têm nível de ocupação de 13,8\% e as pessoas pretas e pardas, com 60 anos de idade ou mais, de $21,1 \%$. No entrelaçamento entre gênero, geração e cor se aprofundam as desigualdades sociais que caracterizam o Brasil (Tabelas 7.1 e 1.1).

A seguir observaremos o comportamento do mercado de trabalho, em 2017, sensível às diferenças sócio-espaciais que expõem a heterogeneidade regional que caracteriza o Brasil. Do ponto de vista da distribuição dos ocupados, 63\% estavam no setor de serviços; $13 \%$ na indústria, 9,5\%, na agricultura; $7,7 \%$ na construção civil e 6,8\% nos serviços domésticos (Gráfico 7.3).

Em todas as regiões, mais da metade dos ocupados está no setor de serviços, cuja característica de elevada heterogeneidade comporta tanto atividades modernas, quanto atividades tradicionais, e também aquelas relacionadas à educação, saúde e serviços públicos, altamente intensivas em força de trabalho. Portanto, a maior ou menor presença dessas atividades responde por dinâmicas diferenciadas, podendo tanto expres- 
imply different dynamics, representing either the increasing demand, due to the per capita income rise, or its cushion role in times of economic crises.

In the North and Northeast Regions, employment in agricultural activities is fairly high, respectively $16.9 \%$ and $13.7 \%$, above the average employment in the country in that activity and also above the industrial employment recorded in those Regions. In the North, the employment in the industry was of $10.3 \%$ and in the Northeast, of $9.2 \%$. In both Regions, $1 / 3$ of the employed persons are distributed in the activities of civil construction (8.2\%), agriculture and domestic services (7.1\%), in which the prevalence of low social protection, high informality and low income produce negative effects on job quality.

On the other extreme, the South and Southeast Regions stand out for high employment-to-population ratios in the industry, respectively, $17.9 \%$ and $14.1 \%$, in line with the importance of the activity in those Regions. Employment in the industrial sector usually offers more protection, with labor contracts and access to social welfare, besides higher salaries. On the other hand, there are important differences in relation to agricultural employment: whereas in the Southeast Region there is just $5.5 \%$ of employment in the activity - aligned with its productive matrix; in the South, it accounts for $10.7 \%$ of the employed persons, in line with the strong presence of the agricultural business. The high level of mechanization in the crops in the South and CentralWest cause a lower insertion of workers in relation to the other agricultural Regions, but the figures are still very significant, though.

In the Central-West Region, the distribution of the employed persons by activity indicates the relatively reduced presence of employment in the industry, $10.5 \%$ - a percentage really close to the one recorded in the North Region (10.3\%), and a high percentage of employed persons in the services sector, with $64.1 \%$; in agriculture, with $9.9 \%$; in civil construction, with $7.8 \%$; and in domestic services, with $7.6 \%$ whose percentage is the highest among the Regions. The activities of agriculture, civil construction and domestic services, which typically present the worst insertion conditions, absorb $1 / 4$ of the employed.

The quality of the jobs has, as an important indicator, the contribution to the social security system. Thus, the percentage of $36.4 \%$ of the employed persons who do not contribute to the social security in the country is quite worrisome. The negative highlight is to self-employed workers, which account for nearly $1 / 4$ of the employed persons and present a percentage of $69.7 \%$ of non-contributors (Table 1.26). Even in the South Region, which records the lowest level of non-contributors, $1 / 4$ of the employed are inserted in a context that suggests precarity. In the North and Northeast Regions, the situation is more critical, since more than half of employed persons are not covered by social security 
sar o aumento da demanda, decorrente da elevação da renda per capita, quanto indicar seu funcionamento como colchão amortecedor em momentos de crise econômica.

Nas Regiões Norte e Nordeste, a ocupação em atividades agrícolas é bastante elevada, respectivamente $16,9 \%$ e $13,7 \%$, níveis superiores à média de ocupados no País nesta atividade e também superior à ocupação na indústria registrada nessas regiões. No Norte, a ocupação na indústria foi de 10,3\% e no Nordeste de 9,2\%. Em ambas as regiões $1 / 3$ dos ocupados estão distribuídos nas atividades de construção civil $(8,2 \%)$, agricultura e serviços domésticos $(7,1 \%)$, nas quais a prevalência da baixa proteção social, elevada informalidade e baixos rendimentos produz efeitos negativos sobre a qualidade do emprego.

No polo oposto, as Regiões Sul e Sudeste destacam-se por elevados níveis de ocupação na indústria, respectivamente 17,9\% e 14,1\%, em sintonia com a importância assumida por esta atividade nas regiões. Usualmente as ocupações no setor industrial apresentam maior proteção, com contratos de trabalho e acesso a benefícios sociais, além de melhores níveis de remuneração. Por outro lado, há diferenças importantes em relação à ocupação na agricultura, enquanto a Região Sudeste apresenta apenas 5,5\% de ocupação nesta atividade, em acordo com sua matriz produtiva, no Sul ela responde por $10,7 \%$ dos ocupados, em consonância com a forte presença da atividade agrícola. O elevado grau de mecanização das lavouras no Sul e no Centro-Oeste geram uma menor absorção de trabalhadores relativamente a outras regiões agrícolas, mas ainda assim bastante significativa.

Na Região Centro-Oeste a distribuição das pessoas ocupadas por atividade indica presença relativamente reduzida de ocupação na indústria, 10,5\%, percentual muito próximo ao registrado na Região Norte (10,3\%) e percentual elevado de ocupados no setor de serviços, com $64,1 \%$, na agricultura, com $9,9 \%$, na construção civil, com $7,8 \%$ e nos serviços domésticos, com 7,6\%, cujo percentual é o maior dentre todas as regiões. As atividades de agricultura, construção civil e serviços domésticos, que tipicamente apresentam piores condições de inserção, absorvem $1 / 4$ dos ocupados.

A qualidade da ocupação tem como importante indicador a contribuição à previdência social, por isso o percentual de $36,4 \%$ de ocupados que não contribuem para a previdência no País é preocupante. $O$ destaque negativo são os trabalhadores por conta própria, que respondem por cerca de $1 / 4$ dos ocupados, e apresenta um percentual de $69,7 \%$ dos que não são contribuintes (Tabela 1.26). Mesmo na Região Sul, que registra o menor nível de não contribuintes, $1 / 4$ dos ocupados estão inseridos em uma situação que sugere precariedade na inserção. Nas Regiões Norte e Nordeste a situação é mais crítica, uma vez que mais da metade dos ocupados não tem a cobertura da previdência social, respectivamente $54,5 \%$ e $51,4 \%$, aprofundando as 
- respectively $54.5 \%$ and $51.4 \%$-, increasing the social and regional inequalities (Graph 7.2). Of note is the drawback in the indicators in relation to 2016, with increasing percentage of non-contributors in all Regions, as it can be seen in Brazil in Figures 2018 (OLIVEIRA, 2018).

The distribution of persons by employment position reveals that $67.7 \%$ are in the employed population share (including domestic workers): $25.3 \%$ are self-employed, $4.6 \%$, employers and $2.5 \%$, contributing family workers, i. e., non-paid workers. The North Region presents the lower proportion of employed persons (58.1\%) and the Southeast Region, the highest one (71.1\%). The expansion of salaried workers in the North and Northeast shows that the economic dynamization of those Regions had influence on the transformation of the regional producing structures.

Considering labor contracts as a way of assessing the quality of the jobs, we can see that the participation in the wage economy has occurred in a precarious and rather unequal way. Whereas the Southeast and South present the greatest proportions of workers with a formal labor contract - respectively, $46.9 \%$ and $45.6 \%$-, Northeast and North have the highest proportions of workers without a formal labor contract - respectively, $27 \%$ and $24 \%$. Of note is that, in the North and Northeast, the proportion of persons with a formal labor contract ( $23.6 \%$ in the North and $27.4 \%$ in the Northeast) and without a formal labor contract ( $24 \%$ in the North and $27 \%$ in the Northeast) is really close. The Central-West Region presents a distribution of employment type edging the national average. Those data suggest that there is a long way to go in order to improve the quality of the workers' insertion in the labor market and, especially, to overcome regional inequalities (Table 7.1).

The domestic workers represented $6.8 \%$ of the employed persons in 2017 , which is alone a sign of the persistence of the social inequalities in the country. The Central-West and Southeast Regions present the two biggest proportion of domestic workers in relation the total number of the employed persons - respectively, $7.6 \%$ and $7.2 \%$. Although there has been advances in the labor legislation, the proportion of domestic workers without a labor contract is twice as big as that of workers with a formal labor contract. The situation gets even worse in the Northeast and North, where, respectively, $80.5 \%$ and $79.1 \%$ of the domestic workers do not have a formal labor contract (Tables 7.1 and 1.26).

In addition, the North and Northeast present the biggest proportions of uneducated employed persons or workers with less than 1 year of schooling, respectively $-4.1 \%$ and $5.8 \%$-, and the lowest proportion of employed person with 12 or more years of schooling, both with $53.1 \%$. At last, it is still very significant and worrisome the considerable proportion of uneducated employed persons in Brazil and the fact that $24.1 \%$ of the employed population had just up to eight years of schooling. (Table 7.1) 
desigualdades sociais e regionais (Gráfico 7.2). Destaque-se a piora dos indicadores em relação a 2016, com a elevação do percentual de não contribuintes em todas as regiões, conforme pode ser observado no Brasil em Números 2018 (OLIVEIRA, 2018).

A distribuição das pessoas por posição na ocupação revela que $67,7 \%$ o fazem na condição de empregados (incluindo trabalhadores domésticos), 25,3\% como conta própria, 4,6\% como empregadores e 2,5\% como trabalhador familiar auxiliar, ou seja, sem remuneração. A Região Norte apresenta a menor proporção de empregados $(58,1 \%)$ e a Região Sudeste, a maior (71,1\%). A expansão do assalariamento no Norte e Nordeste revela que a dinamização econômica dessas regiões surtiram efeitos na transformação das estruturas produtivas regionais.

Considerando a existência de carteira de trabalho assinada para aferir a qualidade da ocupação, observa-se que a inserção na economia salarial tem se dado de forma pouco protegida e sobretudo desigual. Enquanto Sudeste e Sul apresentam as maiores proporções de trabalhadores com carteira assinada, respectivamente $46,9 \%$ e $45,6 \%$, Nordeste e Norte apresentam as maiores proporções de trabalhadores sem carteira de trabalho assinada, respectivamente $27 \%$ e $24 \%$. Destaque-se ainda no Norte e Nordeste que a proporção de pessoas com carteira $(23,6 \%$, no Norte e $27,4 \%$, no Nordeste) e sem carteira de trabalho assinada ( $24 \%$, no Norte e $27 \%$, no Nordeste) é muito próxima. A Região Centro-Oeste apresenta a distribuição da posição da ocupação próxima da média nacional. Estes dados sugerem que há muito a caminhar para elevar a qualidade da inserção dos trabalhadores no mercado de trabalho e, especialmente, de superação das desigualdades regionais (Tabela 7.1).

Os trabalhadores domésticos representavam 6,8\% dos ocupados em 2017, o que por si só sugere a persistência das desigualdades sociais no País. As Regiões Centro-Oeste e Sudeste apresentam as duas maiores proporções de trabalhadores domésticos em relação ao conjunto dos ocupados, respectivamente 7,6\% e 7,2\%. Em que pese os avanços da legislação na área, a proporção de trabalhadores domésticos sem carteira é mais do que o dobro daqueles com carteira assinada. A situação se agrava sobretudo no Nordeste e Norte, onde respectivamente $80,5 \%$ e $79,1 \%$ dos trabalhadores domésticos não possuíam carteira de trabalho assinada (Tabelas 7.1 e 1.26).

Adicionalmente, as Regiões Norte e Nordeste apresentam as maiores proporções de ocupados sem instrução ou com menos de 1 ano de estudo, respectivamente, $4,1 \%$ e $5,8 \%$, as menores proporções de ocupados com 12 anos ou mais de instrução, ambas $53,1 \%$. Por fim, ainda é muito significativa e preocupante a proporção não desprezível de ocupados sem instrução no Brasil e o fato de que $24,1 \%$ dos ocupados tenham somente até 8 anos de estudo (Tabela 7.1). 


\section{References}

OLIVEIRA, H. S. de. Trabalho. Brasil em Números. Rio de Janeiro, v. 26, p. 171-187, 2018. Available from: <https://biblioteca.ibge.gov.br/index.php/ biblioteca-catalogo?view=detalhes\&id=72>. Cited: May 2019.

SÍNTESE de indicadores sociais: uma análise das condições de vida da população brasileira: 2018. Rio de Janeiro: IBGE, 2018. 143 p. Available from: <https://www.ibge.gov.br/estatisticas/sociais/trabalho/9221-sintese-deindicadores-sociais.html?=\&t=o-que-e >. Cited: May 2019.

Translated by: Gisele Flores Caldas Manhães

\section{Additional Tables}

Available from the IBGE web portal on the Internet, on: <https:// www.ibge.gov.br/estatisticas/sociais/trabalho/9221-sintese-deindicadores-sociais.html?=\&t=o-que-e>. Cited: May 2019.

Table 1.1 - Long-term indicators of the labor market of persons aged 14 and over, with indication of the coefficient of variation, according to groups of age, sex and color or race - 2012-2017

Table 1.2 - Long-term indicators of the labor market of persons aged 14 and over, with indication of the coefficient of variation, according to level of schooling, sex and color or race - 2012-2107

Table 1.3 - Unemployment rate of persons aged 14 and over, by sex, age groups and color or race, with indication of the coefficient of variation, according to Major Regions, Federation Units and Municipalities of Capitals

Table 1.5 - Persons aged 14 and older employed in the reference week, total and proportion in formal jobs, by sex and color or race, with indication of the coefficient of variation, according to Major Regions, Federation Units and Municipalities of Capitals

Table 1.24-Persons in the potential workforce who did not look for work in the reference month by sex, color or race and age groups, with indication of the coefficient of variation, according to the main reason for not having searched for a job - 2016 and 2017

Table 1.26 - Persons aged 14 and older employed in the reference week as self-employed workers and employers, and percentage distribution by contribution to social security, with indication of the coefficient of variation, according to selected characteristics - 2017 


\section{Referências}

OLIVEIRA, H. S. de. Trabalho. Brasil em Números. Rio de Janeiro, v. 26, p. 171-187, 2018. Disponível em: <https://biblioteca.ibge.gov.br/index.php/bibliotecacatalogo?view=detalhes\&id=72>. Acesso em: maio 2019.

SÍNTESE de indicadores sociais: uma análise das condições de vida da população brasileira: 2018. Rio de Janeiro: IBGE, 2018. 143 p. Disponível em: <https://www.ibge. gov.br/estatisticas/sociais/trabalho/9221-sintese-de-indicadores-sociais.html?=\&t=oque-e>. Acesso em: maio 2018.

\section{Tabelas adicionais}

Disponíveis no portal do IBGE na Internet, no endereço: <https://www.ibge.gov.br/ estatisticas/sociais/trabalho/9221-sintese-de-indicadores-sociais.html?=\&t=o-que-e>. Acesso em: maio 2019.

Tabela 1.1 - Indicadores estruturais do mercado de trabalho das pessoas de 14 anos ou mais de idade, com indicação do coeficiente de variação, segundo grupos de idade, sexo e cor ou raça - 2012-2017

Tabela 1.2 - Indicadores estruturais do mercado de trabalho das pessoas de 14 anos ou mais de idade, com indicação do coeficiente de variação, segundo nível de instrução, sexo e cor ou raça - 2012 - 2017

Tabela 1.3 - Taxa de desocupação das pessoas de 14 anos ou mais de idade, por sexo, grupos de idade e cor ou raça, com indicação do coeficiente de variação, segundo Grandes Regiões, Unidades da Federação e Municípios das Capitais

Tabela 1.5 - Pessoas de 14 anos ou mais de idade ocupadas na semana de referência, total e proporção em trabalhos formais, por sexo e cor ou raça, com indicação do coeficiente de variação, segundo Grandes Regiões, Unidades da Federação e Municípios das Capitais Tabela 1.24 - Pessoas na força de trabalho potencial que não procuraram trabalho no mês de referência, por sexo, cor ou raça e grupos de idade, com indicação do coeficiente de variação, segundo o principal motivo de não ter tomado providência para conseguir trabalho- 2016 e 2017

Tabela 1.26 - Pessoas de 14 anos ou mais de idade ocupadas na semana de referência como trabalhadores por conta própria e empregadores, e distribuição percentual por contribuição para a previdência social, com indicação do coeficiente de variação, segundo características selecionadas - 2017 
Tabela 7.1 - Distribuição das pessoas de 14 anos ou mais de idade, ocupadas na semana de referência, por Grandes Regiões, segundo algumas características - 2017

Table 7.1 - Distribution of persons 14 years old and over, employed in the reference week, by Major Regions and some characteristics - 2017

(continua/to be continued)

Distribuição das pessoas de 14 anos ou mais de idade, ocupadas na semana de referência/

Distribution of persons 14 years old and over, employed in

Características/

the reference week (\%)

Characteristics

\begin{tabular}{|c|c|c|c|c|}
\hline \multirow[b]{2}{*}{$\begin{array}{l}\text { Brasil/ } \\
\text { Brazil }\end{array}$} & \multicolumn{4}{|c|}{ Grandes Regiões/ Major Regions } \\
\hline & $\begin{array}{l}\text { Norte / } \\
\text { North }\end{array}$ & $\begin{array}{l}\text { Nordeste/ Sudeste/ } \\
\text { Northeast Southeast }\end{array}$ & $\begin{array}{l}\text { Sul/ } \\
\text { South }\end{array}$ & $\begin{array}{c}\text { Centro- } \\
\text { Oeste/ } \\
\text { Central- } \\
\text { West }\end{array}$ \\
\hline
\end{tabular}

Grupos de idade/

Age groups

14 a 17 anos/
14 to 17 years old
18 ou 19 anos/
18 to 19 years old
20 a 24 anos/
20 a 24 years old
25 a 29 anos/
25 a 29 years old
30 a 39 anos/
30 to 39 years old
40 a 49 anos/
40 to 49 years old
50 a 59 anos/
50 to 59 years old
60 anos ou mais/
60 years old and over

Grupos de anos de estudo/

Years of schooling

Sem instrução e menos de 1 ano/

No schooling and less than 1 year

1 a 4 anos/

1 to 4 years

5 a 8 anos/

5 to 8 years

9 a 11 anos/

9 to 11 years

12 anos ou mais/

12 years and over

$\begin{array}{llllll}100,0 & 100,0 & 100,0 & 100,0 & 100,0 & 100,0\end{array}$

$\begin{array}{rrrrrr}1,8 & 3,0 & 2,0 & 1,3 & 2,1 & 2,0 \\ 2,9 & 3,1 & 2,8 & 2,7 & 3,4 & 2,9 \\ 10,3 & 10,8 & 10,5 & 9,8 & 10,8 & 10,7 \\ 11,7 & 12,4 & 12,1 & 11,3 & 11,8 & 11,5 \\ 26,8 & 27,9 & 28,0 & 26,5 & 25,0 & 27,8 \\ 22,8 & 22,4 & 23,0 & 22,9 & 22,3 & 22,8 \\ 16,4 & 14,3 & 15,2 & 17,3 & 17,3 & 15,3 \\ 7,4 & 6,3 & 6,4 & 8,1 & 7,5 & 7,0\end{array}$

$100,0 \quad 100,0 \quad 100,0 \quad 100,0 \quad 100,0 \quad 100,0$

$\begin{array}{llllll}2,6 & 4,1 & 5,8 & 1,3 & 1,1 & 2,5\end{array}$

$\begin{array}{llllll}4,1 & 6,3 & 7,0 & 2,7 & 2,7 & 3,8\end{array}$

$\begin{array}{llllll}17,4 & 20,1 & 19,2 & 15,6 & 18,8 & 17,3\end{array}$

$\begin{array}{llllll}15,6 & 16,4 & 14,9 & 14,8 & 17,9 & 16,0\end{array}$

$\begin{array}{llllll}60,3 & 53,1 & 53,1 & 65,6 & 59,6 & 60,3\end{array}$ 


\section{Tabela 7.1 - Distribuição das pessoas de 14 anos ou mais de idade, ocupadas na semana de referência, por Grandes Regiões, segundo algumas características - 2017}

Table 7.1 - Distribution of persons 14 years old and over, employed in the reference week, by Major Regions and some characteristics - 2017

(conclusão/concluded)

\begin{tabular}{|c|c|c|c|c|c|c|}
\hline \multirow{3}{*}{$\begin{array}{l}\text { Características/ } \\
\text { Characteristics }\end{array}$} & \multicolumn{6}{|c|}{$\begin{array}{l}\text { Distribuição das pessoas de } 14 \text { anos ou mais de idade, } \\
\text { ocupadas na semana de referência/ } \\
\text { Distribution of persons } 14 \text { years old and over, employed } \\
\text { in the reference week (\%) }\end{array}$} \\
\hline & \multicolumn{6}{|c|}{ Grandes Regiões/ Major Regions } \\
\hline & $\begin{array}{l}\text { Brasil/ } \\
\text { Brazil }\end{array}$ & $\begin{array}{l}\text { Norte / } \\
\text { North }\end{array}$ & $\begin{array}{l}\text { Nordeste/ } \\
\text { Northeast }\end{array}$ & $\begin{array}{l}\text { Sudeste/ } \\
\text { Southeast }\end{array}$ & $\begin{array}{l}\text { Sul/ } \\
\text { South }\end{array}$ & $\begin{array}{l}\text { Centro- } \\
\text { Oeste/ } \\
\text { Central- } \\
\text { West }\end{array}$ \\
\hline $\begin{array}{l}\text { Posição na ocupação no trabalho principal/ } \\
\text { Status in employment in the main job }\end{array}$ & 100,0 & 100,0 & 100,0 & 100,0 & 100,0 & 100,0 \\
\hline Empregado/Employee & 67,7 & 58,1 & 63,6 & 71,1 & 67,5 & 70,2 \\
\hline $\begin{array}{l}\text { Com carteira de trabalho assinada/ } \\
\text { With a formal contract }\end{array}$ & 39,8 & 23,6 & 27,4 & 46,9 & 45,6 & 40,1 \\
\hline $\begin{array}{l}\text { Militares e funcionários públicos } \\
\text { estatutários/ } \\
\text { Military and statutory public officers }\end{array}$ & 8,5 & 10,6 & 9,2 & 7,5 & 8,1 & 10,3 \\
\hline $\begin{array}{l}\text { Sem carteira de trabalho assinada/ } \\
\text { Without a format contract }\end{array}$ & 19,5 & 24,0 & 27,0 & 16,7 & 13,8 & 19,7 \\
\hline Empregado (1)/ Employee (1) & 60,9 & 52,3 & 56,6 & 63,9 & 62,0 & 62,6 \\
\hline $\begin{array}{l}\text { Com carteira de trabalho assinada/ } \\
\text { With a formal contract }\end{array}$ & 37,7 & 22,4 & 26,0 & 44,4 & 43,8 & 37,5 \\
\hline $\begin{array}{l}\text { Militares e funcionários públicos } \\
\text { estatutários/ } \\
\text { Military and statutory public officers }\end{array}$ & 8,5 & 10,6 & 9,2 & 7,5 & 8,1 & 10,3 \\
\hline $\begin{array}{l}\text { Sem carteira de trabalho assinada/ } \\
\text { Without a format contract }\end{array}$ & 14,7 & 19,4 & 21,4 & 12,1 & 10,1 & 14,8 \\
\hline Trabalhador doméstico/Domestic worker & 6,8 & 5,8 & 7,0 & 7,2 & 5,5 & 7,6 \\
\hline $\begin{array}{l}\text { Com carteira de trabalho assinada/ } \\
\text { With a formal contract }\end{array}$ & 2,1 & 1,2 & 1,4 & 2,5 & 1,8 & 2,7 \\
\hline $\begin{array}{l}\text { Sem carteira de trabalho assinada/ } \\
\text { Without a format contract }\end{array}$ & 4,7 & 4,6 & 5,6 & 4,7 & 3,7 & 4,9 \\
\hline Conta própria/Own account & 25,3 & 31,7 & 29,3 & 22,9 & 23,8 & 23,2 \\
\hline Empregador/Employer & 4,6 & 3,5 & 3,7 & 4,7 & 5,9 & 5,3 \\
\hline $\begin{array}{l}\text { Trabalhador familiar auxiliar/ } \\
\text { Contributing family worker }\end{array}$ & 2,5 & 6,8 & 3,4 & 1,3 & 2,8 & 1,3 \\
\hline
\end{tabular}

Fonte/Source: IBGE, Diretoria de Pesquisas, Coordenação de Trabalho e Rendimento, Pesquisa Nacional por Amostra de Domicílios Contínua 2017.

Nota: Informações das entrevistas realizadas nos domicílios visitados pela primeira vez em cada um dos quatro trimestres do ano./Note: Information of the interviews carried out in the housing units visited for the first time in each one of the four quarters of the year.

(1) Exclusive trabalhador doméstico./ Except domestic worker. 
Tabela 7.2 - Distribuição das pessoas de 14 anos ou mais de idade, ocupadas na semana de referência, por Grandes Regiões, segundo

os grupamentos de atividade do trabalho principal - 2017

Table 7.2 - Distribution of persons 14 years old and over, employed in the reference week, by Major Regions and groups of section of activity in the main job - 2017

(continua/to be continued)

Distribuição das pessoas de 14 anos ou mais de idade, ocupadas na semana de referência/

Distribution of persons 14 years old and over,

Grupamentos de atividade do trabalho principal/

Groups of section of activity in the main job employed in the reference week (\%)

\begin{tabular}{|c|c|c|c|c|c|}
\hline \multirow[b]{2}{*}{$\begin{array}{l}\text { Brasil/ } \\
\text { Brazil }\end{array}$} & \multicolumn{5}{|c|}{ Grandes Regiões/ Major Regions } \\
\hline & $\begin{array}{l}\text { Norte/ } \\
\text { North }\end{array}$ & $\begin{array}{l}\text { Nordeste/ } \\
\text { Northeast }\end{array}$ & $\begin{array}{l}\text { Sudeste/ } \\
\text { Southeast }\end{array}$ & $\begin{array}{l}\text { Sul/ } \\
\text { South }\end{array}$ & $\begin{array}{c}\text { Centro- } \\
\text { Oeste/ } \\
\text { Central- } \\
\text { West }\end{array}$ \\
\hline 100,0 & 100,0 & 100,0 & 100,0 & 100,0 & 100,0 \\
\hline
\end{tabular}

Total (1)

Agricultura, pecuária, produção florestal, pesca e aquicultura/

Agriculture, forestry and fishing

Indústria geral/

$13,0 \quad 10,3$

$9,5 \quad 16,9$

13,7

$5,5 \quad 10,7$

9,9

General industry (2)

Construção/

$7,7 \quad 6,8$

8,2

$7,6 \quad 7,6$

7,8

Construction

Comércio; reparação de veículos automotores e motocicletas/ $19,2 \quad 20,2$

21,0

$18,3 \quad 18,5$

19,9

Wholesale and retail trade; repair of

motor vehicles and motorcycles

Transporte, armazenagem e correios/

$5,0 \quad 4,7$

4,5

$5,4 \quad 5,0$

4,2

Transport and storage

Alojamento e alimentação/

$5,7 \quad 6,4$

5,9

6,0

4,6

5,5

Accommodation and food service

activities

Informação, comunicação e atividades financeiras, imobiliárias, profissionais e administrativas/

Information, comumunication and financial, real estate, professional and administrative activities (3) 


\section{Tabela 7.2 - Distribuição das pessoas de 14 anos ou mais de idade, ocupadas na semana de referência, por Grandes Regiões, segundo os grupamentos de atividade do trabalho principal - 2017}

Table 7.2 - Distribution of persons 14 years old and over, employed in the reference week, by Major Regions and groups of section of activity in the main job - 2017

(conclusão/concluded)

Distribuição das pessoas de 14 anos ou mais de idade, ocupadas na semana de referência/

Grupamentos de atividade do trabalho principal/ Groups of section of activity in the main job
Distribution of persons 14 years old and over, employed in the reference week (\%)

Grandes Regiões/ Major Regions

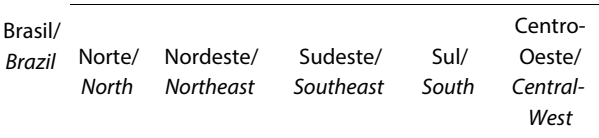

Administração pública, educação, saúde humana e serviços sociais/

Public administration, education,

human health and social services (4)

\begin{tabular}{lllllll} 
Outros serviços/Other services (5) & 5,0 & 3,9 & 4,5 & 5,6 & 4,3 & 5,2 \\
Serviços domésticos/Domestic services & 6,8 & 5,8 & 7,1 & 7,2 & 5,6 & 7,6 \\
\hline
\end{tabular}

Fonte/Source: IBGE, Diretoria de Pesquisas, Coordenação de Trabalho e Rendimento, Pesquisa Nacional por Amostra de Domicílios Contínua 2017.

Nota: Informações das entrevistas realizadas nos domicílios visitados pela primeira vez em cada um dos quatro trimestres do ano./Note: Information of the interviews carried out in the housing units visited for the first time in each one of the four quarters of the year.

(1) Inclusive as pessoas em atividades maldefinidas/Including persons with activity not adequately defined.(2) Grupamento composto das seguintes seções de atividade: indústrias de transformação; indústrias extrativas; eletricidade e gás; água, esgoto, atividades de gestão de resíduos e descontaminação/Group composed of the following sections of activity: manufacturing; mining and quarrying; electricity, gas, steam and air conditioning supply; water supply; sewerage, waste management and remediation activities. (3) Grupamento composto das seguintes seções de atividade: informação e comunicação; atividades financeiras, de seguros e serviços relacionados; atividades imobiliárias; atividades profissionais, científicas e técnicas; atividades administrativas e serviços complementares/Group composed of the following sections of activity: information and communication; financial and insurance activities; real estate activities; professional, scientific and technical activities; administrative and support service activities.(4) Grupamento composto das seguintes seções de atividade: administração pública, defesa e seguridade social; educação; saúde humana e serviços sociais/Group composed of the following sections of activity: public administration and defence, compulsory social security; education; human health and social work activities. (5) Grupamento composto das seguintes seções de atividade: artes, cultura, esporte e recreação; outras atividades de serviços; organismos internacionais e outras instituições extraterritoriais/ Group composed of the following sections of activity: arts, entertainment and recreation; other service activities; activities of extraterritorial organizations and bodies. 


\section{Gráfico 7.1 - Taxa de participação na força de trabalho, na semana de referência, das pessoas de 14 anos ou mais de idade, por sexo, segundo os grupos de idade - Brasil - 2017}

Graph 7.1 - Labor force participation rate in the reference week of persons 14 years old and over, by sex and age groups - Brazil - 2017

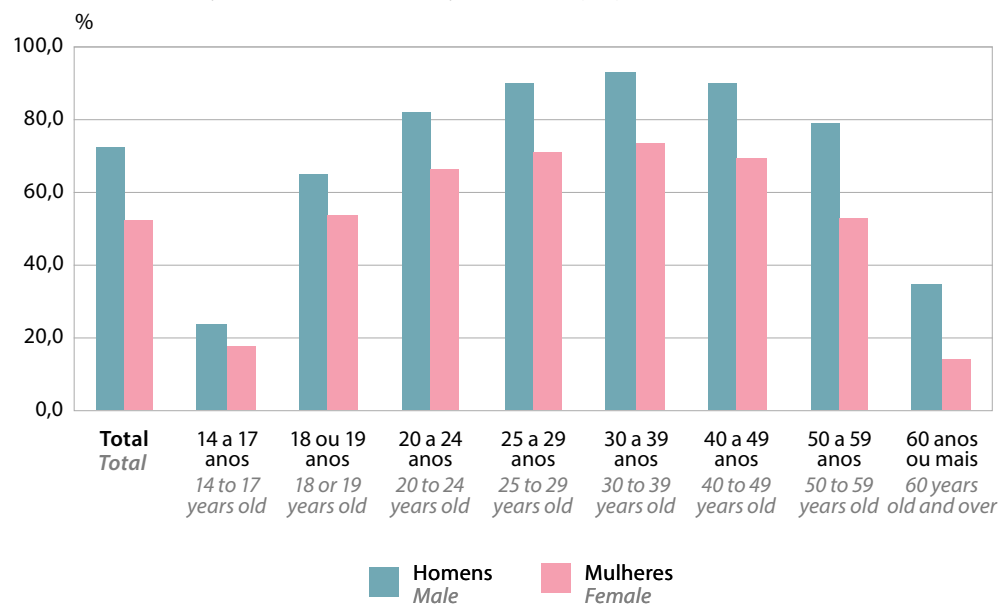

Fonte/Source: IBGE, Diretoria de Pesquisas, Coordenação de Trabalho e Rendimento, Pesquisa Nacional por Amostra de Domicílios Contínua 2017.

Nota: Informações das entrevistas realizadas nos domicílios visitados pela primeira vez em cada um dos quatro trimestres do ano./Note: Information of the interviews carried out in the housing units visited for the first time in each one of the four quarters of the year. 
Gráfico 7.2 - Distribuição das pessoas de 14 anos ou mais de idade, ocupadas na semana de referência, por contribuição para instituto de previdência em qualquer trabalho, segundo as Grandes Regiões - 2017 Graph 7.2 - Distribution of persons 14 years old and over, employed in the reference week, by contribution to social security in any job and Major Regions - 2017

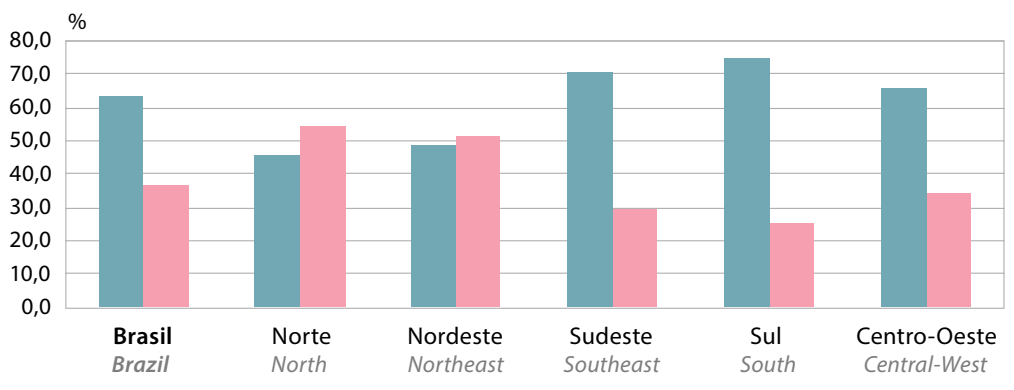
Contribuinte
Contributor
Não contribuinte
Non contributor

Fonte/Source: IBGE, Diretoria de Pesquisas, Pesquisa Nacional por Amostra de Domicílios Contínua 2017. Nota: Informações das entrevistas realizadas nos domicílios visitados pela primeira vez em cada um dos quatro trimestres do ano./Note: Information of the interviews carried out in the housing units visited for the first time in each one of the four quarters of the year.

\section{Gráfico 7.3 - Percentual de pessoas ocupadas no grupamento da indústria geral, na população de 14 anos ou mais de idade, ocupada na semana de referência, por Grandes Regiões - 2017}

Graph 7.3 - Percentage of employed persons in the group general industry in the population 14 years old and over, employed in the reference week,

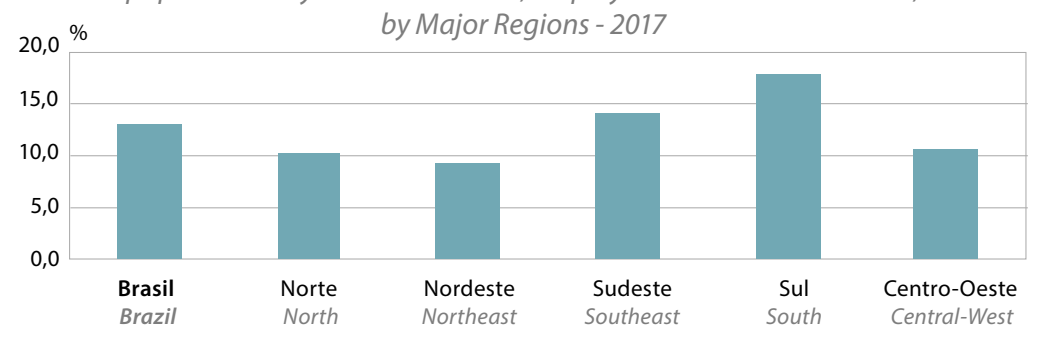

Fonte/Source: IBGE, Diretoria de Pesquisas, Coordenação de Trabalho e Rendimento, Pesquisa Nacional por Amostra de Domicílios Contínua 2017.

Nota: Informações das entrevistas realizadas nos domicílios visitados pela primeira vez em cada um dos quatro trimestres do ano./Note: Information of the interviews carried out in the housing units visited for the first time in each one of the four quarters of the year. 



\section{Participação Política Political Participation}

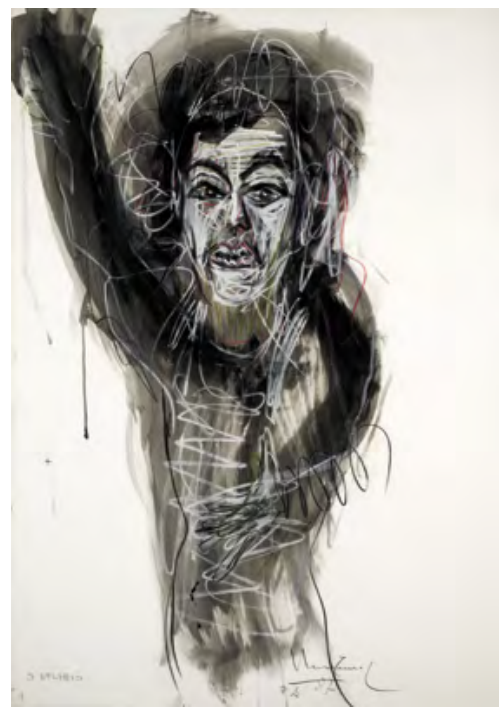

O delírio, 1987

Delirium

Iberê Camargo 


\title{
Political Participation
}

\author{
Ednaldo Ribeiro ${ }^{1}$ \\ Julian Borba ${ }^{2}$
}

An analysis of the political culture and of the participation patterns in effect since the enactment of the Federal Constitution of Brazil of 1988 has pointed out that Brazilians have become neither more democratic, nor more participative. At best, we would have a relatively stable pattern, with recurrent episodes of reduction in different indicators, by means of which voters assess the political institutions, their adherence to democratic rules and involvement in electoral and nonelectoral forms of participation (RIBEIRO; BORBA; CASALECHI, 2018). Likewise, assessments of the performance of the party and electoral systems in Brazil pointed to a double pattern. On the one hand, a stable dispute for the most important position in Brazil since 1994 the Presidency of the Republic, with coalitions around the Workers' Party (PT) and the Brazilian Social Democracy Party (PSDB) - winning six elections in a row. Such national polarization was reflected in the elections for governor, by means of blocks led by both parties. On the other hand, though still in the field of the party system, we had had a scenario of increasing fragmentation in the legislative assembly since 2002. That fragmentation already pointed to an increase in the instability of the system (CARREIRÃO, 2014).

$\overline{1 \mathrm{PhD}}$ in Sociology from the Federal University of Paraná - UFPR and Associate Professor of the State University of Maringá - UEM and of the Program of Political Science of the UFPR.

$2 \mathrm{PhD}$ in Political Science from the Federal University of Rio Grande do Sul - UFRGS and Associate Professor of the Federal University of Santa Catarina - UFSC. 


\title{
Participação Política
}

\author{
Ednaldo Ribeiro ${ }^{1}$ \\ Julian Borba ${ }^{2}$
}

Uma análise da cultura política e dos padrões de participação desde a promulgação da Constituição Federal do Brasil de 1988 indicou que durante este período, os brasileiros não se tornaram nem mais democráticos, nem mais participativos. $\mathrm{Na}$ melhor das hipóteses teríamos um padrão relativamente estável, com recorrentes episódios de redução, em diferentes indicadores da avaliação que os eleitores fazem das instituições políticas, da sua adesão às normas democráticas e do seu envolvimento em formas eleitorais e não eleitorais de participação (RIBEIRO; BORBA; CASALECHI, 2018). Da mesma forma, avaliações sobre o funcionamento do sistema partidário e eleitoral do País, indicavam para um duplo padrão. Por um lado, uma estabilidade na disputa eleitoral pelo cargo mais importante no País (desde 1994) a presidência da República, com coligações em torno do Partido dos Trabalhadores (PT) e o Partido da Social Democracia Brasileira (PSDB) sagrando-se vitoriosas em seis pleitos consecutivos. Tal polarização nacional se refletia nas eleições para governador, através de blocos liderados por ambos partidos. Por outro lado, mas ainda no campo do sistema partidário, tínhamos um cenário de fragmentação partidária crescente no legislativo desde 2002. Essa fragmentação, já indicava um aumento da instabilidade do sistema (CARREIRÃO, 2014).

1 Doutor em Sociologia pela Universidade Federal do Paraná (UFPR) e Professor Associado da Universidade Estadual de Maringá (UEM) e do Programa de Ciência Política da UFPR.

2 Doutor em Ciência Política pela Universidade Federal do Rio Grande do Sul (UFRGS) e Professor Associado da Universidade Federal de Santa Catarina (UFSC). 
Seemingly, the sum of the political and economic crises that Brazil has faced since 2013 has caused deep changes in this scenario and leveraged its elements of instability. The electoral results of 2018 seemed to be the biggest evidence of that.

We believe that such results are only understandable due to the persistent dissatisfaction of the population in relation to the practical results of the institutions and of the performance of its operators. That democratic deficit, associated to a context of economic and political crisis, has produced high rates of political distrust, which led, in turn, to radical changes in the vote destination: the increase of electoral abstention and of the percentage of blank and void votes; the increase of the party fragmentation in the legislative assembly; and the electoral decline of the traditional parties and emergence of new political forces in Brazil.

The data from the Brazilian Institute of Geography and Statistics IBGE on the 2018 elections help us understand this scenario. In global terms, the critical argument in relation to the traditional authorities has been followed by the reduction in the participation of citizens in the voluntary electoral processes and by the increase in the blank and void votes in the mandatory ones (BLAIS; RUBENSON, 2012).

In the Brazilian case, that happens in a context of significant improvement in the electoral infrastructure and continuous increase of the electorate. Comparing the data from 2014 and 2018, we notice an increase of 542,496 voters, adding up to $146,805,548$. The electorate, which was distributed among 473,797 sections in 2016, had 479,516 sections in 2018, which represents an increase by more than 5,000 units. The biggest gains took place in the North and Northeast Regions, where 712 and 1,278 new sections were created, respectively (Table 8.1).

Despite the structural improvement, we notice that electoral abstention has hit its highest percentage since 1998, 20.3\%. Concerning blank and void votes, albeit part of the invalidation can be caused by voter errors, it is reasonable to suppose that part of it represents dissatisfaction with the available alternatives. In Brazil, evidences of dissatisfaction can be noticed when observing in Table 8.2 the average percentages of 3.9 and 11.1 points in the elections for state governors, highlighted by the state of Pernambuco, which registered $6.84 \%$ of blank votes and $22.9 \%$ of void votes. Those data represent a significant rise in relation to the state elections in 2014, which recorded a total $6.22 \%$ of blank and void votes (CASALECCHI, 2018). Table 8.4 presents the data for the presidential election and points out a national average of $2.0 \%$ and $5.6 \%$ for blank and void 
Ao que tudo indica, o somatório das crises política e econômica que o País atravessou desde 2013 provocaram profundas alterações neste cenário e potencializaram os seus elementos de instabilidade. Os resultados eleitorais de 2018 parecem ter sido a maior evidência disso.

Acreditamos que tais resultados somente são compreensíveis diante do persistente descontentamento da população em relação aos resultados práticos das instituições e do desempenho dos seus operadores. Esse déficit democrático, associado a um contexto de crise econômica e política, gerou altas taxas de desconfiança política, se refletindo, por sua vez, em mudanças radicais no destino do voto: o aumento da abstenção eleitoral, e no percentual de votos brancos e nulos; a ampliação da fragmentação partidária no legislativo; e o declínio eleitoral dos partidos tradicionais e o surgimento de novas forças políticas no País.

Os dados do Instituto Brasileiro de Geografia e Estatística (IBGE) sobre as eleições de 2018 colaboram para a compreensão desse cenário. Em termos globais o discurso crítico em relação às autoridades tradicionais tem sido acompanhado pela redução da participação dos cidadãos em processos eleitorais facultativos e pelo aumento das anulações e votos brancos em contextos de obrigação (BLAIS; RUBENSON, 2012).

No caso brasileiro, isso ocorre em um contexto de significativa melhora da infraestrutura eleitoral e ampliação contínua do eleitorado. Comparando os dados de 2014 e 2018, observamos um acréscimo de 542496 eleitores, chegando ao total 146805548 . Esse eleitorado, que em 2016 se encontrava distribuído entre 473797 seções, no pleito de 2018 tinha à sua disposição 479516 seções, o que representa um acréscimo de mais de 5000 unidades. Os maiores ganhos ocorreram nas Regiões Norte e Nordeste, com a criação de 712 e 1278 novas seções, respectivamente (Tabela 8.1).

A despeito dessa melhoria estrutural, constatamos que a abstenção eleitoral atingiu agora o seu maior percentual desde 1998, alcançando $20,3 \%$. No que diz respeito aos votos brancos e nulos, ainda que parte das anulações possa ser resultado de erro do eleitor, é plausível supor que parte represente a manifestação de descontentamento com as alternativas disponíveis. Em nosso País podemos observar indícios dessa insatisfação ao constatarmos na Tabelas 8.2 percentuais médios de 3,9 e 11,1 pontos nas eleições para os executivos estaduais, com destaque para o Estado de Pernambuco que registrou 6,84\% de brancos e 22,9\% de nulos. Esses dados representam uma considerável elevação em relação às eleições estaduais de 2014, que registraram $6,22 \%$ de brancos e nulos somados (CASALECCHI, 2018). A Tabela 8.4 apresenta os dados para a eleição presidencial e indica média nacional 2,0\% e 
votes, respectively, highlighted by São Paulo, with $3.06 \%$ of blank votes and $8.35 \%$ of void votes.

The scenario that emerged from the ballots in 2018 redesigned the national political game. Those who attended the elections distributed their votes along 35 parties, listed in Chart 8.1, increasing the scenario of party fragmentation, which had been growing since the elections in 2002. Between 1989 and 2002, an average of 18 parties were represented in the House of Representatives, a figure that changes to 20 in 2006, to 22 in 2010, to 28 in 2014, and hit 30 in 2018. In comparative terms, Nicolau (2017) presents data compiled by Michael Gallagher relative to 1,167 elections for lower houses between 1919 and 2015 in 137 countries, showing that out of the four elections that produced the biggest fragmentation in the world in these houses, three were the elections of 2006, 2010 and 2014 in Brazil.

Table 8.3 summarizes those significant changes in the composition of the executive and legislative powers, both in the states and in the federal government. Winning three disputes for the executive state power, the Social Liberal Party - PSL caught up with the PSDB and the Brazilian Democratic Movement - MDB. Comparing the data from 2010 and 2014, quite significant changes were noticed in the party scenario of state governments. In 2010, six parties had elected governors, a figure that turned into nine, in 2014, and into 13, in 2018. In terms of party power, the PSDB was the party that elected most governors in 2010, eight, followed by the Brazilian Socialist Party, with six. They were followed by the PT and MDB with five, and, lastly, by the Democrats - DEM, with two and the Party of National Mobilization PMN, with one. In the elections of 2014, the MDB was the party that elected most governors, expanding to seven the number of elected governors, the PSDB decreased to five and the PT remained stable, also with five elected governors. Elected governors from the PSB declined to three, the Democratic Labor Party - PDT and the Social Democratic Party - PSD elected two, and the Communist Party of Brazil - PCdoB, the Progressive Party - PP and the Republican Party of Social Order - PROS, one governor. In 2018, the PT elected the biggest number of governors, four, followed by the MDB, PSL and PSB, with three each. They were followed by the PSD, the Social Christian Party PSC and DEM, with two. Finally, PDT, PP, PCdoB, the Humanist Party of Solidarity - PHS and Novo elected one governor each.

A general analysis of the results shows that the fragmentation gradually increases from 2010 to 2018, thus decreasing the electoral power of the parties. If, in 2010, the major party controlled eight states, it counted on half of that in 2018. Moreover, the election of 
$5,6 \%$, respectivamente para brancos e nulos, tendo como destaques São Paulo, com $3,06 \%$ de votos brancos e $8,35 \%$ de anulações.

O cenário que emergiu das urnas em 2018 redesenhou o jogo político nacional. Aqueles que compareceram distribuíram seus votos por 35 partidos, listados no Quadro 8.1, ampliando o cenário de fragmentação partidária, que já vinha aumentando desde as eleições de 2002. Entre 1989 e 2002 havia uma média de 18 partidos representados na Câmara dos Deputados, número que passa para 20 em 2006, 22 em 2010, 28 em 2014, chegando a 30 em 2018. Em termos comparativos, Nicolau (2017) apresenta dados compilados por Michael Gallagher relativos a 1167 eleições para câmaras baixas entre 1919 e 2015 em 137 países, mostrando que entre as quatro eleições que produziram a mais alta fragmentação do mundo nestas câmaras, três delas foram as eleições de 2006, 2010 e 2014 no Brasil.

A Tabela 8.3 sintetiza essas mudanças significativas na composição dos poderes Executivo e Legislativo tanto nos estados quanto no Governo Federal. Nas disputas pelos executivos estaduais, o Partido Social Liberal (PSL) saindo vitorioso em três estados, alcançou o PSDB e o Movimento Democrático Brasileiro (MDB). Comparando com dados de 2010 e 2014, verificam-se alterações bastante significativas também no quadro partidário nos governos estaduais. Em 2010, seis partidos haviam eleito governadores, número que passa para nove em 2014, e 13 em 2018. Em termos de força partidária, em 2010 o PSDB foi o partido que elegeu mais governadores, oito, seguido pelo Partido Socialista Brasileiro (PSB), com seis. Logo em seguida apareciam PT e PMDB com cinco, e, por fim, Democratas (DEM), com dois e Partido da Mobilização Nacional (PMN), com um. Já nas eleições de 2014 o PMDB foi o partido que mais elegeu governadores, ampliando para sete o número de eleitos, o PSDB diminuiu para cinco e o PT ficou estável, também com cinco governadores eleitos. O PSB declinou para três, o Partido Democrático Trabalhista (PDT) e o Partido Social Democrático (PSD) elegeram dois, e os Partido Comunista do Brasil (PCdoB), Partido Progressista (PP) e Partido Republicano da ordem Social (PROS), um governador. Em 2018 foi a vez do PT eleger o maior número de governadores, quatro, seguido por PMDB, PSL e PSB com três. Em seguida aparecem Partido Social Cristão (PSD), PSC e DEM com dois. Por fim, com um govenador cada, temos PDT, PP, PCdoB, Partido Humanista da Solidariedade (PHS) e Novo.

Numa análise geral dos resultados, o que impressiona é que a fragmentação aumenta gradativamente de 2010 a 2018, diminuindo com isso a força eleitoral relativa dos partidos. Se em 2010 a principal legenda controlava oito estados, em 2018 
2018 seemed to break the logic in which the central parties in the presidential dispute, hitherto the PSDB and PT, would coordinate the state political game, having the MDB as a third independent force. This is visible both in terms of the electoral decline of the PSDB and MDB and the emergence of relevant new party powers in the dispute, like the PSL, which elected three governors and also the president of the Republic. Other relevant data that evidence the size of the party fragmentation that resulted from the last elections are those related to the parties of vice-governors elected in 2018. According to Table 8.3, vice-governors were elected by 20 different parties.

In spite of the significant power of the traditional parties, like the MDB (92 elected), PT (83 elected) and PSDB (73 elected), less relevant parties conquered a big number of chairs in the state assemblies, in which the PSL (76 elected) stood out. An example of the dimension of the changes in the composition of the state benches can be seen when such data are compared with those from 2014. In that election, the same parties elected 142 (MDB), 108 (PT) and 97 (PSDB). In that same election, the PSL elected only 17 representatives. Together, the first three parties had more than $40 \%$ of the chairs of the state parliaments in 2010, declining to 33\% in 2014 and reaching 24\% in 2018.

Nevertheless, the changes are more significant at federal level. The PSL managed to elect 52 representatives for the House of Representatives, standing only behind the PT (with less three chairs) and much ahead of the MDB (34 federal representatives elected) and PSDB (with 29 federal representatives). Resuming the comparison with data from previous elections, the PSL had elected only one federal representative in 2014 . On the other hand, the three biggest elected 70 (PT), 66 (MDB) and 54 (PSDB). These three parties together controlled more than $37 \%$ of the federal representatives in 2014 . In 2018 , this figure retreated to $23 \%$.

In the Senate, the election of 2018 renewed two-thirds of the house. In that election, the MDB elected seven senators, Rede Sustentabilidade, five, PP, five, and, with four elected ones, we had the PT, PSDB, DEM and PSD in addition to the PSL (Table 8.3). In the overall picture, 20 parties elected senators in 2018. In order to assess the strength of the changes towards the fragmentation of the system, the number of parties that elected senators hit 15 in the last election in which two-thirds of the house (2010) were replaced. Still comparing with previous elections, while the three biggest parties - PT, MDB and PSDB - had 32\% of the senators in 2010, this figure declines to slightly more than 15\% from 2018 onward. 
passou a contar com metade disso. Ademais, a eleição de 2018 parece ter quebrado aquela lógica de que os partidos centrais na disputa presidencial, até então PSDB e PT, coordenariam o jogo político estadual, com o MDB sendo uma terceira força independente. Isso é visível tanto pelo declínio eleitoral de PSDB e MDB, quanto pelo surgimento de novas forças partidárias relevantes na disputa, como PSL, que além de eleger três governadores, elegeu também o presidente da República. Um outro dado relevante e demonstrativo do tamanho da fragmentação partidária que resultou das últimas eleições é relativo aos partidos dos vice-governadores eleitos em 2018. Conforme a Tabela 8.3, os vice-governadores foram eleitos por 20 diferentes partidos.

Nas assembleias estaduais, apesar de legendas tradicionais continuarem com força expressiva, como MDB (92 eleitos), PT (83 eleitos) e PSDB (73 eleitos), partidos com pouca relevância até então conquistam um grande número de cadeiras, com destaque absoluto para o PSL (76 eleitos). Um exemplo do tamanho das mudanças na composição das bancadas estaduais pode ver verificado quando se comparam tais dados com 2014. Naquela eleição, os mesmos partidos elegeram 142 (PMDB), 108 (PT), 97 (PSDB). Nesse mesmo pleito o PSL elegeu apenas 17 deputados. Juntos, os três primeiros partidos possuíam mais de $40 \%$ das cadeiras dos parlamentos estaduais em 2010, declinando para 33\% em 2014, e chegando a 24\% em 2018.

É no nível federal, todavia, que as alterações são mais significativas. O PSL conseguiu eleger 52 deputados para a Câmara dos Deputados, ficando atrás apenas do PT (com três cadeiras a menos) e muito à frente do MDB (34 deputados federais eleitos) e PSDB (com 29 deputados federais). Retomando a comparação com dados de eleições anteriores, em 2014 o PSL havia eleito apenas um deputado federal. Já os três maiores, elegeram 70 (PT), 66 (PMDB) e 54 (PSDB). Os três partidos controlavam juntos mais de $37 \%$ dos parlamentares federais em 2014. Em 2018 este número declina para $23 \%$.

No Senado, a eleição de 2018 renovou 2/3 da casa. Nesta eleição, o MDB elegeu sete senadores, a Rede Sustentabilidade, cinco, PP, cinco, e, com quatro eleitos, tivemos, além do PSL, o PT, PSDB, DEM e PSD (Tabela 8.3). No quadro geral, 20 partidos elegeram senadores em 2018. Para avaliar a força das mudanças rumo à fragmentação do sistema, na última eleição em que foram substituídos $2 / 3$ da casa (2010), o número de partidos que elegeram senadores chegou a 15. Comparando ainda com eleições anteriores, enquanto os três maiores partidos (PT, PMDB e PSDB) possuiam 32\% do total de senadores em 2010, a partir de 2018 este número declina para pouco mais de $15 \%$. 
The whole set of data discussed points out a picture of significant changes in the national politics, leveraged by negative attitudes and willingness of the electorate in relation to the national political institutions and leaderships. Seemingly, the persistent political distrust has undermined the civic engagement of our electorate and has also worsened the already worrying fragmentation of our party system. The reconfiguration of the political forces at national and state level is undeniable and the future will tell about its consequences on governability and also on the worn relationship between citizenship, political institutions and its operators.

\section{References}

BLAIS, A.; RUBENSON, D. The source of turnout decline: new values or new contexts? Comparative Political Studies, London, v.46, n.1, p. 95-117, 2012. Available from: <https://journals.sagepub.com/loi/cps?year=2013>. Cited: May 2019.

CARREIRÃO, Y. S. O sistema partidário brasileiro: um debate com a literatura recente. Revista Brasileira de Ciência Política, Brasília, v. 14, p. 255-295, 2014. Available from: <http://periodicos.unb.br/index.php/rbcp/issue/archive>. Cited: May 2019.

CASALECCHI, G. A. Participação política. Brazil in Figures, Rio de Janeiro, v. 26, 2018. Available from: <https://biblioteca.ibge.gov.br/index.php/bibliotecacatalogo?view=detalhes\&id=72>. Cited: May 2019.

NICOLAU, J. Os quatro fundamentos da competição política no Brasil (1994-2014). Journal of Democracy em Português, São Paulo, v. 6, n. 1, p. 90-113, 2017. Available from: <http://www.plataformademocratica.org/ publicacoes\#JournalDemocracy>. Cited: May 2019.

RIBEIRO, E.; BORBA, J.; CASALECCHI, G. A constituição cidadã e a cultura política: uma sociedade mais participativa e democrática? In: HOLLANDA, C. B. de; VEIGA, L. F.; AMARAL, O. E. do (Org.). A Constituição de 88 trinta anos depois. Curitiba ; Rio de Janeiro: Ed. UFPR: Konrad Adenauer Stiftung, 2018. (Pesquisa). p. 7-46. 
O conjunto dos dados discutidos indicam um quadro de mudanças consideráveis na política nacional impulsionadas por disposições e atitudes negativas do eleitorado em relação às lideranças e instituições políticas nacionais. A desconfiança política persistente, ao que tudo indica, tem fragilizado o engajamento cívico de nosso eleitorado e também agravado a já preocupante fragmentação de nosso sistema partidário. A reconfiguração das forças políticas no contexto nacional e também nos estados é inegável e o futuro nos dirá as suas consequências sobre a governabilidade e também sobre a desgastada relação entre cidadania, instituições políticas e seus operadores.

\section{Referências}

BLAIS, A.; RUBENSON, D. The source of turnout decline: new values or new contexts? Comparative Political Studies, London, v.46, n.1, p. 95-117, 2012. Disponível em: <https:// journals.sagepub.com/loi/cps?year=2013 >. Acesso em: maio 2019.

CARREIRÃO, Y. S. O sistema partidário brasileiro: um debate com a literatura recente. Revista Brasileira de Ciência Política, Brasília, v. 14, p. 255-295, 2014. Disponível em: <http://periodicos.unb.br/index.php/rbcp/issue/archive>. Acesso em: maio 2019.

CASALECCHI, G. A. Participação política. Brasil em números, Rio de Janeiro, v. 26, 2018. Disponível em: <https://biblioteca.ibge.gov.br/index.php/bibliotecacatalogo?view=detalhes\&id=72>. Acesso em: maio 2019.

NICOLAU, J. Os quatro fundamentos da competição política no Brasil (1994-2014). Journal of Democracy em Português, São Paulo, v. 6, n. 1, p. 90-113, 2017. Disponível em: <http://www.plataformademocratica.org/publicacoes\#JournalDemocracy>. Acesso em: maio 2019.

RIBEIRO, E.; BORBA, J.; CASALECCHI, G. A constituição cidadã e a cultura política: uma sociedade mais participativa e democrática? In: HOLLANDA, C. B. de; VEIGA, L. F.; AMARAL, O. E. do (Org.). A Constituição de 88 trinta anos depois. Curitiba; Rio de Janeiro: Ed. UFPR : Konrad Adenauer Stiftung, 2018. (Pesquisa). p. 7-46. 
Tabela 8.1 - Média de eleitores por seção,

seções e eleitores existentes - 2018

Table 8.1 - Average voters by polling section, polling sections and voters - 2018

\begin{tabular}{|c|c|c|c|}
\hline $\begin{array}{l}\text { Grandes Regiões e } \\
\text { Unidades da Federação/ } \\
\text { Major Regions and } \\
\text { Federation Units }\end{array}$ & $\begin{array}{l}\text { Média de eleitores } \\
\text { por seção/ } \\
\text { Average voters by } \\
\text { polling section }\end{array}$ & $\begin{array}{l}\text { Seções/ } \\
\text { Polling } \\
\text { sections }\end{array}$ & $\begin{array}{l}\text { Eleitores } \\
\text { existentes/ } \\
\text { Voters }\end{array}$ \\
\hline Brasil /Brazil & 306 & 479516 & 146805548 \\
\hline Norte/North & 288 & 39989 & 11535807 \\
\hline Rondônia & 253 & 4654 & 1175733 \\
\hline Acre & 252 & 2174 & 547680 \\
\hline Amazonas & 325 & 7466 & 2428098 \\
\hline Roraima & 258 & 1291 & 333464 \\
\hline Pará & 296 & 18553 & 5499283 \\
\hline Amapá & 301 & 1704 & 512110 \\
\hline Tocantins & 251 & 4147 & 1039439 \\
\hline Nordeste/Northeast & 281 & 139731 & 39222149 \\
\hline Maranhão & 244 & 18604 & 4537237 \\
\hline Piauí & 237 & 9988 & 2370894 \\
\hline Ceará & 264 & 24001 & 6344483 \\
\hline Rio Grande do Norte & 305 & 7782 & 2373619 \\
\hline Paraíba & 274 & 10472 & 2867649 \\
\hline Pernambuco & 314 & 20897 & 6570072 \\
\hline Alagoas & 332 & 6587 & 2187967 \\
\hline Sergipe & 294 & 5364 & 1577058 \\
\hline Bahia & 288 & 36036 & 10393170 \\
\hline Sudeste/Southeast & 332 & 192410 & 63904445 \\
\hline Minas Gerais & 311 & 50534 & 15700966 \\
\hline Espírito Santo & 304 & 9058 & 2754728 \\
\hline Rio de Janeiro & 348 & 35650 & 12408340 \\
\hline São Paulo & 340 & 97168 & 33040411 \\
\hline Sul/South & 302 & 70801 & 21396031 \\
\hline Paraná & 298 & 26792 & 7971087 \\
\hline Santa Catarina & 312 & 16275 & 5070212 \\
\hline Rio Grande do Sul & 301 & 27734 & 8354732 \\
\hline Centro-Oeste/Central-West & 294 & 36585 & 10747116 \\
\hline Mato Grosso do Sul & 274 & 6848 & 1877982 \\
\hline Mato Grosso & 291 & 8020 & 2330281 \\
\hline Goiás & 302 & 14764 & 4454497 \\
\hline Distrito Federal & 300 & 6953 & 2084356 \\
\hline
\end{tabular}

Fonte/Source : Repositório de Dados Eleitorais. Eleitorado. Eleições 2018. In: Tribunal Superior Eleitoral. Eleitor e eleições.Brasília, DF: TSE, 2018. Disponível em/Available from: <http://www.tse.jus.br/eleicoes/ estatisticas/repositorio-de-dados-eleitorais-1/repositorio-de-dados-eleitorais> Acesso em: jan. 2019/Cited: Jan. 2019.

Nota: Dados de dezembro de 2018./ Note: Data of December 2018. 
Tabela 8.2 - Distribuição percentual dos resultados da apuração para governador - 2018

Table 8.2 - Percentage distribution of vote cast for governor - 2018

\begin{tabular}{|c|c|c|c|}
\hline \multirow{2}{*}{$\begin{array}{c}\text { Unidades da Federação } \\
\text { e exterior/Federation Units } \\
\text { and abroad }\end{array}$} & \multicolumn{3}{|c|}{ Distribuição percentual (\%)/ Percentage distribution (\%) } \\
\hline & $\begin{array}{l}\text { Votos válidos/ } \\
\text { Valid votes }\end{array}$ & $\begin{array}{l}\text { Votos brancos/ } \\
\text { Blank votes }\end{array}$ & $\begin{array}{l}\text { Votos nulos/ } \\
\text { Void votes }\end{array}$ \\
\hline Rondônia & 87,19 & 3,23 & 9,58 \\
\hline Acre & 94,06 & 1,63 & 4,31 \\
\hline Amazonas & 91,48 & 1,55 & 6,97 \\
\hline Roraima & 94,16 & 1,37 & 4,47 \\
\hline Pará & 87,72 & 2,63 & 9,64 \\
\hline Amapá & 92,96 & 1,56 & 5,48 \\
\hline Tocantins & 84,79 & 1,73 & 13,48 \\
\hline Maranhão & 87,38 & 2,89 & 9,73 \\
\hline Piauí & 86,95 & 3,17 & 9,89 \\
\hline Ceará & 82,47 & 4,70 & 12,83 \\
\hline Rio Grande do Norte & 86,90 & 3,07 & 10,03 \\
\hline Paraíba & 79,02 & 4,67 & 16,31 \\
\hline Pernambuco & 70,17 & 6,84 & 22,99 \\
\hline Alagoas & 76,50 & 6,10 & 17,39 \\
\hline Sergipe & 80,06 & 3,89 & 16,05 \\
\hline Bahia & 81,97 & 3,82 & 14,21 \\
\hline Minas Gerais & 79,86 & 5,25 & 14,90 \\
\hline Espírito Santo & 86,92 & 5,17 & 7,92 \\
\hline Rio de Janeiro & 81,79 & 4,69 & 13,51 \\
\hline São Paulo & 80,15 & 5,52 & 14,33 \\
\hline Paraná & 85,37 & 5,84 & 8,78 \\
\hline Santa Catarina & 86,63 & 4,87 & 8,50 \\
\hline Rio Grande do Sul & 86,73 & 5,17 & 8,10 \\
\hline Mato Grosso do Sul & 88,36 & 3,67 & 7,97 \\
\hline Mato Grosso & 81,46 & 5,49 & 13,05 \\
\hline Goiás & 83,54 & 5,13 & 11,33 \\
\hline Distrito Federal & 88,92 & 3,70 & 7,38 \\
\hline
\end{tabular}

Fonte/Source: Estatísticas. Repositório de dados eleitorais. In: Tribunal Superior eleitoral. Eleitor e eleições. Brasília, DF: TSE, 2018. Disponível em/Available from: <http://www.tse.jus.br/eleicoes/ estatisticas/repositorio-de-dados-eleitorais-1/repositorio-de-dados-eleitorais $>$.Acesso em: jan. 2019/ Cited: Jan. 2019. 
Tabela 8.3 - Candidatos eleitos por cargo, segundo os partidos políticos - 2018

Table 8.3 - Candidates elected by political party - 2018

(continua/to be continued)

\begin{tabular}{|c|c|c|c|c|}
\hline $\begin{array}{l}\text { Partido político/ } \\
\text { Political party }\end{array}$ & $\begin{array}{c}\text { Deputado } \\
\text { Distrital/ District } \\
\text { Deputy }\end{array}$ & $\begin{array}{c}\text { Deputado } \\
\text { Estadual/ State } \\
\text { Deputy }\end{array}$ & $\begin{array}{c}\text { Deputado } \\
\text { Federal/ Federal } \\
\text { Deputy }\end{array}$ & $\begin{array}{c}\text { Governador/ } \\
\text { Governor }\end{array}$ \\
\hline Total & 24 & 1035 & 513 & 27 \\
\hline AVANTE & 2 & 13 & 7 & - \\
\hline DC & - & 10 & 1 & - \\
\hline DEM & - & 53 & 29 & 2 \\
\hline MDB & 1 & 92 & 34 & 3 \\
\hline NOVO & 1 & 11 & 8 & 1 \\
\hline PATRI & - & 16 & 5 & - \\
\hline PC do B & - & 21 & 9 & 1 \\
\hline PCB & - & - & - & - \\
\hline PCO & - & - & - & - \\
\hline PDT & 2 & 51 & 28 & 1 \\
\hline PHS & 1 & 14 & 6 & 1 \\
\hline PMB & - & 3 & - & - \\
\hline PMN & - & 6 & 3 & - \\
\hline PODE & 1 & 21 & 11 & - \\
\hline PP & 1 & 69 & 38 & 1 \\
\hline PPL & - & 4 & 1 & - \\
\hline PPS & - & 21 & 8 & - \\
\hline PR & 1 & 42 & 33 & - \\
\hline PRB & 2 & 40 & 30 & - \\
\hline PROS & 2 & 18 & 8 & - \\
\hline PRP & 1 & 11 & 4 & - \\
\hline PRTB & - & 16 & - & - \\
\hline PSB & 2 & 63 & 32 & 3 \\
\hline PSC & 1 & 29 & 8 & 2 \\
\hline PSD & 1 & 57 & 34 & 2 \\
\hline PSDB & - & 73 & 29 & 3 \\
\hline PSL & - & 76 & 52 & 3 \\
\hline PSOL & 1 & 17 & 10 & - \\
\hline PSTU & - & - & - & - \\
\hline PT & 2 & 83 & 55 & 4 \\
\hline РTB & - & 31 & 10 & - \\
\hline PTC & 1 & 11 & 2 & - \\
\hline PV & & 27 & 4 & - \\
\hline REDE & 1 & 7 & 1 & - \\
\hline SOLIDARIEDADE & - & 29 & 13 & - \\
\hline
\end{tabular}




\section{Tabela 8.3 - Candidatos eleitos por cargo, segundo os partidos políticos - 2018}

Table 8.3 - Candidates elected by political party - 2018

(conclusão/concluded)

\begin{tabular}{|c|c|c|c|c|c|}
\hline $\begin{array}{l}\text { Partido político/ } \\
\text { Political party }\end{array}$ & $\begin{array}{c}\text { Vice- } \\
\text { governador/ } \\
\text { Vice-governor }\end{array}$ & $\begin{array}{l}\text { Senador/ } \\
\text { Senator }\end{array}$ & $\begin{array}{c}\text { Presidente/ } \\
\text { President }\end{array}$ & & $\begin{array}{l}\text { Vice-presidente/ } \\
\text { Vice-president }\end{array}$ \\
\hline Total & 27 & 54 & & 1 & 1 \\
\hline AVANTE & 1 & - & & - & - \\
\hline DC & - & - & & - & - \\
\hline DEM & 2 & 4 & & - & - \\
\hline MDB & 1 & 7 & & - & - \\
\hline NOVO & 1 & - & & - & - \\
\hline PATRI & - & - & & - & - \\
\hline PC do B & 2 & - & & - & - \\
\hline PCB & - & - & & - & - \\
\hline PCO & - & - & & - & - \\
\hline PDT & 3 & 2 & & - & - \\
\hline PHS & 1 & 2 & & - & - \\
\hline PMB & - & - & & - & - \\
\hline PMN & - & - & & - & - \\
\hline PODE & - & 1 & & - & - \\
\hline PP & 1 & 5 & & - & - \\
\hline PPL & - & - & & - & - \\
\hline PPS & - & 2 & & - & - \\
\hline PR & 1 & 1 & & - & - \\
\hline PRB & 1 & 1 & & - & - \\
\hline PROS & 2 & 1 & & - & - \\
\hline PRP & - & 1 & & - & - \\
\hline PRTB & 1 & - & & - & 1 \\
\hline PSB & 1 & 2 & & - & - \\
\hline PSC & 1 & 1 & & - & - \\
\hline PSD & 1 & 4 & & - & - \\
\hline PSDB & 1 & 4 & & - & - \\
\hline PSL & 2 & 4 & & 1 & - \\
\hline PSOL & - & - & & - & - \\
\hline PSTU & - & - & & - & - \\
\hline PT & 2 & 4 & & - & - \\
\hline PTB & 1 & 2 & & - & - \\
\hline PTC & 1 & - & & - & - \\
\hline PV & - & - & & - & - \\
\hline REDE & - & 5 & & - & - \\
\hline SOLIDARIEDADE & - & 1 & & - & - \\
\hline
\end{tabular}

Fonte/Source: Estatísticas. Repositório de dados eleitorais. Eleições 2018. In: Tribunal Superior Eleitoral. Eleitore eleições. Brasília, DF: TSE, 2018. Disponível em/Available from: <http://www.tse.jus.br/eleicoes/ estatisticas/repositorio-de-dados-eleitorais-1/repositorio-de-dados-eleitorais $>$.Acesso em jan. 2019/ Cited: Jan. 2019.

Nota: Dados de dezembro de 2018./Note: Data of December 2018. 


\section{Gráfico 8.1 - Governadores eleitos, por partido político - 2018 \\ Graph 8.1 - Governors elected, by political party - 2018}

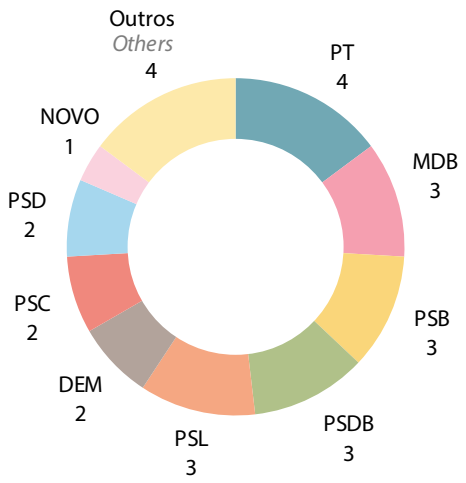

Fonte/Source: Repositório de Dados Eleitorais. Eleitorado. Eleições 2018. In: Tribunal Superior Eleitoral. Eleitor e eleições. Brasília, DF: TSE, 2018. Disponível em/Available from: <http://www.tse.jus.br/eleicoes/ estatisticas/repositorio-de-dados-eleitorais-1/repositorio-de-dados-eleitorais>. Acesso em: jan. 2019/Cited: Jan. 2019.

Nota: Dados de dezembro de 2018./Note: Data of December 2018.

\section{Gráfico 8.2 - Senadores eleitos, por partido político - 2018}

\section{Graph 8.2 - Senators elected, by political party - 2018}

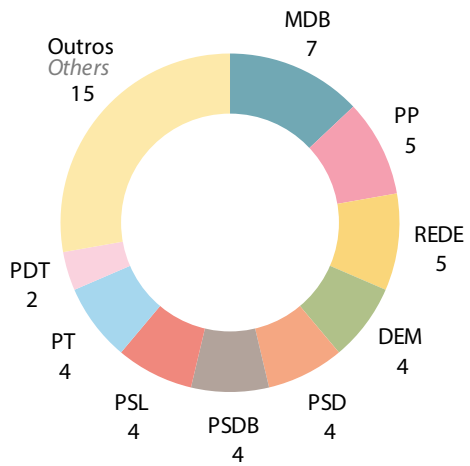

Fonte/Source: Estatísticas de eleitorado. Eleições 2018. In: Tribunal Superior Eleitoral. Eleitor e eleições. Brasília, DF: TSE, 2018.Disponível em/Available from: <http://www.tse.jus.br/eleicoes/estatisticas/ repositorio-de-dados-eleitorais-1/repositorio-de-dados-eleitorais>. Acesso em: jan. 2019/Cited: Jan. 2019. 


\section{Quadro 8.1 - Partidos políticos com votação - 2018}

Figure 8.1 - Political parties with votes - 2018

\begin{tabular}{|c|c|}
\hline Sigla/Initials & Partido/Party \\
\hline AVANTE & Partido Avante \\
\hline DC & Partido Democrata Cristã \\
\hline DEM & Partido Democrata \\
\hline MDB & Partido Movimento Democrático Brasileiro \\
\hline NOVO & Partido Novo \\
\hline PATRI & Partido Patriota \\
\hline PC do B & Partido Comunista do Brasil \\
\hline PCB & Partido Comunista Brasileiro \\
\hline PCO & Partido da Causa Operaria \\
\hline PDT & Partido Democrático Trabalhista \\
\hline PHS & Partido Humanista da Solidariedade \\
\hline PMB & Partido da Mulher Brasileira \\
\hline PMN & Partido da Mobilização Nacional \\
\hline PODE & Partido Podemos \\
\hline PP & Partido Progressista \\
\hline PPL & Partido Patria Livre \\
\hline PPS & Partido Popular Socialista \\
\hline PR & Partido da República \\
\hline PRB & Partido Republicano Brasileiro \\
\hline PROS & Partido Republicano da Ordem Social \\
\hline PRP & Partido Republicano Progressista \\
\hline PRTB & Partido Renovador Trabalhista Brasileiro \\
\hline PSB & Partido Socialista Brasileiro \\
\hline PSC & Partido Social Cristão \\
\hline PSD & Partido Social Democrático \\
\hline PSDB & Partido da Social Democrata Brasileira \\
\hline PSL & Partido Social Liberal \\
\hline PSOL & Partido do Socialismo e Liberdade \\
\hline PSTU & Partido Socialista dos Trabalhadores Unificado \\
\hline PT & Partido dos Trabalhadores \\
\hline PTB & Partido Trabalhista Brasileiro \\
\hline PTC & Partido Trabalhista Cristão \\
\hline PV & Partido Verde \\
\hline REDE & Rede Sustentabilidade \\
\hline SD & Solidariedade \\
\hline
\end{tabular}

Fonte/Source: Partidos políticos registrados no TSE. In: Tribunal Superior Eleitoral. Partidos. Brasília, DF: TSE, 2018.Disponível em/Available from : <http://www.tse.jus.br>. Acesso em: jan. 2019/Cited: Jan. 2019. Nota: Dados de Dezembro de 2018. / Note: Data of December 2018. 



\section{Preços Prices}

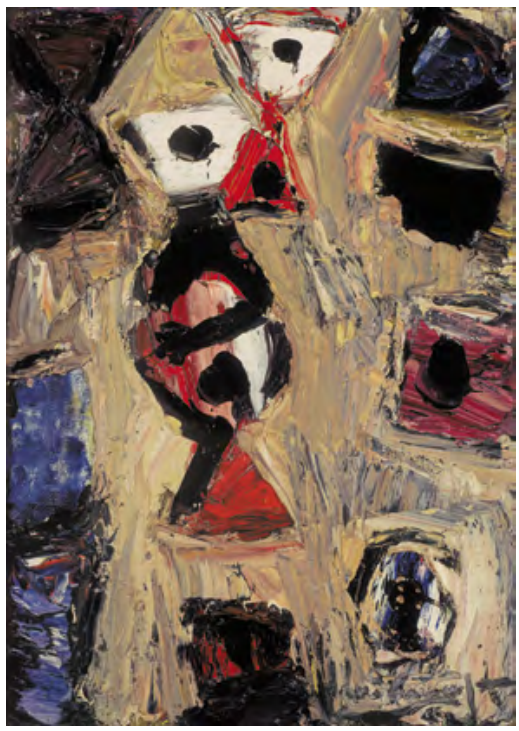

Ascensão I, 1973

Ascension I

Iberê Camargo 


\section{Prices}

\section{Aniela Fagundes Carrara ${ }^{1}$}

Understanding the price movement either in general or in specific segments is of key importance, not only for providing assessment of the real purchase power of a certain period, but mainly for the fact that prices are an item of extreme importance for the macroeconomic analysis as a whole, since they influence and are influenced by variables, such as interest rates, exchange rate and Gross Domestic Product-GDP, among others, which, together, comprise the economic environment of a country. Therefore, this chapter is dedicated to understanding the behavior of prices along the year of 2018 in the Brazilian economy, aiming at contributing to a better interpretation of the economic scenario of that period.

Concerning the price level or the inflation in Brazil per se, it is known that Brazil has faced turbulent periods, like in the 1980s, with the difficulty to maintain the inflation at rates reasonably close to the goal set forth by the policy formulators. It substantiates the prices theme as a relevant issue, which should be constantly discussed and studied.

$1 \mathrm{PhD}$ in Applied Economics from the Luiz de Queiroz College of Agriculture of the University of São Paulo - ESALQ/USP. Professor in the School of Economic Sciences of the Federal University of Mato Grosso - UFMT, Rondonópolis campus, and researcher of the Center for Advanced Studies in Applied Economics of the Luiz de Queiroz College of Agriculture of the University of São Paulo - CEPEA/ESALQ/USP. 


\section{Preços}

\section{Aniela Fagundes Carrara ${ }^{1}$}

A compreensão das oscilações dos preços, tanto de modo geral quanto de segmentos específicos, é de suma importância, não apenas por proporcionar avaliações sobre o poder de compra real de um determinado período, mas, principalmente, pelo fato de os preços constituírem um item de extrema relevância para a análise macroeconômica como um todo, já que influenciam e são influenciados por variáveis, tais como taxas de juros, câmbio, Produto Interno Bruto (PIB), dentre outras, que juntas constituem o ambiente econômico de um país. Desse modo, o presente capítulo se dedica ao entendimento do comportamento dos preços ao longo do ano de 2018 na economia brasileira, visando contribuir para um melhor entendimento do cenário econômico do período.

No que tange aos níveis de preços ou, propriamente dito, à inflação no Brasil, é sabido que o País já passou por períodos conturbados, como a década de 1980, com a dificuldade em alguns períodos de se manter a inflação em taxas aceitavelmente próximas ao objetivo estipulado pelos formuladores de política, o que consubstancia o tema preços como um assunto relevante, que deve ser constantemente debatido e estudado.

1 Doutora em Economia Aplicada pela Escola Superior de Agricultura "Luiz de Queiroz" da Universidade de São Paulo (ESALQ/USP). Docente do Curso de Ciências Econômicas da Universidade Federal de Mato Grosso (UFMT), campus Rondonópolis e pesquisadora do Centro de Estudos Avançados em Economia Aplicada da Escola Superior de Agricultura "Luiz de Queiroz" da Universidade de São Paulo (CEPEA/ESALQ/USP). 
The current system used in Brazil to control the level of prices is the inflation targeting regime - RMI, adopted to replace the exchange rate targeting regime, which became unbearable after a number of speculative attacks in the 1990s. The targeting regime basically consists of the periodic publication of the numerical targets for the inflation, as well as of intervals for its variation, established by the National Monetary Council - CMN, being the basic interest rate of the Special System for Settlement and Custody - SELIC the major monetary policy instrument. In this context, the Extended National Consumer Price Index - IPCA, measured by the Brazilian Institute of Geography and Statistics - IBGE (10 anos..., 2011), is the official measurement of of inflationhe IPCA, calculated by the IBGE in the scope of the National System of Consumer Price Indexes - SNIPC, encompasses the families living in urban areas in the metropolitan areas of Belém, Fortaleza, Recife, Salvador, Belo Horizonte, Vitória, Rio de Janeiro, São Paulo, Curitiba and Porto Alegre, besides Brasília (DF) and the municipalities of Campo Grande and Goiânia, with monthly earnings between one and 40 minimum wages, whatever the source of the earnings. This index is split into the following groups: i) food and beverages; ii) housing; iii) household articles; iv) wearing apparel; v) transportation; vi) health and personal care; vii) personal expenses; viii) education; and ix) communication (SISTEMA..., 2014).

Concerning the year of 2018 , which is the focus of this analysis, the target set forth for the inflation was $4.5 \%$ with tolerance bands of 1.5 percentage points. According to the Focus Bulletin (Boletim Focus) of December 29, 2017 (FOCUS..., 2017), the expectations of the economic actors for that year were that the cumulative inflation stayed at $3.96 \%$, i.e., below the target. However, it ended 2018 at 3.75\%, after the two-digit inflation reached in 2015, being the second consecutive year in which the price level stood below the center set forth by the target, since the IPCA ended the year of 2017 at $2.95 \%$, pointing out a good anchorage of the inflation expectations. Yet, it is important to stress that the economic environment of that period corroborated to such a result, since the economy kept a quite weak pace, having the industrial activity as a negative highlight. This, together with the other domestic and foreign factors, contributed to the rise of only $1.1 \%$ of the GDP in 2018 , below the initial expectations.

Considering the groups that comprise the IPCA, the data of Table 9.1 show that the group corresponding to communication was the only one that registered a negative cumulative change in the year (-0.09\%) and the other groups changed positively, highlighted by education, 
Atualmente, o sistema utilizado no Brasil para controlar os níveis de preços é o regime de metas de inflação (RMI), adotado em substituição ao regime monetário de metas cambiais, que se tornou insustentável após diversos ataques especulativos na década de 1990. O regime de metas consiste basicamente na publicação periódica de metas numéricas para a inflação, bem como de intervalos para a sua variação, definidos pelo Conselho Monetário Nacional (CMN), sendo a taxa básica de juros do Sistema Especial de Liquidação e de Custódia (SELIC) o instrumento principal de política monetária. E neste contexto, tem-se como medida oficial da inflação o Índice de Preços ao Consumidor Amplo (IPCA), mensurado pelo Instituto Brasileiro de Geografia Estatística (IBGE) (10 anos..., 2011).

O IPCA é calculado pelo IBGE no âmbito do Sistema Nacional de Índices de Preços ao Consumidor (SNIPC) e abrange as famílias residentes em áreas urbanas das regiões metropolitanas de Belém, Fortaleza, Recife, Salvador, Belo Horizonte, Vitória, Rio de Janeiro, São Paulo, Curitiba e Porto Alegre, além de Brasília (DF) e dos Municípios de Campo Grande e Goiânia, com rendimentos mensais que vão de um a 40 salários mínimos, qualquer que seja a fonte dos rendimentos. Tal índice é dividido nos seguintes grupos: i) alimentação e bebidas; ii) habitação; iii) artigos de residência; iv) vestuário; v) transportes; vi) saúde e cuidados pessoais; vii) despesas pessoais; viii) educação; e ix) comunicação (SISTEMA..., 2014).

No que tange ao ano de 2018, que é o foco da análise aqui proposta, a meta estipulada para a inflação era de $4,5 \%$, com bandas de 1,5 pontos percentuais. Em relação às expectativas dos agentes econômicos para tal ano, segundo o Boletim Focus de 29.12.2017 (FOCUS..., 2017), a perspectiva era que a inflação acumulada fosse de $3,96 \%$, ou seja, abaixo da meta. Porém, o que se verificou foi que a mesma terminou 2018 em 3,75\%, sendo o segundo ano seguido, após a inflação de dois dígitos alcançada em 2015, em que o nível dos preços ficou abaixo do centro estipulado para meta, já que em 2017 o IPCA terminou o ano em 2,95\%, o que indica uma boa ancoragem das expectativas de inflação. Mas é importante ressaltar que a conjuntura econômica do período cooperou para tal resultado, uma vez que a economia manteve um ritmo bastante fraco, sendo a atividade industrial um destaque negativo, que em conjunto com os demais fatores internos e externos contribuiu para que $o$ PIB crescesse apenas 1,1\% em 2018, abaixo das expectativas iniciais.

Considerando os grupos que compõem o IPCA, é possível observar, por meio dos dados da Tabela 9.1, que o grupo correspondente à comunicação foi o único que apresentou uma variação acumulada negativa no ano $(-0,09 \%)$. Os demais grupos variaram positivamente, com destaque para a educação, que apresentou a maior 
which recorded the biggest oscillation (5.32\%), followed by housing $(4.72 \%)$, transportation (4.19\%), food and beverages (4.04\%) and health and personal care $(3.95 \%)$, all of them posting cumulative changes above the general inflation. Along the year of 2018, some monthly movements stood out, like the rise of $3.89 \%$ in the prices of the group of education, in February, particularly due to the adjustments in the tuitions, and the increase in the prices of the group of housing in June (2.48\%) and July (1.54\%), influenced by the rises in the electricity fare. Indeed, June stood out for the high level of prices, not only due to the group mentioned above, but also as a result of the rise in the prices of the segment of food and beverages, particularly due to the truckers' strike in May 2018, which also contributed to increase the prices of the group of transportation, though at a lower level.

Concerning specifically the food and non-food products, since food products are very important in the computation of the IPCA, Graph 9.1 shows that the prices of food products registered a bigger oscillation in 2018 compared with the prices of non-food products and the overall IPCA - which is natural, due to the inherent seasonality of most of these products. However, it is important to highlight that the peak of the prices in June can be attributed to the truckers' strike, as already mentioned, which jeopardized the supply of food, especially the perishable ones, like milk, meat and fruits, as pointed out by Barros and Osaki (2018). This is so true that the prices of food products returned to the level they were before the event.

In regard to price indexes, other indicators are available besides the IPCA. Among them, one of the most relevant is the National Consumer Price Index - INPC, also calculated by the IBGE under the scope of the SNIPC, which encompasses families with monthly earnings between one and five minimum wages, whose reference person is salaried. Such index comprises the same groups as the IPCA and has the same territorial coverage. The great difference of the INPC is that it better represents the inflation of the salaried persons with lower earnings.

Comparing the cumulative change of the IPCA and INPC in 2018, it is possible to notice by means of Table 9.2 that the annual cumulative change of the INPC in 2018 was smaller than that of the IPCA by 0.32 percentage points, closing the year at $3.43 \%$. This result reflected the fact that groups with lower weights in the INPC, like education and health, recorded a high inflation in 2018. Indeed, differences between these two indexes is common, as shown in Table 9.2. Despite the fact 
oscilação (5,32\%), seguida da habitação $(4,72 \%)$, do grupo de transportes $(4,19 \%)$, do grupo de alimentação e bebidas $(4,04 \%)$ e do grupo de saúde e cuidados pessoais $(3,95 \%)$, sendo que estes segmentos exibiram variações acumuladas maiores do que a inflação geral. Destaca-se que ao longo do ano de 2018, algumas movimentações mensais se sobressaíram, como a elevação de 3,89\% nos preços do grupo educação, em fevereiro, muito por conta dos reajustes nas mensalidades escolares e o crescimento dos preços do grupo habitação em junho $(2,48 \%)$ e julho $(1,54 \%)$, influenciado pela alta nas tarifas de energia elétrica.

Aliás, junho foi um mês que se destacou pelo elevado nível de preços, não só por conta do grupo citado acima, mas também devido à elevação dos preços no segmento de alimentação e bebidas, muito por conta da greve dos caminhoneiros, ocorrida em maio de 2018, que também contribuiu para o aumento dos preços do grupo dos transportes, porém em menor patamar.

Tratando em específico dos produtos alimentícios e não alimentícios, uma vez que os alimentos têm uma grande relevância no calculo do IPCA, o Gráfico 9.1 mostra que os preços dos produtos alimentícios apresentaram uma maior oscilação ao longo do ano de 2018, se comparado aos preços dos produtos não alimentícios e ao IPCA geral, o que é natural, por conta da sazonalidade inerente à boa parte destes produtos. Porém, é importante ressaltar o pico de preço apresentado pelos mesmos no mês de junho, que, como já enfatizado, pode ser creditado à greve dos caminhoneiros, que acabou por prejudicar o abastecimento dos alimentos, principalmente dos perecíveis, tais como leite, carnes e frutas, conforme apontam Barros e Osaki (2018). Tanto que, após tal evento, os preços dos produtos alimentícios voltam a oscilar entre os patamares anteriores ao ocorrido.

Em se tratando de índices de preços, além do IPCA existem outros indicadores: dentre eles, um de grande relevância é o Índice Nacional de Preços ao Consumidor (INPC), também calculado pelo IBGE no âmbito do SNIPC, e que abrange as famílias com rendimentos mensais de um a cinco salários mínimos, em que a pessoa de referência é assalariada. Tal índice é constituído pelos mesmos grupos que compõem o IPCA e tem a mesma abrangência territorial. O grande diferencial do INPC é que este índice consegue representar melhor a inflação dos assalariados que possuem rendimentos menores.

Contrapondo a variação acumulada em 2018 do IPCA e do INPC, é possível observar por meio da Tabela 9.2 que em 2018 a variação anual acumulada do INPC foi menor que a do IPCA em 0,32 pontos percentuais, fechando o ano em 3,43\%. Este resultado reflete o fato de que grupos de menor peso para o INPC, como educação e saúde, 
that the two indexes comprise the same groups, the weight of the segments is proportional to the level of income and, consequently, to the profiles of the expenses that each index covers.

Continuing the detailing of the analysis, Graph 9.2 shows the monthly change of the National Index of Civil Construction - INCC for 2017 and 2018. This index is calculated by the IBGE through the National System of Costs Survey and Indexes of Construction - SINAPI, bringing prices not included in the price indexes previously discussed. It is possible to notice in Graph 9.2 that this index swung at higher levels in 2018 than in 2017, in the periods from April to June and from August to October. To better understand those oscillations, Table 9.3 brings the average cost $\left(R \$ / m^{2}\right)$, the index number (base Dec 1998=100) and the cumulative change in the civil construction in 2018, for the Major Regions and Federation Units. Through this table, it is possible to pinpoint that, among all the Regions, the average cost of civil construction was higher in the Southeast Region ( $\left.R \$ 1,158.29 / \mathrm{m}^{2}\right)$, which stayed above the national average cost $\left(\mathrm{R} \$ 1,113.88 / \mathrm{m}^{2}\right)$. In fact, only the Northeast Region closed the year below that cost. On the other hand, the analysis of the cumulative change in the year of the prices of this sector shows that the highest one was recorded in the North Region (5.30\%), which stood above the national change (4.41\%). A factor that could have contributed to such result was the collective work agreement of the sector in the state of Pará, the state that posted the highest cumulative change in the cost of civil construction among all the states (6.26\%). Also regarding the regions, the South registered the second highest cumulative change $(4.70 \%)$, followed by the Northeast (4.58\%) and the Southeast, which recorded a cumulative change of $4.20 \%$, only above the Central-West Region (3.80\%), which was the area that posted the lowest oscillation in the year.

It is important to understand which the most relevant items in the total cost of civil construction are. Graph 9.3 shows that material has a cost per $\mathrm{m}^{2}$ slightly higher $\left(\mathrm{R} \$ 579.33 / \mathrm{m}^{2}\right)$ in relation to workforce ( $R \$ 534.55 / \mathrm{m}^{2}$ ) in the national average cost. As a result, material represented $52.01 \%$ of such cost and workforce, $47.98 \%$, in 2018 .

Also concerning the cumulative change of the INCC, Table 9.4 brings a time series of this index from 2009 to 2018, showing that the lowest level of this index throughout the period was in the year of 2013, when it reached $0.52 \%$. In the latest years, the index hit $6.64 \%$ in 2016 , fell to $3.82 \%$ in 2017 and closed 2018 at $4.41 \%$. 
apresentaram inflação elevada em 2018. Aliás, é comum haver diferenças entre as variações destes dois índices, como fica claro por meio da Tabela 9.2. Isso porque, apesar de os dois índices serem constituídos pelos mesmos grupos, em cada um deles o peso dos segmentos difere por conta do patamar de renda e, por conseguinte, do perfil das despesas que cada índice abrange.

Prosseguindo com o detalhamento da análise, o Gráfico 9.2 expõe a variação mensal do Índice Nacional da Construção Civil (INCC) para os anos de 2017 e 2018. Tal índice é calculado pelo IBGE através do Sistema Nacional de Pesquisa de Custos e Índices da Construção Civil (SINAPI) e traz preços excluídos dos índices de preços discutidos acima. É possível verificar através do Gráfico 9.2 que no ano de 2018 o índice em questão oscilou em patamares mais elevados que em 2017, nos períodos de abril a junho e de agosto a outubro.

Para entender melhor tais oscilações a Tabela 9.3 traz o custo médio $\left(\mathrm{R} \$ / \mathrm{m}^{2}\right)$, o número índice (base dez. 1998=100) e a variação acumulada no ano de 2018 na construção civil, para as Grandes Regiões e as Unidades da Federação. Por meio de tal tabela é possível identificar que, dentre todas as regiões, o custo médio da construção civil foi maior na Região Sudeste ( $R \$ 1$ 158,29/ m²), valor este que ficou acima do custo médio nacional ( $R \$ 1$ 113,88/ m²); aliás, apenas a Região Nordeste fechou o ano abaixo de tal custo. Por outro lado, se for analisada a variação acumulada no ano, dos preços de tal setor, a mais alta foi a da Região Norte (5,30\%), que ficou acima da variação nacional $(4,41 \%)$. um dos fatores que pode ter contribuído para tal resultado foi o dissídio coletivo do setor no Estado do Pará, que apresentou a maior variação acumulada, dentre todos os estados, no custo da construção civil $(6,26 \%)$. Ainda em relação às regiões, o Sul apresentou a segunda maior variação acumulada $(4,70 \%)$, seguida do Nordeste $(4,58 \%)$ e do Sudeste, que apresentou uma variação acumulada de $4,20 \%$, acima apenas da Região Centro-Oeste $(3,80 \%)$, região que apresentou menor oscilação no ano.

Dentro do custo total da construção civil, é importante entender quais itens são os mais relevantes. Logo, por meio do Gráfico 9.3 visualiza-se que o material tem um custo por $\mathrm{m}^{2}$ ligeiramente maior ( $\mathrm{R} \$ 5 \mathrm{79}, 33 / \mathrm{m}^{2}$ ) em relação à mão de obra ( $\mathrm{R} \$ 534,55 / \mathrm{m}^{2}$ ) no custo médio nacional, assim, observa-se que o material representou $52,01 \%$ de tal custo e a mão de obra 47,98\%, no ano de 2018 .

Ainda em relação à variação acumulada do INCC, a Tabela 9.4 traz um histórico deste índice de 2009 a 2018, que permite verificar que em todo o período considerado, o nível mais baixo do índice foi no ano de 2013 , quando chegou a $0,52 \%$. Nos últimos anos o índice atingiu 6,64\% em 2016, em 2017 caiu para 3,82\%, fechando 2018 com 4,41\%. 
Taking the information in a disaggregated form, like in Graph 9.4 that shows the monthly change of the parcels of material and workforce in the composition of the national cost of civil construction for 2018 , it is possible to notice that workforce shows a positive and more intense oscillation between March and July 2018, which is the traditional period of wage adjustments resulting from collective work agreements. Conversely, material swung at a higher level - average change of $0.51 \%$ against $0.20 \%$ for workforce - , though not having peaks as intense as workforce. Due to the downturn of the sector in 2018, less collective work agreements were accomplished, providing more highlight to the parcel of material in the computation of the index.

Lastly, Graph 9.5 provides a better view of the cumulative changes of the cost of civil construction at regional and national levels already shown in Table 9.3, making clear that the North was the region that registered the highest cumulative change (5.30\%) in 2018, above the national one (4.41\%).

Therefore, the price movements along the year of 2018, either in the general scope or in specific sectors like civil construction, were quite moderate, showing no trend of significant rises, particularly due to the economic environment at that moment, characterized by a moderate growth.

\section{References}

10 anos de metas para a inflação: 1999-2009. Brasília, DF: Banco Central do Brasil, 2011. 454 p.

BARROS, G.; OSAKI, M. Alimentos e crise logística no Brasil. Piracicaba: Cepea, 2018. Available from: <https://www.cepea.esalq.usp.br/br/opiniao-cepea/ alimentos-e-crise-logistica-no-brasil.aspx>. Cited: May 2019.

FOCUS: relatório de mercado. Brasília, DF: Banco Central do Brasil, 2017. Available from: <https://www.bcb.gov.br/publicacoes/focus/29122017>. Cited: May 2019.

SISTEMA nacional de índices de preços ao consumidor: estruturas de ponderação a partir da pesquisa de orçamentos familiares 2008-2009. 2. ed. Rio de Janeiro: IBGE, 2014. 322 p. (Relatórios metodológicos, v. 39). CD-ROM enclosed Available from: <https://biblioteca.ibge.gov.br/visualizacao/livros/ liv86320.pdf>. Cited: May 2019. 
Se as informações forem tratadas de modo desagregado, como no Gráfico 9.4, que apresenta a variação mensal das parcelas de materiais e de mão de obra na composição do custo nacional da construção civil para 2018, é possível verificar que a segunda apresenta uma oscilação positiva e mais intensa entre março e julho de 2018, que é o período em que tradicionalmente acontecem os ajustes salariais oriundos de acordos coletivos. Já o material oscilou em um patamar maior (média de variação de $0,51 \%$ contra $0,20 \%$ da mão de obra), porém sem constituir picos tão robustos quanto os da mão de obra. Isso porque em 2018, por conta do desaquecimento do setor, uma quantidade menor de acordos salariais foram efetuados, proporcionando um destaque maior para a parcela dos materiais, no cômputo do índice.

Por fim, o Gráfico 9.5 permite uma melhor visualização das variações acumuladas do custo da construção civil, por região e a nível nacional já expostas pela Tabela 9.3, deixando claro que no ano de 2018, dentre as cinco regiões, a Norte foi a que apresentou a mais alta variação acumulada (5,30\%), acima da nacional $(4,41 \%)$.

Desta forma, tem-se que ao longo do ano de 2018 as movimentações de preço, tanto no âmbito geral, quanto em setores específicos, como o de construção civil, foram bastante comedidas, sem qualquer tendência de alta expressiva, muito por conta da conjuntura econômica do momento, caracterizada por um modesto crescimento.

\section{Referências}

10 anos de metas para a inflação: 1999-2009. Brasília, DF: Banco Central do Brasil, 2011. $454 \mathrm{p}$.

BARROS, G.; OSAKI, M. Alimentos e crise logística no Brasil. Piracicaba: Cepea, 2018. Disponível em: <https://www.cepea.esalq.usp.br/br/opiniao-cepea/alimentos-e-criselogistica-no-brasil.aspx>. Acesso em: maio 2019.

FOCUS: relatório de mercado. Brasília, DF: Banco Central do Brasil, 2017. Disponível em: <https://www.bcb.gov.br/publicacoes/focus/29122017> . Acesso em: maio 2019.

SISTEMA nacional de índices de preços ao consumidor: estruturas de ponderação a partir da pesquisa de orçamentos familiares 2008-2009. 2. ed. Rio de Janeiro: IBGE, 2014. 322 p. (Relatórios metodológicos, v. 39). Acompanha CD-ROM em bolso. Disponível em: <https://biblioteca.ibge.gov.br/visualizacao/livros/liv86320.pdf >. Acesso em: maio 2019. 
Tabela 9.1 - Índice Nacional de Preços ao Consumidor

Amplo - IPCA - 2018

Table 9.1 - Extended National Consumer Price Index - IPCA - 2018

(continua/to be continued)

\begin{tabular}{|c|c|c|c|c|c|}
\hline \multirow[b]{2}{*}{$\begin{array}{c}\text { Mês/ } \\
\text { Month }\end{array}$} & \multicolumn{5}{|c|}{$\begin{array}{c}\text { Variação mensal, por grupos de produtos (\%)/ } \\
\text { Monthly change by groups of products (\%) }\end{array}$} \\
\hline & $\begin{array}{l}\text { IPCA/ } \\
\text { IPCA }\end{array}$ & $\begin{array}{c}\text { Alimentação } \\
\text { e bebidas/ } \\
\text { Food and } \\
\text { beverages }\end{array}$ & $\begin{array}{l}\text { Habitação/ } \\
\text { Housing }\end{array}$ & $\begin{array}{l}\text { Artigos de } \\
\text { residência/ } \\
\text { Household } \\
\text { articles }\end{array}$ & $\begin{array}{c}\text { Vestuário/ } \\
\text { Wearing apparel }\end{array}$ \\
\hline Janeiro/January & 0,29 & 0,74 & (-) 0,85 & 0,14 & $(-) 0,98$ \\
\hline Fevereiro/February & 0,32 & (-) 0,33 & 0,22 & 0,03 & $(-) 0,38$ \\
\hline Março/March & 0,09 & 0,07 & 0,19 & 0,08 & 0,33 \\
\hline Abril/April & 0,22 & 0,09 & 0,17 & 0,22 & 0,62 \\
\hline Maio/May & 0,40 & 0,32 & 0,83 & (-) 0,06 & 0,58 \\
\hline Junho/June & 1,26 & 2,03 & 2,48 & 0,34 & $(-) 0,16$ \\
\hline Julho/July & 0,33 & (-) 0,12 & 1,54 & 0,47 & $(-) 0,60$ \\
\hline Agosto/August & (-) 0,09 & (-) 0,34 & 0,44 & 0,56 & 0,19 \\
\hline Setembro/September & 0,48 & 0,10 & 0,37 & 0,11 & $(-) 0,02$ \\
\hline Outubro/October & 0,45 & 0,59 & 0,14 & 0,76 & 0,33 \\
\hline Novembro/November & (-) 0,21 & 0,39 & (-) 0,71 & 0,48 & (-) 0,43 \\
\hline Dezembro/December & 0,15 & 0,44 & (-) 0,15 & 0,57 & 1,14 \\
\hline $\begin{array}{l}\text { Acumulado no ano/ } \\
\text { Cumulative in the year }\end{array}$ & 3,75 & 4,04 & 4,72 & 3,74 & 0,61 \\
\hline
\end{tabular}


Tabela 9.1 - Índice Nacional de Preços ao Consumidor

Amplo - IPCA - 2018

Table 9.1 - Extended National Consumer Price Index - IPCA - 2018

(conclusão/concluded)

Variação mensal, por grupos de produtos (\%)/

Monthly change by groups of products (\%)

\begin{tabular}{|c|c|c|c|c|c|}
\hline $\begin{array}{l}\text { Mês/ } \\
\text { Month }\end{array}$ & $\begin{array}{l}\text { Transportes/ } \\
\text { Transportation }\end{array}$ & $\begin{array}{l}\text { Saúde e cuida- } \\
\text { dos pessoais/ } \\
\text { Health and } \\
\text { personal care }\end{array}$ & $\begin{array}{l}\text { Despesas } \\
\text { pessoais/ } \\
\text { Personal } \\
\text { expenses }\end{array}$ & $\begin{array}{l}\text { Educação/ } \\
\text { Education }\end{array}$ & $\begin{array}{l}\text { Comunicação/ } \\
\text { Communication }\end{array}$ \\
\hline Janeiro/January & 1,10 & 0,42 & 0,22 & 0,22 & 0,11 \\
\hline Fevereiro/February & 0,74 & 0,38 & 0,17 & 3,89 & 0,05 \\
\hline Março/March & (-) 0,25 & 0,48 & 0,05 & 0,28 & $(-)$ 0,33 \\
\hline Abril/April & 0,00 & 0,91 & 0,12 & 0,08 & (-) 0,07 \\
\hline Maio/May & 0,40 & 0,57 & 0,11 & 0,06 & 0,16 \\
\hline Junho/June & 1,58 & 0,37 & 0,33 & 0,02 & 0,00 \\
\hline Julho/July & 0,49 & 0,07 & 0,31 & (-) 0,08 & 0,08 \\
\hline Agosto/August & (-) 1,22 & 0,53 & 0,36 & 0,25 & 0,03 \\
\hline Setembro/September & 1,69 & 0,28 & 0,38 & 0,24 & (-) 0,07 \\
\hline Outubro/October & 0,92 & 0,27 & 0,25 & 0,04 & 0,02 \\
\hline Novembro/November & (-) 0,74 & (-) 0,71 & 0,36 & 0,04 & (-) 0,07 \\
\hline Dezembro/December & (-) 0,54 & 0,32 & 0,29 & 0,21 & 0,01 \\
\hline $\begin{array}{l}\text { Acumulado no ano/ } \\
\text { Cumulative in the year }\end{array}$ & 4,19 & 3,95 & 2,98 & 5,32 & (-) 0,09 \\
\hline
\end{tabular}

Fonte/Source: Índice nacional de preços ao consumidor amplo - IPCA 2018. In: IBGE. Sidra: sistema IBGE de recuperação automática. Rio de Janeiro, [2018]. Disponível em /Available from: <https://sidra. ibge.gov.br/home/ipca/brasil>.Acesso em: jan. 2019/Cited: Jan . 2019. 
Tabela 9.2 - Variação acumulada no ano do Índice Nacional de Preços ao Consumidor - INPC e do Índice Nacional de Preços ao

Consumidor Amplo - IPCA - 2005-2018

Table 9.2 - Cumulative change in the year of the Extended National Consumer Price Index - IPCA and of the National Consumer Price Index - INPC - 2005-2018

\begin{tabular}{|c|c|c|c|c|c|}
\hline \multirow{2}{*}{$\begin{array}{l}\text { Ano/ } \\
\text { Year }\end{array}$} & \multicolumn{2}{|c|}{$\begin{array}{l}\text { Variação acumulada no ano/ } \\
\text { Cumulative change in the year }\end{array}$} & \multirow{2}{*}{$\begin{array}{l}\text { Ano/ } \\
\text { Year }\end{array}$} & \multicolumn{2}{|c|}{$\begin{array}{l}\text { Variação acumulada no ano/ } \\
\text { Cumulative change in the year }\end{array}$} \\
\hline & IPCA & INPC & & IPCA & INPC \\
\hline 2005 & 5,69 & 5,05 & 2012 & 5,84 & 6,20 \\
\hline 2006 & 3,14 & 2,81 & 2013 & 5,91 & 5,56 \\
\hline 2007 & 4,46 & 5,16 & 2014 & 6,41 & 6,23 \\
\hline 2008 & 5,90 & 6,48 & 2015 & 10,67 & 11,28 \\
\hline 2009 & 4,31 & 4,11 & 2016 & 6,29 & 6,58 \\
\hline 2010 & 5,91 & 6,46 & 2017 & 2,95 & 2,07 \\
\hline 2011 & 6,50 & 6,08 & 2018 & 3,75 & 3,43 \\
\hline
\end{tabular}

Fonte/Source: Índice nacional de preços ao consumidor amplo - IPCA 2005-2018. In: IBGE. Sidra: sistema IBGE de recuperação automática. Rio de Janeiro, [2018]. Disponível em/Available from: <https://sidra.ibge.gov.br/home/ipca/brasil>. Acesso em: jan. 2019/Cited: Jan. 2019.

\section{Gráfico 9.1 - Variação mensal do Índice Nacional de Preços ao Consumidor Amplo - IPCA - 2018}

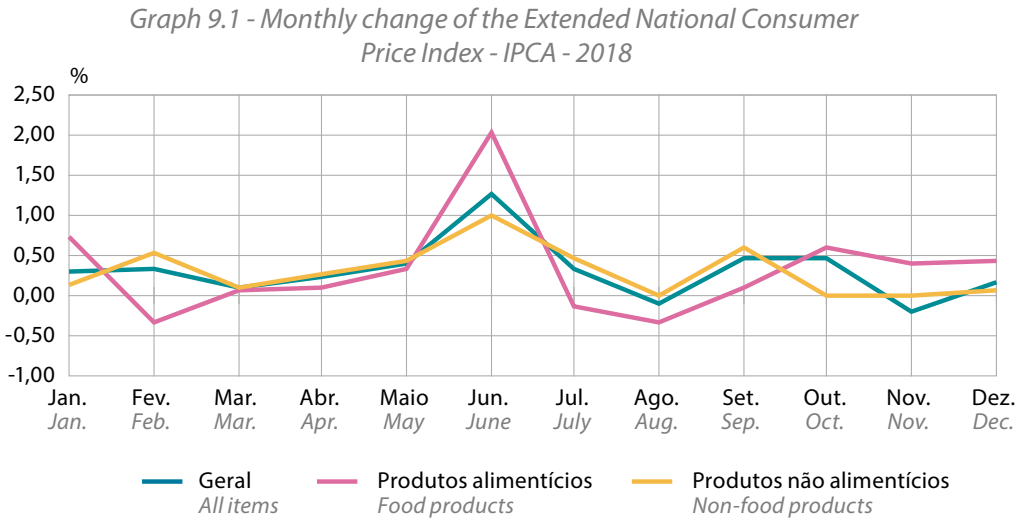

Fonte/Source: Índice nacional de preços ao consumidor amplo - IPCA 2018. In: IBGE. Sidra: sistema IBGE de recuperação automática. Rio de Janeiro, [2018]. Disponível em/Available from: <https://sidra.ibge. gov.br/home/ipca/brasil>. Acesso em: jan. 2019/Cited: Jan. 2019. 
Tabela 9.3 - Custo médio, número-índice e variação acumulada no ano, na construção civil, segundo as Grandes Regiões e Unidades da Federação - Dezembro 2018

Table 9.3 - Average cost, index-number and cumulative change in the year in civil construction, by Major Regions and Federation Units - December 2018

\begin{tabular}{|c|c|c|c|}
\hline $\begin{array}{l}\text { Grandes Regiões e } \\
\text { Unidades da Federação/ } \\
\text { Major Regions and } \\
\text { Federation Units }\end{array}$ & $\begin{array}{l}\text { Custo médio } \\
\begin{array}{c}\left(\mathrm{R} \$ / \mathrm{m}^{2}\right) / \\
\text { Average } \\
\text { cost }\left(R \$ / \mathrm{m}^{2}\right)\end{array}\end{array}$ & $\begin{array}{l}\text { Número-índice } \\
\text { (dez./98=100)/ } \\
\text { Index number } \\
(\text { Dec./98 = 100) }\end{array}$ & $\begin{array}{c}\text { Variação acumulada } \\
\text { no ano (\%)/ } \\
\text { Cumulative change } \\
\text { in the year (\%) }\end{array}$ \\
\hline Brasil/Brazil & 1113,88 & 557,48 & 4,41 \\
\hline Norte /North & 1122,05 & 559,10 & 5,30 \\
\hline Rondônia & 1154,81 & 643,82 & 3,95 \\
\hline Acre & 1233,68 & 654,87 & 4,97 \\
\hline Amazonas & 1084,24 & 530,89 & 5,16 \\
\hline Roraima & 1174,34 & 487,67 & 5,64 \\
\hline Pará & 1113,23 & 533,59 & 6,26 \\
\hline Amapá & 1088,67 & 528,80 & 3,31 \\
\hline Tocantins & 1161,34 & 610,61 & 3,53 \\
\hline Nordeste/Northeast & 1037,37 & 560,38 & 4,58 \\
\hline Maranhão & 1067,74 & 562,45 & 5,07 \\
\hline Piauí & 1055,20 & 701,20 & 4,08 \\
\hline Ceará & 1035,47 & 598,03 & 4,22 \\
\hline Rio Grande do Norte & 1024,77 & 516,56 & 6,31 \\
\hline Paraíba & 1085,18 & 600,09 & 4,58 \\
\hline Pernambuco & 1013,57 & 541,93 & 3,77 \\
\hline Alagoas & 1022,21 & 510,76 & 3,50 \\
\hline Sergipe & 969,37 & 515,13 & 3,70 \\
\hline Bahia & 1034,79 & 547,74 & 5,07 \\
\hline Sudeste/Southeast & 1158,29 & 554,50 & 4,20 \\
\hline Minas Gerais & 1041,74 & 573,25 & 4,17 \\
\hline Espírito Santo & 1013,29 & 562,01 & 4,28 \\
\hline Rio de Janeiro & 1224,98 & 558,25 & 2,65 \\
\hline São Paulo & 1213,25 & 547,97 & 4,77 \\
\hline Sul/South & 1157,34 & 553,50 & 4,70 \\
\hline Paraná & 1131,77 & 541,25 & 4,94 \\
\hline Santa Catarina & 1247,88 & 675,99 & 3,86 \\
\hline Rio Grande do Sul & 1113,03 & 505,18 & 5,17 \\
\hline Centro-Oeste/Central-West & 1124,32 & 573,97 & 3,80 \\
\hline Mato Grosso do Sul & 1092,69 & 513,83 & 3,09 \\
\hline Mato Grosso & 1126,15 & 642,55 & 4,36 \\
\hline Goiás & 1096,67 & 579,34 & 2,56 \\
\hline Distrito Federal/Federal District & 1182,17 & 522,04 & 5,28 \\
\hline
\end{tabular}

Fonte/Source: IBGE, Diretoria de Pesquisas, Coordenação de Índices de Preços. 
Tabela 9.4 - Variação acumulada no ano do Índice Nacional da Construção Civil - 2009-2018

Table 9.4 - Cumulative change in the year of the National Index of Civil Construction - 2009-2018

\begin{tabular}{|c|c|c|c|}
\hline $\begin{array}{l}\text { Ano/ } \\
\text { Year }\end{array}$ & $\begin{array}{c}\text { Variação acumulada } \\
\text { no ano (\%)/ } \\
\text { Cumulative change } \\
\text { in the year (\%) }\end{array}$ & $\begin{array}{l}\text { Ano/ } \\
\text { Year }\end{array}$ & $\begin{array}{c}\text { Variação acumulada } \\
\text { no ano (\%)/ } \\
\text { Cumulative change } \\
\text { in the year (\%) }\end{array}$ \\
\hline 2009 & 5,85 & 2014 & 6,20 \\
\hline 2010 & 7,36 & 2015 & 5,50 \\
\hline 2011 & 5,65 & 2016 & 6,64 \\
\hline 2012 & 5,68 & 2017 & 3,82 \\
\hline 2013 & 0,52 & 2018 & 4,41 \\
\hline
\end{tabular}

Fonte/Source: IBGE, Diretoria de Pesquisas, Coordenação de Índices de Preços.

\section{Gráfico 9.2 - Variação mensal do Índice Nacional da Construção Civil - 2017-2018}

Graph 9.2 - Monthly change of the National Index of Civil

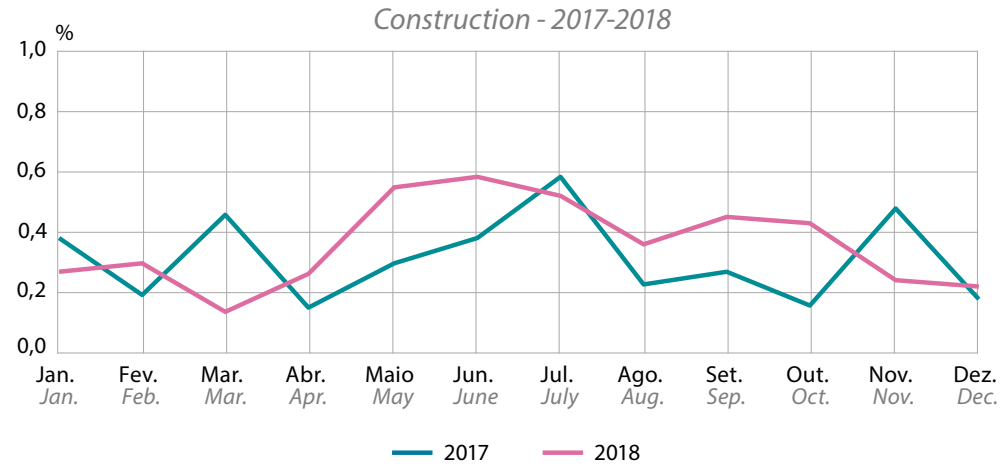

Fonte/Source: IBGE, Diretoria de Pesquisas, Coordenação de Índices de Preços. 


\section{Gráfico 9.3 - Custo total por metro quadrado,}

parcela de materiais e mão de obra - dez. 2018

Graph 9.3 - Cost per square meter, total,

of material and of labor force - Dec. 2018

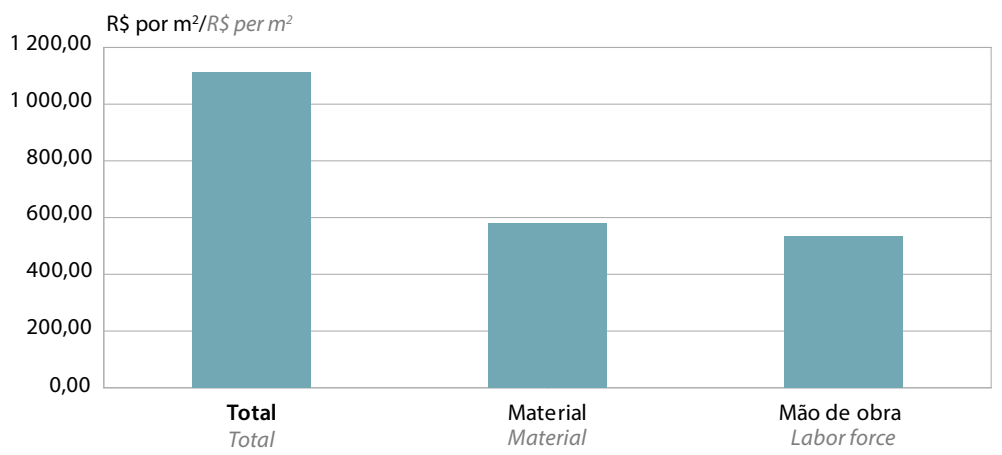

Fonte/Source: IBGE, Diretoria de Pesquisas, Coordenação de Índices de Preços.

Gráfico 9.4 - Variação mensal das parcelas de materiais e de mão de obra na composição do Custo Nacional da Construção Civil - 2018

Graph 9.4-Monthly change of material and of labor force in the composition of the National Cost of Civil Construction - 2018

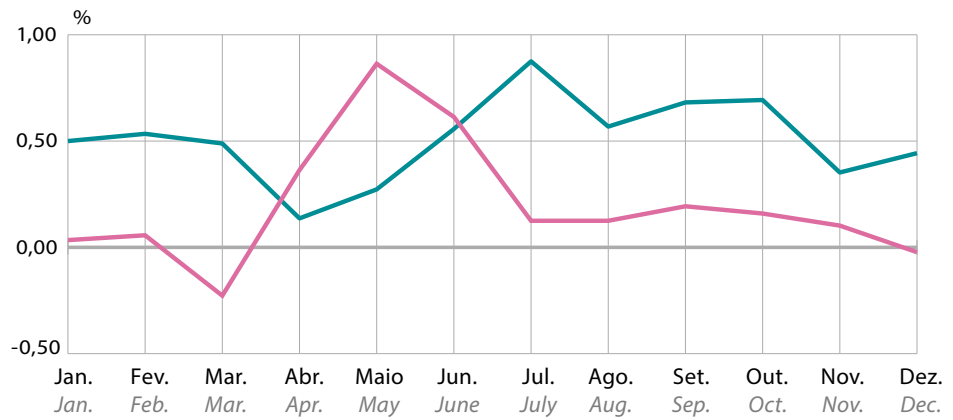

Material $\quad$ Mão de obra
Material
Laborforce

Fonte/Source: IBGE, Diretoria de Pesquisas, Coordenação de Índices de Preços. 


\section{Gráfico 9.5 - Variação acumulada do Custo Nacional e Custos Regionais da Construção Civil - 2018}

Graph 9.5 - Cumulative change of the National and Regional Costs of Civil Construction - 2018

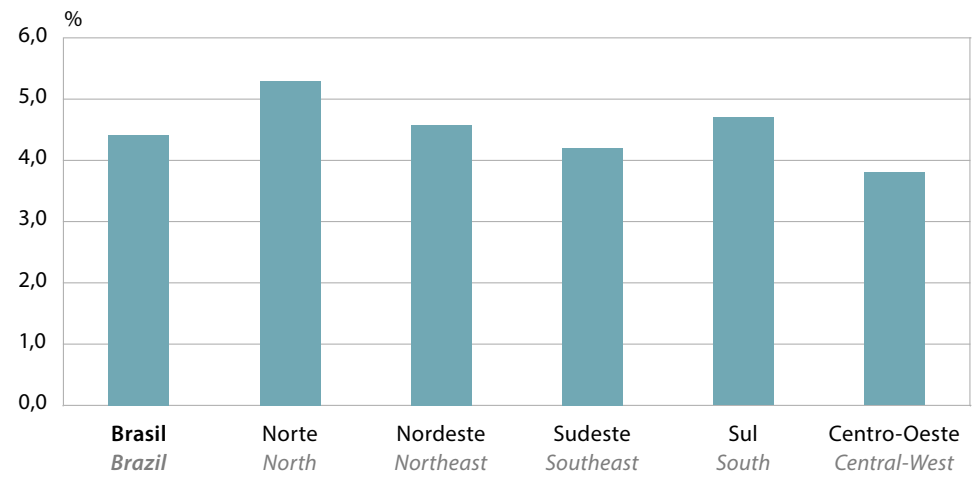

Fonte/Source: IBGE, Diretoria de Pesquisas, Coordenação de Índices de Preços. 


\section{Contas Nacionais National Accounts}

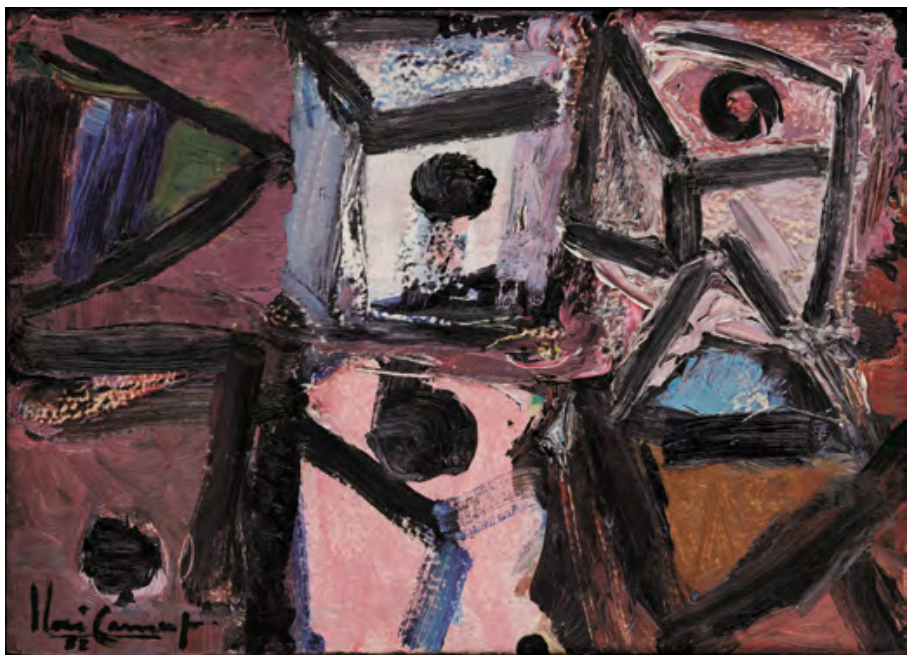

Dado cor-de-rosa, 1982

Pink dice

Iberê Camargo 


\title{
National Accounts
}

\author{
Manoel Pires ${ }^{1}$
}

The System of National Accounts measures the economic evolution of a country by means of useful indicators that monitor its development, either from a historical point of view or in comparison with other countries. In Brazil, the Brazilian Institute of Geography and Statistics (IBGE) is responsible for collecting information, for calculating and releasing those indicators aiming at a better understanding of the Brazilian economy. In order to reach that objective, the IBGE participates in several national and international forums, with the main goals of following the best international practices and of adopting the best available techniques to standardize statistical information, work on its comparability and adjust it according to the ongoing changes in society. In methodological terms, the IBGE follows the recommendations of the United Nations' System of National Accounts 2008.

Brazil in Figures presents those indicators, summarized, to readers interested in knowing, in a simple and objective way, about the real economic situation of the country between the years 20162018, according to the main annual and quarterly indicators available. Nevertheless, the System of National Accounts if far more comprehensive and it is recommended that readers consult other IBGE surveys on the same topic for a more complete view of the status of the Brazilian economy.

\footnotetext{
$1 \mathrm{PhD}$ in Economics from the University of Brasília (UnB), Co-researcher at the UnB and associate researcher at the Brazilian Institute of Economics of Getúlio Vargas Foundation (IBRE/FGV).
} 


\title{
Contas Nacionais
}

\author{
Manoel Pires ${ }^{1}$
}

O Sistema de Contas Nacionais mede a evolução econômica de um país, apresentando indicadores úteis para acompanhar seu desempenho seja do ponto de vista histórico ou de forma comparada com outros países. No Brasil, o Instituto Brasileiro de Geografia e Estatística (IBGE) é o órgão responsável por coletar as informações, calcular e divulgar esses indicadores que buscam melhor compreensão da economia brasileira. Para isso, o IBGE participa de vários fóruns nacionais e internacionais a fim de acompanhar as melhores práticas internacionais e introduzir as melhores técnicas disponíveis, com o objetivo de padronizar as informações estatísticas para torná-las comparáveis e adequá-las às transformações em curso na sociedade. Em termos metodológicos, o IBGE segue as recomendações do Sistema de Contas Anuais de 2008 da Organização das Nações Unidas (ONU).

O Brasil em Números apresenta esses indicadores de forma sucinta para o leitor interessado em entender a real situação econômica do País de forma simples e objetiva entre os anos de 2016-2018, utilizando os principais indicadores com periodicidade anual e trimestral. O Sistema de Contas Nacionais, contudo, é bem mais abrangente e recomenda-se ao leitor interessado que consulte as demais pesquisas do IBGE nesse tema para uma visão completa da economia brasileira.

1 Doutor em economia pela Universidade de Brasília (UnB), Pesquisador Colaborador da UnB e pesquisador associado do Instituto Brasileiro de Economia da Fundação Getulio Vargas (IBRE/FGV). 
The decade of the 2010s has been remarkable with regard to political, economic and social aspects. In the end of 2009, the English magazine The Economist released an issue with Christ the Redeemer on the cover, in the shape of a rocket, as a reference to the fantastic economic performance of Brazil in the year that followed the big global financial crisis (THE ECONOMIST, 2009).

Actually, the Brazilian economy recorded an increase of $7.5 \%$ in 2010. Since then, a historical recession resulting from a series of macroeconomic adjustments and marked by major political uncertainty has lowered expectations. In 2014 , the economy grew by $0.5 \%$ only, and in the following year, it declined by $3.6 \%$. The current edition of Brazil in Figures presents data that show how the Brazilian economy has gone out of recession and how the recovery has been gradual, as well as the most recent structural transformations.

Table 10.1 shows the evolution of the main macroeconomic indicators in nominal terms: Gross Domestic Product (GDP), consumption, investment, gross savings and net borrowing, which refers to the difference between savings (source of resources) and investments (use of resources). By using the GDP deflator to obtain values measured on the same price basis, it is possible to conclude that the Brazilian economy shrank by $3.31 \%$ in 2016 and expanded $1.06 \%$ in 2017 and $1.12 \%$ in 2018. Considering those deflators, we observe that the GDP per capita was virtually stagnated between 2016 and 2018.

Table 10.2 presents the decomposition of GDP from the perspective of demand in terms of participation in the main sectors of economic activity. The table shows there was slight increase in the participation of industry and of services in the total output measured at basic prices (without transport margin and indirect taxes). On the other hand, agriculture recorded decrease. That process is known and occurs as the income per capita increase and the country advances. In this case, there is a shift in the composition of demand to services with bigger aggregation of technology in this sector, increasing its participation in the economy.

Table 10.3 brings the GDP decomposition from the perspective of demand: household and government consumption, exports and imports. Those figures are released in nominal values and in percentage of the GDP. It is possible to see that household consumption reached $64.33 \%$ of the GDP, having increased its participation in 2018 and made up for the decrease in 2017, when it reached $63.99 \%$ of the GDP. Government consumption, in turn, reduced its participation in the three years, having fallen from $20.39 \%$ to $19.72 \%$ of the GDP. Investment also increased its 
A década de 2010 tem sido surpreendente em seus aspectos políticos, econômicos e sociais. No final de 2009, a revista inglesa The Economist publicou uma edição em que apresentava em sua capa o Cristo Redentor em forma de foguete, em referência ao fantástico desempenho econômico que vigeu no Brasil durante o ano que se seguiu à grande crise financeira global (THE ECONOMIST, 2009). Com efeito, a economia brasileira apresentou crescimento de 7,5\% em 2010. De lá para cá, uma recessão histórica resultante de uma série de ajustes macroeconômicos e de elevada incerteza política, frustrou essa expectativa. Em 2014, a economia cresceu apenas $0,5 \%$ e no ano seguinte encolheu 3,6\%. Essa edição do Brasil em Números apresenta dados que mostram como a economia brasileira saiu da recessão e como a recuperação tem sido gradual, bem como as transformações estruturais mais recentes.

A Tabela 10.1 apresenta a evolução dos principais indicadores macroeconômicos em termos nominais: Produto Interno Bruto (PIB), consumo, investimento, poupança bruta e a necessidade de financiamento, que se refere à diferença entre poupança (fonte de recursos) e os investimentos (uso de recursos). Usando o deflator do PIB para se obter valores medidos na mesma base de preços, é possível concluir que a economia brasileira se contraiu 3,31\% em 2016 e se expandiu 1,06\% em 2017 e 1,12\% em 2018. Com base nesses deflatores também é possível verificar que entre 2016 e 2018 o PIB per capita ficou praticamente estagnado.

A Tabela 10.2 apresenta a decomposição do PIB pelo lado da oferta, decompondo sua participação entre os principais setores de atividade da economia. Essa tabela mostra que houve ligeiro aumento da participação da indústria e do setor de serviços no total da produção medida a preços básicos (sem margens de transporte e impostos indiretos). Por outro lado, houve recuo da agropecuária. Esse processo é conhecido e ocorre na medida em que a renda per capita aumenta e o país se desenvolve. Nessa situação, ocorre uma mudança na composição da demanda na direção dos serviços com maior agregação de tecnologia nesse setor, aumentando sua participação na economia.

A Tabela 10.3 divulga a decomposição do PIB pelo lado da demanda: consumo das famílias e do governo, investimentos, exportações e importações. Esses valores são divulgados em valores nominais e em percentual do PIB. É possível verificar que o consumo das famílias atingiu 64,33\% do PIB, aumentando sua participação em 2018 e compensando a queda verificada em 2017 , quando alcançou $63,99 \%$ do PIB. $O$ consumo do governo, por sua vez, perdeu participação durante todos os três anos, caindo de $20,39 \%$ do PIB para $19,72 \%$ do PIB. O investimento também ganhou participação ao longo desses três anos, saindo de $14,97 \%$ para $15,42 \%$ do PIB. Nesse caso, 
participation throughout those three years, having changed from $14.97 \%$ of the GDP to $15.42 \%$ of the GDP. In that case, since investment is the item of demand that is mostly affected by recession, it is advisable to monitor its behavior prior to the beginning of a crisis. In fact, in 2014, investment reached $20.55 \%$ of the GDP and that difference evidences there is enough room for economic recovery.

Exports and imports of goods and services increased their participation in relation to GDP throughout those three years. In summary, the recovery of the economy took place with slight deceleration of investment that depart from a very low basis, with bigger participation in foreign trade and decrease of government consumption.

Table 10.4 decomposes many of those data along quarters in 2017 and 2018. As a result, it is possible to observe the behavior of the quarterly increase rate of GDP and its components from the perspective of demand in comparison with the same quarter in the previous year. In 2017, the increase rate of GDP followed a clear trend to acceleration throughout the year: in Q1 2017 the economy grew 0.1\%, with acceleration to reach Q4 at 2.2\%. In the beginning of that year, the highlight was the excellent performance of agriculture, which increased at a two-digit rate for two consecutive quarters. Throughout the acceleration of increase, also relevant was the recovery of industry and services which, in the last quarter, increased at a rate of $2.5 \%$ and $2.0 \%$, respectively. Until Q3, industry was still marked by a decline in production.

In 2018, the increase of the Brazilian economy decelerated to a level close to $1.0 \%$. The deceleration reflected a weaker performance in agriculture, which had grown at rates way below those in the previous year. Industry recorded deceleration of increase, with a change from 1.2\% in Q1 2018 to $0.5 \%$ in Q4 the same year. Lastly, the services sector decelerated up to a stable pattern of increase by $1.0 \%$. That is the way how the System of National Accounts describes the economic situation of the country.

Table 10.5 shows some summarized indicators that are useful in a reflection about economic growth. The investment rate is important to measure the evolution of the capital stock per worker, one of the determining elements of long-term economic growth, and had slight acceleration in the three-year period, from $15.5 \%$ to $15.8 \%$ of the GDP. It is important to advance more: the bigger the investment, the bigger the output capacity of the economy without pressure by the inflation rate. 
como o investimento é o item da demanda que mais é afetado pelas recessões, é bom verificar o seu comportamento antes do início da crise. Com efeito, em 2014, o investimento atingiu $20,55 \%$ do PIB e essa diferença mostra haver grande espaço para a recuperação da economia.

As exportações e as importações de bens e serviços aumentaram sua participação em relação ao PIB ao longo desses três anos. Em resumo, a recuperação da economia se deu com uma ligeira aceleração do investimento, que parte de uma base muito baixa, maior participação no comércio exterior e com redução do consumo governamental.

A Tabela 10.4 decompõe várias dessas informações ao longo dos trimestres de 2017 e 2018. Com isso é possível verificar o comportamento da taxa de crescimento trimestral do PIB e seus componentes pelo lado da oferta, em relação ao mesmo trimestre do ano anterior. Em 2017, a taxa de crescimento do PIB apresentou clara tendência de aceleração ao longo do ano: no primeiro trimestre de 2017 a economia cresceu $0,1 \%$, acelerando para chegar no quarto trimestre crescendo a 2,2\%. No início desse ano, o destaque se deu pelo excepcional desempenho da agropecuária, que cresceu a dois dígitos por dois trimestres seguidos. Ao longo desse processo de aceleração do crescimento, foi importante a recuperação da indústria e dos serviços, que no último trimestre cresceram à taxa de $2,5 \%$ e 2,0\%, respectivamente. Até o terceiro trimestre, por exemplo, a indústria ainda apresentava encolhimento na produção.

Em 2018, a economia brasileira desacelerou seu crescimento para patamares mais próximos a 1,0\%. Essa desaceleração refletiu um desempenho mais fraco na agropecuária, que cresceu a taxas bem inferiores a observada no ano anterior. A indústria apresentou um crescimento que desacelerou ao longo do ano, saindo de $1,2 \%$ no primeiro trimestre de 2018 , até encolher $0,5 \%$ no quarto trimestre do referido ano. Por fim, o setor de serviços desacelerou até estabilizar seu padrão de crescimento na faixa de $1,0 \%$. É dessa forma que o Sistema de Contas Nacionais retrata a situação econômica do País.

A Tabela 10.5 apresenta alguns indicadores sintéticos que são úteis para pensar o crescimento econômico. A taxa de investimento é importante para medir a evolução do estoque de capital por trabalhador, um dos determinantes do crescimento econômico de longo prazo e apresentou pequena aceleração no triênio, saindo de $15,5 \%$ para $15,8 \%$ do PIB. É importante avançar mais, pois quanto maior o investimento, maior é a capacidade de produção da economia sem que haja pressões de inflação. 
The second variable presented is the savings rate. In macroeconomic terms, the savings rate (domestic and foreign) is equivalent to the investment rate. When the domestic savings rate is below the investment rate, as it is the case of Brazil, there is a need to incorporate foreign savings. In other words, in such conditions, Brazil imports capital from the rest of the world. That analysis is often called macroeconomic consistency analysis, for, when that difference becomes very significant, there is increased dependence on changes in global economy and the process can become unworkable. In Brazil, that difference was once very high, being was close to $-4.0 \%$ of the GDP in 2014. One of the adjustments resulting from the recession of 2015-2016 was exactly the reduction of that difference to safer levels: in 2016, it fell to $-2.1 \%$ and reached $-1.3 \%$ of the GDP in 2018.

Finally, Table 10.5 brings the level of economic opening measured by the sum, in GDP percentage, of exports and imports. That is an important indicator because the level of commercial opening represents the level of integration with other economies in the world, being also a source of long-term economic increase. The more open the economy, the bigger its access to production inputs, the bigger its competitiveness and specialization and that tends to increase company productivity. Since Brazil is relatively closed, that indicator tends to be low. Our level of commercial opening has increased, but there is still a long way to go, nevertheless.

Brazil in Figures presents an important summary of what we know about Brazil by means of statistics and indicators. From those surveys, it is possible to monitor the Brazilian economy, make diagnoses and create public policies that can bring more development into the country. The more we know that reality, the bigger our capacity to produce a more developed and fair society.

\section{Reference}

THE ECONOMIST. New York, Nov. 14th 2009. Available from: <https://www. economist.com/printedition/covers?print_region=76980>.Cited:May 2019. 
A segunda variável apresentada é a taxa de poupança. Em termos macroeconômicos, a taxa de poupança (doméstica e externa) equivale à taxa de investimento. Quando a taxa de poupança doméstica é inferior à taxa de investimento, como é o caso do Brasil, há necessidade de absorver poupança externa. Em outras palavras, nessa condição, o Brasil importa capital do resto do mundo. Essa análise muitas vezes é chamada consistência macroeconômica, pois quando esse diferencial se torna muito significativo, há elevada dependência em relação a mudanças na economia global e o processo pode se tornar insustentável. No Brasil, esse diferencial já foi bem maior: em 2014 ficou próximo de -4,0\% do PIB. Um dos ajustes trazidos pela recessão de 20152016 foi exatamente reduzir essa diferença para patamares mais seguros: em 2016 a diferença caiu para -2,1\% e em 2018 alcançou -1,3\% do PIB.

Por fim, a Tabela 10.5 apresenta o grau de abertura da economia medido pela soma, em percentual do PIB, das exportações e importações. Esse indicador é importante porque o grau de abertura comercial apresenta o grau de integração com as demais economias do mundo e também uma fonte de crescimento econômico de longo prazo. Quanto mais aberta for a economia, maior seu acesso a insumos de produção, maior o grau de competição e especialização e, com isso, mais produtiva as empresas tendem a ser. Como o Brasil é relativamente fechado, esse indicador tende a ser baixo. Nos últimos três anos, contudo, o grau de abertura comercial se expandiu, mas há muito a avançar ainda.

O Brasil em Números apresenta um resumo importante do que sabemos sobre o Brasil através de estatísticas e indicadores. Por meio dessas pesquisas, é possível acompanhar a economia brasileira, elaborar diagnósticos e desenvolver políticas públicas que possam trazer mais desenvolvimento para o País. Quanto mais conhecermos essa realidade, maior nossa capacidade de produzir uma sociedade mais desenvolvida e justa.

\section{Referência}

THE ECONOMIST. New York, Nov. 14th 2009. Disponível em: <https://www.economist. com/printedition/covers?print_region=76980 >. Acesso em: maio 2019. 
Tabela 10.1 - Principais agregados macroeconômicos - 2016-2018 Table 10.1 - Main macroeconomic aggregates - 2016-2018

\begin{tabular}{|c|c|c|c|}
\hline \multirow{2}{*}{$\begin{array}{l}\text { Principais agregados/ } \\
\text { Main aggregates }\end{array}$} & \multicolumn{3}{|c|}{$\begin{array}{l}\text { Valor }(1000000 \mathrm{R} \$) / \\
\text { Value }(1,000,000 \mathrm{R} \$)\end{array}$} \\
\hline & 2016 & 2017 & 2018 \\
\hline $\begin{array}{l}\text { Produto interno bruto/ } \\
\text { Gross domestic product }\end{array}$ & 6267205 & 6553843 & 6827586 \\
\hline $\begin{array}{l}\text { Renda nacional bruta/ } \\
\text { Gross national income }\end{array}$ & 6136492 & 6432355 & 6723719 \\
\hline $\begin{array}{l}\text { Renda disponível bruta (1)/ } \\
\text { Gross disposable income (1) }\end{array}$ & 6145672 & 6439700 & 6731762 \\
\hline $\begin{array}{l}\text { Consumo final/ } \\
\text { Final consumption }\end{array}$ & 5303658 & 5502733 & 5738493 \\
\hline $\begin{array}{l}\text { FBC/ } \\
\text { Gross capital formation }\end{array}$ & 938490 & 985412 & 1053000 \\
\hline $\begin{array}{l}\text { Poupança bruta (1)/ } \\
\text { Gross saving (1) }\end{array}$ & 842014 & 936966 & 993268 \\
\hline $\begin{array}{l}\text { Capacidade (+) ou necessidade (-) de finan- } \\
\text { ciamento/ } \\
\text { Net lending (+) or net borrowing (-) }\end{array}$ & (-) 95521 & (-) 47241 & (-) 58122 \\
\hline $\begin{array}{l}\text { Produto interno bruto per capita/ } \\
\text { Gross domestic product per capita }\end{array}$ & 30548 & 31691 & 32747 \\
\hline
\end{tabular}

Fontes/Sources : 1. Sistema de contas nacionais: Brasil 2016. Rio de Janeiro: IBGE, 2018. Disponível em/Available from: <https://www.ibge.gov.br/estatisticas-novoportal/economicas/contasnacionais/9052-sistema-de-contas-nacionais-brasil.html>. Acesso em: jan. 2019/Cited: Jan . 2019. 2. Indicadores IBGE. Contas nacionais trimestrais: indicadores de volume e valores correntes out./dez. 2018. Rio de Janeiro: IBGE, 2018. Disponível em/Available from : <https://www.ibge.gov.br/estatisticasnovoportal/economicas/contas-nacionais/9300-contas-nacionais-trimestrais.html>. Acesso em: jan. 2019/Cited: Jan . 2019.

Nota: Os dados de 2017 e 2018 são preliminares baseados em Contas Nacionais Trimestrais./ Note: Preliminary data for 2017 and 2018 are based on the Quarterly National Accounts.

(1) Inclui as transferências de capital por impossibilidade de identificá-las, até o momento./ (1) Including capital transfers due to the impossibility of identifying them up to now. 
Tabela 10.2 - Participação percentual dos impostos e do valor adicionado, a preços básicos no Produto Interno Bruto - PIB, e dos setores de atividade, no valor adicionado a preços básicos - 2016-2018 Table 10.2 - Percentage participation of taxes and of value added at basic prices in the Gross Domestic Product - GDP, and of the sectors of activity, in value added at basic prices - 2016-2018

\begin{tabular}{|c|c|c|c|}
\hline \multirow{2}{*}{$\begin{array}{l}\text { Especificação/ } \\
\text { Item }\end{array}$} & \multicolumn{3}{|c|}{$\begin{array}{l}\text { Participação percentual (\%)/ } \\
\text { Percentage participation (\%) }\end{array}$} \\
\hline & 2016 & 2017 & 2018 \\
\hline $\begin{array}{l}\text { Produto interno bruto/ } \\
\text { Gross domestic product }\end{array}$ & 100,0 & 100,0 & 100,0 \\
\hline $\begin{array}{l}\text { Impostos/ } \\
\text { Taxes }\end{array}$ & 13,6 & 13,9 & 14,6 \\
\hline $\begin{array}{l}\text { Valor adicionado a preços básicos / } \\
\text { Value added at basic prices }\end{array}$ & 86,4 & 86,1 & 85,4 \\
\hline $\begin{array}{l}\text { Valor adicionado a preços básicos / } \\
\text { Value added at basic prices }\end{array}$ & 100,0 & 100,0 & 100,0 \\
\hline $\begin{array}{l}\text { Agropecuária/ } \\
\text { Agriculture }\end{array}$ & 5,7 & 5,4 & 5,1 \\
\hline $\begin{array}{l}\text { Indústria (1)/ } \\
\text { Industry (1) }\end{array}$ & 21,2 & 21,3 & 21,6 \\
\hline $\begin{array}{l}\text { Serviços/ } \\
\text { Services }\end{array}$ & 73,1 & 73,3 & 73,3 \\
\hline
\end{tabular}

Fontes/Sources: 1. Sistema de contas nacionais: Brasil 2016. Rio de Janeiro: IBGE, 2018. Disponível em/Available from: <https://www.ibge.gov.br/estatisticas-novoportal/economicas/contasnacionais/9052-sistema-de-contas-nacionais-brasil.html>. Acesso em: jan. 2019/Cited: Jan . 2019. 2. Indicadores IBGE. Contas nacionais trimestrais: indicadores de volume e valores correntes out./dez. 2018. Rio de Janeiro: IBGE, 2018. Disponível em/Available from : <https://www.ibge.gov.br/estatisticasnovoportal/economicas/contas-nacionais/9300-contas-nacionais-trimestrais.html>. Acesso em: jan. 2019/Cited : Jan . 2019.

Nota: Os dados de 2017 e 2018 são preliminares baseados em Contas Nacionais Trimestrais./ Note: Preliminary data for 2017 and 2018 are based on the Quarterly National Accounts.

(1) Inclusive eletricidade, gás, água e construção./ (1) Including electricity, gas, water and construction. 


\section{Tabela 10.3 - Composição do Produto Interno Bruto - PIB, sob a ótica da despesa - 2016-2018 \\ Table 10.3 - Composition of Gross Domestic Product - GDP, considering expenditures - 2016-2018}

\begin{tabular}{|c|c|c|c|c|c|c|}
\hline \multirow{2}{*}{$\begin{array}{l}\text { Composição/ } \\
\text { Composition }\end{array}$} & \multicolumn{3}{|c|}{$\begin{array}{l}\text { Valor (1 } 000000 \mathrm{R} \$) / \\
\text { Value }(1,000,000 \mathrm{R} \$)\end{array}$} & \multicolumn{3}{|c|}{$\begin{array}{l}\text { Percentual do PIB (\%)/ } \\
\text { Percentage of GDP (\%) }\end{array}$} \\
\hline & 2016 & 2017 & 2018 & 2016 & 2017 & 2018 \\
\hline $\begin{array}{l}\text { Produto interno bruto/ } \\
\text { Gross domestic product }\end{array}$ & 6267205 & 6553843 & 6827586 & 100,00 & 100,00 & 100,00 \\
\hline $\begin{array}{l}\text { Consumo final/ } \\
\text { Final consumption }\end{array}$ & 5303658 & 5502733 & 5738493 & 84,63 & 83,96 & 84,05 \\
\hline $\begin{array}{l}\text { Despesa de consumo das } \\
\text { famílias (1)/ }\end{array}$ & 4026013 & 4193880 & 4392357 & 64,24 & 63,99 & 64,33 \\
\hline $\begin{array}{l}\text { Final consumption expenditure of } \\
\text { households (1) }\end{array}$ & & & & & & \\
\hline $\begin{array}{l}\text { Despesa de consumo do governo } \\
\text { Final consumption expenditure } \\
\text { of general government }\end{array}$ & 1277645 & 1308853 & 1346136 & 20,39 & 19,97 & 19,72 \\
\hline $\begin{array}{l}\text { Formação bruta de capital/ } \\
\text { Gross capital formation }\end{array}$ & 938490 & 985412 & 1053000 & 14,97 & 15,04 & 15,42 \\
\hline $\begin{array}{l}\text { Exportação de bens e serviços/ } \\
\text { Exports of goods and services }\end{array}$ & 781577 & 824045 & 1010848 & 12,47 & 12,57 & 14,81 \\
\hline $\begin{array}{l}\text { Importação de bens e serviços (-)/ } \\
\text { Imports of goods and services (-) }\end{array}$ & (-) 756520 & (-) 758347 & (-) 974755 & (-) 12,07 & (-) 11,57 & (-) 14,28 \\
\hline
\end{tabular}

Fontes/Sources: 1. Sistema de contas nacionais: Brasil 2016. Rio de Janeiro: IBGE, 2018. Disponível em/Available from: <https://www.ibge.gov.br/estatisticas-novoportal/economicas/contasnacionais/9052-sistema-de-contas-nacionais-brasil.html>. Acesso em: jan. 2019/Cited: Jan . 2019. 2. Indicadores IBGE. Contas nacionais trimestrais: indicadores de volume e valores correntes out./dez. 2018. Rio de Janeiro: IBGE, 2018. Disponível em/Available from: <https://www.ibge.gov.br/estatisticasnovoportal/economicas/contas-nacionais/9300-contas-nacionais-trimestrais.html>. Acesso em: jan. 2019/Cited: Jan. 2019.

Nota: Os dados de 2017 e 2018 são preliminares baseados em Contas Nacionais Trimestrais./ Note: Preliminary data for 2017 and 2018 are based on the Quarterly National Accounts.

(1) Os dados de consumo das famílias incluem o consumo das famílias + despesa de consumo das instituições sem fins de lucro a serviço das famílias./ (1) Data for household consumption include household consumption + consumption expenditure of non-profit institutions serving households consumption expenditure. 
Tabela 10.4 - Variação da taxa trimestral do Produto Interno Bruto - PIB, por setor de atividade - 2017-2018

Table 10.4 - Quarterly rate change of the Gross Domestic Product - GDP, by sector of activity - 2017-2018

\begin{tabular}{|c|c|c|c|c|c|c|c|c|}
\hline \multirow{3}{*}{$\begin{array}{l}\text { Setor de atividade/ } \\
\text { Sector of activity }\end{array}$} & \multicolumn{8}{|c|}{$\begin{array}{c}\text { Taxa trimestral (\%)/ } \\
\text { Quarterly rate (\%) }\end{array}$} \\
\hline & \multicolumn{4}{|c|}{2017} & \multicolumn{4}{|c|}{2018} \\
\hline & $\begin{array}{l}10 \text { tri- } \\
\text { mestre/ } \\
1 s t \\
\text { quarter }\end{array}$ & $\begin{array}{l}20 \text { tri- } \\
\text { mestre/ } \\
\text { 2nd } \\
\text { quarter }\end{array}$ & $\begin{array}{l}30 \text { tri- } \\
\text { mestre/ } \\
\text { 3rd } \\
\text { quarter }\end{array}$ & $\begin{array}{l}4{ }^{\circ} \text { tri- } \\
\text { mestre/ } \\
4 \text { th } \\
\text { quarter }\end{array}$ & $\begin{array}{l}10 \text { tri- } \\
\text { mestre/ } \\
1 \text { st } \\
\text { quarter }\end{array}$ & $\begin{array}{l}2^{\circ} \text { tri- } \\
\text { mestre/ } \\
\text { 2nd } \\
\text { quarter }\end{array}$ & $\begin{array}{l}30 \text { tri- } \\
\text { mestre/ } \\
3 r d \\
\text { quarter }\end{array}$ & $\begin{array}{c}40 \text { tri- } \\
\text { mestre/ } \\
4 \text { th } \\
\text { quarter }\end{array}$ \\
\hline $\begin{array}{l}\text { Produto interno bruto a } \\
\text { preço de mercado / } \\
\text { Gross domestic product at } \\
\text { market prices }\end{array}$ & 0,1 & 0,6 & 1,4 & 2,2 & 1,2 & 0,9 & 1,3 & 1,1 \\
\hline $\begin{array}{l}\text { Agropecuária / } \\
\text { Agriculture }\end{array}$ & 18,7 & 14,2 & 8,8 & 4,5 & (-) 3,0 & 0,3 & 2,5 & 2,4 \\
\hline $\begin{array}{l}\text { Indústria / } \\
\text { Industry }\end{array}$ & (-) 1,8 & (-) 2,2 & (-) 0,3 & 2,5 & 1,2 & 0,8 & 0,8 & (-) 0,5 \\
\hline $\begin{array}{l}\text { Serviços / } \\
\text { Services }\end{array}$ & (-) 1,3 & 0,1 & 1,2 & 2,0 & 1,8 & 1,1 & 1,2 & 1,1 \\
\hline $\begin{array}{l}\text { Valor adicionado a preços } \\
\text { básicos / } \\
\text { Value added at basic prices }\end{array}$ & 0,2 & 0,6 & 1,2 & 2,0 & 1,0 & 0,9 & 1,3 & 1,2 \\
\hline
\end{tabular}

Fonte/Source: Indicadores IBGE. Contas nacionais trimestrais: indicadores de volume e valores correntes out./dez. 2018. Rio de Janeiro: IBGE, 2018. Disponível em/Available from : <https://www.ibge.gov.br/ estatisticas-novoportal/economicas/contas-nacionais/9300-contas-nacionais-trimestrais.html>. Acesso em: jan. 2019/Cited : Jan . 2019.

Notas: 1. Dados preliminares.

2. Variação percentual em relação ao mesmo trimestre do ano anterior./ Notes: 1. Preliminary data.

2. Percentage change from the same quarter of previous year. 
Tabela 10.5 - Principais relações macroeconômicas - 2016-2018

Table 10.5 - Main macroeconomic relationships - 2016-2018

\begin{tabular}{|c|c|c|c|}
\hline \multirow{2}{*}{$\begin{array}{l}\text { Principais relações/ } \\
\text { Main relationships }\end{array}$} & \multicolumn{3}{|c|}{$\begin{array}{l}\text { Percentual (\%)/ } \\
\text { Percentage (\%) }\end{array}$} \\
\hline & 2016 & 2017 & 2018 \\
\hline $\begin{array}{l}\text { Taxa de investimento/ } \\
\text { Investment rate }\end{array}$ & 15,5 & 15,0 & 15,8 \\
\hline $\begin{array}{l}\text { Taxa de poupança/ } \\
\text { Saving rate }\end{array}$ & 13,4 & 14,3 & 14,5 \\
\hline $\begin{array}{l}\text { Grau de abertura da economia/ } \\
\text { Degree of openness of the economy }\end{array}$ & 24,5 & 24,1 & 29,1 \\
\hline
\end{tabular}

Fonte/Source: IBGE, Diretoria de Pesquisas, Coordenação de Contas Nacionais.

Nota: Os dados de 2017 e 2018 são preliminares baseados em Contas Nacionais Trimestrais./ Note: Preliminary data for 2017 and 2018 are based on the Quarterly National Accounts. 


\section{Agropecuária Agriculture}

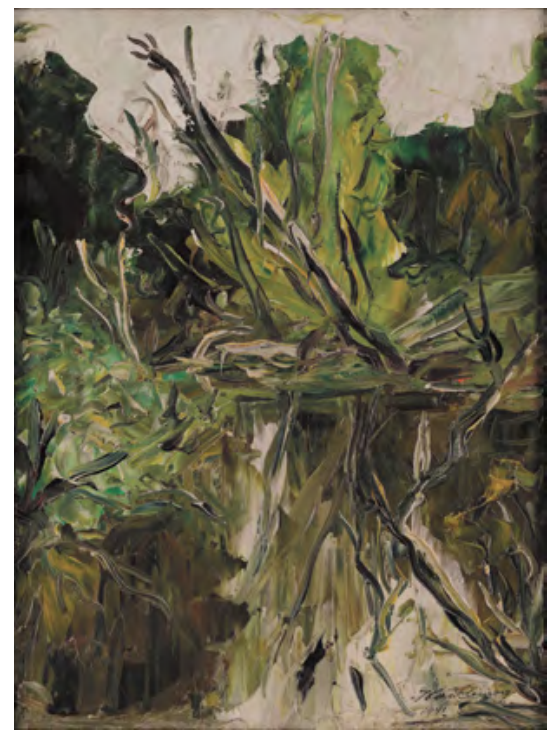

Jaguari, 1941

Jaguari

Iberê Camargo 


\title{
Agriculture
}

\author{
Daniela Dias Kühn ${ }^{1}$ \\ Paulo Dabdab Waquil2
}

Agriculture is a fundamental productive activity in Brazil, not only because of the production of food, fibers, fuels and raw-material for the industry, but also because of land occupation and use of workforce, income generation in the rural areas and its links with the agribusiness and trade. The main purpose of this brief text is to provide an overview of the activity in the most recent period of the Brazilian economy.

Such overview is grounded on data from the following IBGE surveys: Municipal Agricultural Production (PAM), Municipal Livestock Production (PPM), Survey of Stocks, Quarterly Survey of Animal Slaughter and Forestry Activities (PEVS) - all of them available on the IBGE System of Automatic Recovery (SIDRA), which also shows the contribution of some variables by Federation Units or Major Regions. The text also presents the status of crops, livestock farming, wood production and silviculture, including a section in the end dedicated to final remarks.

1 Assistant professor at the School of Economics and International Relations (DERI) of the Federal University of Rio Grande do Sul (UFRGS) and permanent professor at the Postgraduate Program in Rural Development (PGDR/UFRGS). Economist, Master and PhD in Rural Development from the PGDR/UFRGS.

2 Full professor at the School of Economics and International Relations (DERI) of the Federal University of Rio Grande do Sul (UFRGS) and at the Postgraduate Programs in Rural Development (PGDR/UFRGS) and at the Center of Studies and Research in Agribusiness (CEPAN/UFRGS). Agricultural Engineer, Master and PhD from the University of Wisconsin, United States. 


\title{
Agropecuária
}

\author{
Daniela Dias Kühn' \\ Paulo Dabdab Waquil2
}

A agropecuária é uma atividade produtiva fundamental no Brasil, não somente pela produção de alimentos, fibras, combustíveis e matérias primas para a indústria, mas também pela ocupação e utilização das terras, emprego de mão de obra, geração de renda no campo e seus encadeamentos agroindustriais e comerciais. O objetivo principal deste breve texto é apresentar um panorama geral desta atividade no período mais recente da economia brasileira.

O panorama utiliza os dados da Pesquisa Agrícola Municipal (PAM), Pesquisa da Pecuária Municipal (PPM), Pesquisa de Estoques, Pesquisa Trimestral do Abate de Animais e a Produção da Extração Vegetal e da Silvicultura (PEVS), disponibilizadas no Sistema IBGE de Recuperação Automática (SIDRA), referindo inclusive à participação de algumas dessas variáveis por Unidades da Federação ou por Grandes Regiões. O texto apresenta o panorama dos cultivos, da pecuária, da produção madeireira e da silvicultura, assim como uma seção dedicada às considerações finais.

1 Professora adjunta do Departamento de Economia e Relações Internacionais (DERI) da Universidade Federal do Rio Grande do Sul (UFRGS) e professora permanente do Programa de Pós-Graduação em Desenvolvimento Rural (PGDR/UFRGS). Economista, mestre e doutora em Desenvolvimento Rural pelo PGDR/UFRGS.

2 Professor titular do Departamento de Economia e Relações Internacionais (DERI) da Universidade Federal do Rio Grande do Sul (UFRGS) e dos Programas de Pós-Graduação em Desenvolvimento Rural (PGDR/UFRGS) e do Centro de Estudos e Pesquisa em Agronegócios (CEPAN/UFRGS). Engenheiro Agrônomo, mestre e doutor em Economia Agrícola pela University of Wisconsin, Estados Unidos. 


\section{Crop production: temporary and permanent crops}

In the last ten years (2007-2017), among the main items of crop production, there has been a rise in the amount produced, in the planted area and in the production value. The produced amount of cereals, legumes and oilseeds grew $78.64 \%$, going from 133.5 to 238.4 metric tons (PRODUÇÃO..., [2018b]). However, rather than the percentage value, it is the production increase that calls the attention: a growth of more than 100 million metric tons of grains in just one decade, in a period when no other country presented a similar change. Throughout the period, production decrease took place in just two years (2009 and 2016), due to long droughts in the main grain producing areas of the country.

In the period, the planted area growth was lower, equivalent to $33.49 \%$, expanding from a surface of 45.8 to 61.2 million hectares. The greatest part of the production growth was due to yield increases of the crops by area. On the other hand, the change in the production value for cereals, legumes and oilseeds was bigger, going from 56.7 to more than 174.6 billion reais, which can be attributable to the products' price rise. The greatest production value increase does not reveal much on the yield generated in the activity, as it also depends on the costs involved in the processes of production and trade.

Among the main crop products, the three with the largest harvested area in 2017 were: soybeans, with almost 34 million hectares; corn, with more than 17 million hectares; sugarcane, with a little more than 10 million hectares. Other products with more than one million hectares harvested in the country were beans, rice, coffee and cassava. Mato Grosso was the Federation Unit that boosted the production of soybeans, corn and upland cottonseed; São Paulo is the biggest producer of sugarcane, orange, banana and tomato; Minas Gerais comes as first in coffee and potatoes. Rio Grande do Sul appears as the biggest national producer of rice, tobacco and grapes, whereas Paraná is the greatest producer of beans and Pará, of cassava and acai berries. Four states (São Paulo, Mato Grosso and Rio Grande do Sul) concentrate $53.8 \%$ of the national agricultural production. When Minas Gerais, Goiás, Bahia and Mato Grosso do Sul are counted in, the figure goes to $80.8 \%$ of the agricultural production in the country (PRODUÇÃO..., [2018a]).

In the last few years, there was also a change in the stocks of the main grains in the country. In the 2016-2017 period, there was a recomposition of the stocks of corn, rice and soybeans, with a growth of $63.75 \%, 48.53 \%$ and $36.14 \%$, respectively. In relation to the stocks of 


\section{Produção vegetal: cultivos temporários e permanentes}

Nos últimos dez anos (2007-2017), nos principais itens da produção vegetal, percebe-se um aumento tanto na quantidade produzida, quanto na área plantada e no valor da produção. A quantidade produzida de cereais, leguminosas e oleaginosas cresceu $78,64 \%$, passando de 133,5 para 238,4 milhões de toneladas (PRODUÇÃO..., [2018b]). Entretanto, mais do que a variação percentual, chama a atenção o aumento na produção de mais de 100 milhões de toneladas de grãos em apenas um decênio, considerando que nenhum outro país apresentou variação desta magnitude no período. Ao longo do período, somente em dois anos, houve pequena queda de produção (2009 e 2016), por estiagens prolongadas nas principais regiões produtoras de grãos.

Neste período, o crescimento da área plantada foi menor, equivalente a 33,49\%, passando de uma superfície de 45,8 para 61,2 milhões de hectares. A maior parte do crescimento da produção se deve a aumentos de rendimento dos cultivos por unidade de área. Por outro lado, a variação no valor da produção de cereais, leguminosas e oleaginosas foi maior, passando de 56,7 para mais de 174,6 bilhões de reais, que pode ser compreendido também pela contribuição da elevação dos preços dos produtos. A maior elevação do valor da produção não permite afirmar algo sobre a renda gerada na atividade, a qual depende também dos custos envolvidos nos processos de produção e comercialização.

Entre os principais produtos vegetais, os três com maior área colhida em 2017 foram: a soja, com quase 34 milhões de hectares; o milho, com mais de 17 milhões de hectares; e a cana-de-açúcar, com pouco mais de 10 milhões de hectares. Outros produtos com mais de um milhão de hectares colhidos no País foram o feijão, arroz, café e mandioca. O Mato Grosso foi a Unidade da Federação que aparece como maior produtora de soja, milho e algodão herbáceo; São Paulo é o maior produtor de cana-de-açúcar, laranja, banana e tomate; Minas Gerais aparece como o maior produtor de café e de batata inglesa. O Rio Grande do Sul consta como o maior produtor nacional de arroz, tabaco e uva, enquanto o Paraná é o maior estado produtor de feijão, e o Pará o maior produtor de mandioca e açaí. Quatro estados (São Paulo, Mato Grosso, Paraná e Rio Grande do Sul) concentram 53,8\% da produção agrícola nacional. Incluindo os Estados de Minas Gerais, Goiás, Bahia e Mato Grosso do Sul, identifica-se 80,8\% da produção agrícola do País (PRODUÇÃO..., [2018a].

Ao longo dos anos mais recentes, percebeu-se também uma variação nos estoques dos principais grãos do País. Na passagem 2016-2017 ocorreu a recomposição dos estoques de milho, arroz e soja, com o crescimento de $63,75 \%, 48,53 \%$ e $36,14 \%$, 
wheat and coffee, there was a drop of $28.17 \%$ and $23.40 \%$, respectively, in the same period (PESQUISA..., [2018b]).

In general, in the period between 2007 and 2017, Brazilian crop production kept a strong growth, meeting the demands of both domestic and foreign markets. There was expansion in the planted area with some activities, especially soybeans, which spread over new areas; however, some other traditional crops, such as beans and cassava, lost area. The greatest highlight was the yield increase by crop hectare. It resulted from the changes in the technological patterns and in the use of inputs, now more intensive. Hindrances to the continuity of such crop performances can be attributable to the limited access and use of resources, environmental impacts, reduced possibilities of income gain due to the proximity to productivity limits and restricted access to the markets.

\section{Animal production}

Brazil has, in animal production, a great and diverse relevance, occupying large areas for animal farming, generation of animal products and factory farming. Between 2016 and 2017, there were little variations in the animal inventories of the country. Cattle inventories, which had been declining along time, have now presented a little reduction of $1.5 \%$, falling from 218.2 to 214.9 million animals. The inventories of hogs and pigs and poultry were the ones with the biggest rises, respectively of $3.0 \%$ and $6.0 \%$, reaching 41.1 million hogs and pigs and 1.42 billion poultry. On the other hand, sheep and goats had reductions of $2.3 \%$ and $1.9 \%$, respectively (PESQUISA..., [2018a]). Such moves tend to show that the reduction of cattle, sheep and goats, in more extensive production schemes, is probably a result of the advance of temporary crops, mainly soybeans, into pasture lands.

Even with the oscillations in the animal inventories, meat production went on growing. The amount of carcasses has grown along the last years. Considering the period from 2012 to 2017, the weight of cattle carcasses went through three years of reduction, but in the last year it started to grow again, reaching almost 7.7 million metric tons, $4.49 \%$ above the value in 2012 (PESQUISA..., [2018a]).

Milk is the most representative animal product in the Brazilian livestock production, reaching more than 33 million liters per year. Between 2016 and 2017, there was a small decrease of $0.5 \%$ in the amount produced of this item, but also a bigger drop, of $6.0 \%$, in the production value, indicating that the market that pushes, through 
respectivamente. Em relação aos estoques de trigo e café, houve uma queda de $28,17 \%$ e 23,40\%, respectivamente, para o mesmo período (PESQUISA..., [2018b]).

De forma geral, no período compreendido entre 2007 e 2017, a produção vegetal no Brasil manteve forte crescimento, respondendo às demandas tanto no mercado interno como externo. Houve a expansão da área cultivada com algumas atividades, especialmente a soja que avançou sobre novas áreas, mas a retração de áreas de outros cultivos mais tradicionais, como o feijão e a mandioca. Contudo, o fator que mais se destacou foi o aumento no rendimento por hectare dos cultivos, resultante de mudanças nos padrões tecnológicos e utilização mais intensiva de insumos. Possíveis limitações à continuidade deste desempenho da produção vegetal podem ser expressas pelas restrições no acesso e utilização de recursos, impactos ambientais, redução das possibilidades de ganhos de rendimento pela aproximação dos limites de produtividade, e restrições no acesso a mercados.

\section{Produção animal}

O Brasil tem, na produção animal, uma relevância grande e diversificada, ocupando extensas áreas para a manutenção dos rebanhos, geração de produtos de origem animal, e produção de animais para o abate. Entre 2016 e 2017, existiram pequenas variações no efetivo dos rebanhos no País. O rebanho bovino, que ao longo do tempo vinha apresentando crescimento, agora apresentou uma pequena redução de 1,5\%, caindo de 218,2 para 214,9 milhões de animais. Os efetivos de suínos e aves foram os que apresentam os maiores aumentos, respectivamente de 3,0\% e 6,0\%, atingindo 41,1 milhões de suínos e 1,42 bilhão de aves. Por outro lado, os rebanhos de ovinos e caprinos tiveram reduções de 2,3\% e 1,9\% respectivamente (PESQUISA..., [2018a]). Tais movimentos permitem apontar que a redução dos rebanhos bovino, ovino e caprino, em sistemas de produção mais extensivos, é um possível resultado do avanço dos cultivos de lavouras temporárias, principalmente a soja, também sobre áreas de pastagens.

Mesmo com as variações nos efetivos dos rebanhos, a produção de carnes seguiu em crescimento. A quantidade produzida de carcaças teve crescimento ao longo dos últimos anos. Considerando o período de 2012 a 2017, o peso das carcaças bovinas passou por três anos de redução, mas no último ano voltou a crescer, atingindo quase 7,7 milhões de toneladas, 4,49\% acima do valor de 2012 (PESQUISA..., [2018a]).

O leite é o produto de origem animal mais presente na produção pecuária brasileira, atingindo mais de 33 bilhões de litros por ano. Entre 2016 e 2017, houve uma pequena queda de $0,5 \%$ na quantidade produzida deste item, mas uma queda maior, de $6,0 \%$, no valor da produção, indicando um mercado que pressiona, através dos preços, a estrutura de custos dos produtores. Entre os outros produtos de origem 
prices, the cost structure of producers. Among the other animal products, in the period of 2016-2017, the highest growth, both in amount produced and in production values, was in the production of hen eggs, with a change of $11.60 \%$ and $18.30 \%$, respectively. On the other hand, the production of wool, fish and shrimp had decreases, the amount produced of shrimp (21.4\%) represented the sharpest drop, but it was offset by the price increase, almost keeping the production value stable. Considering that production of freshwater fish, the biggest production was of tilapias, which surpassed the mark of 283 thousand metric tons and encompassed $58.37 \%$ of fish farming production (PESQUISA..., [2018a]).

Also in animal production, Brazil had changes in the producing structure in the last years, which led to differences in the animal inventories. Some more extensive systems have been replaced by intensive ones, by means of more input in the pursuit for a better performance, although at higher costs. This trend depends on the price behavior in the domestic and foreign markets. Meat production and other animal products are still faced with issues as quality and sanity in order to consolidate the current markets and open new ones.

\section{Wood production and silviculture}

The total data on wood production in the country, both for vegetal extraction and silviculture, indicate that there has been a reduction in the production of vegetal charcoal (metric tons) of $2.86 \%$, in the period from 2016-2017. In that same period, the production of logs (in $\mathrm{m}^{3}$ ) also decreased by $1.70 \%$, representing small changes in the energy matrix in the rural area. However, wood production (in $\mathrm{m}^{3}$ ) increased by $4.73 \%$. Silviculture is responsible for the production of $92 \%$ of the country's wood, producing in 2017 almost 140 million $\mathrm{m}^{3}$ of wood. Of this total, more than 87 million $\mathrm{m}^{3}$ (63\% of the total) was destined to the production of pulp and paper. Considering the total area of forest plantations of eucalyptus, pine and other species in the Brazilian Major Regions, for the year 2017, the production encompassed a total area of 9.8 million hectares, with a higher occupation in the South $(36.5 \%)$ and Southeast Regions (34.0\%), followed by the Central-West (15.8\%), Northeast (9.0\%) and North Regions (4.7\%) (PRODUCTION ..., [2018b]).

\section{Final remarks}

In general, between 2016 and 2017, the production growth process and productivity rise of the main products were quite evident. The loss of dynamism, which can sometimes be seen in other economic sectors, has not occurred in the recent years of the agricultural activity. 
animal, no período 2016-2017, o maior crescimento, tanto em quantidade produzida como em valor de produção, foi da produção de ovos de galinha, com uma variação de $11,60 \%$ e $18,30 \%$, respectivamente. Por outro lado, a produção de lã, peixes e camarões mostrou reduções, sendo a mais significativa a redução na quantidade produzida de camarões, de $21,4 \%$, mas que foi compensada por elevação no preço, praticamente mantendo o valor da produção estável. Considerando a produção de peixes em águas doces, a maior produção foi de tilápias, que ultrapassou a marca das 283 mil toneladas e abarcou 58,37\% da produção da piscicultura (PESQUISA..., [2018a]).

Também na produção animal o Brasil apresentou mudanças em sua estrutura produtiva nos anos mais recentes, levando a alterações nos efetivos dos rebanhos. Alguns sistemas mais extensivos têm sido substituídos por sistemas intensivos, utilizando mais insumos em busca de um melhor desempenho, embora com custos mais elevados, trajetória que é dependente do comportamento de preços nos mercados internos e externos. A produção de carnes e outros produtos de origem animal ainda mantém como desafio o enfrentamento das questões associadas à qualidade e sanidade para a consolidação dos atuais e para a abertura de novos mercados.

\section{Produção madeireira e silvicultura}

Os dados totais para a produção madeireira no País, tanto da extração vegetal como da silvicultura, indicam que há uma redução na produção de carvão vegetal (medida em toneladas) de 2,86\%, no período 2016-2017. No mesmo período, a produção de lenha (em $\mathrm{m}^{3}$ ) também decresceu em 1,70\%, representando pequenas mudanças na base energética no meio rural. Entretanto, a produção de madeira em tora $\left(\mathrm{em} \mathrm{m}^{3}\right.$ ) aumentou em $4,73 \%$. A silvicultura é responsável pela produção de 92\% da madeira em tora do País, produzindo, em 2017, quase 140 milhões de $\mathrm{m}^{3}$ do produto. Deste total, mais de 87 milhões de $\mathrm{m}^{3}$ (63\% do total) teve como destino a produção de papel e celulose. Considerando a área total dos cultivos florestais de eucalipto, pinus e outras espécies nas Grandes Regiões brasileiras, para o ano de 2017, a produção utilizou uma área total de 9,8 milhões de hectares, com maior ocupação nas Regiões Sul $(36,5 \%)$ e Sudeste $(34,0 \%)$, seguidas da Região Centro-Oeste (15,8\%), Nordeste $(9,0 \%)$ e Norte (4,7\%) (PRODUÇÃO..., [2018b]).

\section{Considerações finais}

De uma maneira geral, percebe-se entre 2016 e 2017, a manutenção de um processo de crescimento da produção e da produtividade nos principais produtos, aqui evidenciados. A perda de dinamicidade que eventualmente pode ser descrita em outros setores econômicos, não se retrata nos anos recentes na atividade agropecuária. 
The search for specialization and the insertion of new technologies to provide productivity gains and a better position in the international rankings also require studies to identify the impacts or consequences of such an expansion. The pursuit for productive indicators should not be detached from the concern about the extinction of the producing factors themselves, as landscape changes and water resources - a very much discussed issue.

It is also important to highlight that the better position in the markets depends not only on the performance of the production sector, but also on a major attention to the trading processes, including investment in infrastructure to make it easier to store and drain the agricultural production flows. In the domestic sphere, measures such as more favorable policies of credit access and technical assistance, support to family farming, incentive to the price and risk management are important to preserve the dynamism of the sector. In the international context, both the bilateral negotiation processes and the strengthening of the regional agreements already in effect can help consolidate and expand the markets for the Brazilian agriculture.

\section{References}

PESQUISA da pecuária municipal 2016-2017. In: IBGE. Sidra: sistema IBGE de recuperação automática. Rio de Janeiro, [2018a]. tab.74, 3939, 3940. Available from: <https://sidra.ibge.gov.br/pesquisa/ppm/quadros/brasil/2017>. Cited: Apr 2019.

PESQUISA de estoques 2011-2017. In: IBGE. Sidra: sistema IBGE de recuperação automática. Rio de Janeiro, [2018b]. tab. 255. Available from: <https://sidra.ibge.gov.br/home/estoques>. Cited: Apr 2019.

PRODUÇÃO agrícola municipal 2007-2017. In: IBGE. Sidra: sistema IBGE de recuperação automática. Rio de Janeiro, [2018b]. tab. 5457. Available from: <https://sidra.ibge.gov.br/pesquisa/pam/tabelas>. Cited: Apr 2019.

PRODUÇÃO da extração vegetal e da silvicultura 2016-2017. In: IBGE. Sidra: sistema IBGE de recuperação automática. Rio de Janeiro, [2018b]. tab. 289, 291, 5930. Available from: <https://sidra.ibge.gov.br/pesquisa/pevs/ quadros/brasil/2017>. Cited: Jan 2019.

PESQUISA trimestral do abate de animais 2012-2017. In: IBGE. Sidra: sistema IBGE de recuperação automática. Rio de Janeiro, [2018c]. tab.1092. Available from: <https://sidra.ibge.gov.br/home/abate/brasil>. Cited: Dec 2018.

Translated by: Gisele Flores Caldas Manhães 
A busca por especialização e incorporação de tecnologia que permitam ganhos de produtividade e um melhor posicionamento produtivo no cenário internacional, também exige estudos que identifiquem os impactos ou consequências dessa expansão. A busca pelos indicadores produtivos não deve prescindir de cuidados em relação à exaustão dos próprios fatores produtivos, como as transformações da paisagem e o debate sobre a utilização dos recursos hídricos.

Também é importante destacar que o melhor posicionamento nos mercados depende não apenas do desempenho do setor produtivo, mas também de uma maior atenção aos processos de comercialização com investimentos em infraestrutura, possibilitando melhores fluxos para o armazenamento e escoamento da produção agropecuária. No cenário doméstico, medidas como as políticas mais favoráveis de acesso a crédito e assistência técnica, manutenção do apoio à agricultura familiar, incentivos à gestão de riscos de produção e de preços, são importantes para preservar o dinamismo deste setor. No cenário internacional, tanto os processos de negociação bilateral, como o fortalecimento dos acordos regionais já firmados, podem ajudar na consolidação e ampliação dos mercados para a agropecuária brasileira.

\section{Referências}

PESQUISA da pecuária municipal 2016-2017. In: IBGE. Sidra: sistema IBGE de recuperação automática. Rio de Janeiro, [2018a]. tab.74, 3939, 3940. Disponível em: <https://sidra.ibge.gov.br/pesquisa/ppm/quadros/brasil/2017>. Acesso em:abr. 2019.

PESQUISA de estoques 2011-2017. In: IBGE. Sidra: sistema IBGE de recuperação automática. Rio de Janeiro, [2018b]. tab. 255. Disponível em: <https://sidra.ibge.gov. br/home/estoques>. Acesso em: abr. 2019.

PRODUÇÃO agrícola municipal 2007-2017. In: IBGE. Sidra: sistema IBGE de recuperação automática. Rio de Janeiro, [2018a]. tab. 5457. Disponível em: <https://sidra.ibge.gov. br/pesquisa/pam/tabelas>. Acesso em: abr. 2019.

PRODUÇÃO da extração vegetal e da silvicultura 2016-2017. In: IBGE. Sidra: sistema IBGE de recuperação automática. Rio de Janeiro, [2018b]. tab. 289, 291, 5930. Disponível em: <https://sidra.ibge.gov.br/pesquisa/pevs/quadros/brasil/2017>. Acesso em: jan. 2019.

PESQUISA trimestral do abate de animais 2012-2017. In: IBGE. Sidra: sistema IBGE de recuperação automática. Rio de Janeiro, [2018c]. tab.1092. Disponível em: <https:// sidra.ibge.gov.br/home/abate/brasil>. Acesso em: dez. 2018. 


\section{Tabela 11.1 - Principais produtos agrícolas, segundo valor da produção e}

principal Unidade da Federação produtora - 2017

Table 11.1 - Major agricultural crops, according to the value of production and main producer Federation Unit - 2017

\begin{tabular}{|c|c|c|c|c|c|}
\hline \multirow{2}{*}{$\begin{array}{c}\text { Principais } \\
\text { produtos/ } \\
\text { Main products }\end{array}$} & \multirow{2}{*}{$\begin{array}{l}\text { Área } \\
\text { colhida } \\
\text { (ha)/ } \\
\text { Harvested } \\
\text { area } \\
\text { (ha) }\end{array}$} & \multirow{2}{*}{$\begin{array}{l}\text { Quanti- } \\
\text { dade } \\
\text { produ- } \\
\text { zida (t)/ } \\
\text { Total } \\
\text { production (t) }\end{array}$} & \multirow{2}{*}{$\begin{array}{c}\text { Rendi- } \\
\text { mento } \\
\text { médio } \\
\text { (kg/ha)/ } \\
\text { Average } \\
\text { yield } \\
(\mathrm{kg} / \mathrm{ha})\end{array}$} & \multicolumn{2}{|c|}{$\begin{array}{l}\text { Principal produtor/ } \\
\text { Major producer }\end{array}$} \\
\hline & & & & $\begin{array}{l}\text { Unidades da } \\
\text { Federação/ } \\
\text { Federation } \\
\text { Units }\end{array}$ & $\begin{array}{l}\text { Quantidade } \\
\text { produzida (t)/ } \\
\text { Production }(t)\end{array}$ \\
\hline $\begin{array}{l}\text { Soja (em grão)/ } \\
\text { Soybean (grain) }\end{array}$ & 33936223 & 114599168 & 3377 & Mato Grosso & 30479870 \\
\hline $\begin{array}{l}\text { Cana-de-açúcar/ } \\
\text { Sugarcane }\end{array}$ & 10184340 & 758548292 & 74482 & São Paulo & 450424570 \\
\hline $\begin{array}{l}\text { Milho (em grão)/ } \\
\text { Corn (grain) }\end{array}$ & 17393563 & 97721860 & 5618 & Mato Grosso & 29942322 \\
\hline $\begin{array}{l}\text { Café (em grão)/ } \\
\text { Coffee beans }\end{array}$ & 1800398 & 2680515 & 1489 & Minas Gerais & 1454779 \\
\hline $\begin{array}{l}\text { Mandioca/ } \\
\text { Cassava }\end{array}$ & 1314851 & 18876470 & 14356 & Pará & 4234797 \\
\hline $\begin{array}{l}\text { Arroz (em casca)/ } \\
\text { Paddy rice }\end{array}$ & 2008117 & 12469516 & 6210 & Rio Grande do Sul & 8733110 \\
\hline $\begin{array}{l}\text { Laranja/ } \\
\text { Oranges } \\
\text { Algodão herbáceo }\end{array}$ & 631686 & 17459908 & 27640 & São Paulo & 13357732 \\
\hline $\begin{array}{l}\text { (em caroço)/ } \\
\text { Upland cottonseed }\end{array}$ & 927987 & 3842872 & 4141 & Mato Grosso & 2578596 \\
\hline $\begin{array}{l}\text { Banana/ } \\
\text { Bananas }\end{array}$ & 465434 & 6675100 & 14342 & São Paulo & 1084514 \\
\hline $\begin{array}{l}\text { Feijão (em grão)/ } \\
\text { Bean seed }\end{array}$ & 2795284 & 3033017 & 1085 & Paraná & 691867 \\
\hline $\begin{array}{l}\text { Fumo (em folha)/ } \\
\text { Tobacco (leaves) }\end{array}$ & 398418 & 880881 & 2211 & Rio Grande do Sul & 414488 \\
\hline $\begin{array}{l}\text { Açaí/ } \\
\text { Acaiberry/ }\end{array}$ & 195006 & 1334517 & 6843 & Pará & 1274056 \\
\hline $\begin{array}{l}\text { Tomate/ } \\
\text { Tomatoes }\end{array}$ & 61534 & 4230150 & 68745 & São Paulo & 930163 \\
\hline $\begin{array}{l}\text { Uva } \\
\text { Grape }\end{array}$ & 75510 & 1912034 & 25322 & Rio Grandedo Sul & 956887 \\
\hline $\begin{array}{l}\text { Batata-inglesa/ } \\
\text { Potatoes }\end{array}$ & 118030 & 3656846 & 30982 & Minas Gerais & 941590 \\
\hline
\end{tabular}

Fonte/Source: Produção agrícola municipal 2017. In: IBGE. Sidra: sistema IBGE de recuperação automática. Rio de Janeiro, [2018]. tab. 5457. Disponível em/Available from:<https://sidra.ibge.gov.br/ pesquisa/pam/tabelas>. Acesso em: jan. 2019/Cited: Jan. 2019.

(1) Quantidade produzida em mil frutos e rendimento médio em frutos/ha. / Quantity produced in one thousand fruits and average yield in fruits/ha. 
Tabela 11.2 - Efetivo dos rebanhos e das aves - 2016-2017

Table 11.2 - Number of livestock and poultry on farms - 2016-2017

Tipos/

Type
Efetivos (1 000 cabeças)/Number (1,000 head)

2017
Bovinos/

Cattle

Bubalinos/

Buffaloes

Equinos/

Horses

Suínos - total (1)/

Hogs and pigs - total (1)

Suínos - matrizes de suínos/

Hogs and pigs - breeding sows

Caprinos/

Goats

Ovinos/

Sheep

Galináceos (2)/

Poultry (2)

Galinhas/

Hens

Codornas/

Quails
218200

214900

1371

1381

5576

5502

39893

41099

4832

4745

9775

9592

18404

17976

1345405

1425700

217879

242767

13810

15474

Fonte/Source: Pesquisa da pecuária municipal 2016-2017. In: IBGE. Sidra: sistema IBGE de recuperação automática. Rio de Janeiro, [2018]. tab. 3939. Disponível em/Availabe from: <https://sidra.ibge.gov.br/ pesquisa/ppm/tabelas/brasil/2017>. Acesso em: dez. 2018/Cited:Dec. 2018.

(1) Inclui matrizes de suínos/ Including breeding sows. (2) Inclui galinhas/ Including hens. 
Tabela 11.3 - Quantidade e valor dos produtos de origem animal e variação anual - 2016-2017

Table 11.3 - Amount and value of products of animal origin and annual variation - 2016-2017

\begin{tabular}{|c|c|c|c|c|c|c|}
\hline \multirow[t]{2}{*}{$\begin{array}{l}\text { Produtos/ } \\
\text { Products }\end{array}$} & \multicolumn{2}{|c|}{$\begin{array}{l}\text { Quantidade produzida/ } \\
\text { Total production }\end{array}$} & \multirow{2}{*}{$\begin{array}{c}\text { Variação/ } \\
\text { Change } \\
2017 / \\
2016\end{array}$} & \multicolumn{2}{|c|}{$\begin{array}{l}\text { Valor da produção/ } \\
\text { Value of production } \\
\quad(1000 \mathrm{R} \$)\end{array}$} & \multirow{2}{*}{$\begin{array}{c}\text { Variação/ } \\
\text { Change } \\
2017 / \\
2016\end{array}$} \\
\hline & 2016 & 2017 & & 2016 & 2017 & \\
\hline $\begin{array}{l}\text { Leite (1 } 000 \text { litros)/ } \\
\text { Milk (1,000 liters) }\end{array}$ & 33656162 & 33490810 & (-) 0,5 & 39480372 & 37099058 & (-) 6,0 \\
\hline $\begin{array}{l}\text { Ovos de galinha ( } 1000 \text { dúzias)/ } \\
\text { Hen eggs (1,000 dozens) }\end{array}$ & 3802943 & 4245284 & 11,6 & 11451517 & 13548015 & 18,3 \\
\hline $\begin{array}{l}\text { Ovos de codorna ( } 1000 \text { dúzias)/ } \\
\text { Quail eggs ( } 1,000 \text { dozens) }\end{array}$ & 273419 & 290820 & 6,4 & 265703 & 278000 & 4,6 \\
\hline $\begin{array}{l}\text { Mel de abelha }(\mathrm{t}) / \\
\text { Honey }(t)\end{array}$ & 39619 & 41594 & 5,0 & 471084 & 513907 & 9,1 \\
\hline $\begin{array}{l}\text { Casulos de bicho-da-seda (t)/ } \\
\text { Silkworn cocoons ( } t \text { ) }\end{array}$ & 2855 & 3035 & 6,3 & 48189 & 52653 & 9,3 \\
\hline $\begin{array}{l}\text { Lã }(\mathrm{t}) / \\
\text { Wool (t) }\end{array}$ & 9756 & 9367 & (-) 4,0 & 87179 & 82821 & (-) 5,0 \\
\hline $\begin{array}{l}\text { Peixes }(\mathrm{t}) / \\
\text { Fish }(t)\end{array}$ & 498206 & 485254 & (-) 2,6 & 3204742 & 3071140 & (-) 4,2 \\
\hline $\begin{array}{l}\text { Camarão (t)/ } \\
\operatorname{Shrimp}(t)\end{array}$ & 52119 & 40967 & (-) 21,4 & 888933 & 887786 & (-) 0,1 \\
\hline
\end{tabular}

Fonte/Source: Pesquisa da pecuária municipal 2016-2017. In: IBGE. Sidra sistema IBGE de recuperação automática. Rio de Janeiro, [2018]. tab. 74, 3940. Disponível em/Available from: <https://sidra.ibge. gov.br/pesquisa/ppm/tabelas/brasil/2017>. Acesso em: dez. 2018/Cited :Dec. 2018. 
Tabela 11.4 - Produção madeireira da extração vegetal e da silvicultura - 2016-2017

Table 11.4 - Production from wood wild crop harvesting and silviculture 2016-2017

\begin{tabular}{|c|c|c|}
\hline \multirow{2}{*}{$\begin{array}{l}\text { Produtos/ } \\
\text { Products }\end{array}$} & \multicolumn{2}{|c|}{ Quantidade obtida/ Total production } \\
\hline & 2016 & 2017 \\
\hline
\end{tabular}

Extração vegetal/Wild crop harvesting

Carvão vegetal ( $\mathrm{t}) /$

Charcoal ( $t$ )

Lenha $\left(\mathrm{m}^{3}\right) /$

Firewood (cubic meters)

Madeira em tora $\left(\mathrm{m}^{3}\right) /$

11454256

12232762

Logwood (cubic meters)

Silvicultura/ Silviculture

Carvão vegetal (t)/

Charcoal ( $t$ )

Lenha $\left(\mathrm{m}^{3}\right) /$

53354902

55524110

Firewood (cubic meters)

Madeira em tora $\left(\mathrm{m}^{3}\right) /$

133732370

139826511

Logwood (cubic meters)

Para papel e celulose $\left(\mathrm{m}^{3}\right) /$

85152174

87739560

For paper and pulp $\left(\mathrm{m}^{3}\right)$

Para outras finalidades $\left(\mathrm{m}^{3}\right) /$

48580196

52086951

For other uses $\left(\mathrm{m}^{3}\right)$

Fonte/Source: Produção da extração vegetal e da silvicultura 2016-2017. In: IBGE. Sidra: sistema IBGE de recuperação automática. Rio de Janeiro, [2018]. tab. 289, 291. Disponível em/Available from: <https://sidra.ibge.gov.br/pesquisa/pevs/quadros/brasil/2017>.Acesso em: jan. 2019/Cited: Jan. 2019. 


\section{Gráfico 11.1 - Área plantada, quantidade produzida e valor da produção de cereais, leguminosas e oleaginosas - 2007-2017}

Graph 11.1 - Planted area, amount produced and value of production of cereals, legumes and oilseeds - 2007-2017

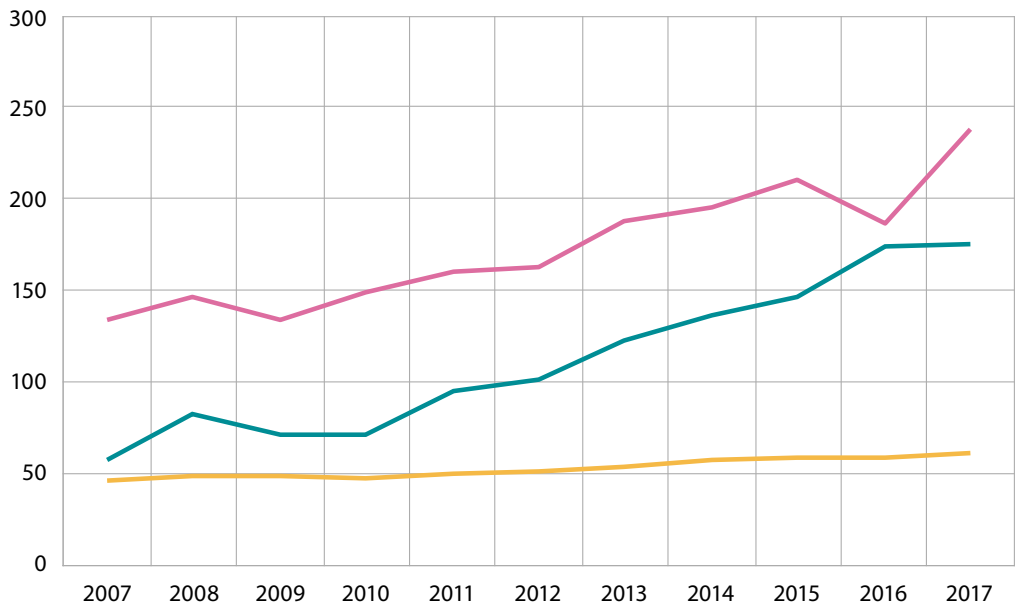

— Valor da produção (R\$ bilhões) Value of production (billions of $R \$$ )
Quantidade produzida (1 $000000 \mathrm{t})$ Amount produced $(1,000,000 t)$

Área plantada (1 $000000 \mathrm{ha})$

Planted area $(1,000,000$ ha $)$

Fonte/Source: Produção agrícola municipal 2007-2017. In: IBGE. Sidra: sistema IBGE de recuperação automática. Rio de Janeiro, [2018]. tab. 5457. Disponível em/Available from: <https://sidra.ibge. gov.br/pesquisa/pam/tabelas>. Acesso em: jan. 2019/Cited: Jan. 2019.

Nota: Compreende a produção de algodão arbóreo (em caroço), algodão herbáceo (em caroço), amendoim em casca, arroz em casca, aveia em grão, centeio em grão, cevada em grão, feijão em grão, girassol em grão, mamona, milho em grão, soja em grão, sorgo em grão, trigo em grão e triticale em grão./Note: Comprises the production of tree cotton (in seed), upland cotton (in seed), peanuts (in shell), rice (in the husk), oat (grain), rye (grain), barley (grain), beans (grain), and sunflower (grain), castor beans, corn (grain), soybeans (grain), sorghum (grain), wheat (grain) and triticale (grain). 


\section{Gráfico 11. 2 - Participação das Unidades da Federação no valor da produção agrícola - 2017}

Graph 11.2 -Brazilian states participation in the value of agricultural production - 2017

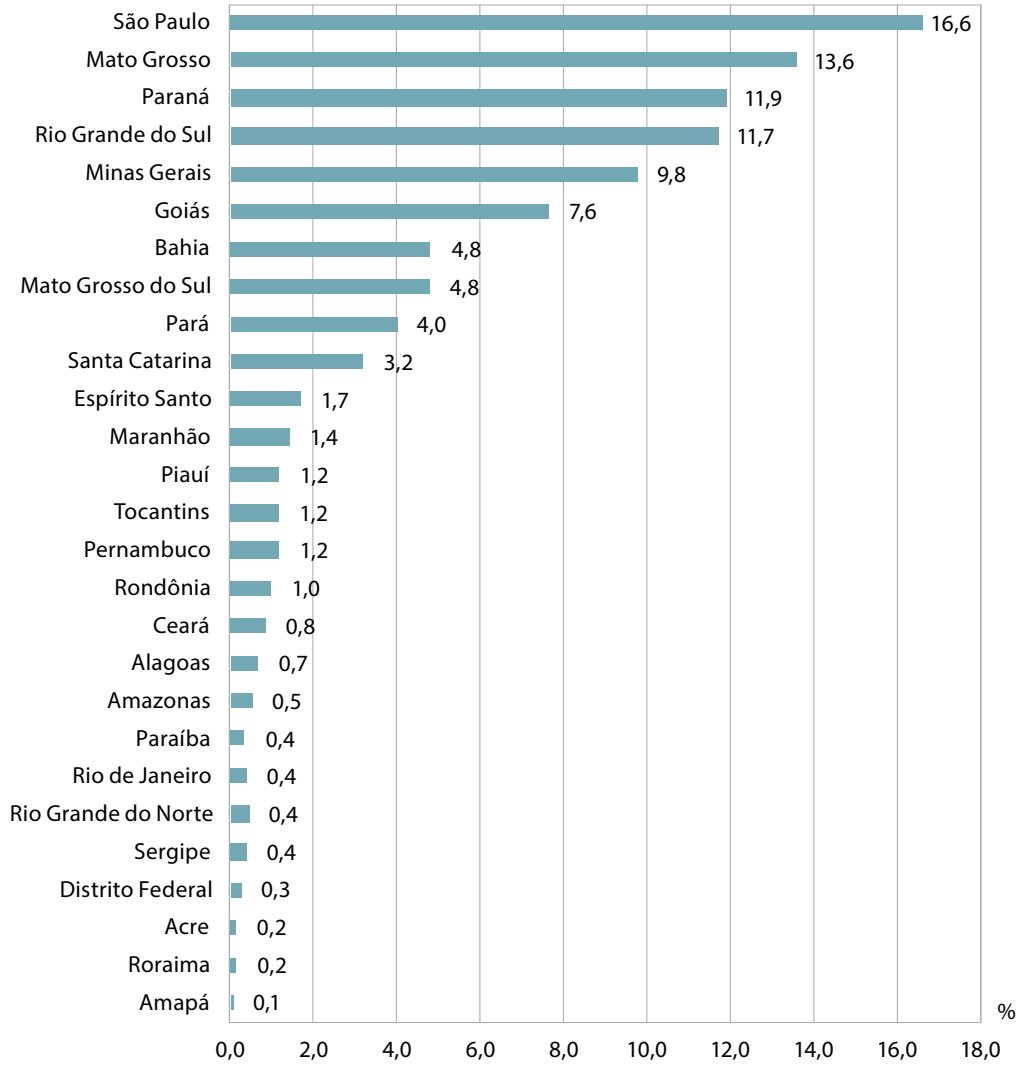

Fonte/Source: Produção agrícola municipal 2017. In: IBGE. Sidra: sistema IBGE de recuperação automática. Rio de Janeiro, [2018]. Disponível em/Available from: <https://sidra.ibge.gov.br/ pesquisa/pam/tabelas>. Acesso em: jan. 2019/Cited: Jan. 2019. 


\section{Gráfico 11.3 - Estoques dos principais produtos armazenados em 31.12 - 2011-2017}

Graph 11.3 - Stocks of main products stored on Dec 31 - 2011-2017

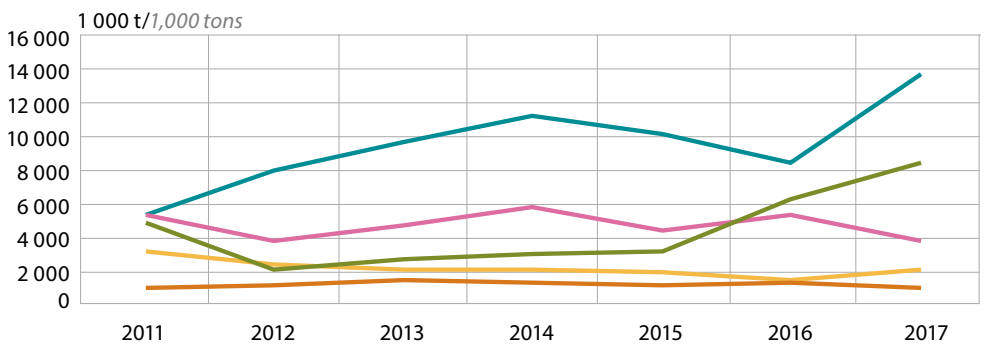
$\begin{array}{lll}\text { Milho (em grão) } & \text { Trigo (em grão) } & \text { Wheat (grain) }\end{array} \quad \begin{gathered}\text { Arroz (em casca) } \\ \text { Corn (grain) }\end{gathered}$
- Soja (em grão)
Soybeans (grain)
Café (em grão)
Coffe beans

Fonte/Source: Pesquisa de 2011-2017. In: IBGE. Sidra: sistema IBGE de recuperação. In: IBGE. Sidra: sistema IBGE de recuperação automática. Rio de Janeiro, [2018]. tab. 255. Disponível em/Available from: <https://sidra.ibge.gov.br/home/estoques/brasil>. Acesso em: jan. 2019/Cited: Jan. 2019.

\section{Gráfico 11.4 - Peso das carcaças - 2012-2017}

\section{Graph 11.4 - Weight of carcasses - 2012-2017}

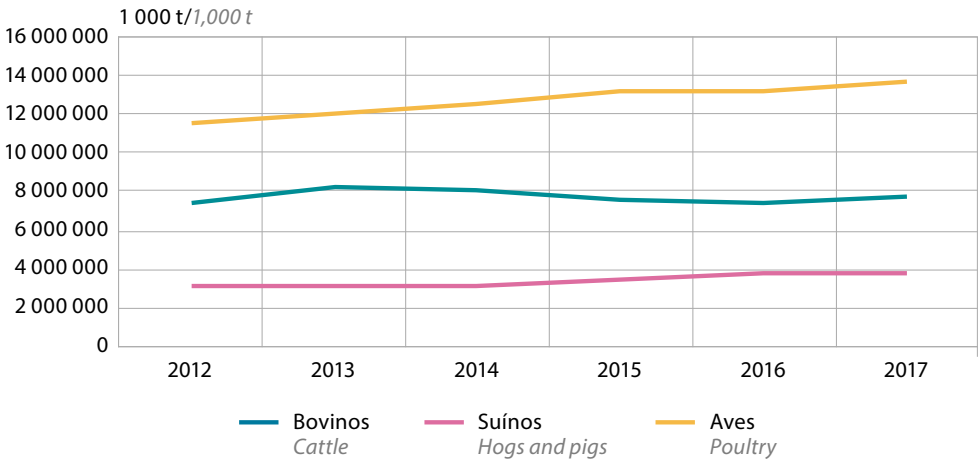

Fonte/Source: Pesquisa trimestral do abate de animais 2012-2017. In: IBGE. Sidra: sistema IBGE de recuperação automática. Rio de Janeiro, [2018]. tab. 1092. Disponível em/Availabe from: <https://sidra. ibge.gov.br/home/abate>. Acesso em: dez. 2018/Cited: Dec. 2018. 


\section{Gráfico 11.5 - Participação das principais espécies \\ na produção da piscicultura - 2017 \\ Graph 11.5 - Participation of the main species \\ in the production of fish farming - 2017}

$10,8 \%$

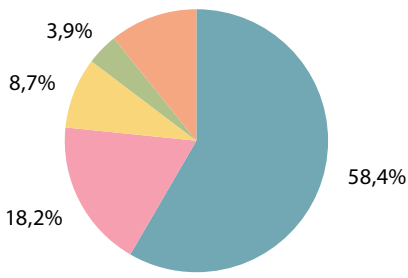

\begin{tabular}{llll|l} 
Tilápia & Tambaqui & Tambacu e Tambatinga & Carpa & $\begin{array}{l}\text { Outros peixes } \\
\text { Otherfishes }\end{array}$ \\
Tilapia & Tambaqui & Tambacuand Tambatinga & Carp & Thand
\end{tabular}

Fonte/Source: Pesquisa da pecuária municipal 2017. In: IBGE. Sidra: sistema IBGE de recuperação automática. Rio de Janeiro, [2018]. tab. 3940. Disponível em/Availabe from: <https://sidra.ibge.gov.br/pesquisa/ppm/ tabelas/brasil/2017>. Acesso em: dez. 2018/Cited:Dec. 2018.

\section{Gráfico 11.6 - Área total existente em 31.12 dos efetivos da silvicultura, por Grandes Regiões - 2017 \\ Graph 11.6 - Total silviculture area existing on Dec 31, by Major Regions - 2017}

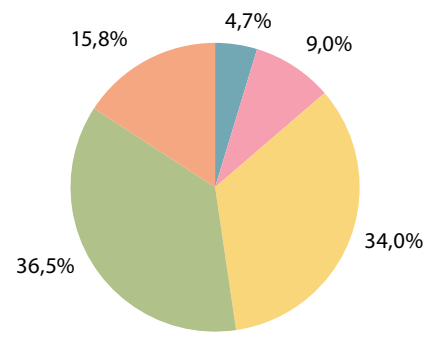
Norte
Nordeste
Sudeste
Sul
North
Northeast
Southeast
South
Centro-Oeste
Central-West

Fonte/Source: Produção da extração vegetal e da silvicultura 2017. In: IBGE. Sidra: sistema IBGE de recuperação automática. Rio de Janeiro, [2018]. tab. 5930. Disponível em/Available from:

<https://sidra.ibge.gov.br/pesquisa/pevs/quadros/brasil/2017>. Acesso em: jan. 2019/Cited: Jan. 2019.

Nota: Compreende a área total dos cultivos florestais de eucalipto, pinus e outras espécies.

Note: Comprises the total area of forestry of eucalyptus, pine and other species. 



\section{Indústria Industry}

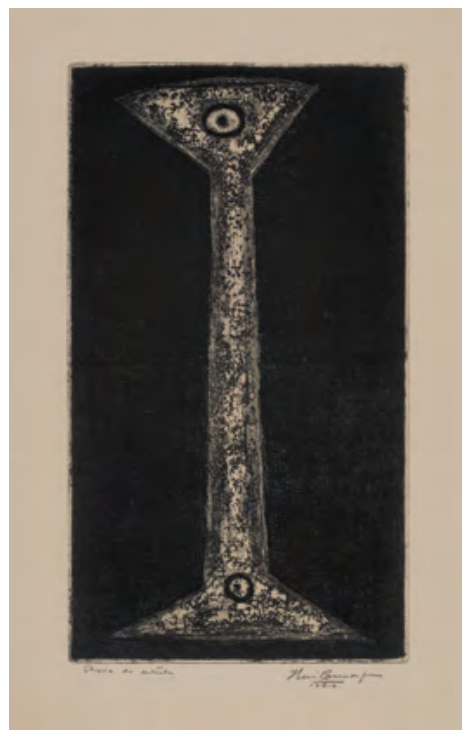

Um carretel, 1960

Spool

Iberê Camargo 


\title{
Industry
}

\author{
Ricardo Dathein ${ }^{1}$
}

\section{Brazilian industry: facing structural and cyclical challenges}

The Brazilian industry has faced interconnected structural and cyclical difficulties for several decades now. According to data from the United Nations Industrial Development Organization (UNIDO), the contribution of the aggregated value from the Brazilian manufacturing industry to the world overall, in figures of 2010, was $2.80 \%$ in the year 2008 and $1.98 \%$ in the year 2017. As stated by Morceiro and Guilhoto (2019), the participation of manufacturing in the Gross Domestic Product (GDP), at prices of 2018, was about $14.4 \%$ in 2008 and fell to $11.3 \%$ in 2018 , with the worst performances (with premature deindustrialization) recorded by the knowledge and technology-intensive sectors. On the other hand, manufacturing exports from Brazil, which reached $0.81 \%$ of the world total in 2008 , had their participation reduced to $0.61 \%$ in 2017 , according to the World Trade Organization (WTO).

There was a recovery of the industrial output in 2017 and 2018, after the significant decrease in previous years, both in terms of the industry overall and of the average of manufacturing industry. Nevertheless, that recovery was not enough to cover losses and stayed, in 2018, way below the 2017 figure (Table 12.1). Since the performance in the first semester of 2018 was significantly better than in the entire year, the

1 Full professor at the School of Economic Sciences of the Federal University of Rio Grande do Sul (UFRGS). 


\title{
Indústria
}

\author{
Ricardo Dathein ${ }^{1}$
}

\section{Indústria brasileira: enfrentando desafios estruturais e conjunturais}

A indústria brasileira tem passado por dificuldades estruturais e conjunturais inter-relacionadas, que vem desde já várias décadas. Segundo dados da Organização das Nações Unidas para o Desenvolvimento Industrial (UNIDO) (United Nations Industrial Development Organization), a participação do valor agregado da indústria manufatureira brasileira no total mundial, em valores de 2010 , foi de $2,80 \%$ no ano de 2008 e de 1,98\% no ano de 2017. Segundo Morceiro e Guilhoto (2019), a participação das manufaturas no Produto Interno Bruto (PIB), a preços de 2018, foi de cerca de $14,4 \%$ em 2008 e reduziu-se para 11,3\% em 2018, sendo que os piores desempenhos (com desindustrialização prematura) estão ocorrendo nos setores intensivos em conhecimento e tecnologia. Por outro lado, as exportações manufatureiras brasileiras, que chegaram a $0,81 \%$ das mundiais em 2008, reduziram essa participação para 0,61\% em 2017, segundo a Organização Mundial do Comércio (OMC) (World Trade Organization - WTO).

Houve uma recuperação da produção industrial em 2017 e 2018, depois da forte queda dos anos anteriores, tanto para a indústria total quanto para a média da indústria de transformação. No entanto, essa recuperação foi insuficiente para cobrir as perdas e ficou, em 2018, muito inferior à de 2017 (Tabela 12.1). Pior que isso, como

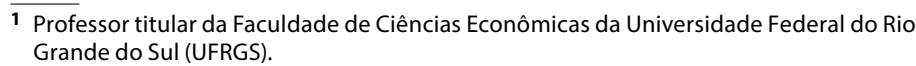


second semester that year soon indicated a reversal of the recovery trends.

The dynamics of the industrial output varied significantly among the sectors. A comparison of the three years displayed in Table 12.1 allows a classification into patterns. One first group is that of sectors that had a significant decrease in 2016 and recovered very well in 2017 and/or 2018, or at a rather equivalent pace. It encompasses motor vehicles, computer equipment, electronic and optical products, tobacco products, basic metals, textiles, rubber, and plastic items and maintenance, repair and installation of machinery and equipment. $A$ second pattern is that of sectors that did not recover, or recovered only partially, after a pronounced decrease, including machinery and equipment, petroleum products, furniture, metal products, nonmetallic mineral products, miscellaneous products and, to a certain extent, mining and quarrying industry itself. A third group includes sectors that recorded a significant decrease of output in 2016 and remained on a downward trend in the following years. It covers other transportation equipment, electrical machinery and apparatuses and printing and reproduction of recorded media. In the fourth group, there are sectors of unstable patterns, with a weak performance, in general having recorded a decrease in 2016, a recovery in 2017 and a decline in 2018 once again. It encompasses beverages, apparel, leather, travel articles and footwear and other chemicals.

Two sectors have not been affected: wood and pulp and paper. And two others have specific characteristics: food products, which did not have a negative performance in 2016 or 2017, but which faced a steep decrease in 2018; and pharmaceuticals, which, after a significant decrease in output in 2016 and 2017, recovered in 2018.

The industrial crisis of 2015 and 2016 is one of the biggest in history, not only due to its magnitude, but to the low intensity of the recovery that followed. In the analysis by economic category (Graph 12.1), it is observed that the cumulative decrease in capital goods in 2015-2016 was $38.1 \%$, whereas the cumulative increase in 2017-2018 was only $14.1 \%$. For intermediate goods, respectively, those figures were $-12.0 \%$ and $+2.1 \%$. For durable consumer goods, $-35.6 \%$ and $+21.8 \%$. And for semi-durable and non-durable goods, also respectively, $-10.0 \%$ and $+0.6 \%$. Besides, except for capital goods, the increase in 2018 was below that in 2017. So, the levels observed before the crisis are still far from being reached. 
o desempenho do primeiro semestre de 2018 foi bastante superior ao do ano como um todo, o que foi se demonstrando no segundo semestre desse ano é que já havia uma reversão da tendência de recuperação.

A dinâmica da produção industrial foi muito diferenciada entre setores. Pode-se fazer uma classificação em alguns padrões, comparando os três anos da Tabela 12.1. Um primeiro grupo é dos setores que tiveram uma queda muito intensa em 2016 e se recuperaram também de forma muito forte em 2017 e/ou 2018, ou de forma mais ou menos equivalente. Nesse caso, incluem-se veículos automotores, equipamentos de informática, produtos eletrônicos e ópticos, produtos de fumo, metalurgia, produtos têxteis, produtos de borracha e de material plástico e manutenção, reparação e instalação de máquinas e equipamentos. Um segundo padrão é dos setores que, depois de forte queda, não se recuperaram, ou só parcialmente, no qual estão incluídos máquinas e equipamentos, derivados de petróleo, móveis, produtos de metal, produtos de minerais não metálicos, produtos diversos e, de certa forma, a própria indústria extrativa. Um terceiro grupo é o dos setores que apresentaram forte queda de produção em 2016 e continuaram retrocedendo nos anos seguintes, o que abarca outros equipamentos de transporte, máquinas, aparelhos e materiais elétricos e impressão e reprodução de gravações. Como quarto grupo, há um conjunto de setores de padrão oscilante, com desempenho fraco, em geral com queda em 2016, recuperação em 2017 e nova redução em 2018, como bebidas, confecção, couros, artigos para viagem e calçados e outros produtos químicos.

Há também dois setores que não foram afetados negativamente, madeira e celulose e papel. E há outros dois setores com características específicas, o de produtos alimentícios, que não teve desempenho negativo em 2016 e 2017, mas que apresentou forte queda em 2018, e produtos farmoquímicos e farmacêuticos, que, ao contrário, depois de importante redução de produção em 2016 e 2017, recuperou-se em 2018. A crise industrial de 2015 e 2016 é uma das maiores da história não só por sua magnitude, mas também pela baixa intensidade de recuperação posterior. Fazendo-se a análise por categorias econômicas (Gráfico 12.1), observa-se que a queda acumulada para bens de capital em 2015-2016 foi de 38,1\%, enquanto a recuperação acumulada em 2017-2018 foi de apenas 14,1\%. Para bens intermediários, respectivamente, esses números foram de $-12,0 \%$ e $+2,1 \%$. Para bens de consumo duráveis, de $-35,6 \%$ e $+21,8 \%$, respectivamente. E para bens de consumo semiduráveis e não duráveis, também respectivamente, de $-10,0 \%$ e $+0,6 \%$. Além disso, com exceção de bens de capital, o crescimento de 2018 foi inferior ao de 2017. Portanto, os patamares de antes da crise ainda estão distantes de serem atingidos. 
The analysis of the industrial output by selected products (Table 12.2), from 2014 to 2016-2017, shows that, except for petroleum and pulp, production recorded a decrease. For cars and agricultural equipment, there was a recovery, but at a level that was not enough to hit the result of 2014 again. In the case of petroleum, there was a substantial and steady increase, of 16.3\%, between 2014 and 2017.

As for the physical output of crude steel, between 2012 and 2017, Brazil was stagnated, differently from India and China, which recorded a strong increase. In spite of that, our country remains as a very important producer in the international scenario. China was the biggest producer in 2017, way ahead the second position (Graph 12.2). In the Latin America scenario, Brazil is the major producer, with an output significantly bigger than that of Mexico, the second in the ranking (Graph 12.3). In recent years, Venezuela, Ecuador, Chile and Argentina have faced a significant decrease in their physical output, whereas Peru and Mexico have recorded an increase.

In the case of change of the industrial output by intensity of electricity consumption, the biggest decreases in 2016 came from sectors with low and medium consumption levels, whereas the main recoveries in 2017 took place in areas with medium and high consumption, mainly. The recovery in 2018 was mainly concentrated in sectors with medium consumption, maintaining its path along the year (Table 12.3). The sectors with low and high electricity consumption levels, on the contrary, had a worse performance in the second semester of 2018, also with a negative reversal of the trend in that indicator.

In 2016, the Southeast Region concentrated $49.2 \%$ of the Brazilian industrial units, $51.1 \%$ of the employed persons and $61.5 \%$ of the wage bill. In terms of net revenue of sales, gross value of industrial output (GVIO) and manufacturing value added (MVA), figures were $54.7 \%, 55.2 \%$ and $57.2 \%$, respectively (Table 12.4). That is, Brazil kept an enormous industrial concentration in quantitative and qualitative terms.

For the industry overall and for the manufacturing industry, both MVA and GVIO recorded, in real terms, significant decreases in 2015 and 2016 , and in the latter figures were close to those in 2007. Mainly in relation to manufacturing industry, for the sectors of high, mediumhigh and medium-low technological intensity, both MVA and GVIO values in 2016 were lower than in 2007, in real terms. The ones that made up for those increases were sectors of low technological intensity, which, despite the decline between 2014 and 2016, still had figures above those in 2007. Productivity (MVA/Employed persons) 
Analisando-se a produção industrial física por produtos selecionados (Tabela 12.2), na evolução de 2014 a 2016-2017, nota-se que, fora petróleo e celulose, a produção decaiu. Para automóveis e máquinas agrícolas, houve recuperação, mas insuficiente para voltar ao patamar de 2014. No caso do petróleo, o crescimento foi substancial e contínuo, de 16,3\% entre 2014 e 2017.

Especificamente sobre a produção física de aço bruto, entre 2012 e 2017, enquanto Índia e China tiveram forte crescimento, o Brasil ficou estagnado. Mesmo assim, permanece como um produtor muito importante no contexto internacional. Para 2017, a China foi o maior produtor, muito distante do segundo lugar (Gráfico 12.2). Comparativamente à América Latina, o Brasil aparece como maior produtor, substancialmente acima da produção do México, segundo classificado (Gráfico 12.3). Nos anos recentes, Venezuela, Equador, Chile e Argentina apresentaram forte redução de produção física, enquanto houve crescimento para Peru e México.

No caso da variação da produção industrial por intensidade de consumo de energia elétrica, as maiores reduções em 2016 foram nos setores com médio e baixo consumo, as maiores recuperações de 2017 foram nas áreas de médio e alto consumo, enquanto a recuperação de 2018 de concentrou nos setores de médio consumo, principalmente, mantendo sua trajetória no ano (Tabela 12.3). No entanto, nos setores de baixo e alto consumo de energia, ao contrário, o desempenho foi inferior no segundo semestre de 2018, mostrando também por esse indicador uma reversão negativa de tendência.

Em 2016, a Região Sudeste concentrou 49,2\% das unidades industriais brasileiras, $51,1 \%$ do pessoal ocupado e $61,5 \%$ da massa salarial. Em termos de receita líquida de vendas, valor bruto da produção industrial (VBPI) e valor da transformação industrial (VTI), essa concentração foi de $54,7 \%, 55,2 \%$ e 57,2\%, respectivamente (Tabela 12.4). Ou seja, o Brasil manteve uma intensa concentração industrial em termos quantitativos e qualitativos.

Para a indústria total e para a indústria de transformação, tanto o VTI quanto o VBPI tiveram, em termos reais, fortes quedas em 2015 e 2016, tendo nesse último ano aproximado seus valores aos de 2007. Especificamente em relação à indústria manufatureira, para os setores de alta, média alta e média baixa intensidade tecnológica, tanto os valores do VTI quanto do VBPI de 2016 foram menores que os de 2007, em termos reais. $\mathrm{O}$ que compensou essas quedas foram os setores de baixa intensidade tecnológica, que, apesar das reduções entre 2014 e 2016, ainda permaneceram com valores acima dos de 2007. A produtividade (VTI/Ocupados) apresentou fraco desempenho entre 2007 e 2016 para a indústria total e de transformação. Ocorreu 
recorded a weak performance between 2007 and 2016 for the overall and manufacturing industry. Growth was observed in the mining and quarrying industry, but that same sector recorded decreases after 2011. In this case, also, regarding productivity, industries of low technological intensity, despite their lower compared averages, recorded a steady increase and made up for the decreases in the other ones.

The coefficient of value aggregation (MVA/GVIO), likewise, was basically stagnated between 2007 and 2016, for both the overall and manufacturing industry. There was an increase up to 2011, and decline followed. The highest levels of aggregation took place in the sectors of medium-low technological intensity, whereas the lowest levels were those from the sectors of medium-high technological intensity.

The Brazilian industry has had low rates of increase in productivity. Besides, a process of deindustrialization is in progress, being more pronounced in sectors of higher technological intensity. As a result, innovation capacity is also jeopardized, and that accounts for the low levels detected by the Survey of Technological Innovation (PINTEC) of the Brazilian Institute of Geography and Statistics (IBGE), as well as the difficulty to increase the innovation rates. This process, in an international context of expansion of knowledge economy and formation of global chains of value, may be generating unlearning processes (AROCENA; SUTZ, 2005). The economic complexity index (ECI) of Brazil detects those problems. That indicator fell from 0.517 in 2005 to 0.138 in 2016, in such a way that Brazil fell from the 40th to the $53 \mathrm{rd}$ position in the ranking. So, in negative international and national scenarios, such as in recent years, trends are very dependent on the reduction of costs, considering the low performance of productivity and innovation.

The national scenario was negative for investments in industry in 2018. The level of utilization of the average installed capacity of industry, according to data from the Getúlio Vargas Foundation (FGV), which was $84.0 \%$ in the average of years 2010 to 2014 , was reduced to an average level of $75.1 \%$ between 2015 and 2018, having remained at only $75.8 \%$ in 2018.

A fundamental element of basic autonomous demand, which is government investment itself, is strongly reduced now, due to austerity policies. Whereas, with regard to GDP, in the year 2008, public investment was $3.5 \%$ and private investment, $15.9 \%$, and in $2010,4.6 \%$ and $16.0 \%$, in 2017 figures were only $1.9 \%$ and $13.8 \%$, respectively. So, despite the exchange and interest rates that become more favorable every day, industry has not been able to recover sufficiently or consistently. 
crescimento para as indústrias extrativas, mas mesmo esse setor apresentou redução após 2011. Também nesse caso, para a produtividade, as indústrias de baixa intensidade tecnológica, mesmo tendo um nível médio muito inferior às demais, apresentou crescimento contínuo e compensou parcialmente a queda das demais.

O coeficiente de agregação de valor (VTI/VBPI), da mesma forma, ficou basicamente estagnado entre 2007 e 2016, tanto para a indústria total quanto para a de transformação. Houve crescimento até 2011 e, após, redução. Os maiores patamares de agregação de valor ocorreram nos setores de média baixa intensidade tecnológica, enquanto os menores patamares são dos setores de média alta intensidade tecnológica.

A indústria brasileira tem apresentado baixas taxas de crescimento de sua produtividade. Além disso, há em andamento um processo de desindustrialização, de forma mais intensa em setores de maior intensidade tecnológica. Com isso, a capacidade de inovação também fica comprometida, o que explica seus baixos níveis, detectados pelas Pesquisa de Inovação Tecnológica (PINTEC) do Instituto Brasileiro de Geografia e Estatística (IBGE), e a dificuldade de aumento das taxas de inovação. Esse processo, em um contexto internacional de expansão da economia do conhecimento e de formação de cadeias globais de valor, pode estar gerando processos de desaprendizado (AROCENA; SUTZ, 2005). O índice de complexidade econômica $(\mathrm{ECl})$ do Brasil detecta esses problemas. Esse indicador reduziu-se de 0,517 em 2005 para 0,138 em 2016, de forma que a classificação do Brasil no ranking caiu da $40^{\text {a }}$ para a $53^{\text {a }}$ colocação. Assim, em contextos internacionais e nacionais negativos, como os dos anos recentes, a trajetória fica muito dependente de redução de custos, tendo em vista o baixo desempenho da produtividade e da inovação.

O contexto nacional foi negativo para o investimento industrial em 2018. O nível de utilização da capacidade instalada média da indústria, segundo dados da Fundação Getulio Vargas (FGV), que foi de $84,0 \%$ na média dos anos 2010 a 2014, reduziu-se para um patamar médio de $75,1 \%$ entre 2015 e 2018, tendo se mantido em apenas 75,8\% em 2018.

Um elemento de demanda autônoma fundamental, que é o investimento governamental, está fortemente reduzido nesse momento, com políticas de austeridade. Enquanto, em relação ao PIB, no ano de 2008 esse investimento público foi de 3,5\% e o investimento privado de 15,9\%, e em 2010 de 4,6\% e 16,0\%, em 2017 foram de apenas $1,9 \%$ e $13,8 \%$, respectivamente. Assim, mesmo com taxas de câmbio e de juros em níveis relativamente mais favoráveis, a indústria não tem conseguido se recuperar de forma suficiente e consistente. 
On the other hand, the international context has also grown worse. The terms of trade, according to data from the Foreign Trade Study Center Foundation (FUNCEX), went from an index of 95.0 in 2005 to 129.0 in 2011 (average of $2006=100$ ). That led to stimulus from foreign demand which, aggregated to stimulus from domestic demand, accounted for an improvement in industrial performance in the period. Nonetheless, terms of trade fell significantly after 2011, and reached 109.2, in 2018.

So, given that low pace of recovery, there is even a possibility of permanent production and employment losses, disconnected from previous trends. That is, a cyclical recovery is taking place, but previous levels are not to be reached in the short and medium terms, with an L-shaped trend and not a V-shaped one.

\section{References}

AROCENA, R.; SUTZ, J. Conhecimento, inovação e aprendizado: sistemas e políticas no Norte e no Sul. In: LASTRES, H. M. M.; CASSIOLATO, J. E.; ARROIO, A. (Org.). Conhecimento, sistemas de inovação e desenvolvimento. Rio de Janeiro: Ed. UFRJ : Contraponto, 2005. 450 p. (Economia e sociedade).

BOLETIM DO OBSERVATÓRIO DA INDÚSTRIA. Rio de Janeiro: Centro Internacional Celso Furtado de Políticas para o Desenvolvimento, n. 2, 2018. Available from: <http://centrocelsofurtado.org.br/arquivos/ image/201809181712380.Boletim\%20do\%20Observat\%C3\%B3rio\%20 da\%20Ind\%C3\%BAstria\%202\%20(2018).pdf>. Cited: May 2019.

HIRATUKA, C.; SARTI, F. Transformações na estrutura produtiva global, desindustrialização e desenvolvimento industrial no Brasil. Revista de Economia Política, São Paulo, v. 37, n.1, p. 189-207, 2017. Available from: <http://www.rep.org.br/all_issue.asp>.Cited: May 2019.

MORCEIRO, P. C.; GUILHOTO, J. J. M. Desindustrialização setorial e estagnação de longo prazo da manufatura brasileira. Textos para Discussão, São Paulo: Núcleo de Economia Regional e Urbana da Universidade de São Paulo, 01-2019. Available from: <http://www.usp. $\mathrm{br} /$ nereus/?txtdiscussao=desindustrializacao-setorial-e-estagnacao-delongo-prazo-da-manufatura-brasileira>. Cited: May 2019.

SICSU, J. Brasil: é uma depressão, não foi apenas uma recessão. Revista de Economia Contemporânea, Rio de Janeiro, v. 23, n. 1, p. 1-41, 2019. Available from: <https://revistas.ufrj.br/index.php/rec/article/view/24294>. Cited: May 2019. 
Por outro lado, o contexto internacional também piorou. Os termos de troca, segundo dados da Fundação Centro de Estudos do Comércio Exterior (FUNCEX), passaram de um índice de 95,0 em 2005 para 129,0 em 2011 (média de $2006=100$ ), o que gerou estímulos de demanda externa que, agregados aos estímulos de demanda interna, explicaram uma melhora do desempenho da indústria nesse período. No entanto, depois de 2011, os termos de troca reduziram-se muito, chegando a um nível de 109,2 em 2018.

Desse modo, pelo ritmo baixo de recuperação, coloca-se inclusive a questão da possibilidade de perdas produtivas e de emprego definitivas, com uma trajetória desconectada da anterior. Ou seja, a recuperação cíclica ocorre sem que se alcancem nos curto e médio prazos os patamares anteriores, com uma trajetória cíclica em forma de L e não de $V$.

\section{Referências}

AROCENA, R.; SUTZ, J. Conhecimento, inovação e aprendizado: sistemas e políticas no Norte e no Sul. In: LASTRES, H. M. M.; CASSIOLATO, J. E.; ARROIO, A. (Org.). Conhecimento, sistemas de inovação e desenvolvimento. Rio de Janeiro: Ed. UFRJ : Contraponto, 2005. 450 p. (Economia e sociedade).

BOLETIM DO OBSERVATÓRIO DA INDÚSTRIA. Rio de Janeiro: Centro Internacional Celso Furtado de Políticas para o Desenvolvimento, n. 2, 2018. Disponível em: $<$ http:// centrocelsofurtado.org.br/arquivos/image/201809181712380.Boletim $\% 20$ do $\% 20$ Observat\%C3\%B3rio\%20da\%20lnd\%C3\%BAstria\%202\%20(2018).pdf >. Acesso em: maio 2019.

HIRATUKA, C.;SARTI,F.Transformações na estrutura produtiva global, desindustrialização e desenvolvimento industrial no Brasil. Revista de Economia Política, São Paulo, v. 37, n.1, p. 189-207, 2017. Disponível em: <http://www.rep.org.br/all_issue.asp>. Acesso em: maio 2019.

MORCEIRO, P.C.; GUILHOTO, J. J. M. Desindustrialização setorial e estagnação de longo prazo da manufatura brasileira. Textos para Discussão, São Paulo: Núcleo de Economia Regional e Urbana da Universidade de São Paulo, 01-2019. Disponível em: <http:// www.usp.br/nereus/?txtdiscussao=desindustrializacao-setorial-e-estagnacao-delongo-prazo-da-manufatura-brasileira>. Acesso em: maio 2019.

SICSU, J. Brasil: é uma depressão, não foi apenas uma recessão. Revista de Economia Contemporânea, Rio de Janeiro, v. 23, n. 1, p. 1-41, 2019. Disponível em: <https://revistas. ufrj.br/index.php/rec/article/view/24294>. Acesso em: maio 2019. 


\section{Tabela 12.1 - Produção industrial, segundo as seções e atividades de indústria - 2016-2018}

Table 12.1 - Industrial output, according to industry sectors and activities - 2016-2018

(continua/to be continued)

\begin{tabular}{|c|c|c|c|c|c|}
\hline \multirow{3}{*}{$\begin{array}{c}\text { Seções e atividades } \\
\text { de indústria/ } \\
\text { Industry sectors and activities }\end{array}$} & \multicolumn{5}{|c|}{ Produção industrial/ Industrial Output } \\
\hline & \multirow[b]{2}{*}{2016} & \multicolumn{2}{|c|}{2017} & \multicolumn{2}{|c|}{2018} \\
\hline & & $\begin{array}{l}\text { Total } \\
\text { no ano/ } \\
\text { Total in } \\
\text { the year }\end{array}$ & $\begin{array}{c}\text { 10 semes- } \\
\text { tre/ } \\
1 s t \\
\text { semester }\end{array}$ & $\begin{array}{l}\text { Total } \\
\text { no ano/ } \\
\text { Total in } \\
\text { the year }\end{array}$ & $\begin{array}{c}\text { 10 semes- } \\
\text { tre/ } \\
1 s t \\
\text { semester }\end{array}$ \\
\hline $\begin{array}{l}\text { Indústria geral/ } \\
\text { General industry }\end{array}$ & (-) 6,40 & 2,50 & 0,90 & 1,10 & 2,30 \\
\hline $\begin{array}{l}\text { Indústria extrativa/ } \\
\text { Mining and quarrying }\end{array}$ & (-) 9,40 & 4,50 & 8,10 & 1,30 & $(-) 0,60$ \\
\hline Indústrias de transformação/ & (-) 6,00 & 2,20 & $(-) 0,10$ & 1,10 & 2,80 \\
\hline \multicolumn{6}{|l|}{ Manufacturing } \\
\hline $\begin{array}{l}\text { Produtos alimentícios/ } \\
\text { Food products }\end{array}$ & 0,50 & 1,20 & $(-) 2,00$ & $(-) 5,10$ & $(-) 1,10$ \\
\hline $\begin{array}{l}\text { Bebidas/ } \\
\text { Beverages }\end{array}$ & (-) 3,10 & 0,80 & (-) 1,50 & $(-) 0,10$ & 2,70 \\
\hline $\begin{array}{l}\text { Produtos do fumo/ } \\
\text { Tobacco products }\end{array}$ & $(-) 21,70$ & 20,40 & 15,60 & $(-) 4,00$ & $(-) 7,70$ \\
\hline $\begin{array}{l}\text { Produtos têxteis/ } \\
\text { Textiles }\end{array}$ & (-) 4,60 & 5,60 & 5,50 & $(-) 2,40$ & (-) 1,10 \\
\hline $\begin{array}{l}\text { Confecção de artigos do vestuário e acessórios/ } \\
\text { Apparel and accessories }\end{array}$ & (-) 5,80 & 3,50 & 5,60 & $(-)$ 3,30 & $(-) 3,80$ \\
\hline $\begin{array}{l}\text { Couros, artigos para viagem e calçados/ } \\
\text { Leather, travel articles and footwer }\end{array}$ & $(-) 1,30$ & 0,80 & 2,30 & (-) 2,30 & (-) 5,70 \\
\hline $\begin{array}{l}\text { Produtos de madeira/ } \\
\text { Wood products }\end{array}$ & 1,30 & 1,80 & $(-) 1,30$ & 3,30 & 7,30 \\
\hline $\begin{array}{l}\text { Celulose, papel e produtos de papel/ } \\
\text { Pulp, paper and paper products }\end{array}$ & 2,30 & 3,30 & 2,10 & 4,90 & 3,90 \\
\hline $\begin{array}{l}\text { Impressão e reprodução de gravações/ } \\
\text { Printing and reproduction of recorded media }\end{array}$ & (-) 11,10 & (-) 10,20 & (-) 14,80 & (-) 1,30 & (-) 1,40 \\
\hline $\begin{array}{l}\text { combustíveis/ } \\
\text { Coke, petroleum products and biofuels }\end{array}$ & (-) 8,50 & (-) 4,20 & (-) 7,70 & 1,00 & 0,90 \\
\hline $\begin{array}{l}\text { limpeza e de higiene pessoal/ } \\
\text { Toiletries, soaps, detergents, cleaning and }\end{array}$ & (-) 1,30 & 2,30 & 0,00 & 1,40 & 2,40 \\
\hline $\begin{array}{l}\text { Outros produtos químicos/ } \\
\text { Other chemicals }\end{array}$ & (-) 1,00 & 0,60 & (-) 1,20 & (-) 0,40 & (-) 1,20 \\
\hline $\begin{array}{l}\text { Produtos farmoquímicos e farmacêuticos/ } \\
\text { Pharmaceuticals and chemicals }\end{array}$ & (-) 1,70 & (-) 5,20 & (-) 5,00 & 6,10 & 1,60 \\
\hline $\begin{array}{l}\text { Produtos de borracha e de material plástico/ } \\
\text { Rubber and plastic products }\end{array}$ & (-) 6,60 & 4,60 & 2,60 & 0,90 & 2,70 \\
\hline
\end{tabular}




\section{Tabela 12.1 - Produção industrial, segundo as seções e atividades}

de indústria - 2016-2018

Table 12.1 - Industrial output, according to industry sectors and activities - 2016-2018

(conclusão/concluded)

\begin{tabular}{|c|c|c|c|c|c|}
\hline \multirow{3}{*}{$\begin{array}{l}\text { Seções e atividades } \\
\text { de indústria/ } \\
\text { Industry sectors and activities }\end{array}$} & \multicolumn{5}{|c|}{ Produção industrial/ Industrial output } \\
\hline & \multirow[b]{2}{*}{2016} & \multicolumn{2}{|c|}{2017} & \multicolumn{2}{|c|}{2018} \\
\hline & & $\begin{array}{l}\text { Total } \\
\text { no ano/ } \\
\text { Total in } \\
\text { the year }\end{array}$ & $\begin{array}{l}\text { 10 semes- } \\
\text { tre/ } \\
1 \text { st } \\
\text { semester }\end{array}$ & $\begin{array}{l}\text { Total } \\
\text { no ano/ } \\
\text { Total in } \\
\text { the year }\end{array}$ & $\begin{array}{l}10 \text { semes- } \\
\text { tre/ } \\
1 s t \\
\text { semester }\end{array}$ \\
\hline $\begin{array}{l}\text { Produtos de minerais não metálicos/ } \\
\text { Non-metallic mineral products }\end{array}$ & $(-) 10,60$ & (-) 2,20 & (-) 5,10 & 0,40 & $(-) 0,90$ \\
\hline Metalurgia/ & (-) 6,00 & 4,70 & 4,00 & 4,00 & 5,80 \\
\hline $\begin{array}{l}\text { Basic metals } \\
\text { Produtos de metal, exceto máquinas e equipa- } \\
\text { mentos/ }\end{array}$ & (-) 10,60 & (-) 1,40 & (-) 2,00 & 2,70 & 0,50 \\
\hline $\begin{array}{l}\text { Metal products, except machinery and equipment } \\
\text { Equipamentos de informática, produtos eletrô- }\end{array}$ & & & & & \\
\hline $\begin{array}{l}\text { nicos e ópticos/ } \\
\text { Computer, electronic and optical products }\end{array}$ & $(-) 14,00$ & 20,20 & 19,80 & 2,60 & 17,60 \\
\hline $\begin{array}{l}\text { Máquinas, aparelhos e materiais elétricos/ } \\
\text { Electrical machinery and apparatus }\end{array}$ & (-) 7,30 & (-) 3,50 & (-) 6,70 & (-) 0,20 & $(-) 1,10$ \\
\hline $\begin{array}{l}\text { Máquinas e equipamentos/ } \\
\text { Machinery and equipment }\end{array}$ & $(-) 11,70$ & 2,80 & 1,90 & 3,40 & 4,30 \\
\hline $\begin{array}{l}\text { Veículos automotores, reboques e carrocerias/ } \\
\text { Motor vehicles, trailers and semi-trailers }\end{array}$ & $(-) 12,10$ & 17,20 & 11,80 & 12,60 & 18,40 \\
\hline $\begin{array}{l}\text { Outros equipamentos de transporte/ } \\
\text { Other transportation equipment }\end{array}$ & (-) 19,70 & (-) 10,30 & $(-) 12,50$ & (-) 2,10 & $(-) 3,50$ \\
\hline $\begin{array}{l}\text { Móveis/ } \\
\text { Furniture }\end{array}$ & $(-) 10,10$ & 4,50 & (-) 3,90 & (-) 0,30 & 5,20 \\
\hline $\begin{array}{l}\text { Produtos diversos/ } \\
\text { Other manufacturing }\end{array}$ & (-) 8,60 & 4,10 & 4,30 & (-) 0,30 & $(-) 1,30$ \\
\hline $\begin{array}{l}\text { Manutenção, reparação e instalação de } \\
\text { máquinas e equipamentos/ } \\
\text { Repair and installation of machinery and } \\
\text { equipment }\end{array}$ & (-) 7,40 & 6,80 & 6,60 & (-) 1,00 & 1,60 \\
\hline
\end{tabular}

Fonte/Source: IBGE, Diretoria de Pesquisas, Coordenação de Indústria, Pesquisa Industrial Mensal: Produção Física Brasil 2016-2018.

Notas: 1. Taxas de crescimento da produção industrial (Base: igual período do ano anterior).

2. As taxas anuais de crescimento de Impressão e reprodução de gravações e Manutenção, reparação e instalação de máquinas e equipamentos têm início em 2013.

Notes: 1. Growth rates of industrial output (Base: same period of previous year).

2. The annual growth rate of Printing and reproduction of recorded media and Repair and installation of machinery and equipment began in 2013. 
Tabela 12.2 - Produção industrial - 2014-2017

Table 12.2 - Mining and manufacturing production - 2014-2017

\begin{tabular}{|c|c|c|c|c|c|}
\hline $\begin{array}{l}\text { Produtos selecionados/ } \\
\text { Selected products }\end{array}$ & $\begin{array}{c}\text { Unidade de } \\
\text { medida/ } \\
\text { Unit }\end{array}$ & 2014 & 2015 & 2016 & 2017 \\
\hline Aço bruto/ & $1000 t$ & 33897 & 33256 & 31275 & $\ldots$ \\
\hline Crude steel & 1,000 tons & & & & \\
\hline Petróleo/ & $1000 \mathrm{~m}^{3}$ & 130835 & 141446 & 146067 & 152139 \\
\hline Petroleum & 1,000 cu.meters & & & & \\
\hline Gás natural/ & $1000000 \mathrm{~m}^{3}$ & 31895 & 35126 & 37890 & 27717 \\
\hline Natural gas & $1,000,000$ cu.meters & & & & \\
\hline $\begin{array}{l}\text { Máquinas agrícolas automotrizes/ } \\
\text { Self-propelled agricultural machine }\end{array}$ & $\begin{array}{l}\text { Unidade } \\
\text { Unit }\end{array}$ & 83353 & 55938 & 54032 & 65656 \\
\hline $\begin{array}{l}\text { Automóveis/ } \\
\text { Automobiles }\end{array}$ & $\begin{array}{l}\text { Unidade } \\
\text { Unit }\end{array}$ & 2502293 & 2017639 & 2176784 & 2386086 \\
\hline Papel/ & $1000 t$ & 10397 & 10357 & 10335 & $\ldots$ \\
\hline Paper & 1,000 tons & & & & \\
\hline Celulose/ & $1000 t$ & 16465 & 17370 & 18773 & $\ldots$ \\
\hline Cellulose & 1,000 tons & & & & \\
\hline
\end{tabular}

Fonte/Source: Anuário estatístico do Brasil 2017. Rio de Janeiro: IBGE, v. 77, 2017. Disponível em/ Available from : <https://biblioteca.ibge.gov.br/index.php/biblioteca-catalogo?view=detalhes\&id=720 >. Acesso em: jan. 2019/Cited: Jan. 2019. 


\section{Gráfico 12.1 - Taxas anuais de crescimento da produção industrial, por grandes categorias econômicas - 2015-2018}

Graph 12.1 - Annual growth rates of industrial output, by major

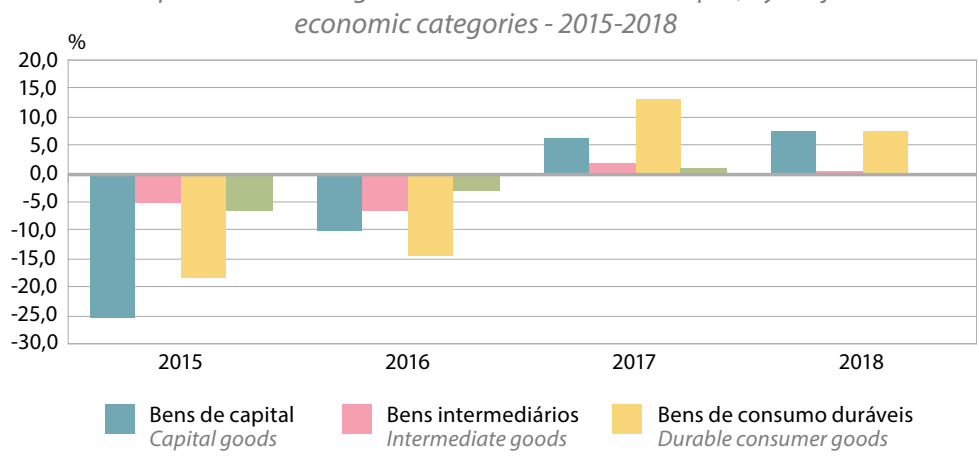

Bens de consumo semiduráveis e não duráveis

Semi and non-durable consumer goods

Fonte/Source: IBGE, Diretoria de Pesquisas, Coordenação de Indústria, Pesquisa Industrial Mensal: Produção Física Brasil 2015-2018.

\section{Tabela 12.3 - Produção industrial e grau de intensidade de energia elétrica - 2016-2018 \\ Table 12.3 - Industrial output and intensity of eletricity consumption - 2016-2018}

\begin{tabular}{|c|c|c|c|c|c|c|}
\hline \multirow[b]{2}{*}{$\begin{array}{l}\text { Especificação/ } \\
\text { Item }\end{array}$} & \multicolumn{2}{|c|}{2016} & \multicolumn{2}{|c|}{2017} & \multicolumn{2}{|c|}{2018} \\
\hline & $\begin{array}{l}\text { Total } \\
\text { no ano/ } \\
\text { Total in } \\
\text { the year }\end{array}$ & $\begin{array}{c}10 \text { semes- } \\
\text { tre/1st } \\
\text { semester }\end{array}$ & $\begin{array}{c}\text { Total } \\
\text { no ano/ } \\
\text { Total in } \\
\text { the year }\end{array}$ & $\begin{array}{c}1^{\circ} \text { semes- } \\
\text { tre/1st } \\
\text { semester }\end{array}$ & $\begin{array}{c}\text { Total } \\
\text { no ano/ } \\
\text { Total in } \\
\text { the year }\end{array}$ & $\begin{array}{c}10 \text { semes- } \\
\text { tre/1st } \\
\text { semester }\end{array}$ \\
\hline Indústria geral/ General industry & (-) 6,40 & (-) 8,90 & 2,50 & 0,90 & 1,10 & 2,30 \\
\hline \multicolumn{7}{|l|}{$\begin{array}{l}\text { Grau de intensidade de energia } \\
\text { elétrica/Intensity of electrity } \\
\text { consumption }\end{array}$} \\
\hline Alto/High & (-) 3,70 & $(-) 6,00$ & 2,70 & 0,60 & (-) 0,30 & 0,50 \\
\hline Médio/Medium & (-) 8,10 & (-) 10,30 & 3,30 & 2,60 & 2,50 & 1,80 \\
\hline Baixo/Low & (-) 6,80 & (-) 9,40 & 2,00 & (-) 0,20 & 1,10 & 3,80 \\
\hline
\end{tabular}

Fonte/Source: IBGE, Diretoria de Pesquisas, Coordenação de Indústria, Pesquisa Industrial Mensal: Produção Física Brasil 2016-2018.

Nota: Taxas de crescimento da produção industrial (Base: igual período do ano anterior)./ Note: Growth rates of industrial output (Base: same period of previous year). 
Tabela 12.4 - Variáveis selecionadas das unidades locais industriais de empresas industriais com 5 ou mais pessoas ocupadas, segundo as

Grandes Regiões e as Unidades da Federação - 2016

Table 12.4 - Selected variables of industrial local units with 5 or more employed persons, by Major Regions and Federtion Units - 2016

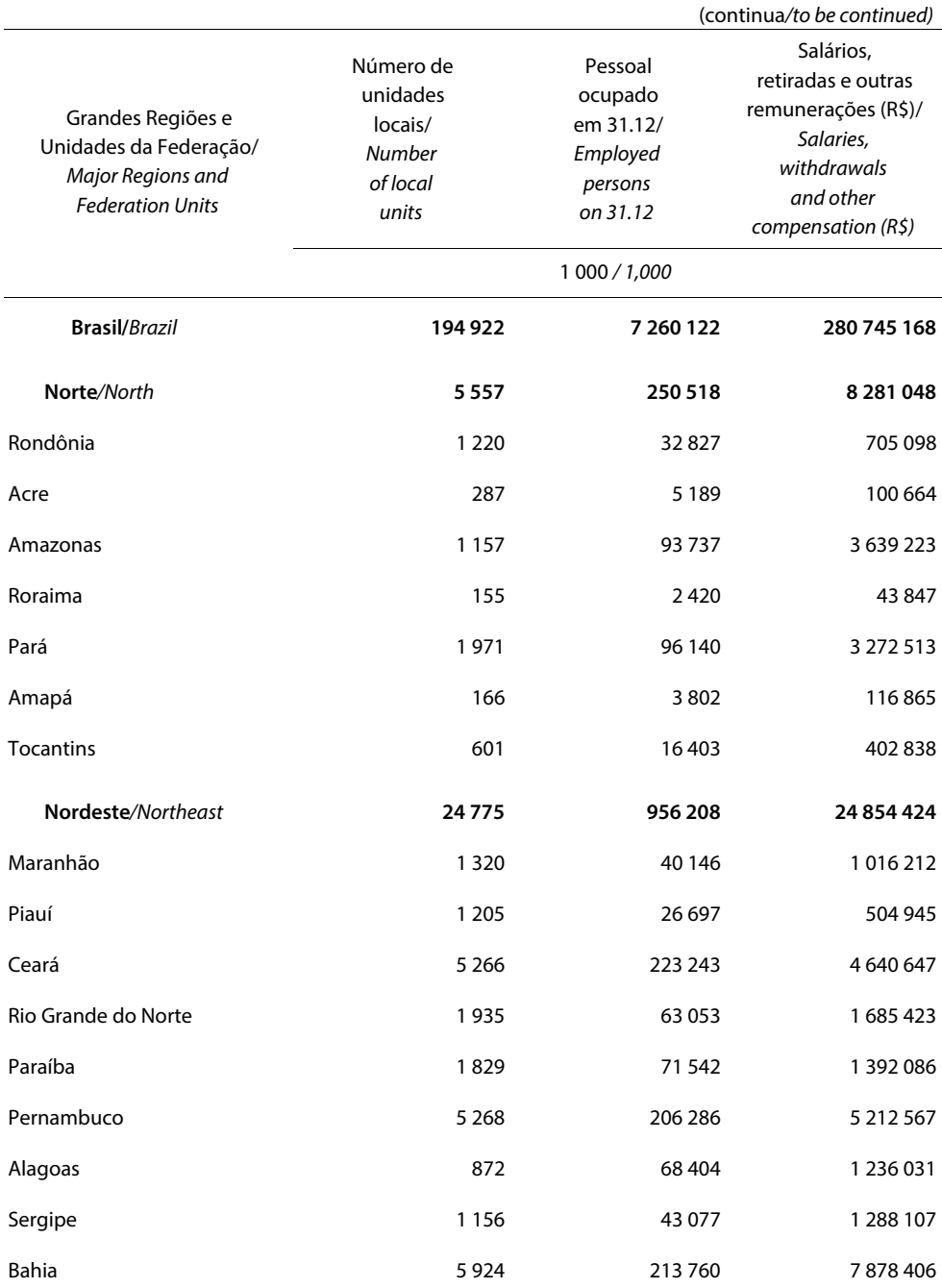


Tabela 12.4 - Variáveis selecionadas das unidades locais industriais de empresas industriais com 5 ou mais pessoas ocupadas, segundo as Grandes Regiões e as Unidades da Federação - 2016

Table 12.4 - Selected variables of industrial local units with 5 or more employed persons, by Major Regions and Federtion Units - 2016

\begin{tabular}{|c|c|c|c|}
\hline \multirow[t]{2}{*}{$\begin{array}{l}\text { Grandes Regiões e } \\
\text { Unidades da Federação/ } \\
\text { Major Regions and } \\
\text { Federation Units }\end{array}$} & $\begin{array}{l}\text { Número de } \\
\text { unidades } \\
\text { locais/ } \\
\text { Number } \\
\text { of local } \\
\text { units }\end{array}$ & $\begin{array}{c}\text { Pessoal } \\
\text { ocupado } \\
\text { em 31.12/ } \\
\text { Employed } \\
\text { persons } \\
\text { on } 31.12\end{array}$ & $\begin{array}{c}\text { Salários, } \\
\text { retiradas e outras } \\
\text { remunerações }(\mathrm{R} \$) / \\
\text { Salaries, } \\
\text { withdrawals } \\
\text { and other } \\
\text { compensation }(R \$)\end{array}$ \\
\hline & & $1000 / 1,000$ & \\
\hline Sudeste/Southeast & 95912 & 3708960 & 172718291 \\
\hline Minas Gerais & 23339 & 791331 & 25716122 \\
\hline Espírito Santo & 4362 & 123027 & 4553141 \\
\hline Rio de Janeiro & 9832 & 387722 & 27054673 \\
\hline São Paulo & 58379 & 2406880 & 115394355 \\
\hline Sul/South & 55816 & 1901865 & 61933517 \\
\hline Paraná & 17832 & 623115 & 20728246 \\
\hline Santa Catarina & 18583 & 638854 & 19243838 \\
\hline Rio Grande do Sul & 19401 & 639896 & 21961433 \\
\hline Centro-Oeste/Central-West & 12862 & 442571 & 12957888 \\
\hline Mato Grosso do Sul & 1778 & 93812 & 2704846 \\
\hline Mato Grosso & 3152 & 94714 & 2598248 \\
\hline Goiás & 6771 & 224792 & 6774806 \\
\hline Distrito Federal/Federal District & 1161 & 29253 & 879988 \\
\hline
\end{tabular}


Tabela 12.4 - Variáveis selecionadas das unidades locais industriais de empresas industriais com 5 ou mais pessoas ocupadas, segundo as Grandes Regiões e as Unidades da Federação - 2016

Table 12.4 - Selected variables from industrial local units with 5 or more employed persons, by Major Regions and Federtion Units - 2016

(continuação/to be continued)

\begin{tabular}{|c|c|c|c|c|}
\hline $\begin{array}{l}\text { Grandes Regiões e } \\
\text { Unidades da Federação/ } \\
\text { Major Regions and } \\
\text { Federation Units }\end{array}$ & $\begin{array}{l}\text { Receita } \\
\text { líquida de } \\
\text { vendas/ } \\
\text { Net revenue } \\
\text { of sales }\end{array}$ & $\begin{array}{c}\text { Valor bruto } \\
\text { da produção } \\
\text { industrial/ } \\
\text { Gross value } \\
\text { of industrial } \\
\text { production }\end{array}$ & $\begin{array}{c}\text { Custos das } \\
\text { operações } \\
\text { industriais/ } \\
\text { Costs of } \\
\text { industrial } \\
\text { operations }\end{array}$ & $\begin{array}{c}\text { Valor da } \\
\text { transformação } \\
\text { industrial/ } \\
\text { Gross value } \\
\text { added }\end{array}$ \\
\hline & \multicolumn{4}{|c|}{$1000 \mathrm{R} \$ / 1,000 \mathrm{R} \$$} \\
\hline Brasil/Brazil & 2632562646 & 2507866422 & 1413254503 & 1094612166 \\
\hline Norte/North & 151538565 & 143703019 & 74402051 & 69300965 \\
\hline Rondônia & 10335997 & 10205612 & 7201713 & 3003901 \\
\hline Acre & 1309659 & 1326233 & 929843 & 396389 \\
\hline Amazonas & 78884751 & 72180264 & 36699868 & 35480394 \\
\hline Roraima & 273188 & 262739 & 135056 & 127681 \\
\hline Pará & 53518462 & 52815344 & 24559446 & 28255897 \\
\hline Amapá & 1006596 & 1150204 & 631025 & 519180 \\
\hline Tocantins & 6209912 & 5762623 & 4245100 & 1517523 \\
\hline Nordeste/Northeast & 276428821 & 261232451 & 146704733 & 114527973 \\
\hline Maranhão & 16568122 & 16018348 & 9708241 & 6310107 \\
\hline Piauí & 4617150 & 4659786 & 2897326 & 1762459 \\
\hline Ceará & 41763632 & 35957843 & 19593716 & 16364128 \\
\hline Rio Grande do Norte & 12631679 & 13359146 & 5677326 & 7681819 \\
\hline Paraíba & 10697552 & 10524765 & 5903185 & 4621834 \\
\hline Pernambuco & 55794610 & 54649240 & 33583861 & 21065381 \\
\hline Alagoas & 7443422 & 7654323 & 3886502 & 3767824 \\
\hline Sergipe & 8169252 & 9506372 & 5281206 & 4225168 \\
\hline Bahia & 118743402 & 108902628 & 60173370 & 48729253 \\
\hline
\end{tabular}


Tabela 12.4 - Variáveis selecionadas das unidades locais industriais de empresas industriais com 5 ou mais pessoas ocupadas, segundo as Grandes Regiões e as Unidades da Federação - 2016

Table 12.4 - Selected variables from industrial local units with 5 or more employed persons, by Major Regions and Federtion Units - 2016

(conclusão/concluded)

\begin{tabular}{|c|c|c|c|c|}
\hline $\begin{array}{l}\text { Grandes Regiões e } \\
\text { Unidades da Federação/ } \\
\text { Major Regions and } \\
\text { Federation Units }\end{array}$ & $\begin{array}{l}\text { Receita } \\
\text { líquida de } \\
\text { vendas/ } \\
\text { Net revenue } \\
\text { of sales }\end{array}$ & $\begin{array}{c}\text { Valor bruto } \\
\text { da produção } \\
\text { industrial/ } \\
\text { Gross value } \\
\text { of industrial } \\
\text { production }\end{array}$ & $\begin{array}{c}\text { Custos das } \\
\text { operações } \\
\text { industriais/ } \\
\text { Costs of } \\
\text { industrial } \\
\text { operations }\end{array}$ & $\begin{array}{c}\text { Valor da } \\
\text { transformação } \\
\text { industrial/ } \\
\text { Gross value } \\
\text { added }\end{array}$ \\
\hline & \multicolumn{4}{|c|}{$1000 \mathrm{R} \$ / 1,000 \mathrm{R} \$$} \\
\hline Sudeste/Southeast & 1439479486 & 1385347619 & 758749275 & 626598349 \\
\hline Minas Gerais & 265101335 & 253685712 & 143281676 & 110404036 \\
\hline Espírito Santo & 45261864 & 52232818 & 26191060 & 26041765 \\
\hline Rio de Janeiro & 204640983 & 206563235 & 92640799 & 113922435 \\
\hline São Paulo & 924475304 & 872865854 & 496635740 & 376230113 \\
\hline Sul/South & 571849677 & 539052297 & 320015197 & 219037097 \\
\hline Paraná & 215915557 & 197360150 & 117856571 & 79503577 \\
\hline Santa Catarina & 140721128 & 139481016 & 79106762 & 60374252 \\
\hline Rio Grande do Sul & 215212992 & 202211131 & 123051864 & 79159268 \\
\hline Centro-Oeste/Central-West & 193266097 & 178531036 & 113383247 & 65147782 \\
\hline Mato Grosso do Sul & 36818024 & 37461804 & 21642047 & 15819757 \\
\hline Mato Grosso & 56237781 & 47106811 & 32005169 & 15101640 \\
\hline Goiás & 93473438 & 88277655 & 56957815 & 31319836 \\
\hline Distrito Federal/Federal District & 6736854 & 5684766 & 2778216 & 2906549 \\
\hline
\end{tabular}

Fonte/Source: Pesquisa industrial anual. Empresa 2016. Rio de Janeiro: IBGE, v. 35, n.1, 2016. Disponível em/Available from: <https://www.ibge.gov.br/estatisticas-novoportal/economicas/industria/9042pesquisa-industrial-anual.html>.Acesso em: jan. 2019/Cited: Jan. 2019. 


\section{Gráfico 12.2 - Produção de aço bruto, por países selecionados - 2017}

Graph 12.2 - Production of crude steel, by selected countries - 2017

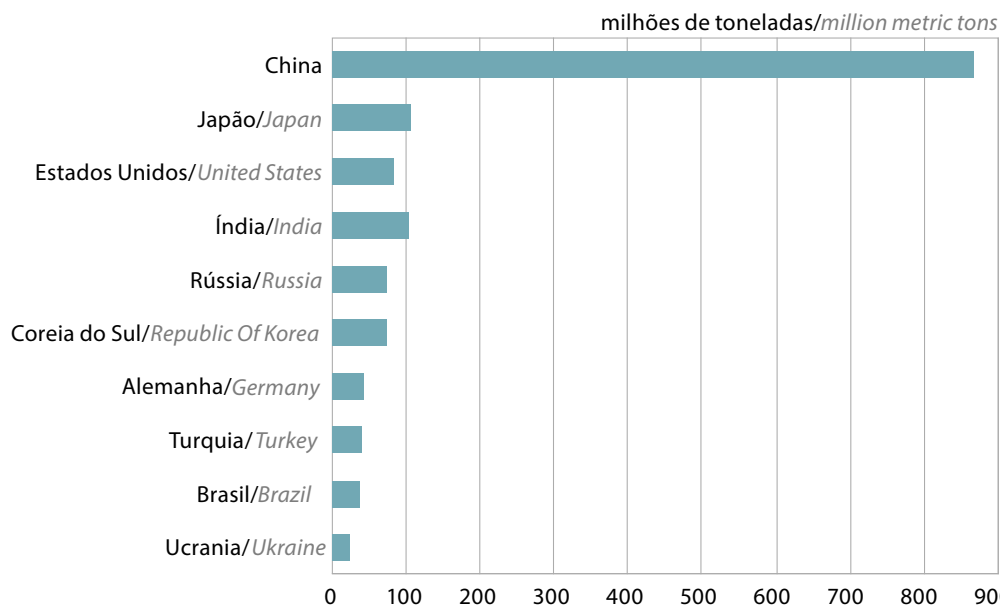

Fonte/Source: Worldsteel Association.

\section{Gráfico 12.3 - Produção de aço bruto - América Latina - 2017}

Graph 12.3 - Production of crude steel - Latin America - 2017

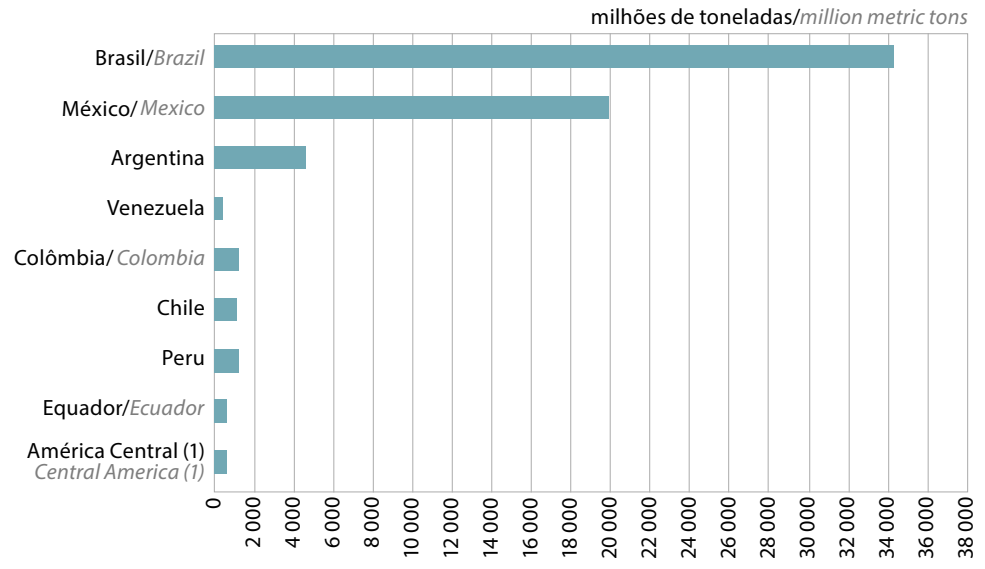

Fonte/Source: Asociación Latinoamericana del Acero (Alacero).

(1) Ámerica Central: Cuba, Guatemala e El Salvador./(1) Central America: Cuba, Guatemala and El Salvador. 


\section{Energia Energy}

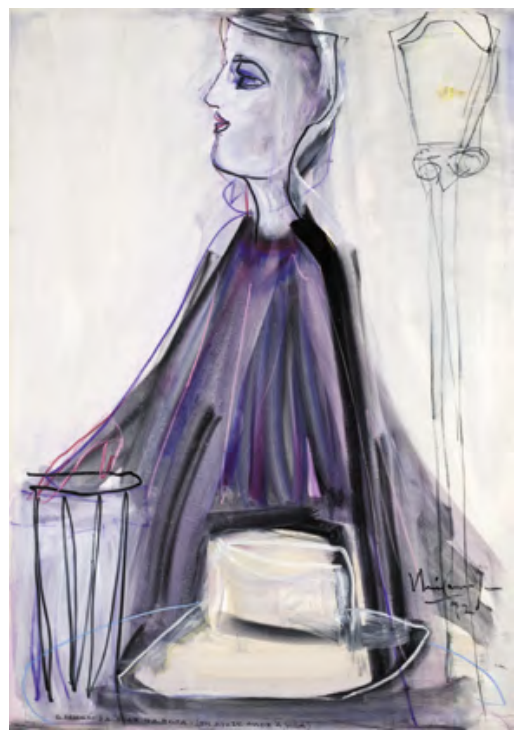

O homem da flor na boca: um ato de amor à vida, 1992

Man with the flower-mouth: an act of love for life

\section{Iberê Camargo}




\title{
Energy
}

\author{
Rafael Garaffa ${ }^{1}$
}

André F.P. Lucena ${ }^{2}$

\section{Overview of the energy sector and sectoral challenges}

The energy sector is responsible for the transformation and transportation of energy sources for final uses ${ }^{3}$ (energy and nonenergy), crossing all the sectors of the economy. In Brazil, the transformation sector comprises the extraction of petroleum, natural gas and mineral coal; petroleum refining; alcohol distillation; generation of electricity; and production of coke.

This chapter addresses the recent picture of the energy sector and the challenges related to the consumption of energy in Brazil. In a brief analysis, this chapter highlights uses and sources of energy consumed by each sector, such as: transportation, industry, buildings and agriculture, besides the energy sector on its own.

1 Master in Energy Planning from the Energy Planning Program of the Alberto Luiz Coimbra Institute of Post-Graduation and Engineering Research of the Federal University of Rio de Janeiro - COPPE/UFRJ.

$2 \mathrm{PhD}$ in Energy Planning and Professor of the Energy Planning Program of the Alberto Luiz Coimbra Institute of Post-Graduation and Engineering Research of the Federal University of Rio de Janeiro - COPPE/UFRJ.

3 Final use or energy services - lighting, driving force, heat generation, heating, refrigeration, etc. -, being lubricants, asphalt, solvents and other products used for non-energy purposes. 


\title{
Energia
}

\author{
Rafael Garaffa ${ }^{1}$ \\ André F.P. Lucena²
}

\section{Panorama do setor energético e desafios setoriais}

O setor energético é responsável pela transformação e transporte de fontes de energia para usos finais ${ }^{3}$ (energéticos e não energéticos), sendo transversal a todos os setores da economia. No Brasil, o setor de transformação compreende a extração de petróleo, gás natural e carvão mineral; o refino de petróleo; a destilação de álcool; a geração de eletricidade; e a produção de coque.

Este capítulo aborda o panorama recente do setor energético e os desafios relacionados ao consumo de energia no País. Em uma breve análise, o capítulo destaca usos e fontes de energia consumidos por cada setor, quais sejam: transportes, industrial, edificações e agropecuário, além do próprio setor energético.

1 Mestre em Planejamento Energético pelo Programa de Planejamento Energético do Instituto Alberto Luiz Coimbra de Pós-Graduação e Pesquisa de Engenharia da Universidade Federal do Rio de Janeiro (COPPE/UFRJ).

2 Doutor em Planejamento Energético e Professor do Programa de Planejamento Energético do Instituto Alberto Luiz Coimbra de Pós-Graduação e Pesquisa de Engenharia da Universidade Federal do Rio de Janeiro (COPPE/UFRJ).

3 Usos finais ou serviços energéticos (iluminação, força motriz, geração de calor, aquecimento, refrigeração etc.), sendo lubrificantes, asfalto, solventes e outros produtos, utilizados para fins não energéticos. 


\section{Overview of the energy system}

The domestic supply and the final consumption of energy changed little between 2015 and 2017 (Table 13.1). In this period, the supply of renewable energy sources ${ }^{4}$ increased, as the generation of renewable energy - wind and solar - in the Northeast Region advanced (Table 13.2) and the supply of fossil sources consequently dropped (Graph 13.2).

The production of primary energy continuously increased over the last years, due to the production of petroleum of the pre-salt layer (Graph 13.1), making Brazil one of the major global producers of petroleum (Table 13.3). Nevertheless, the country remains dependent on the imported natural gas - mainly for addressing thermoelectric power (Graph 13.5) - and on petroleum products, as covered later.

In 2017, the final consumption of energy was distributed among the sectors of energy (10.1\%), transportation (32.7\%), industry (32.9\%), buildings (14.5\%) and agriculture (4.0\%), in addition to $5.8 \%$ destined to non-energy final consumption (BALANÇO..., 2018). Between 2005 and 2014, the consumption of petroleum products and electricity continuously increased (Graph 13.3), especially to address the sectors of transportation and services (Graph 13.4). From 2014 onward, the reduction of the economic activity interrupted the growth trend of the final consumption, as revealed by the evolution of energy consumption in relation to the sectoral value added (Graph 13.6).

\section{Sectoral challenges}

The search for safe, reliable, low cost, low environmental impact and higher efficiency energy sources are common goals of all the sectors. Nevertheless, it is not always possible to meet such objectives, considering the imperfections of the market and a number of restrictions (budget, location, etc.). The following sub-sections explore the sectoral challenges related to the consumption of energy.

\section{Energy sector}

In Brazil, the agents of the energy sector frequently face regulatory, institutional, economic and market barriers, which hamper the expansion of the infrastructure, distorting the supply and consumption of energy in Brazil.

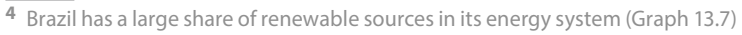
and a hydroelectric potential in the North Region (Table 13.4), though with recognized environmental restrictions to exploit it.
} 


\section{Panorama do sistema energético}

A oferta interna e o consumo final de energia sofreram pouca variação, entre 2015 e 2017 (Tabela 13.1). Neste período, houve incremento na oferta de fontes renováveis de energia ${ }^{4}$, com avanço da geração elétrica renovável (eólica e solar) na Região Nordeste (Tabela 13.2) e consequente queda relativa na oferta de fontes fósseis (Gráfico 13.2).

A produção de energia primária elevou-se continuamente nos últimos anos, devido à produção de petróleo da camada pré-sal (Gráfico 13.1), tornando o Brasil um dos principais países produtores globais de petróleo (Tabela 13.3). Contudo, permanece a dependência por gás natural importado - principalmente, para atendimento à geração termoelétrica (Gráfico 13.5) - e por derivados de petróleo, conforme tratado adiante.

Em 2017, o consumo final de energia distribuiu-se entre os setores energético $(10,1 \%)$, transportes $(32,7 \%)$, industrial $(32,9 \%)$, edificações $(14,5 \%)$ e agropecuário $(4,0 \%)$, além de $5,8 \%$ destinados ao consumo final não energético (BALANÇO..., 2018). Entre 2005 e 2014, houve crescimento continuado do consumo de derivados de petróleo e eletricidade (Gráfico 13.3), notadamente para atendimento aos setores transportes e serviços (Gráfico 13.4). No entanto, a partir de 2014, a redução da atividade econômica interrompeu a tendência de crescimento do consumo final, conforme evidencia a evolução do consumo de energia em relação ao valor agregado setorial (Gráfico 13.6).

\section{Desafios setoriais}

A busca por fontes de energia seguras, confiáveis, de menor custo, baixo impacto ambiental e maior eficiência são objetivos comuns a todos os setores. Entretanto, diante de imperfeições de mercado e restrições diversas (orçamentárias, locacionais etc.), nem sempre é possível atingir tais objetivos. As subseções seguintes exploram os desafios setoriais relacionados ao consumo de energia.

\section{Setor energético}

No Brasil, as agentes do setor energético deparam-se frequentemente com barreiras regulatórias, institucionais, econômicas e de mercado, que dificultam a expansão da infraestrutura, gerando distorções na oferta e consumo de energia no País.

\footnotetext{
4 O Brasil possui elevada participação de fontes renováveis em seu sistema energético (Gráfico 13.7) e com potencial hidroelétrico na Região Norte (Tabela 13.4), embora com reconhecidas restrições ambientais para seu aproveitamento.
} 
The growth of the domestic production of petroleum has reduced the foreign dependence on crude petroleum, though there is an increasing dependence on imported petroleum products, mainly naphtha, gasoline and diesel fuel (Graph 13.8). Between 2005 and 2014, investment decisions involving mega-projects limited the expansion of the Brazilian refining park, in time to meet the domestic demand for fuels with more restricted specifications for the level of sulfur (KÖBERLE et al., 2018).

Additionally, the limited expansion of the pipeline networks for transportation and distribution reduced the exploitation of the domestic supply of natural gas for thermoelectric power, increasing the dependence on the imported input by ship (liquefied natural gas - LNG). The electricity system also faces permanent challenges of modernization and replacement of the infrastructure in the end of service life, of integration of intermittent sources to the National Interconnected System - SIN, as well as of restrictions to the expansion related to socio-environmental and land issues.

\section{Transportation sector}

The transportation sector comprises the road, air, water and railway modals. Nevertheless, the activity of road transportation represented nearly $60 \%$ of the Brazilian cargo transportation matrix and more than $90 \%$ of the Brazilian passenger transportation matrix in $2017^{5}$. Petroleum products are, thus, the major source of energy in this sector, being diesel fuel the most consumed (44\%), followed by gasoline (29\%) and ethanol (16\%) (BALANÇO..., 2018).

The pattern of energy efficiency of the transportation system is directly affected by the degradation of the infrastructure and by the lack of systemic modal integration, which might be its main challenge. There are a number of barriers for the use of more efficient modals and vehicles, whether technical, economic or even cultural (RATHMANN, 2017).

\section{Industrial sector}

The industrial sector is broad and heterogeneous in its use of energy. The major consumers of energy are the sub-sectors of: nonferrous and other items from basic metals, like pig iron and steel, and iron alloys; as well as food and beverages; and pulp and paper, being electricity (20\%), natural gas (11\%) and sugarcane bagasse (20\%) the 5 Transportation activity measured in number of tonnes-kilometer transported
(cargo) and number of passengers-kilometer transported (passengers). 
O crescimento da produção doméstica de petróleo reduziu a dependência externa por petróleo bruto, entretanto há uma crescente dependência por derivados de petróleo importados, principalmente, nafta, gasolina e óleo diesel (Gráfico 13.8). Entre 2005 e 2014, decisões de investimento envolvendo megaprojetos limitaram a expansão do parque de refino brasileiro, a tempo de atender a demanda doméstica por combustíveis com especificações mais restritas para o teor de enxofre (KÖBERLE et al., 2018).

Adicionalmente, limitações na expansão da rede de gasodutos de transporte e distribuição reduziram o aproveitamento da oferta doméstica de gás natural para geração termoelétrica, elevando a dependência pelo insumo importado por navio (gás natural liquefeito - GNL). O sistema elétrico também enfrenta desafios permanentes de modernização e substituição da infraestrutura em fim de vida útil, de integração de fontes intermitentes ao Sistema Interligado Nacional (SIN), além de restrições à expansão relacionadas a questões socioambientais e fundiárias.

\section{Setor transportes}

O setor transportes compreende os modais rodoviário, aéreo, hidroviário e ferroviário. Contudo, a atividade de transporte rodoviário representou, em 2017, cerca de $60 \%$ da matriz de transporte brasileira de carga e mais de $90 \%$ da matriz de transporte brasileira de passageiros 5 . Os derivados de petróleo são, portanto, a principal fonte de energia do setor, sendo o diesel o combustível mais consumido (44\%), além da gasolina (29\%) e do etanol (16\%) (BALANÇO..., 2018).

O padrão de eficiência energética do sistema de transportes é diretamente afetado pela degradação da infraestrutura e pela falta de integração modal sistêmica, talvez, o seu principal desafio. Há diversas barreiras identificadas no uso de veículos e modais mais eficientes, sejam elas técnicas, econômicas ou mesmo culturais (RATHMANN, 2017).

\section{Setor industrial}

O setor industrial é amplo e heterogêneo em seus usos de energia. Os principais consumidores de energia são os subsetores: não ferrosos e outros da metalurgia, como ferro gusa e aço, e ferro-ligas; além de alimentos e bebidas; e papel e celulose, sendo a eletricidade (20\%), o gás natural (11\%) e o bagaço da cana-de-açúcar (20\%) as fontes

\footnotetext{
5 Atividade de transporte mensurada em número de toneladas-quilômetro transportados (carga) e número de passageiros-quilômetro transportados (passageiros).
} 
most consumed sources in industry (BALANÇO..., 2018). Sectors like non-ferrous and other items from basic metals are electric-intensive in its energy consumption, whereas the consumption of natural gas takes place mostly in chemical and non-metallic items (ceramic). The consumption of sugarcane bagasse stands out due to its use as energy for the production of sugar, the reason why the sub-sector of food and beverages is the one that consumes most energy in the industrial sector (27\%, in 2017) (BALANÇO..., 2018).

Graph 13.9 shows the evolution, between 2008 and 2017, of the final consumption of energy (stacked columns; left axis) and the final consumption of energy in relation to the Gross Domestic Product - GDP of the sector (lines; right axis), with the industry average represented by the black line - about 0.2 tonnes of oil equivalent (toe) per thousand US dollars, in 2013. The most intensive sectors in consumption of energy in relation to the GDP are basic metals and pulp and paper, with values above 1.0 toe/thousand US dollars, in 2013.

The energy efficiency measures in industry are the major opportunity to reduce the consumption of energy. Such measures involve different solutions, like instrumentation and pressure control; highperformance furnaces and motors; lighting systems; refrigeration; pumping; and compression, among others, capable of making the industrial processes less energy intensive. Nevertheless, there are a number of barriers, whether technical, economic or even cultural, that limit the adoption of those measures. Moreover, limitations in the expansion of the infrastructure of the energy and transportation sectors rise the cost of inputs and services for the industrial sector, like electricity and logistics cost.

\section{Buildings sector}

The buildings sector comprises the residential, commercial and services sectors; as well as the public sector. Electricity is the major source consumed in the commercial and services sector in different uses (driving force; process heat; direct heating; refrigeration; lighting, etc.), as well as in lighting, in the public sector. Besides electricity, the residential sector has LPG and firewood as the major sources of energy, used for cooking and direct heating.

In 2017, the building sector accounted for 51\% of the final consumption of electricity in Brazil. The presence of cultural, technological, financial and market barriers, as well as transaction costs and problems related to the main agent (tenant/landlord) are frequent. Such barriers distort the real opportunity cost of investments in energy efficiency and lead, for example, to the 
mais consumidas na indústria (BALANÇO..., 2018). Setores como não ferrosos e outros da metalurgia são eletrointensivos em seu consumo energético, enquanto o consumo de gás natural ocorre majoritariamente na química e em não metálicos (cerâmica). O consumo de bagaço de cana se destaca devido ao uso como energético para produção de açúcar, razão pela qual o subsetor de alimentos e bebidas é aquele que mais consome energia no setor industrial (27\%, em 2017) (BALANÇO..., 2018).

O Gráfico 13.9 apresenta a evolução, entre 2008 e 2017, do consumo final de energia (colunas empilhadas; eixo à esquerda) e o consumo final de energia em relação ao Produto Interno Bruto (PIB) do setor (linhas; eixo à direita), com a média da indústria representada pela linha tracejada preta - cerca de 0,2 toneladas equivalentes de petróleo (tep) por milhares de dólares americanos, em 2013. Os setores mais intensivos no consumo de energia em relação ao PIB são a metalurgia e o setor de papel e celulose, com valores superiores a 1,0 tep/milhares de dólares americanos, em 2013.

As medidas de eficiência energética na indústria constituem a principal oportunidade para redução do consumo de energia. Tais medidas envolvem diferentes soluções, como instrumentação e controle de pressão; fornos e motores de alto rendimento; sistemas de iluminação; refrigeração; bombeamento; e compressão, dentre outros, capazes de tornar os processos industriais menos energointensivos. Há, entretanto, diversas barreiras, sejam elas técnicas, econômicas ou mesmo culturais, que limitam a adoção dessas medidas. Ademais, limitações na expansão da infraestrutura dos setores energético e transportes elevam o custo de insumos e serviços para o setor industrial, como a eletricidade e o custo logístico.

\section{Setor edificações}

O setor de edificações compreende os setores residencial; comercial e serviços; além do setor público. A eletricidade é a principal fonte consumida no setor comercial e serviços em diferentes usos (força motriz; calor de processo; aquecimento direto; refrigeração; iluminação etc.), assim como no setor público, na iluminação. $O$ setor residencial tem entre suas principais fontes de energia, além da eletricidade, 0 GLP e lenha, utilizados para cocção e aquecimento direto.

Em 2017, o setor de edificações foi responsável por 51\% do consumo final de eletricidade no País. A presença de barreiras culturais, tecnológicas, financeiras e de mercado, além de custos de transação e problemas de agente principal (locatário/locador) são frequentes. Tais barreiras distorcem o real custo de oportunidade de investimentos em eficiência energética e levam, por exemplo, à aquisição de equipamentos mais baratos, porém nem sempre eficientes no uso energético (GONZÁLEZ-MAHECHA et 
acquisition of cheaper - though not always efficient - equipment in the energy use (GONZÁLEZ-MAHECHA et al., 2019). In addition, the challenges of this sector involve the long service life of the buildings, which rise the risk of locking in inefficient infrastructures.

\section{Agricultural sector}

The use of energy sources has changed significantly in the agricultural sector, keeping pace with its modernization. In 2017, the major energy sources used were diesel fuel (use in agricultural machinery), firewood (grain drying and heat generation in aviculture) and electricity (irrigation), with shares of $45.9 \%, 30.0 \%$ and $23.6 \%$, respectively, in the final consumption of the sector (BALANÇO..., 2018).

\section{Final remarks}

Historically speaking, Brazil has an energy matrix with a large relative share of renewable sources, mainly due to hydroelectricity and sugarcane products. Nevertheless, the expansion of the energy sector is prime to the economic growth and improvement of life quality. In comparative terms, the per capita consumption of energy in Brazil is still low (about 1.25 per capita toe, whereas the average figure for the Organization for Economic Cooperation and Development - OECD is about 4.0 per capita toe, as well as it is unevenly distributed along regions and income classes. To the regulatory, institutional, economic and market challenges and expansion of the energy infrastructure, one should add the need to employ safe, reliable, low-cost and low environmental impact sources of energy.

In 2015, Brazil announced the commitment to reduce the emission of green-house effect gases in 2025 at a level 37\% below that of 2005 in the 21st Conference of the Parties, of the 2015 United Nations Climate Change Conference - COP-21, in Paris. Historically speaking, the emission from deforestation comprises a relevant parcel of the Brazilian emission. Despite the strong drop between 2005 and 2012, deforestation is increasing once again in Brazil. Such trend reversal may create additional challenges to the energy sector in terms of the decabornization effort (ROCHEDO et al., 2018). Therefore, the reduction of the deforestation rates, exploitation of energy resources from sustainable biomass and a bio-economy based on the use of biological assets and biodiversity are of prime importance for the Brazilian energy sector. 
al., 2019). Além disso, os desafios do setor envolvem a longa vida útil das edificações, que elevam o risco de aprisionamento (lock-in) em infraestruturas ineficientes.

\section{Setor agropecuário}

O uso de fontes energéticas mudou significativamente no setor agropecuário, acompanhando sua modernização. Em 2017, os principais energéticos utilizados foram o óleo diesel (uso em maquinário agrícola), a lenha (secagem de grãos e na geração de calor na avicultura) e a eletricidade (irrigação), com participações, de 45,9\%, 30,0\% e 23,6\%, respectivamente, no consumo final do setor (BALANÇO..., 2018).

\section{Conclusão}

O Brasil tem historicamente uma matriz energética com alta participação relativa de fontes renováveis, principalmente em função da hidroeletricidade e dos produtos da cana-de-açúcar. Entretanto, a expansão do setor energético é necessária ao crescimento econômico e à melhora na qualidade de vida. Em termos comparativos, o consumo de energia per capita no Brasil ainda é baixo (cerca de 1,25 tep per capita, enquanto a média para países da Organização para a Cooperação e Desenvolvimento Econômico (OCDE) é de aproximadamente 4,0 tep per capita), além de desigualmente distribuído entre regiões e classes de renda. Aos desafios regulatórios, institucionais, econômicos e de mercado à expansão da infraestrutura energética, soma-se a necessidade de empregar fontes de energia seguras, confiáveis, de baixo custo e baixo impacto ambiental.

Em 2015, o Brasil apresentou na 21aㅡ Conferência das Partes, da Convenção-Quadro das Nações Unidas sobre Mudança de Clima (COP-21), em Paris, o compromisso de redução de emissões de gases de efeito estufa em 2025 para níveis 37\% abaixo daqueles de 2005. Historicamente, as emissões de desmatamento compreendem uma parcela relevante das emissões brasileiras. Apesar da forte queda entre 2005 e 2012, o desmatamento voltou a crescer no Brasil. Tal reversão de tendência pode criar desafios adicionais ao setor energético em termos de esforço de descarbonização (ROCHEDO et al., 2018). Portanto, a redução nas taxas de desmatamento, o aproveitamento de recursos energéticos de biomassa sustentável e uma bioeconomia baseada no uso dos ativos biológicos e de biodiversidade são de fundamental importância para o setor energético brasileiro. 


\section{References}

BALANÇO energético nacional 2018: ano base 2017. Rio de Janeiro: Empresa de Pesquisa Energética - EPE, 2018. Available from: <http:// www.epe.gov.br/pt/publicacoes-dados-abertos/publicacoes $>$. Cited: May 2019.

GONZÁLEZ-MAHECHA, R. E. et al. Greenhouse gas mitigation potential and abatement costs in the Brazilian residential sector. Energy and Buildings, New York, v. 184, p. 19-33, Feb. 2019. Available from: $<$ https://www.sciencedirect.com/journal/energy-and-buildings $>$. Cited: May 2019.

KÖBERLE, A. C. et al. Are conventional energy megaprojects competitive? Suboptimal decisions related to cost overruns in Brazil. Energy Policy, Amsterdam, v. 122, p. 689-700, Nov. 2018. Available from: <https://www.sciencedirect.com/journal/energy-policy/issues>. Cited: May 2019.

RATHMANN, R. (Org.). Modelagem setorial de opções de baixo carbono para o setor de transportes. Brasília, DF: Ministério da Ciência, Tecnologia, Inovações e Comunicações: ONU Meio Ambiente, 2017. 458 p. (Opções de mitigação de emissões de gases de efeito estufa em setores-chave do Brasil). Available from: <http://www.mctic.gov.br/mctic/export/ sites/institucional/ciencia/SEPED/clima/arquivos/projeto_opcoes_ mitigacao/publicacoes/Transportes.pdf>. Cited: May 2019.

ROCHEDO, P. R. R. et al. The threat of political bargaining to climate mitigation in Brazil. Nature Climate Change, v. 8, n. 8, p. 695-698, Aug. 2018. Available from: <https://www.nature.com/nclimate/volumes >. Cited: May 2019.

Translated by: La-Fayette Côrtes Neto 


\section{Referências}

BALANÇO energético nacional 2018: ano base 2017. Rio de Janeiro: Empresa de Pesquisa Energética - EPE, 2018. Disponível em: <http://www.epe.gov.br/pt/ publicacoes-dados-abertos/publicacoes $>$. Acesso em: maio 2019.

GONZÁLEZ-MAHECHA, R. E. et al. Greenhouse gas mitigation potential and abatement costs in the Brazilian residential sector. Energy and Buildings, New York, v. 184, p. 1933, Feb. 2019. Disponível em: <https://www.sciencedirect.com/journal/energy-andbuildings $>$. Acesso em: maio 2019.

KÖBERLE, A. C. et al. Are conventional energy megaprojects competitive? Suboptimal decisions related to cost overruns in Brazil. Energy Policy, Amsterdam, v. 122, p. 689-700, Nov. 2018. Disponível em: <https://www.sciencedirect.com/journal/energy-policy/ issues>. Acesso em: maio 2019.

RATHMANN, R. (Org.). Modelagem setorial de opções de baixo carbono para o setor de transportes. Brasília, DF: Ministério da Ciência, Tecnologia, Inovações e Comunicações: ONU Meio Ambiente, 2017.458 p. (Opções de mitigação de emissões de gases de efeito estufa em setores-chave do Brasil). Disponível em: <http://www.mctic.gov.br/mctic/ export/sites/institucional/ciencia/SEPED/clima/arquivos/projeto_opcoes_mitigacao/ publicacoes/Transportes.pdf>. Acesso em: maio 2019.

ROCHEDO, P. R. R. et al. The threat of political bargaining to climate mitigation in Brazil. Nature Climate Change, v. 8, n. 8, p. 695-698, Aug. 2018. Disponível em: <https://www. nature.com/nclimate/volumes>. Acesso em: maio 2019. 


\section{Tabela 13.1 - Dados gerais de energia - 2015-2017 \\ Table 13.1 - General energy data - 2015-2017}

\begin{tabular}{|c|c|c|c|c|}
\hline $\begin{array}{l}\text { Especificação/ } \\
\text { Item }\end{array}$ & $\begin{array}{l}\text { Unidade/ } \\
\text { Unit }\end{array}$ & 2015 & 2016 & 2017 \\
\hline Oferta interna de energia/ & $10^{6}$ tep/ & 300 & 288 & 293 \\
\hline Domestic energy supply & $10^{6}$ toe & & & \\
\hline Per capital & tep/hab & 1,46 & 1,39 & 1,41 \\
\hline Per capita & toe/inhab & & & \\
\hline Por PIB/ & tep/1 000 US\$ & 0,101 & 0,101 & 0,101 \\
\hline Per GDP & toe $/ 1,000$ US\$ & & & \\
\hline Consumo final de energia/ & $10^{6}$ tep/ & 261 & 256 & 260 \\
\hline Final energy consumption & $10^{6}$ toe & & & \\
\hline Geração de eletricidade/ & TWh & 485 & 480 & 491 \\
\hline Electricity generation & $T W h$ & & & \\
\hline Produção de petróleo/ & $10^{3} \mathrm{~b} / \mathrm{d} /$ & 2529 & 2600 & 2707 \\
\hline Petroleum production & $10^{3} \mathrm{~b} / \mathrm{d}$ & & & \\
\hline Importação total de energia/ & $10^{3} \mathrm{bep} / \mathrm{d} /$ & 1472 & 1253 & 1390 \\
\hline Total energy imports & $10^{3}$ boe $/ d$ & & & \\
\hline Exportação total de energia/ & $10^{3} \mathrm{bep} / \mathrm{d} /$ & 999 & 1083 & 1276 \\
\hline Total energy exports & $10^{3} \mathrm{boe} / \mathrm{d}$ & & & \\
\hline
\end{tabular}

Fonte/Source: Balanço energético nacional 2018: ano base 2017. Brasília, DF: Empresa de Pesquisa Energética - EPE, 2017. Disponível em/Available from : <https://ben.epe.gov.br>. Acesso em: jan. 2019/ Cited: Jan. 2019.

Nota: tep - tonelada equivalente de petróleo; bep - barril equivalente de petróleo; b/d - barril por dia; produção de petróleo inclui óleo de xisto e líquidos de gás natural; 1 tep $=7,05$ bep (barril equivalente de petróleo.

Note: toe - tonne of oil equivalent; boe - barrel of oil equivalent; b/d - barrel per day. 
Tabela 13.2 - Geração de energia elétrica - 2016-2017

Table 13.2 - Generation of Electricity - 2016-2017

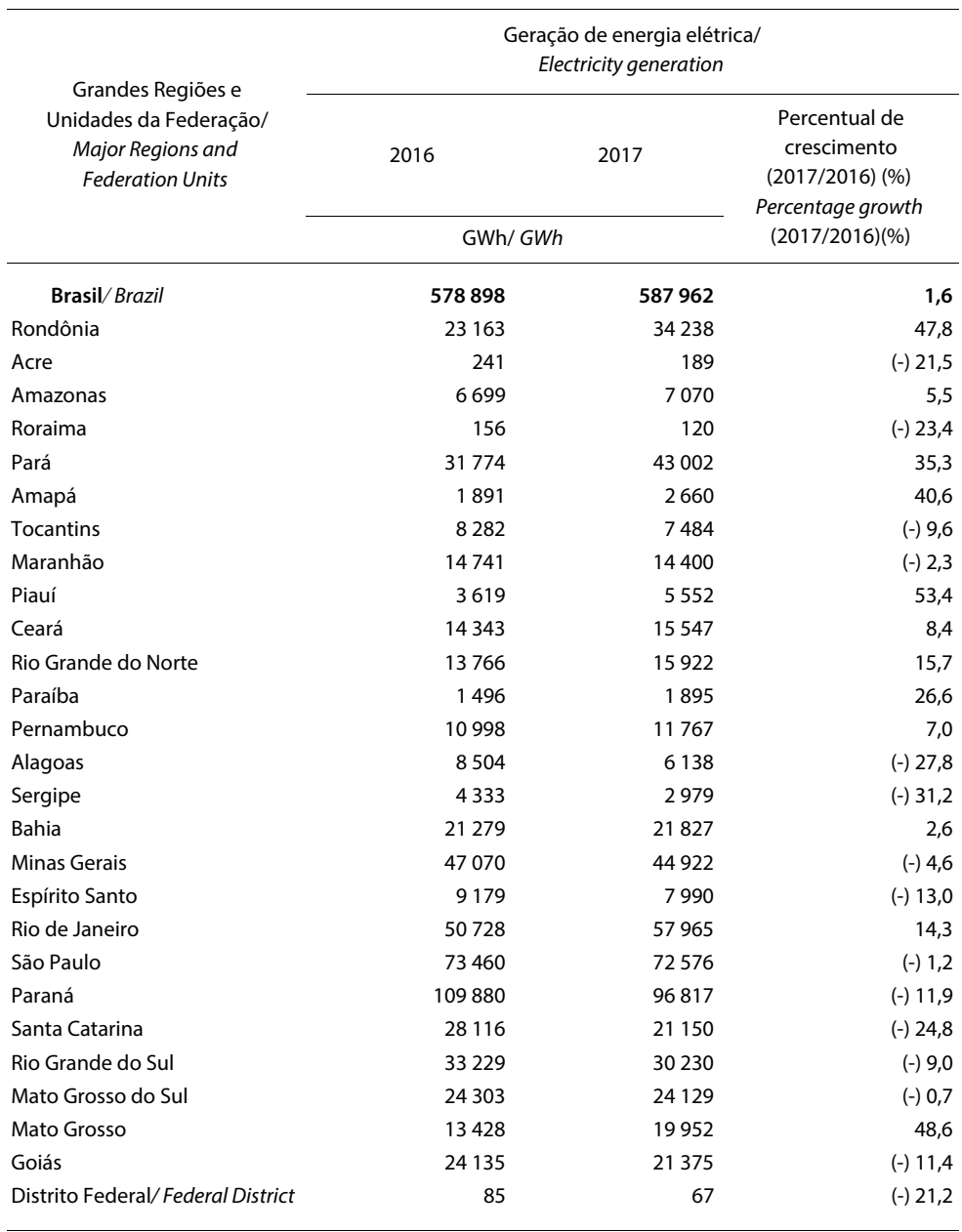

Fonte/Source: Balanço energético nacional 2018: ano base 2017. Brasília, DF: Empresa de Pesquisa Energética - EPE, 2017. Disponível em/Available from : <https://ben.epe.gov.br>. Acesso em: jan. 2019/ Cited: Jan . 2019.

Nota: Inclusive geração de autoprodutores./Note: Including generation from auto-producers. 


\section{Tabela 13.3 - Produção de petróleo e oferta interna de energia, por países selecionados - 2017 \\ Table 13.3 - Petroleum production and total primary energy supply, by selected country - 2017}

\begin{tabular}{|c|c|c|c|}
\hline \multirow{2}{*}{$\begin{array}{l}\text { Países selecionados/ } \\
\text { Selected countries }\end{array}$} & \multirow{2}{*}{$\begin{array}{l}\text { Produção de petróleo } \\
\text { (1 } 000 \text { bbl/dia) (1)/ } \\
\text { Petroleum production } \\
(1,000 \text { barrels per day) (1) }\end{array}$} & \multicolumn{2}{|c|}{$\begin{array}{l}\text { Oferta interna de energia/ } \\
\text { Total primary energy supply }\end{array}$} \\
\hline & & $\begin{array}{l}\text { Total }\left(10^{6} \text { tep }\right) / \\
\text { Total }\left(10^{6} \text { toe }\right)\end{array}$ & $\begin{array}{l}\text { tep per capital } \\
\text { toe per capita }\end{array}$ \\
\hline Alemanha/Germany & 142 & 314 & 3,82 \\
\hline Argentina/Argentina & 480 & 86 & 1,94 \\
\hline Brasil/ Brazil & 2707 & 293 & 1,40 \\
\hline Canadá/ Canada & 4856 & 291 & 7,95 \\
\hline Chile/Chile & 6 & 38 & 2,11 \\
\hline Estados Unidos/United States & 14309 & 2137 & 6,59 \\
\hline França/France & 95 & 245 & 3,77 \\
\hline Itália/Italy & 108 & 154 & 2,59 \\
\hline Japão/Japan & 25 & 429 & 3,37 \\
\hline Reino Unido/United Kingdom & 1026 & 176 & 2,66 \\
\hline
\end{tabular}

Fonte/Source: International Energy Agency - IEA.

(1) Inclusive NGL - Líquidos de Gás Natural. / (1) Including NGL - Natural Gas Liquids.

\section{Gráfico 13.1 - Produção de energia primária - Brasil - 2005-2017 Graph 13.1 - Primary energy production - Brazil - 2005-2017}

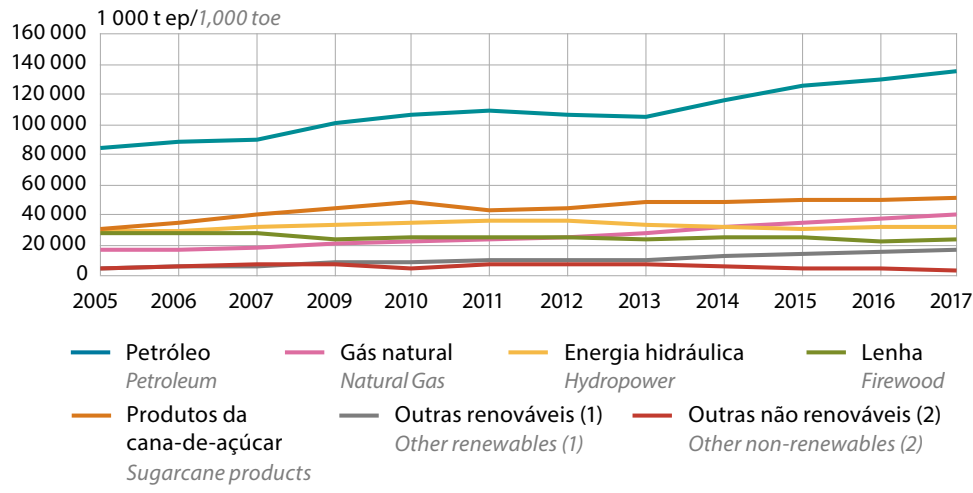

Fonte/Source: Balanço energético nacional 2018: ano base 2017. Brasília, DF: Empresa de Pesquisa Energética - EPE, 2017. Disponível em/Available from: <https://ben.epe.gov.br>. Acesso em: jan. 2019/Cited: Jan. 2019. (1) Inclui energia eólica, energia solar, biodiesel, lixívia e outros resíduos renováveis./ (1) Includes wind, solar, biodiesel, black liquor and other renewable wastes. (2) Inclui carvão mineral vapor e metalúrgico, urânio e gases industriais./ (2) Includes steam and metallurgical coal, Uranium and industrial gases. 
Tabela 13.4 - Potencial hidrelétrico, segundo as bacias hidrográficas - 2018 Table 13.4 - Hydroelectric potential, according to river basin - 2018

\begin{tabular}{|c|c|c|c|c|c|}
\hline \multirow{2}{*}{$\begin{array}{l}\text { Bacias hidrográficas/ } \\
\text { River basins }\end{array}$} & \multicolumn{5}{|c|}{$\begin{array}{l}\text { Potencial hidrelétrico (Potência instalada-MW)/ } \\
\text { Hydroelectric potential (Installed power-MW) }\end{array}$} \\
\hline & $\begin{array}{l}\text { Total/ } \\
\text { Total }\end{array}$ & $\begin{array}{l}\text { Em operação/ } \\
\text { In operation }\end{array}$ & $\begin{array}{l}\text { Inventário/ } \\
\text { Inventory }\end{array}$ & $\begin{array}{l}\text { Estimado/ } \\
\text { Estimated }\end{array}$ & $\begin{array}{l}\text { Outros (1)/ } \\
\text { Others (1) }\end{array}$ \\
\hline Total/ Total & 246241 & 107421 & 72774 & 43618 & 22428 \\
\hline Amazônica/Amazon & 94935 & 23246 & 38538 & 30595 & 2556 \\
\hline Tocantins/Tocantins & 26936 & 13253 & 8383 & 1875 & 3425 \\
\hline $\begin{array}{l}\text { Atlântico Norte e Nordeste/ North } \\
\text { and Northeast Atlantic }\end{array}$ & 2905,4 & 812 & 871 & 707 & 516 \\
\hline São Francisco/São Francisco & 22606 & 10786 & 3649 & 1561 & 6610 \\
\hline Atlântico Leste/ Eastern Atlantic & 13987 & 5455 & 5759 & 1423 & 1350 \\
\hline Paraná/Paraná & 62789 & 43636 & 9645 & 5086 & 4423 \\
\hline Uruguai/Uruguay & 11729 & 6415 & 4059 & 342 & 913 \\
\hline Atlântico Sudeste/ Southeast Atlantic & 10353 & 3818 & 1870 & 2031 & 2634 \\
\hline
\end{tabular}

Fonte/Source: Potencial hidrelétrico brasileiro por bacia hidrográfica. In: Eletrobras. Sistema de Informações do Potencial Hidrelétrico Brasileiro (Sipot). Rio de Janeiro: [2018]. Disponível em/Available from : <http://eletrobras.com/pt/AreasdeAtuacao/geracao/sipot/PotencialHidrel\%C3\%A9tricoBrasileiroBacia-Dezembro2017.pdf>. Acesso em/Cited : Jan. 2019.

Nota: Dados de dezembro 2018./Note: Data for December 2018.

\section{Gráfico 13.2 - Evolução da oferta interna de energia - Brasil - 2005-2017 Graph 13.2 - Primary Energy Supply - Brazil - 2005-2017}

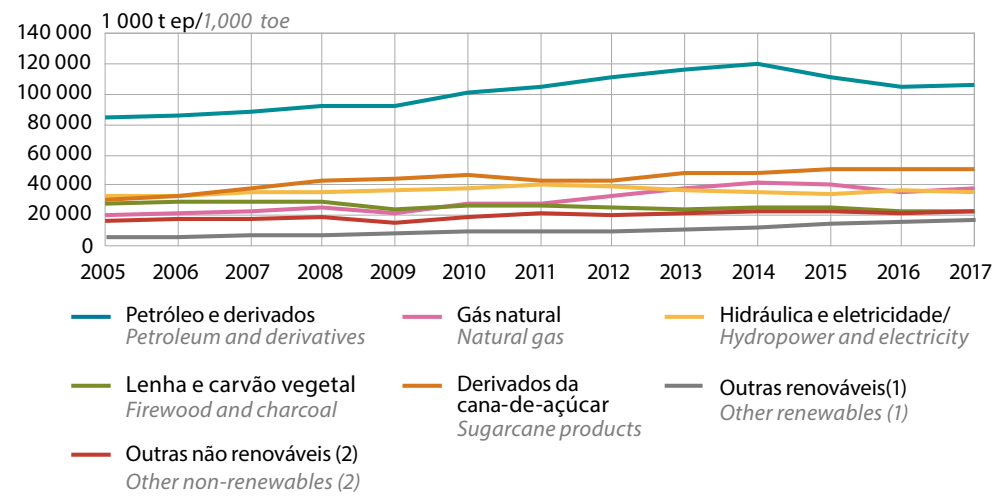

Fonte/Source: Balanço energético nacional 2018: ano base 2017. Brasília, DF: Empresa de Pesquisa Energética - EPE, 2017. Disponível em/Available from: <https://ben.epe.gov.br>. Acesso em: jan. 2019/Cited: Jan. 2019.

(1) Inclui energia eólica, energia solar, biodiesel, lixívia e outros resíduos renováveis./ Includes wind, solar, biodiesel, black liquor and other renewable wastes. (2) Inclui carvão mineral vapor e metalúrgico, urânio e gases industriais./Includes steam and metallurgical coal, Uranium and industrial gases. 


\section{Gráfico 13.3 - Evolução do consumo final de energia, por fonte - Brasil - 2005-2017}

\section{Graph 13.3 - Evolution of final energy consumption, by source - Brazil - 2005-2017}

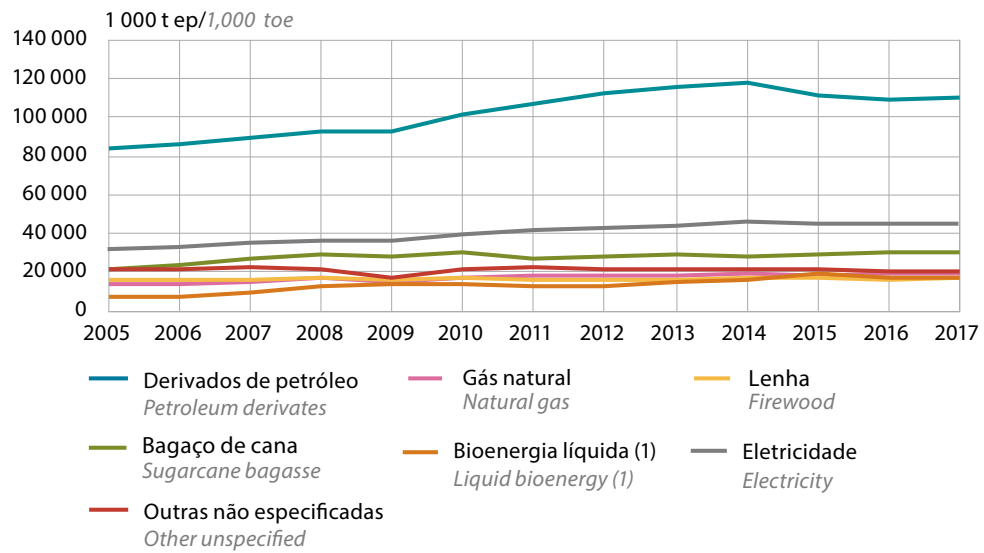

Fonte/Source: Balanço energético nacional 2018: ano base 2017. Brasília, DF: Empresa de Pesquisa Energética - EPE, 2017. Disponível em/Available from: <https://ben.epe.gov.br>. Acesso em: jan. 2019/Cited: Jan. 2019.

\section{Gráfico 13.4 - Evolução do consumo final de energia, por setor - Brasil - 2005-2017}

Graph 13.4 - Evolution of final energy consumption, by sector - Brazil - 2005-2017

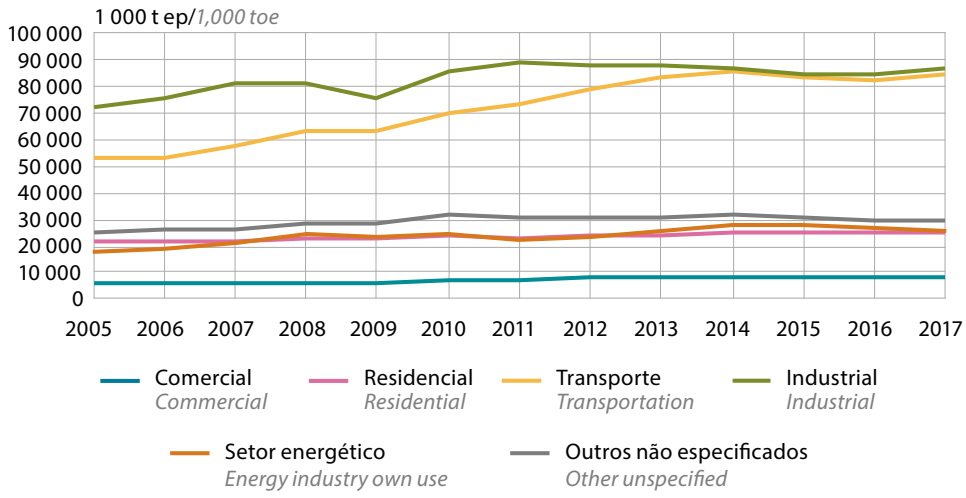

Fonte/Source: Balanço energético nacional 2018: ano base 2017. Brasília, DF: Empresa de Pesquisa Energética - EPE, 2017. Disponível em/Available from: <https://ben.epe.gov.br>. Acesso em: jan. 2019/Cited: Jan. 2019. 


\section{Gráfico 13.5 - Dependência externa de energia, por fonte - Brasil - 2005-2017}

Graph 13.5 - Dependence on foreign energy, by source - Brazil - 2005-2017

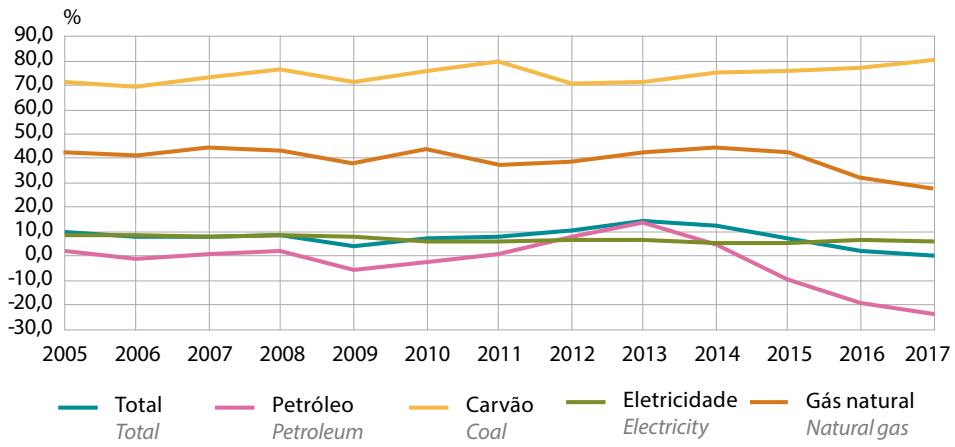

Fonte/Source: Balanço energético nacional 2018: ano base 2017. Brasília, DF: Empresa de Pesquisa Energética - EPE, 2017. Disponível em/Available from: <https://ben.epe.gov.br>. Acesso em: jan. 2019/Cited: Jan. 2019. Nota: Valores negativos correspondem a exportação líquida./Note: Negative values correspond to net export.

\section{Gráfico 13.6 - Evolução do consumo final de energia em relação ao valor agregado, por setor - Brasil - 2005-2017}

Graph 13.6 - Final energy consumption in relation to the added value, by sector - Brazil - 2005-2017

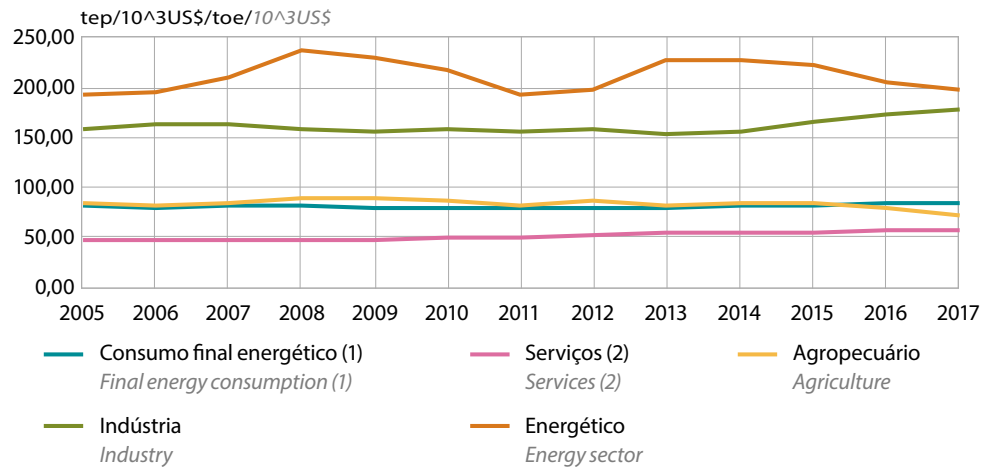

Fonte/Source: Balanço energético nacional 2018: ano base 2017. Brasília, DF: Empresa de Pesquisa Energética - EPE, 2017. Disponível em/Available from: <https://ben.epe.gov.br>. Acesso em: jan. 2019/ Cited: Jan. 2019.

Nota: Dólar constante PPC de 2011./Note: Constant PPP dollar of 2011.

(1) Inclusive consumo residencial./Including residential consumption. (2) Não inclui transportes./ Not including transportation. 


\section{Gráfico 13.7 - Participação de fontes renováveis na matriz energética - 2017-2018}

Graph 13.7 - Share of renewable sources in the energy matrix - 2017-2018

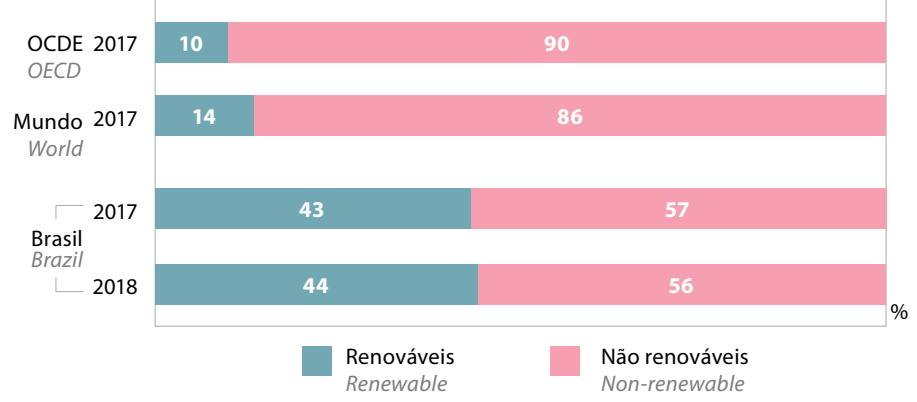

Fontes/Sources: 1. Resenha energética brasileira 2018. Ano base 2017. Brasília, DF: Empresa de Pesquisa Energética - EPE, 2018. Disponível em/Available from: <http://epe.gov.br/pt/publicacoesdados-abertos/publicacoes/balanco-energetico-nacional-2018>. Acesso em: jan. 2019/Cited: Jan. 2019. 2. Agência Internacional de Energia/International Energy Agency.

\section{Gráfico 13.8 - Importação de derivados de petróleo e outros combustíveis - Brasil - 2008-2017}

Graph 13.8-Imports of petroleum products and other fuels - Brazil - 2008-2017

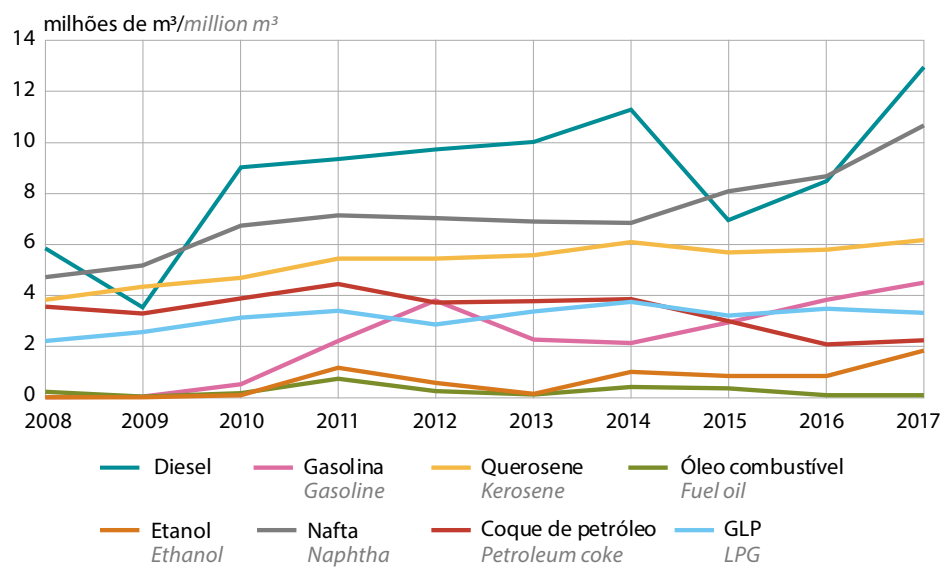

Fonte/Source: Balanço energético nacional 2018: ano base 2017. Brasília, DF: Empresa de Pesquisa Energética - EPE, 2018. Disponível em/Available from: <http://www.epe.gov.br/pt/publicacoesdados-abertos/publicacoes>. Acesso em: maio 2019/Cited: May 2019. 


\section{Gráfico 13.9 - Consumo final de energia do setor industrial e por PIB de cada setor - Brasil - 2008-2017}

Graph 13.9- Final consumption of energy in the industrial sector and by GDP of the industrial sector - Brazil - 2008-2017

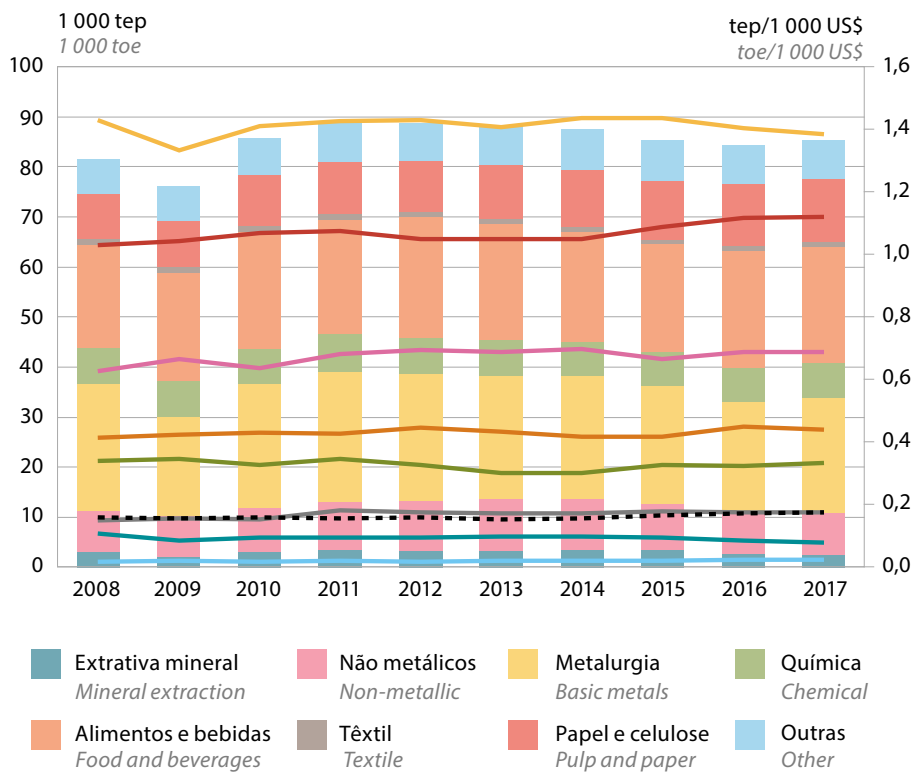

Consumo final de energia/PIB do setor (tep/1000 US\$)

Final consumption of energy/GDP of the sector (toe/1 000 US\$)

- - - Indústria (média)

Industry (average)

$\begin{array}{lccc}\text { Extrativa mineral } & \text { Não metálicos } & \text { Metalurgia } & \text { Química } \\ \text { Mineral extraction } & \text { Non-metallic } & \text { Basic metals } & \text { Chemical } \\ \text { Alimentos e bebidas } & \text { Têxtil } & \text { Textile } & \text { Papel e celulose } \\ \text { Food and beverages } & \text { Pulpand paper } & \text { Outras } \\ \text { Other }\end{array}$

Fonte/Source: Balanço energético nacional 2018: ano base 2017. Rio de Janeiro: Empresa de Pesquisa Energética - EPE, 2018. Disponível em/Available from: <http://www.epe.gov.br/pt/publicacoesdados-abertos/publicacoes>. Acesso em: maio 2019/Cited: May 2019 



\section{Comércio Trade}

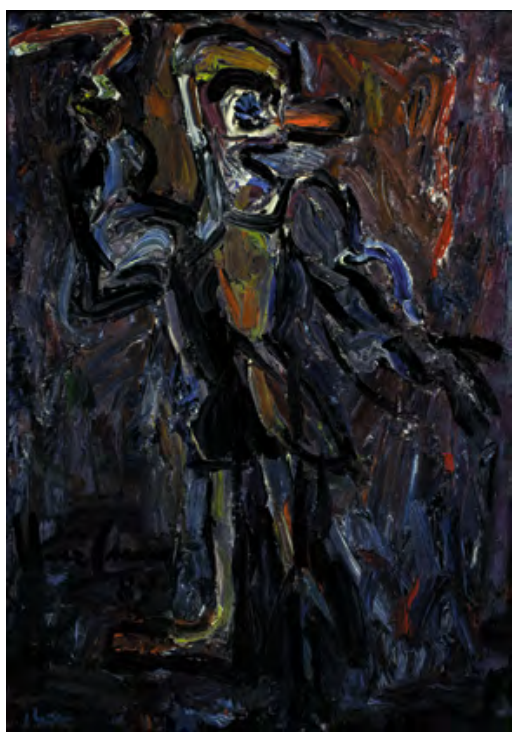

Palhaço, 1987

Clown

Iberê Camargo 


\section{Trade}

\section{Geisa Daise Gumiero Cleps ${ }^{1}$}

Going shopping is a regular activity in people's lives. Virtually all the goods needed for survival are purchased. That apparently simple fact has great significance, since it characterizes our contemporary society to which the generalization of consumption is a fundamental aspect in the constitution of the economy and in the reorganization of the geographic space.

The analysis of commercial activities leads to the understanding of social relations, the living space in the everyday circumstances of cities. In History, the birth of the city precedes that of markets, since the latter came as a consequence of the social and territorial division of labor and of the formation of surpluses. These events have made possible the emergence of a place for exchanges and the intraurban organization of cities.

As cities expanded, new places of attraction for the reproduction of commercial capital were created and incorporated by the space producing agents, resulting in the advent of new urban centralities and in the concentration of tertiary equipment.

In the contemporary society, consuming has become an everyday action marked by the acquisition of goods that aim at the satisfaction of the population's needs, which can be either basic ones for survival or others created by means of communication and information.

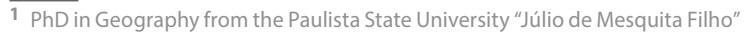
(Unesp) and Associate Professor at the Federal University of Uberlândia. 


\section{Comércio}

\section{Geisa Daise Gumiero Cleps ${ }^{1}$}

Fazer compras é algo bastante comum na vida das pessoas. Praticamente todos os bens necessários à sobrevivência são comprados. Esse fato de aparência simples tem grande significado, caracteriza a sociedade contemporânea na qual a generalização do consumo representa aspecto de fundamental importância na constituição da economia e na reorganização do espaço geográfico.

A análise das atividades comerciais permite compreender as relações sociais, o espaço de vida no cotidiano das cidades. Na história, a cidade precede a origem dos mercados, os quais surgiram a partir da divisão social e territorial do trabalho e da formação de excedente. Estes acontecimentos possibilitam o surgimento do lugar das trocas e a organização intraurbana das cidades.

À medida que as cidades se expandiam, novos lugares de atração para a reprodução do capital comercial foram criados e incorporados pelos agentes produtores do espaço, possibilitando o surgimento de novas centralidades urbanas e de concentração dos equipamentos terciários.

Na sociedade contemporânea, consumir tornou-se um ato cotidiano marcado pela aquisição de mercadorias que visam satisfazer as necessidades da população, sejam elas básicas de sobrevivência ou criadas pelos meios de comunicação e de informação. $\mathrm{O}$ consumo invade o cotidiano e direciona o comportamento das pessoas

1 Doutora em Geografia pela Universidade Estadual Paulista "Júlio de Mesquita Filho" (Unesp) e Professora Associada da Universidade Federal de Uberlândia (UFU). 
Consumption invades everyday life and affects people's behavior with an idealized concept that the purchasing of objects can lead one to happiness. With that renewed meaning, happiness has been turned into a good, acquired social value and invaded the lives of citizens, promoting changes in their habits and lifestyles and in the urban space.

The need of consumption has led to the specialization of exchanging activities, mainly in retail trade, with the concentration and centralization of enterprises which, in search of competition and monopoly, form commercial networks. As the place of social reproduction and of the commercial capital, the city is shaped by new tertiary forms that organize, reorganize, (dis)organize the structure of cities.

Many current forms of trade, like shopping malls and hypermarkets, have become locations for spectacles and temples for marketing goods. For many persons, going shopping is a moment of leisure and entertainment. That extrapolates the value based on the use and the value of exchange of goods.

With the transformations in the world of production and labor, goods move in international markets at a much higher speed, having become more global and caused important changes in the space of trade. So, the action of the capital and its agents on the territories is also geopolitical, for it creates power of decision and of implementation of commercial enterprises from social actions, standardizing and implementing new forms of control, of ruling and regulation of the productive restructuring of capital.

In order to meet the interests of transnational groups that need to build global spaces controlled by networks headquartered in many territories integrated, ruled and controlled by the capital, different commercial transactions made hegemonic by the financial capital have appeared. In global exchanges, the spaces of production, without defined frontiers, face nations that try to establish themselves against the reproduction of capital imposed by global enterprises. That process expresses the spatial formatting of the transnational capital dominance.

In a scenario of changes, of economic and social contradictions, there are forms of exchange established mainly at international level. They transcend frontiers and turn places for the exchange of products into spaces consumed as goods. The space of cities is also consumed by commercial structures that, in turn, attribute a value to the locations and give new meanings to them. 
idealizando que a felicidade será encontrada na aquisição de objetos. Com novo significado, a felicidade tornou-se mercadoria, adquiriu valor social, invadia a vida do cidadão promovendo mudanças nos hábitos, no estilo de vida e nos espaços urbanos.

A necessidade de consumo levou à especialização das atividades de troca, especialmente do comércio varejista com a concentração e a centralização de empresas que, na busca de competição e monopólio, formam redes comerciais. Como lugar da reprodução social e do capital comercial, a cidade é moldada pelas novas formas terciárias que organizam, reorganizam, (des)estruturam as cidades.

Muitas formas de comércio da atualidade, a exemplo dos shoppings centers e hipermercados, transformaram-se em espaços de espetáculos, em templos da mercadoria. Para muitas pessoas fazer compras significa um momento de descontração e entretenimento. Extrapola-se assim, o valor de uso e o valor de troca da mercadoria.

Com as transformações no mundo da produção e do trabalho, as mercadorias circulam em mercados globais com uma velocidade muito maior, tornaram-se globalizadas e provocaram importantes mudanças no espaço do comércio. Assim, ação do capital e de seus agentes sobre os territórios é também geopolítica, pois cria poder de decisão e de implantação de empreendimentos comerciais mediante ações sociais, padronizando e implementando novas formas de controle, de comando e regulação e de reestruturação produtiva do capital.

Para atender o interesse dos grupos transnacionais surgiram diferentes transações comerciais hegemonizadas pelo capital financeiro que precisam construir espaços globalizados, controlados por redes sediadas em vários territórios, integrados, comandados e controlados pelo capital. Nas trocas globais, os espaços de produção, sem fronteiras definidas, depararam-se com nações que tentam impor-se à reprodução do capital imposta pelas empresas globais. Este processo expressa a formatação espacial do domínio do capital transnacional.

Num cenário de mudanças, de contradições econômicas e sociais, surgem formas de trocas que se estabelecem espacialmente em nível mundial. Transcendem as fronteiras e transformam o local de troca de produtos em espaços que são consumidos como mercadoria. $O$ espaço das cidades também passa a ser consumido pelas estruturas comerciais que, por sua vez, atribuem valor ao lugar concedendoIhe novos significados.

Ao examinar a atividade comercial há que se ressaltar que a mesma se apresenta composta pelo comércio varejista e o atacadista. $O$ comércio varejista é representado pelos supermercados, hipermercados, shopping centers, lojas de departamento, 
When examining trade activity one should highlight that it consists of retail and wholesale trade. Retail is represented by supermarkets, hypermarkets, shopping malls, department stores, fairs, markets, vehicle concessionaires and other establishments characterized by the direct selling to consumers, usually in small amounts. Wholesale, on the other hand, is characterized by the commercialization of goods to registered legal persons such as institutions, restaurants, enterprises and retail trade establishments.

The Brazilian Institute of Geography and Statistics (IBGE) defines wholesale trade as that which sells goods to users that will manufacture, resell or incorporate them as a physical asset. It is responsible for intermediating sales between producers and retail resellers (PESQUISA..., 2016).

According to the Brazilian Association of Wholesalers and Distributors of Manufactured Products (ABAD), wholesale trade in Brazil comprises three dimensions: wholesale-distributor, which trades goods and has the function of delivering them to clients; cash and carry wholesaler, in which the client goes to an establishment, chooses the products and carries them to their establishment; and over-the-counter wholesaler, the most traditional type of all, in which a salesperson helps the customer in a wholesale establishment.

Considering the conceptual and theoretical reflections presented, the quantification of data on the trade sector reveals the dynamics of that activity as well as its importance to society, to cities and to the Brazilian economy.

The Annual Survey of Trade (PAC), conducted in 2016 by the IBGE, shows there were 1,546,546 commercial enterprises in the country that year. Among those, 1,205,003 enterprises were listed as retailers (74.07\% of the total), 195,304 belonged to wholesale trade $(17.23 \%)$ and 146,339 were traders of vehicles, pieces and motorcycles ( $8.7 \%$ of the total), as shown in Table 14.1. The data also show a predominance of retail establishments. Retail and automotive establishments, together, amounted to $83 \%$ of the trade establishments.

Concerning the participation of segments in the total revenue of retail trade and vehicles, presented in Graph 14.1, figures show that $23.2 \%$ of the revenues had been generated by the cash and carry food sector represented by supermarkets and hypermarkets; $17.6 \%$ by vehicles and pieces; $14.2 \%$ by trade of fuels; $8.6 \%$ by department, household appliances and furniture stores; $8.1 \%$ of the establishments corresponded to warehouses, grocery stores and food products 
feiras, mercados, concessionárias de veículos e outros, que se caracterizam pela venda direta ao consumidor, geralmente em pequena quantidade. Enquanto que $o$ comércio atacadista é aquele que desempenha a função de comercialização destinada, principalmente, a pessoas jurídicas que possuam cadastro de pessoa jurídica como instituições, restaurantes empresas e estabelecimentos comerciantes de varejo.

O Instituto Brasileiro de Geografia e Estatística (IBGE) define o comércio atacadista como aquele que revende mercadorias a usuários que as transformarão, revenderão ou incorporarão ao ativo fixo. Aquele que intermedia vendas entre produtores e revendedores varejistas (PESQUISA..., 2016).

De acordo com a Associação Brasileira de Atacadistas e Distribuidores de Produtos Industrializados (ABAD), o comércio atacadista do Brasil comporta três modalidades: 0 atacado-distribuidor, que comercializa a mercadoria e também assume a função de entregá-la ao cliente; o atacado de autosserviço no qual o cliente vai até o estabelecimento, serve-se dos produtos e os transporta até o seu estabelecimento; e o atacado de balcão, mais tradicional de todos, em que o cliente é atendido pelo vendedor no estabelecimento atacadista.

A partir das reflexões teórico-conceituais apresentadas, a quantificação de dados sobre o setor comercial revela a dinâmica desta atividade bem como a sua importância para a sociedade, para as cidades e para a economia brasileira.

A Pesquisa Anual de Comércio (PAC), realizada em 2016 pelo IBGE, demonstra que naquele ano existiam 1546546 empresas comerciais no País. Destas, 1205003 foram cadastradas como varejistas (representando 74,07\% do total), 195304 pertenciam ao comércio atacadista (17,23\%) e 146339 por empreendimentos que comercializavam veículos, peças e motocicletas (correspondendo a $8,7 \%$ do total), conforme demonstrado na Tabela 14.1. Os dados revelam ainda o predomínio de estabelecimentos de varejo. Somando-se os estabelecimentos varejistas com os automotivos chega-se a $83 \%$ dos estabelecimentos de comércio.

Ao observar a participação dos segmentos na receita total do comércio varejista e de veículos, apresentada no Gráfico 14.1 , os números demostram que $23,2 \%$ das receitas foram geradas pelo setor de autosserviço alimentar representados pelos supermercados e hipermercados; $17,6 \%$ por veículos e peças; $14,2 \%$ na comercialização de combustíveis; $8,6 \%$ lojas de departamento, eletrodomésticos e móveis; $8,1 \%$ dos estabelecimentos correspondiam a armazéns, mercearias e produtos alimentícios; $7,7 \%$ ao setor farmacêutico; $7,3 \%$ da receita foi gerada pela comercialização de tecidos e artigos do vestuário. 
shops: $7.7 \%$ to the pharmaceutical sector; $7.3 \%$ of the revenue was generated by the trade of fabric and wearing apparel.

In this scenario, putting together the participation of supermarkets, hypermarkets, and grocery stores, it is possible to state that they accounted for the generation of $31.8 \%$ of the revenue of the sector. It is worth highlighting that the big commercial centers hold a spatial and economic monopoly, as they trade several products in one same place. The diversity of items on sale goes beyond food products: wearing apparel, automotive products, household items, electronic items and others are also included.

The hegemony of sales imposed by those network-enterprises has taken place since their establishment in the country, after the second half of the 20th century, a period marked by the internationalization of the sector. In that period, the Brazilian consumer market, according to data from the IBGE, had 206 million inhabitants, being a major market to be supplied. Despite the reduction of sales in the period due to the deceleration of the market, the sector remained as the leader in retail trade.

With reference to the number of enterprises, employed persons and total net revenue and net sales revenue, the data presented in Tables 14.2 e 14.3 highlight the importance of retail trade which, in 2016 , had an overall revenue of $\mathrm{R} \$ 1,509$ billion reais; net sales revenue of $45.1 \%$ in the sector; employed $7,429,558$ workers $(74.1 \%)$ who performed their activities in 1,205,003 enterprises (77.9\%), and whose wages amounted to approximately $\mathrm{R} \$ 138.724$ billion reais $(64.6 \%)$.

In the same period, the total wholesale trade revenue was $\mathrm{R} \$ 1,546.972$ billion reais; $45.3 \%$ of the net sales revenue. Data also show the sector had 195,304 enterprises (12.6\%), employed 1,728,820 persons $(17.2 \%$ of the total), whose wages amounted to $\mathrm{R} \$ 56$ billion reais ( $25.9 \%)$. The data on trade of vehicles, pieces and motorcycles indicate it had a revenue of $\mathrm{R} \$ 323,414$ million reais; net revenue of sales of $9.6 \%$; with a total 146,339 enterprises $(9.5 \%)$ that employed 871,756 persons $(8.7 \%)$ and wages amounting to $\mathrm{R} \$ 20$ billion reais (9.5\%). In Brazil, most trade enterprises are in the retail sector; nevertheless, wholesale trade is bigger in terms of the revenue generated.

As for the total amount generated by both segments, considering the total revenue of approximately $\mathrm{R} \$ 3.4$ billion, it is worth highlighting that wholesale trade accounted for $\mathrm{R} \$ 1.547$ billion, retail trade, for $\mathrm{R} \$ 1.510$ billion and the automotive sector for $\mathrm{R} \$ 323$ million. Graph 
Nesse cenário, somando-se a participação dos supermercados, hipermercados, armazéns e mercearias, pode-se aferir que estes foram responsáveis pela geração de $31,8 \%$ das receitas do setor. Há que se salientar que as grandes superfícies comerciais exercem monopólio econômico e espacial, comercializando vários produtos no mesmo lugar. A diversidade de itens colocados à venda vai além dos voltados para a alimentação, inclui artigos de vestuário, produtos automotivos, eletrodomésticos, eletrônicos e outros.

A hegemonia de vendas imposta por estas empresas-rede ocorre desde sua implantação no País, a partir da segunda metade do Século XX, marcada pela internacionalização do setor. Naquele período, o mercado consumidor brasileiro, de acordo com os dados do IBGE, contava com 206 milhões de habitantes, constituindo um grande mercado para abastecer. Apesar do recuo nas vendas no período devido o desaquecimento do mercado, o setor manteve-se na liderança do varejo.

No que se refere ao número de empresas, pessoal ocupado e receita líquida total e receita líquida de revenda, as informações apresentadas nas Tabelas 14.2 e 14.3 reforçam a importância do comércio varejista que, no ano de 2016, obteve receita total de R\$ 1509 bilhões de reais; receita líquida de revende de 45,1\% no setor; empregava 7429558 trabalhadores (74,1\%) os quais exerciam suas atividades laborais em 1205003 empresas (77,9\%), cujos salários correspondiam a aproximadamente $\mathrm{R} \$ 138724$ bilhões de reais $(64,6 \%)$.

No mesmo período, considerando as mesmas informações, pode-se aferir que a receita total do comércio atacadista foi de R\$ 1546972 bilhões de reais; 45,3\% da receita líquida de revenda. Os dados revelam ainda que o setor possuía 195304 empresas (12,6\%), empregava 1728820 trabalhadores (17,2\% do total) que no conjunto receberam remunerações equivalente a $\mathrm{R} \$ 56$ bilhões de reais $(25,9 \%)$. Para o comércio de veículos, peças e motocicletas os dados informam que o mesmo gerou receita no valor de R\$ 323414 milhões de reais; um valor líquido de revenda no total de 9,6\%; com um total de 146339 empresas (9,5\%) que empregavam 871756 trabalhadores (8,7\%); somados os salários deste pessoal ocupado chegaram a $\mathrm{R} \$ 20$ bilhões de reais $(9,5 \%)$. Há no Brasil um número maior de empresas de varejo. Contudo, no que concerne à renda gerada, o comércio atacadista supera o valor gerado pelo varejo.

Com relação ao valor total gerado pelo conjunto, em relação à receita total que chegou a aproximadamente $\mathrm{R} \$ 3,4$ bilhões, destaca-se que o comércio atacadista foi responsável pelo faturamento de R\$ 1547 bilhões, o varejista R\$ 1510 bilhões e o setor automotivo por R\$323 milhões. O Gráfico 14.2 apresenta dados que justificam a participação do setor atacadista no que concerne a receita total do setor e revelam que 
14.2 presents data that justify the participation of the wholesale segment in terms of the overall revenue of the sector and show that $24 \%$ of the overall revenue was generated by the segment of fuels; $19.4 \%$ by the trade of food products, $11.7 \%$ by goods in general; $10.7 \%$ by pharmaceuticals; $7.8 \%$ by fresh agricultural products; $5 \%$ by machinery and equipment; and $21.3 \%$ by other products. The data reveal the diversity of products traded by wholesale enterprises.

With reference to the participation of enterprises by ranges of employed persons, Graph 14.3, shows there were 3,263,067.402 persons employed in the trade sector in 2016. The biggest enterprises, with 500 or more employees, corresponded to 1,040,638. 973 (31.9\%). The small ones, which employed up to 19 persons, were 927,143. 581 (28.9\%); those employing 20 to 29 persons, made up a total of $420,694.509$ (12.9\%); enterprises employing 50 to 99 persons were $281,444.433$ ones (8.6\%); a total of $365,924.442$ trade employees worked in enterprises that had between 100 and 249 persons employed (11.2\%); and the ones with 250 to 499 persons had, together, 227,221.464 employees (7.0\%)

With regard to the net operating revenue, the data in Graphs 14.4 and 14.5 , respectively, show that the enterprises with more than 500 employees accounted for a generated net revenue of $R \$ 1,040,638,973$. Enterprises that employed up to 19 workers were also a highlight in terms of net revenue, a total of $\mathrm{R} \$ 927,143,581$.

Graph 14.5 shows, in accordance with the aforementioned data, the generation of net operating revenue in the trade sector. It is observed that enterprises with up to 19 employees held $53.7 \%$ of the trade workers. Together with those enterprises that employed up to 49 persons, the percentage increases to $66 \%$. Small enterprises were responsible for the generation of a big number of positions. An explanation to that includes the transformations experienced by the production sector and the increase in the number of small-sized enterprises. Commercial automation, changes in the world of labor, due to outsourcing and subcontracting, for example, have led to a reduction of the number of jobs in big-sized enterprises since these transferred to others some parts of production and services. Many smaller enterprises now are in charge of the production process previously carried out by the big ones.

In this changing scenario, the tertiary sector has tried to adapt to a social behavior marked by new habits and lifestyles. That reinforces the idea that a market designed for the consumption of goods and services is a major guide of the economy, as revealed by the figures presented herein. 
$24 \%$ da receita total foi gerada pelo segmento de combustíveis; $19,4 \%$ pela comercialização de produtos alimentícios, $11,7 \%$ por mercadorias em geral; $10,7 \%$ por produtos farmacêuticos; $7,8 \%$ por produtos agropecuários in natura; $5 \%$ representado por máquinas e equipamentos e; $21,3 \%$ por outros produtos. Os dados demonstram diversidade de produtos comercializados através das empresas atacadistas.

Ao averiguar a participação das empresas por faixa de pessoal ocupado, Gráfico 14.3, em 2016 havia 3263067402 pessoas trabalhando no setor de comércio. As maiores empresas, que empregavam quinhentos ou mais pessoas, correspondiam a 1040638973 (31,9\%). As pequenas empresas que ocupavam até 19 funcionários geraram 927143581 empregos (28,9\%); as que empregavam de 20 a 29 pessoas, totalizaram 420694509 (12,9\%); as que empregavam de 50 a 99 trabalhadores absorviam 281444433 pessoas (8,6\%); 365924442 comerciários estavam empregados em empresas que possuíam de cem a 249 funcionários (11,2\%); e, as que empregavam de 250 a 499 pessoas somavam 227221464 trabalhadores (7,0\%)

Com relação à receita operacional líquida, os dados dos Gráficos 14.4 e 14.5 evidenciam que, de modo geral, as empresas que possuíam mais de 500 funcionários foram responsáveis pela geração de renda líquida de R\$ 1040638 973. As que empregavam até 19 trabalhadores também se destacaram com a geração de renda líquida, total de R\$ 927143581.

Corroborando com estes dados, o Gráfico 14.5 apresenta a geração de renda operacional líquida no setor comercial. Observa-se que as empresas que possuíam até 19 funcionários absorviam $53,7 \%$ dos trabalhadores do comércio. Somada às que empregavam até 49 funcionários, o percentual aumenta para $66 \%$. As pequenas empresas foram responsáveis pela geração de grande número de postos de trabalho. Tal fato pode ser explicado pelo processo de transformação no sistema produtivo e pelo aumento do número de pequenas empresas. A automação comercial, as transformações no mundo do trabalho, a exemplo da terceirização e da subcontratação, reduziram os postos de trabalho em grandes empresas que repassaram a pequenas partes da produção e dos serviços. Surgiram várias empresas menores que realizam parcela significativa do processo produtivo gerado anteriormente pelas grandes.

Neste cenário de mudanças o setor terciário tem procurado se adequar ao comportamento social marcado por novos hábitos e estilos de vida. O que reforça a ideia de que o mercado criado para o consumo de bens e serviços constitui um importante condutor da economia, fato revelado pelos dados quantitativos apresentados. 


\section{References}

CLEPS, G. D. G. O comércio atacadista de Uberlândia (MG): mudanças tecnológicas e estratégias territoriais. 1997. Dissertação (mestrado) - Instituto de Geociências e Ciências Exatas (IGCE), Universidade Estadual Paulista "Júlio de Mesquita Filho" (Unesp), Rio Claro. 1997. 180 f. 1997.

O comércio e a cidade: novas territorialidades urbanas. Sociedade \& Natureza, Uberlândia, v. 16, n. 30, p. 117-132, 2004. Available from: <http://www.seer.ufu.br/index.php/sociedadenatureza/issue/ archive/2>. Cited: May 2019.

Estratégias de reprodução do capital e as novas espacialidades urbanas: O comércio de auto-serviço em Uberlândia (MG). 2005. Tese (doutorado) - Instituto de Geociências e Ciências Exatas (IGCE), Universidade Estadual Paulista "Júlio de Mesquita Filho" (Unesp), Rio Claro. 2005. 317 f. Available from: <https://repositorio.unesp.br/bitstream/ handle/11449/104335/cleps_gdg_dr_rcla.pdf?seq>. Cited: May 2019.

NÚMEROS do setor. São Paulo: Associação Brasileira de Atacadistas e Distribuidores de Produtos Industrializados - ABAD, [2019]. Available from: <https://abad.com.br/servicos/dados-do-setor/>. Cited: May 2019.

PESQUISA ANUAL DE COMÉRCIO. Rio de Janeiro: IBGE, 2016.v. 26. Available from: <https://www.ibge.gov.br/estatisticas/economicas/comercio/9075pesquisa-anual-de-comercio.html?=\&t=o-que-e>. Cited: May 2019.

Translated by: Aline Milani Romeiro Pereira 


\section{Referências}

CLEPS, G. D. G. O comércio atacadista de Uberlândia (MG): mudanças tecnológicas e estratégias territoriais. 1997. Dissertação (mestrado) - Instituto de Geociências e Ciências Exatas (IGCE), Universidade Estadual Paulista "Júlio de Mesquita Filho" (Unesp), Rio Claro. 1997. 180 f. 1997.

- O comércio e a cidade: novas territorialidades urbanas. Sociedade \& Natureza, Uberlândia, v. 16, n. 30, p. 117-132, 2004. Disponível em: <http://www. seer.ufu.br/index.php/sociedadenatureza/issue/archive/2>. Acesso em: maio 2019.

. Estratégias de reprodução do capital e as novas espacialidades urbanas:

O comércio de auto-serviço em Uberlândia (MG). 2005. Tese (doutorado) - Instituto de Geociências e Ciências Exatas (IGCE), Universidade Estadual Paulista "Júlio de Mesquita Filho" (Unesp), Rio Claro. 2005. 317 f. Disponível em: <https://repositorio.unesp.br/ bitstream/handle/11449/104335/cleps_gdg_dr_rcla.pdf?seq>. Acesso em: maio 2019.

NÚMEROS do setor. São Paulo: Associação Brasileira de Atacadistas e Distribuidores de Produtos Industrializados - ABAD, [2019]. Disponível em: <https://abad.com.br/ servicos/dados-do-setor/>. Acesso em: maio 2019.

PESQUISA ANUAL DE COMÉRCIO. Rio de Janeiro: IBGE, 2016. v. 26. Disponível em: $<$ https://www.ibge.gov.br/estatisticas/economicas/comercio/9075-pesquisa-anualde-comercio.html?=\&t=o-que-e $>$. Acesso em: maio 2019. 
Tabela 14.1 - Dados gerais do comércio - 2016

Table 14.1 - General data of trade - 2016

\begin{tabular}{|c|c|c|c|c|}
\hline \multirow[b]{2}{*}{$\begin{array}{l}\text { Dados gerais/ } \\
\text { General data }\end{array}$} & \multicolumn{4}{|c|}{ Comércio/Trade } \\
\hline & $\begin{array}{l}\text { Total/ } \\
\text { Total }\end{array}$ & $\begin{array}{c}\text { Veículos, } \\
\text { peças e } \\
\text { motocicletas/ } \\
\text { Vehicles, } \\
\text { pieces and } \\
\text { motorcycles }\end{array}$ & $\begin{array}{l}\text { Atacadista/ } \\
\text { Wholesale }\end{array}$ & $\begin{array}{l}\text { Varejista/ } \\
\text { Retail }\end{array}$ \\
\hline $\begin{array}{l}\text { Número de empresas/ } \\
\text { Number of companies }\end{array}$ & 1546646 & 146339 & 195304 & 1205003 \\
\hline $\begin{array}{l}\text { Unidades locais com receita } \\
\text { de revenda/ } \\
\text { Local branches with revenue } \\
\text { from sales }\end{array}$ & 1685096 & 159175 & 217233 & 1308688 \\
\hline $\begin{array}{l}\text { Receita líquida de revenda } \\
(1000 \mathrm{R} \$) / \\
\text { Net revenue from } \\
\text { sales }(1,000 \mathrm{R} \$)\end{array}$ & 3263067402 & 313684171 & 1477918858 & 1471464373 \\
\hline $\begin{array}{l}\text { Pessoal ocupado/ } \\
\text { Employed persons }\end{array}$ & 10030152 & 871765 & 1728829 & 7429558 \\
\hline $\begin{array}{l}\text { Salários e retiradas } \\
(1000 \mathrm{R} \$) /\end{array}$ & 214793082 & 20492447 & 55576499 & 138724136 \\
\hline $\begin{array}{l}\text { Salaries and withdrawals } \\
(1,000 R \$)\end{array}$ & & & & \\
\hline
\end{tabular}

Fonte/Source: Pesquisa anual de comércio 2016. Rio de Janeiro: IBGE, v. 28, 2018. Disponível em/ Available from: <https://www.ibge.gov.br/estatisticas-novoportal/economicas/comercio/9075pesquisa-anual-de-comercio.html>.Acesso em: jan. 2019/Cited: Jan. 2019. 


\section{Tabela 14.2 - Número de empresas, pessoal ocupado, salários e receita total, segundo as divisões do comércio - 2016 Table 14.2 - Number of companies, employed persons, salaries and total revenue, by trade segments - 2016}

\begin{tabular}{|c|c|c|c|c|}
\hline $\begin{array}{l}\text { Divisões do comércio/ } \\
\text { Trade segments }\end{array}$ & $\begin{array}{l}\text { Número } \\
\text { de empresas/ } \\
\text { Number of } \\
\text { companies }\end{array}$ & $\begin{array}{l}\text { Pessoal } \\
\text { ocupado } \\
(1000) / \\
\text { Employed } \\
\text { persons } \\
(1,000)\end{array}$ & $\begin{array}{c}\text { Salários, retiradas } \\
\text { e outras remunerações } \\
\text { (bilhões } \mathrm{R} \$ \text { )/ } \\
\text { Salaries, withdrawals } \\
\text { and other compen- } \\
\text { sation (billions } R \$ \text { ) }\end{array}$ & $\begin{array}{c}\text { Receita total } \\
\text { (bilhões R\$)/ } \\
\text { Total revenue } \\
\text { (billions } R \$ \text { ) }\end{array}$ \\
\hline Total/ Total & 1546646 & 10030 & 215 & 3380 \\
\hline $\begin{array}{l}\text { Comércio de veículos, } \\
\text { peças e motocicletas/ } \\
\text { Sale of vehicles, pieces and } \\
\text { motorcycles }\end{array}$ & 146339 & 872 & 20 & 323 \\
\hline $\begin{array}{l}\text { Comércio atacadista/ } \\
\text { Wholesale trade }\end{array}$ & 195304 & 1729 & 56 & 1547 \\
\hline $\begin{array}{l}\text { Comércio varejista } \\
\text { Retail trade }\end{array}$ & 1205003 & 7430 & 139 & 1510 \\
\hline
\end{tabular}

Fonte/Source: Pesquisa anual de comércio 2016. Rio de Janeiro: IBGE, v. 28, 2018. Disponível em/ Available from: <https://www.ibge.gov.br/estatisticas-novoportal/economicas/comercio/9075pesquisa-anual-de-comercio.html>. Acesso em: jan. 2019/Cited: Jan . 2019.

\section{Tabela 14.3 - Participação das divisões do comércio - 2016 Table 14.3 - Participation of trade segments - 2016}

\begin{tabular}{|c|c|c|c|c|}
\hline \multirow[b]{2}{*}{$\begin{array}{l}\text { Divisões do comércio/ } \\
\text { Trade segments }\end{array}$} & \multicolumn{4}{|c|}{ Participação (\%)/ Participation (\%) } \\
\hline & $\begin{array}{c}\text { Número } \\
\text { de empresas/ } \\
\text { Number } \\
\text { of companies }\end{array}$ & $\begin{array}{l}\text { Pessoal } \\
\text { ocupado/ } \\
\text { Employed } \\
\text { persons }\end{array}$ & $\begin{array}{l}\text { Salários e outras } \\
\text { remunerações/ } \\
\text { Salaries and other } \\
\text { compensation }\end{array}$ & $\begin{array}{c}\text { Receita líquida } \\
\text { de revenda/ } \\
\text { Net revenue from } \\
\text { sales }\end{array}$ \\
\hline Total/ Total & 100,0 & 100,0 & 100,0 & 100,0 \\
\hline $\begin{array}{l}\text { Comércio de veículos, peças } \\
\text { e motocicletas/ } \\
\text { Sale of vehicles, pieces and } \\
\text { motorcycles }\end{array}$ & 9,5 & 8,7 & 9,5 & 9,6 \\
\hline $\begin{array}{l}\text { Comércio atacadista/ } \\
\text { Wholesale trade }\end{array}$ & 12,6 & 17,2 & 25,9 & 45,3 \\
\hline $\begin{array}{l}\text { Comércio varejista } \\
\text { Retail trade }\end{array}$ & 77,9 & 74,1 & 64,6 & 45,1 \\
\hline
\end{tabular}

Fonte/Source: IBGE, Diretoria de Pesquisas, Coordenação de Serviços e Comércio, Pesquisa Anual de Comércio 2016. 


\section{Gráfico 14.1 - Participação dos segmentos na receita total do comércio varejista e de veículos - Brasil - 2016 \\ Graph 14.1 - Participation of segments in total revenue of retail and vehicle trade - Brazil - 2016}

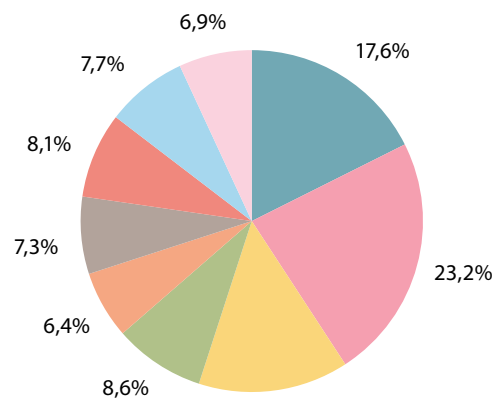

$14,2 \%$

Veículos e peças

Vehicles and pieces

Lojas de departamento, eletrodomésticos e móveis Department, household appliances and furniture stores

Armazéns, mercearias e produtos alimentícios Stores, grocery stores and food products
Super/Hipermercados

Supermarkets/Hypermarkets

Material de construção

Construction material

Produtos farmacêuticos

Pharmaceuticals
Combustíveis

Fuels

Tecidos e artigos do vestuário Textiles and wearing apparel

Outros

Other

Fonte/Source: IBGE, Diretoria de Pesquisas, Coordenação de Serviços e Comércio, Pesquisa Anual de Comércio 2016. 


\section{Gráfico 14.2 - Participação dos segmentos na receita total do comércio atacadista - Brasil - 2016 \\ Graph 14.2 - Participation of activities in total revenue of whosale trade - Brazil - 2016}

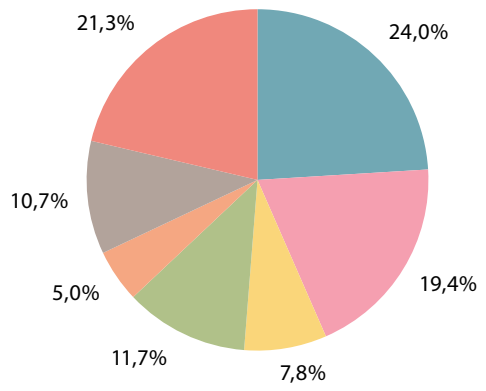

Combustíveis Fuels

Mercadorias em geral Miscellaneous goods
Produtos alimentícios, bebidas e fumo

Food products, beverages and tobacco
Produtos agropecuários in natura

Raw agricultural products
Máquinas e equipamentos industriais Industrial machinery and equipment
Produtos farmacêuticos Pharmaceuticals

Outros

Other

Fonte/Source: : IBGE, Diretoria de Pesquisas, Coordenação de Serviços e Comércio, Pesquisa Anual de Comércio 2016. 
Gráfico 14.3 - Participação das empresas, por faixas de pessoal ocupado, na receita operacional líquida do comércio - 2016

Graph 14.3 - Participation of companies, by ranges of employed persons, in net operating revenue of trade - 2016

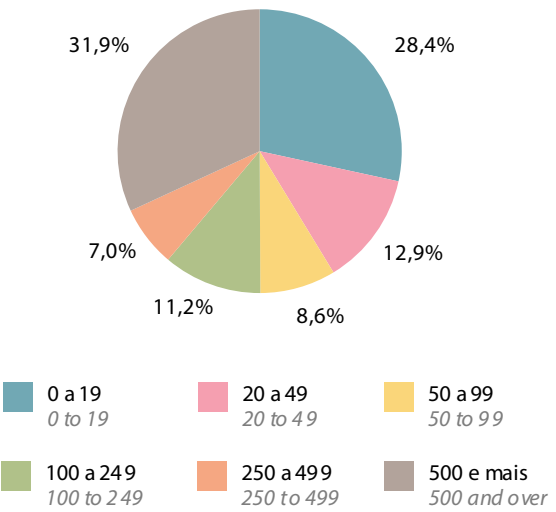

Fonte/Source: IBGE, Diretoria de Pesquisas, Coordenação de Serviços e Comércio, Pesquisa Anual de Comércio 2016.

\section{Gráfico 14. 4 - Evolução da receita operacional líquida, por faixas de pessoal ocupado - 2015-2016}

Graph 14.4 - Evolution of net operating revenue, by ranges of employed persons - 2015-2016

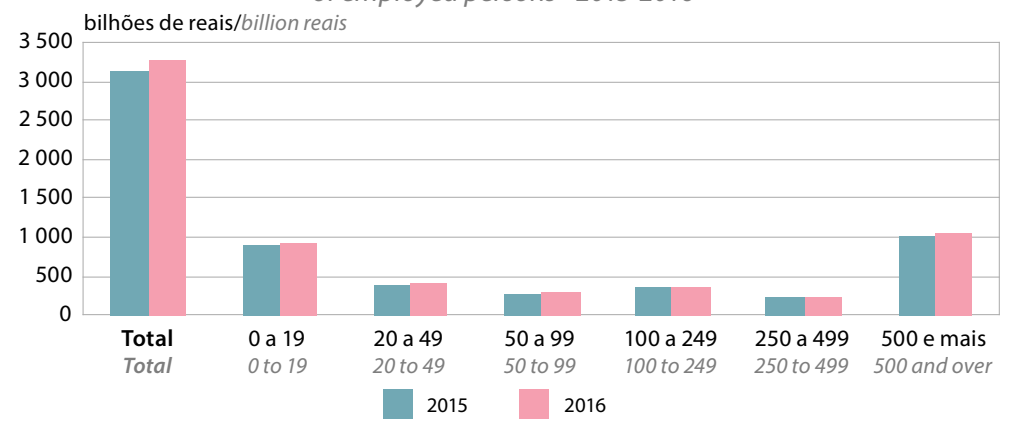

Fonte/Source: IBGE, Diretoria de Pesquisas, Coordenação de Serviços e Comércio, Pesquisa Anual de Comércio 2015-2016. 
Gráfico 14.5 - Participação das empresas, por faixas de pessoal ocupado, no total de pessoal ocupado do comércio - 2016

Graph 14.5 - Participation of companies in total employed persons in trade, by ranges of employed persons - 2016

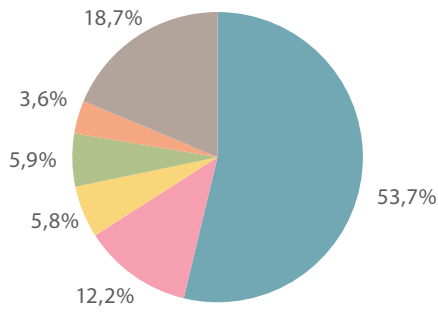

\begin{tabular}{|c|c|c|}
\hline 0 a 19 & 20 a 49 & 50 a 99 \\
\hline 0 to 19 & 20 to 49 & 50 to 99 \\
\hline 100 a 249 & 250 a 499 & 500 e mais \\
\hline 100 to 249 & 250 to 499 & 500 and over \\
\hline
\end{tabular}

Fonte/Source: IBGE, Diretoria de Pesquisas, Coordenação de Serviços e Comércio, Pesquisa Anual de Comércio 2016. 



\section{Transportes Transportation}

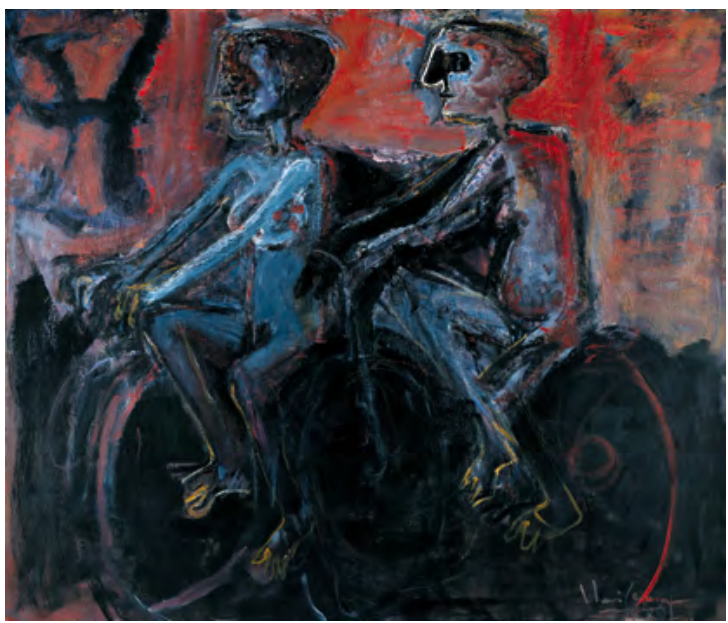

Ciclistas, 1989

Cyclists

Iberê Camargo 


\title{
Transportation
}

\author{
Márcio de Almeida D'Agosto' \\ Daniel Neves Schmitz Gonçalves ${ }^{2}$
}

Being a country of continental size, Brazil had three times increase in the movement passenger-kilometer - p.km - of passengers and 2.3 times increase in that of cargo - tonnes per $\mathrm{km}$ in a period of 30 years, between 1989 and 2018. In that period, the Brazilian Gross Domestic Product - GDP increased 5.5 times in absolute values and the population rose $45 \%$. As in all the world, cargo transportation in Brazil shows a strong correlation with the GDP and passenger transportation with the per capita GDP, since these activities, through their several modes, comprise essential resources for the economic and social development.

This chapter analyzes the recent evolution of the Brazilian transportation sector, showing the current scenario through the consolidation of data and historical information. It is based on the consolidated information from the Brazilian Institute of Geography and Statistics - IBGE, supported by the Freight Transport Laboratory - LTC of the Program of Transportation Engineering - PET of the Alberto Luiz Coimbra Institute for Graduate Studies and Research in Engineering - COPPE of the Federal University of Rio de Janeiro - UFRJ, according to the tables and figures attached to this text.

$\overline{1 \mathrm{PhD}}$ in Transportation Engineering from COPPE/UFRJ. Associate Professor at PET/COPPE/UFRJ and Coordinator of the LTC.

2 Master in Transportation Engineering from the Military Institute of Engineering - IME and doctoral candidate in Transportation Engineering from COPPE/UFRJ. Researcher at the LTC/PET/COPPE/UFRJ. 


\title{
Transportes
}

\author{
Márcio de Almeida D 'Agosto' \\ Daniel Neves Schmitz Gonçalves²
}

Sendo um país de dimensões continentais, no período de 30 anos, entre 1989 e 2018, o Brasil apresentou crescimento de três vezes na movimentação passageiro-quilômetro (p.km) de passageiros e de 2,3 vezes de cargas (toneladas por km). Neste período o Produto Interno Bruto (PIB) aumentou 5,5 vezes, em valores absolutos, e a população aumentou $45 \%$. Como em todo o mundo, no Brasil o transporte de cargas apresenta forte correlação com o PIB e o transporte de passageiros com o PIB per capta, porque estas atividades, por meio dos seus diversos modos, compõem recursos essenciais para o desenvolvimento econômico e social.

Este Capítulo analisa a evolução recente do setor de transportes brasileiro, apresentando o quadro atual por meio da consolidação de dados e informações históricas. Isso foi feito partindo de informações consolidadas pelo Instituto Brasileiro de Geografia e Estatística (IBGE) com o apoio do Laboratório de Transporte de Carga (LTC) do Programa de Engenharia de Transporte (PET) do Instituto Alberto Luiz Coimbra de Pós-Graduação e Pesquisa de Engenharia (COPPE) da Universidade Federal do Rio de Janeiro (UFRJ), conforme tabelas e figuras apresentadas em complemento ao texto.

1 Doutor em Engenharia de Transportes pela COPPE/UFRJ. Professor Associado do PET/ COPPE/UFRJ e Coordenador do LTC.

2 Mestre em Engenharia de Transportes pelo Instituto Militar de Engenharia (IME), doutorando em Engenharia de Transportes COPPE/UFRJ. Pesquisador do LTC/PET/COPPE/ UFRJ. 


\section{Overview of the modal division of transportation in Brazil}

Graph 15.1 shows the modal division of transportation in Brazil. It shows the predominance of the road mode for passenger transportation, with more than $91 \%$ of the transportation momentum (p.km) being carried out through this mode, whereas water and railway transportation, together, do not reach $2.0 \%$ and air transportation reaches $6.6 \%$, even considering that it covers longer distances. On the other hand, the modal division of cargo transportation is less unbalanced, with about 58\% carried out through the road mode, $29 \%$ through railways and $13 \%$ through the other modes, being the smallest parcel $(0.1 \%)$ through the air mode, which is usually the most expensive one. It is important to highlight that the participation of the railway mode has been about $26 \%$ over the last five years. It happens that the activity and thus the participation of the road and water modes significantly dropped due to the economic downturn.

Since the 1950s, the historical predominance of road transportation in the movement of passengers and cargo, in a country of continental size like Brazil, has led to the rise of transportation costs, which impacts on the logistical costs and, thus, on the increase of the final prices of products. This situation also leads to the excessive consumption of fossil fuels, a non-renewable source of energy that emits carbon dioxide, mainly greenhouse gas, responsible for the increase of the global warmth, the major global environmental challenge of the 21st century. In the cities, the burn of fossil fuels by transportation can be considered the major source of air pollutants, responsible for health problems in the residents, like diseases of the respiratory, cardiovascular and neurological systems.

To balance the modal division of the transportation, using more the railway and water modes - inland and coastal navigation - for cargo and using more the railway mode for passengers, is a need which is related to the intense and constant application of investments in the infrastructure required to improve the supply of those modes which have a higher cost of implementation and a lower cost of operation and maintenance, compared with the road mode.

\section{Profile of road transportation}

Based on the consolidated data of vehicle licensing annually published by the Brazilian Association of Motor Vehicle Manufacturers - ANFAVEA, adjusted by means of scrapping curves revised by Gonçalves, Goes e D'Agosto (2019), it is estimated that the fleet of Brazilian cars and 


\section{Panorama da divisão modal dos transportes no Brasil}

O Gráfico 15.1 apresenta a divisão modal dos transportes no Brasil. Nele se verifica predominância do modo rodoviário para o transporte de passageiros, com mais de 91\% do momento de transporte (p.km) sendo realizado por este modo, enquanto o transporte aquático e ferroviário somados não chegam a representar 2,0\% e o transporte aéreo, mesmo considerando que se realiza a maiores distâncias, atinge $6,6 \%$. Por outro lado, a divisão modal do transporte de cargas é menos desequilibrada, com cerca de $58 \%$ realizado pelo modo rodoviário, $29 \%$ por ferrovias e $13 \%$ pelos demais modos, com a menor parcela $(0,1 \%)$ pelo modo aéreo, usualmente o mais caro. É importante salientar que a participação nos últimos cinco anos do modo ferroviário é de cerca de $26 \%$. Ocorre que a atividade, e consequentemente a participação dos modos rodoviário e aquático caíram significativamente devido à recessão.

Desde a década de 1950, a predominância histórica do transporte rodoviário na movimentação de passageiros e cargas, num país de extensão continental como o Brasil, conduz à elevação dos custos de transporte, que impacta nos custos logísticos e consequentemente no aumento dos preços finais dos produtos. Esta situação também leva ao consumo excessivo de combustíveis fósseis, fonte não renovável de energia com consequente emissão de dióxido de carbono, principal gás de efeito estufa, responsável pelo agravamento do aquecimento global, principal desafio ambiental global do Século XXI. Nas cidades, a queima de combustíveis fósseis pelos transportes pode ser considerada como a principal fonte de poluentes atmosféricos, responsáveis por problemas de saúde nos residentes, como doenças do sistema respiratório, cardiovascular e neurológicas.

Equilibrar a divisão modal dos transportes, por meio de maior utilização dos modos ferroviário e aquático (navegação interior e navegação marítima de cabotagem) para carga, e do modo ferroviário para os passageiros, é uma necessidade que está relacionada com a aplicação constante e intensa de investimentos em infraestrutura necessária à ampliação da oferta destes modos que apresentam maior custo de implantação e menores custos de operação e manutenção, se comparados ao modo rodoviário.

\section{O perfil do transporte rodoviário}

Com base nos dados consolidados de licenciamento de veículos publicados anualmente pela Associação Nacional dos Fabricantes de Veículos Automotores (ANFAVEA), ajustados por meio de curvas de sucateamento revisada por Gonçalves, Goes e D'Agosto (2019), estima-se que no período de 1980 a 2018, a frota de automóveis 
light commercial vehicles has risen 5.1 times in the period between 1980 and 2018. In this same period, the fleet of trucks tripled and the fleet of buses, either for urban use or for interstate and international transportation, increased 3.3 times. Moreover, the fleet of motorcycles dramatically increased 68 times.

It is estimated that, in this period, the fleet of cars and light commercial vehicles changed from slightly more than nine million to nearly 46 million vehicles, placing Brazil with about five inhabitants per vehicle, a rate still far from those reached in developed countries, which record figures between one and two inhabitants per vehicle. The United States stand out with a stable value of 1.2 inhabitants per vehicle between 2001 and 2015 .

Beyond the boost received in the period of economic upturn and better income distribution, which occurred in the first decade of the 21st century, the increase in the fleet of cars and light commercial vehicles in Brazil was due to the incentive given by the federal government to the car industry between 2012 and December 2014, the reduction of the rate of the Excise Tax on Industrialized Products - IPI. The difference in the inhabitants per vehicle relation when comparing Brazil with the other countries listed in Graph 15.2 is due to the low per capita income of most of its population. Hitting a level like that of the United States is quite questionable, however, considering the aspects already presented concerning the waste of energy resources and the environmental impacts stemmed from the excessive use of individual motor transportation.

In the case of trucks, the most significant increases were in the classes of light commercial vehicles (total gross weight - TGW between 6 and 10 tonnes) and heavy-duty trucks (TGW higher than or equal to 15 tonnes or combined total gross weight CTGW higher than or equal to 40 tonnes), which demonstrates a better specialization of the road transportation of cargo, through the adaptation of the vehicles to urban use (light commercial vehicles) and to long-distance transfers (heavy-duty trucks).

Based on a survey from the National Confederation of Transportation CNT, Table 15.1 shows the profile of the Brazilian road network and the big challenge that Brazil faces in implementing road transportation considering that only $13.7 \%$ of its roads are paved. This situation is not supposed to change in the short term, considering that slightly more than a $10 \%$ increase in the road network is planned to be implemented in a time horizon not yet established by the government. 
e comerciais leves brasileiros tenha crescido 5,1 vezes. Neste mesmo período a frota de caminhões triplicou e a frota de ônibus, tanto para uso urbano quanto para o transporte interestadual e internacional, aumentou 3,3 vezes. Além disso, houve um aumento vertiginoso de 68 vezes na frota de motocicletas.

Estima-se que no período a frota de automóveis e veículos comerciais leves tenha passado de pouco mais de nove milhões para quase 46 milhões de veículos, colocando o Brasil com aproximadamente cinco habitantes por veículo, taxa ainda distante das obtidas para os países desenvolvidos, que apresentam valores entre um e dois habitantes por veículo e onde os Estados Unidos se destacam com valor estável de 1,2 habitantes por veículo entre 2001 e 2015.

Além do impulso recebido no período de crescimento econômico e melhor distribuição de renda, que ocorreu na primeira década do Século XXI, o aumento da frota de automóveis e veículos comerciais leves no Brasil deveu-se ao incentivo dado pelo governo federal à indústria automobilística entre 2012 e dezembro de 2014, por meio da redução da alíquota do Imposto Sobre Produtos Industrializados (IPI). A diferença na relação habitantes por veículo, quando se compara o Brasil com os demais países listados no Gráfico 15.2, deve-se à baixa renda per capita da grande maioria da sua população, muito embora atingir níveis como os dos Estados Unidos sejam bastantes questionáveis se considerados os aspectos já apresentados quanto ao desperdício de recursos energéticos e aos impactos ambientais oriundos do excessivo uso do transporte individual motorizado.

No caso dos caminhões, os aumentos mais expressivos se deram nas classes de caminhões leves (peso bruto total (PBT) entre 6 e 10 toneladas) e pesados (PBT maior ou igual a 15 toneladas ou peso bruto total combinado (PBTC) maior ou igual a 40 toneladas) o que demonstra uma melhor especialização do transporte rodoviário de cargas, por meio da adequação dos veículos ao uso urbano (veículos leves) e as transferências de longa distância (veículos pesados).

Com base em levantamento da Confederação Nacional dos Transportes (CNT), a Tabela 15.1 mostra o perfil da malha rodoviária brasileira e o grande desafio que o País enfrenta em efetivar o transporte rodoviário tendo em vista que apenas 13,7\% da extensão de suas rodovias são pavimentadas. Esta situação parece que não vai se alterar no curto prazo, tendo em vista os pouco mais de $10 \%$ de extensão de rodovias planejadas com previsão de implantação em um horizonte não definido pelo governo. 
The profile of the road transportation shows the critical situation of this important transportation mode and the compelling need of huge and continuous investments in the road infrastructure, aiming at improving its quality and expanding the road network.

\section{Profile of railway transportation}

Table 15.2 shows that the three concessionary railways with the highest useful tonne transported per kilometer - TKU, a measurement defined as the net transported cargo (tonne) times the distance covered $(\mathrm{km})$, add up to more than $3 / 4$ of the total transported in 2016 (81\%). They are: Carajás Railway - EFC (39.9\%), Vitória to Minas Railway - EFVM (21.9\%) and MRS Logística S.A. (19.2\%). It is important to highlight that more than $2 / 3$ of the cargo is ore, being transported by more efficient railways in terms of cost (R\$/TKU) and energy use in megajoules per tonne-kilometer (MJ/t.km).

Concerning the railway transportation of passengers in the same year under analysis (2016), it is noticed that $87 \%$ (p.km) and more than half of the operation line are in the Metropolitan Areas of São Paulo and Rio de Janeiro, which demonstrates its concentration in the major Brazilian cities and the poor dissemination of this transportation mode in the other metropolises.

\section{Profile of waterway transportation}

Waterway transportation accounts for only $9.3 \%$ of the cargo transported in Brazil, despite the large amount and extension of the Brazilian rivers and nearly $8,500 \mathrm{~km}$ of coast. The extension of the waterway network corresponds to $2.7 \%$ of the road network in Brazil, adding up to $41,795 \mathrm{~km}$, of which only $47 \%$ is economically used. This occurs either because the path of the rivers passes through areas with low productive potential or because of the low depth of the riverbeds, with long, though very winding, paths.

Inland navigation has a participation of about $1.0 \%$ in the modal division and more than half of the cargo transported in 2018 was dry bulk, distributed among agricultural (soybean $43 \%$, corn $25 \%$ and soybean bran $4.0 \%$ ) and non-agricultural (iron ore $12 \%$ and sand $7.0 \%$ ).

Unlike inland navigation, in which the transportation is divided into several groups of goods, three groups prevail in coastal navigation: fuels and mineral oils, bauxite and containers. Together, they accounted for more than $88 \%$ of the 163 million tonnes transported 
O perfil do transporte rodoviário apresentado demonstra a situação crítica deste importante modo de transporte e a premente necessidade de investimentos pesados e contínuos em infraestrutura viária, com melhoria da qualidade e ampliação da malha rodoviária.

\section{O perfil do transporte ferroviário}

Verifica-se na Tabela 15.2 que as três concessionárias com maior tonelada por quilômetro útil (TKU), medida definida pelo produto da carga líquida transportada (tonelada) pela distância percorrida $(\mathrm{km})$, somam mais de $3 / 4$ do total transportado em 2016 (81\%), são elas: Estrada de Ferro Carajás (EFC) (39,9\%), Estrada de Ferro Vitória a Minas (EFVM) (21,9\%) e a MRS Logística S.A. (19,2\%). É importante ressaltar que mais de $2 / 3$ da carga movimentada é de minério, sendo transportados por ferrovias mais eficientes em termos de custo (R\$/TKU) e uso de energia em megajoules por tonelada-quilômetro (MJ/t.km).

No tocante ao transporte ferroviário de passageiros, para o mesmo ano de análise (2016), observa-se que $87 \%$ (p.km) e mais da metade da linha operacional encontram-se nas Regiões Metropolitanas de São Paulo e do Rio de Janeiro, o que demonstra a concentração nas grandes cidades brasileiras e pouca difusão deste modo de transporte nas outras metrópoles nacionais.

\section{O perfil do transporte aquático}

O transporte aquático representa apenas 9,3\% das cargas transportadas no Brasil, apesar da grande quantidade e extensão dos rios brasileiros e dos quase $8500 \mathrm{~km}$ de costa. A extensão da malha hidroviária corresponde a 2,7\% da malha rodoviária do Brasil, com total de 41795 km, onde só $47 \%$ são utilizadas economicamente. Isto se dá ou porque o trajeto dos rios passa por áreas com baixo potencial produtivo, ou devido à baixa profundidade do leito, com traçado extenso, mas muito sinuoso.

A navegação interior possui uma participação de aproximadamente 1,0\% na divisão modal, e mais da metade da carga transportada em 2018 foi granel sólido, distribuindo-se entre agrícola (soja $43 \%$, milho $25 \%$ e farelo de soja $4,0 \%$ ) e não agrícola (minério de ferro $12 \%$ e areia $7,0 \%$ ).

Diferente da navegação interior, onde o total transportado divide-se em diversos grupos de mercadoria, na navegação de cabotagem existe a predominância de três grupos: os combustíveis e óleos minerais, a bauxita e os contêineres. Juntos, foram responsáveis por mais de $88 \%$ dos 163 milhões de toneladas transportadas 
in 2018. Their participation in the modal division varied from $8.2 \%$ to $14.4 \%$ in the last 10 years. Their current participation is $8.6 \%$.

Waterway transportation (of passengers) is responsible for about $0.05 \%$ of the national transportation of passengers. Most of it is in the Amazon region, where waterway transportation is the most important transportation means; and in the Metropolitan Area of Rio de Janeiro.

\section{Profile of air transportation}

Air transportation has shown a small participation in the movement of cargo in Brazil, with $0.11 \%$ of the total in 2018. On the other hand, its share in the modal division has risen in transportation of passengers, reaching $6.6 \%$. Graph 15.4 shows the number of domestic and international flights between 2009 and 2018, pointing out to an increase between 2009 and 2012 (35\%). That trend fell in 2013 , confirmed by five consecutive years of decreasing number of domestic flights in Brazil; and there was a sign of increase in 2018 (1.0\%). Conversely, the number of international flights increased $43 \%$ (2009-2014), followed by an average drop of $7.0 \%$ for three consecutive years and an upturn of $11 \%$ in 2018.

Assessing only the number of flights is a superficial way to establish the evolution of the air mode. The evolution of the transportation momentum should also be checked (p.km and t.km) in the period. Table 15.4 shows these data and points out the significant increase of the activity in the period under analysis, both in the transportation of passengers (79\%) and of cargo (56\%).

\section{Profile of pipeline transportation}

Beyond the transportation of water, the largest network of pipeline transportation in the world and that belongs to the sector of sanitation, pipeline transportation all over the world is only carried out for a very specialized fraction of cargo, highlighted by fluids (petroleum, fuels derived from petroleum and biofuels, like ethanol) and natural gas. Due to its specialization, pipeline transportation corresponds to about $3.3 \%$ of the activity of cargo transportation, divided into oil (64\%), gas (12\%) and ore (26\%) pipelines. 
em 2018. Sua participação na divisão modal variou entre $8,2 \%$ a $14,4 \%$, nos últimos 10 anos. Atualmente sua participação é de 8,6\%.

O transporte aquático de passageiros é responsável por cerca de $0,05 \%$ do transporte nacional de passageiros. A maior parte desse transporte se dá na região amazônica, onde é o mais importante meio de transporte e na Região Metropolitana do Rio de Janeiro.

\section{O perfil do transporte aéreo}

O transporte aéreo tem apresentado uma pequena participação na movimentação de cargas no Brasil, com 0,11\% do total em 2018. Por outro lado, sua participação na divisão modal tem crescido no transporte de passageiros, chegando a 6,6\%. O Gráfico 15.4 apresenta o número de voos domésticos e internacionais entre os anos de 2009 e 2018 e percebe-se o aumento entre 2009 e 2012 (35\%). Em 2013 , houve uma redução nessa tendência, confirmada por cinco anos consecutivos de decréscimo do número de voos domésticos no Brasil e um sinal de acréscimo em 2018 (1,0\%). Por outro lado, o número de voos internacionais apresentou um crescimento de 43\% (2009-2014), seguido de uma queda em média de 7,0\% por três anos consecutivos e uma retomada de 11\% em 2018.

Avaliar apenas o número de voos torna-se superficial para determinar a evolução do modo aéreo. É preciso verificar também evolução do momento de transporte (p.km e t.km) no período. A Tabela 15.4 apresenta esses dados e permite verificar o crescimento expressivo da atividade no período analisado, tanto no transporte de passageiros (79\%) como no de carga (56\%).

\section{O perfil do transporte por dutos}

Além do transporte de água, maior rede de transporte dutoviário no mundo e que se posiciona no setor de saneamento, no mundo todo o transporte por dutos se dá apenas para uma fração muito especializada de cargas, onde se destacam os líquidos (petróleo, combustíveis derivados de petróleo e biocombustíveis, como o etanol) e o gás natural. Em função da sua especialização, o transporte dutoviário corresponde por cerca de $3,3 \%$ da atividade do transporte de carga, dividido em oleodutos (64\%), gasodutos (12\%) e minerodutos (26\%). 


\section{Final remarks}

Transportation fosters the economic and social development and it plays a key role in the progress of the nations. The historical association of the evolution of the transportation momentum with the GDP shows that the desired return of the economic growth in Brazil will boost the transportation activity over the next years. Nevertheless, the predominance of the road mode in the modal division of transportation leads to higher costs, energy consumption and environmental impacts when compared with other modes, like railway and waterway transportation, mainly in countries of continental size like Brazil. To reverse this scenario, investments should be directed to the infrastructure that favors active transportation (hiking and cycling), collective road transportation (buses, bus rapid transit - BRT and bus rapid systems - BRS) and mass transportation (subways and trains) for the transportation of passengers in the urban areas, as well as high capacity transportation (railways, inland and coasting navigation) for the transportation of cargo, improving its use for shipping containers. In addition, attention should be given to the improvement, maintenance and conservation of the road network, whose performance does not match the importance of the role it plays.

\section{Reference}

GONÇALVES, D. N. S.; GOES, G. V.; D'AGOSTO, M. A. Transportes no Brasil: panorama e cenários prospectivos para atendimento da contribuição nacionalmente determinada. Rio de Janeiro: Instituto Brasileiro de Transporte Sustentável, 2019.

Translated by: La-Fayette Côrtes Neto 


\section{Considerações finais}

O transporte é uma atividade indutora de desenvolvimento econômico e social e tem papel fundamental para o progresso das nações. A histórica associação da evolução do momento de transporte com o PIB demonstra que o desejável retorno ao crescimento econômico do Brasil dinamizará a atividade de transporte nos próximos anos. Porém, a predominância do modo rodoviário na divisão modal do transporte conduz a maiores custos, consumo de energia e impactos ambientais se comparado a outros modos, como o ferroviário e aquático, principalmente em países de dimensões continentais como o Brasil. Reverter este quadro passa por direcionar investimentos em infraestrutura que privilegiem os transportes ativos (caminhada e ciclismo), rodoviários coletivos (ônibus, bus rapid transit (BRT) e bus rapid systems (BRS)) e de massa (metrôs e trens) para o transporte de passageiros nas áreas urbanas, bem como o transporte de maior capacidade (ferrovias, navegação interior e navegação marítima de cabotagem) para o transporte de cargas, ampliando seu uso para o embarque da carga geral conteinerizada. Adicionalmente, atenção deve ser dada à ampliação, manutenção e conservação da rede de rodovias cujo desempenho não faz justiça à importância do papel que desempenha.

\section{Referência}

GONÇALVES, D. N. S.; GOES, G. V.; D'AGOSTO, M. A. Transportes no Brasil: panorama e cenários prospectivos para atendimento da contribuição nacionalmente determinada. Rio de Janeiro: Instituto Brasileiro de Transporte Sustentável, 2019. 
Tabela 15.1 - Extensão das malhas viárias do País - 2018

Table 15.1 - Extension of transportation networks in Brazil - 2018

\begin{tabular}{cc}
$\begin{array}{c}\text { Especificação/ } \\
\text { Item }\end{array}$ & $\begin{array}{c}\text { Extensão das malhas viárias }(\mathrm{km}) / \\
\text { Extension of transportation network }(\mathrm{km})\end{array}$ \\
\hline
\end{tabular}

Malha rodoviária/Road network

Federal/Federal 76454

Pavimentada/Paved 65615

Não pavimentada/Unpaved

10839

Estaduais Transitórias, Estaduais e Municipais/

1486938

Temporary State Roads, State and Municipal Roads

Pavimentada/Paved

147838

Não pavimentada/Unpaved

1339100

Rede Planejada/Planned Network

157309

Malha ferroviária/Railway network

Nacional /National

Concedida/Granted

29074

Malha hidroviária/Waterway network

Rede fluvial nacional/National river network

41795

Vias utilizadas economicamente/Economic exploited waterwc

19464

Fonte/Source: Boletim estatístico [da Confederação Nacional dos Transportes]. Brasília, DF: CNT, ago. 20 Disponível em/Available from: <http://www.cnt.org.br/boletim/boletim-estatistico-cnt $>$. Acesso em: jan. 2019 /Cited: Jan. 2019.

Nota: Até agosto de 2018/Note: Until August 2018. 


\section{Tabela 15.2 - Dados gerais do transporte ferroviário - 2016-2017}

Table 15.2 - General data of railway transportation - 2016-2017

\begin{tabular}{|c|c|c|c|c|c|c|c|c|}
\hline \multirow[t]{2}{*}{$\begin{array}{c}\text { Concessionárias/ } \\
\text { Concessionary railways }\end{array}$} & \multicolumn{2}{|c|}{$\begin{array}{l}\text { Carga transportada } \\
\text { (mil toneladas) } \\
\text { (tu)/ } \\
\text { Transported freight } \\
\text { (thousand tonnes) }\end{array}$} & \multicolumn{2}{|c|}{$\begin{array}{l}\text { Locomotivas/ } \\
\text { Locomotives }\end{array}$} & \multicolumn{2}{|c|}{$\begin{array}{c}\text { Vagões/ } \\
\text { Freight } \\
\text { cars }\end{array}$} & \multicolumn{2}{|c|}{$\begin{array}{l}\text { Carga transportada } \\
\text { x km útil (mil } \\
\text { toneladas) (tku)/ } \\
\text { Transported freight } x \\
\text { km (thousand } \\
\text { tonnes)(tku) }\end{array}$} \\
\hline & 2016 & 2017 & 2016 & 2017 & 2016 & 2017 & 2016 & 2017 \\
\hline \multicolumn{9}{|l|}{ América Latina Logística } \\
\hline Malha Norte S.A & 14906 & 859 & 142 & 142 & 3847 & 3847 & 22998 & 1325 \\
\hline \multicolumn{9}{|l|}{ América Latina Logística } \\
\hline Malha Oeste S.A & 3505 & 277 & 45 & 45 & 831 & 831 & 797 & 40 \\
\hline \multicolumn{9}{|l|}{ América Logística Malha } \\
\hline Paulista S.A & 6013 & 438 & 276 & 276 & 5515 & 5515 & 4556 & 359 \\
\hline \multicolumn{9}{|l|}{ América Latina Logística } \\
\hline Malha Sul S.A & 18345 & 1079 & 364 & 364 & 9525 & 9525 & 11831 & 664 \\
\hline Estrada de Ferro Carajás & 155252 & 14089 & 307 & 307 & 17853 & 17853 & 136268 & 12357 \\
\hline \multicolumn{9}{|l|}{ Ferrovia Paraná Oeste } \\
\hline S.A & 440 & 31 & 15 & 15 & 504 & 504 & 131 & 14 \\
\hline \multicolumn{9}{|l|}{ Estrada de Ferro Vitória } \\
\hline a Minas & 129601 & 11042 & 318 & 318 & 18738 & 18738 & 74559 & 6386 \\
\hline \multicolumn{9}{|l|}{ Ferrovia Centro- } \\
\hline Atlântica S.A. & 24993 & 1681 & 578 & 578 & 17593 & 17593 & 19045 & 1014 \\
\hline \multicolumn{9}{|l|}{ Ferrovia Norte-Sul } \\
\hline Tramo Norte & 5029 & 205 & 17 & 17 & 3025 & 3025 & 4454 & 164 \\
\hline \multicolumn{9}{|l|}{ Ferrovia Tereza Cristina } \\
\hline S.A. & 2898 & 232 & 17 & 17 & 443 & 443 & 224 & 18 \\
\hline \multicolumn{9}{|l|}{ Transnordestina } \\
\hline Logística S.A & 1320 & 107 & 99 & 99 & 1769 & 1769 & 652 & 52 \\
\hline MRS Logística S.A. & 141501 & 10342 & 757 & 757 & 11224 & 11224 & 65646 & 4743 \\
\hline
\end{tabular}

Fonte/Source: Evolução do transporte ferroviário de cargas. Brasília, DF: Agência Nacional de Transportes Terrestres, 2017. Disponível em/Available from: <http://portal.antt.gov.br/index.php/content/view/1588 html>. Acesso em: jan. 2019/Cited: Jan. 2019.

Nota: Até janeiro de 2016/2017./ Note: Until January 2016/2017. 
Tabela 15.3 - Movimento de carga, por tipo de navegação - 2010-2018 Table 15.3 - Cargo transportation by modal of navigation - 2010-2018

\begin{tabular}{|c|c|c|c|}
\hline \multirow{2}{*}{$\begin{array}{l}\text { Anos / } \\
\text { Years }\end{array}$} & \multicolumn{3}{|c|}{ Movimento de carga (1 $000 \mathrm{t}) /$ Cargo movement $(1,000 \mathrm{t})$} \\
\hline & $\begin{array}{l}\text { Longo curso/ } \\
\text { Deep sea }\end{array}$ & $\begin{array}{l}\text { Cabotagem/ } \\
\text { Cabotage }\end{array}$ & $\begin{array}{c}\text { Outras navegações/ } \\
\text { Others }\end{array}$ \\
\hline 2010 & 613009 & 185657 & 31991 \\
\hline 2011 & 657677 & 193449 & 34428 \\
\hline 2012 & 670479 & 201398 & 32519 \\
\hline 2013 & 684162 & 204742 & 40443 \\
\hline 2014 & 713582 & 212991 & 42298 \\
\hline 2015 & 753340 & 212712 & 42207 \\
\hline 2016 & 741557 & 212393 & 44118 \\
\hline 2017 & 803268 & 221840 & 60974 \\
\hline 2018 & 822806 & 230592 & 64068 \\
\hline
\end{tabular}

Fonte/Source: Anuário estatístico aquaviário 2018. Brasília, DF: Agência Nacional de Transportes Aquaviários, [2019]. Disponível em/Available from : <http://web.antaq.gov.br/anuario/>. Acesso em: jan. 2019/ Cited: Jan . 2019.

\section{Gráfico 15.1 - Matriz de transporte de passageiros e cargas, por modalidades - Brasil - 2018 \\ Graph 15.1 - Matrix of passenger and cargo tranportation by mode - Brazil - 2018}

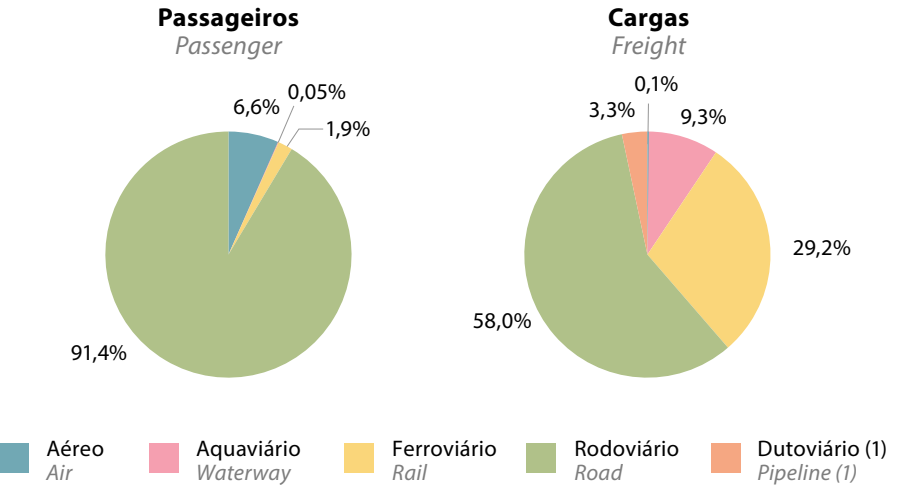

Fonte/Source: Boletim estatístico [da Confederação Nacional dos Transportes]. Brasília, DF: CNT, out. 2017. Disponível em/Available from: <http://www.cnt.org.br/boletim/boletim-estatistico-cnt>.

Acesso em: abr. 2018/Cited: Apr. 2018.

(1) Não se aplica a transporte de passageiros./ (1) Not applicable to passenger transportation. 
Gráfico 15.2 - Habitantes por autoveículo em alguns países - 2001/2015

Graph 15.2 - Inhabitants per vehicle in selected countries - 2001/2015

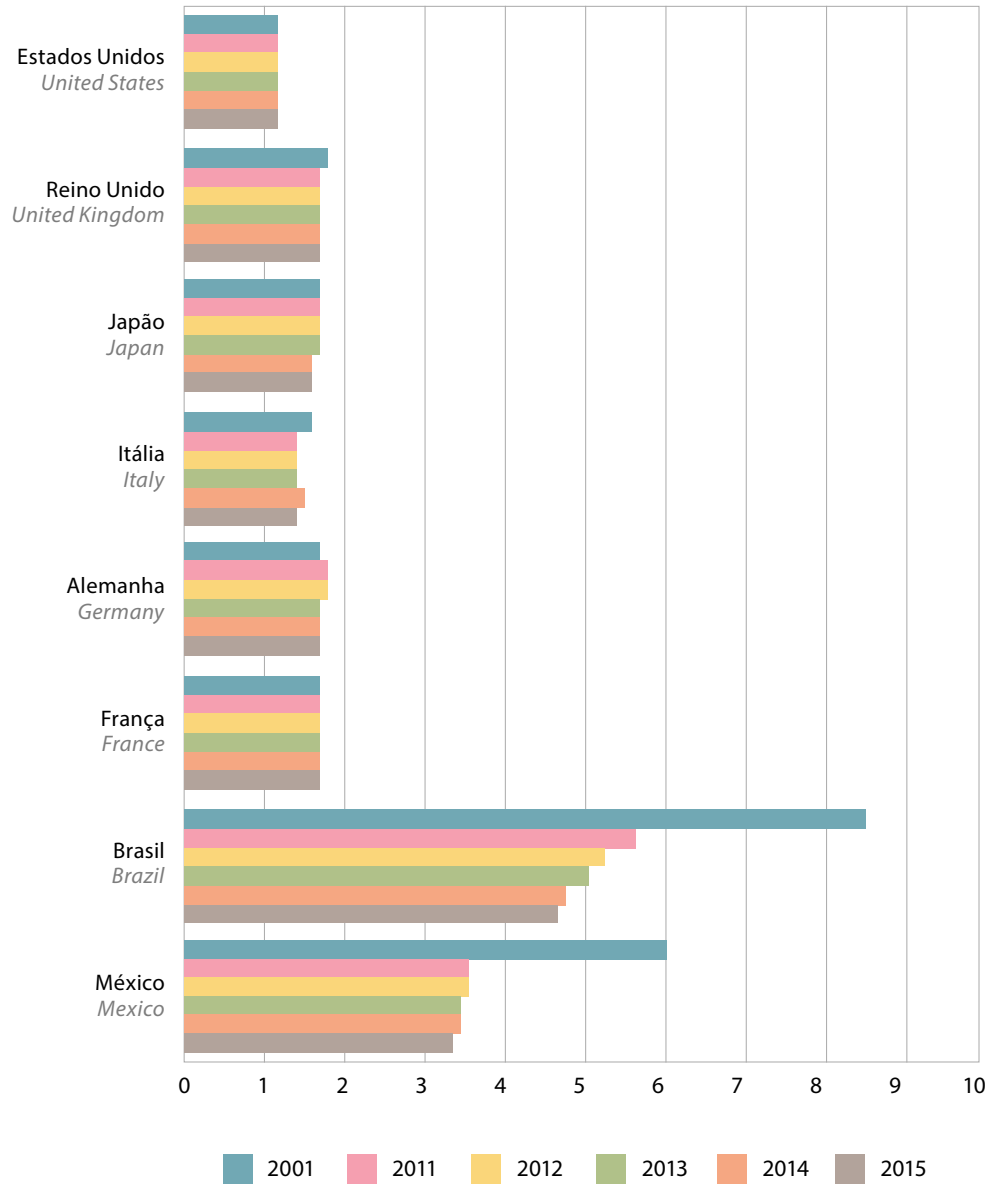

Fonte/Source: Anuário da indústria automobilística brasileira 2017. São Paulo: Associação Nacional dos Fabricantes de Veículos Automotores, 2017. Disponível em/Available from:

<http://www.virapagina.com.br/anfavea2017>. Acesso em: jan. 2019/Cited: Jan. 2019. 
Gráfico 15.3 - Movimento de carga, por tipo de navegação - 2010-2018

Graph 15.3 - Cargo transportation by modal of navigation - 2010-2018

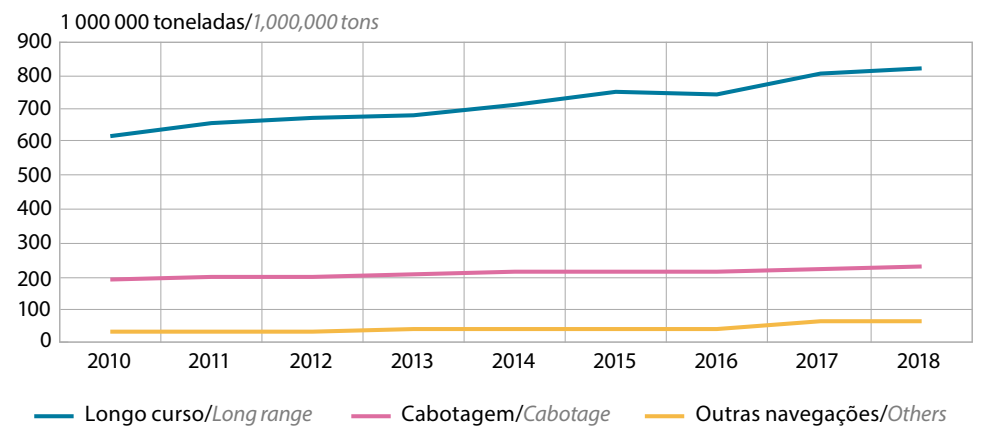

Fonte/Source: Anuário estatístico aquaviário 2018. Brasília, DF: Agência Nacional de Transportes Aquaviários, [2019]. Disponível em/Available from: <http://web.antaq.gov.br/anuario/>.Acesso em: feb. 2019/Cited: Feb. 2019.

\section{Gráfico 15.4 - Evolução da quantidade de voos - 2009-2018}

Graph 15.4 - Evolution of the number of flights - 2009-2018

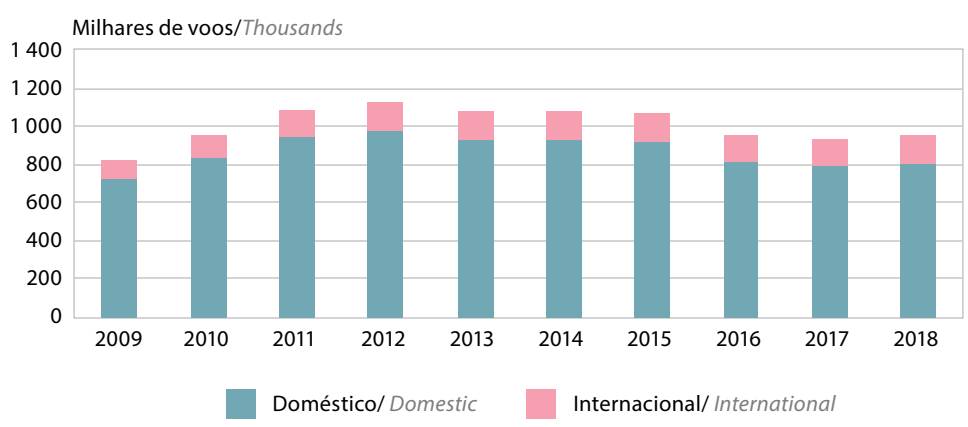

Fonte/Source: Agência Nacional de Aviação Civil (ANAC). 


\section{Gráfico 15.5 - Evolução da quantidade de passageiros transportada}

2009-2018

Graph 15.5 - Evolution of the number of passengers transported - 2009-2018

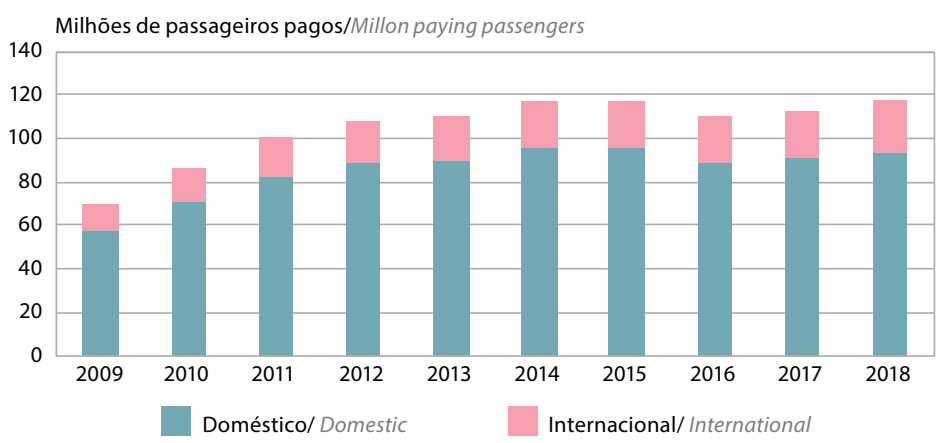

Fonte/Source: Agência Nacional de Aviação Civil (ANAC).

\section{Gráfico 15.6 - Carga aérea transportada - 2009-2018}

Graph 15.6 - Air cargo transported - 2009-2018

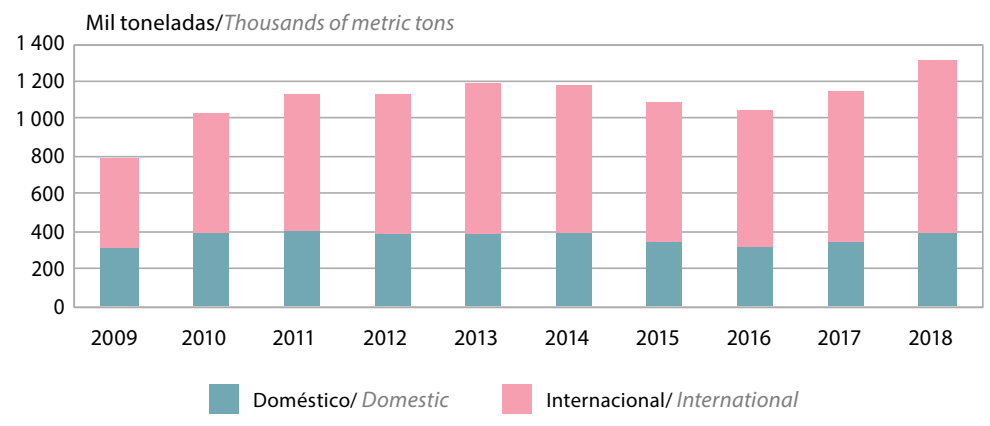

Fonte/Source: Agência Nacional de Aviação Civil (ANAC). 



\section{Turismo Tourism}

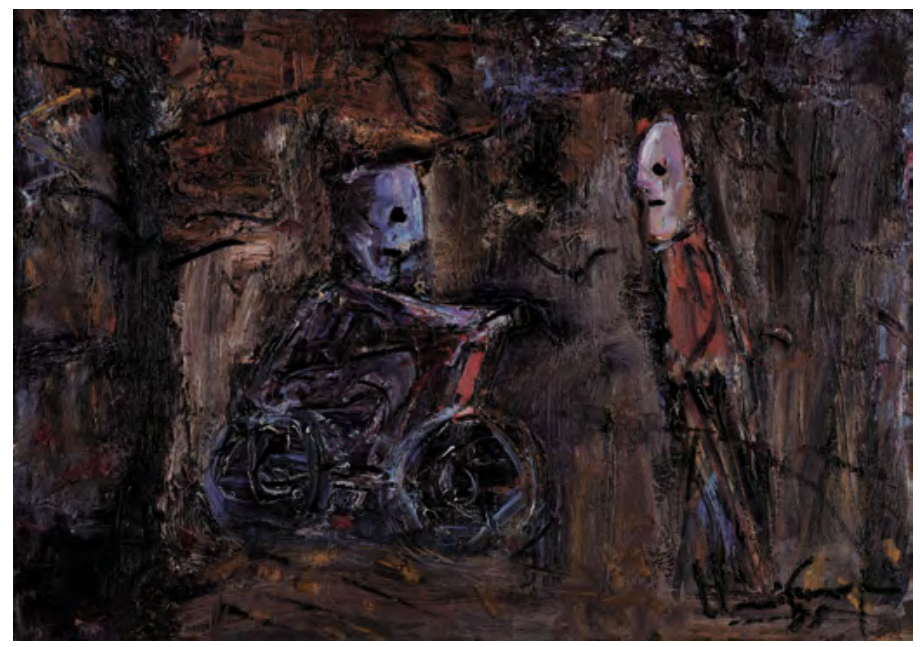

Outono no Parque da Redenção II, 1988 Fall in the Park of Redemption II

\section{Iberê Camargo}




\section{Tourism}

\section{Ari da Silva Fonseca Filho' ${ }^{1}$}

International travels have grown sharply, consolidating the tourism sector as one of the major propellers of the economic development. It comes as the third sector in the world in exports, being essential for job and income generation, circulation of capital and prosperity in communities all over the world (RESULTADOS..., 2018). Conversely, the popularization of trips has expanded tourism in such a way that it could itself represent the greatest threat to its own existence.

Mass tourism, today worldly popularized by the term "overtourism", is disseminated from the perspective of the residents affected by growing tourism flows in their cities. It is a kind of tourism that is not represented by the social class of the person who travels, but by the high flow of tourists that search for the same destinations. This phenomenon increases due to the communication expansion when it comes to tourism destinations. That may occur through media influence, which produces a number of report news on the same localities, through cultural industries with mass dissemination of audiovisual content on certain locations and also through the social media, which shares and spreads information on touristic attractions, sets trends and encourages consuming desires. Added to those elements are the rise in low-budget flights, increase in sea

\footnotetext{
$1 \mathrm{PhD}$ and Master in Education from the School of Education of the São Paulo University (USP). Graduated in Tourism from the State University of Ponta Grossa (UEPG). Professor of the Postgraduate Program in Tourism (PPGTUR) and of the Graduate Courses in Tourism and Technology in Hotel Business of the School of Tourism and Hotel Business (FTH) of the Federal Fluminense University (UFF).
} 


\title{
Turismo
}

\author{
Ari da Silva Fonseca Filho'
}

As viagens internacionais crescem fortemente, consolidando o setor de turismo como um dos principais impulsionadores do desenvolvimento econômico. É visto como o terceiro setor exportador do mundo, essencial para geração de empregos, renda, circulação de capital e prosperidade de comunidades em todo o mundo (RESULTADOS..., 2018). Em contrapartida, essa popularização das viagens tem expandido o turismo de forma que ele próprio pode representar a grande ameaça para sua existência.

O turismo de massa, hoje mundialmente popularizado pelo termo overtourism, é difundido pela perspectiva de moradores afetados pelos fluxos turísticos existentes em grande volume em suas cidades. É um tipo de turismo que não é representado pela classe social do indivíduo que viaja, mas sim, pelos elevados fluxos de turistas que buscam destinos comuns. Esse fenômeno se desponta devido à expansão da comunicação acerca de destinações turísticas. Isso pode ocorrer por influências da mídia, que produz uma infinidade de reportagens das mesmas localidades, da indústria cultural com produções audiovisuais que difundem locações massivamente e, ainda, das redes sociais, compartilhando e promovendo informações sobre lugares turísticos, ditando tendências e estimulando desejos de consumo. Agregado

1 Doutor e mestre em Educação pela Faculdade de Educação da Universidade de São Paulo (USP). É bacharel em Turismo pela Universidade Estadual de Ponta Grossa (UEPG). Professor do Programa de Pós-Graduação em Turismo (PPGTUR) e dos cursos de bacharelado em Turismo e Tecnologia em Hotelaria da Faculdade de Turismo e Hotelaria (FTH) da Universidade Federal Fluminense (UFF). 
cruises, simplified reservations by means of web sites or applications. All these, together with other factors, can explain the tourism boom around the world.

Tourism is a subjective experience, caused by the desire of an individual to understand the place through its people's culture and natural environment. The act of traveling allows individuals to let go of themselves and reach out for other people, sometimes similar, sometimes different from them, to tolerate diversities with the purpose of achieving knowledge, exercising respect and experiencing the human and transformational aspect of trips.

Therefore, the rising numbers in tourism in the world are a concern and should bring about a critical reflection upon the purposes of official institutions that work with tourism aiming at economic profit. Tourism is not limited to that perspective, it rather makes individuals leave their comfort zone, attempting to interact with places distinct from their original ones, taking the risk of that being either a pleasant or an unpleasant experience.

\section{The figures of the Brazilian tourism in 2017}

According to the World Tourism Organization (RESULTADOS..., 2018), the figures of the international tourism are the highest in seven years. All over the world, in the year 2017, the estimate is that there was a $7.0 \%$ growth in international tourist arrivals. Europe had significant results, achieving $8.0 \%$ more international arrivals than in 2016 . The African continent had the same figure, $8.0 \%$ in the comparison with the previous year, consolidating the activity. Asia and the Pacific got $6.0 \%$, the Middle East had 5.0\% and the American continent came with 3.0\%.

Aiming at presenting the Brazilian tourism figures, the surveys carried out by the Ministry of Tourism were considered, with the purpose of tracing the tourism flows of the federation, indicating the tourist arrivals in Brazil, the continents and the emissary countries; the chosen tourist destination, the distribution of the destinations among the Federation Units; expenditures in the balance of payments of the tourism-account (2010-2017); the concentration of agencies that are under the Registry of Tourism Service Providers (Cadastur) - an important register kept by the federal government to assure the tourism goods and services traded in the country are legal and professional; the revenue of the balance of payments of the tourismaccount (2010-2017); and, at last, the exchange rate and result of the balance of payments of the tourism-account (2008-2017). 
a esses elementos, pode-se indicar que o aumento de voos de baixo custo, crescimento de cruzeiros marítimos, hospedagem com reservas simplificadas por meio de sites ou aplicativos, somam-se a outros fatores que podem explicar o aumento do turismo no mundo.

O turismo é uma experiência subjetiva, provocada pelo desejo do indivíduo em compreender o lugar por meio da cultura de um povo e do seu meio ambiente natural. $\mathrm{O}$ ato de viajar permite ao indivíduo sair de si mesmo e encontrar-se com outros, conviver com semelhantes ou diferentes, tolerar a diversidade com a finalidade de conhecimento, de exercitar o respeito e espírito de vivenciar a face humana e transformadora da viagem.

Deste modo, provoca-se uma preocupação com os números crescentes do turismo no mundo, cuja reflexão deve ser crítica aos propósitos de instituições oficiais que apenas promovem turismo pelo viés economicista. $O$ turismo não se limita a esse perfil, mas provoca no sujeito um desprendimento, um convite para sair de sua zona de conforto com a finalidade de interação com o lugar distinto do habitual, correndo-se o risco de ser um processo aprazível ou não.

\section{Os números do turismo brasileiro em 2017}

Segundo a Organização Mundial do Turismo (RESULTADOS..., 2018), os números do turismo internacional são os mais altos em sete anos. Estima-se que, em todo mundo, no ano de 2017 , houve um crescimento de $7,0 \%$ nas chegadas de turistas internacionais. A Europa obteve resultados consideráveis, tendo 8,0\% mais de chegadas internacionais se comparada ao ano de 2016. Da mesma forma, o continente africano consolidou-se com 8,0\% em comparação ao ano anterior, Ásia e Pacífico com $6,0 \%$, Oriente Médio com 5,0\% e o continente americano com 3,0\%.

Com o intuito de apresentar os números do turismo brasileiro, consideraram-se as pesquisas realizadas pelo Ministério do Turismo anualmente, com finalidade de se conhecer os fluxos turísticos da federação, tendo o critério de indicar a chegada de turistas no Brasil, continentes e países emissivos; destinos turísticos escolhidos, a distribuição destes por estados da federação; despesas da balança de pagamentos da conta turismo (2010-2017); concentração de agências que apresentam o Cadastro de Prestadores de Serviços Turísticos (Cadastur) um importante cadastro feito pelo governo federal para garantir a legalidade e o profissionalismo dos serviços e produtos turísticos comercializados no País; apresentação da receita da balança de pagamentos da conta turismo (2010-2017); e por fim, a taxa de câmbio e saldo da balança de pagamentos da conta turismo (2008-2017). 
In order to do so, Table 16.1 presents tourist arrivals in Brazil (20152017), with 6,305,838 tourists in 2015, increasing to 6,546,696, in 2016, to reach $6,588,770$ tourists, in 2017 - which results in a $4.5 \%$ increase in the period. It should be noted that in 2016 Brazil hosted the Olympic Games, an international sporting event, which generated a lot of expectation about the rise in the number of foreign tourists in the country.

As to the continental origin of tourists, the American continent still leads. In 2015, North America sent 734,450 tourists, with a slight rise in 2016, reaching 735,062, whereas in 2107 there was a reduction to 605,961 tourists, representing a $17.5 \%$ drop in the period. It is worth highlighting that the United States, in 2015, was the origin-country of 575,769 of the tourists; in 2016 that figure shrank to 570,350 and in 2017 there was another reduction to 475,232, or 17.5\%. Mexico, in 2015 , was the origin-country of 90,361 tourists; in 2016, it increased to 94,609 and in 2017 , it went down to 81,778 , representing a drop of $9.5 \%$ in the period. Canada, in 2015, presented 68,293 tourists; in 2016, it rose to 70,103 (2.6\%) and in 2017 , it reduced to 48,951 tourists (30\% in relation to the previous year).

South America kept the position of geographic area that sends most tourists to Brazil. Argentina leads as the country with the highest number of tourists. In 2015, there were 2,079,823; in 2016, the number increased to 2,294,900 (10.3\%) and in 2017, there was another increase, reaching 2,622,327 (14.3\%). Chile, in 2015, sent 306,331 tourists; in 2016, it had a rise of $311,813(1.8 \%)$ and, in 2017 , it went up to $342,143(9.7 \%)$. Uruguay, in 2015, sent 267,321 tourists; in 2016, there were 284,113 and, in 2107, it achieved the figure of 328,098 tourists, representing a rise of $22.7 \%$ in the period. In 2015, Paraguay sent, 301 831; in 2016, 316,714 (4.9\%) and, in 2017, 336,646 tourists (6.3\%). Colombia, in 2015, sent 118,866 tourists, in 2016 the number went up to $135,192(13.7 \%)$ and, in 2017, there were 140,363 tourists (3.8\%).

In 2015, Europe sent 1,631,514, while, in 2016, there was a reduction to $1,606,495(1.5 \%)$, and, in 2017 , that figure fell again, reaching $1,451,544$ tourists (9.6\%). France, in 2015, sent 261,075; in 2016, the number was $263,774(1.0 \%)$ and, in 2017 , there was a reduction to 254,153 tourists (3.64\%). Germany, in 2015, sent 224,549 tourists; in 2016, there was a reduction to $221,513(1.3 \%)$ and, in 2017 , it fell to $203,045(8.3 \%)$. In 2015 , Italy had 202,015 tourists; in 2016 , it fell to $181,493(10.1 \%)$ and, in 2017, it went down to 171,654 (5.4\%). England, in 2015, sent 189 269 tourists; in 2016, it increased the figure to 202,671 (7.1\%) and, in 2017, it fell to 185,858 (8.3\%). Similarly, in Portugal there were 162,305 
Para tanto, a Tabela 16.1 apresenta as chegadas de turistas no Brasil (2015-2017), sendo 6305838 turistas em 2015, com aumento para 6546696 em 2016 e, em 2017, outro aumento para 6588770 turistas, representando aumento de 4,5\% nesse período. É válido ressaltar que no ano de 2016 foram realizados os Jogos Olímpicos de 2016, um evento esportivo internacional, cuja expectativa foi grande com relação ao aumento de turistas estrangeiros no País.

Referente à origem continental dos turistas, o continente americano permanece na liderança. Em 2015, a América do Norte apresentou 734450 turistas, com pequeno aumento em 2016, atingindo 735062 turistas, enquanto em 2017 houve redução para 605961 turistas, o que representa 17,5\% de redução no período. Vale destacar que os Estados Unidos, em 2015, era o país de origem de 575796 dos turistas, em 2016 reduziu para 570350 e em 2017 houve mais uma redução para 475 232, ou seja, 17,5\%. O México, em 2015, era o país de origem de 90361 turistas, em 2016 aumentou para 94609 e, em 2017, diminuiu para 81 778, representando queda de 9,5\% no período. O Canadá, em 2015, apresentava 68293 turistas, em 2016 aumentou para 70103 (2,6\%) e, em 2017, reduziu para 48951 turistas (30\% em relação ao ano anterior).

A América do Sul manteve-se como a região geográfica de maior emissão de turistas para o Brasil. A Argentina lidera, sendo o país que apresenta maior número de turistas. Em 2015 foram 2079823 turistas, em 2016 aumentou para 2294900 (10,3\%) e, em 2017, teve outro aumento, chegando a 2622327 (14,3\%). O Chile, em 2015, enviou 306331 turistas, em 2016 teve aumento para 311813 (1,8\%) e, em 2017, aumentou para 342143 (9,7\%). O Uruguai, em 2015, enviou 267321 turistas, em 2016 foram 284113 e, em 2017, atingiram o número de 328098 turistas, representando aumento de 22,7\% no período. O Paraguai enviou, em 2015, 301 831, em 2016, 316 714 (4,9\%) e, em 2017, 336646 turistas (6,3\%). A Colômbia, em 2015, enviou 118866 turistas, em 2016 foram 135192 (13,7\%) e, em 2017, foram 140363 turistas (3,8\%).

A Europa, em 2015, enviou 1631 514, enquanto no ano de 2016 houve redução para 1606495 (1,5\%) e, em 2017, reduziu novamente, atingindo o número de 1451544 turistas (9,6\%). A França, em 2015, enviou 261 075, em 2016 foram 263774 (1,0\%) e, em 2017, houve redução para 254153 turistas (3,64\%). A Alemanha, em 2015, enviou 224549 turistas, em 2016 houve redução para 221513 (1,3\%) e, no ano de 2017, reduziu para 203045 (8,3\%). A Itália, em 2015, apresentou 202015 turistas, em 2016 foram reduzidos para 181493 (10,1\%) e, em 2017, reduziu para 171654 (5,4\%). A Inglaterra, em 2015, enviou 189269 turistas, em 2016 aumentou para 202671 (7,1\%) e, em 2017, reduziu para 185858 (8,3\%). Da mesma forma, em Portugal foram 162305 turistas 
tourists in 2015, with a reduction to 149,968 in 2016 (7.6\%) and, in 2017, a further decrease, reaching 144,095 tourists (11.2\%).

In 2015, Asia sent 299,270 tourists; in 2016, the figure increased to 304,786 (1.8\%) and, in 2017 , it reduced to 255,841 (16.0\%). The country with the highest number of visitors was Japan, with 70,102 tourists in 2015 , increasing in 2016 to 79,754 (13.8\%) and shrinking to 60,342 (24.3\%) in 2017.

Oceania also showed significant numbers, however, without distinction of countries. In 2015, we had 55,421 tourists coming from that continent, in 2016 they were increased to 66,116 (19.3\%) and, in 2017 , reduced to 43,380 (34.4\%). Graph 16.1 shows the ten most visited Brazilian cities by foreign tourists for leisure in 2016-2017.

The tourist destinations chosen by foreign tourists for leisure (20162017) are highlighted in Graph 16.1, which ranks the ten most visited Brazilian cities. The municipality of Rio de Janeiro leads the ranking with $27.0 \%$, followed by Florianópolis with $19.6 \%$ and Foz do Iguaçu with $12.5 \%$. São Paulo comes in 4th with $7.8 \%$. The municipality of Armação dos Búzios (RJ) comes in 5th with 7.5\%. Bombinhas (SC) is the 6th in the rank, with $6.2 \%$ of the tourists. Salvador recorded $5.8 \%$, while Balneário Camboriú (SC) had $4.3 \%$ and Itapema (SC), 3.7\%. Angra dos Reis (RJ) received $3.4 \%$ of the tourists. It is worth noting that Santa Catarina was the state with the highest number of municipalities in the list (four), followed by the state of Rio de Janeiro (with three municipalities).

Table 16.2 presents the numbers of the tourist arrivals in Brazil, by Federation Units, in 2017. The Southeast Region received the highest number of tourists, especially São Paulo $(2,144,606)$, since it has the largest international airport in Brazil. Next are Rio de Janeiro $(1,355,616)$ and Minas Gerais $(56,504)$. In the South Region, the State of Rio Grande do Sul had the highest number $(1,270,618)$, followed by Paraná $(892,629)$ and Santa Catarina $(205,470)$. The Northeast Region received the greatest number of tourists in the State of Bahia $(157,913)$, Pernambuco $(83,151)$ and Rio Grande do Norte $(26,598)$. It should be noted that these figures are computed in view of the arrival of foreign tourists at Brazilian airports. Thus, big cities, with airports that concentrate more international flights, are at the top of this ranking.

Table 16.3 presents the data on the tourist agencies registered in the Cadastur, for the year 2017. As a whole, there were 19450 registered agencies, with a highlight to the State of São Paulo, with 6,113 (31.43\%), Rio de Janeiro, with 2,502 (12.9\%), Minas Gerais, with 1,656 (8.5\%), Rio Grande do Sul, with 1,105 (5.7\%) and Paraná, with 1,035 (5.32\%). The State of Pernambuco registered 1,025 agencies (5.3\%). 
em 2015, com redução para 149968 em 2016 (7,6\%) e, em 2017, nova diminuição chegando em 144095 turistas (11,2\%).

A Ásia, em 2015, enviou 299270 turistas, em 2016 foram aumentados para 304786 $(1,8 \%)$ e, no ano de 2017, reduziu para 255841 (16,0\%). O país que mais se destacou em números foi o Japão, com 70102 turistas no ano de 2015, aumentados em 2016 para 79754 (13,8\%) e, em 2017, reduzidos para 60342 turistas (24,3\%).

A Oceania também apresentou números significativos, porém, sem a distinção de países. Em 2015, tivemos 55421 turistas oriundos desse continente, em 2016 foram aumentados para 66116 (19,3\%) e, em 2017, reduzidos para 43380 (34,4\%).

Os destinos turísticos escolhidos pelos turistas estrangeiros para lazer (2016-2017) estão destacados no Gráfico 16.1, trazendo um ranking das dez cidades brasileiras mais visitadas. O Município do Rio de Janeiro lidera o ranking com $27,0 \%$, seguido de Florianópolis com 19,6\% e Foz do Iguaçu com 12,5\%. São Paulo está em 4이 lugar com 7,8\%. O Município de Armação dos Búzios (RJ) está em 5o lugar com 7,5\%. Bombinhas (SC) encontra-se em 60 lugar, com 6,2\% dos turistas. Salvador apresentou $5,8 \%$. Balneário Camboriú (SC) apresentou 4,3\% e Itapema (SC) com 3,7\%. Angra dos Reis (RJ) recebeu 3,4\% de turistas. É válido destacar que Santa Catarina foi o estado que apresentou o maior número de municípios (quatro municípios), seguido do Estado do Rio de Janeiro (três municípios).

A Tabela 16.2 apresentou os números referentes às chegadas de turistas no Brasil, por Unidades da Federação, no ano de 2017. A Região Sudeste foi a que mais recebeu turistas, com destaque para São Paulo em primeiro lugar (2 144 606), já que possui o maior aeroporto internacional do Brasil. Em seguida, o Rio de Janeiro (1 355 616) e Minas Gerais (56 504). Na Região Sul, o Estado do Rio Grande do Sul apresentou o maior número (1 270 618), seguido de Paraná (892 629) e Santa Catarina (205 470). A Região Nordeste recebeu maior número de turistas no Estado da Bahia (157 913), Pernambuco (83 151) e Rio Grande do Norte (26 598). Cabe ressaltar que esses números são computados tendo em vista a entrada de turistas estrangeiros pelos aeroportos do Brasil. Assim, as cidades de maior porte, com aeroportos que concentram maior quantidade de voos internacionais, estão no topo desse ranking.

A Tabela 16.3 apresentou os dados sobre as agências de turismo cadastradas no Cadastur, referente ao ano de 2017. No total, foram 19450 agências cadastradas, com destaque para o Estado de São Paulo com 6113 (31,43\%), o Rio de Janeiro com 2502 (12,9\%), Minas Gerais com 1.656 (8,5\%), Rio Grande do Sul com 1105 (5,7\%), Paraná com 1035 (5,32\%). O Estado de Pernambuco registrou 1025 agências (5,3\%). 
Graph 16.2 presents data on the expenditure of the tourism account balance of payments (2010-2017), estimated in dollars. And for that period, there was a positive change from 30\% (2011) to 31\% (2017). On the other hand, Graph 16.3 indicates a negative change in the revenue of the balance of payments of the tourism-account in the 2010-2017 period, going from $14 \%$ (2011) to $-4 \%$ (2017).

Graph 16.4, relative to the exchange rate and balance of payments balance of the tourism account (2008-2017), identified that, in 2017, the revenue was 5,809 and the expenditure reached the mark of 19,002 , with a final balance of $-13,192$ (amounts quoted in millions of US dollars, from January to December of that year). Finally, the exchange rate averaged 3,1925 (in US dollars).

Finally, the tourism figures are relevant for the design of public policies aimed at tourism development in the scope of the federation. The fact that tourism is more than just numbers, financial moves and profit should be highlighted, as the main result of the activity relates to knowledge building, expanded worldview and deeper understanding of individuals and their human condition. Therefore, there is an urgent need for a shift of view by the State and by private enterprises, since their actions should target the territorial organization for the activity, engagement of host populations, hospitality and guidance to tourists, protection of cultural heritage. Those are the essential elements that produce both balance and local development on a fairer, less excluding basis.

\section{References}

ANUÁRIOESTATÍSTICO DETURISMO 2018. Brasília, DF: Ministério do Turismo, v.45. Ano base 2017. Available from: <http://www.dadosefatos.turismo.gov. br/2016-02-04-11-53-05.html>. Cited: May 2019.

RESULTADOS del turismo internacional en 2017: los más altos en siete años. Madrid: Organización Mundial del Turismo, PR n. 18003, 15 enero 2018. Available from: <http://media.unwto.org/es/press-release/2018-01-15/ resultados-del-turismo-internacional-en-2017-los-mas-altos-en-siete-anos>. Cited: May 2019. 
O Gráfico 16.2 apresentou dados referentes às despesas da balança de pagamentos da conta turismo (2010-2017), estimadas em dólares. E, para esse período, houve tendência positiva de 30\% (2011) para 31\% (2017). Por outro lado, o Gráfico 16.3 indica variação negativa da receita da balança de pagamentos da conta-turismo no período de $2010-2017$ que passa de $14 \%$ (2011) para -4\% (2017).

O Gráfico 16.4, referente à taxa de câmbio e saldo da balança de pagamentos da conta-turismo (2008-2017), identificou que, no ano de 2017, a receita foi de 5809 e a despesa atingiu a marca de 19 002, tendo saldo final de -13 192 (valores cotados em milhões de dólares americanos, no período de janeiro a dezembro do referido ano). Por fim, a taxa de câmbio apresentou a média de 31925 (em dólar americano).

Contudo, os números do turismo são premissas relevantes para estruturar políticas públicas com a finalidade de desenvolvimento do turismo no âmbito da federação. Ressalta-se que o turismo não se reduz apenas aos números, às movimentações e às arrecadações financeiras, já que o principal retorno da viagem é a apreensão do conhecimento, a ampliação da visão de mundo do indivíduo e de sua condição humana. Assim, há urgente necessidade de mudança da visão do Estado e da iniciativa privada no turismo, pois suas atuações devem almejar a organização territorial da atividade, o engajamento de populações anfitriãs, a hospitalidade e orientações aos turistas, a proteção ao patrimônio cultural, sendo estes elementos essenciais para se obter equilíbrio e também um desenvolvimento local mais justo e menos excludente.

\section{Referências}

ANUÁRIO ESTATÍ́STICO DE TURISMO 2018. Brasília, DF: Ministério do Turismo, v. 45. Ano base 2017. Disponível em: <http://www.dadosefatos.turismo.gov.br/2016-02-0411-53-05.html>. Acesso em: maio 2019.

RESULTADOS del turismo internacional en 2017: los más altos en siete años. Madri: Organización Mundial del Turismo, PR n. 18003, 15 enero 2018. Disponível em: <http:// media.unwto.org/es/press-release/2018-01-15/resultados-del-turismo-internacionalen-2017-los-mas-altos-en-siete-anos>. Acesso em: maio 2019. 
Tabela 16.1 - Chegadas de turistas no Brasil - 2015-2017

Table 16.1 - Tourist arrivals to Brazil - 2015-2017

(continua/to be continued)

\begin{tabular}{|c|c|c|c|}
\hline \multirow{2}{*}{$\begin{array}{l}\text { País de residência } \\
\text { permanente/ } \\
\text { Country of } \\
\text { permanent residence }\end{array}$} & \multicolumn{3}{|c|}{$\begin{array}{c}\text { Chegadas de turistas/ } \\
\text { Tourist arrivals }\end{array}$} \\
\hline & 2015 & 2016 & 2017 \\
\hline Total/Total & 6305838 & 6546696 & 6588770 \\
\hline África/Africa & 110983 & 81391 & 70351 \\
\hline América Central/Central America & 53709 & 51412 & 49320 \\
\hline América do Norte/North America & 734450 & 735062 & 605961 \\
\hline Canadá/Canada & 68293 & 70103 & 48951 \\
\hline Estados Unidos/United States & 575796 & 570350 & 475232 \\
\hline México/Mexico & 90361 & 94609 & 81778 \\
\hline América do Sul/South America & 3420349 & 3701344 & 4112327 \\
\hline Argentina/Argentina & 2079823 & 2294900 & 2622327 \\
\hline Bolívia/Bolivia & 108149 & 138106 & 126781 \\
\hline Chile/Chile & 306331 & 311813 & 342143 \\
\hline Colômbia/Colombia & 118866 & 135192 & 140363 \\
\hline Paraguai/Paraguay & 301831 & 316714 & 336646 \\
\hline Peru/Peru & 113078 & 114276 & 115320 \\
\hline Uruguai/Uruguay & 267321 & 284113 & 328098 \\
\hline Venezuela/Venezuela & 80488 & 61160 & 53950 \\
\hline Outros/Other countries & 44462 & 45070 & 46699 \\
\hline Ásia/Asia & 299270 & 304786 & 255841 \\
\hline Japão/Japan & 70102 & 79754 & 60342 \\
\hline Outros/Other countries & 229168 & 225032 & 195499 \\
\hline
\end{tabular}


Tabela 16.1 - Chegadas de turistas no Brasil - 2015-2017

Table 16.1 - Tourist arrivals to Brazil - 2015-2017

(conclusão/concluded)

\begin{tabular}{|c|c|c|c|}
\hline \multirow{2}{*}{$\begin{array}{l}\text { País de residência } \\
\text { permanente/ } \\
\text { Country of } \\
\text { permanent residence }\end{array}$} & \multicolumn{3}{|c|}{$\begin{array}{c}\text { Chegadas de turistas/ } \\
\text { Tourist arrivals }\end{array}$} \\
\hline & 2015 & 2016 & 2017 \\
\hline Europa/Europe & 1631514 & 1606495 & 1451544 \\
\hline Alemanha/Germany & 224549 & 221513 & 203045 \\
\hline Áustria/Austria & 26575 & 23531 & 20358 \\
\hline Bélgica/Belgium & 34423 & 35577 & 28458 \\
\hline Espanha/Spain & 151029 & 147846 & 137202 \\
\hline França/France & 261075 & 263774 & 254153 \\
\hline Holanda/Netherlands & 66870 & 72268 & 59272 \\
\hline Inglaterra/England & 189269 & 202671 & 185858 \\
\hline Itália/Italy & 202015 & 181493 & 171654 \\
\hline Portugal/Portugal & 162305 & 149968 & 144095 \\
\hline Suíça/Switzerland & 70319 & 69074 & 69484 \\
\hline Outros/Other countries & 243085 & 238780 & 177965 \\
\hline Oceânia/Oceania & 55421 & 66116 & 43380 \\
\hline Não especificado/Unspecified & 142 & 90 & 46 \\
\hline
\end{tabular}

Fonte/Source: Anuário estatístico de turismo 2018. Brasília, DF: Ministério do Turismo, v. 45, 2018. Ano base 2017. Disponível em/Available from : <http://www.dadosefatos.turismo.gov.br/2016-02-04-11-5305.html>. Acesso em: jan. 2019/Cited: Jan. 2019. 
Tabela 16.2 - Chegadas de turistas no Brasil, por Unidades da Federação de acesso - 2015-2017

Table 16.2 - Tourist arrivals to Brazil, by Federation Unit of arrival - 2015-2017

\begin{tabular}{|c|c|c|c|}
\hline \multirow{2}{*}{$\begin{array}{l}\text { Unidades da Federação de acesso/ } \\
\text { Federation Unit of arrival }\end{array}$} & \multicolumn{3}{|c|}{$\begin{array}{c}\text { Chegadas de turistas/ } \\
\text { Tourist arrivals }\end{array}$} \\
\hline & 2015 & 2016 & 2017 \\
\hline Total/Total & 6305838 & 6546696 & 6588770 \\
\hline Amazonas & 50290 & 45364 & 33627 \\
\hline Pará & 20708 & 38238 & 30524 \\
\hline Pernambuco & 66232 & 62405 & 83151 \\
\hline Bahia & 151660 & 132339 & 157913 \\
\hline Ceará & 78711 & 77514 & 74497 \\
\hline Rio de Janeiro & 1375978 & 1480121 & 1355616 \\
\hline Minas Gerais & 47929 & 34099 & 56504 \\
\hline São Paulo & 2248811 & 2248297 & 2144606 \\
\hline Paraná & 758973 & 846387 & 892629 \\
\hline Rio Grande do Norte & 28580 & 29355 & 26598 \\
\hline Rio Grande do Sul & 1080478 & 1106845 & 1270618 \\
\hline Mato Grosso do Sul & 56601 & 77028 & 80270 \\
\hline Santa Catarina & 149133 & 203662 & 205470 \\
\hline Distrito Federal/Federal District & 107208 & 79356 & 76747 \\
\hline Outros/Others & 84546 & 85686 & 100000 \\
\hline
\end{tabular}

Fonte/Source: Anuário estatístico de turismo 2018. Brasília, DF: Ministério do Turismo, v. 45, 2018. Ano base 2017. Disponível em/Available from: <http://www.dadosefatos.turismo.gov.br/2016-02-04-11-5305.html>. Acesso em: jan. 2019/Cited: Jan . 2019. 
Tabela 16.3 - Agências de turismo cadastradas no CADASTUR - 2017

Table 16.3 - Travel and tourism agencies listed in CADASTUR - 2017

Unidades da Federação/Federation Units

Agências/Agencies

Brasil/Brazil

19450

Rondônia

166

Acre

133

Amazonas

285

Roraima

Pará

263

Amapá

Tocantins

Maranhão

234

Piauí

Ceará

Rio Grande do Norte 201

Paraíba 305

Pernambuco

1025

Alagoas 299

Sergipe 199

Bahia

Minas Gerais

Espírito Santo

Rio de Janeiro

São Paulo

Paraná

Santa Catarina

Rio Grande do Sul

Mato Grosso do Sul

Mato Grosso

Goiás

Distrito Federal/Federal District

423

Fonte/Source: Anuário estatístico de turismo 2018. Brasília, DF: Ministério do Turismo, v. 45, 2018. Ano base 2017. Disponível em/Available from: $<$ http://www.dadosefatos.turismo.gov.br/2016-02-04-11-5305.html>. Acesso em: jan. 2019/Cited : Jan . 2019. 


\section{Gráfico 16.1 - Dez cidades brasileiras mais visitadas pelos turistas estrangeiros, para lazer - 2016-2017}

Graph 16.1 - Ten most visited cities in Brazil by foreign tourists, for leisure - 2016-2017

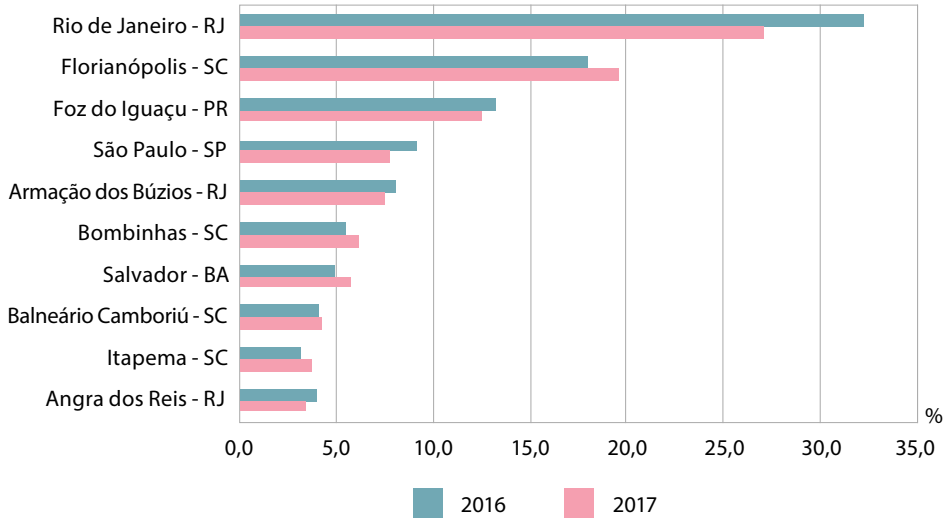

Fonte/Source: Anuário estatístico de turismo 2018. Brasília, DF: Ministério do Turismo, v. 45, 2018. Ano base 2017. Disponível em/Available from: <http://www.dadosefatos.turismo.gov.br/ 2016-02-04-11-53-05.html>. Acesso em: jan. 2019/Cited: Jan. 2019.

\section{Gráfico 16.2 - Despesa da balança de pagamentos da conta turismo - 2010-2017 \\ Graph16.2 - Expenditure in the balance of payments of tourism account - 2010-2017}

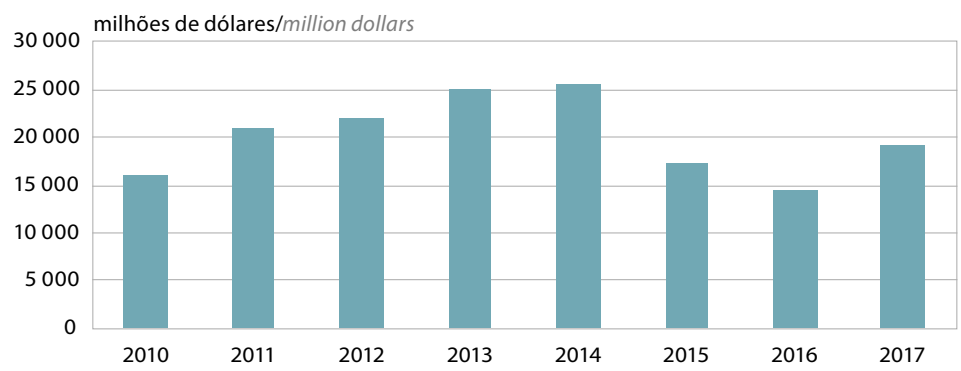

Fonte/Source: Receita e despesa cambial turística. Dados e fatos: estudos, pesquisas e dados sobre o setor de turismo. Brasília, DF: Ministério do Turismo, [2018]. Disponível em/Available from: <http://www.dadosefatos.turismo.gov.br/estat\%C3\%ADsticas-e-indicadores/receita-cambial.html>. Acesso em: jan. 2019/Cited:jan. 2019. 


\section{Gráfico 16.3 - Receita da balança de pagamentos da conta turismo - 2010-2017}

Graph 16.3 - Revenue in the balance of payments of tourism account - 2010-2017

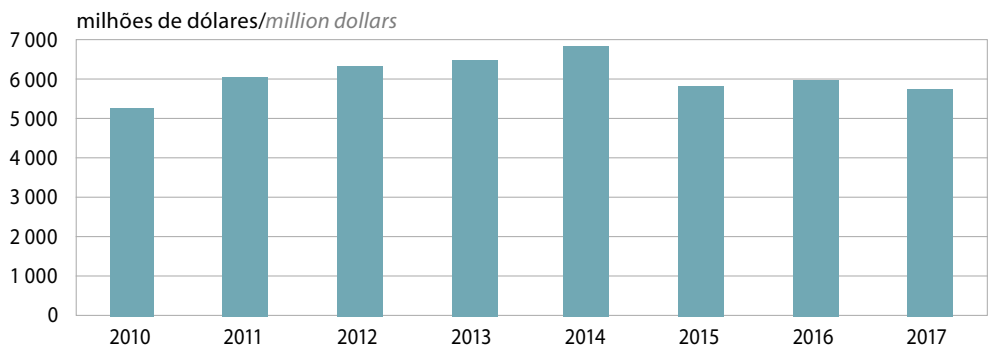

Fonte/Source: Receita e despesa cambial turística. Dados e fatos: estudos, pesquisas e dados sobre o setor de turismo. Brasília, DF: Ministério do Turismo, [2018]. Disponível em/Available from:

<http://www.dadosefatos.turismo.gov.br/estatísticas-e-indicadores/receita-cambial.html>.

Acesso em: jan. 2019/Cited: Jan. 2019.

\section{Gráfico 16.4 - Taxa de câmbio e saldo da balança de pagamentos da conta turismo - 2008-2017 \\ Graph 16.4 - Exchange rate and balance of tourism account - 2008-2017}

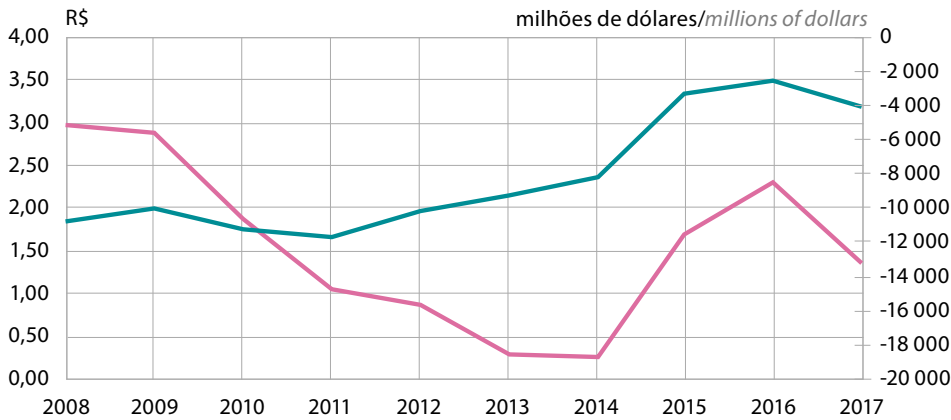

_ Taxa de câmbio - Livre - Dólar americano (venda) - Média anual

Exchange rate - Free - USD (sale) - Annual average
- Saldo da conta turismo

Balance of tourism account

Fonte/Source: Anuário estatístico de turismo 2018. Brasília, DF: Ministério do Turismo, v. 45, 2018. Ano base 2017. Disponível em/Available from: <http://www.dadosefatos.turismo.gov.br/2016-02-04-1153-05.html>. Acesso em: jan. 2019/Cited: Jan. 2019.. 



\section{Comunicações Communications}

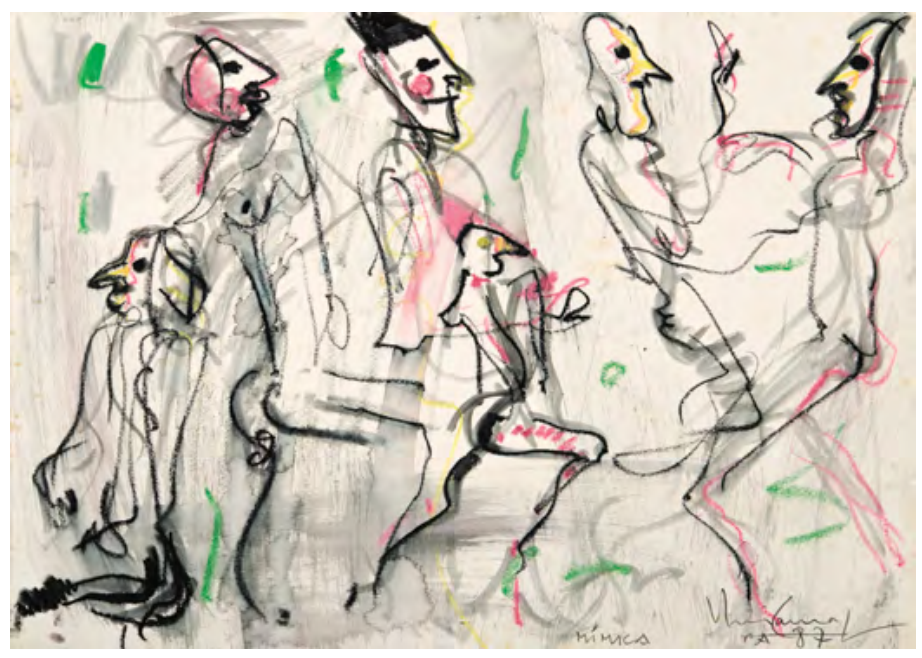

Mímica, 1987

Mimic

Iberê Camargo 


\title{
Communications
}

\author{
Basilio Sartor ${ }^{1}$
}

In recent decades, the communication field has been affected by the so-called new information and communication technologies (ICTs), notably the Internet, which became popular in the beginning of the 1990s. The emergence of those technologies reconfigured the production, the distribution and consumption of data and of information and cultural products worldwide. Those changes were not limited to the technological dimension of communication devices, but had important effects on social relations, culture and democracy.

The unidirectional communication model of traditional media (newspapers, radio and television), specifically, has been transformed as a result of the possibilities for interactions in networks, recently expanded due to Internet access via mobile devices. Once restricted to the role of a receiver, the user of new technologies now intervenes in the production and dissemination of contents and participates more actively in the construction of mediatic narratives.

On the one hand, the ICTs enable the democratization of communication: they reduce costs of communication products and services, give public visibility to issues and productions excluded from mainstream means of communication and promote new forms of organization in networks

$1 \mathrm{PhD}$ in Information and Communication from the Postgraduate Program in Information and Communication of the Federal University of Rio Grande do Sul (PPGCOM/UFRGS). Professor at the Journalism course of the Faculty of Library Science and Communication of the Federal University of Rio Grande do Sul (Fabico/UFRGS). 


\title{
Comunicações
}

\author{
Basilio Sartor ${ }^{1}$
}

Nas últimas décadas, as comunicações sofreram o impacto das chamadas novas tecnologias de informação e comunicação (NTICs), notadamente a Internet, que começou a se popularizar a partir dos anos 1990. A emergência dessas tecnologias reconfigurou mundialmente os processos de produção, distribuição e consumo de dados e produtos informativos e culturais. Essas transformações não se limitaram à dimensão tecnológica dos dispositivos comunicacionais, como também produziram efeitos importantes sobre as relações sociais, a economia, a cultura e a democracia.

Em especial, o modelo unidirecional de comunicação das mídias tradicionais (jornal, rádio e televisão) transformou-se em decorrência das possibilidades de interação em rede, ampliadas mais recentemente pelo acesso à Internet via dispositivos móveis. Antes limitado ao papel de receptor, o usuário das novas tecnologias passou a intervir na produção e disseminação de conteúdos, participando de forma mais ativa da construção de narrativas midiáticas.

De um lado, as NTICs oferecem possibilidades de democratização da comunicação: reduzem custos de serviços e produtos comunicacionais, permitem conferir visibilidade pública a pautas e produções excluídas dos meios de comunicação de massa e promovem novas formas de organização em rede e mobilização social. De outro

1 Doutor em Comunicação e Informação pelo Programa de Pós-Graduação em Comunicação e Informação da Universidade Federal do Rio Grande do Sul (PPGCOM/UFGRS). Professor no curso de Jornalismo da Faculdade de Biblioteconomia e Comunicação da Universidade Federal do Rio Grande do Sul (Fabico/UFRGS). 
and of social mobilization. On the other hand, digital exclusion, inequalities of access, the high concentration of companies that hold the market of digital platforms, and cases of privacy violation and improper use of personal data for political and commercial purposes restrict or go against the democratic potential of the ICTs. Other factors, such as the influence of algorithms on the consumption of information from social media and the low level of media literacy of the public which makes it vulnerable to strategies of opinion manipulation, such as the dissemination of fake news - also contribute to restrain the initial optimism in relation to those technologies.

In this context, the process of media convergence should also be observed. It is characterized by the association and the hybridism between communication products and services (newspapers, radio and television, Internet, mobile telephony, social media and applications). At the same time that companies in the sector started to offer associated services (for example, TV subscriptions and broadband Internet access), users started to consume different contents using the same means, as the smartphone, which allows one to make phone calls, exchange messages, read news, listen to the radio, watch television and access all types of audiovisual products with the same device.

One of the implications of this product is related to the way of producing and consuming media content. Productions from different media started to be distributed and accessed through the Internet, by means of computers and smartphones, out of fixed schedules set for radio and tv programs and fragmented into segments of different genres or formats. Services on demand allowed the access to those productions anywhere, anytime, from any device connected to the web. From a market perspective, major business conglomerates have been formed aiming at rationalizing costs and maximizing profits by means of the control of production and distribution of contents.

\section{The national context}

In this global scenario, Brazil still faces historical problems related to the sector and now made more complex by the impact of ICTs and of media convergence. The concept of communication as a fundamental right, established in the Constitution of 1988 (Articles 220 to 224), is still little known in the country. The lack of regulation on the constitutional principle of complementarity of private, public and state broadcast system (Article 223) makes it difficult to attain its educational, cultural and informative purposes, since it results in the predominance of great private communication groups that operate in the market rather in 
lado, a exclusão digital, as desigualdades de acesso, a alta concentração da propriedade de empresas que detêm o mercado de plataformas digitais e os casos de violação de privacidade e de uso indevido de dados pessoais para fins comerciais e políticos restringem ou operam na direção contrária ao potencial democratizante das NTICs. Outros fatores, como a influência dos algoritmos no consumo de informações em redes sociais digitais e o baixo nível de letramento midiático do público - que o torna vulnerável a estratégias de manipulação da opinião, como a disseminação de fake news - também contribuem para refrear o inicial otimismo em relação a essas tecnologias.

Neste contexto, o processo de convergência das mídias também deve ser observado. Ele é caracterizado pela associação e pelo hibridismo de serviços e produtos de comunicação (jornais, rádio e televisão, Internet, telefonia móvel, redes sociais digitais e aplicativos). Ao mesmo tempo em que empresas do setor passaram a oferecer serviços de forma associada (por exemplo, TV por assinatura e acesso à banda larga), os usuários passaram a consumir diferentes conteúdos por meio de um mesmo suporte, como é o caso do smartphone, que permite fazer ligações telefônicas, trocar mensagens, ler notícias, ouvir rádio, assistir televisão e acessar todo tipo de produção audiovisual com o mesmo dispositivo.

Uma das implicações deste processo relaciona-se à forma de produzir e de consumir conteúdos midiáticos. Produções de diferentes mídias passaram a ser distribuídas e acessadas também pela Internet, por meio de computadores e smartphones, fora dos horários das grades de programação fixa das emissoras de rádio e TV e fragmentados em programas ou blocos de diferentes gêneros ou formatos. Serviços on demand permitiram o acesso a essas produções a qualquer hora e em qualquer lugar, a partir de qualquer aparelho conectado à rede. Do ponto de vista do mercado, formaram-se grandes conglomerados empresariais que buscam racionalizar custos e maximizar lucros por meio do controle da produção de conteúdos e de sua distribuição.

\section{O contexto nacional}

Neste cenário global, o Brasil ainda enfrenta problemas históricos relacionados ao setor e agora complicados pelo impacto das NTICs e da convergência das mídias. A concepção de comunicação como direito fundamental, presente na Constituição de 1988 (Art. 220 a 224), ainda é pouco difundida no País. A falta de regulamentação do princípio constitucional da complementaridade dos sistemas privado, público e estatal de radiodifusão (Art. 223) dificulta o cumprimento de suas finalidades edu- 
pursuit of the maximization of profit (and of possible political interests) than according to the demands of citizenship.

Although the ICTs make the power of traditional media more relative each day, one should consider that radio broadcast companies are still an important source of information and cultural production in the country. Besides, for the sake of convergence, they also work as major producers of content for digital means. In this respect, one's being given full right to communication in Brazil still depends on the solution of problems such as the tendency to form monopolies and oligarchies of communication means, political or business instrumentalization for the granting of broadcast channels, lack of investment and of institutional autonomy by public stations, and disparities in the access to communication services.

From a normative point of view, the sector deals with regulatory and institutional dispersion. Radio broadcasting (broadcast radio and TV channels) is still regulated by the former Brazilian Telecommunications Code, Law no. 4,117, of August 27, 1962. Telephony and subscription TV are under the General Telecommunications Law, no.472, of July 16, 1997, which granted private enterprises the right to control telephone services and created the National Telecommunications Agency (Anatel). In turn, postal services are regulated by Law no. 6,538, of June 22,1978 . Such fragmentation has been frequently criticized as it results in different treatment to similar services, in legal insecurity and in a mismatch between the public policies for the sector.

Promulgated in 2014, the Brazilian Civil Rights Framework for the Internet, Law no. 12.965, of April 23, 2014, established the rights and obligations of Internet providers and online service users. Brazil then became one of the first countries in the world to adopt the principle of neutrality, which guarantees to every user the same quality of access to the web, not allowing Internet providers to limit connection and speed according to content, origin, destination or service accessed. In 2018, the approval of the General Law of Protection to Personal Data, Law no. 13.709, of August 14, 2018, was considered a further advance (but late in comparison with other countries), that time towards the regulation of the collection and treatment of data provided by citizens, including legal support to them. However, in a scenario of political instability and of competition between the demands from civil society and companies in the sector, the real application of those laws and the implementation of public policies to meet the principles established by law is still a matter of dispute. 
cativas, culturais e informativas, pois resulta na predominância de grandes grupos privados de comunicação que operam no mercado mais segundo a lógica da maximização dos lucros (e de eventuais interesses políticos) do que conforme as demandas da cidadania.

Embora as NTICs tornem cada vez mais relativo o poder das mídias tradicionais, é preciso considerar que as empresas de radiodifusão ainda são uma importante fonte de acesso à informação e à produção cultural no País. Além disso, por meio da convergência, elas também atuam como grandes produtoras de conteúdo para os meios digitais. Nesse sentido, a efetivação plena do direito à comunicação no Brasil ainda depende da solução de problemas como a tendência à formação de monopólios e oligopólios na propriedade dos meios, a instrumentalização política ou empresarial das outorgas de canais de radiodifusão, a falta de investimentos e de autonomia institucional das emissoras públicas e as disparidades no acesso aos serviços de comunicação.

Do ponto de vista normativo, o setor convive com uma dispersão regulatória e institucional. A radiodifusão (rádio e TV aberta) é ainda normatizada pelo antigo Código Brasileiro de Telecomunicações, Lei n. 4.117, de 27.08.1962. Já a telefonia e a TV por assinatura são regidas pela Lei Geral de Telecomunicações, Lei n. 9.472, de 16.07.1997, que permitiu a abertura dos serviços telefônicos à iniciativa privada e criou a Agência Nacional de Telecomunicações (Anatel). Por sua vez, os serviços postais obedecem à Lei n. 6.538, de 22.06.1978. Essa fragmentação tem sido com frequência criticada por gerar diferenças de tratamento de serviços semelhantes, insegurança jurídica e descompasso em termos de políticas públicas para o setor.

Promulgado em 2014, o Marco Civil da Internet, Lei n. 12.965, de 23.04.2014, estabeleceu os direitos e deveres dos usuários e das empresas provedoras de acesso e serviços online. Com ele, o Brasil tornou-se um dos primeiros países do mundo a adotar o princípio da neutralidade, que garante a todos os usuários a mesma qualidade de acesso à rede, proibindo os provedores de restringir a conexão e a velocidade de acordo com o conteúdo, a origem, o destino ou o serviço acessado. Em 2018, a aprovação da Lei Geral de Proteção de Dados Pessoais, Lei n. 13.709, de 14.08.2018, foi considerada outro avanço (embora tardio em relação a diversos países), desta vez no sentido de regular a coleta e o tratamento dos dados dos cidadãos, amparando-os juridicamente. Contudo, num cenário de instabilidade política e de embate entre as demandas da sociedade civil e das empresas do setor, a aplicação efetiva dessas leis e a implementação de políticas públicas que atendam aos princípios estabelecidos na legislação configuram ainda um campo de disputas. 


\section{The data}

Data from the communication sector in Brazil point to retraction or stabilization of figures on several services in the last few years, after a cycle of expansion. In 2018, the data presented in the graphs and tables below evidence decreases in several indicators related to postal services, telecommunications and radio broadcasting, although some specific segments have recorded slight increase. In general terms, that trend can be considered a result of the economic crisis that has affected the country, together with the deficit in terms of public policies to promote the universalization of access to communication services. Besides a tendency to retraction, regional disparities in the access to products and services constitute another important aspect to be observed.

\section{Postal services}

In the last few years, there has been a decrease in some indicators related to the services of the Brazilian Post and Telegraph Company (Correios). As shown in Table 17.1, since 2015, there has been a steady decrease in the number of units owned by the company and also of treatment and distribution branches. Data of 2018 reinforce that tendency, although they evidence a slight increase in the number of outsourced units and the stabilization of figures about staff and mail boxes (which had fallen by $46 \%$ in 2017). Table 17.2 also indicates a downward trend in the postal traffic, with a decrease in figures relative to its own postal service, international objects distributed, the competitor's postal services and the objects distributed in Brazil.

In spite of that, it is important to highlight that in 2017 and 2018, revenue figures surpassed the total expenses (Table 17.1), with profit for the postal company, after a two-year period of losses (2015 and 2016). The increase of electronic trade, which requires the delivery of products by mail, can result in an increment in the postal business in the next few years.

\section{Telephony}

The evolution of telephony figures in Brazil shows that in 2018 there was a decrease in the number of landlines and also of mobile telephones in the country, compared to the previous year. As for landline, Graph 17.1 shows that the figures were practically stable from 2010 to 2016, with a decrease in 2017 and, again, in 2018, the year when, for the first time in the current decade, there were less than 40 million fixed telephone terminals in the country. Mobile telephony, 


\section{Os dados}

Os dados do setor de comunicações no Brasil indicam retração ou estabilização dos números relativos a diversos serviços nos últimos anos, após um ciclo de expansão. Em 2018, os dados apresentados nos gráficos e tabelas a seguir evidenciam queda em vários indicadores relacionados aos serviços postais, às telecomunicações e à radiodifusão, ainda que segmentos pontuais apresentem ligeiro crescimento. De modo geral, essa tendência pode ser explicada pela crise econômica que tem afetado o País, aliada ao déficit em termos de políticas públicas que promovam a universalização do acesso aos serviços de comunicação. Além da tendência à retração, as disparidades regionais no acesso a produtos e serviços constituem outro ponto importante a ser observado.

\section{Serviços postais}

Nos últimos anos, registra-se decréscimo em alguns indicadores relacionados aos serviços da Empresa Brasileira de Correios e Telégrafos (Correios). Conforme demonstra a Tabela 17.1, desde 2015 há uma redução continuada no número de agências próprias e de unidades de tratamento e distribuição. Os dados de 2018 reafirmam essa tendência, embora evidenciem ligeiro aumento das unidades terceirizadas e estabilização nos números de pessoal e de caixas de coletas (que haviam sofrido redução de $46 \%$ em 2017). A Tabela 17.2 também aponta tendência decrescente de tráfego postal, com queda nos números relativos ao serviço postal próprio, objetos internacionais distribuídos, serviço postal concorrente e objetos distribuídos no Brasil.

Apesar disso, é importante observar que em 2017 e 2018 os valores de receita superaram o total de despesas (Tabela 17.1), registrando lucro para os Correios, após um biênio de prejuízos (2015 e 2016). O crescimento do comércio eletrônico, que demanda entregas de produtos via remessa postal, pode vir a resultar em incremento nos negócios dos Correios nos próximos anos.

\section{Telefonia}

A evolução nos números da telefonia no Brasil indica que em 2018 houve redução na quantidade de telefones fixos e também de telefones móveis no País, no comparativo com o ano anterior. No caso da telefonia fixa, o Gráfico 17.1 mostra que os números são praticamente estáveis de 2010 a 2016, com queda em 2017 e, novamente, em 2018, ano em que, pela primeira vez na atual década, registram-se menos de 40 milhões de terminais fixos no País. Já a telefonia móvel, que teve crescimento con- 
which recorded consistent increase between 2010 and 2014 (with a change in the period from about 202 million to more than 280 mobile telephones), started to fall in 2015, being on a downward trend up to 2018, when the nearly 229 million mobile telephones registered in the country represented the lowest figure since 2011.

Table 17.3 shows the distribution of telephones in use in the country, by Federation Units. Considering the total (landline and mobile), São Paulo is the state that concentrates most telephone lines (more than 77 million), whereas Roraima holds the fewest (only 556 thousand), evidencing the high disparity between the areas.

\section{TV and radio broadcasting}

The figures relative to TV subscription services started to decline in 2014, as shown in Table 17.4. In 2018 alone, TV providers lost 550 thousand subscribers. In terms of density, there were 25.3 TV subscriptions per each 100 housing units last year, a lower result than in the four previous years. Besides the scenario of economic retraction, an explanation to that trend is the popularization of ondemand services, which charge cheaper fares than TV subscription companies for the access of audiovisual productions.

Also last year, when there was a decrease in the number of TV relay transmitters and medium-wave (MW), short-wave (SW) and tropical wave (TW) radio stations, the number of TV signal generators increased by about $4.5 \%$ against 2017 , with a positive change of $1.3 \%$ in the total of modulated frequency radio stations (MF) ${ }^{2}$. Community radio stations recorded an increase of only $0.8 \%$ in 2018 , reinforcing the trend to a low increase of that segment in the last four years.

\section{Broadband}

Table 17.5 shows that the accesses to broadband have increased moderately in the country since 2015. In 2018, that increment was about $7.4 \%$, in comparison with 2017 . It is important to point out that the Southeast Region concentrates more than half of the approximately 31 million accesses to broadband registered in the country last year, whereas the North Region had only 3.6\% of that total.

The number of accesses to mobile broadband fell by $2.2 \%$ in 2018 , against 2017, after a period of moderate increase, as shown in Table

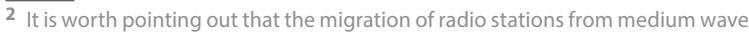
(MW) to modulated frequency (MF) is currently in progress, so that the former can be available for mobile telephony. 
sistente entre 2010 e 2014 (variando no período de cerca de 202 milhões para mais de 280 milhões de celulares), começou a recuar em 2015, em trajetória descendente até 2018 , quando os cerca de 229 milhões de celulares registrados no País representam o menor número desde 2011.

A Tabela 17.3 mostra a distribuição dos telefones em serviço no País, por Unidades da Federação. Considerando-se o total (fixos e móveis), São Paulo é o estado que concentra o maior número de telefones (mais de 77 milhões), enquanto Roraima detém o menor (apenas $556 \mathrm{mil}$ ), evidenciando alto nível de disparidade entre as regiões.

\section{Televisão e radiodifusão}

Os números relativos ao serviço de TV por assinatura entraram em declínio a partir de 2014, conforme demonstra a Tabela 17.4. Somente em 2018, as operadoras perderam 550 mil assinantes. Em termos de densidade, registraram-se, no último ano, 25,3 assinaturas de TV para cada 100 domicílios, número inferior ao verificado nos quatro anos anteriores. Além do cenário de retração econômica, pode explicar essa tendência a popularização dos serviços on demand, como a Netflix, que oferecem tarifas mais baixas que as TVs por assinatura para o acesso a produções audiovisuais. Ainda no último ano, enquanto houve queda no número de retransmissoras de TV e de rádios de ondas médias (OM), ondas curtas (OC) e ondas tropicais (OT), verificou-se crescimento de cerca de 4,5\% no número de geradores de TV, em relação a 2017, e variação positiva de $1,3 \%$ no total de rádios de frequência modulada (FM)². Já o número de rádios comunitárias teve aumento de apenas 0,8\% em 2018, reforçando a tendência de baixo crescimento deste segmento nos últimos quatro anos.

\section{Banda larga}

A Tabela 17.5 demonstra que os acessos à banda larga fixa vêm crescendo de forma moderada no País desde 2015. Em 2018, esse incremento foi da ordem de 7,4\%, na comparação com 2017. Importante observar que a Região Sudeste concentra mais da metade dos cerca de 31 milhões de acessos à banda larga fixa registrados no País no último ano, enquanto a Região Norte representa apenas 3,6\% deste total.

Por sua vez, o número de acessos à banda larga móvel apresentou redução de 2,2\% em 2018, na comparação com 2017, após um período de expansão moderada, con-

2 Vale pontuar que segue em curso a migração das rádios de ondas médias (OM) para a frequência modulada (FM), a fim de liberar a faixa OM para a telefonia celular. 
17.6. Once again, regional disparities appear: whereas the Southeast accounts for approximately $46 \%$ of the more than 184 million accesses to broadband registered in the country last year, that percentage is reduced to $7.3 \%$ in the North and to $8.6 \%$ in the Central-West Region.

Considering the growing importance of the Internet, not only for the access to information and public policies by the population, but also for the access to services and transactions that currently take place in online environments, the evolution of broadband indicators (mainly of the mobile mode, which is sometimes the only form of access to the web) and the regional contrasts still constitute problems to be faced in the perspective of achieving universalization of that essential service to citizens.

Translated by: Aline Milani Romeiro Pereira 
forme a Tabela 17.6. Novamente, observam-se disparidades regionais: enquanto o Sudeste soma cerca de $46 \%$ dos mais de 184 milhões de acessos à banda móvel registrados no País no último ano, este percentual cai para $7,3 \%$ no Norte e $8,6 \%$ no Centro-Oeste.

Considerando-se a crescente importância da Internet não apenas para o acesso da população a informações e políticas públicas, mas também a diversos serviços e transações que atualmente se realizam em ambientes online, a evolução nos indicadores da banda larga (sobretudo a móvel, que muitas vezes constitui o único modo de acesso à rede) e os contrastes regionais configuram problemas a serem enfrentados na perspectiva de universalização deste serviço essencial ao cidadão. 
Tabela 17.1 - Organização dos Correios e Telégrafos - 2014-2018

Table 17.1 - Organization of Postal and Telegraph

Services - 2014-2018

\begin{tabular}{lrrrrr}
\hline $\begin{array}{c}\text { Sistema postal/ } \\
\text { Postal system }\end{array}$ & 2014 & 2015 & 2016 & 2017 & 2018 \\
\hline $\begin{array}{l}\text { Unidades próprias/ } \\
\text { State-owned units }\end{array}$ & 6480 & 6511 & 6495 & 6374 & 6301 \\
\end{tabular}

Unidades terceirizadas/

7274

7135

6610

5349

5407

Outsourced units

Caixas de coleta/

18424

17865

17865

9608

9608

Mail collection boxes

Unidades de tratamento

e distribuição/

1296

1292

1273

1237

1210

Treatment and distribution units

Pessoal/

120461

118220

115469

107988

107988

Personnel

Receita total (1 $000000 \mathrm{R} \$) /$

$17693,08 \quad 18838,73 \quad 20849,87 \quad 18568,93 \quad$ (1) 17853,22

Total revenue $(1,000,000 R \$)$

Despesa total (1 $000000 \mathrm{R} \$$ )/

$17683,1720959,96$

22339,38

17901,62

(1) 17742,73

Total expenditure $(1,000,000 R \$)$

Fonte/Source: Empresa Brasileira de Correios e Telégrafos (Correios), Superintendência de Controladoria.

(1) Resultados de 2018 referem-se ao acumulado até novembro./ 2018 results refers to the cumulative rate up to November. 
Tabela 17.2 - Tráfego postal - 2014-2018

Table 17.2 - Postal traffic - 2014-2018

\begin{tabular}{|c|c|c|c|c|c|}
\hline \multirow{2}{*}{$\begin{array}{l}\text { Sistema postal/ } \\
\text { Postal system }\end{array}$} & \multicolumn{5}{|c|}{$\begin{array}{l}\text { Tráfego postal (mihões de objetos)/ } \\
\text { Postal traffic (millions of objects) }\end{array}$} \\
\hline & 2014 & 2015 & 2016 & 2017 & 2018 (1) \\
\hline $\begin{array}{l}\text { Serviço postal próprio - (C) e (RM) (2)(3)/ } \\
\text { State-owned postal service (C) and (MR) (2)(3) }\end{array}$ & 8524 & 8227 & 7193 & 6220 & 5276 \\
\hline $\begin{array}{l}\text { Objetos internacionais distribuidos/ } \\
\text { International objects distributed }\end{array}$ & 156 & 62 & 53 & 78 & 64 \\
\hline $\begin{array}{l}\text { Serviço postal concorrente - (C)/ } \\
\text { Competing postal service }(C)\end{array}$ & 1506 & 1190 & 1049 & 948 & 883 \\
\hline $\begin{array}{l}\text { Objetos distribuídos no Brasil/ } \\
\text { Objects distributed in Brazil }\end{array}$ & 8680 & 8290 & 7247 & 6298 & 5340 \\
\hline
\end{tabular}

Fonte/Source: Empresa Brasileira de Correios e Telégrafos (Correios), Superintendência de Controladoria.

(1) Resultado de 2018 até o mês de novembro. (2) $C=$ Concorrencial. (3) RM = Reserva de Mercado/

(1) Results from 2018 until November.(2) $C=$ Competitive. (3) $M R=$ Market Reserve.

\section{Gráfico 17.1 - Evolução dos terminais telefônicos - 2010-2018}

Graph 17.1 - Telephone lines in service - 2010-2018

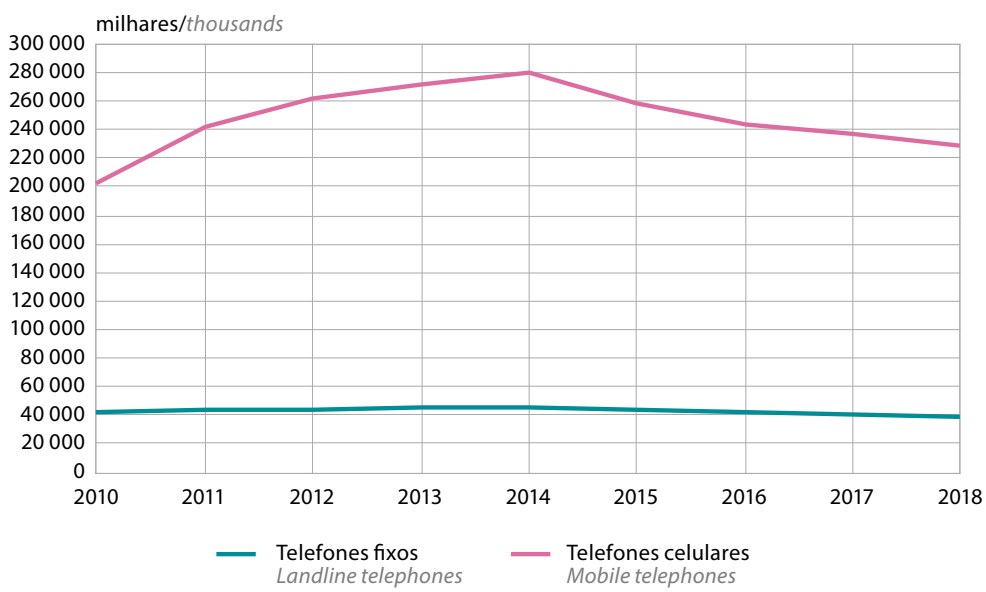

Fonte/Source: Agência Nacional de Telecomunicações (Anatel).

Nota: Dados de 2018 relativos a dezembro./Note: 2018 data relative to December. 
Tabela 17.3 - Telefones em serviço - 2018

Table 17.3 - Telephones in service - 2018

\begin{tabular}{|c|c|c|c|}
\hline \multirow[b]{2}{*}{$\begin{array}{l}\text { Unidades da Federação/ } \\
\text { Federation Units }\end{array}$} & \multicolumn{3}{|c|}{ Telefones em serviço $(1000) /$ Telephones in service $(1,000)$} \\
\hline & $\begin{array}{l}\text { Total/ } \\
\text { Total }\end{array}$ & $\begin{array}{l}\text { Telefones } \\
\text { celulares/ } \\
\text { Mobile } \\
\text { phones }\end{array}$ & $\begin{array}{l}\text { Telefones } \\
\text { fixos/ } \\
\text { Landline } \\
\text { phones }\end{array}$ \\
\hline Brasil/Brazil & 267518 & 229211 & 38307 \\
\hline Rondônia & 1935 & 1775 & 160 \\
\hline Acre & 843 & 760 & 84 \\
\hline Amazonas & 3792 & 3527 & 265 \\
\hline Roraima & 556 & 508 & 48 \\
\hline Pará & 7640 & 7221 & 419 \\
\hline Amapá & 762 & 727 & 36 \\
\hline Tocantins & 1714 & 1577 & 137 \\
\hline Maranhão & 5713 & 5432 & 281 \\
\hline Piauí & 3430 & 3237 & 193 \\
\hline Ceará & 9167 & 8546 & 621 \\
\hline Rio Grande do Norte & 3531 & 3291 & 240 \\
\hline Paraíba & 4228 & 3948 & 280 \\
\hline Pernambuco & 10432 & 9536 & 896 \\
\hline Alagoas & 3139 & 2937 & 202 \\
\hline Sergipe & 2224 & 2048 & 176 \\
\hline Bahia & 15009 & 13688 & 1321 \\
\hline Minas Gerais & 25450 & 21764 & 3686 \\
\hline Espírito Santo & 4501 & 3817 & 683 \\
\hline Rio de Janeiro & 23714 & 19292 & 4422 \\
\hline São Paulo & 77368 & 62996 & 14372 \\
\hline Paraná & 15759 & 12972 & 2787 \\
\hline Santa Catarina & 9595 & 7936 & 1659 \\
\hline Rio Grande do Sul & 15156 & 12881 & 2275 \\
\hline Mato Grosso do Sul & 3551 & 3093 & 458 \\
\hline Mato Grosso & 4313 & 3839 & 474 \\
\hline Goiás & 8587 & 7402 & 1185 \\
\hline Distrito Federal/Federal District & 5409 & 4462 & 947 \\
\hline
\end{tabular}

Fonte/Source: Agência Nacional de Telecomunicações (ANATEL).

Nota: Dados até dezembro/Note: Data up to December. 
Tabela 17.4 - Televisão e radiodifusão - 2014-2018

Table 17.4 - Television and radio broadcasting - 2014-2018

\begin{tabular}{|c|c|c|c|c|c|}
\hline $\begin{array}{l}\text { Indicadores/ } \\
\text { Indicators }\end{array}$ & 2014 & 2015 & 2016 & 2017 & 2018 \\
\hline \multicolumn{6}{|c|}{ Televisão por assinatura/Pay TV } \\
\hline $\begin{array}{l}\text { Serviço de televisão por assinatura } \\
\text { (1 } 000 \text { assinaturas)/ }\end{array}$ & 19569 & 19122 & 18821 & 18125 & 17575 \\
\hline \multicolumn{6}{|l|}{$\begin{array}{l}\text { Pay TV services }(1,000 \\
\text { subscriptions) }\end{array}$} \\
\hline $\begin{array}{l}\text { Densidade serviço TV por assinatura } \\
\text { (assinaturas/100 domicílios)/ }\end{array}$ & 29,7 & 28,0 & 27,3 & 25,9 & 25,3 \\
\hline \multicolumn{6}{|l|}{$\begin{array}{l}\text { Pay TV services density } \\
\text { (Subscriptions / } 100 \text { households) }\end{array}$} \\
\hline \multicolumn{6}{|c|}{ Radiodifusão/Radio Broadcasting } \\
\hline $\begin{array}{l}\text { Geradores de TV (estação)/ } \\
\text { TV Generators (stations) }\end{array}$ & 542 & 541 & 545 & 558 & $\ldots$ \\
\hline $\begin{array}{l}\text { Retransmissora de TV (estação)/ } \\
\text { TV re-transmitters (stations) }\end{array}$ & 11308 & 12595 & 13630 & 13790 & $\ldots$ \\
\hline $\begin{array}{l}\text { Rádios FM (estação)/ } \\
\text { FM radios (stations) }\end{array}$ & 3208 & 3222 & 3533 & 3839 & $\ldots$ \\
\hline $\begin{array}{l}\text { Rádios OM (estação)/ } \\
\text { MW radios (stations) }\end{array}$ & 1781 & 1781 & 1790 & 1679 & $\ldots$ \\
\hline $\begin{array}{l}\text { Rádios OC (estação)/ } \\
\text { SW radios (stations) }\end{array}$ & 62 & 61 & 61 & 61 & $\ldots$ \\
\hline $\begin{array}{l}\text { Rádios OT (estação)/ } \\
\text { TW radios (stations) }\end{array}$ & 73 & 73 & 72 & 71 & $\ldots$ \\
\hline $\begin{array}{l}\text { Rádios comunitárias (estação)/ } \\
\text { Community radios (stations) }\end{array}$ & 4650 & 4727 & 4775 & 4830 & $\ldots$ \\
\hline
\end{tabular}

Fonte/Source: Aqência Nacional de Telecomunicacões (ANATEL). 


\section{Tabela 17.5 - Banda larga fixa, por Grandes Regiões e Unidades da Federação - 2015-2018}

Table 17.5 - Fixed broadband access, by Major Regions and Federation Units 2015-2018

\begin{tabular}{|c|c|c|c|c|}
\hline \multirow{2}{*}{$\begin{array}{c}\text { Grandes Regiões e } \\
\text { Unidades da Federação/ } \\
\text { Major Regions and Federation Units }\end{array}$} & \multicolumn{4}{|c|}{$\begin{array}{l}\text { Acessos a banda larga fixa (1 } 000 \text { acessos)/ } \\
\text { Fixed broadband access (1,000 accesses) }\end{array}$} \\
\hline & 2015 & 2016 & 2017 & 2018 \\
\hline Brasil/ Brazil & 25490,7 & 26759,4 & 28907,6 & 31048,2 \\
\hline Norte/North & 886,5 & 962,7 & 1055,0 & 1142,5 \\
\hline Rondônia & 130,4 & 138,6 & 144,9 & 144,4 \\
\hline Acre & 51,1 & 54,4 & 61,3 & 63,5 \\
\hline Amazonas & 243,6 & 267,2 & 282,0 & 321,1 \\
\hline Roraima & 35,1 & 37,2 & 37,8 & 36,8 \\
\hline Pará & 279,8 & 302,3 & 352,8 & 391,1 \\
\hline Amapá & 48,7 & 58,3 & 65,2 & 66,1 \\
\hline Tocantins & 97,7 & 104,7 & 111,0 & 119,5 \\
\hline Nordeste/Northeast & 3007,3 & 3141,3 & 3594,6 & 3968,0 \\
\hline Maranhão & 194,7 & 220,5 & 268,9 & 286,6 \\
\hline Piauí & 143,1 & 157,1 & 170,6 & 191,7 \\
\hline Ceará & 582,2 & 591,2 & 739,6 & 838,1 \\
\hline Rio Grande do Norte & 253,4 & 268,7 & 339,6 & 369,0 \\
\hline Paraíba & 246,3 & 256,3 & 290,1 & 329,1 \\
\hline Pernambuco & 504,9 & 518,3 & 543,6 & 567,3 \\
\hline Alagoas & 147,8 & 149,7 & 161,5 & 173,9 \\
\hline Sergipe & 145,4 & 159,6 & 184,4 & 208,9 \\
\hline Bahia & 789,5 & 819,9 & 896,2 & 1003,4 \\
\hline Sudeste/Southeast & 15060,4 & 15718,8 & 16561,0 & 17569,4 \\
\hline Minas Gerais & 2408,5 & 2622,4 & 2896,0 & 3250,2 \\
\hline Espírito Santo & 470,9 & 488,2 & 561,6 & 581,0 \\
\hline Rio de Janeiro & 2888,8 & 3017,7 & 3162,4 & 3287,2 \\
\hline São Paulo & 9292,3 & 9590,5 & 9941,0 & 10450,9 \\
\hline Sul/South & 4462,5 & 4726,5 & 5258,6 & 5812,1 \\
\hline Paraná & 1779,0 & 1843,7 & 2064,6 & 2250,3 \\
\hline Santa Catarina & 1100,1 & 1204,1 & 1358,1 & 1532,1 \\
\hline Rio Grande do Sul & 1583,4 & 1678,7 & 1835,9 & 2029,7 \\
\hline Centro-Oeste/Central-West & 2074,1 & 2210,1 & 2438,4 & 2556,3 \\
\hline Mato Grosso do Sul & 329,2 & 347,8 & 391,8 & 410,3 \\
\hline Mato Grosso & 327,6 & 359,7 & 393,5 & 424,7 \\
\hline Goiás & 785,1 & 850,2 & 946,6 & 991,1 \\
\hline Distrito Federal/Federal District & 632,2 & 652,4 & 706,5 & 730,1 \\
\hline
\end{tabular}

Fonte/Source: Agência Nacional de Telecomunicações (ANATEL). 
Tabela 17.6 - Banda larga móvel, por Grandes Regiões e

Unidades da Federação - 2015-2018

Table 17.6 - Mobile broadband access, by Major Regions and Federation Units 2015-2018

\begin{tabular}{|c|c|c|c|c|}
\hline \multirow{2}{*}{$\begin{array}{c}\text { Grandes Regiões e } \\
\text { Unidades da Federação/ } \\
\text { Major Regions and Federation Units }\end{array}$} & \multicolumn{4}{|c|}{$\begin{array}{l}\text { Acessos a banda larga móvel (1 } 000 \text { acessos)/ } \\
\text { Mobile broadband access (1,000 accesses) }\end{array}$} \\
\hline & 2015 & 2016 & 2017 & 2018 \\
\hline Brasil/Brazil & 180485,8 & 183704,1 & 188855,1 & 184570,7 \\
\hline Norte/North & 12698,4 & 12788,9 & 13251,8 & 13653,8 \\
\hline Rondônia & 1579,3 & 1575,5 & 1610,1 & 1575,7 \\
\hline Acre & 597,6 & 618,7 & 633,8 & 642,1 \\
\hline Amazonas & 2715,7 & 2714,4 & 2879,4 & 3032,6 \\
\hline Roraima & 366,8 & 386,0 & 413,9 & 446,4 \\
\hline Pará & 5624,5 & 5594,2 & 5758,5 & 5985,6 \\
\hline Amapá & 580,6 & 564,7 & 591,5 & 624,0 \\
\hline Tocantins & 1233,9 & 1335,4 & 1364,6 & 1347,5 \\
\hline Nordeste/Northeast & 42893,8 & 42991,7 & 43936,4 & 43400,5 \\
\hline Maranhão & 3974,1 & 4146,0 & 4371,4 & 4512,9 \\
\hline Piauí & 2538,1 & 2625,8 & 2705,5 & 2652,6 \\
\hline Ceará & 7097,3 & 7063,2 & 7142,5 & 6886,9 \\
\hline Rio Grande do Norte & 2877,7 & 2801,9 & 2855,5 & 2761,6 \\
\hline Paraíba & 3047,3 & 2968,6 & 3056,4 & 3010,8 \\
\hline Pernambuco & 7975,3 & 7761,2 & 7974,0 & 7896,9 \\
\hline Alagoas & 2397,9 & 2373,7 & 2425,4 & 2404,1 \\
\hline Sergipe & 1707,5 & 1693,2 & 1728,0 & 1758,3 \\
\hline Bahia & 11278,5 & 11558,0 & 11677,6 & 11516,4 \\
\hline Sudeste/Southeast & 84010,3 & 85274,3 & 87398,5 & 84683,9 \\
\hline Minas Gerais & 16727,2 & 17472,5 & 18327,0 & 18277,5 \\
\hline Espírito Santo & 2785,1 & 2932,1 & 3095,7 & 3215,9 \\
\hline Rio de Janeiro & 18490,0 & 18482,5 & 18511,2 & 17359,4 \\
\hline São Paulo & 46008,0 & 46387,1 & 47464,6 & 45831,1 \\
\hline Sul/South & 25070,7 & 26447,4 & 27511,7 & 26956,4 \\
\hline Paraná & 9235,5 & 9801,4 & 10240,3 & 10214,5 \\
\hline Santa Catarina & 6012,9 & 6304,9 & 6569,5 & 6478,4 \\
\hline Rio Grande do Sul & 9822,4 & 10341,1 & 10701,9 & 10263,5 \\
\hline Centro-Oeste/Central-West & 15812,7 & 16201,9 & 16756,8 & 15876,2 \\
\hline Mato Grosso do Sul & 2351,6 & 2490,8 & 2589,8 & 2546,3 \\
\hline Mato Grosso & 2986,1 & 3123,9 & 3322,8 & 3269,5 \\
\hline Goiás & 6076,0 & 6243,2 & 6472,8 & 6127,0 \\
\hline Distrito Federal/Federal District & 4399,0 & 4344,0 & 4371,4 & 3933,3 \\
\hline
\end{tabular}

Fonte/Source: Agência Nacional de Telecomunicações (ANATEL). 



\section{Finanças Públicas Public Finances}

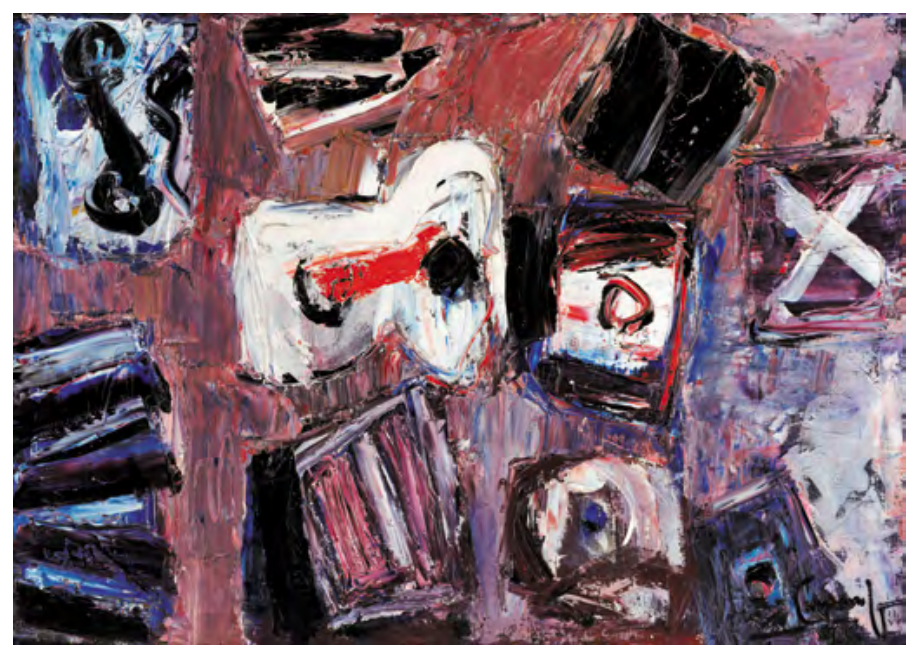

Símbolos, 1976

Symbols

\section{Iberê Camargo}




\title{
Public Finances
}

\author{
Wagner Nóbrega ${ }^{1}$
}

From 2013 to 2018, both the gross debt and the total net debt of the public sector hit their highest values in relation to the Gross Domestic Product-GDP. The most recent year in which that value was surpassed was in 2002 (59.9\%).

Even increasing continuously since 2013, it should be noticed that the net debt grew at decreasing rates from 2017 onward, in contrast to the growth between 2013 and 2016, as it can be seen in Graph 18.3. In the face of that, this article proposes to cast a light on the following issue: is the performance of the public accounts in 2018 part of the growth control of the public debt?

In order to do that, this article begins by pointing out the theoretical context that justifies the concern with the debt control and introducing a potential basic rule for this control. Next, it presents a descriptive reading of the participation and behavior of each of the most aggregate constraints of the net and gross debts. It is expected that the readers gather those constraints with the biggest changes and possible impacts in terms of the basic rule initially introduced, and that they make their own judgment on a possible growth control of the public debt.

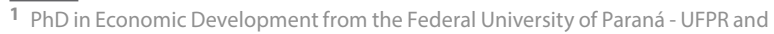
Associate Professor of the Federal University of Sergipe - UFS. 


\title{
Finanças Públicas
}

\author{
Wagner Nóbrega ${ }^{1}$
}

Tanto a dívida bruta, quanto a dívida líquida total do setor público atingiram seus mais altos valores relativamente ao Produto Interno Bruto (PIB) no ano de 2018, desde 2013. O ano mais recente a superar aquele percentual é 2002 (59,9\%).

Mesmo tendo aumentado sucessivamente desde 2013, deve-se observar que a partir de 2017 o crescimento da dívida líquida se dá a taxas decrescentes, ao contrário do que acontece entre 2013 e 2016, como pode ser visto no Gráfico 18.3. Diante disso, o presente artigo propõe e tenta lançar luz sobre a seguinte questão: o desempenho das contas públicas em 2018 faz parte de um processo de controle do crescimento da dívida pública?

Para alcançar o intuito proposto, o presente trabalho começa indicando o contexto teórico que justifica a preocupação com o controle da dívida e apresentando uma possível regra básica desse controle. Em seguida, apresenta-se uma leitura descritiva da participação e do comportamento de cada um dos condicionantes mais agregados das dívidas líquida e bruta. Espera-se que ao final o leitor reúna aqueles de maiores variações e possíveis impactos em termos da regra básica apresentada inicialmente, e faça seu próprio julgamento sobre um possível controle do crescimento da dívida pública.

1 Doutor em Desenvolvimento Econômico pela Universidade Federal do Paraná (UFPR) e Professor Associado da Universidade Federal de Sergipe (UFS). 


\section{The debt control as a policy rule}

Some of the main theses and empirical tests concerning the problems on the credibility of the monetary and fiscal policies in developing countries, in the context of the relation between the administration of the public accounts and the state of the economy in that relation, are shown by Mendonza (2009). Aligned with this approach, the Central Bank of Brazil - BCB and the National Treasure managed to keep the debt low and sustainable from 1999 onward, in order to improve the performance of the economy, as explained by Tiberto and Montes (2014). Aiming at minimizing the net cost expected for the long term, the debt administration may allow oscillations of increases and reductions of the debt in the short term ${ }^{2}$; besides, issues specific to the process of implementation of those efforts lead to that. Starting from the basic identity of funding of the government, the rule of the debt management is understood:

$$
G-T+i B_{i}+j B_{x} \equiv \dot{M}+\dot{B}_{i}+B_{x}+T C
$$

where:

$G$ are the government expenditures,

$T$ are the taxes,

$i$ is the interest rate of the domestic debt,

$\dot{B_{i}}$ is the amount,

$j$ is the interest rate of the foreign debt,

$B_{x}$ is the amount of domestic debt securities,

$\dot{M}$ is the variation of the monetary base,

$B_{i}$ is the variation of the issuance of domestic securities,

$B_{x}$ is the variation of the issuance of foreign securities; and

$T C$ is the balance of the current account.

By writing the above identity as an equation, in such a way to isolate $B$, besides considering the domestic and foreign debts as only one, and relating all the variables to the GDP, we arrive at the following basic form:

$$
\Delta b=d+(r-\rho) b-\lambda m-t c
$$

$\overline{2}$ On the implementation of the joint efforts of the BCB and the National Treasure to lengthen and change the debt profile, see, for example, Sobreira (2002). On the short-term variations of the debt compatible with its management, a great example of theoretical work is that of Ferrari and Rodosthenous (2019). 


\section{O controle da dívida como regra de política}

Algumas das principais teses e testes empíricos com respeito aos problemas sobre a credibilidade das políticas monetária e fiscal, no contexto da relação entre a administração das contas públicas e o estado da economia naquela relação, em países emergentes, são apresentadas por Mendonza (2009). Alinhada a essa abordagem, no Brasil, a partir de 1999, o Banco Central do Brasil (BCB)e o Tesouro Nacional combinaram esforços com o objetivo de manter a dívida baixa e sustentável, para melhorar o desempenho da economia, conforme explicado por Tiberto e Montes (2014). A administração da dívida, perseguindo a minimização do custo líquido esperado para o longo prazo, pode permitir oscilações de aumentos e reduções da dívida no curto prazo $^{2}$, além de questões específicas ao processo de implementação daqueles esforços e a forma levarem a isso. Partindo-se da identidade básica de financiamento do governo a seguir, entende-se, porém, a regra de gestão da dívida:

$$
G-T+i B_{i}+j B_{x} \equiv \dot{M}+\dot{B_{i}}+B_{x}+T C
$$

onde:

$G$ são os gastos do governo,

$T$ são os impostos,

$i$ é a taxa de juros da dívida interna,

$B_{i}$ é o montante de títulos de dívida interna,

$j$ é a taxa de juros da dívida externa,

$B_{x}$ é o montante de títulos de dívida externa,

$\dot{M}$ é a variação da base monetária,

$\dot{B}_{i}$ é a variação de emissão de títulos internos,

$B_{x}$ é a variação de emissão de títulos no exterior, e

$T C$ é o saldo da balança em transações correntes.

Escrevendo a identidade acima como equação, de forma a isolar-se $B$, além de considerar-se uma só as dívidas interna e externa, bem como fazer-se todas as variáveis com relação ao PIB, chegamos à seguinte forma básica:

$$
\Delta b=d+(r-\rho) b-\lambda m-t c
$$

$\overline{2}$ Sobre o processo de implementação dos esforços conjuntos do BCB e do Tesouro Nacional para o alongamento e mudança do perfil da dívida, ver, por exemplo, Sobreira (2002). Sobre as variações de curto prazo da dívida condizentes com a gestão da mesma, um ótimo exemplo de trabalho teórico é o de Ferrari e Rodosthenous (2019). 
where:

$b$ is the debt/GDP relation,

$d$ is the primary deficit in relation to the GDP,

$r$ is the interest rate paid by the debt,

$\rho$ is the change rate of the GDP,

$\lambda$ is the change rate of the monetary base,

$m$ is the monetary base in relation to the GDP, and

$t c$ is the balance in current transactions/GDP relation.

The BCB chooses $\dot{M}$ according to the monetary policy. This results in $\lambda m$. Next, the Treasure adjusts the other variables in the fiscal part, in order to minimize $\Delta b$. That is the rule of debt control, consistent with the regime of monetary dominance adopted in Brazil in 1994.

\section{Constraints of the recent performance of the debt ${ }^{3}$}

According to Table 18.1, the biggest deductions of the public debt were due to surpluses of the adjustments of the exchange rate and currency parity, as well as to the growth of the GDP. The Brazilian creditor position in real debt securities indexed by the exchange rate was decisive for the benefit caused by the difference of the interest rate in relation to the exchange rate.

The reduction of the interest rate, of minor impact, followed the larger issuance of securities indexed by the rate of the Special System for Settlement and Custody - Selic, though that reduction cannot be attributed to this, as it will be seen later.

Of such low values, the adjustment to equity valuation and privatizations, in turn, slightly influenced the debt since they began being calculated.

Table 18.2 unveils other monetary instruments of policy. It should be noticed that the growth of the gross debt began to decrease before that of the net debt, due to the negative net issuance in 2016 and $2018^{4}$. They reveal the intention to reduce the debt.

The downturn of both the net debt and the gross debt over the last years is demonstrated in Graph 18.1.

The debt profile changed with the deceleration of its growth. If, on the one hand, the parcel of the securities indexed by Selic had

3 All the debt data in the tables of this article are related to the GDP.

4 With a Pearson correlation index of 0.9 in the period, the gross debt was strongly associated with the net issuance. 
onde:

$b$ é a relação dívida/PIB,

$d$ é o déficit primário com relação ao PIB,

$r$ é a taxa de juros paga pela dívida,

$\rho$ é a taxa de variação do PIB,

$\lambda$ é a taxa de variação da base monetária,

$m$ é a base monetária relativamente ao PIB, e

tc é a relação saldo em transações correntes/PIB é a relação saldo em transações correntes/PIB.

O BCB escolhe $\dot{M}$ em função da política monetária. Disto resulta $\lambda m$. Em seguida, o Tesouro ajusta as demais variáveis na parte fiscal, de maneira a minimizar $\Delta b$. Essa é a regra de controle da dívida, consistente com o regime de dominância monetária adotado no Brasil em 1994.

\section{Condicionantes do desempenho recente da dívida ${ }^{3}$}

As maiores deduções da dívida pública, conforme Tabela 18.1, aconteceram através dos superávits de ajustes de variação cambial e paridade de moedas, bem como do crescimento do PIB. A posição credora brasileira em títulos da dívida real indexada pelo câmbio foi determinante para o benefício causado pela diferença dos juros com relação ao câmbio.

A redução dos juros, de menor impacto acompanhou a maior emissão de títulos indexados à taxa do Sistema Especial de Liquidação e de Custódia (Selic), mas não se pode atribuir a isso aquela redução, como se verá adiante.

O ajuste patrimonial e as privatizações, por sua vez, de tão baixos, pouco influenciaram a dívida tratada, desde que os mesmos passaram a ser calculados.

A Tabela 18.2 revela outros instrumentos monetários de política. Observa-se que o crescimento da dívida bruta começou a diminuir antes do da dívida líquida, por conta das emissões líquidas negativas em 2016 e $2018^{4}$. Elas revelam a intencionalidade em reduzir-se a dívida.

Esse arrefecimento nos últimos anos tanto da dívida líquida, quanto da dívida bruta é demonstrado no Gráfico 18.1 .

3 Todos os dados de dívida das tabelas deste artigo são relativos ao PIB.

4 Com índice de correlação de Pearson de 0,9 no período, a dívida bruta se mostrou fortemente associada à emissão líquida. 
increased at each year since 2016 (Graph 18.2), on the other hand, this movement was followed by the drop of the average term of the government bonds after 2016 (Graph 18.3). Lastly, considering that the $B C B$ resumed the reverse swap ${ }^{5}$ operations in 2016, aiming at zeroing the stock of swaps in the debt, the largest share of securities indexed by Selic increased the degree of freedom of the monetary policy in the long term, allowing it to concentrate in its purposes.

The net borrowing of the public sector allows to attribute the reduction of the debt growth to the government spheres. In Table 18.3, the drop in the net payment of interests by the federal government in 2016 and the net surplus of the payment of interests by the BCB in 2018 were the biggest reducers of the central government net borrowing in those years in relation to the previous ones. In 2017, the responsibility for the decrease of net borrowing of the public sector was attributed to the reduction of the deficit of net payment of interests by the regional governments, which apparently began to replace their domestic debts for foreign ones. Therefore, the drop of the interest rate cannot be explained by a single phenomenon.

The contribution of the reduction of the primary deficit to the performance of the net borrowing mentioned above was due to the resumption of the primary surpluses by the federal government since 2017, which increased in 2018. The primary surpluses of the federal government in 2017 and 2018 were sufficient to reduce the net borrowing in the federal sphere, for they offset in $35.5 \%$ and $40.8 \%$, respectively, the deficit of the National Institute of Social Security - INSS, despite its increasing trend since 2002, except for the years of 2008, 2010 and 2011.

The operations in charge of the $\mathrm{BCB}$ - whose most part comprises the foreign reserves - were surplus and 2.6 times higher than the foreign debt of the federal government, with which it reduced almost constantly the impact of the increase of the domestic debt of the federal government in the total debt (Table 18.4).

In Graph 18.4, it can be noticed that the generation of primary surplus by the sub-national governments follows a declining trend, not contributing to the downturn of their net debts, which are virtually reversed.

Looking at Table 18.5, it can be noticed that despite the parcels of each region in their total net debts have changed quite little, the Southeast and South Regions are the only ones in which the debt in relation to the current

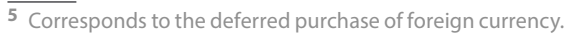


O perfil da dívida mudou com a desaceleração de seu crescimento. Se, de um lado, a parcela dos títulos indexados pela Selic aumentou a cada ano, desde 2016 (Gráfico 18.2), de outro, esse movimento foi seguido, pela queda do prazo médio dos títulos públicos depois de 2016 (Gráfico 18.3). Considerando-se, finalmente, que em 2016 o BCB retomou as operações de swap reverso ${ }^{5}$, com o objetivo de zerar o estoque de swap na dívida, a maior participação de títulos indexados à Selic aumentou o grau de liberdade da política monetária no longo prazo e concentração da mesma nas suas finalidades.

A necessidade de financiamento do setor público permite atribuir a redução do crescimento da dívida a esferas de governo. Na Tabela 18.3, a queda do pagamento líquido de juros por parte do governo federal em 2016 e o superávit líquido de pagamento de juros pelo BCB em 2018 foram os maiores redutores das necessidades do governo central naqueles anos relativamente aos anteriores. Já no ano de 2017, a responsável pela diminuição da necessidade de financiamento do setor público foi a redução do déficit de pagamento líquido de juros pelos governos regionais, que aparentemente, começaram a substituir suas dívidas internas por externas. Assim, não se pode atribuir a queda dos juros a um só fenômeno.

A contribuição da redução do déficit primário para o desempenho das necessidades de financiamento acima citado decorreu da retomada dos superávits primários por parte do governo federal, desde 2017, aumentado em 2018. Os superávits primários do governo federal de 2017 e 2018 foram suficientes para reduzir a necessidade de financiamento na esfera federal, porque compensaram em, respectivamente, 35,5\% e $40,8 \%$ o déficit do Instituto Nacional do Seguro Social (INSS), apesar da trajetória de crescimento deste último desde 2002, excetuada nos anos de 2008, 2010 e 2011.

As operações a cargo do BCB - cuja maior parte é composta por reservas internacionais - foram superavitárias e 2,6 vezes superiores à dívida externa do governo federal, com o que diminuiu quase de forma constante o impacto do aumento da dívida interna do governo federal na dívida total (Tabela 18.4).

No Gráfico 18.4, pode ser observado que a geração de superávit primário por parte dos governos subnacionais segue uma tendência declinante, não contribuindo para o arrefecimento da dívida líquida dos mesmos, que lhes é praticamente inversa.

Com o auxílio da Tabela 18.5, observa-se que embora quase não tenha havido mudança nas parcelas que cabem a cada região no somatório de suas dívidas líquidas, as Regiões Sudeste e Sul são as únicas nas quais a dívida com relação à receita corrente

$\overline{5}$ Equivale à compra futura de moeda estrangeira. 
revenue hit its peak in 2018. They are also the most indebted regions ${ }^{6}$. For both regions, the increase in the net debt/net current revenue relation was due to the renegotiation of Law no. 9,496, of September 11, 1997 or Provisional Measure no. 2,185-35, of August 24, 2001 (restructuring of the state and municipal debts) ${ }^{7}$. For the other regions, it was the increase of the foreign debt that mostly pressed this relation.

After accounting for nearly $25 \%$ of the total expense, according to Table 18.6 , the refinancing of the debts dropped consecutively in the years of 2017 and 2018, becoming the major responsible for the drop of the total expense in 2017, although the current expenses and the other capital expenses have increased uninterruptedly, except for 2015. Even with the above-mentioned reductions, the refinanced part of the debt approached the amortized part in 2018, reducing its superiority by three times in relation to the latter, compared with 2016.

While hitting its highest values in 2018 , the compulsory expenditures with personnel and social charges, as well as with interests and debt burden, together, only surpassed the refinanced debts in three out of the seven years in the period under analysis.

The other current expenditures ${ }^{8}$ amounted to not less than 2.2 times the sum of the expenditures with personnel and social charges, interests and debt burden.

As pointed out in Table 18.7, 87.7\% of the increase in the expenses was made with social charges. Those expenses are not typified as social, as in the case of financial expenditures. Even so, they were the third smallest expenditure in that category since the year 2000, with the other two smallest expenditures happening in the years of 2017 and 2016.

Conversely, the functions of national defense, social security, education, labor and health received some of the biggest public expenses in their respective categories in 2018 at prices of 2000.

$\overline{6}$ The Southeast Region concentrated $72 \%$ of the total net debt among the subnational governments in this period, being the only region whose net debt is higher than the net current revenue. The South Region, in turn, accounted for nearly $13 \%$ of the total debt.

7 For the South Region, the increase in the expenses with that renegotiation was 1.65 times higher than the increase of the net current revenue, which remained virtually constant. For the Southeast, the increase in the expenses with the renegotiation represented $67 \%$ of the increase of the net current revenue - the highest one among all regions.

8 Cost expenditures. 
atingiu o máximo em 2018. Essas são, também as regiões mais endividadas ${ }^{6}$. Para as duas regiões, o aumento da relação dívida líquida/receita corrente líquida decorreu da renegociação Lei n. 9.496, de 11.09.1997 ou Medida Provisória n. 2.185-35, de 24.08.2001 (restruturação da dívida de estados e municípios)7. Para as demais regiões, foi o aumento da dívida externa que mais pressionou a relação tratada.

Depois de responder por cerca de $25 \%$ do total da despesa, conforme a Tabela 18.6, os refinanciamentos de dívidas caíram seguidamente nos anos de 2017 e 2018, tornando-se os principais responsáveis pela queda da despesa total no ano de 2017, mesmo tendo as despesas correntes e as demais despesas de capital aumentado ininterruptamente, exceto em 2015. Mesmo assim, com as reduções citadas, a parte refinanciada da dívida se aproximou em 2018 da parte amortizada, reduzindo em três vezes sua superioridade com relação a essa última, comparada a 2016.

Mesmo tendo atingido seus maiores valores em 2018, as despesas obrigatórias com pessoal e encargos sociais, bem como juros e encargos da dívida, juntas só superaram as dívidas refinanciadas em três dos sete anos do período considerado.

As outras despesas correntes 8 equivaleram a nunca menos do que 2,2 vezes a soma das despesas com pessoal e encargos sociais, juros e encargos da dívida.

$87,7 \%$ do aumento dos gastos foi feita com encargos sociais, com indicado na Tabela 18.7. Esses gastos não são tipificados como sociais, a exemplo de despesas financeiras. Mesmo assim, essa foi a terceira menor despesa naquela categoria desde o ano 2000 , sendo que as outras duas menores despesas nessa categoria aconteceram nos anos de 2017 e 2016.

As funções defesa nacional, previdência, educação, trabalho e saúde, ao contrário, receberam em 2018 alguns dos maiores gastos públicos em suas respectivas categorias a preços de 2000 , desde então.

6 A Região Sudeste concentrou $72 \%$ do total da dívida líquida dentre os governos subnacionais no período tratado, sendo a única região cuja dívida líquida é superior à receita corrente líquida. A Região Sul, por sua vez, respondeu por cerca de 13\% do total da dívida.

7 Para a Região Sul o aumento da despesa com aquela renegociação foi 1,65 vezes superior ao aumento da receita corrente líquida, que praticamente se manteve constante. Para o Sudeste, o aumento de gastos com a renegociação tratada representou $67 \%$ do aumento da receita corrente líquida (esta, a maior dentre todas as regiões).

8 Despesas de custeio. 


\section{References}

DÍVIDA PÚBLICA FEDERAL. Relatório anual 2017. Brasília, DF: Secretaria do Tesouro Nacional, n. 15, 2018. Available from: <http://www.stn.gov. br/documents/10180/269444/RAD+2017/73b6e764-0a77-4c99-9f793a3d9e7c5c1f>. Cited: May 2019.

FERRARI, G.; RODOSTHENOUS, N. Optimal control of debt-to-gdp ratio in an n-state regime switching economy. ArXiv, New York: Cornell University, n. 1808.01499, v. 2, 2019. Available from: <https://arxiv.org/ abs/1808.01499v2>. Cited: May 2019.

MENDONZA, R. U. A review of financial stability instruments for emerging market economies. Cesifo Economic Studies, Oxford, v. 55, n. 2, p. 353-397, Jun. 2009. Available from: <https://academic.oup.com/cesifo/issue> . Cited: May 2019.

SOBREIRA, R. Alongamento da dívida pública federal interna: o que foi feito e o que se pode esperar. Revista Análise Econômica, v. 20, n. 38, 2002. Available from: <https://seer.ufrgs.br/AnaliseEconomica/issue/archive>. Cited: May 2019.

TIBERTO, B. P.; MONTES, G. C. A importância da administração da dívida pública para a construção da reputação fiscal e redução do risco-país: evidências empíricas para o Brasil. In: ENCONTRO NACIONAL DEECONOMIA, 42., 2014, Natal. Anais...Natal: Associação Nacional dos Centros de PósGraduação em Economia, 2014. Available from: <https://en.anpec.org.br/ previous-editions.php?r=encontro-2014>. Cited: May 2019.

Translated by: La-Fayette Côrtes Neto 


\section{Referências}

DÍVIDA PÚBLICA FEDERAL. Relatório anual 2017. Brasília, DF: Secretaria do Tesouro Nacional, n. 15, 2018. Disponível em: <http://www.stn.gov.br/documents/10180/269444/ RAD+2017/73b6e764-0a77-4c99-9f79-3a3d9e7c5c1f >. Acesso em: maio 2019.

FERRARI, G.; RODOSTHENOUS, N. Optimal control of debt-to-gdp ratio in an n-state regime switching economy. ArXiv, New York: Cornell University, n. 1808.01499, v. 2, 2019. Disponível em: <https://arxiv.org/abs/1808.01499v2>. Acesso em: maio 2019.

MENDONZA, R. U. A review of financial stability instruments for emerging market economies. Cesifo Economic Studies, Oxford, v. 55, n. 2, p. 353-397, Jun. 2009. Disponível em: <https://academic.oup.com/cesifo/issue>. Acesso em: maio 2019.

SOBREIRA, R. Alongamento da dívida pública federal interna: o que foi feito e o que se pode esperar. Revista Análise Econômica, v. 20, n. 38, 2002. Disponível em: $<$ https://seer.ufrgs.br/AnaliseEconomica/issue/archive>. Acesso em: maio 2019.

TIBERTO, B. P.; MONTES, G. C. A importância da administração da dívida pública para a construção da reputação fiscal e redução do risco-país: evidências empíricas para o Brasil. In: ENCONTRO NACIONAL DE ECONOMIA, 42., 2014, Natal. Anais...Natal: Associação Nacional dos Centros de Pós-Graduação em Economia, 2014. Disponível em: <https://en.anpec.org.br/previous-editions.php?r=encontro-2014>. Acesso em: maio 2019. 
Tabela 18.1 - Evolução da dívida líquida do setor público - 2007-2018 Table 18.1 - Public sector net debt evolution - 2007-2018

\begin{tabular}{|c|c|c|c|c|c|c|}
\hline \multirow{2}{*}{$\begin{array}{l}\text { Especificação/ } \\
\text { Item }\end{array}$} & \multicolumn{6}{|c|}{ Percentual do PIB (\%)/Percent of GDP (\%) } \\
\hline & 2007 & 2008 & 2009 & 2010 & 2011 & 2012 \\
\hline $\begin{array}{l}\text { Dívida líquida total - saldo/ } \\
\text { Total net debt - balance }\end{array}$ & 44,5 & 37,6 & 40,9 & 38,0 & 34,5 & 32,2 \\
\hline $\begin{array}{l}\text { Necessidade de financiamento do setor público/ } \\
\text { Public sector net borrowing }\end{array}$ & 2,7 & 2,0 & 3,2 & 2,4 & 2,5 & 2,3 \\
\hline $\begin{array}{l}\text { Primário/ } \\
\text { Primary }\end{array}$ & $(-) 3,2$ & $(-)$ 3,3 & $(-) 1,9$ & $(-) 2,6$ & (-) 2,9 & $(-) 2,2$ \\
\hline $\begin{array}{l}\text { Juros nominais/ } \\
\text { Nominal interest }\end{array}$ & 6,0 & 5,3 & 5,1 & 5,0 & 5,4 & 4,4 \\
\hline Variação cambial e paridade de moedas/ & 0,7 & $(-) 3,4$ & 2,8 & 0,5 & $(-) 1,7$ & $(-) 1,3$ \\
\hline \multicolumn{7}{|l|}{ Exchange rate and interest rate parity } \\
\hline $\begin{array}{l}\text { Reconhecimento de dívidas e privatizações/ } \\
\text { Recognition of debt and privatizations }\end{array}$ & $(-) 0,1$ & 0,0 & $(-) 0,1$ & 0,0 & 0,0 & $(-) 0,1$ \\
\hline $\begin{array}{l}\text { Efeito crescimento PIB - dívida/ } \\
\text { GDP growth effect - debt }\end{array}$ & (-) 5,3 & (-) 5,6 & $(-) 2,5$ & (-) 5,8 & $(-) 4,3$ & $(-) 3,1$ \\
\hline \multirow{2}{*}{$\begin{array}{l}\text { Especificação/ } \\
\text { Item }\end{array}$} & \multicolumn{6}{|c|}{ Percentual do PIB (\%)/Percent of GDP (\%) } \\
\hline & 2013 & 2014 & 2015 & 2016 & 2017 & 2018 \\
\hline $\begin{array}{l}\text { Dívida líquida total - saldo/ } \\
\text { Total net debt - balance }\end{array}$ & 30,5 & 32,6 & 35,6 & 46,2 & 51,6 & 53,8 \\
\hline $\begin{array}{l}\text { Necessidade de financiamento do setor público/ } \\
\text { Public sector net borrowing }\end{array}$ & 3,0 & 6,0 & 10,2 & 9,0 & 7,8 & 7,1 \\
\hline $\begin{array}{l}\text { Primário/ } \\
\text { Primary }\end{array}$ & (-) 1,7 & 0,6 & 1,9 & 2,5 & 1,7 & 1,6 \\
\hline $\begin{array}{l}\text { Juros nominais/ } \\
\text { Nominal interest }\end{array}$ & 4,7 & 5,4 & 8,4 & 6,5 & 6,1 & 5,5 \\
\hline $\begin{array}{l}\text { Variação cambial e paridade de moedas/ } \\
\text { Exchange rate and interest rate parity }\end{array}$ & (-) 1,5 & (-) 1,4 & (-) 6,1 & 3,1 & (-) 0,4 & (-) 2,5 \\
\hline $\begin{array}{l}\text { Reconhecimento de dívidas e privatizações/ } \\
\text { Recognition of debt and privatizations }\end{array}$ & (-) 0,1 & (-) 0,1 & 0,1 & (-) 0,1 & 0,1 & 0,0 \\
\hline $\begin{array}{l}\text { Efeito crescimento PIB - dívida/ } \\
\text { GDP growth effect - debt }\end{array}$ & (-) 3,1 & (-) 2,4 & (-) 1,2 & (-) 1,5 & (-) 2,0 & (-) 2,4 \\
\hline
\end{tabular}

Fonte/Source: Tabelas especiais. Dívida líquida e necessidades de financiamento do setor público. In: Estatísticas. Brasília, DF: Banco Central do Brasil, [2019]. Disponível em/Available from: <https://www. bcb.gov.br/estatisticas/tabelasespeciais>. Acesso em: jan. 2019/Cited: Jan. 2019. 
Tabela 18.2 - Evolução da dívida bruta do governo geral - 2012-2018 Table 18.2 - General government gross debt evolution - 2012-2018

\begin{tabular}{llllllll}
\hline \multirow{2}{*}{$\begin{array}{c}\text { Especificação/ } \\
\text { Item }\end{array}$} & \multicolumn{7}{c}{ Percentual do PIB (\%) / Percent of GDP (\%) } \\
\cline { 2 - 8 } & 2012 & 2013 & 2014 & 2015 & 2016 & 2017 & 2018 \\
\hline $\begin{array}{l}\text { Dívida bruta total - saldo/ } \\
\text { Total gross debt - balance }\end{array}$ & 53,67 & 51,54 & 56,28 & 65,50 & 69,86 & 74,07 & 76,69 \\
& & & & & & &
\end{tabular}

Necessidade de financiamento/ Net borrowing

$\begin{array}{lllllll}6,78 & 2,67 & 8,34 & 9,72 & 7,87 & 7,09 & 5,45\end{array}$

Emissões líquidas/ Net issues

1,61

(-) 2,45

2,92

2,27

(-) 0,30

0,38

(-) 0,46

Juros nominais/

5,17

5,12

5,42

7,45

8,16

6,71

5,91

Nominal interest

Variação cambial e paridade de moedas/ Exchange rate and interest rate parity

0,21

0,39

0,39

1,44

(-) 0,78

0,04

0,61

Reconhecimento de dívidas e privatizações/ Recognition of debt and 0,07 0,01 0,00

0,10

0,10

0,14

0,01 privatizations

Efeito crescimento

PIB - dívida/

(-) 4,67

(-) 5,20

(-) 3,99

(-) 2,04

(-) 2,84

(-) 3,06

(-) 3,46

GDP growth effect - debt

Fonte/Source: Tabelas especiais. Dívida líquida e necessidades de financiamento do setor público. In: Estatísticas. Brasilia, DF: Banco Central do Brasil, [2019]. Disponível em/Available from: <https://www.bcb.gov.br/estatisticas/tabelasespeciais>. Acesso em: jan. 2019/Cited: Jan. 2019. 


\section{Tabela 18.3 - Necessidades de financiamento do setor público}

2015-2018

Table 18.3 - Public sector net borrowing - 2015-2018

\begin{tabular}{|c|c|c|c|c|}
\hline \multirow{2}{*}{$\begin{array}{l}\text { Especificação/ } \\
\text { Item }\end{array}$} & \multicolumn{4}{|c|}{$\begin{array}{l}\text { Fluxo acumulado no ano (\% do PIB }) / \\
\text { Cumulative flow in the year (\% of GDP) }\end{array}$} \\
\hline & 2015 & 2016 & 2017 & 2018 \\
\hline I. Nominal / & 10,22 & 8,98 & 7,80 & 7,09 \\
\hline \multicolumn{5}{|l|}{ I. Nominal balance } \\
\hline $\begin{array}{l}\text { Governo central/ } \\
\text { Central government }\end{array}$ & 8,57 & 7,62 & 7,01 & 6,20 \\
\hline $\begin{array}{l}\text { Governos estaduais/ } \\
\text { State government }\end{array}$ & 1,22 & 1,08 & 0,65 & 0,77 \\
\hline $\begin{array}{l}\text { Governos municipais/ } \\
\text { Municipal government }\end{array}$ & 0,26 & 0,18 & 0,06 & 0,09 \\
\hline $\begin{array}{l}\text { Empresas estatais/ } \\
\text { State-owned enterprises }\end{array}$ & 0,17 & 0,11 & 0,08 & 0,02 \\
\hline II. Juros nominais/ & 8,37 & 6,49 & 6,12 & 5,52 \\
\hline \multicolumn{5}{|l|}{ II. Nominal interest } \\
\hline $\begin{array}{l}\text { Governo central/ } \\
\text { Central government }\end{array}$ & 6,63 & 5,08 & 5,20 & 4,51 \\
\hline $\begin{array}{l}\text { Governos estaduais/ } \\
\text { State government }\end{array}$ & 1,37 & 1,18 & 0,76 & 0,84 \\
\hline $\begin{array}{l}\text { Governos municipais/ } \\
\text { Municipal government }\end{array}$ & 0,27 & 0,14 & 0,07 & 0,08 \\
\hline $\begin{array}{l}\text { Empresas estatais/ } \\
\text { State-owned enterprises }\end{array}$ & 0,10 & 0,09 & 0,09 & 0,09 \\
\hline III. Primário/ & 1,86 & 2,49 & 1,69 & 1,57 \\
\hline III. Primary & & & & \\
\hline $\begin{array}{l}\text { Governo central/ } \\
\text { Central government }\end{array}$ & 1,95 & 2,54 & 1,81 & 1,69 \\
\hline $\begin{array}{l}\text { Governos estaduais/ } \\
\text { State government }\end{array}$ & (-) 0,15 & (-) 0,11 & (-) 0,11 & (-) 0,07 \\
\hline $\begin{array}{l}\text { Governos municipais/ } \\
\text { Municipal government }\end{array}$ & (-) 0,01 & 0,03 & (-) 0,01 & 0,02 \\
\hline $\begin{array}{l}\text { Empresas estatais/ } \\
\text { State-owned enterprises }\end{array}$ & 0,07 & 0,02 & (-) 0,01 & (-) 0,06 \\
\hline
\end{tabular}

Fonte/Source: Tabelas especiais. Necessidades de Financiamento do Setor Público (NFSP). In: Estatísticas. Brasília, DF: Banco Central do Brasil, [2019]. Disponível em/Available from: <https://www.bcb.gov.br/estatisticas/tabelasespeciais>. Acesso em: jan. 2019/Cited: Jan . 2019. 
Tabela 18.4 - Dívida líquida do setor público - 2015-2018

Table 18.4 - Public sector net debt - 2015-2018

\begin{tabular}{|c|c|c|c|c|}
\hline \multirow{2}{*}{$\begin{array}{l}\text { Especificação/ } \\
\text { Item }\end{array}$} & \multicolumn{4}{|c|}{ Percentual do PIB (\%)/ Percent of GDP (\%) } \\
\hline & 2015 & 2016 & 2017 & 2018 \\
\hline $\begin{array}{l}\text { I. Dívida líquida total } \\
\text { I. Total net debt }\end{array}$ & 35,64 & 46,16 & 51,62 & 53,76 \\
\hline $\begin{array}{l}\text { Governo Federal/ } \\
\text { Federal government }\end{array}$ & 25,03 & 35,86 & 41,44 & 43,08 \\
\hline $\begin{array}{l}\text { Banco Central/ } \\
\text { Central Bank }\end{array}$ & (-) 3,13 & (-) 2,51 & (-) 2,77 & (-) 2,88 \\
\hline $\begin{array}{l}\text { Governos estaduais/ } \\
\text { State government }\end{array}$ & 11,01 & 10,95 & 11,05 & 11,61 \\
\hline $\begin{array}{l}\text { Governos municipais/ } \\
\text { Municipal government }\end{array}$ & 1,86 & 0,98 & 1,00 & 1,06 \\
\hline $\begin{array}{l}\text { Empresas estatais/ } \\
\text { State-owned enterprises }\end{array}$ & 0,87 & 0,88 & 0,91 & 0,89 \\
\hline $\begin{array}{l}\text { II. Dívida líquida interna } \\
\text { II. Net domestic debt }\end{array}$ & 54,86 & 61,54 & 67,03 & 70,51 \\
\hline $\begin{array}{l}\text { Governo Federal/ } \\
\text { Federal government }\end{array}$ & 22,75 & 33,95 & 39,68 & 41,09 \\
\hline $\begin{array}{l}\text { Banco Central/ } \\
\text { Central Bank }\end{array}$ & 20,61 & 16,64 & 16,29 & 18,00 \\
\hline $\begin{array}{l}\text { Governos estaduais/ } \\
\text { State government }\end{array}$ & 9,11 & 9,39 & 9,50 & 9,88 \\
\hline $\begin{array}{l}\text { Governos municipais/ } \\
\text { Municipal government }\end{array}$ & 1,66 & 0,81 & 0,83 & 0,87 \\
\hline $\begin{array}{l}\text { Empresas estatais/ } \\
\text { State-owned enterprises }\end{array}$ & 0,72 & 0,76 & 0,74 & 0,67 \\
\hline $\begin{array}{l}\text { III. Dívida líquida externa } \\
\text { III. Net foreign debt }\end{array}$ & (-) 19,22 & (-) 15,38 & (-) 15,41 & (-) 16,75 \\
\hline $\begin{array}{l}\text { Governo Federal/ } \\
\text { Federal government }\end{array}$ & 2,28 & 1,91 & 1,76 & 1,99 \\
\hline $\begin{array}{l}\text { Banco Central/ } \\
\text { Central Bank }\end{array}$ & (-) 23,74 & (-) 19,15 & (-) 19,06 & (-) 20,89 \\
\hline $\begin{array}{l}\text { Governos estaduais/ } \\
\text { State government }\end{array}$ & 1,90 & 1,56 & 1,55 & 1,73 \\
\hline $\begin{array}{l}\text { Governos municipais/ } \\
\text { Municipal government }\end{array}$ & 0,20 & 0,17 & 0,17 & 0,19 \\
\hline $\begin{array}{l}\text { Empresas estatais/ } \\
\text { State-owned enterprises }\end{array}$ & 0,15 & 0,12 & 0,17 & 0,22 \\
\hline
\end{tabular}

Fonte/Source: Tabelas especiais. Composição da Dívida Líquida do Setor Público (DLSP).In: Estatísticas. Brasília, DF: Banco Central do Brasil, [2019]. Disponível em/Available from: <https://www.bcb.gov.br/ estatisticas/tabelasespeciais>. Acesso em: jan. 2019/Cited: Jan. 2019. 
Tabela 18.5 - Dívida líquida e superávit primário, por Grandes Regiões - 2015-2018

Table 18.5 - Net debt and primary surplus, according to Major Regions - 2015-2018

\begin{tabular}{|c|c|c|c|c|}
\hline \multirow{2}{*}{$\begin{array}{l}\text { Especificação/ } \\
\text { Item }\end{array}$} & \multicolumn{4}{|c|}{$\begin{array}{c}\text { Receita corrente líquida (\%)/ } \\
\text { Current net revenue (\%) }\end{array}$} \\
\hline & 2015 & 2016 & 2017 & 2018 \\
\hline \multicolumn{5}{|l|}{ I. Dívida líquida } \\
\hline \multicolumn{5}{|l|}{ I. Net debt } \\
\hline $\begin{array}{l}\text { Norte/ } \\
\text { North }\end{array}$ & 19,82 & 17,80 & 17,16 & 17,62 \\
\hline $\begin{array}{l}\text { Nordeste/ } \\
\text { Northeast }\end{array}$ & 30,86 & 26,33 & 27,25 & 30,29 \\
\hline $\begin{array}{l}\text { Centro-Oeste/ } \\
\text { Central-West }\end{array}$ & 38,89 & 39,18 & 37,32 & 38,17 \\
\hline $\begin{array}{l}\text { Sudeste/ } \\
\text { Southeast }\end{array}$ & 122,00 & 115,95 & 119,12 & 125,37 \\
\hline $\begin{array}{l}\text { Sul/ } \\
\text { South }\end{array}$ & 69,06 & 66,94 & 65,42 & 70,25 \\
\hline $\begin{array}{l}\text { II. Superávit primário } \\
\text { II. Primary surplus }\end{array}$ & & & & \\
\hline $\begin{array}{l}\text { Norte/ } \\
\text { North }\end{array}$ & (-) 0,32 & 1,17 & 0,23 & 1,10 \\
\hline $\begin{array}{l}\text { Nordeste/ } \\
\text { Northeast }\end{array}$ & 0,28 & 0,27 & 0,43 & (-) 1,54 \\
\hline $\begin{array}{l}\text { Centro-Oeste/ } \\
\text { Central-West }\end{array}$ & 3,91 & 1,63 & 0,39 & 0,83 \\
\hline $\begin{array}{l}\text { Sudeste/ } \\
\text { Southeast }\end{array}$ & 1,56 & (-) 0,57 & 2,34 & 1,79 \\
\hline $\begin{array}{l}\text { Sul/ } \\
\text { South }\end{array}$ & 0,66 & 0,92 & (-) 0,77 & (-) 1,37 \\
\hline
\end{tabular}

Fonte/Source: Tabelas especiais. Estatísticas fiscais regionalizadas. In: Banco Central do Brasil. Brasília, DF, [2019]. Disponível em/Available from: <https://www.bcb.gov.br/estatisticas/tabelasespeciais >. Acesso em: jan. 2019/Cited: Jan. 2019. 
Tabela 18.6 - Despesa liquidada da União - 2013-2018

Table 18.6 - Government paid expenses - 2013-2018

\begin{tabular}{|c|c|c|c|c|c|c|}
\hline \multirow{2}{*}{$\begin{array}{l}\text { Despesa/ } \\
\text { Expense }\end{array}$} & \multicolumn{6}{|c|}{$\begin{array}{l}\text { Valor nominal (1 } 000000 \mathrm{R} \$) / \\
\text { Nominal value }(1,000,000 \mathrm{R} \$)\end{array}$} \\
\hline & 2013 & 2014 & 2015 & 2016 & 2017 & 2018 \\
\hline Total/Total & 1780986 & 2159760 & 2255000 & 2546280 & 2462688 & 2714009 \\
\hline $\begin{array}{l}\text { Despesas correntes/ } \\
\text { Current expenditures }\end{array}$ & 1133182 & 1271865 & 1431877 & 1539092 & 1603335 & 1815763 \\
\hline $\begin{array}{l}\text { Pessoal e encargos sociais/ } \\
\text { Payroll and social charges }\end{array}$ & 204500 & 220201 & 235825 & 255668 & 281304 & 294586 \\
\hline $\begin{array}{l}\text { Juros e encargos da dívidal } \\
\text { Debt interests and charges }\end{array}$ & 141691 & 170351 & 208363 & 204892 & 203109 & 279594 \\
\hline $\begin{array}{l}\text { Outras despesas correntes/ } \\
\text { Other current expenditures }\end{array}$ & 786991 & 881314 & 987688 & 1078532 & 1118921 & 1241583 \\
\hline $\begin{array}{l}\text { Despesas de capital/ } \\
\text { Capital expenditure }\end{array}$ & 188771 & 271077 & 251225 & 353367 & 396720 & 449991 \\
\hline $\begin{array}{l}\text { Investimentos/ } \\
\text { Investments }\end{array}$ & 19524 & 21568 & 13306 & 17280 & 18858 & 44044 \\
\hline $\begin{array}{l}\text { Inversões financeiras/ } \\
\text { Financial investment }\end{array}$ & 51541 & 58757 & 55948 & 64641 & 57486 & 67799 \\
\hline $\begin{array}{l}\text { Amortização da Dívida } \\
\text { Debt Amortization }\end{array}$ & 117706 & 190752 & 181971 & 271446 & 320376 & 338148 \\
\hline $\begin{array}{l}\text { Amortização/refinanciamento } \\
\text { da dívida/ } \\
\text { Debt amortization/refinancing }\end{array}$ & 459033 & 616818 & 571898 & 653822 & 462633 & 448254 \\
\hline
\end{tabular}

Fonte/Source: Séries históricas. Despesa da União por grupo de natureza 2013-2018. Brasília, DF: Ministério da Fazenda, Sistema Integrado de Administração Financeira do Governo Federal, [2018]. Disponível em/Available from: <http://www.tesouro.fazenda.gov.br/series-historicas >. Acesso em: jan. 2019/Cited: Jan. 2019. 
Tabela 18.7 - Despesa liquidada da União, por áreas

de atuação/funções - 2017-2018

Table 18.7 - Government paid expenses, according to practice areas - 2017-2018

\begin{tabular}{|c|c|c|}
\hline \multirow{2}{*}{$\begin{array}{c}\text { Áreas de atuação/funções/ } \\
\text { Practice areas }\end{array}$} & \multicolumn{2}{|c|}{$\begin{array}{l}\text { Valor nominal }(1000000 \mathrm{R} \$) / \\
\text { Nominal value }(1,000,000 \mathrm{R} \$)\end{array}$} \\
\hline & 2017 & 2018 \\
\hline Total/Total & 2000055 & 2190694 \\
\hline $\begin{array}{l}\text { Educação/ } \\
\text { Education }\end{array}$ & 88631 & 90928 \\
\hline $\begin{array}{l}\text { Cultura/ } \\
\text { Culture }\end{array}$ & 950 & 960 \\
\hline $\begin{array}{l}\text { Saúde/ } \\
\text { Health }\end{array}$ & 101423 & 107759 \\
\hline $\begin{array}{l}\text { Defesa Nacional/ } \\
\text { National Defense }\end{array}$ & 63157 & 71059 \\
\hline $\begin{array}{l}\text { Saneamento/ } \\
\text { Sanitation }\end{array}$ & 715 & 559 \\
\hline $\begin{array}{l}\text { Meio ambiente/ } \\
\text { Environment }\end{array}$ & 2909 & 3471 \\
\hline $\begin{array}{l}\text { Previdência social/ } \\
\text { Social security }\end{array}$ & 654512 & 681664 \\
\hline $\begin{array}{l}\text { Assistência social/ } \\
\text { Social assistance }\end{array}$ & 84099 & 87977 \\
\hline $\begin{array}{l}\text { Trabalho/ } \\
\text { Labor }\end{array}$ & 69900 & 70861 \\
\hline $\begin{array}{l}\text { Organização agrária/ } \\
\text { Agrarian organization }\end{array}$ & 1736 & 1571 \\
\hline $\begin{array}{l}\text { Energia/ } \\
\text { Energy }\end{array}$ & 1701 & 1753 \\
\hline $\begin{array}{l}\text { Encargos especiais/ } \\
\text { Special charges }\end{array}$ & 815473 & 950221 \\
\hline $\begin{array}{l}\text { Outras/ } \\
\text { Others }\end{array}$ & 114850 & 121911 \\
\hline
\end{tabular}

Fonte/Source : Relatório resumido da execução orçamentária 2017-2018. Brasília, DF: Tesouro Nacional, [2018]. Disponível em/Available fom: <https://www.tesouro.fazenda.gov.br>. Acesso em: jan. 2019/ Cited: Jan. 2019.

Nota: Exclusive as despesas intra-orçamentárias./Note: Excludes intra-budgetary expenditure. 


\section{Gráfico 18.1 - Dívida do setor público - 2008-2018}

Graph 18.1 - Public debt - 2008-2018

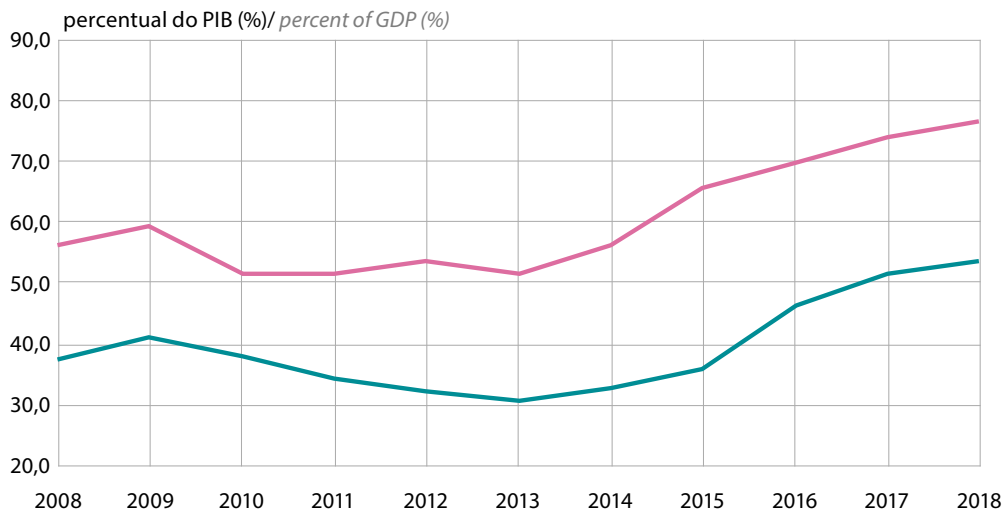

— Dívida líquida do setor público/

- Dívida bruta do governo geral/

Net Public Debt

Gross general government debt

Fonte/Source: Tabelas especiais. Dívida líquida e necessidades de financiamento do setor público. In: Estatísticas. Brasilia, DF: Banco Central do Brasil, [2019]. Disponível em/Available from: <https://www. bcb.gov.br/estatisticas/tabelasespeciais>. Acesso em: jan. 2019/Cited: Jan. 2019. 


\section{Gráfico 18.2 - Dívida líquida do setor público - 2008-2018}

Graph 18.2 - Public sector net debt - 2008-2018

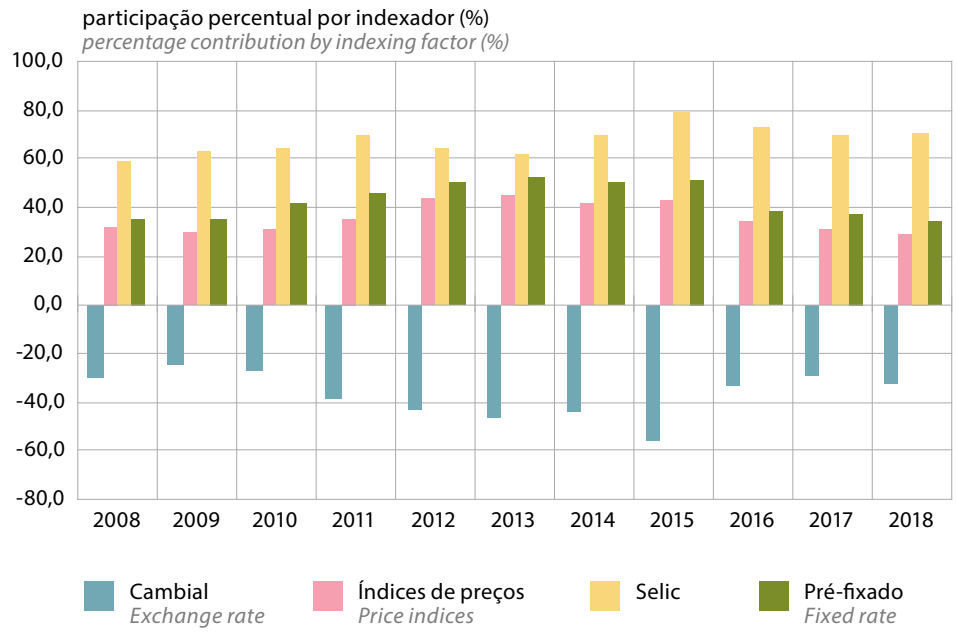

Fonte/Source: Tabelas especiais. Dívida líquida e necessidades de financiamento do setor público. Participação percentual por indexador.In: Estatísticas. Brasília, DF: Banco Central do brasil, [2019]. Disponível em/Available from: <https://www.bcb.gov.br/estatisticas/tabelasespeciais $>$. Acesso em: jan. 2019/Cited: Jan. 2019.

\section{Gráfico 18.3 - Prazo médio dos títulos federais - 2009-2018}

Graph 18.3 - Average term of federal securities - 2009-2018

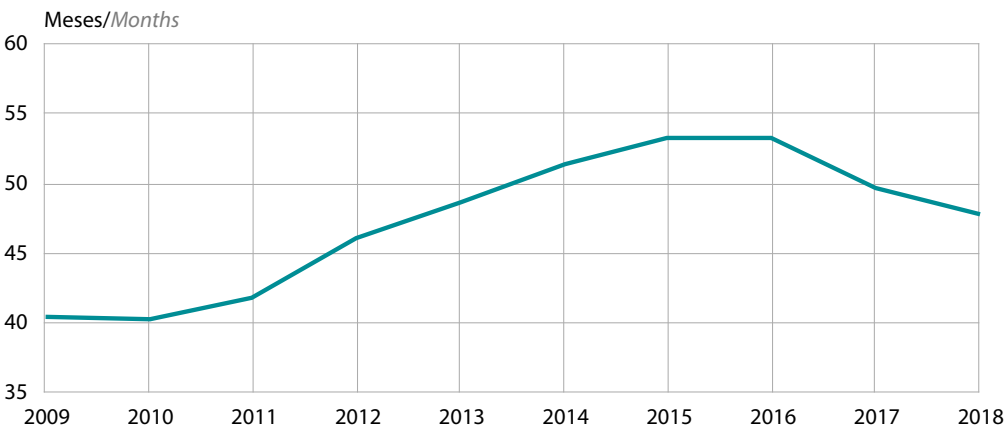

Fonte/Source: Séries temporais. Dívida mobiliária federal. Títulos consolidados do Tesouro Nacional e Banco Central. In: Banco Central do Brasil. SGS: sistema gerenciador de séries temporais. Brasília, DF, [2019]. Código 10621. Disponível em/Available from: <http://www4.bcb.gov.br/pec/series/port/ aviso.asp>. Acesso em: jan. 2019/Cited: Jan. 2019. 
Gráfico 18.4 - Dívida líquida dos governos regionais - 2008-2018

Graph 18.4 - Net debt of regional governments - 2008-2018

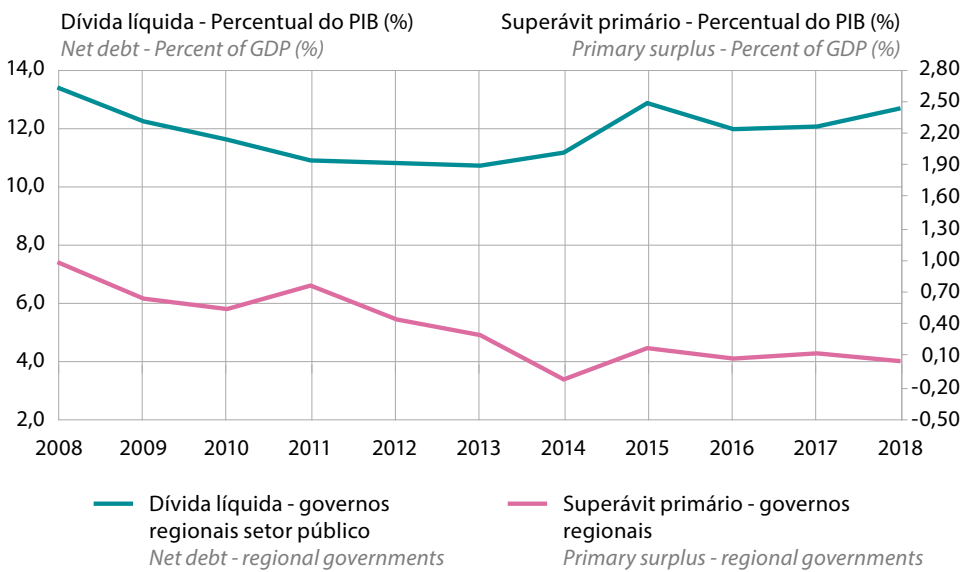

Fonte/Source: Séries temporais. In: Banco Central do Brasil. SGS: Sistema Gerenciador de Séries Temporais. Brasília, DF, [2019]. Código 4506, 5500. Disponível em/Available from:

<http://www4.bcb.gov.br/pec/series/port/aviso.asp>. Acesso em: jan. 2019/Cited: Jan. 2019. 



\section{Comércio Exterior Foreign Trade}

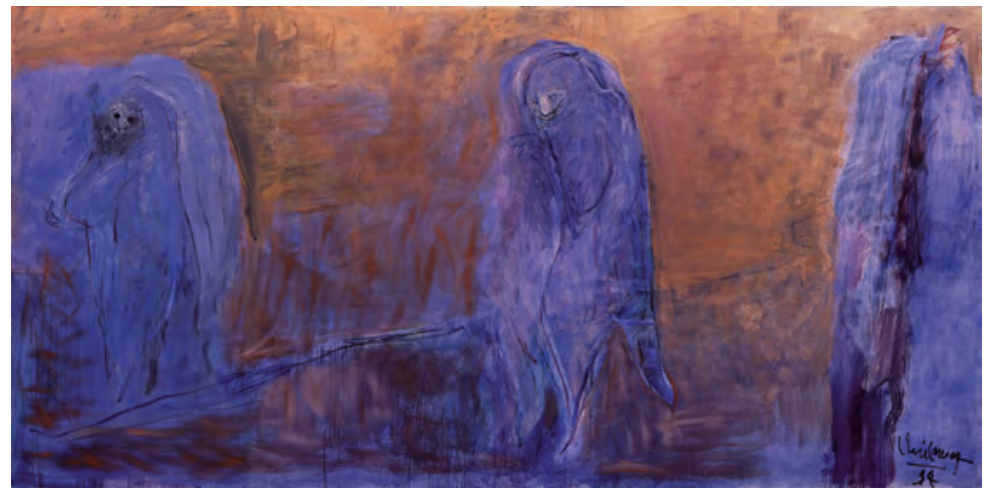

Solidão, 1994

Solitude

Iberê Camargo 


\title{
Foreign Trade
}

\author{
André Moreira Cunha ${ }^{1}$
}

The Brazilian foreign accounts performed well in 2018 , with a moderate deficit in current transfers - $\mathrm{CT}$ and net capital inflow registered in the capital and financial accounts - CFA.

Table 19.1 provides the aggregate data of the balance of payments - BP between 2015 and 2018. It unveils an economy able to produce surpluses in trade of goods, yet producing deficits in services and incomes. As the structural balance of these accounts is negative ${ }^{2}$, the final result in current transactions strongly depends on the performance of the balance of trade. Such characteristic was reassured in 2018, with a deficit in CT of US\$14.5 billion, which amounts to an increase of $+100.6 \%$ on top of the 2017 deficit (US\$7.2 billion). On the other hand, the relation between the balance in CT and the Gross Domestic Product - GDP stayed at $-0.8 \%$, a moderate level compared with the historical average between 1947 and 2018, which is -1.9\%. Whenever the external accounts were mostly deteriorated and followed by currency crises, such deficit surpassed $4.0 \%$ of the GDP3.

1 Associate Professor of the Department of Economics and International Relations of the Federal University of Rio Grande do Sul - UFRGS and Researcher of the National Council for Scientific and Technological Development - CNPq. Email: andre.cunha@ufrgs.br.

2 The Central Bank of Brazil has released the results of the BP since 1947. The services and primary income accounts were systematically negative throughout this period.

3 Such level points to what the literature on financial crises suggests. For further details, consult: PILBEAM, K. International finance. 4th ed. Hampshire: Palgrave Macmillan, 2013. 545 p. 


\title{
Comércio Exterior
}

\author{
André Moreira Cunha ${ }^{1}$
}

Em 2018, houve um desempenho favorável nas contas externas do Brasil, com déficit moderado em transações correntes (TC) e entrada líquida de capitais registrada na conta capital e financeira (CCF).

A Tabela 19.1 fornece os dados agregados do balanço de pagamento (BP) entre 2015-2018. Revela-se uma economia capaz de gerar saldos superavitários no comércio de mercadorias, mas que é deficitária em serviços e rendas. Como o saldo estrutural destas contas é negativo ${ }^{2}$, o resultado final em transações correntes depende fortemente do desempenho da balança comercial. Em 2018, esta característica foi reafirmada, com o déficit em TC de US\$14,5 bilhões, o que equivale a um incremento de $+100,6 \%$ sobre o déficit de 2017 (US\$ 7,2 bilhões). Já a relação entre o saldo em TC e o Produto Interno Bruto (PIB) ficou em - $0,8 \%$, um patamar moderado diante da média histórica para 1947-2018, que é de -1,9\%. Em momentos de maior deterioração das contas externas e que usualmente foram sucedidos por crises cambiais tal déficit superava os $4,0 \%$ do $\mathrm{PIB}^{3}$.

1 Professor Associado do Departamento de Economia e Relações Internacionais da Universidade Federal do Rio Grande do Sul (UFRGS) e Pesquisador do Conselho Nacional de Desenvolvimento Científico e Tecnológico (CNPq). E-mail: andre.cunha@ufrgs.br.

2 O Banco Central do Brasil disponibiliza os resultados de BP desde o ano de 1947. Em todo esse período as contas de serviços e renda primária foram sistematicamente negativas.

3 Tal patamar converge com o que sugere a literatura sobre crises financeiras. Para maiores detalhes, consultar: PILBEAM, K. International finance. 4th ed. Hampshire: Palgrave Macmillan, 2013. 545 p. 
Still in 2018, the trade surplus was US\$53.6 billion, given the difference between exports of US\$239.0 billion and imports of US\$185.4 billion. A change of $-16.3 \%$ was recorded between this balance and that of 2017 , as a result of an increase in the foreign acquisition of goods $(+21.0 \%)$ compared with sales $(+10 \%)^{4}$. The services account posted a deficit of US\$33.9 billion, maintaining a stable level (+0.3\%) against that registered in the previous year. The primary income account, which includes different forms of compensation of labor and capital, recorded a deficit of US\$36.7 billion, a value $8.4 \%$ lower than that reported in 2017. The secondary income account - donations, unilateral transfers from migrants, etc. - posted a surplus: US\$2.5 billion, with a change of $-4.2 \%$.

Graph 19.1 highlights the evolution of the exports, imports and balance of trade between 2011 and 2018. It is noticed that the domestic downturn and low dynamism, particularly after 2015, strongly hit the international acquisitions, whose average level varied from US\$230 billion/year (2011-2014) to US\$160 billion/year (20152018). In those same periods, exports changed from US\$241 billion/ year to US\$208 billion/year and the average trade balances evolved from US\$11 billion/year to US\$48 billion/year. The foreign trade was mostly affected by the reduction of the imports in the midst of the loss of pace of the Brazilian income. In the international arena, the drop in the prices of the commodities and the lower dynamism of the global trade contributed to the results of the exports (AZEVÊDO, 2018).

Tables 19.2 and 19.3 present, respectively, the exports ${ }^{5}$ and imports 6 of goods by aggregate factor and category of use of the products. Concerning the foreign sales, basic products (US\$119.0 billion) and semimanufactured (US\$30.7 billion) prevailed, representing $62.5 \%$ of the total

$\overline{4} \ln 2018$, the global trade rose $10 \%$. The Brazilian share in the overall trade stayed at $1.2 \%$ (exports) and $0.9 \%$ (imports), corresponding to the 27 th and 28 th positions in the international ranking, respectively. For further details, consult: AZEVÊDO, R. Global trade growth loses momentum as trade tensions persist. In: WORLD Trade Report 2018. Lausanne: World Trade Organization - WTO, 2018. 236 p. Available from:<https://www.wto.org/english/res_e/publications_e/ world_trade_report18_e.pdf>. Cited: May 2019.

5 China (26.8\%) remains the major destination of the exports of Brazilian goods. Soybean grains, crude petroleum and iron ore accounted for $82 \%$ of the Chinese acquisitions. China was followed by the European Union (17.6\%), South American countries (14.7\%) and the United States (12.0\%).

6 The countries from the European Union and China, both with $19.2 \%$, and the United States (16.0\%) are the major sources of the Brazilian imports. 
Ainda em 2018, o superávit comercial foi de US\$53,6 bilhões, dada a diferença entre as exportações de US\$239,0 bilhões e as importações de US\$185,4 bilhões. Verificou-se uma variação de $-16,3 \%$ daquele saldo frente ao de 2017 , fruto de um incremento maior das compras externas de mercadorias (+ $21,0 \%)$ com respeito às vendas $(+10, \%)^{4}$. A conta de serviços foi deficitária em US\$ 33,9 bilhões, com a manutenção de um nível estável $(+0,3 \%)$ frente ao registrado no ano anterior. A conta de renda primária, que inclui as distintas formas de remuneração do trabalho e do capital, foi deficitária em US\$36,7 bilhões, valor 8,4\% inferior àquele observado em 2017. A conta de rendas secundárias (doações, transferências unilaterais de migrantes etc.) foi superavitária: US\$2,5 bilhões, com variação de $-4,2 \%$.

A Figura 19.1 evidencia a evolução das exportações, importações e saldo comercial entre 2011 e 2018. Verifica-se que o quadro de recessão e de baixo dinamismo doméstico, especialmente depois de 2015, atingiu fortemente as compras internacionais, cujo patamar médio variou de US\$230 bilhões/ano (2011-2014) a US\$160 bilhões/ano (2015-2018). Nestes mesmos períodos, as exportações passaram de US\$ 241 bilhões/ano para US\$ 208 bilhões/ano e os saldos comerciais médios evoluíram de US\$ 11 bilhões/ano para US\$ 48 bilhões/ano. $O$ ajuste comercial externo se deu, fundamentalmente, pela redução das importações em meio à perda de vigor no crescimento da renda brasileira. No plano internacional, a queda nos preços das commodities e o menor dinamismo do comércio global em geral contribuíram para os resultados das exportações (AZEVÊDO, 2018).

As Tabelas 19.2 e 19.3 apresentam, respectivamente, as exportações ${ }^{5}$ e importações ${ }^{6}$ de mercadorias por fator agregado e categoria de uso dos produtos. Com respeito às vendas externas, há o predomínio dos produtos básicos (US\$119,0 bilhões) e semimanufaturados (US\$ 30,7 bilhões), que representaram $62,5 \%$ do total transacionado. Os

4 Em 2018, o comércio global cresceu 10\%. A participação brasileira nos totais mundiais ficou em 1,2\% (exportações) e 0,9\% (importações), o que equivale, respectivamente, às posições $27^{\mathrm{a}}$ e $28^{\mathrm{a}}$ no ranking internacional. Para maiores detalhes, consultar: AZEVÊDO, R. Global trade growth loses momentum as trade tensions persist. In: WORLD Trade Report 2018. Lausanne: World Trade Organization - WTO, 2018. 236 p. Disponível em:<https://www.wto.org/english/ res_e/publications_e/world_trade_report18_e.pdf >. Acesso em: maio 2019.

5 A China (26,8\%) segue como o principal destino das exportações de mercadorias do Brasil. Soja em grãos, petróleo bruto e minério de ferro respondem por $82 \%$ das compras chinesas. Na sequência deste parceiro asiático vem a União Europeia (17,6\%), os países da América do Sul $(14,7 \%)$ e os Estados Unidos (12,0\%).

6 Os países da União Europeia e a China, ambos com 19,2\%, e Estados Unidos (16,0\%) são as principais fontes das importações brasileiras. 
transactions. Manufactured products (US\$86.5 billion) accounted for $36.1 \%$ of the total exports, with $1.4 \%$ in special operations (US\$3.5 billion).

The profile of the Brazilian exports of goods has been significantly changing, especially after 2008. Up to that year and for nearly one quarter of century, the most intense movement was towards the improvement of the relative share of manufactured products. Nevertheless, the basic and semi-manufactured products have managed to account for, on average, about $58 \%$ of the exports over the last 10years. Such a characteristic deserves more attention from the experts and economic policy-makers, inasmuch as the diversification and sophistication of the exports are directly related to the higher growth of the income in the long term (MCMILLAN; RODRIK; SEPÚLVEDA, 2016; UNITED NATIONS..., 2018).

The analysis of the structure of the imports of goods shows that raw materials, intermediate goods and fuels and lubricants prevailed. Such aggregates accounted for slightly more than $71.6 \%$ of the international acquisitions of goods between 2016 and 2018, a proportion close to the average of the last 20 years (72.4\%). Capital goods (15.8\%) and consumer goods (14.1\%) - durable and non-durable - also recorded a relative share close to their respective historical averages, in the total imported in 2018.

The analysis of the capital and financial account (Table 19.1) shows the capacity of the Brazilian economy of net acquiring financial assets, which is expressed in the negative values in the items of these accounts. In 2018, the balance of the financial account was US\$9.3 billion, which includes the following modes: direct investment, portfolio investment, derivatives and other investments. The net inflow was of US\$74.2 billion only in direct investment, a value $45.9 \%$ higher than that registered in 2017.

Concerning the stock of assets and liabilities registered in the international investment position - IIP (ESTATÍSTICAS..., [2019]), it is possible to see that the Brazilian economy had US\$894 billion in assets abroad in the end of 2018, from which US\$378 billion (or $43 \%$ of that total) were the official reserves of the Central Bank of Brazil. On the other hand, the liabilities hit US\$1,494 billion. As a result, the IIP was negative by US\$600 billion. To put it into perspective, the economy faced the following situation in December 2001: US\$109 billion in assets - US\$36 billion in official reserves (33\% of the total assets) -, US\$371 billion in liabilities and a difference, also negative, of US\$ 262 billion. 
produtos manufaturados (US\$ 86,5 bilhões) responderam por $36,1 \%$ das exportações totais, com 1,4\% em operações especiais (US\$ 3,5 bilhões).

O perfil das exportações brasileiras de mercadorias vem se alterando de forma significativa, especialmente depois de 2008. Até esse ano e por cerca de um quarto de século, o movimento mais intenso foi no sentido da ampliação na participação relativa dos produtos manufaturados. Porém, nos últimos 10 anos, os produtos básicos e semimanufaturados passaram a responder, em média, por cerca $58 \%$ das exportações. Esta característica merece maior atenção de especialistas e formuladores de política econômica, na medida em que a diversificação e a sofisticação das exportações estão diretamente relacionadas ao maior crescimento da renda no longo prazo (MCMILLAN; RODRIK; SEPÚLVEDA, 2016; UNITED NATIONS..., 2018).

Ao se observar a estrutura das importações de mercadorias, verifica-se o predomínio das matérias-primas, bens intermediários e combustíveis e lubrificantes. Tais agregados responderam por pouco mais de $71,6 \%$ das compras internacionais de bens entre 2016 e 2018, proporção que se aproxima da média dos últimos 20 anos (72,4\%). Os bens de capital $(15,8 \%)$ e os bens de consumo $(14,1 \%)$ - duráveis e não duráveis - também apresentaram participações relativas no total importado em 2018 próximas às suas respectivas médias históricas.

Ao se analisar a conta capital e financeira (Tabela 19.1), percebe-se a capacidade de a economia brasileira captar liquidamente capitais, o que se expressa em valores negativos nos itens dessas contas. Em 2018, o saldo da conta financeira foi de US\$ 9,3 bilhões, o que inclui as seguintes modalidades: investimento direto, investimento em portfólio, derivativos e outros investimentos. Somente em investimento direto, a captação líquida foi de US\$ 74,2 bilhões, valor $45,9 \%$ superior àquele registrado em 2017.

Do ponto de vista dos estoques de ativos e passivos registrados na posição internacional de investimentos (PII) (ESTATÍSTICAS..., [2019]), é possível perceber que a economia brasileira possuía, ao término de 2018, US\$ 894 bilhões em ativos no exterior, dos quais US\$ 378 bilhões (ou 43\% daquele total) eram as reservas oficiais do Banco Central do Brasil. Já os passivos atingiram US\$ 1494 bilhões. Com isso, a PIl era negativa em US\$ 600 bilhões. Para se colocar em perspectiva, em dezembro de 2001, a economia tinha a seguinte situação: US\$109 bilhões em ativos - US\$ 36 bilhões em reservas oficiais (33\% dos ativos totais) -, US\$ 371 bilhões em passivos e uma diferença, também negativa, de US\$ 262 bilhões. 
As a proportion of the GDP, the assets changed from $20 \%$ to $48 \%$, and the liabilities evolved from $66 \%$ to $80 \%$ between 2001 and 2018 . As a result, the IIP changed from $-46 \%$ to $-32 \%$. Such difference is due, to a great extent, to the accrual of foreign reserves, highlighted in Graph 19.2. If the total assets increased eight times in this period, the reserves varied more than 10 times. Conversely, the liabilities quadrupled and hit a record level in 2018.

In summary, the foreign economic relations of the Brazilian economy were positive in 2018 , a fact that stood out in a more general context of an economy with low growth and high unemployment. The trade of goods was a surplus, the current account showed a moderate deficit and there was a net inflow of capital, particularly of the type of direct investment. Yet, the structural characteristics of smaller diversification and complexity of the exports and of a negative IIP suggest that we should be cautious when extrapolating the shortterm performance in the future.

In particular, the Brazilian foreign accounts are potentially exposed to the problems derived from the following facts (LÉLIS et al., 2018; UNITED NATIONS...,2018): at the international level, trade frictions are not negligible, as well as the potential instability derived from any asset imbalance in the financial markets; at the national level, trade balances tend to be counter-cyclical, which implies a deterioration whenever the increase of the domestic income is more dynamic. The income elasticity of the Brazilian imports is higher and have grown faster over the years compared with the income elasticity of the exports.

Expressed in different indicators that relate external liabilities and level of reserves, the external liquidity of the Brazilian economy can decrease either with the increase of the former and/or drop of the latter. On the other hand, the external solvency depends on the exports capacity with respect to the external liabilities. They grow continuously, while the sales of goods increasingly depend on the commodities market, whose price dynamics may not favor them, as well as on the overall performance of the global economy.

\section{References}

AZEVÊDO, R. Global trade growth loses momentum as trade tensions persist. In: WORLD Trade Report 2018. Lausanne: World Trade Organization WTO, 2018. 236 p. Available from:<https://www.wto.org/english/res_e/ publications_e/world_trade_report18_e.pdf>. Cited: May 2019. 
Como proporção do PIB, os ativos foram de $20 \%$ para $48 \%$, e os passivos evoluíram de $66 \%$ para $80 \%$ entre 2001 e 2018. Com isso, a PII passou de $-46 \%$ para $-32 \%$. Essa diferença se deve, em grande medida, ao acúmulo de reservas internacionais destacado na Figura 19.2. Se os ativos totais cresceram oito vezes no período em tela, as reservas variaram em mais de 10 vezes. Já os passivos se multiplicaram por quatro e atingiram um patamar recorde em 2018.

Em síntese, em 2018 as relações econômicas exteriores da economia brasileira foram positivas, fato que se destaca no contexto mais geral de uma economia que apresenta um quadro de baixo crescimento e elevado desemprego. $O$ comércio de mercadorias foi superavitário, a conta corrente apresentou um déficit moderado e houve captação líquida de capitais, especialmente na modalidade de investimento direto. Todavia, as características estruturais de menor diversificação e complexidade da estrutura exportadora e de uma PII negativa sugerem que se deve ter cautela em extrapolar o desempenho conjuntural para o futuro.

Em particular, as contas externas brasileiras estão potencialmente expostas aos problemas derivados dos seguintes fatos (LÉLIS et al., 2018; UNITED NATIONS...,2018). No plano internacional, há as tensões comerciais não desprezíveis e a potencial instabilidade derivada de desequilíbrios patrimoniais diversos nos mercados financeiros. No plano interno, os saldos comerciais tendem a ser contra cíclicos, o que implica em deterioração em momentos de maior dinamismo no crescimento da renda doméstica. A elasticidade-renda das importações brasileiras é maior e cresce mais ao longo dos anos com respeito à elasticidade renda das exportações.

Por sua vez, a liquidez externa da economia brasileira, expressa em distintos indicadores que relacionam passivos externos e nível de reservas, pode diminuir com a elevação dos primeiros e/ou queda do segundo. Já a solvência externa depende da capacidade exportadora com respeito aos passivos externos. Estes não param de crescer ao passo que as vendas de mercadorias dependem, cada vez mais, do comportamento do mercado de commodities, cuja dinâmica de preços pode não ser favorável, bem como do desempenho geral da economia global.

\section{Referências}

AZEVÊDO, R. Global trade growth loses momentum as trade tensions persist. In: WORLD Trade Report 2018. Lausanne: World Trade Organization - WTO, 2018. 236 p. Disponível em:<https://www.wto.org/english/res_e/publications_e/world_trade_report18_e. pdf>. Acesso em: maio 2019. 
ESTATÍSTICAS de balanço de pagamentos. Tabelas especiais. Brasília, DF: Banco Central do Brasil, [2019]. Available from: <https://www.bcb.gov.br/ estatisticas/tabelasespeciais>. Cited: May 2019.

LÉLIS, M. T. C. et al. Economic growth and balance-of-payments constraint in Brazil: an analysis of the 1995-2013 period. Revista Economia, Niterói, v. 19, n. 1, p. 38-56, Jan./ Apr. 2018. Available from: <http://www.anpec.org. br/novosite/br/revista>. Cited: May 2019.

MCMILLAN, M.; RODRIK, D.; SEPÚLVEDA, C. (Ed.). Structural change, fundamentals, and growth: a framework and case studies. Washington, DC: International Food Policy Research Institute, 2016. 330 p. Available from: $<$ http://drodrik.scholar.harvard.edu/files/dani-rodrik/files/structural_ change_fundamentals_and_growth.pdf>. Cited: May 2019.

PILBEAM, K. International finance. 4th ed. Hampshire: Palgrave Macmillan, 2013. 545 p.

UNITED NATIONS CONFERENCE ON TRADE AND DEVELOPMENT. Trade and development report 2018: power, platforms and the free trade delusion. New York; Geneva: United Nations, 2018. 162 p. Available from: <https://unctad. org/en/PublicationsLibrary/tdr2018_en.pdf>.Cited: May 2019

Translated by: La-Fayette Côrtes Neto 
ESTATÍSTICAS de balanço de pagamentos. Tabelas especiais. Brasília, DF: Banco Central do Brasil, [2019]. Disponível em: <https://www.bcb.gov.br/estatisticas/ tabelasespeciais>. Acesso em: maio 2019.

LÉLIS, M. T. C. et al. Economic growth and balance-of-payments constraint in Brazil: an analysis of the 1995-2013 period. Revista Economia, Niterói, v. 19, n. 1, p. 38-56, Jan./ Apr. 2018. Disponível em: <http://www.anpec.org.br/novosite/br/revista>. Acesso em: maio 2019.

MCMILLAN, M.; RODRIK, D.; SEPÚLVEDA, C. (Ed.). Structural change, fundamentals, and growth: a framework and case studies. Washington, DC: International Food Policy Research Institute, 2016. 330 p. Disponível em: <http://drodrik.scholar.harvard.edu/ files/dani-rodrik/files/structural_change_fundamentals_and_growth.pdf $>$. Acesso em: maio 2019.

PILBEAM, K. International finance. 4th ed. Hampshire: Palgrave Macmillan, 2013. 545 p. UNITED NATIONS CONFERENCE ON TRADE AND DEVELOPMENT. Trade and development report 2018: power, platforms and the free trade delusion. New York; Geneva: United Nations, 2018. 162 p. Disponível em: <https://unctad.org/en/PublicationsLibrary/ tdr2018_en.pdf >. Acesso em: maio 2019. 
Tabela 19.1 - Balanço de pagamentos - 2015-2018

Table 19.1 - Balance of payments - 2015-2018

\begin{tabular}{|c|c|c|c|c|}
\hline \multirow{2}{*}{$\begin{array}{l}\text { Especificação/ } \\
\text { Item }\end{array}$} & \multicolumn{4}{|c|}{$\begin{array}{l}\text { Valor (1 } 000000 \text { US\$)/ } \\
\text { Value (1,000,000 US\$) }\end{array}$} \\
\hline & 2015 & 2016 & 2017 & 2018 \\
\hline $\begin{array}{l}\text { Balança comercial/ } \\
\text { Trade balance }\end{array}$ & 17655 & 45037 & 64028 & 53587 \\
\hline $\begin{array}{l}\text { Exportações/ } \\
\text { Exports }\end{array}$ & 190077 & 184453 & 217243 & 239034 \\
\hline $\begin{array}{l}\text { Importações/ } \\
\text { Imports }\end{array}$ & 172422 & 139416 & 153215 & 185447 \\
\hline $\begin{array}{l}\text { Serviços/ } \\
\text { Services }\end{array}$ & (-) 36915 & (-) 30447 & (-) 33850 & (-) 33952 \\
\hline $\begin{array}{l}\text { Renda Primária/ } \\
\text { Primary income }\end{array}$ & (-) 37963 & (-) 41544 & (-) 40045 & (-) 36668 \\
\hline $\begin{array}{l}\text { Renda secundária/ } \\
\text { Secondary income }\end{array}$ & 2751 & 2944 & 2632 & 2522 \\
\hline $\begin{array}{l}\text { Transações correntes/ } \\
\text { Current account }\end{array}$ & (-) 54472 & (-) 24009 & (-) 7235 & (-) 14511 \\
\hline $\begin{array}{l}\text { Conta capital/ } \\
\text { Capital account }\end{array}$ & 461 & 274 & 379 & 440 \\
\hline $\begin{array}{l}\text { Conta financeira/ } \\
\text { Financial account }\end{array}$ & (-) 51177 & (-) 10259 & (-) 443 & (-) 9318 \\
\hline $\begin{array}{l}\text { Investimento direto (líquido)/ } \\
\text { Direct investment (net) }\end{array}$ & (-) 57200 & (-) 58684 & (-) 50905 & (-) 74254 \\
\hline $\begin{array}{l}\text { Erros e omissões/ } \\
\text { Errors and omissions }\end{array}$ & 2834 & 13476 & 6413 & 4754 \\
\hline
\end{tabular}

Fonte/Source: Banco Central do Brasil, Departamento de Estatísticas. 


\section{Tabela 19.2 - Exportação - 2016-2018 \\ Table 19.2 - Exports - 2016-2018}

\begin{tabular}{lccr}
\hline \multicolumn{1}{c}{$\begin{array}{c}\text { Especificação/ } \\
\text { Item }\end{array}$} & \multicolumn{3}{c}{$\begin{array}{c}\text { Valor (1 000 000 US\$ Fob)/ } \\
\text { Value (1,000,000 US\$ Fob) }\end{array}$} \\
\cline { 2 - 4 } \multicolumn{1}{c}{\begin{tabular}{l}
\multicolumn{1}{c}{ Total/Total } \\
Produtos básicos/
\end{tabular}} & 185280 & 217805 & 239679 \\
$\begin{array}{l}\text { Primary products } \\
\text { Produtos semimanufaturados/ }\end{array}$ & 79175 & 101089 & 119029 \\
$\begin{array}{l}\text { Semi-manufactured products } \\
\text { Produtos manufaturados/ }\end{array}$ & 27965 & 31442 & 30665 \\
$\begin{array}{l}\text { Manufactured products } \\
\text { Operações especiais/ }\end{array}$ & 73947 & 80284 & 86513 \\
Special operations & 4193 & 4989 & 3471 \\
\hline
\end{tabular}

Fonte/Source: Séries temporais. Tabelas especiais. Setor externo. In: Banco Central do Brasil. SGS: sistema gerenciador de séries temporais. Brasília, DF, [2018]. Disponível emVAvailable from: <http://www4. bcb.gov.br/pec/series/port/aviso.asp>. Acesso em: jan. 2019/Cited: Jan. 2019.

Tabela 19.3 - Importação - 2016-2018

Table 19.3 - Imports - 2016-2018

\begin{tabular}{|c|c|c|c|}
\hline \multirow{2}{*}{$\begin{array}{l}\text { Especificação/ } \\
\text { Item }\end{array}$} & \multicolumn{3}{|c|}{$\begin{array}{l}\text { Valor (1 } 000000 \text { US\$ Fob)/ } \\
\text { Value (1,000,000 US\$ Fob) }\end{array}$} \\
\hline & 2016 & 2017 & 2018 \\
\hline Total/Total & 137557 & 150730 & 181191 \\
\hline $\begin{array}{l}\text { Bens de capital/ } \\
\text { Capital goods }\end{array}$ & 18355 & 16132 & 28572 \\
\hline $\begin{array}{l}\text { Bens de consumo/ } \\
\text { Consumer goods }\end{array}$ & 21726 & 23266 & 25472 \\
\hline $\begin{array}{l}\text { Duráveis/ } \\
\text { Durable }\end{array}$ & 4442 & 4918 & 6227 \\
\hline $\begin{array}{l}\text { Semi e Não duráveis/ } \\
\text { Semi and Non-durable }\end{array}$ & 17283 & 18349 & 19245 \\
\hline $\begin{array}{l}\text { Matérias-primas e bens intermediários/ } \\
\text { Raw materials and intermediate goods }\end{array}$ & 85070 & 93758 & 105117 \\
\hline $\begin{array}{l}\text { Combustíveis e lubrificantes/ } \\
\text { Fuels and lubricants }\end{array}$ & 12406 & 17574 & 22030 \\
\hline
\end{tabular}

Fonte/Source: Séries temporais.Tabelas especiais. Setor externo. In: Banco Central do Brasil. SGS: sistema gerenciador de séries temporais. Brasília, DF, [2018]. Disponível em/Available from: <http://www4. bcb.gov.br/pec/series/port/aviso.asp>. Acesso em: jan. 2019/Cited: Jan. 2019. 


\section{Gráfico 19.1 - Comércio exterior - 2011-2018}

\section{Graph 19.1 - Foreign trade - 2011-2018}

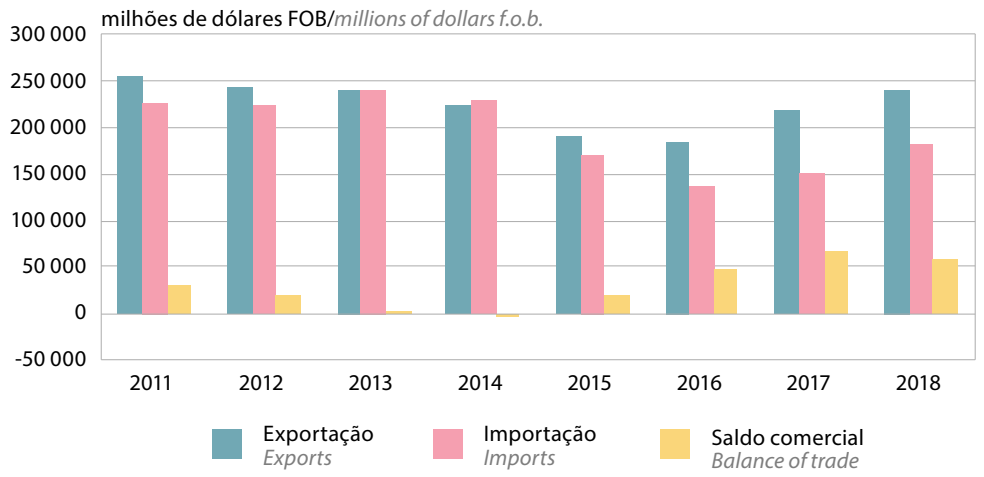

Fonte/Source: Brasil. Secretaria de Comércio Exterior. ComexStat: estatísticas de comércio exterior. Exportação e importação geral. Brasília, DF: Secex, 2019. Disponível em/Available from: <http://comexstat.mdic.gov.br/pt/home>. Acesso em: jan. 2019/Cited: Jan. 2019.

\section{Gráfico 19.2 - Reservas internacionais - 2003-2018}

\section{Graph 19.2 - International reserves - 2003-2018}

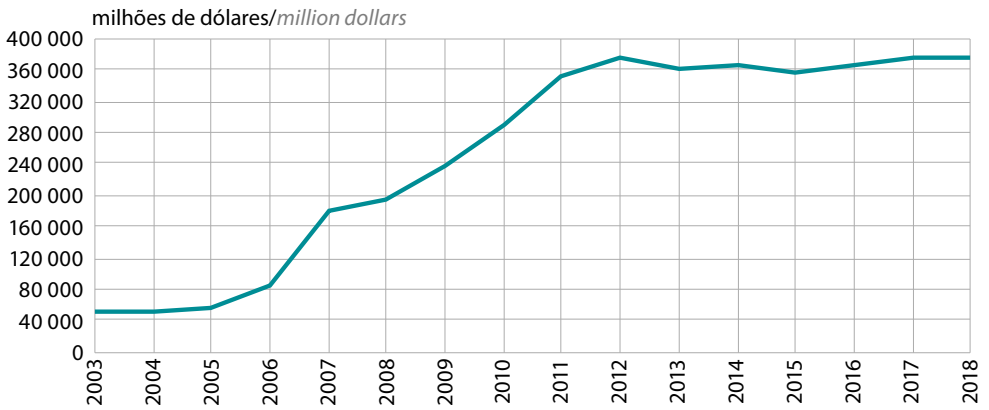

Fonte/Source: Séries temporais. Tabelas especiais. Setor externo. In: Banco Central do Brasil. SGS: sistema gerenciador de séries temporais. Brasília, DF, [2018]. Disponível em/Available from: <http://www4.bcb.gov.br/pec/series/port/aviso.asp>. Acesso em: jan. 2019/Cited: Jan 2019. 


\section{Ciência e Tecnologia Science and Technology}

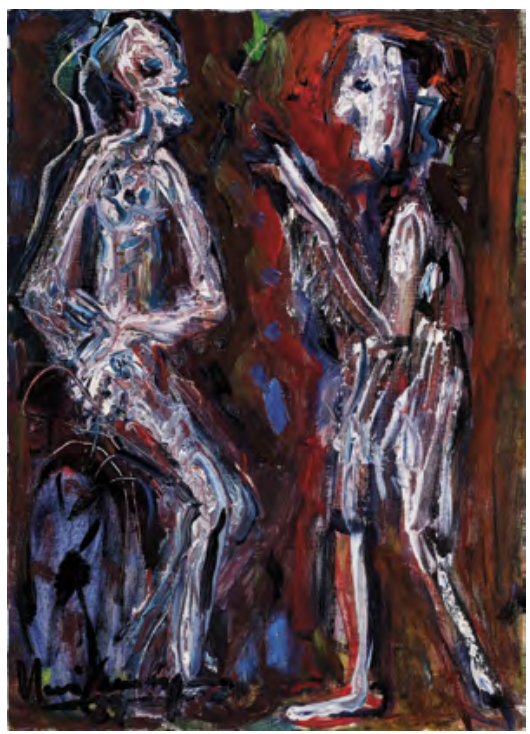

Diálogo, 1987

Dialogue

Iberê Camargo 


\title{
Science and Technology
}

\author{
Roberto Muniz Barretto de Carvalho ${ }^{1}$
}

\section{Science, Technology and Innovation}

In the last few decades, science and technology in Brazil have recorded a significant growth. The report entitled Research in Brazil (CROSS; THOMSON; SINCLAIR, c2017), produced by Clarivate Analytics for Brazil's Centre for Improvement of Higher Education Personnel (CAPES), "presents elements that confirm the significant improvement of Brazil in the research field from 2011 to 2016" (RELATÓRIO..., [2019]). The data presented herein, compiled by the Brazilian Institute of Geography and Statistics (IBGE), among others, will help us understand the scenario of expansion and improvement of science and technology in the country and its possible drawbacks and problems.

\section{Data analysis: advances and drawbacks}

One of the most significant aspects in the last two decades of science and technology expansion in Brazil, and which somehow evidences the achievements made, is the number of articles published in international journals. Table 20.5 shows a steady rise of Brazilian articles, both in absolute figures and versus the overall number of articles published in the world. In 2016, science and technology in

$\overline{1 \mathrm{PhD}}$ in Compared Studies on the Americas from the University of Brasilia (UnB) and Member of the Career Committee of Brazil's National Council for Scientific and Technological Development (CNPq). 


\title{
Ciência e Tecnologia
}

\author{
Roberto Muniz Barretto de Carvalho'
}

\section{Ciência, Tecnologia e Inovação}

Nas duas últimas décadas a ciência e tecnologia desenvolvidas no Brasil apresentaram um crescimento significativo. O relatório intitulado Research in Brazil (CROSS; THOMSON; SINCLAIR, c2017) produzido pela Clarivate Analytics para a Coordenação de Aperfeiçoamento de Pessoal de Nível Superior (CAPES) "apresenta elementos que corroboram a significativa melhora de desempenho da pesquisa brasileira de 2011 a 2016" (RELATÓRIO..., [2019]). Os dados aqui apresentados, compilados pelo Instituto Brasileiro de Geografia e Estatística (IBGE), entre outros, ajudam a entender este quadro de crescimento e melhora de desempenho da ciência e tecnologia no País e seus possíveis gargalos e problemas.

\section{Análise dos dados: avanços e gargalos}

Um dos dados mais significativos destas duas décadas de crescimento apresentado pela ciência e tecnologia no Brasil, e que traduzem de certa forma seus resultados, é o número de artigos brasileiros publicados em periódicos internacionais (Tabela 20.5). Nesta tabela verifica-se o crescimento constante dos artigos brasileiros, tanto em números absolutos, quanto em relação ao total de artigos publicados no mundo. Em 2016, a ciência e tecnologia no Brasil participa com 2,5\% do total de artigos

1 Doutor em Estudos Comparados sobre as Américas pela Universidade de Brasília (UnB) e Membro da Comissão Interna de Carreira do Conselho Nacional de Desenvolvimento Científico e Tecológico (CNPq). 
Brazil accounted for $2.5 \%$ of the total articles published in the world. Regarding our Latin American neighbors, that is the most significant contribution. In 1996, Brazil published about 38\% of the articles from Latin America and in 2016 that figure changed to about 52\% (BRASIL, 2018). In 2016, according to the report from Clarivate Analytics, "Brazil is the 13th biggest producer of survey publications (papers) at world level" (RELATÓRIO..., [2019]). Nevertheless, the table shows there has been a decrease in the number of papers and stagnation in the participation of Brazil in the world and in the Latin American production: data of 2017 repeat the same performance as in 2016 pointing to a new trend, of either stagnation or decrease of our scientific production.

The table presents another important indicator: citations received by the articles. If the indicator on production of internationally-indexed articles shows the advance of scientific production in Brazil, the citation indicator helps understand its quality and/or relevance, in other words, its impact. From the table it can be observed that is a growing feature: Brazil departs from 1.0 article, in 2002, and reaches 1.9 articles, in 2016. Data of 2017, however, reinforce the aforementioned trend, as the number of citations fell to 1.7 articles.

Information related to citations are sensitive and depend a lot on which bases they are generated from. The data in the table were calculated using the Scopus basis. In the report from Clarivate Analytics, which uses the Web of Science database, Thomson Reuters, the figures are slightly different, although they point to the same scenario: the increased influence of our publications. According to the report:

the impact of Brazil in the world scientific production increased every year from 0.73 in 2011 to 0.86 in 2016, a total 18\%. (...) Nowadays, Brazil produces some very often cited articles and it has reached good rates among the $1 \%$ most cited articles in the world (RELATÓRIO..., [2019]).

The areas of knowledge in which Brazil has more papers indexed are: biochemistry, molecular biology, botany, public health - medicine, veterinary, pharmacology, astronomy, odontology and agriculture. The areas with most often cited papers are: astronomy, astrophysics, ecology, physics, food science and technology, odontology and medicine, and public health (RELATÓRIO..., [2019]).

The results achieved by science and technology in Brazil are closely related to the efforts of the Brazilian state to promote their development. Since 1951, after the institutionalization of science and technology with the creation of the National Council for Scientific 
publicados mundialmente. Em relação aos nossos vizinhos latino-americanos esta relação é mais significativa. Em 1996 o Brasil publicava cerca de 38\% dos artigos com origem na América Latina e em 2016 esta relação passa para cerca de 52\% (BRASIL, 2018). Em 2016, segundo o relatório da Clarivate Analytics, o "Brasil é o 13으 maior produtor de publicações de pesquisa (papers) em nível mundial" (RELATÓRIO..., [2019]). Entretanto, nota-se nesta tabela que há uma redução do crescimento do número de papers e uma estagnação da participação brasileira na produção mundial e latino-americana: os dados de 2017 repetem o desempenho de 2016 apontando uma possível nova tendência, de estagnação ou decréscimo na nossa produção científica.

A tabela também traz um outro indicador importante: as citações recebidas pelos artigos. Se o indicador de produção de artigos indexados internacionalmente mostra o avanço da produção científica brasileira, o indicador de citações ajuda entender a sua qualidade e/ou relevância, em outras palavras, seu impacto. Percebe-se na tabela que este também é crescente: o Brasil parte de 1,0 artigo, em 2002, para 1,9 artigos, em 2016. E aqui também se verifica a possível tendência citada acima ao se analisar os dados de 2017, nos quais o número de citações cai para 1,7 artigos.

As informações relacionadas às citações são sensíveis e dependem muito das bases utilizadas para sua geração. Os dados da tabela apresentada foram calculados a partir da base da Scopus. Já no relatório da Clarivate Analytics, que utiliza a base de dados do Web of Science, Thomson Reuters, os valores são levemente diferentes, embora apontem para o mesmo quadro: o de crescimento do impacto de nossas publicações. Segundo o relatório:

o impacto do Brasil na produção científica mundial aumentou ano a ano de 0,73, em 2011, para $0,86 \mathrm{em} 2016$, um aumento de $18 \%$. (...) Hoje o Brasil produz alguns artigos altamente citados e alcançou boas taxas de citações entre os $1 \%$ dos artigos mais citados no mundo (RELATÓRIO..., [2019]).

As áreas de conhecimento em que o Brasil mais se destaca em quantidade de papers indexados são: bioquímica, biologia molecular, botânica, saúde pública - medicina, veterinária, farmacologia, astronomia, odontologia e agricultura. Já as áreas em que os papers possuem maior número de citações são: astronomia, astrofísica, ecologia, física, ciência e tecnologia de alimentos, odontologia e medicina, na área de saúde pública (RELATÓRIO..., [2019]).

Os resultados da ciência e tecnologia no Brasil estão intimamente relacionados aos esforços do Estado brasileiro em promover seu desenvolvimento. Desde 1951, a partir da institucionalização da ciência e tecnologia com a criação do Conselho 
and Technological Development (CNPq), Brazil has developed and promoted public policies for the sector. Those policies and funding have become a reality since then, in spite of not being regular, both in terms of the elaboration of public policies and of their funding and promotion. The relationship between the socioeconomic development of the country and the growth of national science and technology and vice versa has been established in several academic/ scientific studies. The correlation between the funding of science and technology and their development is also well known.

The most commonly adopted indicator to measure the efforts of countries aiming at the development of science and technology has been the expenditure in that field versus the Gross Domestic Product (GDP). By observing data of Table 20.1, one can see the decrease in that percentage. In 2016, Brazil invested $1.27 \%$ of its GDP in research and development (R\&D). Compared with Ibero-American countries, the Brazilian investment is below that of Canada (1.60\%), of the United States of America (EUA) (2.74\%) and of Portugal (1.29\%). We also invest less than other countries such as China (2.11\%), Korea (4.24\%) and Israel (4.25\%). Nonetheless, our average investment surpasses that from other Latin American (0.68\%) and Ibero-American countries (0.68\%). Table 20.1 shows the composition of the expenditure on science and technology by sector. By analyzing the composition of the expenditure on research and development, one finds out that public investment accounts for $0.66 \%$ of the GDP and private investment, for $0.60 \%$, which gives the impression there is a balance between both sectors. However, it should be highlighted that investments from enterprises encompass state-owned companies (public ones), which are responsible for the biggest volume of investment in science and technology. When it comes to the percentage of industrial enterprises that continuously do research in science and technology, versus the total number of enterprises, figures show that percentage has been changing and decreasing since 2000 , when it was $4.4 \%$. In 2014 , the percentage of industrial enterprises that systematically invest in R\&D fell to $3.6 \%$ (BRASIL, 2018).

It is worth mentioning that public expenditure is also unevenly distributed over the national territory. The Southeast Region is the one allocating and receiving most resources for the science and technology sector in the country. A clear example of such regional inequality can be seen in Table 20.2, about the state resources applied to science and technology. In 2015 they amounted to R\$19 6582 billion. The Southeast Region alone received $\mathrm{R} \$ 143300$ billion, being 
Nacional de Desenvolvimento Científico e Tecnológico (CNPq), o Estado brasileiro vem desenvolvendo e promovendo políticas públicas para o setor. Estas políticas e o financiamento se tornaram presentes desde então, embora não apresentassem uma constância, tanto na elaboração das políticas públicas, quanto, e principalmente, no seu financiamento e promoção. A relação entre desenvolvimento socioeconômico do País e o desenvolvimento da ciência e tecnologia nacional e vice-versa já estão bem estabelecidos em diversos estudos científicos/acadêmicos. A correlação entre o financiamento à ciência e tecnologia e seu desenvolvimento também é bem conhecida.

O indicador mais utilizado para mensurar os esforços realizados pelos países para o desenvolvimento em ciência e tecnologia tem sido o dispêndio nessa área em relação ao Produto Interno Bruto (PIB). Ao se observar os dados da Tabela 20.1, percebe-se uma queda neste percentual. Em 2016, o Brasil investiu 1,27\% do seu PIB em pesquisa e desenvolvimento. Comparado com os países ibero-americanos, 0 investimento brasileiro fica abaixo dos do Canadá (1,60\%), dos Estados Unidos da América (EUA) (2,74\%) e dos de Portugal (1,29\%). São também menores se comparados com os de países em desenvolvimento como o Brasil: China (2,11\%), Correia (4, $24 \%)$ e Israel (4,25\%). Porém, são superiores à média dos países latino-americanos $(0,68 \%)$ e ibero-americanos $(0,68 \%)$. Na Tabela 20.1 é possível observar também a composição deste dispêndio em ciência e tecnologia por setores. Ao se analisar a composição dos dispêndios em pesquisa e desenvolvimento verifica-se que os investimentos públicos respondem por $0,66 \%$ do PIB e os empresariais $0,60 \%$ o que dá a impressão de haver um certo equilíbrio entre estes dois setores. Porém, há que se notar que nos investimentos empresariais estão incluídas as empresas estatais (públicas), que são as que aportam maiores volumes à pesquisa em ciência e tecnologia. Quando se observa o percentual de empresas industriais que fazem pesquisa em ciência e tecnologia contínua em relação ao número total de empresas, verificase que desde 2000, quando este percentual era de 4,4\%, ele vem sofrendo alterações e diminuindo. Em 2014, o percentual de empresas industriais que investem em pesquisa e desenvolvimento de forma contínua, cai para 3,6\% (BRASIL, 2018).

Cabe notar que os dispêndios públicos também estão distribuídos de forma desigual pelo Território Nacional. A Região Sudeste é a que mais aporta e recebe recursos para ciência e tecnologia no País. Um claro exemplo desta desigualdade regional está retratado na Tabela 20.2 sobre os recursos estaduais aplicados em ciência e tecnologia. Em 2015 estes foram da ordem de R\$ 196582 bilhões. Só a Região 
R\$11 8984 from the state of São Paulo, that is, $60.52 \%$ of the total spent by the states.

Graph 20.1 shows the expenditure from the federal government in development by institution. The Ministry of Education receives most resources $(52.8 \%)$, and then the Ministries of Science, Technology, Innovation and Communications (17.2\%), Agriculture, Livestock and Supply (9.9\%), Health (7.7\%) and Economics (4.4\%). Another group of data from the Ministry of Science, Technology, Innovation and Communications, shows that higher-education institutions accounted for $58.7 \%$ of the expenditure on R\&D, followed by the segment of industrial and technological development (10.6\%), agriculture (9.8\%), health (6.6\%), non-specific research (5.3\%) and infrastructure, with $3.6 \%$.

The group of data presented highlight one of the most distinguishing characteristics of the Brazilian National System of Science and Technology (SNCT): its concentration in (federal and state) public universities. Most investments in science and technology in Brazil is directed to public universities, mainly the postgraduation programs, responsible for most of the scientific research in Brazil. A smaller part of that production comes from federal research institutes associated with the Ministry of Science, Technology, Innovation and Communications and from public companies, for example, the Brazilian Agricultural Research Corporation (Embrapa) and the Brazilian State Oil Company (Petrobras). Private institutions and enterprises conduct very few research activities. A recent study by the Organisation for Economic Co-operation and Development (OECD) entitled Perspectivas de la OCDE sobre ciencia, tecnologia e innovación 2016 (OECD views on science, technology and innovation , 2016), highlights some determining topics for Brazil, such as the improvement in the qualification of human resources in general and for science and technology: "Human capital is the main drawback in the Brazilian innovation system. The proportion of the adult population with a higher education degree is very low and the performance of youth aged 15 in the science field is very poor" (PERSPECTIVAS..., c2018).

Table 20.3 presents the increasing number of students in Master's and Doctor's programs, and of the those that obtain a degree. In 2017, a total 61147 persons earned a master's degree in Brazil (at academic and professional levels) and a total 21591 got a PhD degree. Nevertheless, despite that increase, versus the total number of residents, the index of PhDs per one thousand residents in 2010 was 1.9 , which can be considered low in comparison with the index 
Sudeste recebeu R\$ 143300 bilhões, sendo que destes o Estado de São Paulo aportou R\$ 11898 , ou seja, 60,52\% do total despendidos pelos estados.

0 Gráfico 20.1 indica os dispêndios do governo federal em pesquisa e desenvolvimento por instituições. Observa-se que o Ministério da Educação recebe a maior parte dos recursos $(52,8 \%)$ seguido pelo Ministério da Ciência, Tecnologia, Inovações e Comunicações (17,2\%), pelo Ministério da Agricultura, Pecuária e Abastecimento (9,9\%), pelo Ministério da Saúde (7,7\%) e pelo Ministério da Economia (4,4\%). Em outro conjunto de dados do Ministério da Ciência, Tecnologia, Inovações e Comunicações, observa-se que as instituições de ensino superior ficam com $58,7 \%$ dos dispêndios em pesquisa e desenvolvimento, seguidos pela área de desenvolvimento tecnológico industrial $(10,6 \%)$, agricultura $(9,8 \%)$, saúde $(6,6 \%)$, pesquisas não orientadas (5,3\%) e infraestrutura, com 3,6\%.

O conjunto dos dados apresentados ressaltam uma das características marcantes do Sistema Nacional de Ciência e Tecnologia (SNCT) brasileiro: sua concentração nas universidades públicas (federais e estaduais). A maior parte dos investimentos em ciência e tecnologia no Brasil é direcionada às universidades públicas, especificamente aos cursos de pós-graduação, nos quais se desenvolve a maioria das pesquisas científicas brasileiras. Uma menor parte da produção científica nacional vem dos institutos de pesquisas federais vinculados ao Ministério da Ciência, Tecnologia, Inovações e Comunicações e das empresas públicas, como por exemplo, da Empresa Brasileira de Pesquisa Agropecuária (Embrapa) e da Petróleo Brasileiro (Petrobras). As instituições e empresas privadas quase não realizam atividades de pesquisa. Em um recente estudo da Organização para a Cooperação e Desenvolvimento Econômico (OCDE) intitulado Perspectivas de la OCDE sobre ciencia, tecnologia e innovación 2016, são destacados alguns temas candentes para o Brasil, tais como a melhoria na formação de recursos humanos em geral e para ciência e tecnologia: " O Capital humano é o grande gargalo do sistema de inovação brasileiro. A proporção da população adulta com educação superior é muito baixa e o desempenho em ciências dos jovens com 15 anos é muito pobre" (PERSPECTIVAS..., c2018).

A Tabela 20.3 apresenta a evolução crescente do número de alunos nos cursos de mestrado e doutorado, assim como daqueles que se titulam. Em 2017, o Brasil formou 61147 mestres (níveis acadêmico e profissional) e 21591 doutores. Contudo, apesar do crescimento verificado, ao se considerar a sua relação com o número total de habitantes, o índice de doutores por grupo de mil habitantes era em 2010 de 1,9, o que pode ser considerado baixo se comparado com o índice dos EUA, 8 doutores por mil habitantes, ou da França com quatro por mil habitantes. Os dados da Tabela 
in the USA, 8 PhDs per one thousand residents, or in France, with four PhDs per one thousand residents. The data in Table 20.4 indicate a positive increase in survey institutions, of their research groups and researchers. However, as indicated above, the proportion of PhDs among researchers is expected to increase. In 1993, researchers with a PhD degree represented 51\% of the Brazilian overall. In 2014, that figure increased to 65\% and remained so in 2016 (DIRETÓRIO..., [2019]). These drawbacks and deficiencies of the national science and technology system are also visible in the low application of the knowledge generated, in either technology or innovation. Table 20.6 presents patent claims and the corresponding decisions. The number of claims, which had been increasing since 2013, fell from 2016 to 2017 and recorded a new decrease in 2018. Although the number of decisions has also fallen from 2017 to 2018, the number of patents granted increased, with a change from 6 250, in 2017, to 11 090, in 2018. Accounting for the decline in decisions is the great number of rejected claims and of withdrawn patents. The bigger number of granted patents seems to be more related to the efforts made by the State to improve and expedite the process of patent granting than to the increase in requests.

\section{Conclusions}

As indicated in the introduction, and based on the data analyzed, science and technology in Brazil have grown significantly and achieved internationally recognized results. The capacity to generate knowledge has expanded significantly, the same way human and material resources for science and technology increased for a given period. What can be derived from the set of data is that the trend to increase probably reached stability in 2016 and started to decrease in 2017, with effects on the scientific production measured in number of articles, citations and patents.

The observed increase, nevertheless, did not solve or reduce the drawbacks preventing the full development of science and technology in the country, such as low level of schooling, low funding - mainly the funding from private companies - and the little transfer of knowledge to society through the generation of technology and innovations.

A partnership between the generation of science, technology and innovation in Brazil depends on the overcoming of five important challenges to national sovereignty and to the social and economic development of the country: better governance/management of the SNCT and of the National Innovation System; expansion and 
20.4 indicam o crescimento positivo das instituições de pesquisa, de seus grupos de pesquisas e pesquisadores. Entretanto, como apontado acima, a proporção de doutores entre os pesquisadores ainda deve melhorar. Em 1993, os pesquisadores com doutorado representavam 51\% dos pesquisadores brasileiros. Em 2014, esta relação sobe para 65\% e permanece assim em 2016 (DIRETÓRIO..., [2019]).

Estes gargalos e deficiências do sistema de ciência e tecnologia nacional também se refletem na baixa aplicação do conhecimento gerado, seja com a geração de tecnologias, ou com inovações. A Tabela 20.6 retrata os pedidos de patentes e suas decisões. O número de pedidos de patente que vinha aumentando desde $2013 \mathrm{sofreu}$ uma queda de 2016 para 2017 e uma nova diminuição em 2018. Embora o número de decisões também sofra uma queda de 2017 para 2018, o número de patentes concedidas aumenta, passando de 6 250, em 2017, para 11 090, em 2018. A queda nas decisões ocorre com o grande número de pedidos indeferidos e patentes arquivadas. Os aumentos nas patentes concedidas parecem estar muito mais relacionados aos esforços realizados pelo Estado para melhorar e dar agilidade aos trâmites de concessão de patentes do que na ampliação de solicitações.

\section{Conclusões}

Conforme foi apontado na introdução e se pode verificar nos dados analisados, a ciência e tecnologia no Brasil apresentou um crescimento significativo e com resultados de destaque internacional. A capacidade de gerar conhecimento ampliou-se significativamente, assim como durante um período cresceram os recursos humanos e materiais para ciência e tecnologia. O que se observa do conjunto dos dados é que esta tendência de crescimento parece ter se estabilizado durante 2016 para começar a diminuir a partir de 2017, com reflexos na produção científica medida pelo número de artigos, citações e patentes.

O crescimento apresentado, entretanto, não resolveu ou mitigou os gargalos para o desenvolvimento pleno da ciência e tecnologia no País, tais como os baixos índices de escolaridade, o baixo financiamento, especialmente o financiamento oriundo das empresas privadas e a pequena transferência de conhecimento para sociedade com a geração de tecnologia e inovações.

Pareceria entre a geração de ciência, tecnologia e inovação no Brasil depende da superação de cinco desafios importantes para a soberania nacional e o desenvolvimento socioeconômico do País: melhor governança/gestão do SNCT e do Sistema Nacional de Inovação; ampliação e estabilidade das fontes de financiamento em ciência, tecnologia e inovação; melhorias no sistema educacional e na formação de 
stability of funding sources in science, technology and innovation; improvements in the educational system and in the qualification of human resources in general; increase and strengthening of public and private capacity and infrastructure in $R \& D$; and support to transfer and dissemination of knowledge in R\&D and in business innovation. Facing those challenges will help configure a strong and sustainable science, innovation and technology system, one that can contribute to national sovereignty and social welfare.

\section{References}

BRASIL. Ministério da Ciência, Tecnologia, Inovações e Comunicações. Indicadores Nacionais de Ciência, Tecnologia e Inovação 2018. Brasília, DF, 2018. Available from: <http://www.mctic.gov.br/mctic/opencms/ indicadores/indicadores_cti.html>. Cited: May 2019.

CROSS, D.; THOMSON, S.; SINCLAIR, A. Research in Brazil: a report for CAPES. Philadelphia: Clarivate Analytics, c2017. 72 p. Available from: <http:// www.capes.gov.br/images/stories/download/diversos/17012018-CAPESInCitesReport-Final.pdf>. Cited: May 2019.

DIRETÓRIO dos Grupos de Pesquisa no Brasil. Lattes. Brasília, DF: CNPq, [2019]. Available from: <http://lattes.cnpq.br/web/dgp/home>. Cited: May 2019.

PERSPECTIVAS de la OCDE em ciencia, tecnologia e innovación em América Latina 2016. Extractos. [Paris]: OCDE, c2018. Available from: <https://www. oecd-ilibrary.org/docserver/9789264303546-es.pdf?expires $=1562340230$ \&id=id\&accname $=$ guest $\&$ checksum $=83455997$ FF00CADB757B4F37E667 AEFE>. Cited: May 2019.

RELATÓRIO da Clarivate para a CAPES revela panorama da produção científica do Brasil (2011-2016). São Paulo: Sistema Integrado de Bibliotecas, Universidade de São Paulo, [2019]. Notícia. Available from: <http://www. sibi.usp.br/noticias/relatorio-da-clarivate-para-capes-revela-panorama-daproducao-cientifica-do-brasil-2011-2016/>. Cited: May 2019.

Translated by: Aline Milani Romeiro Pereira 
recursos humanos em geral; ampliação e fortalecimento da capacidade e infraestrutura pública e privada em pesquisa e desenvolvimento; e apoio à transferência e difusão de conhecimento em pesquisa e desenvolvimento em inovação empresarial. O enfretamento desses desafios deverá configurar um sistema de ciência, tecnologia e inovação robusto, sustentável, capaz de contribuir para a soberania nacional e o bem-estar social.

\section{Referências}

BRASIL. Ministério da Ciência, Tecnologia, Inovações e Comunicações. Indicadores Nacionais de Ciência, Tecnologia e Inovação 2018. Brasília, DF, 2018. Disponível em: <http://www.mctic.gov.br/mctic/opencms/indicadores/indicadores_cti.html>. Acesso em: maio 2019.

CROSS, D.; THOMSON, S.; SINCLAIR, A. Research in Brazil: a report for CAPES. Philadelphia: Clarivate Analytics, c2017. 72 p. Disponível em: <http://www.capes.gov.br/images/ stories/download/diversos/17012018-CAPES-InCitesReport-Final.pdf >. Acesso em: maio 2019.

DIRETÓRIO dos Grupos de Pesquisa no Brasil. Lattes. Brasília, DF: CNPq, [2019]. Disponível em: <http://lattes.cnpq.br/web/dgp/home>. Acesso em: maio 2019.

PERSPECTIVAS de la OCDE em ciencia, tecnologia e innovación em América Latina 2016. Extractos. [Paris]: OCDE, c2018. Disponível em: <https://www.oecd-ilibrary.org/ docserver/9789264303546-es.pdf?expires=1562340230\&id=id\&accname=guest\&che cksum=83455997EF00CADB757B4F37E667AEFE >. Acesso em: maio 2019.

RELATÓRIO da Clarivate para a CAPES revela panorama da produção científica do Brasil (2011-2016). São Paulo: Sistema Integrado de Bibliotecas, Universidade de São Paulo, [2019]. Notícia. Disponível em: <http://www.sibi.usp.br/noticias/relatorio-daclarivate-para-capes-revela-panorama-da-producao-cientifica-do-brasil-2011-2016/>. Acesso em: maio 2019. 
Tabela 20.1 - Investimentos nacionais em pesquisa e desenvolvimento,
por setores, em relação ao Produto Interno Bruto - PIB - 2015-2016

Table 20.1 - National investments in research and development, by sectors, vis-à-vis Gross Domestic Product - GDP - 2015-2016

\begin{tabular}{|c|c|c|c|c|c|c|}
\hline \multirow{3}{*}{$\begin{array}{l}\text { Setores/ } \\
\text { Sectors }\end{array}$} & \multicolumn{6}{|c|}{$\begin{array}{l}\text { Investimentos em P\&D / } \\
\text { Investments in research and development }\end{array}$} \\
\hline & \multicolumn{2}{|c|}{$\begin{array}{l}\text { Total (em milhões } \\
\text { de reais correntes)/ } \\
\text { Total (in current } \\
\text { million Reais) }\end{array}$} & \multicolumn{2}{|c|}{$\begin{array}{l}\text { Percentual em } \\
\text { relação ao total } \\
\text { de P\&D (\%)/ } \\
\text { Percent vis-à-vis } \\
\text { total R\&D (\%) }\end{array}$} & \multicolumn{2}{|c|}{$\begin{array}{l}\text { Percentual em } \\
\text { relação ao PIB } \\
\text { (\%)/ } \\
\text { Percent vis-à-vis } \\
\text { GDP (\%) }\end{array}$} \\
\hline & 2015 & 2016 & 2015 & 2016 & 2015 & 2016 \\
\hline Total/Total & 80501,8 & 79228,3 & 100,00 & 100,00 & 1,34 & 1,27 \\
\hline $\begin{array}{l}\text { Dispêndios públicos/ } \\
\text { Public expenditures }\end{array}$ & 42051,6 & 41499,8 & 52,24 & 52,38 & 0,70 & 0,66 \\
\hline $\begin{array}{l}\text { Dispêndios federais/ } \\
\text { Federal expenditures }\end{array}$ & 27219,8 & 26592,2 & 33,81 & 33,56 & 0,45 & 0,42 \\
\hline $\begin{array}{l}\text { Orçamento/ } \\
\text { Budget }\end{array}$ & 17183,8 & 14636,7 & 21,35 & 18,47 & 0,29 & 0,23 \\
\hline $\begin{array}{l}\text { Pós-graduação/ } \\
\text { Master's and doctoral programs }\end{array}$ & 10036,0 & 11955,6 & 12,47 & 15,09 & 0,17 & 0,19 \\
\hline $\begin{array}{l}\text { Dispêndios estaduais/ } \\
\text { State expenditures }\end{array}$ & 14831,8 & 14907,6 & 18,42 & 18,82 & 0,25 & 0,24 \\
\hline $\begin{array}{l}\text { Orçamento/ } \\
\text { Budget }\end{array}$ & 4259,1 & 3613,3 & 5,29 & 4,56 & 0,07 & 0,06 \\
\hline $\begin{array}{l}\text { Pós-graduação/ } \\
\text { Master's and doctoral programs }\end{array}$ & 10572,7 & 11294,2 & 13,13 & 14,26 & 0,18 & 0,18 \\
\hline $\begin{array}{l}\text { Dispêndios empresariais/ } \\
\text { Enterprise expenditures }\end{array}$ & 38450,1 & 37728,5 & 47,76 & 47,62 & 0,64 & 0,60 \\
\hline $\begin{array}{l}\text { Empresas privadas e estatais/ } \\
\text { Private and government } \\
\text { enterprises }\end{array}$ & 36665,4 & 35687,6 & 45,55 & 45,04 & 0,61 & 0,57 \\
\hline $\begin{array}{l}\text { Pós-graduação (Instituições privadas)/ } \\
\text { Master's and doctoral programs } \\
\text { (Private Institutions) }\end{array}$ & 1784,8 & 2040,8 & 2,22 & 2,58 & 0,03 & 0,03 \\
\hline
\end{tabular}

Fonte/Source : Brasil: Dispêndio nacional em pesquisa e desenvolvimento (P\&D) em valores correntes, emrelação ao total de P\&D e ao produto interno bruto (PIB), por setor institucional, 2000-2016. In: Brasil. Ministério da Ciência, Tecnologia, Inovações e Comunicações. Indicadores Nacionais de Ciência, Tecnologia e Inovação (CT\&l). Brasília, DF, 2018. tab. 2.1.3. Disponível em/Available from:

<http://www.mctic.gov.br/mctic/opencms/indicadores/detalhe/recursos_aplicados/indicadores_ consolidados/2_1_3.html>. Acesso em: jan. 2019/Cited: Jan. 2019. 


\section{Tabela 20.2 - Recursos dos governos estaduais aplicados em ciência e tecnologia - 2011-2016 \\ Table 20.2 - State government resources invested in science and technology - 2011-2016}

\begin{tabular}{|c|c|c|c|c|c|c|}
\hline \multirow{2}{*}{$\begin{array}{l}\text { Grandes Regiões e } \\
\text { Unidades da Federação/ } \\
\text { Major Regions and } \\
\text { Federation Units }\end{array}$} & \multicolumn{6}{|c|}{ Valor (1 $000000 \mathrm{R} \$) /$ Value $(1,000,000 \mathrm{R} \$)$} \\
\hline & 2011 & 2012 & 2013 & 2014 & 2015 & 2016 \\
\hline Brasil/Brazil & 11871,6 & 13650,6 & 15006,6 & 17064,8 & 19658,2 & 19842,6 \\
\hline Norte/North & 427,4 & 515,1 & 587,3 & 627,7 & 598,2 & 609,5 \\
\hline Rondônia & 63,3 & 77,7 & 76,2 & 74,6 & 103,1 & 105,0 \\
\hline Acre & 46,6 & 49,0 & 52,9 & 34,9 & 33,3 & 32,7 \\
\hline Amazonas & 118,7 & 129,4 & 176,0 & 204,5 & 185,9 & 181,6 \\
\hline Roraima & 4,8 & 10,1 & 16,8 & 20,6 & 16,1 & 22,9 \\
\hline Pará & 153,3 & 211,8 & 187,7 & 210,8 & 191,7 & 187,7 \\
\hline Amapá & 6,8 & 10,1 & 12,6 & 26,7 & 6,9 & 5,4 \\
\hline Tocantins & 33,9 & 26,9 & 65,1 & 55,7 & 61,3 & 74,2 \\
\hline Nordeste/Northeast & 1245,1 & 1538,9 & 1533,0 & 2046,4 & 1780,3 & 1976,7 \\
\hline Maranhão & 33,2 & 32,7 & 75,6 & 82,6 & 128,4 & 146,2 \\
\hline Piauí & 52,0 & 55,3 & 88,4 & 104,7 & 73,2 & 110,8 \\
\hline Ceará & 219,8 & 266,0 & 260,4 & 334,8 & 273,0 & 320,8 \\
\hline Rio Grande do Norte & 89,9 & 85,3 & 152,7 & 144,2 & 165,4 & 175,3 \\
\hline Paraíba & 135,7 & 174,0 & 165,9 & 198,3 & 217,4 & 239,6 \\
\hline Pernambuco & 236,6 & 192,0 & 160,1 & 284,2 & 261,3 & 260,2 \\
\hline Alagoas & 21,5 & 37,4 & 38,6 & 55,2 & 32,1 & 30,5 \\
\hline Sergipe & 22,9 & 82,0 & 53,1 & 103,4 & 110,1 & 137,3 \\
\hline Bahia & 433,5 & 614,2 & 538,1 & 739,0 & 519,4 & 556,0 \\
\hline Sudeste/Southeast & 8487,9 & 9514,4 & 10590,9 & 11885,3 & 14330,0 & 13940,0 \\
\hline Minas Gerais & 662,9 & 733,0 & 701,1 & 807,4 & 813,7 & 867,7 \\
\hline Espírito Santo & 116,2 & 144,8 & 143,2 & 51,2 & 140,7 & 144,1 \\
\hline Rio de Janeiro & 800,9 & 844,3 & 960,0 & 1305,1 & 1477,2 & 1252,0 \\
\hline São Paulo & 6908,0 & 7792,3 & 8786,7 & 9721,6 & 11898,4 & 11676,3 \\
\hline Sul/South & 1305,8 & 1545,6 & 1675,3 & 1598,2 & 2058,6 & 2277,8 \\
\hline Paraná & 617,8 & 759,5 & 771,5 & 932,4 & 1007,9 & 1296,1 \\
\hline Santa Catarina & 396,3 & 424,2 & 482,7 & 593,2 & 637,6 & 561,9 \\
\hline Rio Grande do Sul & 291,7 & 361,9 & 421,1 & 72,5 & 413,1 & 419,8 \\
\hline Centro-Oeste/Central-West & 405,5 & 536,6 & 620,1 & 907,3 & 891,1 & 1038,6 \\
\hline Mato Grosso do Sul & 40,2 & 107,9 & 120,3 & 182,1 & 153,0 & 133,5 \\
\hline Mato Grosso & 131,6 & 127,2 & 154,7 & 194,9 & 238,3 & 262,4 \\
\hline Goiás & 101,3 & 149,5 & 174,5 & 151,6 & 153,6 & 279,6 \\
\hline Distrito Federal/Federal District & 132,3 & 152,0 & 170,6 & 378,7 & 346,1 & 363,1 \\
\hline
\end{tabular}

Fonte/Source: Brasil: dispêndios dos governos estaduais em ciência e tecnologia (C\&T) por região e unidade da federação, 2000-2016. In: Brasil. Ministério da Ciência, Tecnologia, Inovações e Comunicações. Indicadores Nacionais de Ciência, Tecnologia e Inovação (CT\&l). Brasília, DF, 2018. tab. 2.3.3. Disponível em/Available from: <http://www.mctic.gov.br/mctic/opencms/indicadores/detalhe/ recursos_aplicados/governos_estaduais/2_3_3.html>. Acesso em: jan. 2019/Cited:Jan. 2019. 


\section{Tabela 20.3 - Indicadores selecionados dos cursos de pós-graduação - 2003-2017}

Table 20.3 - Selected indicators in Master's and Doctoral programs - 2003-2017

\begin{tabular}{|c|c|c|c|c|c|c|}
\hline \multirow{3}{*}{$\begin{array}{l}\text { Ano/ } \\
\text { Year }\end{array}$} & \multicolumn{3}{|c|}{$\begin{array}{l}\text { Alunos novos/ } \\
\text { New students }\end{array}$} & \multicolumn{3}{|c|}{$\begin{array}{l}\text { Alunos matriculados ao final do ano/ } \\
\text { Students enrolled at the end of the year }\end{array}$} \\
\hline & \multicolumn{2}{|c|}{$\begin{array}{c}\text { Mestrado/ } \\
\text { Master's programs }\end{array}$} & \multirow{2}{*}{$\begin{array}{l}\text { Doutorado/ } \\
\text { Doctoral } \\
\text { programs }\end{array}$} & \multicolumn{2}{|c|}{$\begin{array}{c}\text { Mestrado/ } \\
\text { Master's programs }\end{array}$} & \multirow{2}{*}{$\begin{array}{c}\text { Doutorado/ } \\
\text { Doctoral } \\
\text { programs }\end{array}$} \\
\hline & $\begin{array}{l}\text { Acadêmico/ } \\
\text { Academic }\end{array}$ & $\begin{array}{l}\text { Profissional/ } \\
\text { Professional }\end{array}$ & & $\begin{array}{l}\text { Acadêmico/ } \\
\text { Academic }\end{array}$ & $\begin{array}{l}\text { Profissional/ } \\
\text { Professional }\end{array}$ & \\
\hline 2003 & 32878 & 2452 & 11343 & 66951 & 5065 & 40213 \\
\hline 2004 & 34272 & 2795 & 9462 & 69190 & 5809 & 41261 \\
\hline 2005 & 36044 & 2914 & 9784 & 73805 & 6301 & 43942 \\
\hline 2006 & 38948 & 3272 & 10559 & 79050 & 6798 & 46572 \\
\hline 2007 & 41403 & 3684 & 11214 & 84356 & 7638 & 49667 \\
\hline 2008 & 42788 & 4654 & 12858 & 88295 & 9073 & 52750 \\
\hline 2009 & 46004 & 4847 & 14155 & 93016 & 10135 & 57917 \\
\hline 2010 & - & - & - & 98611 & 10213 & 64588 \\
\hline 2011 & - & - & - & 105240 & 12505 & 71890 \\
\hline 2012 & - & - & - & 109515 & 14724 & 79478 \\
\hline 2013 & - & - & - & 109720 & 20810 & 88337 \\
\hline 2014 & - & - & - & 114341 & 25326 & 95383 \\
\hline 2015 & - & - & - & 120050 & 28384 & 102207 \\
\hline 2016 & - & - & - & 126436 & 32742 & 107640 \\
\hline 2017 & - & - & - & 129220 & 37568 & 112004 \\
\hline
\end{tabular}

\begin{tabular}{|c|c|c|c|}
\hline \multirow{3}{*}{$\begin{array}{l}\text { Ano/ } \\
\text { Year }\end{array}$} & \multicolumn{3}{|c|}{ Alunos titulados/Degrees conferred } \\
\hline & \multicolumn{2}{|c|}{ Mestrado/Master's programs } & \multirow{2}{*}{$\begin{array}{c}\text { Doutorado/Doctoral } \\
\text { programs }\end{array}$} \\
\hline & Acadêmico/Academic & Profissional/Professional & \\
\hline 2003 & 25997 & 1652 & 8094 \\
\hline 2004 & 24755 & 1903 & 8093 \\
\hline 2005 & 28605 & 2029 & 8989 \\
\hline 2006 & 29742 & 2519 & 9366 \\
\hline 2007 & 30559 & 2331 & 9915 \\
\hline 2008 & 33360 & 2654 & 10711 \\
\hline 2009 & 35686 & 3102 & 11638 \\
\hline 2010 & 36247 & 3343 & 11314 \\
\hline 2011 & 39544 & 3689 & 12321 \\
\hline 2012 & 42878 & 4260 & 13912 \\
\hline 2013 & 45490 & 6045 & 15650 \\
\hline 2014 & 46245 & 6998 & 17286 \\
\hline 2015 & 47644 & 9023 & 18996 \\
\hline 2016 & 49002 & 10612 & 20603 \\
\hline 2017 & 50306 & 10841 & 21591 \\
\hline
\end{tabular}

Fonte/Source: Brasil: alunos matriculados e titulados nos cursos de mestrado e doutorado, ao final do ano, 1998-2017. Brasília, DF: Ministério da Ciência, Tecnologia, Inovações e Comunicações, 2018. tab. 3.5.1. Disponível em/Available from: <http://www.mctic.gov.br/mctic/opencms/indicadores/detalhe/ Recursos_Humanos/RH_3.5.1.html>. Acesso em: jan. 2019/Cited:Jan. 2019. 
Tabela 20.4 - Instituições, grupos de pesquisa, pesquisadores

e doutores em ciência e tecnologia - 2006/2016

Table 20.4 - Institutions, research groups, researchers and doctors in science and technology - 2006/2016

\begin{tabular}{lrrrrr}
\hline \multicolumn{1}{c}{ Especificação/Item } & \multicolumn{1}{c}{2006} & \multicolumn{1}{c}{2008} & \multicolumn{1}{c}{2010} & \multicolumn{1}{c}{2014} & \multicolumn{1}{c}{2016} \\
\hline Instituições/Institutions & 403 & 422 & 452 & 492 & 531 \\
Grupos de pesquisa/Research groups & 21024 & 22797 & 27523 & 35424 & 37640 \\
Pesquisadores/Researchers & 90320 & 104018 & 128892 & 180262 & 199566 \\
Doutores/Doctors & 57586 & 66785 & 81726 & 116427 & 130140 \\
\hline
\end{tabular}

Fonte/Source: Brasil: instituições, grupos, pesquisadores e pesquisadores doutores, cadastrados no diretório dos grupos de pesquisa do CNPq, 1993/2016. Brasília, DF: Ministério da Ciência, Tecnologia, Inovações e Comunicações, 2018. tab. 3.6.1. Disponível em/Available from: <http://www.mctic. gov.br/mctic/opencms/indicadores/detalhe/Recursos_Humanos/RH_3.6.1.html>. Acesso em: jan. 2019/Cited: Jan. 2019.

\section{Tabela 20.5 - Artigos brasileiros e do mundo publicados em periódicos científicos internacionais indexados pela Scopus e percentual do Brasil em relação ao mundo em número de artigos e de citações recebidas - 2002-2017}

Table 20.5 - Brazilian and World papers published in international scientific journals indexed by Scopus and Brazilian relative contribution to World publication and citation - 2002-2017

\begin{tabular}{lcccc}
\hline \multirow{2}{*}{$\begin{array}{c}\text { Ano/ } \\
\text { Year }\end{array}$} & \multicolumn{2}{c}{$\begin{array}{c}\text { Número de artigos/ } \\
\text { Papers }\end{array}$} & $\begin{array}{c}\text { Brasil em relação ao mundo (\%)/ } \\
\text { Brazil in relation to the World (\%) }\end{array}$ \\
\cline { 2 - 5 } & Brazil/ & $\begin{array}{c}\text { Mundo/ } \\
\text { World }\end{array}$ & $\begin{array}{c}\text { Número de artigos/ } \\
\text { Number of papers }\end{array}$ & $\begin{array}{c}\text { Citações recebidas/ } \\
\text { Citations }\end{array}$ \\
\hline 2002 & 18159 & 1452720 & 1,3 & 1,0 \\
2003 & 19828 & 1513588 & 1,3 & 1,0 \\
2004 & 22578 & 1624317 & 1,4 & 1,1 \\
2005 & 25229 & 1828188 & 1,4 & 1,2 \\
2006 & 32513 & 1912529 & 1,7 & 1,3 \\
2007 & 35091 & 2016724 & 1,7 & 1,3 \\
2008 & 40382 & 2125368 & 1,9 & 1,5 \\
2009 & 44526 & 2215224 & 2,0 & 1,4 \\
2010 & 47928 & 2326602 & 2,1 & 1,5 \\
2011 & 51939 & 2461564 & 2,1 & 1,6 \\
2012 & 56947 & 2576787 & 2,2 & 1,6 \\
2013 & 60064 & 2657699 & 2,3 & 1,6 \\
2014 & 63589 & 2729142 & 2,3 & 1,7 \\
2015 & 64640 & 2671074 & 2,4 & 1,9 \\
2016 & 67624 & 2694183 & 2,5 & 1,7 \\
2017 & 68741 & 2738685 & 2,5 & \\
& & & &
\end{tabular}

Fonte/Source: SCImago Journal \& Country Rank. New York: Elsevier, [2018]. Disponível em/Available from : <https://www.scimagojr.com/>. Acesso em: jan. 2019/Cited: Jan . 2019. 


\section{Tabela 20.6 - Pedidos depositados e decisões dos processos}

sobre patentes - 2013-2018

Table 20.6 - Patent applications filed and patent

decisions - 2013-2018

\begin{tabular}{lrrrrrr}
\hline \multicolumn{1}{c}{ Especificação/Item } & 2013 & 2014 & 2015 & 2016 & 2017 & $2018(1)$ \\
\hline \multicolumn{1}{c}{$\begin{array}{l}\text { Pedidos depositados/Applications filed } \\
\text { Privilégio de invenção/Invention }\end{array}$} & $\mathbf{3 4 0 4 6}$ & 33181 & 33042 & $\mathbf{3 1 0 2 0}$ & $\mathbf{2 8 6 6 7}$ & $\mathbf{2 7 5 5 1}$ \\
Modelo de utilidade/Utility model & 30877 & 30341 & 30217 & 28009 & 25658 & 24857 \\
Certificado de adição/Certificate & 3035 & 2734 & 2719 & 2937 & 2918 & 2587 \\
& 134 & 106 & 106 & 74 & 91 & 107 \\
& & & & & & \\
Decisões/Decisions (2) & 15867 & 22283 & 15737 & 25426 & 44686 & 41428 \\
Patentes arquivadas/Archived patents & 10372 & 16574 & 8978 & 17488 & 34112 & 24637 \\
Patentes concedidas/Granted patents & 3327 & 3123 & 3895 & 4771 & 6250 & 11090 \\
Patentes indeferidas/Denied patents & 2168 & 2586 & 2864 & 3167 & 4324 & 5701 \\
\hline
\end{tabular}

Fonte/Source: Instituto Nacional da Propriedade Industrial (INPI), Assessoria de Assuntos Econômicos (AECON).

(1) Dados preliminares./ Preliminary data. (2) Não abrangem todas as categorias de decisões./Not including all categories of decisions.

\section{Gráfico 20.1 - Dispêndios do governo federal em pesquisa e desenvolvimento, por instituições - 2016 \\ Graph 20.1 - Federal government expenditures on research and development, by institution - 2016}

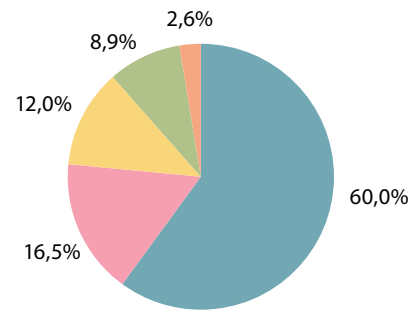

Ministério da Educação Ministry of Education
Ministério da Ciência e Tecnologia Ministry of Science and Technology
Ministério da Agricultura, Pecuária e Abastecimento Ministry of Agriculture, Livestock and Food Supply

\section{Ministério da Saúde}

Ministry of Health
Outras

Others

Fonte/Source: Ministério da Ciência, Tecnologia, Inovações e Comunicações.

Nota: Dados preliminares obtidos por e-mail./Note: Preliminary data received by email. 


\section{Gráfico 20.2 - Artigos brasileiros publicados em periódicos científicos internacionais indexados pela Scopus e respectivo percentual em relação ao mundo - 2002-2017}

Graph 20.2 - Brazilian papers published in international scientific journals indexed by Scopus and respective percent contribution in relation to the world - 2002-2017

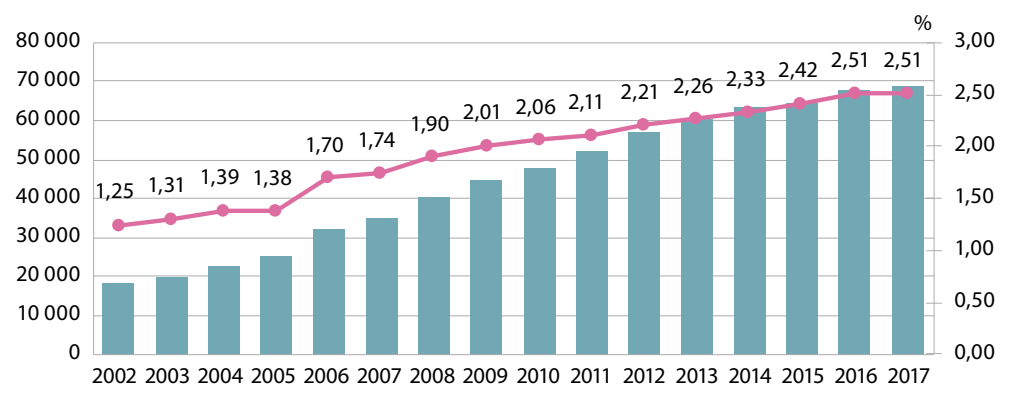

Número de artigos brasileiros Number of Brazilian papers

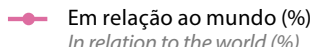

Fonte/Source: SCImago Journal \& Country Rank. New York: Elsevier, [2018]. Disponível em/Available from: <http://www.scimagojr.com/>. Acesso em: jan. 2019/Cited: Jan. 2019. 



\section{Poder Judiciário Judicial Power}

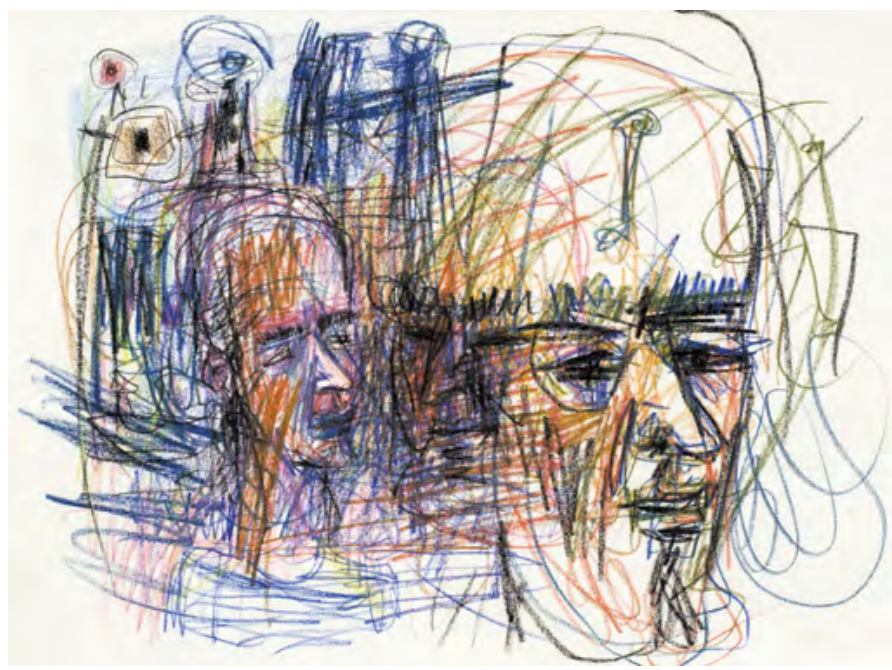

Autorretrato, 1990

Self-portrait

Iberê Camargo 


\title{
Judicial Power
}

\author{
Lucas Delgado ${ }^{1}$ \\ Igor Tadeu Silva Viana Stemler ${ }^{2}$ \\ Gabriela Moreira de Azevedo Soares ${ }^{3}$
}

Activities of the judicial power in Brazil in 2018

The Federal Supreme Court (STF), composed of 11 ministers whose primary duty is the guard of the Federal Constitution of Brazil, of 1988 , is placed on top of the Brazilian Judicial Power. There are four high courts: the Superior Court of Justice (STJ), composed of 33 ministers in charge of ensuring a unified interpretation of the federal legislation; the Superior Court of Labor (TST), with 27 ministers responsible for granting uniformity to decisions on labor actions; the Superior Electoral Court (TSE), composed of seven ministers responsible for securing the organization and rectitude of electoral processes; and the Superior Military Court (STM), with 15 ministers, entitled to judge the military crimes committed by members of the Armed Forces (Navy, Army and Air Force) or by civil citizens against the federal military administration.

1 Researcher at the Department of Judicial Surveys of the National Council of Justice (CNJ) and Master in Law, State and Constitution from the University of Brasília (UnB).

2 Researcher at the Department of Judicial Surveys of the National Council of Justice (CNJ) and bachelor in Statistics from the University of Brasília (UnB).

3 Executive Director at the Department of Judicial Surveys of the National Council of Justice (CNJ) and Master in Statistics from the Federal University of Rio de Janeiro (UFRJ). 


\title{
Poder Judiciário
}

\author{
Lucas Delgado ${ }^{1}$ \\ Igor Tadeu Silva Viana Stemler ${ }^{2}$ \\ Gabriela Moreira de Azevedo Soares ${ }^{3}$
}

\section{Atuação do poder judiciário no Brasil em 2018}

O órgão máximo do Poder Judiciário brasileiro é o Supremo Tribunal Federal (STF) integrado por 11 ministros que tem por função precípua a guarda da Constituição Federal do Brasil, de 1988. São quatro tribunais superiores: o Superior Tribunal de Justiça (STJ), constituído por 33 ministros e responsável por manter a unidade de interpretação da legislação federal; o Tribunal Superior do Trabalho (TST), com 27 ministros e responsável por uniformizar as decisões sobre ações trabalhistas; o Tribunal Superior Eleitoral (TSE), formado por sete ministros e encarregado de zelar pela organização e lisura de todo o processo eleitoral; e o Superior Tribunal Militar (STM), com 15 ministros, com competência para julgar os crimes militares cometidos por integrantes das Forças Armadas (Marinha, Exército e Aeronáutica) ou por civis que atentem contra a administração militar federal.

Para as matérias de competência da justiça federal, atuam no $1^{0}$ grau de jurisdição os juízes federais e como Corte de revisão com algumas competências originárias

1 Pesquisador do Departamento de Pesquisas Judiciárias do Conselho Nacional de Justiça (CNJ) e Mestre em Direito, Estado e Constituição pela Universidade de Brasília (UnB).

2 Pesquisador do Departamento de Pesquisas Judiciárias do Conselho Nacional de Justiça (CNJ) e graduado em Estatística pela Universidade de Brasília (UnB).

3 Diretora Executiva do Departamento de Pesquisas Judiciárias do Conselho Nacional de Justiça (CNJ) e Mestre em Estatística pela Universidade Federal do Rio de Janeiro (UFRJ). 
For issues under the sphere of the federal justice, judges work at the 1st degree of jurisdiction and, as a review court with some primary competencies, the five Federal Regional Courts (TRFs), which are in charge of large areas of the national territory subdivided into five Major Regions.

Their main competencies are: to judge political crimes and criminal offenses against goods, services or interests of the State (including autarchies and public companies); processes related to a foreign country or an international body against a municipality or a resident in Brazil; causes based on treaties or contracts signed between a foreign state or an international body and actions that are directly related to the right of indigenous populations; and to prosecute and judge cases of gross violation of human rights 4 .

The so-called common justice also counts on legal courts and judges with residual competencies encompassing all the matters not covered by the specialized justice, in each Federation Unit. Another instance with analogous duties to the common legal courts is the Legal Court of the Federal District and Territories (TJDFT).

The biggest number of disputes is sent to those bodies of the Legal Power $-70 \%$ of the lawsuits filed and $80 \%$ of those awaiting a final decision are treated by the common justice of every state. The state justice concentrates the biggest number of crime-related actions: 2.4 million new cases and 7.5 million pending ones in the year 2018 are related to criminal matters.

The Military Justice (JMU), responsible for processing and judging member of the Armed Forces, is composed of military judges in the 1 st and 2nd instances and by ministers in the Superior Military Court (STM).

It is a duty of the electoral justice to regulate proceedings to guarantee one's right to vote and to be voted and to judge electoral crimes. It is composed of judges working in first instances at the TRE (Regional Electoral Court) and TSE (Superior Electoral Court). Those judges have cumulative jurisdictions in common justice. Proceedings in electoral courts have a seasonal behavior, with more intense activity in election years, due to instances of challenge of candidacies and preparation of income statements.

\footnotetext{
$\overline{4}$ A total of 28 million new suits were issued just in 2018 and 2.7 million of them were of criminal nature.
} 
os cinco Tribunais Regionais Federais (TRFs), que exercem a jurisdição por extensas porções do Território Nacional divididas em cinco regiões.

Suas principais competências são: julgar crimes políticos e infrações penais praticados contra bens; serviços ou interesse da União (incluindo entidades autárquicas e empresas públicas); processos que envolvam estado estrangeiro ou organismo internacional contra município ou pessoa domiciliada ou residente no Brasil; causas baseadas em tratado ou contrato da União com estado estrangeiro ou organismo internacional e ações que envolvam direito de povos indígenas; e processar e julgar casos de grave violação de direitos humanos ${ }^{4}$.

Completando a chamada justiça comum, com competências residuais em relação a todas as matérias não cometidas às justiças especializadas, tem-se os tribunais de justiça e juízes de direito que exercem suas competências em cada estado da federação. Outro tribunal que exerce competências análogas às competências comuns dos tribunais de justiça dos estados é o Tribunal de Justiça do Distrito Federal e Territórios (TJDFT).

O maior número de litígios é dirigido a esses órgãos do Poder Judiciário - 70\% das ações ingressadas e $80 \%$ das que aguardam solução definitiva tramitam na justiça comum dos estados. É na justiça estadual que se concentram os maiores números de processos criminais: 2,4 milhões de casos novos e 7,5 milhões de pendentes no ano de 2018 estão relacionados à matéria criminal.

A Justiça Militar da União (JMU), responsável por processar e julgar os integrantes das Forças Armadas nos crimes militares, é integrada por juízes militares na $1 \underline{\underline{a}}$ e na $2^{\underline{a}}$ instância e por ministros no STM.

Cabe à justiça eleitoral regulamentar os procedimentos eleitorais, garantir o direito político de votar e ser votado e processar e julgar os crimes eleitorais. Sua composição inclui magistrados que atuam na 1a instância, nos TREs e no TSE. Os magistrados da justiça eleitoral acumulam jurisdição na justiça comum. A demanda processual possui comportamento sazonal, com picos nos anos eleitorais, quando há mais casos de impugnações a registros de candidatura e prestação de contas.

A justiça do trabalho é composta por juízes trabalhistas na $1^{\underline{a}}$ e $2^{\underline{a}}$ instâncias e por ministros no TST. É responsável por julgar conflitos individuais e coletivos que se refiram às relações de emprego. É a única que não possui qualquer competência em matéria criminal.

4 Somente no ano de 2018, ingressaram aproximadamente 28 milhões de processos, dos quais 2,7 milhões tem natureza criminal. 
Labor justice is composed of labor judges in the 1st and 2nd instances and by ministers in the TST. It is responsible for judging individual and collective conflicts related to labor affairs. That is the only body not in charge of any crime-related matters.

As a central body for the control, planning and management of the legal infrastructure, the Constitution establishes the creation of the National Council of Justice (CNJ) ${ }^{5}$, composed of 15 members elected for a two-year term of office, under the responsibility of the STF head.

The CNJ manages the System of Statistics of the Brazilian Judicial Power (SIESP), which encompasses all the data relative to the infrastructure and work of courts in Brazil with reference to several matters under its responsibility; it elaborates the report entitled Justice in Figures, which has presented annual series of statistical information on justice since 2005.

In addition to that, the CNJ develops, establishes and coordinates legal macro-policies at national level in fields such as institutional management, environment, human rights and technology. Among those are the judiciary levelling goals, actions aimed at the application of the Maria da Penha Law, programs of incentive to conciliation and mediation, the implementation of the judicial electronic proceeding and the monitoring and supervision of the prison system.

\section{Judicial Power in figures}

The number of new lawsuits filed in the Judicial Power has been on an upward trend from 1990 so far, despite the scenario of oscillating stabilization observed in the last six years. In 2016 (JUSTIÇA..., 2018), new legal cases hit 29.3 million, that is, a figure five times bigger than in the beginning of the 1990s, and more than in 2017 and 2018.

The search for legal services has been huge, especially when analyzed in relation to the size of the Brazilian population. New cases amount to a total of 11769 per one thousand residents, which means that one out of every six Brazilians filed a lawsuit in 2018. It is indeed more than that, once one same lawsuit can have more than one defendant and one plaintiff.

By the end of 2018, the Judicial Power had almost 78.7 million pending lawsuits awaiting a final decision. The congestion rate, which measures the percentage of lawsuits not closed at the end of the year, ranged between $70.6 \%$ and $73 \%$ in the last ten years. Hypothetically, if no new

\footnotetext{
5 The CNJ was created by the Constitutional Amendment no. 45, of December 30, 2004, and installed on June 14, 2005.
} 
Como órgão central de controle, planejamento e gestão de toda essa estrutura judiciária, a Constituição prevê a existência do Conselho Nacional de Justiça (CNJ), composto por 15 membros, com mandato de dois anos, sob a mesma presidência do STF.

O CNJ é responsável pela gestão do Sistema de Estatística do Poder Judiciário (SIESP) brasileiro que agrega todos os dados relativos à infraestrutura e atuação dos tribunais brasileiros nos mais variados assuntos de sua competência, elaborando o relatório Justiça em Números, que apresenta informações estatísticas oficiais em série anual existente desde 2005.

Além disso, o CNJ desenvolve, estipula e coordena macropolíticas judiciárias de âmbito nacional em áreas como gestão institucional, meio ambiente, direitos humanos e tecnologia. Entre eles estão as metas de nivelamento do judiciário, as ações voltadas à aplicação da Lei Maria da Penha, os programas de incentivo à conciliação e mediação, a implantação do processo judicial eletrônico e o monitoramento e fiscalização do sistema carcerário.

\section{Poder Judiciário em números}

O número de processos novos ingressados no Poder Judiciário apresenta um panorama geral de crescimento de 1990 até o presente, muito embora tenha apresentado um cenário de estabilização com oscilações nos últimos seis anos. ${ }^{5} \mathrm{Em} 2016$ (JUSTIÇA..., 2018), chegou-se ao patamar de 29,3 milhões de casos novos, ou seja, o quíntuplo do verificado no início dos anos 1990, porém mais do que o verificado em 2017 e 2018.

A procura pelos serviços de justiça tem sido enorme, especialmente quando se compara tal quantitativo com o tamanho da população brasileira. São 11769 casos novos por cem mil habitantes, o equivalente a dizer que um a cada seis brasileiros ingressou com ação judicial em 2018. Na verdade, mais do que isso, já que em um mesmo processo pode constar mais de um réu e mais de um autor.

Ao final do ano de 2018 o Judiciário tinha um acervo de quase 78,7 milhões de processos pendentes, aguardando solução definitiva. A taxa de congestionamento, que mede o percentual de processos não finalizados ao final de cada ano, oscilou entre $70,6 \%$ e 73\% nos últimos 10 anos. Em uma situação hipotética, sem que houvesse a entrada de novos processos e com a manutenção do fluxo de baixa na ordem de 31,9 milhões de casos resolvidos ao ano, seriam necessários pelo menos dois anos e meio para liquidar o estoque processual existente. Uma proporção considerável

5 Em 1990, ingressaram cerca de 5,5 milhões de processos novos, de acordo com o Banco Nacional do Poder Judiciário (BNDP), mantido na época pelo Supremo Tribunal Federal (STF). 
cases were opened and if the number of cases solved remained low at about 31.9 million per year, it would take the legal system two and a half years to solve the existing stock of pending cases. A considerable proportion of it, about $39.5 \%$, refers to a single type of lawsuit: tax execution. In those cases, the Public Treasury, by means of the Judicial Power, demands payment from defaulting clients.

To face that volume of cases, the Judicial Power counts on the specialized work of 18141 thousand judges and 272 thousand civil servants, being $80 \%$ performing activities in the judicial field and $20 \%$ in charge of administrative activities. There are about 15 thousand first instance courts in the country; they receive, analyze and judge legal cases. Those courts are located in districts, municipalities of their respective jurisdictions. Almost half (2 702) of the 5570 Brazilian municipalities are headquarters of the Judicial Branch. Among the 15 thousand existing judicial units, 12.2 thousand (81\%) are state, federal or labor courts.

The overall cost of the Judicial Power in 2018 was $\mathrm{R} \$ 93.7$ billion, which is equivalent to $\mathrm{R} \$ 449.5$ per resident and to $1.4 \%$ of the national Gross Domestic Product (GDP). Expenditures increased last year at a percentage below the inflation rate. A total of $90.8 \%$ of the expenses were directed to payroll, which includes, besides earnings and subsidies, benefits and other indemnities. The State Justice, a segment that concentrates $80 \%$ of the legal cases, accounts for $57 \%$ of the expenditures.

The judges solve about 1875 cases per year, that is, each one of them closes, on average, seven suits per business day. The average length of time to judge the merit of a lawsuit in the first instance is about one year and four months, being one year and a month in the labor justice, one year and 11 months in the Federal Justice and one year and eight months in the State Justice.

Although the litigiousness faced by the Brazilian Judicial Power has been reduced in the last few years, it still overburdens the State. Nevertheless, by no means can the Judicial Power be considered inefficient. The productivity of judges is high, so much that the judiciary has not only been able to solve the new cases but also to reduce the pending ones.

\section{The Judiciary Power and the fight against crime in Brazil}

By including fundamental freedoms in rights and material and procedural guarantees, the Constitution of 1988 reaffirmed the 
desse acervo, cerca de 39,5\%, diz respeito a um único tipo de processo: o de execução fiscal. São ações em que a Fazenda Pública, por meio do Poder Judiciário, faz a cobrança de dívidas de contribuintes inadimplentes.

Para enfrentar tal volume de processos, o Poder Judiciário conta com o trabalho especializado de 18141 mil magistrados e de 272 mil servidores, sendo que quase $80 \%$ atuam na área judiciária e $20 \%$ na administrativa. Existem cerca de 15 mil unidades judiciárias de primeiro grau instaladas no País, onde são recebidos, analisados e julgados os processos judiciais. Essas unidades localizam-se em comarcas, municípiossede de suas respectivas jurisdições. Quase metade (2 702) dos 5570 municípios brasileiros são sede do Poder Judiciário. Dentre as 15 mil unidades judiciárias existentes, 12,2 mil (81\%) são varas estaduais, federais ou trabalhistas

O custo total do Poder Judiciário no ano de 2018 foi de $\mathrm{R} \$$ 93,7 bilhões, o equivalente a $\mathrm{R} \$ 449,5$ por habitante e a $1,4 \%$ do Produto Interno Bruto (PIB) nacional. As despesas cresceram no último ano em percentual inferior ao da inflação. Dentre as despesas, 90,8\% foram destinadas ao pagamento de pessoal, que inclui, além de vencimentos e subsídios, também benefícios e outras indenizações indiretas. A Justiça Estadual, segmento que concentra $80 \%$ dos processos judiciais, responde por $57 \%$ das despesas.

Os magistrados resolvem, por ano, cerca de 1875 processos, ou seja, em média, cada um deles baixa sete processos por dia útil. $\mathrm{O}$ tempo médio de duração do processo, apurado de seu início até o seu último movimento no primeiro grau de jurisdição, é de aproximadamente 1 ano e 4 meses, sendo de 1 ano e 1 mês na justiça trabalhista, 1 ano e 11 meses na Justiça Federal e 2 anos e 8 meses na Justiça Estadual.

Muito embora a litigiosidade enfrentada pelo Poder Judiciário brasileiro tenha encontrado um freio nos últimos anos, ela ainda sobrecarrega o Estado, o que não quer dizer, contudo, que o Poder Judiciário seja ineficiente. A produtividade dos magistrados, de modo geral, é alta, tanto que, de modo geral, o Poder Judiciário não somente conseguiu responder aos casos novos ingressados como reduziu o acervo de processos existente.

\section{Poder Judiciário e combate à criminalidade no Brasil}

Ao abrigar liberdades fundamentais em direitos e garantias materiais e processuais, a Constituição de 1988 reafirmou o monopólio do exercício da jurisdição criminal pelo Estado. $O$ devido processo legal, o contraditório, a ampla defesa, os princípios da legalidade penal e do juiz natural, a individualização e humanização das penas, as formas legítimas de aprisionamento, os direitos da pessoa presa e o direito do habeas corpus para tutela geral da liberdade afirmam e reforçam o papel do Poder 
monopoly of the criminal jurisdiction by the State. The due legal process, the principle of audi alteram partem, of criminal law and natural justice, the individualization and humanization of punishment, the legitimate forms of imprisonment, the rights of convicts and the right to habeas corpus for the protection of freedom establish and reinforce the role of the Judicial Power as the agency in charge of the fair balance between the state's punitive intent and the fundamental rights of persons under investigation and defendants.

The legal jurisdiction in Brazil encompasses a myriad of behaviors defined as crime by our laws. The crimes investigated and processed via Judicial Power range between homicides and crimes of lower offensive potential.

The criminal jurisdiction in Brazil has gained notoriety for the action related to the fight against corruption crimes, money laundering and criminal organizations. As seen in Carson e Prado (2014), under the scope of corruption there are crimes with little repercussion, but also schemes devised by political agents working on top positions in the main bodies of the State.

The difficulty to measure the effects of corruption on the Brazilian state contrasts with the volume of cases revealed. The federal justice in the State of Paraná alone has locked more than $\mathrm{R} \$ 3.2$ billion as a result of the Operation Car Wash. That figure may eventually reach a total of R\$12.3 billion in resources (A LAVA JATO..., [2019]).

The key role of the Judicial Power and its members in the scenario of fight against organized crime and corruption is undeniable. There are now 7.8 million pending lawsuits with a congestion rate of $71.5 \%$.

In order to work on such a huge number of cases, a total of 1317 exclusively criminal courts are dedicated to the analysis of injunctions, constitutional remedies, processing of investigations and judgement of criminal actions.

The capacity to solve actions in criminal matters is equally high. A total of 3.1 million cases are opened per year and their average length of time in progress is three years and nine months.

The data relative to criminal actions evidence how complex the delivery of a criminal jurisdiction can be, considering that the State deals with fundamental matters such as life and freedom. The work of the Judicial Power, however, is indispensable for the fight against impunity and for the promotion of values such as transparency and integrity. 
Judiciário como a agência estatal responsável pelo justo equilíbrio entre a pretensão punitiva estatal e os direitos fundamentais dos investigados e réus.

A jurisdição criminal no Brasil engloba uma miríade de condutas definidas como crime pela legislação penal. Os crimes cuja investigação e processamento passam pelo Poder Judiciário variam desde os homicídios aos chamados crimes de menor potencial ofensivo.

A jurisdição criminal no Brasil tem ganhado notoriedade pelas ações relacionadas ao combate a crimes de corrupção, lavagem de dinheiro e organizações criminosas. Como apontam Carson e Prado (2014), a corrupção em sentido amplo engloba uma considerável variedade de crimes que envolvem desde crimes de menor repercussão até os grandes esquemas orquestrados pelos agentes políticos que ocupam a cúpula diretiva dos principais órgãos do Estado.

A dificuldade de se aferir como a corrupção afeta o Estado brasileiro contrasta com a vultuosidade dos casos que tem vindo à tona. Somente nas ações que tramitam na justiça federal no Estado do Paraná relacionadas à Operação Lava Jato, já foram bloqueados por ordem judicial mais de R\$3,2 bilhões, podendo-se chegar, ao final, em $\mathrm{R} \$ 12,3$ bilhões em recursos (A LAVA JATO..., [2019]).

O protagonismo do Poder Judiciário e seus membros neste cenário de combate à criminalidade organizada e corrupção é inegável. Basta mencionar que são 7,8 milhões de processos criminais pendentes com uma taxa de congestionamento de $71,5 \%$.

Para enfrentar essa quantidade de processos são 1317 varas com competências exclusivamente criminais, destinadas à análise de medidas cautelares, remédios constitucionais, processamento de investigações e julgamento de ações penais.

A capacidade de solução de processos em matéria criminal se mostra igualmente elevada. São baixados 3,1 milhões de processos por ano e o tempo médio de tramitação desses processos é de 3 anos e 9 meses.

Os dados relativos aos processos de natureza criminal estão a revelar o quanto a entrega da jurisdição em matéria criminal pode ser complexa uma vez que o Estado lida com questões fundamentais como a vida e a liberdade. A atuação do Poder Judiciário, contudo, é indispensável para o combate à impunidade e para promoção de valores como transparência e integridade. 


\section{References}

CARSON, L.; PRADO, M. M. Mapping corruption and its institutional determinants in Brazil. Manchester: The University of Manchester, Global Development Institute, 2014. (Working Paper Series, 8). Available from: $<$ https://ideas.repec.org/p/bwp/bwppap/iriba_wp08.html>. Cited: May 2019.

JUSTIÇA EM NÚMEROS 2018: ano-base 2017. Brasília, DF: Conselho Nacional de Justiça, 2018. Available from: <http://www.cnj.jus.br/ pesquisas-judiciarias/justicaemnumeros/2016-10-21-13-13-04/pj-justicaem-numeros>. Cited: May 2019.

A LAVA JATO em números no Paraná: resultados da operação. Brasília, DF: Ministério Público Federal, [2019]. Available from: <http://www.mpf. mp.br/grandes-casos/caso-lava-jato/atuacao-na-1a-instancia/atuacao-na1a-instancia/parana/resultado>. Cited: May 2019. 


\section{Referências}

CARSON, L.; PRADO, M. M. Mapping corruption and its institutional determinants in Brazil. Manchester: The University of Manchester, Global Development Institute, 2014. (Working Paper Series, 8). Disponível em: <https://ideas.repec.org/p/bwp/bwppap/ iriba_wp08.html >. Acesso em: maio 2019.

JUSTIÇA EM NÚMEROS 2018: ano-base 2017. Brasília, DF: Conselho Nacional de Justiça, 2018. Disponível em: <http://www.cnj.jus.br/pesquisas-judiciarias/ justicaemnumeros/2016-10-21-13-13-04/pj-justica-em-numeros>. Acesso em: maio 2019.

A LAVA LATO em números no Paraná: resultados da operação. Brasília, DF: Ministério Público Federal, [2019]. Disponível em: <http://www.mpf.mp.br/grandes-casos/ caso-lava-jato/atuacao-na-1a-instancia/atuacao-na-1a-instancia/parana/resultado>. Acesso em: maio 2019. 


\section{Tabela 21.1 - Informações de estrutura, recursos humanos e litigiosidade - 2013-2017 \\ Table 21.1 - Information on structure, human resources and litigiousness - 2013-2017}

\begin{tabular}{|c|c|c|c|c|c|}
\hline $\begin{array}{l}\text { Especificação/ } \\
\text { Specification }\end{array}$ & 2013 & 2014 & 2015 & 2016 & 2017 \\
\hline $\begin{array}{l}\text { Despesas (1 } 000 \mathrm{R} \$) / \\
\text { Expenditures (1,000 R\$) }\end{array}$ & 77443090,0 & 80706915,2 & 84533932,6 & 84846934,6 & 90846325,2 \\
\hline $\begin{array}{l}\text { Despesa com recursos humanos } \\
\text { (1 } 000 \mathrm{R} \$) / \text { Expenditure with human } \\
\text { resources }(1,000 R \$)\end{array}$ & 69529958,9 & 72272721,1 & 75374309,2 & 75948590,2 & 82178298,4 \\
\hline $\begin{array}{l}\text { Gasto com recursos humanos (\%)/ } \\
\text { Expense with human resources (\%) }\end{array}$ & 89,8 & 89,5 & 89,2 & 89,5 & 90,5 \\
\hline $\begin{array}{l}\text { Receitas (1 } 000 \mathrm{R} \$) / \\
\text { Revenue (1,000 R\$) }\end{array}$ & 38807493,3 & 31920433,2 & 47665521,8 & 39041338,0 & 48431158,3 \\
\hline $\begin{array}{l}\text { Receitas/despesas / } \\
\text { Revenue/expenditures (\%) }\end{array}$ & 50,1 & 39,6 & 56,4 & 46,0 & 53,3 \\
\hline Magistrados / Judges & 17088 & 17404 & 17376 & 18011 & 18168 \\
\hline Servidores / Servants & 276773 & 278707 & 278265 & 279013 & 272093 \\
\hline $\begin{array}{l}\text { Força de trabalho auxiliar / Auxiliary } \\
\text { workforce }\end{array}$ & 135984 & 138892 & 155516 & 145321 & 158703 \\
\hline $\begin{array}{l}\text { Carga de trabalho por magistrado/ } \\
\text { Caseload per judge }\end{array}$ & 6232 & 6169 & 6746 & 6696 & 6742 \\
\hline Casos novos/ New cases & 28546494 & 29010480 & 27804636 & 29351145 & 29113579 \\
\hline Casos pendentes / Pending cases & 71646644 & 71985411 & 76921737 & 79662896 & 80069305 \\
\hline Processos baixados / Closed cases & 28087192 & 28441380 & 28652290 & 29427540 & 31017900 \\
\hline $\begin{array}{l}\text { Processos baixados por magistrado/ } \\
\text { Closed cases per judge }\end{array}$ & 1705 & 1696 & 1771 & 1749 & 1819 \\
\hline $\begin{array}{l}\text { Taxa de Congestionamento (\%)/ } \\
\text { Congestion Rate (\%) }\end{array}$ & 71,8 & 71,7 & 72,9 & 73,0 & 72,8 \\
\hline
\end{tabular}

Fonte/Source: Justiça em Números 2018: ano-base 2017. Brasília, DF: Conselho Nacional de Justiça, 2018. Disponivel em/Available from: <http://www.cnj.jus.br/pesquisas-judiciarias/justicaemnumeros/2016-10-21-1313-04/pj-justica-em-numeros>. Acesso em: abr. 2018/Cited:Apr . 2018.

Nota: Valores financeiros corrigidos pelo IPCA, data-base dez/2017./Note: Financial values updated by the IPCA, base Dec 2017. 
Tabela 21.2 - Informações de estrutura, recursos humanos e litigiosidade por ramo de justiça - 2017

Table 21.2 - Information on structure, human resources and litigiousness, by court of justice - 2017

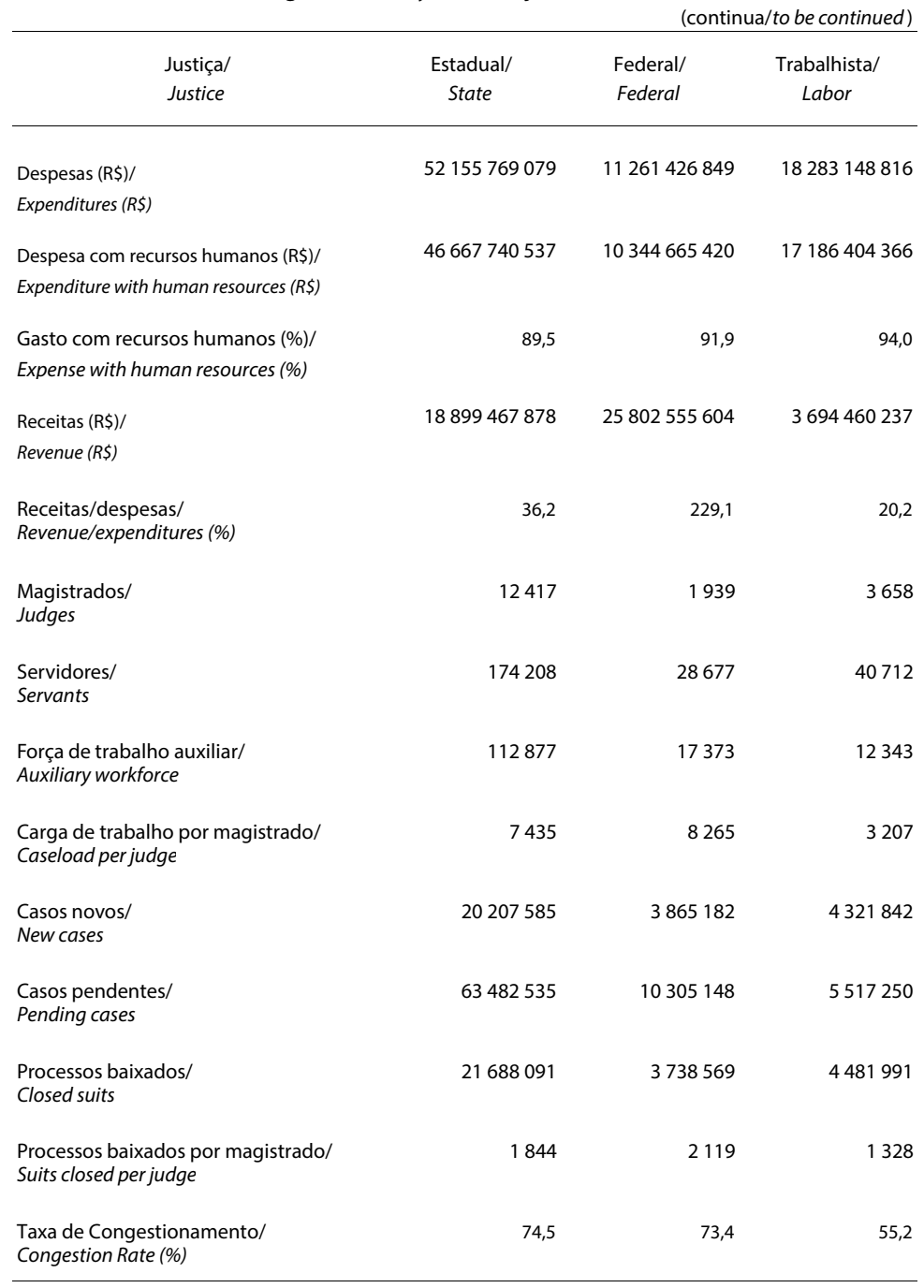




\section{Tabela 21.2 - Informações de estrutura, recursos humanos e litigiosidade por ramo de justiça - 2017}

Table 21.2 - Information on structure, human resources and litigiousness, by court of justice - 2017

\begin{tabular}{|c|c|c|c|}
\hline & & (co & clusão/concluded) \\
\hline $\begin{array}{l}\text { Justiça/ } \\
\text { Justice }\end{array}$ & $\begin{array}{l}\text { Eleitoral/ } \\
\text { Electoral }\end{array}$ & $\begin{array}{l}\text { Militar Estadual/ } \\
\text { State Military }\end{array}$ & $\begin{array}{c}\text { Tribunais } \\
\text { Superiores/ } \\
\text { Superior Courts }\end{array}$ \\
\hline Despesas (R\$)/ & 5488685876 & 151643393 & 3505651148 \\
\hline Expenditures (R\$) & & & \\
\hline Despesa com recursos humanos (R\$)/ & 4929728410 & 139208218 & 2910551491 \\
\hline Expenditure with human resources ( $R \$$ ) & & & \\
\hline Gasto com recursos humanos (\%)/ & 89,8 & 91,8 & 83,0 \\
\hline Expense with human resources (\%) & & & \\
\hline Receitas (R\$)/ & 0 & 1432030 & 33242535 \\
\hline Revenue (R\$) & & & \\
\hline $\begin{array}{l}\text { Receitas/despesas/ } \\
\text { Revenue/expenditures (\%) }\end{array}$ & - & 0,94 & 0,95 \\
\hline $\begin{array}{l}\text { Magistrados/ } \\
\text { Judges }\end{array}$ & 2862 & 41 & 89 \\
\hline $\begin{array}{l}\text { Servidores/ } \\
\text { Servants }\end{array}$ & 21539 & 405 & 6301 \\
\hline $\begin{array}{l}\text { Força de trabalho auxiliar/ } \\
\text { Auxiliary workforce }\end{array}$ & 10970 & 114 & 5026 \\
\hline $\begin{array}{l}\text { Carga de trabalho por magistrado/ } \\
\text { Caseload per judge }\end{array}$ & 225 & 213 & 19196 \\
\hline $\begin{array}{l}\text { Casos novos/ } \\
\text { New cases }\end{array}$ & 169190 & 5150 & 543058 \\
\hline $\begin{array}{l}\text { Casos pendentes/ } \\
\text { Pending cases }\end{array}$ & 135309 & 3308 & 623677 \\
\hline $\begin{array}{l}\text { Processos baixados/ } \\
\text { Closed suits }\end{array}$ & 503740 & 4969 & 599582 \\
\hline $\begin{array}{l}\text { Processos baixados por magistrado/ } \\
\text { Suits closed per judge }\end{array}$ & 176 & 121 & 7939 \\
\hline $\begin{array}{l}\text { Taxa de Congestionamento/ } \\
\text { Congestion Rate (\%) }\end{array}$ & 21,2 & 40,0 & 51,0 \\
\hline
\end{tabular}

Fonte/Source: Justiça em números 2018: ano-base 2017. Brasília, DF: Conselho Nacional de Justiça, 2018. Disponível em/Available from:<http://www.cnj.jus.br/pesquisasjudiciarias/justicaemnumeros/2016-10-21-13-13-04/pj-justica-em-numeros $>$. Acesso em: abr. 2018/Cited: Apr. 2018. 


\section{Gráfico 21.1 - Série histórica do total de processos ingressados - 1990-2017}

Graph 21.1 - Time series of total issued cases - 1990-2017

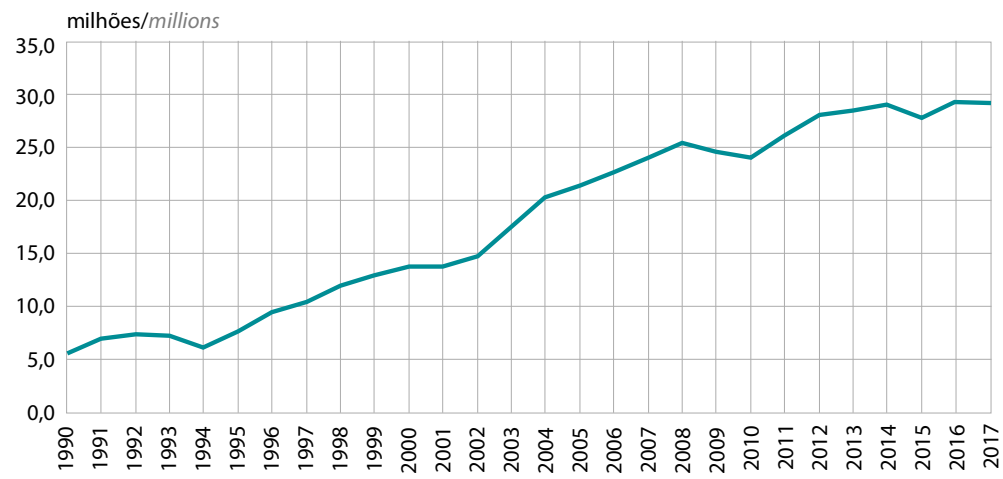

Fontes/ Sources: 1. Banco de Dados do Sistema de Estatísticas do Poder Juciário (SIESP). 2. Justiça em números 2018: ano-base 2017. Brasília, DF: Conselho Nacional de Justiça, 2018. Disponível em/Avaiable from: <http://www.cnj.jus.br/pesquisas-judiciarias/justicaemnumeros/2016-10-21-13-13-04/pj-justica-em-numeros>. Acesso em: abr. 2018/Cited:Apr. 2018.

\section{Gráfico 21.2 - Percentual de processos em tramitação, por ramo de justiça - 2017}

Graph 21.2 - Percentage of cases in progress, by court of justice - 2017

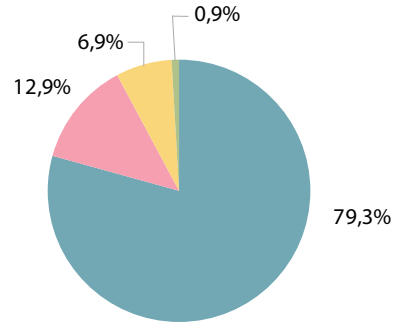

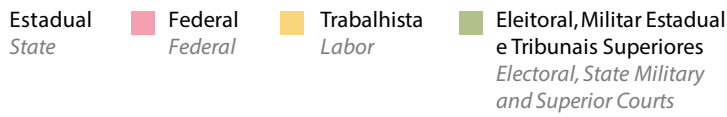

Fonte/Source: Justiça em números 2018: ano-base 2017. Brasília, DF: Conselho Nacional de Justiça, 2018. Disponível em/Available from: <http://www.cnj.jus.br/pesquisas-judiciarias/justicaemnumeros/ 2016-10-21-13-13-04/pj-justica-em-numeros>. Acesso em: abr. 2018/Cited: Apr. 2018. 



\section{Meio Ambiente Environment}

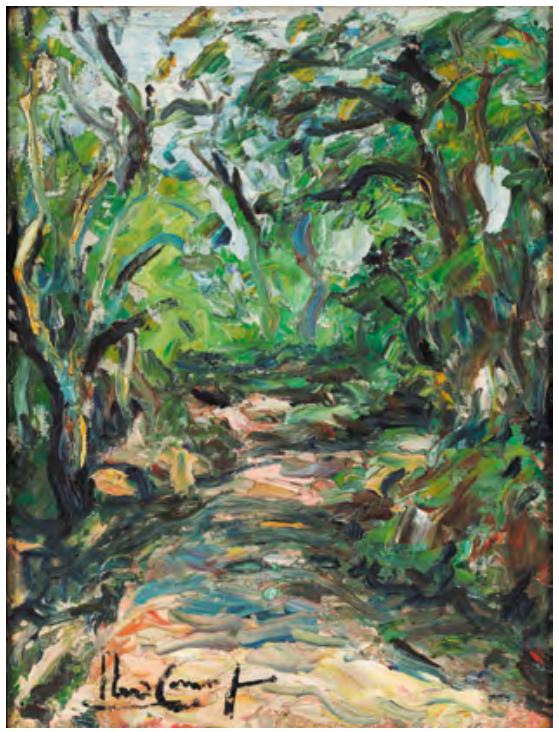

Dentro do mato, 1941-1942 Inside the bush 


\title{
Environment
}

\author{
Roberto Verdum ${ }^{1}$
}

The localization of the Brazilian territory, with a surface of $8,511,965$ $\mathrm{km}^{2}, 93 \%$ of which is in the Tropical Zone, can be considered a key factor to determine the influence of the climate in the social and territorial formation of the country. At first, the wild harvesting of pau-brasil (Brazilwood) in the east side of the former Portuguese colony, especially in the Atlantic Forest, should be mentioned. In that very same ecosystem, sugarcane crops were grown in the end of the 16th century. Coffee, which would feature the next agricultural cycle, would also meet the foreign demands and was grown in the Atlantic Forest, of the araucarias and meridional fields.

However, from the 1930s on, another model would attempt to break those economic cycles grounded basically on agricultural exports. The Brazilian elites adopted an industrialization policy and opened the country to international investment as a way of introducing it to a developmental model. Therefore, the concentration of financial resources in the State would turn it into the great entrepreneur, mostly regarding the construction of the necessary infrastructure to boost the ongoing production processes.

\footnotetext{
1 Full Professor, of the Geography Department, Postgraduate Program in Geography (PPG), Geosciences Institute and PPG in Rural Development, School of Economic Sciences of the Federal University of Rio Grande do Sul (UFRGS). Email: verdum@ufrgs.br
} 


\title{
Meio Ambiente
}

\author{
Roberto Verdum ${ }^{1}$
}

A localização do território do Brasil, que tem uma superfície de 8511965 km² e onde $93 \%$ desta superfície está em Zona Tropical, pode ser considerada como fundamental para caracterizar o papel do tropicalismo na formação socioterritorial do País. Inicialmente, deve-se referenciar a extração do pau-brasil na face leste da antiga colônia portuguesa, especificamente na Mata Atlântica. Neste mesmo ecossistema florestal, desenvolvem-se as plantations de cana-de-açúcar, no Século XVI. O café, que caracterizaria o próximo ciclo agrícola, atenderia também às demandas do mercado mundial e foi cultivado na Mata Atlântica, das araucárias e nos campos meridionais.

No entanto, é a partir dos anos de 1930 que se vislumbra um modelo de desenvolvimento que buscará romper esses ciclos econômicos baseados exclusivamente na exportação de produtos agrícolas. As elites brasileiras adotam a política de industrialização e de abertura aos investimentos internacionais, como sendo a possibilidade de o País ingressar num modelo desenvolvimentista. Assim, a concentração dos recursos financeiros no Estado, caracteriza-o como o grande empreendedor, sobretudo no que se refere à construção de infraestrutura para impulsionar o processo produtivo em marcha.

1 Professor Titular do Departamento de Geografia, Programa de Pós-Graduação em Geografia (PPG), Instituto de Geociências e PPG em Desenvolvimento Rural, Faculdade de Ciências Econômicas da Universidade Federal do Rio Grande do Sul (UFRGS). E-mail: verdum@ufrgs.br 


\section{Socio-spatial dynamics in Brazil and the Brazilian environmental issue}

Often, it is said that the debate on the environmental issue emerges in the 1970s, as a result of the Brazilian environmental movement, which creates the first paradigms against the environmental degradation affecting both society and the ecosystem of the country. However, the Brazilian environmental issue has put down its deeper roots in the 1930s, when the opening to international investment aimed at consolidating policies for an agricultural exporting country and for multinational industrial investment (CHRISTOFOLETTI, 2002).

In order to reinforce that dynamics started in the 1930s, the most recent data on industrial concentration in Brazil show the following distribution: $49 \%$ in the Southeast Region, $29 \%$ in the South and $13 \%$ in the Northeast (IBGE..., 2018). The search for more material basis to meet this developmental model's demands brings along the necessity to actually implement the integration ideal, incorporating the North Region (the Amazon Forest) and Central-West Region (Cerrado and Pantanal) of the country.

\section{Brazilian ecosystems and environmental conflicts}

Concerning agricultural production and the main environmental conflicts in the country, the different ecosystems, the wild harvesting systems and the agroindustry systems can be associated:

- Wild harvesting in the Amazon (latex, mineral and wood);

- Grazing in the Northeast, Southeast, South and Central-West;

- Agroindustry in the Zona da Mata in the Northeast (sugarcane, cotton and cocoa);

- Agroindustry in the Southeast (coffee and sugarcane);

- Agroindustry in the South, Central-West and North (rice and soybeans);

- Forest in the Northeast, Southeast and South (exotic wood: pine, eucalyptus and acacia).

In the Amazon (47\% of the national territory, nearly four million $\mathrm{km}^{2}$ ), the degradation of the forest, through deforestation and fires, has been being identified since the 1970s, by geographers Aziz Ab'Saber and Orlando Valverde, as sated by Borelli (2005) and Kohlhepp (2015). In 2017 , the deforestation of areas covered by forests represented a surface of nearly $6,700 \mathrm{~km}^{2}$, and from 1995 to 2004 the highest level of deterioration was achieved, around $30,000 \mathrm{~km}^{2}$ and $28,000 \mathrm{~km}^{2}$, respectively, as seen in Graphs 22.1 and 22.2. 


\section{Dinâmica sócio-espacial no Brasil e a questão ambiental brasileira}

Frequentemente, destaca-se que é a partir dos anos de 1970 que emerge a discussão sobre a problemática ambiental, sendo esta o resultado do surgimento do movimento ambientalista brasileiro, que elabora os primeiros paradigmas frente às degradações ambientais que afetam a sociedade e os ecossistemas do País. No entanto, pode-se considerar que a questão ambiental brasileira tem suas raízes profundas, a partir dos anos de 1930, quando se estabelece a abertura aos investimentos internacionais que buscam consolidar uma política de um país exportador agrícola e de investimento industrial multinacional (CHRISTOFOLETTI, 2002).

Para reforçar esta dinâmica iniciada nos anos de 1930, os dados mais recentes de concentração industrial no Brasil mostram a seguinte distribuição: $49 \%$ na Região Sudeste, $29 \%$ na Região Sul e $13 \%$ na Região Nordeste (IBGE..., 2018). Na busca de ampliação da base material para atender a esse modelo de desenvolvimento, identifica-se a necessidade de se concretizar a lógica da integração nacional, que incorpora as Regiões Norte (Floresta Amazônica) e Centro-Oeste (Cerrado e o Pantanal) do País.

\section{Ecossistemas brasileiros e seus conflitos ambientais}

No que se refere à produção agrícola e aos principais conflitos ambientais no País, podem- se associar os diferentes ecossistemas, os sistemas extrativos e agroindustriais:

- Extrativo Amazônico (látex, mineral e da madeira);

- Pastoril do Nordeste, Sudeste, Sul, e Centro-oeste;

- Agroindustrial da Zona da Mata no Nordeste (cana-de-açúcar, algodão e cacau);

- Agroindustrial do Sudeste (café e cana-de-açúcar);

- Agroindustrial do Sul, Centro-oeste e Norte (arroz e soja);

- Florestal do Nordeste, Sudeste e Sul (madeira exótica: pinus, eucalipto e acácia).

Na Amazônia, que representa $47 \%$ do Território Nacional, em torno de quatro miIhões de $\mathrm{km}^{2}$, o processo de degradação da floresta, pelos desmatamentos e pelas queimadas, já vem sendo identificado desde a década de 1970, pelos geógrafos Aziz Ab'Saber e Orlando Valverde, conforme Borelli (2005) e Kohlhepp (2015). Em 2017, o desmatamento da área coberta por florestas representou uma superfície em torno de $6700 \mathrm{~km}^{2}$, sendo que nos anos de 1995 e 2004 se atingiram as maiores taxas, em torno de $30000 \mathrm{~km}^{2}$ e 28000 km², respectivamente, Gráficos 22.1 e 22.2 . 
The Northeast (1.5 million $\mathrm{km}^{2}$, nearly $18 \%$ of the National territory) is where the ecosystems of Caatinga, Agreste and Zona da Mata are basically located. The highlight is the sugarcane crop, historically grown in soils that were before part of the Atlantic Tropical Forest. The most significant environmental problems are: desertification and social disorganization that generates historical migration flows of rural exit. Moreover, there is the degradation of fauna and flora, directly or indirectly caused by the increased use of pesticides in the crops, Graph 22.3.

In the South $\left(580,000 \mathrm{~km}^{2}\right.$, or $6.8 \%$ of the Brazilian territory), there is a massive presence of subtropical forests and fields as ecosystems. There, agribusiness was already consolidated in the 1960s (rice, oat, soybean and wheat) as well as livestock farming (cattle, sheep and horses). The most common environmental problems are deforestation, soil degradation through erosion processes, the silting up of watercourses, the process of de-structuring of small (below $25 \mathrm{ha}$ ) and medium (between 100 and 300 ha) family properties and water contamination through chemicals, especially after 2008, when pesticides in Brazil more than doubled, Graph 22.3. As to the Pampa, in the state of Rio Grande do Sul, there is a process of sandy spot formation (sand fields), from the intensification of natural erosive processes in sandy soils, by the introduction of intensive crop systems (corn, soybean and wheat) in the 1970s, Verdum (2012).

In the Central-West (nearly 1.6 million $\mathrm{km}^{2}$, representing $19 \%$ of the National territory), the Cerrado is the main ecosystem. After the integration of this region to the agroindustry production process, there have been several crops expanding and increasing, corresponding to $44.7 \%$ of the national agricultural production. In 2019, the state of Mato Grosso do Sul is expected to produce $27 \%$ of the grains in the country (rice, corn and soybeans, 31.89 metric tons); it is expected to became the first national producer of beans, coffee and cassava (IBGE...,2018).

Among the environmental problems that are identified in this region, the highlights are: degradation of fauna and flora, of soils and water, through ravage, gully formation and consequent sedimentation of the watercourses, as well as through pesticide contamination, Graph 22.3.

In the Southeast (around $927,000 \mathrm{~km}^{2}$, representing $11 \%$ of the national territory), the main ecosystem was the Atlantic Tropical Forest, which nowadays has just nearly $8.0 \%$ of its original area. Currently, São Paulo accounts for $60 \%$ of the sugarcane produced in Brazil. The state surpasses, as a consequence, the historical record of the Northeast production. To reach such a result, the land for cultivation was nearly 8.59 million hectares in the $2018-2019$ crop, occupying the areas that were previously covered by forest. For the production of coffee, the greatest producing states in 2018 and located in the Southeast Region 
No Nordeste, que representa 1,5 milhões de $\mathrm{km}^{2}$, em torno de $18 \%$ do Território Nacional, é onde se localizam essencialmente os ecossistemas da Caatinga, do Agreste e da Zona da Mata. Dá-se destaque ao cultivo da cana-de-açúcar, historicamente desenvolvido em solos que, anteriormente, sustentavam a Floresta Tropical Atlântica. Como problemas ambientais, destacam-se: a desertificação e a desestruturação social que provoca, ainda, um fluxo migratório histórico pelo êxodo rural. Também, identifica-se a degradação da fauna e flora locais, direta ou indiretamente atingidas pelo uso crescente de agrotóxicos nas lavouras, Gráfico 22.3.

No Sul, que representa $580000 \mathrm{~km}^{2}$, ou 6,8\% do território brasileiro, este é essencialmente caracterizado pela presença de ecossistemas florestais subtropicais e campos, onde o agrobusiness está consolidado desde os anos de 1960 (arroz, aveia, soja e trigo), assim como pela criação (bovinos, ovinos e equinos). Identificam-se como problemas ambientais: o desmatamento, a degradação das terras por erosão, o assoreamento dos cursos, o processo de desestruturação das pequenas (abaixo de 25 ha.) e médias (entre 100 e 300 ha.) propriedades familiares e a contaminação da água pelos agroquímicos, sobretudo a partir dos ano de 2008, quando mais do que duplica a comercialização de agrotóxicos no Brasil, Gráfico 22.3. Em relação ao Pampa, no Estado do Rio Grande do Sul, identifica-se o processo de formação de manchas arenosas (areais), oriundas da intensificação de processos erosivos naturais em solos arenosos, pela introdução de sistemas de cultivo intensivo (milho, soja e trigo), desde os anos de 1970, Verdum (2012).

No Centro-Oeste, com uma superfície em torno de 1,6 milhões de $\mathrm{km}^{2}$, que representa $19 \%$ do Território Nacional, há como principal ecossistema o Cerrado. Após a integração dessa região ao processo produtivo agroindustrial, vários são os cultivos que se expandem e se intensificam, representando $44,7 \%$ da produção agrícola nacional, sendo o Estado do Mato Grosso aquele em que se estima para $2019 \mathrm{em}$ torno de $27 \%$ da produção nacional de grãos (arroz, milho e soja, 31,89 milhões de toneladas; e primeiro produtor de feijão, café e mandioca no País) (IBGE..., 2018).

Entre os problemas ambientais que são identificados nessa região, destacam-se: a degradação da fauna e da flora, dos solos e da água, tanto por ravinamento, voçorocamento e consequente assoreamento dos cursos d'água como, também, no que se refere à contaminação por agrotóxicos, Gráfico 22.3.

No Sudeste, com uma superfície em torno de $927000 \mathrm{~km}^{2}$, que representa $11 \%$ do Território Nacional, havia como principal ecossistema a Floresta Tropical Atlântica, sendo que atualmente, em torno de $8,0 \%$ desta floresta existe como remanescente. Atualmente, no Estado de São Paulo se produz $60 \%$ da cana-de-açúcar da produção brasileira, ultrapassando assim, a produção histórica da Região Nordeste do País. Para este cultivo foram ocupados, aproximadamente, 8,59 milhões de hectares na safra 2018-2019, assentados sobre os solos oriundos da antiga cobertura 
were: Minas Gerais, as first, with 30.7 million bags, and 53\% of the production; Espírito Santo, as second, with 12.81 million bags (22\%); São Paulo, next, with 6.07 million bags (10\%) (IBGE..., 2018). Stemming from the historical development of those intensive farming systems, the following environmental problems stand out: fragmentation of the ecosystems and contamination through pesticides, Graph 22.3.

\section{A rural country broken by urbanization: socioenvironmental imbalance}

Looking back at the historical changes that occurred to the rural and urban population in Brazil, of note is the rupture of an essentially rural nation turned into a country inserted in the industrial production model. Initially, with the industrial capital concentrated in the Southeast Region (São Paulo and Rio de Janeiro), a fast process of population growth and urbanization came along. In the 1960s, the total population in the country was 60 million inhabitants, of whom 28 million, or $46 \%$, lived in urban areas. In the demographic estimate of the year 2018 of the IBGE, the Brazilian population was of 208.4 million inhabitants, of whom, $85 \%$ lived in the cities. Nowadays, besides those two states of the federation that characterize the major metropolitan areas of the country, some capitals stand out: Brasília, Salvador, Fortaleza, Belo Horizonte, Manaus, Curitiba and Recife.

With the fast demographic growth, the concentration of industrial capital and the accelerated urbanization, some imbalance in the infrastructure became quite evident: in the drinking water supply, in the sewage treatment, Table 22.2, and in the disposal of solid waste. In relation to water, even though Brazil holds $13.8 \%$ of the fresh water available in the world, and $73 \%$ of such water is in the Amazon - where $4.0 \%$ of the Brazilian population lives, and the availability of water per inhabitant is 35 million liters -, around 23.6 million of Brazilians still have problems receiving treated water. Although in $2016,92.7 \%$ of the Brazilian households had water supply, only $66 \%$ of the households had sanitary sewers, that is, the water situation was still precarious in the areas of greater urban concentration, Table 22.2.

In relation to the collection of solid waste, data indicate that $90 \%$ of the population had this service provided in the 2017; however, almost half of the 5,570 Brazilian municipalities do not have an integrated plan for dealing with and disposing it (IBGE..., 2018). It is also worth highlighting that, in rural areas, the collection conditions are very precarious, especially when it comes to the containers of the chemical products used in rural properties, even more when we consider the increasing growth of the commercialization of those products in the last 10 years, Graph 22.3. 
florestal. Para a produção do café, os maiores estados produtores do País em 2018 e situados na Região Sudeste são: Minas Gerais, em primeiro lugar, com 30,7 milhões de sacas, corresponde a 53\% da produção; Espírito Santo, em segundo, com 12,81 milhões de sacas (22\%); São Paulo, em seguida, com 6,07 milhões de sacas (10\%) (IBGE..., 2018). Como problemas ambientais relacionados ao desenvolvimento histórico destes dois sistemas de cultivos intensivos, destacam-se: a fragmentação dos ecossistemas florestais e a contaminação por agrotóxicos, Gráfico 22.3.

\section{Ruptura de um país rural à urbanização: geração de desequilíbrios sócioambientais}

Ao se resgatar as mudanças históricas que ocorreram em relação à população rural e urbana no Brasil, nota-se a ruptura de um país essencialmente rural, para um país que se insere no modelo de produção industrial. Inicialmente, com capital industrial concentrado na Região Sudeste, Estados de São Paulo e Rio de Janeiro, gerou-se um rápido processo de crescimento populacional e de urbanização. Nos anos de 1960, a população total no País era de 60 milhões de habitantes, sendo que 28 milhões destes, $46 \%$, viviam nas áreas urbanas. Na estimativa demográfica do ano 2018 do IBGE, a população brasileira era de 208,4 milhões de habitantes, sendo que em torno de $85 \%$ deles viviam nas cidades. Atualmente, além daqueles dois estados da federação que caracterizam as maiores regiões metropolitanas do País, podem-se citar as capitais: Brasília, Salvador, Fortaleza, Belo Horizonte, Manaus, Curitiba e Recife.

Com o rápido crescimento populacional, a concentração do capital industrial e a acelerada urbanização alguns desequilíbrios na infraestrutura são característicos desse processo: no abastecimento de água potável, no tratamento de esgotos, Tabela 22.2, e na disposição dos resíduos sólidos. Em relação à água, mesmo que o Brasil detenha $13,8 \%$ da água doce disponível no mundo, que $73 \%$ desta água esteja na Amazônia, onde vive $4,0 \%$ da população brasileira e que a disponibilidade de água por habitante seja de 35 milhões de litros; em torno de 23,6 milhões de brasileiros, ainda têm problemas quanto ao acesso à água tratada. Mesmo que em 2016, $92,7 \%$ dos domicílios brasileiros possuíssem abastecimento de água, somente $66 \%$ dos domicílios contavam com esgotamento sanitário, isto é, ainda era grave a situação de degradação da água nas áreas de maior concentração urbana, Tabela 22.2.

Em relação à coleta de resíduos sólidos, os dados apontam para um atendimento de $90 \%$ da população no ano de 2017; entretanto, quase metade dos 5570 municípios brasileiros não têm um plano integrado para o seu manejo (IBGE..., 2018). Destaca-se ainda que, no meio rural, as condições de coleta são muito precárias, sobretudo em relação aos vasilhames de produtos químicos utilizados nas propriedades rurais, ainda mais se considerarmos o aumento crescente da comercialização destes produtos nos últimos 10 anos, Gráfico 22.3. 


\section{Final remarks}

The relationship between the formation of the Brazilian territory and the environmental conflicts should be analyzed in the light of the dynamics of the tropical nature and the adherence of the country to the capitalism expansion, from the colonial period in the 16th century up to nowadays. Degradation is still very severe, despite the social mobilization, which questions and opposes to the environmental damage identified all over the country from the 1970s on, and the implementation of the National Environmental Policy in the 1980s.

In addition, the relationship between socioeconomic inequalities and spatial differences in terms of environmental damage is becoming more and more evident. Therefore, environmental degradation is linked with the social precariousness of an important share of the population, both in the urban and in the rural area. In the groups of Brazilians with the highest and lowest incomes, the figures show that, in terms of income distribution and environmental degradation, 10\% of the richest tend to degrade more than the $50 \%$ of the poorest. As far as general consumption is concerned, the control has been weak, mainly concerning the richest; however, the low-income population is more susceptible to the impact of environmental degradation.

\section{References}

BORELLI, D. L. et al. Aziz Ab'Sáber: problemas da Amazônia brasileira. Revista Estudos Avançados, São paulo, v. 19, n. 53, p. 7-35, jan./abr. 2005.

CHRISTOFOLETTI, A. et al. (Org.) Geografia e meio ambiente no Brasil. 3. ed. São Paulo: Hucitec : Annablume, 2002. 395 p. (Geografia: teoria e realidade, 28).

IBGE prevê safra de grãos 1,7\% maior em 2019. Rio de Janeiro: Agência IBGE, 2018. Rio de Janeiro, 2018. News on Dec 11. 2018. Available from: $<$ https://agenciadenoticias.ibge.gov.br/agencia-sala-de-imprensa/2013agencia-de-noticias/releases/23359-ibge-preve-safra-de-graos-1-7maior-em-2019>. Cited: May 2019.

KOHLHEPP, G. Pioneiros brasileiros nas pesquisas geográficas de desenvolvimento regional: Orlando Valverde e Hilgard O'Reilly Sternberg. Revista Brasileira de Desenvolvimento Regional, Blumenau, v. 3, n. 1, p. 27-54, 2015. Available from: <http://proxy.furb.br/ojs/index.php/rbdr/ issue/archive>. Cited: May 2019.

VERDUM, R. Descoberta permanente: das areias aos areais. In: SUERTEGARAY, D. M. A.; SILVA, L. A. P. da; GUASSELLI, L. A. (Org.). Arenização: natureza socializada. Porto Alegre: Compasso Lugar-Cultura: Imprensa Livre, 2012. p. 73-83.

Translated by: Gisele Flores Caldas Manhães 


\section{Considerações finais}

Ao analisar a formação do território brasileiro e os conflitos ambientais, conclui-se que são fundamentais nesta relação as dinâmicas de uma natureza tropical e a incorporação do País à expansão do capitalismo, desde o período colonial europeu do Século XVI até os dias de hoje. Mesmo com a mobilização social, que questiona e se opõe às degradações ambientais identificadas em todo o País a partir dos anos de 1970, e da implantação da Política Nacional do Meio Ambiente a partir dos anos de 1980, essas degradações ainda são graves.

Além disso, cada vez mais, revela-se a relação existente entre as disparidades socioeconômicas dos brasileiros e as diferenciações espaciais em termos de degradações ambientais. Assim, associados à degradação ambiental está a precarização social de uma parcela importante da população, tanto no meio urbano como rural. Entre os grupos de brasileiros que possuem maior e menor renda, avalia-se que, na relação entre a distribuição da renda e a degradação ambiental, os $10 \%$ de maior renda têm uma tendência de degradar mais em relação aos 50\% de menor renda. No que se refere ao consumo em geral, este é fracamente controlado, principalmente o daqueles com maior poder aquisitivo; contudo, verifica-se que a população de menor renda está mais submetida aos impactos das degradações ambientais.

\section{Referências}

BORELLI, D. L. et al. Aziz Ab'Sáber: problemas da Amazônia brasileira. Revista Estudos Avançados, São paulo, v. 19, n. 53, p. 7-35, jan./abr. 2005.

CHRISTOFOLETTI, A. et al. (Org.) Geografia e meio ambiente no Brasil. 3. ed. São Paulo: Hucitec: Annablume, 2002. 395 p. (Geografia: teoria e realidade, 28).

IBGE prevê safra de grãos 1,7\% maior em 2019. Rio de Janeiro: Agência IBGE, 2018. Rio de Janeiro, 2018. Notícia de 11 dez. 2018. Disponível em: <https://agenciadenoticias. ibge.gov.br/agencia-sala-de-imprensa/2013-agencia-de-noticias/releases/23359-ibgepreve-safra-de-graos-1-7-maior-em-2019>. Acesso em: maio 2019.

KOHLHEPP, G. Pioneiros brasileiros nas pesquisas geográficas de desenvolvimento regional: Orlando Valverde e Hilgard O'Reilly Sternberg. Revista Brasileira de Desenvolvimento Regional, Blumenau, v. 3, n. 1, p. 27-54, 2015. Disponível em: <http:// proxy.furb.br/ojs/index.php/rbdr/issue/archive>. Acesso em: maio 2019.

VERDUM, R. Descoberta permanente: das areias aos areais. In: SUERTEGARAY, D. M. A.; SILVA, L. A.P. da; GUASSELLI, L. A. (Org.). Arenização:natureza socializada. Porto Alegre: Compasso Lugar-Cultura : Imprensa Livre, 2012. p. 73-83. 
Tabela 22.1 - Número de violações do padrão primário nacional de qualidade do ar de PM10, nas Regiões Metropolitanas de Salvador (Camaçari), Belo Horizonte, Vitória, Rio de Janeiro, São Paulo, Curitiba e Porto Alegre - 1996-2017

Table 22.1 - Number of violations of the national primary ambient air quality standards of PM10 in the metropolitan areas of Salvador (Camaçari), Belo Horizonte, Vitória, Rio de Janeiro, São Paulo, Curitiba and Porto Alegre - 1996-2017 (continua/to be continued)

Anos/

Years de qualidade do ar de PM10/

Number of violations of the national primary ambient air quality standards of PM10

\begin{tabular}{cccccc}
\hline Salvador & Belo & Ritóde & Ro de \\
(Camaçari) (1) & Horizonte & Janeiro & São Paulo & Curitiba & Porto \\
& & $(2)$ & & Alegre
\end{tabular}


Tabela 22.1 - Número de violações do padrão primário nacional de qualidade do ar de PM10, nas Regiões Metropolitanas de Salvador (Camaçari), Belo Horizonte, Vitória, Rio de Janeiro, São Paulo, Curitiba e Porto Alegre - 1996-2017

Table 22.1 - Number of violations of the national primary ambient air quality standards of PM10 in the metropolitan areas of Salvador (Camaçari), Belo Horizonte, Vitória, Rio de Janeiro, São Paulo, Curitiba and Porto Alegre - 1996-2017

(conclusão/concluded)

Número de violações do padrão primário nacional

de qualidade do ar de PM10/

Anos/

Number of violations of the national primary

Years ambient air quality standards of PM10

\begin{tabular}{|c|c|c|c|c|c|c|}
\hline $\begin{array}{c}\text { Salvador } \\
\text { (Camaçari) (1) }\end{array}$ & $\begin{array}{c}\text { Belo } \\
\text { Horizonte }\end{array}$ & Vitória & $\begin{array}{l}\text { Rio de } \\
\text { Janeiro } \\
\text { (2) }\end{array}$ & São Paulo & Curitiba & $\begin{array}{l}\text { Porto } \\
\text { Alegre }\end{array}$ \\
\hline
\end{tabular}

\begin{tabular}{llllllll}
2011 & - & 7 & - & 7 & 1 & 6 & 3 \\
2012 & - & 6 & 16 & 26 & - & 7 & - \\
2013 & $\ldots$ & $\ldots$ & - & 23 & - & 3 & - \\
2014 & $\ldots$ & $\ldots$ & $\ldots$ & 17 & 1 & $\ldots$ & - \\
2015 & $\ldots$ & $\ldots$ & $\ldots$ & $\ldots$ & - & $\ldots$ & - \\
2016 & $\ldots$ & $\ldots$ & $\ldots$ & $\ldots$ & - & $\ldots$ & $\ldots$ \\
2017 & $\ldots$ & $\ldots$ & $\ldots$ & $\ldots$ & - & $\ldots$ & $\ldots$ \\
\hline
\end{tabular}

Fontes/Sources : 1. Central de Tratamento de Efluentes Líquidos, CETREL (Região Metropolitana de Salvador/Pólo Industrial de Camaçari). 2. Fundação Estadual do Meio Ambiente, FEAM (Região Metropolitana de Belo Horizonte); 3. Instituto Estadual de Meio Ambiente e Recursos Hídricos, IEMA (Região Metropolitana de Vitória); 4. Instituto Estadual do Ambiente, INEA (Região Metropolitana do Rio de Janeiro); 5. Companhia Ambiental do Estado de São Paulo, CETESB (Região Metropolitana de São Paulo); 6. Instituto Ambiental do Paraná, IAP (Região Metropolitana de Curitiba); e 7. Fundação Estadual de Proteção Ambiental Henrique Luiz Roessler, FEPAM (Região Metropolitana de Porto Alegre).

(1) Na Região Metropolitana de Salvador, houve monitoramento somente nos municípios vizinhos ao Polo Industrial de Camaçari (10 pontos distribuídos nos municípios de: Câmara, Gravatá, Cobre, Sitio, Lamarão, Concórdia, Escola, Machadinho, Leandrinho e Areias)./(1) Monitoring carried out only in the cities near Camaçari Industrial Complex (10 points distributed in the following municipalities: Câmara, Gravatá, Cobre, Sitio, Lamarão, Concórdia, Escola, Machadinho, Leandrinho e Areias). (2) Resultado de 2015 não informado. /(2) Result of 2015 not informed 


\section{Tabela 22.2 - Média anual da Demanda Bioquímica de Oxigênio - DBO,}

em corpos de água selecionados, nas Unidades da Federação de Pernambuco, Bahia, Espírito Santo, Minas Gerais, Rio de Janeiro, São Paulo, Paraná e Rio Grande do Sul - 2007-2017 Tabela 22.2 - Annual average of Biochemical Oxygen Demand - BOD, in selected water bodies of Pernambuco, Bahia, Espírito Santo, Minas Gerais, Rio de Janeiro, São Paulo, Paraná and Rio Grande do Sul - 2007-2017

(continua/to be continued)

Unidades da Federação e corpos de água selecionados/ Federation Units and selected water bodies
Média anual da Demanda Bioquímica de Oxigênio - DBO (mg/l)/ Annual Average of Biochemical Oxygen Demand - BOD (mg/l)

20072008200920102011201220132014201520162017

\section{Pernambuco}

Bacia do Rio Capibaribe/

Capibaribe River Basin

Bacia do Rio Igarassu/

Igarassu River Basin

Bacia do Rio Ipojuca/

Ipojuca River Basin

Bahia (1)

Bacia do Rio Paraguaçu/

Paraguaçu River Basin

Bacia do Rio São Francisco/

São Francisco River Basin

Rio Jequitinhonha/

Jequitinhonha River

\section{Espírito Santo}

Bacia do Rio Doce/

Doce River Basin

Rio Jucu/

Jucu River

Rio Santa Maria da Vitória/

Santa Maria da Vitória River

\section{Minas Gerais}

Bacia do Rio das Velhas/

Das Velhas River Basin

Bacia do Rio Doce/

Doce River Basin

Rio Jequitinhonha/

Jequitinhonha River

Rio de Janeiro

Bacia do Rio Paraíba do Sul/

Paraíba do Sul River Basin

Bacia do Rio Guandu/

Guandu River Basin

\begin{tabular}{|ccccccccccc|c}
4,8 & 4,2 & 5,1 & 4,3 & 5,5 & 8,4 & 10,7 & 14,1 & 14,8 & 7,9 & $\ldots$ \\
\hline 2,4 & 2,8 & 1,6 & 5,6 & 6,9 & 5,3 & 7,1 & 8,6 & 4,5 & 5,6 & $\ldots$ \\
\hline 5,1 & 4,4 & 7,7 & 4,5 & 13,2 & 10,8 & 16,1 & 24,7 & 11,9 & 17,5 & $\ldots$ \\
\hline & & & & & & & & & & \\
$\ldots$ & 8,6 & 10,0 & 3,4 & 5,8 & 6,4 & 5,0 & 2,4 & 4,0 & 3,4 & 4,8 \\
\hline & 3,5 & 1,9 & 1,0 & 2,1 & 1,9 & 2,1 & 3,8 & 3,8 & $\ldots$ & $\ldots$ \\
\hline & 2,8 & 1,5 & 1,2 & 2,0 & 2,0 & 2,2 & 2,0 & 3,0 & 2,7 & 10,0
\end{tabular}

$\begin{array}{ccccccccccc}1,2 & 2,5 & 2,8 & 4,8 & 2,0 & 3,1 & 3,7 & 3,5 & 3,0 & \ldots & \ldots \\ 3,2 & 1,7 & 1,9 & 3,9 & 1,6 & 2,0 & 3,3 & 3,7 & 3,7 & \ldots & \ldots \\ 1,2 & 2,4 & 1,8 & 6,7 & 1,9 & 2,9 & 3,0 & \ldots & \ldots & \ldots & \ldots\end{array}$

$\begin{array}{lllllllllll}6,7 & 5,7 & 3,9 & 2,8 & 4,2 & 4,9 & 7,3 & 8,7 & 7,9 & 5,5 & 6,6\end{array}$

$\begin{array}{lllllllllll}1,3 & 1,5 & 1,3 & 1,1 & 2,1 & 2,0 & 2,1 & 2,2 & 2,2 & 2,1 & 2,1\end{array}$

$\begin{array}{lllllllllll}2,1 & 2,0 & 2,5 & 1,4 & 2,7 & 2,5 & 2,1 & 2,1 & 2,3 & 2,0 & 2,0\end{array}$

\begin{tabular}{llllll|lllll}
2,0 & 2,3 & 2,1 & 2,2 & 2,4 & $\ldots$ & 2,0 & 2,1 & 2,4 & 2,1 & 2,1
\end{tabular}

$2,2 \quad 13,1 \quad 11,2 \quad 4,6 \quad 3,4$ 


\section{Tabela 22.2 - Média anual da Demanda Bioquímica de Oxigênio - DBO, em corpos de água selecionados, nas Unidades da Federação de Pernambuco, Bahia, Espírito Santo, Minas Gerais, Rio de Janeiro, São Paulo, Paraná e Rio Grande do Sul - 2007-2017}

Tabela 22.2 - Annual average of Biochemical Oxygen Demand - BOD, in selected water bodies of Pernambuco, Bahia, Espírito Santo, Minas Gerais, Rio de Janeiro,

São Paulo, Paraná and Rio Grande do Sul - 2007-2017

(conclusão/concluded)

\begin{tabular}{|c|c|c|c|c|c|c|c|c|c|c|c|}
\hline \multirow{2}{*}{$\begin{array}{c}\text { Unidades da Federação e } \\
\text { corpos de água selecionados/ } \\
\text { Federation Units and selected } \\
\text { water bodies }\end{array}$} & \multicolumn{11}{|c|}{$\begin{array}{l}\text { Média anual da Demanda Bioquímica de Oxigênio - DBO (mg/l)/ } \\
\text { Annual Average of Biochemical Oxygen Demand - BOD (mg/l) }\end{array}$} \\
\hline & 2007 & 2008 & 2009 & 2010 & 2011 & 2012 & 2013 & 2014 & 2015 & 2016 & 2017 \\
\hline \multicolumn{12}{|l|}{ São Paulo } \\
\hline Represa Billings/Alto Tietê/ & 5,4 & 5,6 & 5,8 & 7,4 & 6,9 & 7,4 & 10,9 & 9,2 & 6,9 & 6,7 & 6,8 \\
\hline \multicolumn{12}{|l|}{ Billings Dam/Upper Tietê } \\
\hline Represa Guarapiranga/Alto Tietê/ & 3,4 & 3,8 & 4,1 & 4,5 & 5,4 & 4,2 & 6,8 & 7,3 & 4,4 & 5,4 & 6,7 \\
\hline Guarapiranga Dam/Alto Tietê & & & & & & & & & & & \\
\hline Zona Metropolitan/Alto Tietê/ & 35,9 & 40,9 & 35,7 & 35,8 & 27,7 & 34,3 & 39,2 & 36,2 & 30,2 & 26,3 & 35,4 \\
\hline Metropolitan Area/Upper Tietê & & & & & & & & & & & \\
\hline \multicolumn{12}{|c|}{ Paraná } \\
\hline Rio Iguaçu/Zona Metropolitana (2)/ & 20,4 & 13,0 & 11,3 & 10,2 & 6,3 & 15,4 & 6,5 & 31,5 & 5,4 & 9,1 & 7,6 \\
\hline Iguaçu River/Metropolitan Area (2) & & & & & & & & & & & \\
\hline Bacia do Rio Tibagi/ & 2,1 & 2,4 & 2,4 & 2,0 & 2,2 & 2,1 & 2,0 & $\ldots$ & $\ldots$ & 4,1 & 3,6 \\
\hline \multicolumn{12}{|l|}{ Tibagi River Basin } \\
\hline \multicolumn{12}{|l|}{ Rio Grande do Sul } \\
\hline Rio Caí/ & 1,5 & 1,4 & 1,2 & 1,2 & 2,0 & 2,1 & 1,1 & $\ldots$ & 1,0 & $\ldots$ & $\ldots$ \\
\hline \multicolumn{12}{|l|}{ Caí River } \\
\hline Rio Gravataí/ & 2,9 & 2,9 & 3,6 & 3,0 & 2,4 & 2,6 & 4,2 & ... & 4,0 & ... & $\ldots$ \\
\hline \multicolumn{12}{|l|}{ Gravataí River } \\
\hline Rio dos Sinos/ & 2,6 & 2,7 & 3,8 & 3,0 & 2,8 & 4,0 & 2,6 & $\ldots$ & $\ldots$ & $\ldots$ & $\ldots$ \\
\hline Dos Sinos River & & & & & & & & & & & \\
\hline
\end{tabular}

Fontes/Sources: 1. Instituto do Meio Ambiente e Recursos Hídricos (INEMA). 2. Instituto Estadual de Meio Ambiente e Recursos Hídricos (IEMA). 3. Instituto Mineiro de Gestão das Águas (IGAM) 4. Instituto das Águas do Paraná (AguasParaná). 5. Agência Estadual de Meio Ambiente e Recursos Hídricos (CPRH). 6. Instituto Estadual do Ambiente (INEA). 7. Fundação Estadual de Proteção Ambiental Henrique Luiz Roessler (FePAM). 8. Companhia Ambiental do Estado de São Paulo (CETESB).

Nota: Limite ConAMA da DBO para águas destinadas ao abastecimento público, após tratamento convencional: $5 \mathrm{mg} / \mathrm{l} . /$ Note: C ONAMA limit of BOD for public watter supply after conventional treatment: $5 \mathrm{mg} / \mathrm{l}$.

(1) O INEMA iniciou o monitoramento a partir do mês de julho de 2011./(1) I NEMA started monitoring from July 2011. (2) Refere-se ao subsistema 2 da Região Metropolitana, segundo o Instituto das Águas do Paraná./ (2) Refers to subsystem 2 of the Metropolitan Area, according to the Water Institute of Paraná.

DBO menor ou igual a $5 \mathrm{mg} / \mathrm{l} /$ $B O D$ less than or equal to $5 \mathrm{mg} / \mathrm{l}$
DBO maior que $5 \mathrm{mg} / \mathrm{l} /$ $B O D$ greater than or equal to $5 \mathrm{mg} / \mathrm{l}$ 


\section{Tabela 22.3 - Número e área das Unidades de Conservação Federais, segundo o tipo de uso e as categorias de manejo - 2017 Table 22.3 - Number and areas of Federal Conservation Units, by type of use and management categories - 2017}

Tipo de uso e categorias de manejo/ Type of use and management categories
Unidades de Conservação Federais

\begin{tabular}{|c|c|}
\hline $\begin{array}{l}\text { Número/ } \\
\text { Number }\end{array}$ & $\begin{array}{l}\text { Área }\left(\mathrm{km}^{2}\right) / \\
\text { Area }\left(\mathrm{km}^{2}\right)\end{array}$ \\
\hline 959 & (1) 798061 \\
\hline 147 & 385648 \\
\hline 32 & 74940 \\
\hline 3 & 443 \\
\hline 73 & 264897 \\
\hline 8 & 2692 \\
\hline 31 & 42677 \\
\hline 812 & 412413 \\
\hline 67 & 178225 \\
\hline 62 & 124724 \\
\hline 2 & 1026 \\
\hline- & - \\
\hline 33 & 103266 \\
\hline 13 & 341 \\
\hline 635 & 4831 \\
\hline
\end{tabular}

Proteção Integral/Integral Protection

Estação Ecológica/Ecological Station

Monumento Natural/Natural monument

Parque Nacional/National Park

Refúgio de Vida Silvestre/Wildlife Refuge

Reserva Biológica/Biological Reserve

Uso Sustentável/Sustainable Use

Floresta Nacional/National Forest

Reserva Extrativista/Extractive Reserve

Reserva de Desenvolvimento Sustentável/Sustainable

Development Reserve

Reserva de Fauna/Fauna Reserve

Área de Proteção Ambiental/

Environmental Protection Area

Área de Relevante Interesse Ecológico/

Area of relevant ecological interest

Reservas Particulares do Patrimônio Natural -

RPPN/Private Reserves of Natural Heritage - PRNH

Fonte/Source: Cadastro Nacional de Unidades de Conservação (CNUC). Brasília, DF: Ministério do Meio Ambiente, [2018]. Disponível em/Available from : <http://www.mma.gov.br/areasprotegidas/cadastro-nacional-de-ucs>. Acesso em: jan. 2019/Cited : Jan . 2019.

Nota: Dados consolidados pelo CNUC em 01/02/2018. Disponível em: <http:www.mma.gov.br/areasprotegidas/cadastro-nacional-de-ucs/dados-consolidados >. Acesso em: 02 de março de 2018. / Note: Updated data until 1st February 2018 by CNUC. Available from: <http:www.mma.gov.br/areasprotegidas/cadastro-nacional-de-ucs/dados-consolidados>. Cited: 2nd March 2018.

(1) Considerando sobreposição mapeada, a área passa a ser de $792282 \mathrm{~km}^{2} /$ (1) Considering overlayed mapping, the area is $792,282 \mathrm{~km}^{2}$. 
Gráfico 22.1 - Desflorestamento bruto anual na Amazônia Legal - 1992-2017

Graph 22.1 - Annual gross deforestation in Legal Amazon - 1992-2017

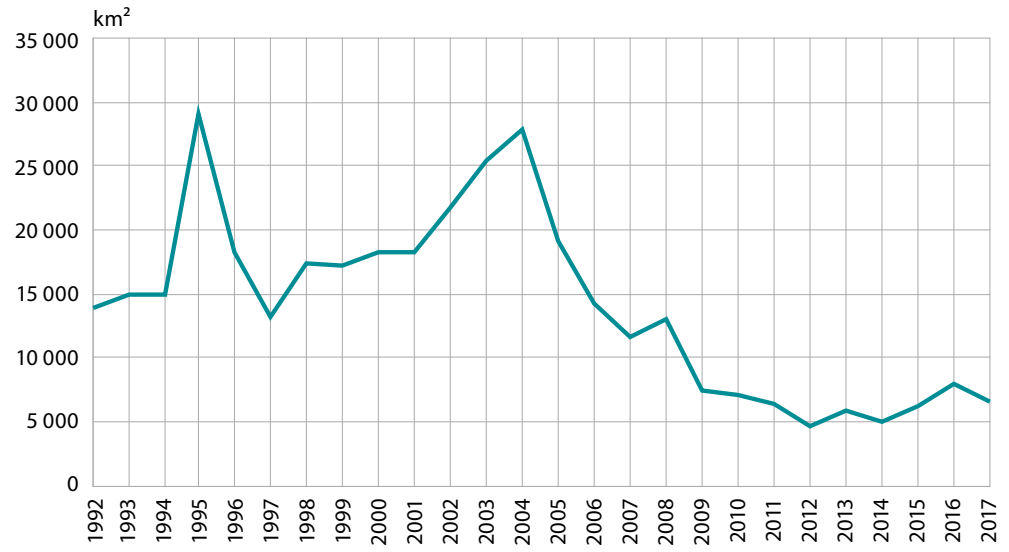

Fonte/Source: Projeto PRODES: monitoramento da floresta amazônica brasileira por satélite. São José dos Campos: Instituto Nacional de Pesquisas Espaciais, [2018]. Disponível em/Available from: <http://www.obt. inpe.br/OBT/assuntos/programas/amazonia/prodes>. Acesso em: jan. 2019/Cited: Jan. 2019.

Nota: Dados referentes ao período entre agosto de 1992 e agosto de 1994 (taxa para 2 anos)./Note: Data for the period between August 1992 and August 1994 (rate for 2 years). 


\section{Gráfico 22.2 - Focos de calor no Brasil, na Amazônia Legal e em Unidades de Conservação e Terras Indígenas - 2008-2017 \\ Graph 22.2 - Hot spots in Brazil, in the Legal Amazon and in Conservation Units and Indian Lands - 2008-2017}

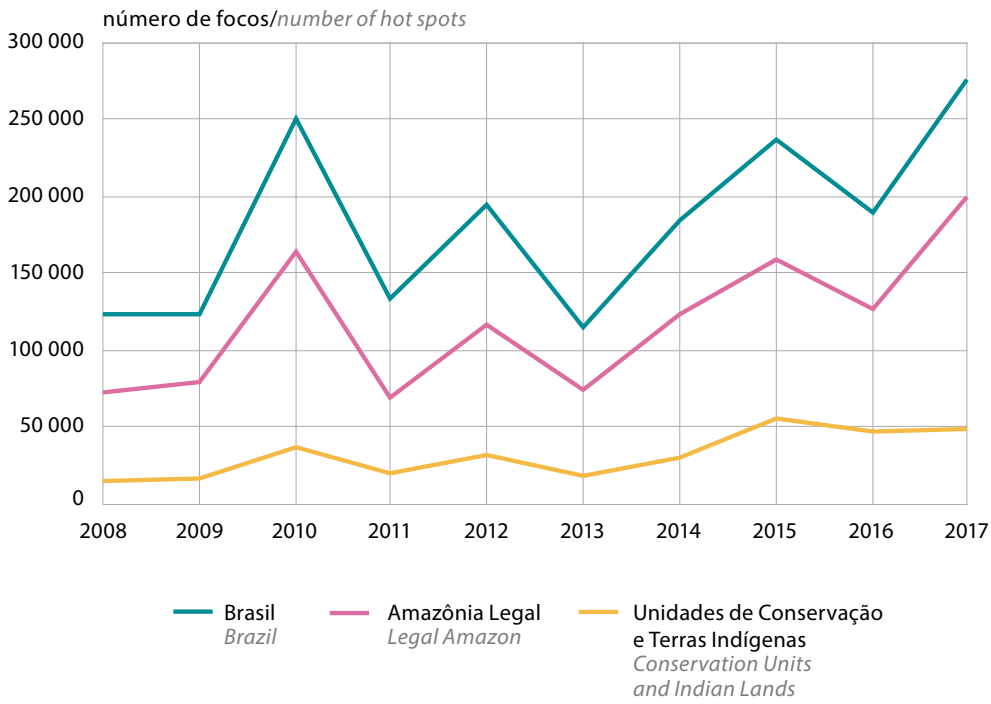

Fontes/Sources: I Instituto Nacional de Pesquisas Espaciais. Programa Queimadas: monitoramento por satélites. São José dos Campos: INPE, [2018]. Disponivel em/Available from: <http://www.inpe.br/ queimadas/portal>. Acesso em: jan. 2019/Cited: Jan. 2019.

Notas: 1. Os dados de focos de calor foram obtidos pelo satétite AQUA M-T.

2. Para o Brasil, o total corresponde à soma dos focos apresentados por cada bioma.

3. Os focos apresentados como sem informação ou indeterminado não foram computados no indicador.

4. Foram consideradas as Unidades de Conservação federais e estaduais./

Notes: 1. Data about hot spots were obtained by AQUA M-T.

2. For Brazil, the total is the sum of hot spots for each biome.

3. Hot spots presented as not informed or indeterminate were not included in the indicator.

4. Considering federal and state Conservation Units. 


\section{Gráfico 22.3 - Comercialização de agrotóxicos e afins, por área plantada - Brasil - 2001-2016}

Graph 22.3 -Commercialization of agrochemicals and the like, by planted area-Brazil - 2001-2016

\section{$\mathrm{Kg} / \mathrm{ha}$ de ingrediente ativo/Kg/ha of active ingredient}

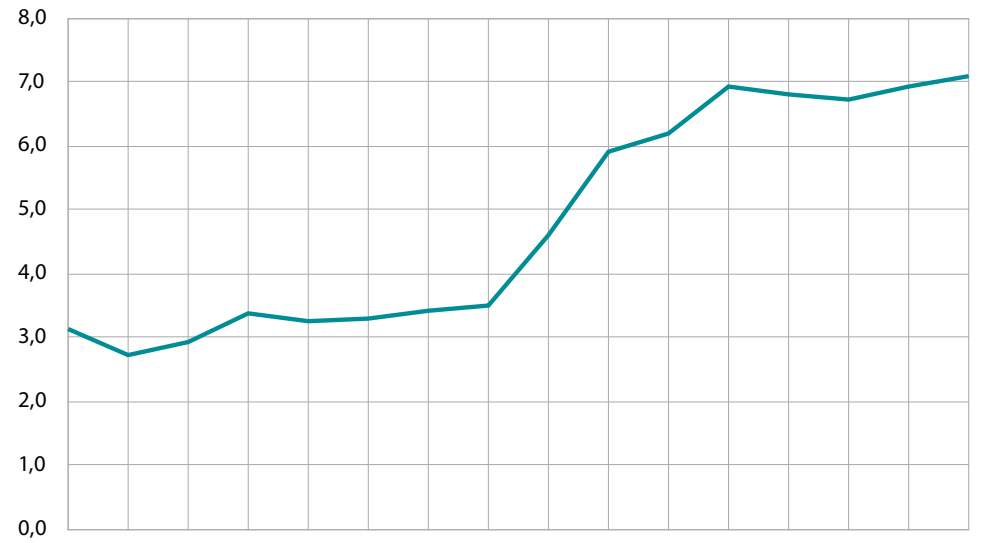

2001200220032004200520062007200820092010201120122013201420152016

Fontes/Sources: 1. Relatórios de comercialização de agrotóxicos: boletim anual de produção, importação, exportação e vendas de agrotóxicos no Brasil 2000-2016. Brasília, DF: Instituto Brasileiro do Meio Ambiente e dos Recursos Naturais Renováveis - Ibama, [2019]. Disponível em/Available from: $<$ http://www.ibama.gov.br/relatorios/quimicos-e-biologicos/reatorios-de-comercializacao-deagrotoxicos>. Acesso em: jan. 2019/Cited: jan. 2019. 2. Levantamento sistemático da produção agrícola: pesquisa mensal de previsão e acompanhamento das safras agrícolas no ano civil 2000-2005. Rio de Janeiro: IBGE, v. 12-17, 2000-2005. Disponível em/Available from: $<\mathrm{ftp} / / / \mathrm{ftp}$.ibge.gov.br/Producao_Agricola/Levantamento_Sistematico_da_Producao_Agricola_ \%5Bmensal\%5D/Fasciculo>. Acesso em: jan. 2019/Cited: Jan. 2019. 3. Produção agrícola municipal 2009-2016. In: IBGE. Sidra: sistema IBGE de recuperação automática. Rio de Janeiro, 2016. Disponível em/Available from: <https://sidra.ibge.gov.br/pesquisa/pam/tabelas>. Acesso em: jan. 2019/Cited: Jan. 2019. Nota: Sem informação para os anos de 2007 e 2008./Note: Data not avaiable for years 2007 e 2008. 



\section{Referências References}

ANUÁRIO DA INDÚSTRIA AUTOMOBILÍSTICA BRASILEIRA 2017. São Paulo: Associação Nacional dos Fabricantes de Veículos Automotores, 2017. Disponível em: $<$ http://www. virapagina.com.br/anfavea2017>. Acesso em: jan. 2019.

ANUÁRIO ESTATÍSTICO AQUAVIÁRIO 2018. Brasília, DF: Agência Nacional de Transportes Aquaviários, [2019]. Disponível em: <http://web.antaq.gov.br/anuario/>. Acesso em: jan. 2019.

ANUÁRIO ESTATÍSTICO DA PREVIDÊNCIA SOCIAL 2016. Brasília, DF: Empresa de Tecnologia e Informações da Previdência Social, v. 24, 2017. Disponível em: <http:// www.previdencia.gov.br/dados-abertos/dados-abertos-previdencia-social/>. Acesso em: jan. 2019.

ANUÁRIO ESTATÍ́STICO DE TURISMO 2018. Brasília, DF: Ministério do Turismo, v. 45, 2018. Ano base 2017. Disponível em: $<$ http://www.dadosefatos.turismo.gov.br/201602-04-11-53-05.html>. Acesso em: jan. 2019.

ANUÁRIO ESTATÍSTICO DO BRASIL 2017. Rio de Janeiro: IBGE, v. 77, 2017. Disponível em: <https://biblioteca.ibge.gov.br/index.php/bibliotecacatalogo?view=detalhes\&id=720>. Acesso em: jan. 2019.

BALANÇO energético nacional 2018: ano base 2017. Brasília, DF: Empresa de Pesquisa Energética-EPE, 2017. Disponível em: <https://ben.epe.gov.br>. Acesso em: jan. 2019.

BOLETIM ESTATÍSTICO [DA CONFEDERAÇÃO NACIONAL DOS TRANSPORTES]. Brasília, DF: CNT, ago. 2018. Disponível em: <http://www.cnt.org.br/boletim/boletimestatistico-cnt>. Acesso em: jan. 2019. 
BRASIL: alunos matriculados e titulados nos cursos de mestrado e doutorado, ao final do ano, 1998-2017. Brasília, DF: Ministério da Ciência, Tecnologia, Inovações e Comunicações, 2018. tab. 3.5.1. Disponível em:<http://www.mctic.gov.br/mctic/opencms/indicadores/ detalhe/Recursos_Humanos/RH_3.5.1.html>. Acesso em: jan. 2019.

BRASIL: dispêndios dos governos estaduais em ciência e tecnologia (C\&T) por região e unidade da federação, 2000-2016. In: BRASIL. Ministério da Ciência, Tecnologia, Inovações e Comunicações. Indicadores Nacionais de Ciência, Tecnologia e Inovação (CT\&l). Brasília, DF, 2018. tab. 2.3.3. Disponível em: <http://www.mctic.gov.br/mctic/ opencms/indicadores/detalhe/recursos_aplicados/governos_estaduais/2_3_3.html>. Acesso em: jan. 2019.

BRASIL: Dispêndio nacional em pesquisa e desenvolvimento (P\&D) em valores correntes, em relação ao total de P\&D e ao produto interno bruto (PIB), por setor institucional, 2000-2016. In: BRASIL. Ministério da Ciência, Tecnologia, Inovações e Comunicações. Indicadores Nacionais de Ciência, Tecnologia e Inovação (CT\&l). Brasília, DF, 2018. tab. 2.1.3. Disponível em: <http://www.mctic.gov.br/mctic/opencms/ indicadores/detalhe/recursos_aplicados/indicadores_consolidados/2_1_3.html >. Acesso em: jan. 2019.

BRASIL: instituições, grupos, pesquisadores e pesquisadores doutores, cadastrados no diretório dos grupos de pesquisa do CNPq, 1993/2016. Brasília, DF: Ministério da Ciência, Tecnologia, Inovações e Comunicações, 2018. tab. 3.6.1. Disponível em: $<$ http://www.mctic.gov.br/mctic/opencms/indicadores/detalhe/Recursos_Humanos/ RH_3.6.1.html>. Acesso em: jan. 2019.

BRASIL. Secretaria de Comércio Exterior. ComexStat: estatísticas de comércio exterior. Exportação e importação geral. Brasília, DF: Secex, 2019. Disponível em: <http:// comexstat.mdic.gov.br/pt/home>. Acesso em: jan. 2019.

ComexStat: estatísticas de comércio exterior. Séries históricas. Estado produtor e estado importador. Disponível em: $<$ http://www.mdic.gov.br/index.php/comercioexterior/estatisticas-de-comercio-exterior/series-historicas>. Acesso em: jan. 2019.

CADASTRO Nacional de Unidades de Conservação (CNUC). Brasília, DF: Ministério do Meio Ambiente, [2018]. Disponível em: <http://www.mma.gov.br/areas-protegidas/ cadastro-nacional-de-ucs>. Acesso em: jan. 2019.

EVOLUÇÃO do transporte ferroviário de cargas. Brasília, DF: Agência Nacional de Transportes Terrestres, 2017. Disponível em: <http://portal.antt.gov.br/index.php/ content/view/15884.html>. Acesso em: jan. 2019.

ESTATÍSTICAS. Repositório de dados eleitorais. Eleições 2018. In: BRASIL. Tribunal Superior eleitoral. Eleitor e eleições. Brasília, DF: TSE, 2018. Disponível em: <http:// www.tse.jus.br/eleicoes/estatisticas/repositorio-de-dados-eleitorais-1/repositoriode-dados-eleitorais $>$. Acesso em: jan. 2019. 
ESTATÍSTICAS de eleitorado. Eleições 2018. In: BRASIL. Tribunal Superior Eleitoral. Eleitor e eleições. Brasília, DF: TSE, 2018. Disponível em: <http://www.tse.jus.br/eleicoes/ estatisticas/repositorio-de-dados-eleitorais-1/repositorio-de-dados-eleitorais $>$. Acesso em: jan. 2019.

INDICADORES IBGE. Contas nacionais trimestrais: indicadores de volume e valores correntes out./dez. 2018. Rio de Janeiro: IBGE, 2018. Disponível em: <https://www.ibge. gov.br/estatisticas-novoportal/economicas/contas-nacionais/9300-contas-nacionaistrimestrais.html>. Acesso em: jan. 2019.

ÍNDICE nacional de preços ao consumidor amplo - IPCA 2005-2018. In: IBGE. Sidra: sistema IBGE de recuperação automática. Rio de Janeiro, [2018]. Disponível em: <https://sidra.ibge.gov.br/home/ipca/brasil>. Acesso em: jan. 2019.

INFORMAÇÕES de saúde (Tabnet). Assistência à saúde. Imunizações desde 1994. In: BRASIL. Ministério da Saúde. Datasus. Brasília, DF, [2018]. Disponível em: <http://www2. datasus.gov.br/DATASUS/index.php?area=0202>. Acesso em: jan. 2019.

INFORMAÇÕES de saúde (Tabnet). Epidemiológicas e morbidade. In: BRASIL. Ministério da Saúde. Datasus. Brasília, DF, [2018]. Disponível em: <http://www2.aids.gov.br/cgi/ tabcgi.exe?tabnet/br.def>. Acesso em: jan. 2019.

INFORMAÇÕES de saúde (Tabnet). Internações hospitalares do [Sistema Único de Saúde - SUS]. In: BRASIL. Ministério da Saúde. Datasus. Brasília, DF, [2018]. Disponível em: <http://tabnet.datasus.gov.br/cgi/deftohtm.exe?sih/cnv/sxuf.def $>$. Acesso em: jan. 2019.

INFORMAÇÕES de saúde (Tabnet). Mortalidade: dados preliminares. In: BRASIL. Ministério da Saúde. Datasus. Brasília, DF, [2018]. Disponível em: <http://tabnet.datasus. gov.br/cgi/tabcgi.exe?sim/cnv/pobt10uf.def>. Acesso em: jan. 2019.

INSTITUTO NACIONAL DE PESQUISAS ESPACIAIS (Brasil). Programa Queimadas: monitoramento por satélites. São José dos Campos: INPE, [2018]. Disponível em: <http://www.inpe.br/queimadas/portal>. Acesso em: jan. 2019.

JUSTIÇA em Números 2018: ano-base 2017. Brasília, DF: Conselho Nacional de Justiça, 2018. Disponível em: <http://www.cnj.jus.br/pesquisas-judiciarias/ justicaemnumeros/2016-10-21-13-13-04/pj-justica-em-numeros>. Acesso em:jan. 2019.

LEVANTAMENTO SISTEMÁTICO DA PRODUÇÃO AGRÍCOLA: pesquisa mensal de previsão e acompanhamento das safras agrícolas no ano civil 2000-2005. Rio de Janeiro: IBGE, v. 12-17, 2000-2005. Disponível em:<ftp://ftp.ibge.gov.br/Producao_Agricola/ Levantamento_Sistematico_da_Producao_Agricola_\%5Bmensal\%5D/Fasciculo $>$. Acesso em: jan. 2019. 
PARTIDOS políticos registrados no TSE. In: BRASIL. Tribunal Superior Eleitoral. Partidos. Brasília, DF: TSE, 2018. Disponível em: <http://www.tse.jus.br>. Acesso em: jan. 2019. PESQUISA ANUAL DE COMÉRCIO 2016. Rio de Janeiro: IBGE, v. 28, 2018. Disponível em: <https://www.ibge.gov.br/estatisticas-novoportal/economicas/comercio/9075pesquisa-anual-de-comercio.html>. Acesso em: jan. 2019.

PESQUISA da pecuária municipal 2016-2017. In: IBGE. Sidra: sistema IBGE de recuperação automática. Rio de Janeiro, [2018]. tab. 74, 3939, 3940. Disponível em: <https://sidra. ibge.gov.br/pesquisa/ppm/tabelas/brasil/2017>. Acesso em: dez. 2018. 2018.

PESQUISA de estoques 2011-2017. In: IBGE. Sidra: sistema IBGE de recuperação automática. Rio de Janeiro, [2018]. tab. 255. Disponível em: <https://sidra.ibge.gov. br/home/estoques/brasil>. Acesso em: jan. 2019.

PESQUISA INDUSTRIAL ANUAL. Empresa 2016. Rio de Janeiro: IBGE, v. 35, n.1, 2016. Disponível em: <https://www.ibge.gov.br/estatisticas-novoportal/economicas/ industria/9042-pesquisa-industrial-anual.html>. Acesso em: jan. 2019.

PESQUISA trimestral do abate de animais 2012-2017. In: IBGE. Sidra: sistema IBGE de recuperação automática. Rio de Janeiro, [2018]. tab. 1092. Disponível em: <https:// sidra.ibge.gov.br/home/abate>. Acesso em: dez. 2018.

POTENCIAL hidrelétrico brasileiro por bacia hidrográfica. In: ELETROBRAS. Sistema de Informações do Potencial Hidrelétrico Brasileiro (SIPOT). Rio de Janeiro: [2018]. Disponível em: <http://eletrobras.com/pt/AreasdeAtuacao/geracao/sipot/Potencial Hidrel\%C3\%A9tricoBrasileiro-Bacia-Dezembro2017.pdf>. Acesso em: jan. 2019.

PRODUÇÃO agrícola municipal 2007-2017. In: IBGE. Sidra: sistema IBGE de recuperação automática. Rio de Janeiro, [2018]. tab. 5457. Disponível em:<https://sidra.ibge.gov. br/pesquisa/pam/tabelas>. Acesso em: jan. 2019.

PRODUÇÃO da extração vegetal e da silvicultura 2016-2017. In: IBGE. Sidra: sistema IBGE de recuperação automática. Rio de Janeiro, [2018]. tab. 289, 291, 5930. Disponível em: <https://sidra.ibge.gov.br/pesquisa/pevs/quadros/brasil/2017>. Acesso em:jan. 2019. PROJETO PRODES: monitoramento da floresta amazônica brasileira por satélite. São José dos Campos: Instituto Nacional de Pesquisas Espaciais, [2018]. Disponível em: <http://www.obt.inpe.br/OBT/assuntos/programas/amazonia/prodes>. Acesso em: jan. 2019. 
RECEITA e despesa cambial turística. Dados e fatos: estudos, pesquisas e dados sobre o setor de turismo. Brasília, DF: Ministério do Turismo, [2018]. Disponível em: <http:// www.dadosefatos.turismo.gov.br/estat\%C3\%ADsticas-e-indicadores/receita-cambial. html>. Acesso em: jan. 2019.

RELATÓRIO resumido da execução orçamentária 2017-2018. Brasília, DF: Tesouro Nacional, [2018]. Disponível em: <https://www.tesouro.fazenda.gov.br>. Acesso em: jan. 2019.

RELATÓRIOS de comercialização de agrotóxicos: boletim anual de produção, importação, exportação e vendas de agrotóxicos no Brasil 2000-2016. Brasília, DF: Instituto Brasileiro do Meio Ambiente e dos Recursos Naturais Renováveis - Ibama, [2019]. Disponível em: <http://www.ibama.gov.br/relatorios/quimicos-e-biologicos/ relatorios-de-comercializacao-de-agrotoxicos>. Acesso em: jan. 2019.

RESENHA energética brasileira 2018. Ano base 2017. Brasília, DF: Empresa de Pesquisa Energética - EPE, 2018. Disponível em: <http://epe.gov.br/pt/publicacoes-dadosabertos/publicacoes/balanco-energetico-nacional-2018>. Acesso em: jan. 2019.

REPOSITÓRIO de Dados Eleitorais. Eleitorado. Eleições 2018. In: BRASIL. Tribunal Superior Eleitoral. Eleitor e eleições. Brasília, DF: TSE, 2018. Disponível em: <http:// www.tse.jus.br/eleicoes/estatisticas/repositorio-de-dados-eleitorais-1/repositoriode-dados-eleitorais>. Acesso em: jan. 2019.

SÉRIES históricas. Despesa da União por grupo de natureza 2013-2018. Brasília, DF: Ministério da Fazenda, Sistema Integrado de Administração Financeira do Governo Federal, [2018]. Disponível em:<http://www.tesouro.fazenda.gov.br/series-historicas>. Acesso em: jan. 2019.

SÉRIES temporais. Dívida mobiliária federal. Títulos consolidados do Tesouro Nacional e Banco Central. In: BANCO CENTRAL DO BRASIL. SGS: sistema gerenciador de séries temporais. Brasília, DF, [2019]. Código 4506, 5500, 10621. Disponível em: <http://www4. bcb.gov.br/pec/series/port/aviso.asp>. Acesso em: jan. 2019.

SÉRIES temporais. Tabelas especiais. Setor externo. In: BANCO CENTRAL DO BRASIL. SGS: sistema gerenciador de séries temporais. Brasília, DF, [2018]. Disponível em: $<$ http:// www4.bcb.gov.br/pec/series/port/aviso.asp>. Acesso em: jan. 2019.

SCIMAGO Journal and Country Rank. New York: Elsevier, [2018]. Disponível em: <http:// www.scimagojr.com/>. Acesso em: jan. 2019. 
SISTEMA de contas nacionais: Brasil 2016. Rio de Janeiro: IBGE, 2018. Disponível em: <https://www.ibge.gov.br/estatisticas-novoportal/economicas/contasnacionais/9052-sistema-de-contas-nacionais-brasil.html>. Acesso em: jan. 2019.

TABELAS especiais. Composição da Dívida Líquida do Setor Público (DLSP). In: BANCO CENTRAL DO BRASIL. Estatísticas. Brasília, DF, [2019]. Disponível em: <https://www. bcb.gov.br/estatisticas/tabelasespeciais>. Acesso em: jan. 2019.

TABELAS especiais. Dívida líquida e necessidades de financiamento do setor público. In: BANCO CENTRAL DO BRASIL. Estatísticas. Brasília, DF, [2019]. Disponível em: <https:// www.bcb.gov.br/estatisticas/tabelasespeciais>. Acesso em: jan. 2019.

TABELAS especiais. Dívida líquida e necessidades de financiamento do setor público. Participação percentual por indexador. In: BANCO CENTRAL DO BRASIL. Estatísticas. Brasília, DF, [2019]. Disponível em: <https://www.bcb.gov.br/estatisticas/ tabelasespeciais>. Acesso em: jan. 2019.

TABELAS especiais. Estatísticas fiscais regionalizadas. In: BANCO CENTRAL DO BRASIL. Estatísticas. Brasília, DF, [2019]. Disponível em: <https://www.bcb.gov.br/estatisticas/ tabelasespeciais>. Acesso em: jan. 2019. 


\section{Equipe Staff}

\section{Editor/Editor}

Susana Cordeiro Guerra

\section{Centro de Documentação}

e Disseminação de Informações - CDDI

Marise Maria Ferreira

Coordenação Executiva/Executive Coordination

Isabela Mateus de Araujo Torres

Desenvolvimento do Projeto/Project Development

Ruy Lemme Cartier

Normalização Bibliográfica e Textual/Bibliographic Standards

Vera Lucia Punzi Barcelos Capone

Versão para o inglês/English Version

Aline Milani Romeiro Pereira

Gisele Flores Caldas Manhães

La-Fayette Côrtes Neto

Coordenação de Produção/Production Coordination

Marisa Sigolo Mendonça Barcelos

Gerência de Editoração/Publishing Management

Fernanda Maciel Jardim

Produção Editorial/Editorial Production

Leonardo Martins

Diagramação/Desktop Publishing

Solange Maria Mello de Oliveira

Preparação das Informações do IBGE/Preparation of IBGE's Information Coordenações da Diretoria de Geociências e da Diretoria de Pesquisas 
Esta publicação foi impressa na

Imprimindo Conhecimento Editora e Gráfica Eirelli sobre papel couché matte $90 \mathrm{~g} / \mathrm{m}^{2}$ em 2019. 
Se o assunto é Brasil, procure o IBGE.

y libgecomunica $\{$ ibgeoficial $\bullet$ ibgeoficial 0 /ibgeoficial www.ibge.gov.br 08007218181 


\section{Brasil em Números}

\section{Brazil in Figures}

\section{A arte de retratar o Brasil}

O Brasil em Números, em versão bilíngue, reúne informações que permitem traçar uma síntese da realidade brasileira em seus múltiplos aspectos. Com seu formato compacto, a publicação busca promover uma leitura prazerosa e instrutiva.

Como fonte de informações, destacam-se os dados advindos de uma grande gama de pesquisas realizadas pelo IBGE. Para complementar, são também utilizados dados produzidos pelo Banco Central do Brasil, Agências Reguladoras e Ministérios Federais e algumas de suas instituições vinculadas.

Sob a forma de tabelas e gráficos, os capítulos apresentam dados sobre o País, incluindo dados comparativos entre os estados brasileiros. Além disso, a obra é enriquecida com artigos de renomados professores, técnicos e pesquisadores.

O presente volume é ilustrado com obras da Fundação lberê, localizada no Município de Porto Alegre, no Estado do Rio Grande do Sul.
The art of portraying Brazil

Brazil in Figures, a bilingual publication, brings together information that provides an overview of the Brazilian reality in its multiple aspects. In its compact format, the publication aims at providing a pleasant and instructive reading.

The publication highlights, as its information source, data from a wide range of surveys carried out by the IBGE. To complement them, data produced by the Central Bank of Brazil, Regulatory Agencies, Federal Ministries and some of their associated institutions are also used.

Grouped into chapters with tables and graphs, the book presents data about Brazil, including crosscomparison of the Brazilian states. In addition, the work is enriched with articles from renowned professors, experts and researchers.

This volume is illustrated with works from the lberê Foundation, located in the municipality of Porto Alegre, in the state of Rio Grande do Sul.

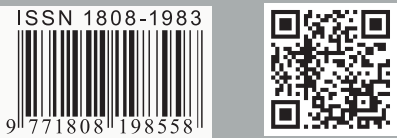

